
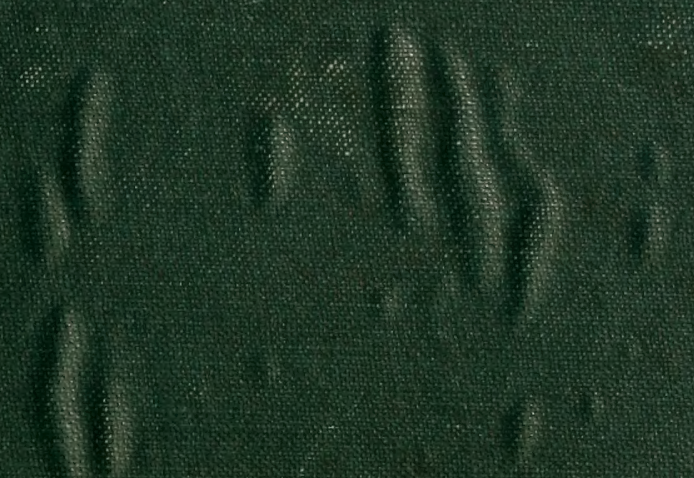

:

8

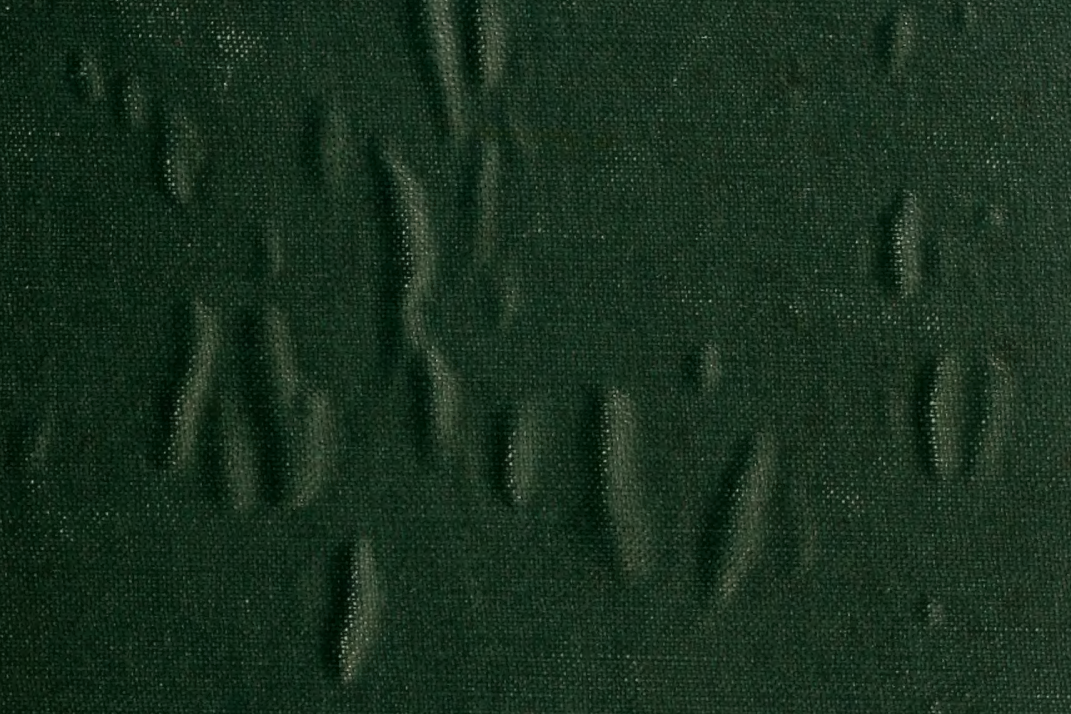

4. 








\section{THE ELASMOBRANCH FISHES}



$6 \mathrm{GlC} 2$ $10 \times 1006 \mathrm{He}$ $\sin \alpha+2$ Lue Lis a s nV E) 
ELASMOBRANCH FISHES
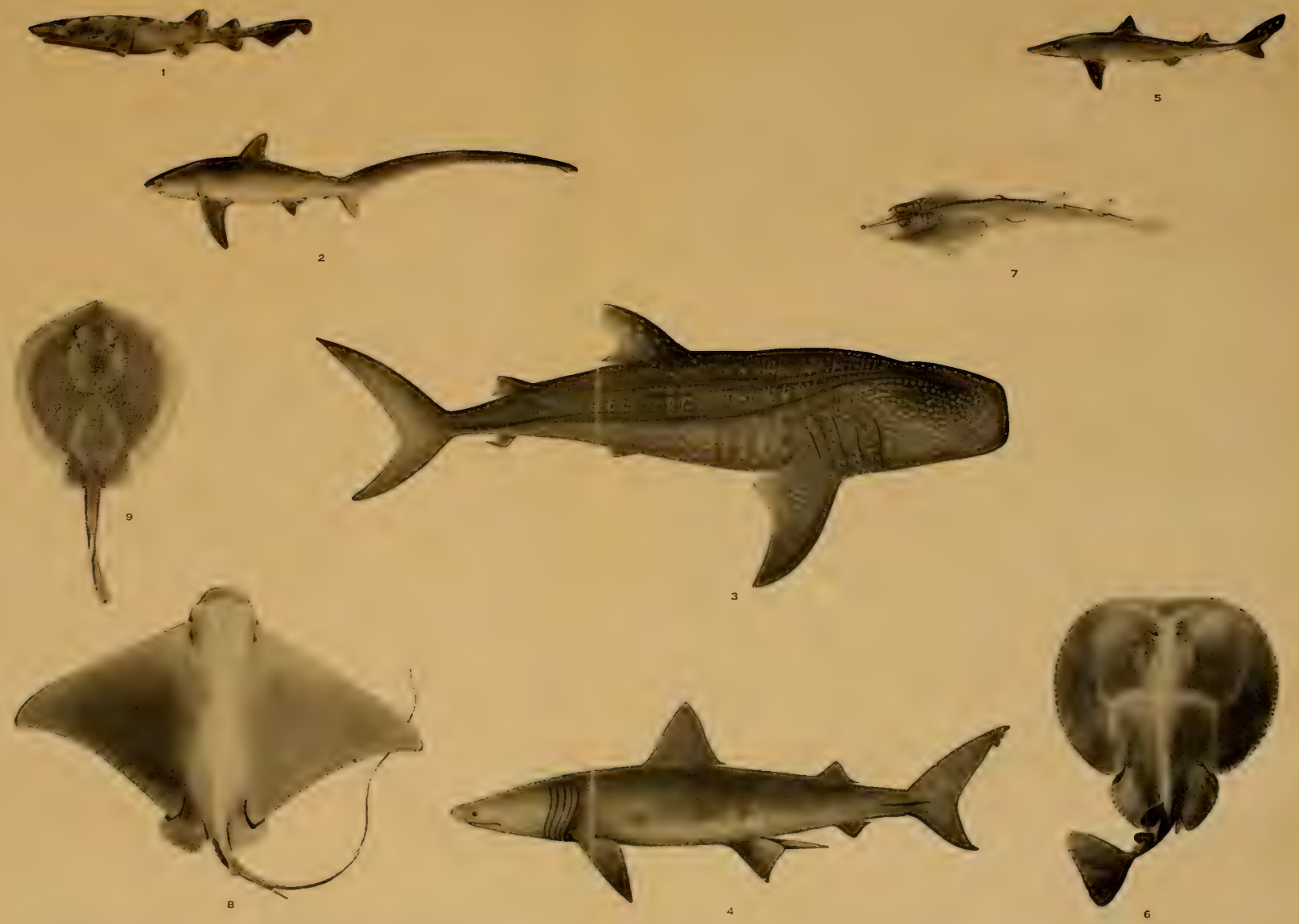

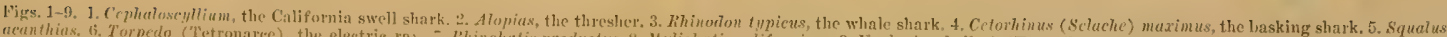

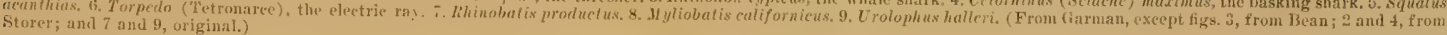




\title{
THE ELASMOBRANCH FISHES
}

\author{
BY \\ J. FRANK DANIEL \\ Professor of Zoology in the University of California
}

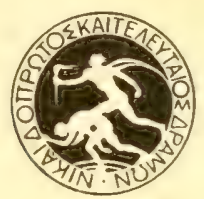

UNIVERSITY OF CALIFORNIA PRESS BERKFLEY, CALIFORNIA I 934 
First Edition Issued June, 1922

SECONd Edition Issued ApriL, 1928

Third, Revised, Edition Issued March, 1934

COPYRIGHT, 1922 AND 1928

$\mathrm{BY}$

J. FRANK DANIEL

COPYRIGHT, 1934

BY THE

REGENTS OF THE UNIVERSITY OF CALIFORNIA

SALES REPRESENTATIVES

University of California Press

Berkeley, California

Cambridge University Press

London, England

For orders originating in Great Britain only 


\section{PREFACE TO FIRST EDITION}

The Elandonancin Fisues are, I believe, unsurpassed as material on which to study the fundamental plan of the vertebrate body. 'The ease with which a large, cartilaginous form may be dissected makes a study of its systems of organs a relatively simple matter, and the comparative simplicity of most of the sistems shows that at least some of the present-day Elasmohranchs olosely approximate the early vertebrates.

The importance of the shark as a type for classroom study has, I think, not been generally appreciated in this country. This has been due in part to the difficulty of obtaining specimens in centers removed from the seaboard; in part, it has been due to the paucity of available literature. This I say in face of the fact that an abundant literature in practically all languages exists. I have attempted to remedy this latter difficulty by adding to each chapter a working bibliography.

In my studies of the Elasmobranchs I have been fortunate in having at hand perhaps the most generalized of these fishes. Heptumchus maculatus. In addition to a study of the systems of organs in this and in other forms, I have attempted to collect and unify the work done by many workers on the various types. These combined studies I present with the hope that they will serve as a guide for undergraduate students of college grade, and at the same time be sufficiently inclusive to be used as a book of reference on the entire subject.

I am inclebted to the seripps Institution for Biological Research for liberal support during five summers at La . Jolla, and to the Research Board of the Cniversity of California for a grant in the final finishing of the plates. I am further indebted to many students who have helped me. Anong them I single out Duncan Dumning, who, as a sophomore and junior student, made many of the most important drawings in the book.

J. Frank Daniel

Berkelet, California,

January 16, 1922. 


\section{PREFACE TO SECOND EDITION}

IN THE SECOND EDITION of the Elasmobranch Fishes I have followed the same plan as in the first, but I have added subject-matter and illustration which should make this edition somewhat more complete. Especially is this true for the chapter on the blood system to which has been added the work of Keys on the hypobranchial arteries of Hexanchus. The findings on Hexanchus supplement and add to my work on Heptanchus and make it more certain that the blood supply to the pectoral area in primitive vertebrates was from the hypobranchial system, rather than from the dorsal aorta (the subclavians) as is true for higher vertebrates. I have also included in this edition Professor Van Wijhe's discovery that the thymus gland in the embryo of Heptanchus cinereus is not ductless, and I have added experimental evidence to show that the cutaneous vessels in Elasmobranchs are true blood-vessels.

Berkeley, California,

J. FranK DANIEL

February 24, 1928.

\section{PREFACE TO THIRD EDITION}

AxIONg THE CONTRIBUtions ADDED to the third edition of Elasmobranch Fishes is the work of Marine on the transformation of the endostyle of Ammocoetes into the thyroid gland of the adult Cyclostome. Other contributions made since the publication of the second edition are on the lymphatic system by Hoyer, on the external carotid artery by O'Donoghue, and on the ampullae of Lorenzini by Dotteryeich.

O'Donoghue has shown that the external carotid in Elasmobranchs, as in higher types, belongs to the lower jaw, and that the artery in the orbit previously designated as the extemal carotid or posterior carotid is, in fact, comparable to the stapedial artery of mammals. Through this work we now have a complete history of the external carotid artery from sharks to man.

Dotterweich has shown that the wall of an ampulla of Lorenzini is made up of two types of cells. One of these, a large goblet or gland cell, pours its secretion into the ampulla; the other type is pyramidal and has an inside hexagonal face which is sensory in nature. An efferent nerve supplies the gland cell, and an afferent nerve leaves each of the sensory cells. 


\section{CONTENTS}

Introduction

\section{EXTERNAL FORM}

External Form of Heptanchus maculatus .

External Form of Elasmobranchs in General

Transitional series

External form in its development $\ldots .10$

Form and position of adult fins _ . . . . . 12

External form of fin and its bearing on function . . . . . . . . . . . . 12

Form of fin in its beginning . . . . . . . . . . . . . . . . . 14

Bibliography

\section{INTEGUMENT}

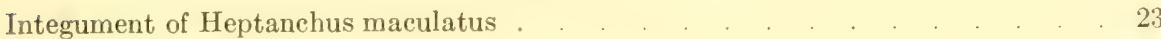

Modified scales _. _ _ _ _ . . . 25

Integument of Elasmobranchs in General . . . . . . . . . . . . . 26

Gland cells

Glands of claspers _. _ _ _ _ . . . . . . 28

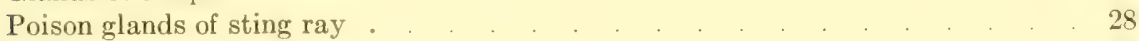

Light organs . _ _ _ _ _ . . . . . . . . . . . 2 29

Placoid scales . . . . . . . . . . . . . . . . 30

Finer anatomy of scale _. . . . . . . . . . . . . . . . . 32

Modification of scales _. . . . . . . . . . . . . . 33

Fin spine . . . . . . . . . . . . . . . . . . . . . . 33

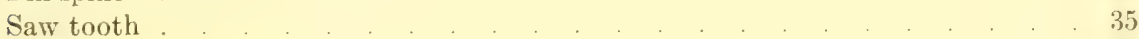

Sting . . . . . . . . . . . . . . 35

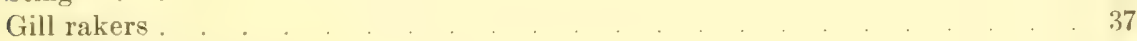

Stomodeal denticles . _ _ . . . . . . . . . . . . . . . . . . . 38

Teeth as modified scales _. . . . . . . . . . . . . . . . . 38

Bibliography _. . . . . . . . . . . . . . . . 39

III. ENDOSKELETON

Endoskeleton of Heptanchus maculatus . . . . . . . . . . . . 43

Axial skeleton . . . . . . . . . . . . . . 43

Skull . . . . . . . . . . . . 4 43

Visceral skeleton _. _ _ _ . . . . . . . . . . 4 44

Spinal column _. . . . . . . . . . . . . . 47

Appendicular skeleton . . . . . . . . . . . . . . . . . . . 49

Skeleton of paired fins . . . . . . . . . 50

Skeleton of unpaired fins . . . . . . . . . . . . . . . . . 51

Dorsal fin . . . . . . . . . . . . . . 51 51

Caudal fin . . . . . . . . . . . . . . . . . 51

Anal fin . . . . . . . . . . . . . . . . . 52

Endoskeleton of Elasmobranchs in General . . . . . . . . . . . . 53

Axial skeleton . . . . . . . . . . . . . 53

Skull _. . . . . . . . . . . . . . . 53

Cranium . . . . . . . . . . . . . . 53

Visceral skeleton —. . 62

Extravisceral arches . . . . . . . . . . . . . . . . . 67

Spinal column . . . . . . . . . . . . . . . . . 69 
Appendicular skeleton . . . . . . . . . . . . . . . . . . . 75

Skeleton of paired fins and of fin girdles . . . . . . . . . . . . . . 75

Pectoral fin skeleton . . . . . . . . . . . . . 75

Pectoral girdle . . . . . . . . . . . . . . . . . . . 79

Pelvic fin skeleton . . . . . . . . . . . . . . . . . . . . 81

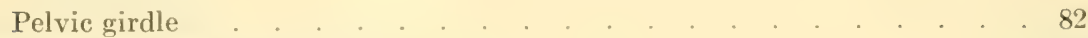

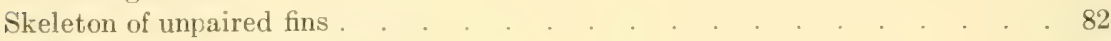

Bibliography . . . . . . . . . . . . . . . . . . . . . 84

IV. MUSCULATURE

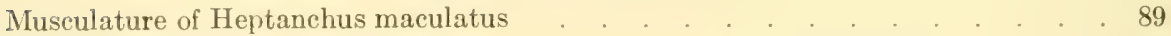

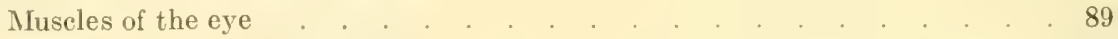

Buccal and pharyngeal muscles . . . . . . . . . . . . . . . . 90

Dorsal constrictors . . . . . . . . . . . . . . . . . 90

Tentral constrictors _. . . . . . . . . . . . . . . . . . . . 91

Interarcuales _ . . . . . . . . . . . . . . . . . . . 9 92

Adductors . . . . . . . . . . . . . . . . . . . . 9 93

Ventral longitudinal muscles . . . . . . . . . . . . . . . . . . . . 93

Muscles of the fins . . . . . . . . . . . . . . . . . . 94 94

Musculature of Elasmobranchs in General _ . . . . . . . . . . . . . 96

Muscles of the eye . . . . . . . . . . . . . . . . . . . . . . . . . . 99

Muscles of visceral arches . . . . . . . . . . . . . . . . . . . . . . 100

Superficial constrictors of pharynx . . . . . . . . . . . . . . . . 101

Dorsal constrictors . . . . . . . . . . . . . . 102

Ventral constrictors . . . . . . . . . . . . . . . . 104

Deeper muscles of pharynx . . . . . . . . . . . . . . . . . . . . . 105

Interarcuales _ _ _ . . . . . . . . . . . . . 106

Adductores arcus . . . . . . . . . . . . . . . . . . . . . 107

Hypobranchial musculature . . . . . . . . . . . . . . . . 108

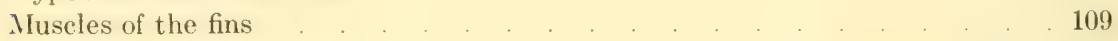

Muscles of the claspers . . . . . . . . . . . . . . . . . . 110

Electric Organ in Elasmobranchs . . . . . . . . . . . . . . . 112

Electric organ of rays . . . . . . . . . . . . . . . . . . . . . . . . 112

Finer anatomy of electric organ . . . . . . . . . . . . . . . . . 114

Bibliography . . . . . . . . . . . . . . . . . . 117

\section{DIGESTIVE TRACT}

Digestive Tract of Heptanchus maculatus _ . . . . . . . . . . . . 121

Mesenterial structures . . . . . . . . . . . . . . . . . . 121

Buccal cavity . . . . . . . . . . . . . . . . . . . . . . . . . . . . 121

Pharynx and associated structures . . . . . . . . . . . . . . . . 122

Oesophagus . . . . . . . . . . . . . . . . . . . . . . 123

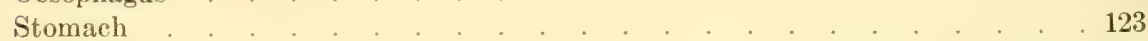

Spleen . . . . . . . . . . . . . . . . . . . . . . . . . . . . . . . . . . . . . . . . . . . 124

Duodenum or middle intestine _. . . . . . . . . . . . . . . . . . . 124

Valvular intestine . . . . . . . . . . . . . . . . . . . . 124

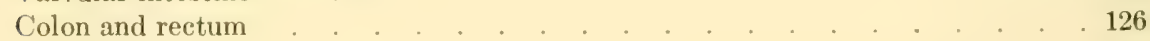

Rectal gland . . . . . . . . . . . . . . . . . . . . . . . . . . . . . . . . . . . . . . . 126

Cloaca . . . . . . . . . . . . . . . . . 126

Abdominal pores (Pori abdominales) . . . . . . . . . . . . . . . . . 126

Digestive Tract of Elasmobranchs in General _ . . . . . . . . . . . . . 127

Mesenteries _. . . . . . . . . . . . . . . . . 127

Buccal cavity . . . . . . . . . . . . . . . . . . . . . . . . . . . . . . . . . . . . . . . . . . . . . . . . . . . .

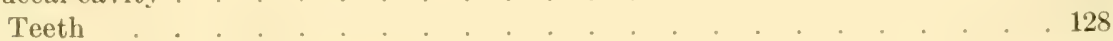

Replacement of teeth . . . . . . . . . . . . . . . . . 131 
Digestive Tract of Elasmobranchs in General-Continued I'I1,t:

Pharynx . . . . . . . . . . . . . . . . 131

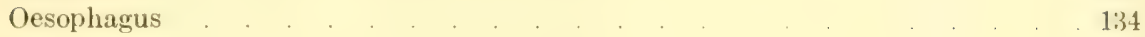

Stomach . . . . . . . . . . . . . . . . . . . . . . . . . . . .

Duodenum or middle intestine _ . . . . . . . . . . . . . 136

Liver . . . . . . . . . . . . . . . . . . . . 137

Pancreas . . . . . . . . . . . . . . . . . . . . . . . . . . . . . . . .

Spleen . . . . . . . . . . . . . . . . . . . . . . . . . . . .

Valvular intestine . . . . . . . . . . . . . . . . . . 139

Colon and rectum _. . . . . . . . . . . . . . . . . . 141

Cloaca . . . . . . . . . . . . . . . . . . . . 141

Abdominal pores . . . . . . . . . . . . . . . . . . . . . . 142

Bibliography . . . . . . . . . . . . . . . . . . . . 143

VI. RESPIRATORY TRACT

Respiratory Tract of Heptanchus maculatus . . . . . . . . . . . 147

Gill pouch or pocket _. . . . . . . . . . . . . . . . . . 147

Spiracle . . . . . . . . . . . 147

Gill or holobranch . . . . . . . . . . . . . 148

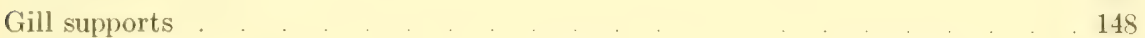

Gill filaments . . . . . . . . . . . . . . . . . . . . . . . 149

Respiratory Tract of Elasmobranchs in General _ . . . . . . . . . 150

Gill pouch or pocket . . . . . . . . . . . . . . . . . 150

Production of respiratory current . . . . . . . . . . . . . 155

Direction of respiratory current . . . . . . . . . . . . . . 156

Circulation of blood in filaments . . . . . . . . . . . . . . . . 157

Respiration or the exchange of gases . . . . . . . . . . . . . . . . 157

Bibliography . . . . . . . . . . . . . . . . . . . . 158

VII. CIRCULATORY SYSTEM

Circulatory System of Heptanchus maculatus _ . . . . . . . . . . 160

Arteries . . . . . . . . . . . . . . . . . . . . . . 161

Ventral aorta . . . . . . . . . . . . . . . . . . . . 161

Afferent arteries of the adult _ . . . . . . . . . . . . . . . 161

Efferent-collectors _. . . . . . . . . . . . . 161

Branches of the efferent-collectors . . . . . . . . . . . 162

Hypobranchial arteries _ . . . . . . . . . . . . . . . . 162

Efferent arteries . . . . . . . . . . . . . . . . . . . . . 16.5

Dorsal aorta . . . . . . . . . . . . . . . . . . . . . . . . . . . . . . . . .

Arterial supply to digestive tract . . . . . . . . . . . . . 166

Coeliac axis and its branches . . . . . . . . . . . . . . . 166

Superior (anterior) mesenteric and its branches _ . _ _ . . . _ . . . 167

Inferior (posterior) mesenteric artery _ _ _ _ _ _ _ _ . . . . . 167

Arterial supply to extremities . . . . . . . . . . . . . . . . 168

Arterial supply to deeper structures _ . . . . . . . . . . . . . 169

Caudal aorta . . . . . . . . . . . . . . . . . . . . . . . . 169

Circulatory System of Elasmobranchs in General _ . . . . . . . . . 170

Heart . . . . . . . . . . . . . . . . . . . 170

Arteries . . . . . . . . . . . . . . . . . . . . . . . 172

Ventral or ascending aorta _ _ . . . . . . . . . . . . . . . . 172

Afferent arteries of adult _. . . . . . . . . . . . . . . . . . . 172

Capillaries . . . . . . . . . . . . . . . . . . . 173

Efferent-collectors . . . . . . . . . . . . . . . . . . 17:3

Branches of efferent-collectors . . . . . . . . . . . . . . . . 178

Hypobranchial arteries . . . . . . . . . . . . . . . . . . . 178

Arterial supply to head _. . . . . . . . . . . . . . . . . 180

Efferent arteries . . . . . . . . . . . . . . . . . . . 182 
Circulatory System of Elasmobranchs in General-Continued page

Arterial supply to trunk _ _ _ _ _ _ . . . . . . 186

Dorsal aorta _. . . . . . . . . . . . . . . . 186

Unpaired arteries . . . . . . . . . . . . . . . . . . . 186

Coeliac axis and its branches . . . . . . . . . . . . 186

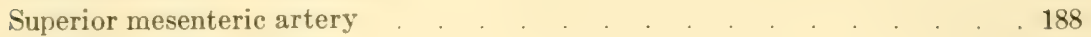

Inferior mesenteric artery _. . . . . . . . . . . . . . . 190

Paired branches of aorta _ _ . . . . . . . . . . . . . . . 191

Subclavians and iliaes . . . . . . . . . . . . . . . . 191

Segmentals _. . . . . . . . . . . 192

Caudal segmentals . . . . . . . . . . . . . . . . . . 193

Bibliography . . . . . . . . . . . . . . 195

\section{CIRCULATORY SYSTEM (Continued)}

Circulatory System of Heptanchus maculatus _ . . . . . . . . . . . 198

Veins . . . . . . . . . . . . . 198

Veins of head . . . . . . . . . . . . . . . . . . . 198

Veins of tail . . . . . . . . . . . . . . . . . . . . . 199

Veins from kidney or mesonephros _ . . . . . . . . . . . . . 200

Veins from digestive tract _. . . . . . . . . . . . . . . . . 200

Veins of body wall _. _ . . . . . . . . . . . . . . 202

Veins of skin . . . . . . . . . . . . . . . . 202

Circulatory System of Elasmobranchs in General . . . . . . . . . . . 204

Veins . . . . . . . . . . . . 204

Anterior cardinal system _. . . . . . . . . . . . . . . . 204

Renal portal system . . _ . . . . . . . . . . . . 208

Posterior cardinal veins . . . . . . . . . . . . . . . . . . 209

Hepatic portal system . . . . . . . . . . . . . . . . . . 210

Development of hepatic portal system _. . . . . . . . . . . . 212

Lateral abdominal system of veins _. . . . . . . . . . . . . . 213

Veins of heart . . . . . . . . . . . . . . . . 2 215

Cutaneous system of veins . . . . . . . . . . . . . . . . . . 216

Nature of cutaneous system of vessels . . . . . . . . . . . . . . . 217

Lymphatic vessels . . . . . . . . . . . . . . . . 2 218

Bibliography . . . . . . . . . . . . . . . 219

\section{NERVOUS SYSTEM}

Nervous System of Heptanchus maculatus _ _ . . . . . . . . . . . 221

Central nervous system _. . . . . . . . . . . . . . . . . . 221

Brain . . . . . . . . . . . . . 221

Spinal cord . . . . . . . . . . . . . . . . . . . 222

Peripheral nervous system . . . . . . . . . . . . . . . . . . . . 222

Cranial nerves . . . . . . . . . . . . . . . . . . . 223

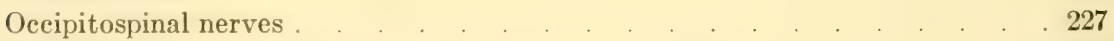

Spinal nerves _. . . . . . . . . . . . . . . . . 227

Nervous System of Elasmobranchs in General . . . . . . . . . . . . 229

Development of central nervous system _ . . . . . . . . . . . . 230

Gross form of brain . . . . . . . . . . . . . 230

Internal view of brain _ _ _ _ . . . . . . . . . . . . . 235

Spinal cord . . . . . . . . . . . . . . . . . 237

Peripheral nervous system . . . . . . . . . . . . . . . . . . 2 238

Cranial nerves . . . . . . . . . . . . . . . . . . . . 238

Spinal nerves . . . . . . . . . . . . . . . . . . . . . 246

Sympathetic or autonomic nervous system _ _ _ . . . . . . . . 247

Bibliography _. . . . . . . . . . . . . . . . 249 
Special Senses of Heptanchus maculatus

Eye .

Ear

Innervation _ . . . . . . . . . . . . . . 261 261

Sensory canal system . . . . . . . . . . . . . . . . . . 261

Special Senses of Elasmobranchs in General _ . . . . . . . . 264

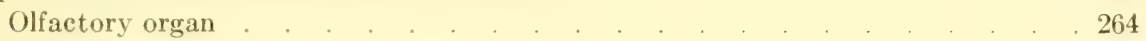

Development of olfactory organ _ . . . . . . . . . 265

Gustatory or taste organs . . . . . . . . . . . . . . . . . . . 265

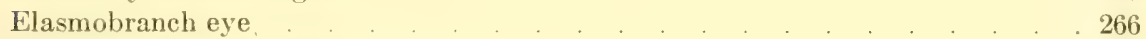

Structure of adult eye . . . . . . . . . . . . . . . . . 267

Finer structure of retina . . . . . . . . . . . . . . . 268

Development of eye . . . . . . . . . . . . . . . . 269

Accommodation apparatus . . . . . . . . . . . . . . . . . . . . . . . 269

Auditory organ . . . . . . . . . . . . . . . . . 271

Innervation of ear . . . . . . . . . . . . . . . . . . 273

Development of ear . . . . . . . . . . . . . . . . . 274

Sensory canal system and ampullary and pit organs . . . . . . . . . . . . 274

Sensory canal system . . . . . . . . . . . . . . . . . . . 274

Function of sensory canal system . . . . . . . . . . . . . 2 279

Ampullary organs . . . . . . . . . . . . . . . . . . . . 279

Pit organs . . . . . . . . . . . . . . . . . . . . . . . 281

Bibliography . . . . . . . . . . . . . . . . . . . . . . 283

XI. UROGENITAL SYSTEM

Urogenital System of Heptanchus maculatus _ . . . . . . . . . . 287

Urinary system . . . . . . . . . . . . . . . . . . 287

Genital system . . . . . . . . . . . . . . . . . . 290 290

Urogenital System of Elasmobranchs in General _ . . . . . . . . . 292

Urinary system . . . . . . . . . . . . . . . . . . 292

Kidney (Mesonephros) _ _ _ . . . . . . . . . . . . . . . . 292

Ducts of kidney . . . . . . . . . . . . . . . . 294

Finer anatomy of kidney _. . . . . . . . . . . . . . . . 296 296

Nephrostome and segmental duct . . . . . . . . . . . . . 296 296

Development of nephrostome and segmental duct . . . . . . . . . . 298

Bowman's capsules . . . . . . . . . . . . . . . . 299

Genital system . . . . . . . . . . . . . . . . 300

Genital organs of male $\quad . \quad 300$

Testes . . . . . . . . . . . . . . 300

Finer anatomy of testis . . . . . . . . . . . . . . . . 301

Vasa efferentia. . . . . . . . . . . . . . . . . 301

Genital organs of female . . . . . . . . . . . . . . . . . 303

Ovaries . . . . . . . . . . . . . . . . . . . . . . . . . . . . . . . . . . . 303

Oviducts . . . . . . . . . . . . . . . . . . . . . . . . . . . . . . 304

Shell glands . . . . . . . . . . . . . . . . . . . 304

Types of egg shells . . . . . . . . . . . . . . . . 305

Uterus . . . . . . . . . . . . . . . . . . . . . . . . . . . . . . 306

Relation of uterus to embryo . . . . . . . . . . . . . . . 307

Secondary sexual characters . . . . . . . . . . . . . . . . . 309

Bibliography . . . . . . . . . . . . . . . . . . . . . . 311

Index . . . . . . . . . . . . . . . . . . . . . . 319 



\section{INTRODUCTION}

$\mathrm{T}$

YHERE LIVES today a vast group of fishes, some of which are littoral, keeping close to shore; others are the nomads of the ocean, roaming vast expanses of its waters; others there are which are pelagic, living near its surface; and still others that are the inhabitants of the profound depths into which sunlight never penetrates - these are the sharks, to the man with nets the most worthless, to the naturalist among the most interesting of living things.

But the vast numbers of today are few in comparison with the hordes which have lived and passed in succession before them. They, the rulers of the waters in bygone ages, have gone down like primitive man, leaving little to tell of their presence. This little, however, is of singular interest. Some of these fishes are known to us only by a spine. Others are represented by bits of armament which show that many of the ancient sharks were clad in a protective covering far more complex than that possessed by any of the living forms. But most of these fishes are known to us by their teeth; of these, the heterodont sharks are most instructive.

Before me are the teeth of a form which swam the primitive seas before the formation of our western mountains. Beside them I place the teeth of another which was taken with hook and line in the Pacific but yesterday. The vast stretch of years separating the life of the one from the life of the other is beyond the comprehension of man, yet the close similarity of plan binding the one form to the other clearly indicates that this of the present is that of the past projected through the ages.

Not upon fragments alone does our information concerning these ancient fishes rest. Within the past few decades our knowledge has been greatly enriched by the discovery of specimens, many parts of which were in an almost perfect state of preservation. This preservation is the more wonderful when it is recalled that even the harder cartilaginous parts are subject to rapid decay. That some of these specimens have escaped the ravages of time makes us hopeful that others of still more archaic forms will yet be unearthed, to complete our records of the ancient history of this group.

Of the extinct types discovered in an excellent state of preservation, Cladoselachus (fig. 10), described by Dean, is one of the oldest and in many ways one of the most generalized and interesting of fishes. From it we have learned much; for even to detail, soft parts like muscle fibers and, in some specimens, visceral organs have been obtained in a remarkable state of preservation. Two other forms, Acanthodes and Pleuracanthus, are of special interest. In an acanthodian type like Climatius(?) (fig. 11) spines have been developed to an unusual degree so that even in the paired fins the fin is composed essentially of web and anterior supporting spine. In this type the spine is essentially a dermal structure encasing the exposed margin of the fins. In other regions of the body the seales show the same tendency toward hypertrophy. Thus around the eye and along the lateral line they are of unusual size. In Pleuracanthus, 
there are many of the present-day characteristies peculiar to the sharks. In addition, by the structure of its limbs and tail, it suggests relationship to the interesting group of Dipnoans or lungfishes.

Equally as interesting as the extinct forms preserved to us in the rocks are others, less ancient though they be, which have come down to us in flesh and blood. Of these living representatives of the past some are among the most

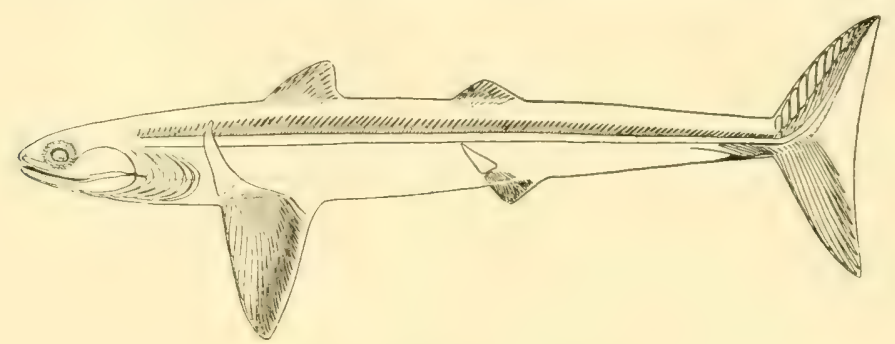

Fig. 10. Cladoselachus. (From Dean.)

interesting and instructive of forms, interesting as antiquities are interesting, instructive as all generalizations are instructive. Among these forms known to us on the California coast are Heterodontus francisci (fig. 17), whose genus is the sole survivor of a group, twenty-five genera of which are buried in the rocks; and Hexanchus corinus and Heptanchus maculatus (fig. 13), the latter

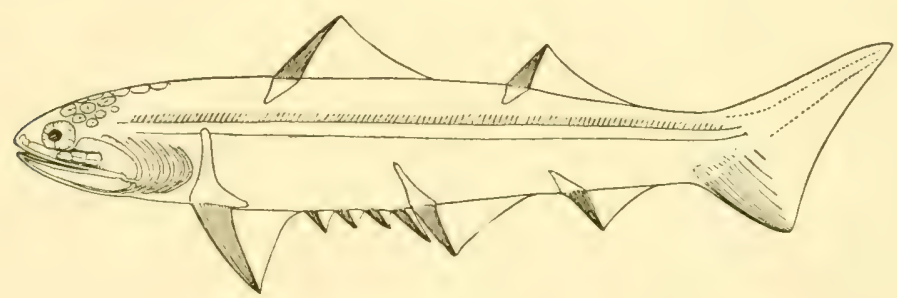

Fig. 11. Climatius(?). (From Dean.)

with generalization of bodily plan surpassing that of any other present-day Elasmobranch.

In addition to the ancient types there are many modern forms. Some of them, like Acanthias (fig. 5, Squalus acanthias), have system upon system so generalized as to approximate a ground plan on which nature has built up its masterpieces of vertebrate life. Other forms, although simple in part, are noted for extreme specialization in certain respects. Among these may be mentioned Cephaloscyllium, the California swell shark (fig. 1), Zygaena, the hammer-head common to many seas, and Alopias, the thresher, a single genus of world-wide distribution (fig. 2).

Still others of the recent sharks, although exceeding Zygaena and Alopias but slightly in size, are singled out as large sharks. Of this group the forms known to occur on the Pacific Coast are Carcharias (Prionace), the "man- 
eater," or great blue shark (fig. 16), and Cetorhinus, the basking shark (fig.4), which not infrequently exceeds twenty-five feet in length. Finally, as an oceasional visitor up this coast may be added the giant of all fishes, Rhinodon typicus (fig. 3), specimens of which have been known to reach fifty feet in length.

To the above recent Elasmobranchs may be added the flattened sharks or rays. Some of the most singular of these are Pristis the sawfish (fig. 19) with nose prolonged into a two-edged saw, and Myliobatis the batfish (fig. 8); Torpedo the electric ray (fig. 6) provided with a powerful battery by means of which shocks of electricity may be administered to food or enemy alike; and lastly, Cephaloptera, the giant of the ray tribe, growing in tropical seas to more than a thousand pounds in weight and sometimes having a measurement from tip to tip of pectorals exceeding twenty feet.

Of the whole group of Elasmobranchs possibly none is of more interest than the remaining notidanid sharks (Heptanchus and Hexanchus). Because of the generalization found in these forms I propose in the following diseussion of the Elasmobranch fishes to use Heptanchus maculatus* (fig. 13) as a type with which to compare in general other Elasmobranchs.

* This shark is variously known as Notorhynehus maculatus Ayres (1855), Heptanchus maculatus Girard (1858), or Heptranchias maculatus Gill (1861). After making a detailed study of this form and noting the marked differences between it and Heptanchus cinereus I am almost persuaded that it merits the generic position aseribed to it by Ayers. Because of the simple meaning of the word Heptanchus, however, and regardless of whether the etymology of the word is or is not correet, I have retained the name given by Girard. 


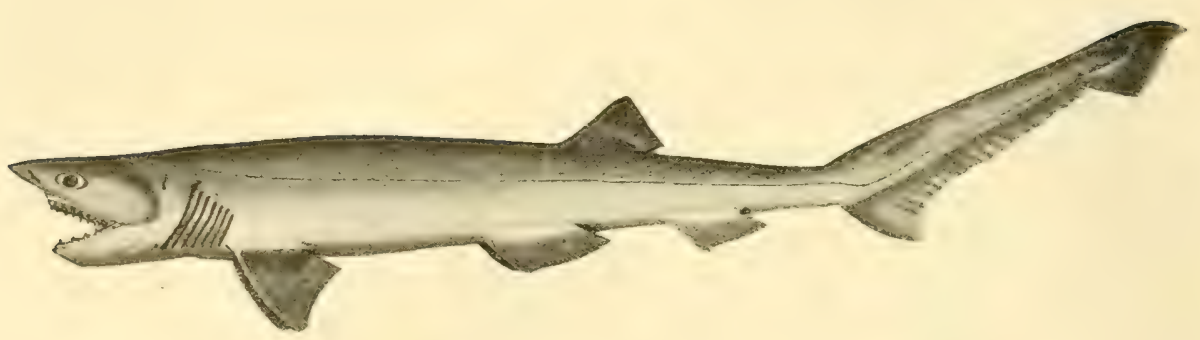

Fig. 12

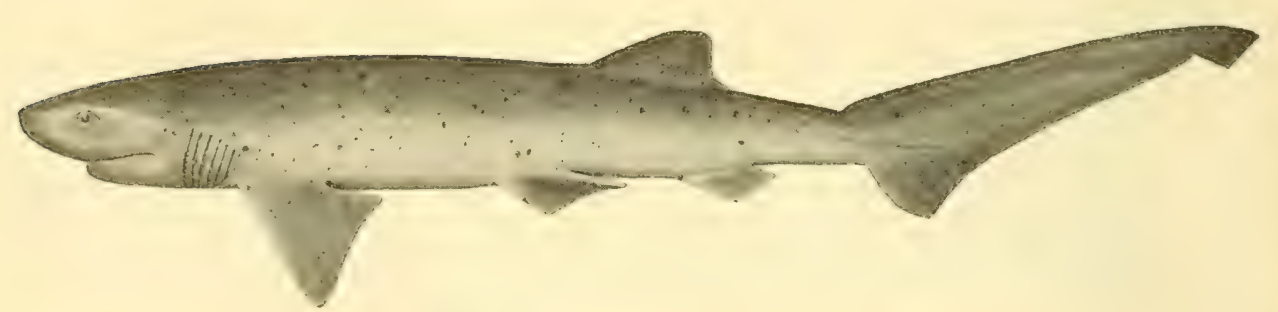

Fig. 13

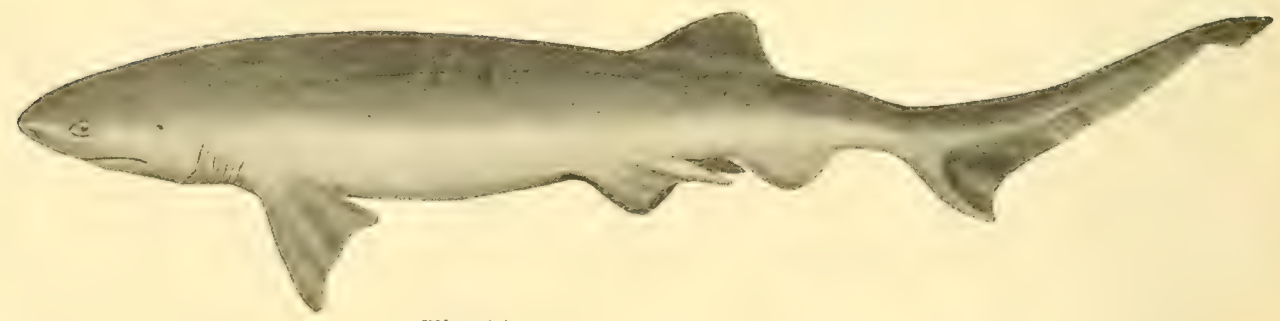

Fig. 14

Fig. 12. Heptanchus cinereus. (From Fitzinger.)

Fig. 13. Heptanchus maculatus. (C. G. Potter, del.)

Fig. 14. Heptanchus indicus. (From Macdonald and Barron.) 


\section{EXTERNAT FORM}

\section{EXTERNAL FORMI OF HEPTANCHUS MACULATUS}

Heptanchus maculatus (fig. 13), in general shape, lacks the grace characteristic of many of the more active and predacious sharks. 'This is due in part to a relatively heavy head; in part it results from the unusual dimensions of the tail. In these features all heptanchid sharks (figs. 12 to 14) are similar. In Hexanchus, a close relative of Heptanchus, the body is still more ungainly. This is readily apparent when a specimen is brought to shore, for on land the body and head are so heavy that they flatten out and become distorted. Notwithstanding this lack of grace in the heptanchid sharks, I agree with Dean (1895) that "Heptanchus, of all living sharks, inherits possibly to the greatest extent the features of its remote ancestors."

The most superficial feature by which Heptanchus may be recognized is the number of its gill clefts ( $c l$., fig. 15). In fact it was from this characteristic that Heptanchus received its name. ${ }^{1}$ Anteriorly the clefts are of large size, but posteriorly they decrease so that the last, which lies just in front of the peetoral fin, is about half the height of the first. Anterior to the first cleft and somewhat dorsally is the modified cleft or spiracle (sp., fig. 15) which in the adult is relatively diminutive in size.

Other superficial characteristies helpful in distinguishing Heptanchus from most other sharks are the position of the nasal apertures and the shape of the mouth. The nasal apertures are more nearly terminal than is usual in the Elasmobranchs. They appear on the broad snout as relatively small crescents, each of which is separated into a dorsal and a ventral part by an overlapping median flap. This flap in fact forms of the nasal cup a tube which provides a passageway for the water current over the olfactory organ. The mouth is of unusual size (figs. 15 and 119). In side view it appears as a deep horizontal slit extending back as far as the segment of the spiracle, and hence cleaving the anterior region almost into dorsal and ventral halves. From this type of eleavage there results an exceptionally heavy lower jaw which gives to this form much of its grotesque appearance.

At the side of the head is the eye, which has an orbit of relatively long horizontal axis. The eye is shielded by an upper and a lower membranous lid, but it is unprovided with the so-called nictitating membrane or third eyelid characteristic of some of the Elasmobranchs.

This shark also possesses, in common with other Elasmobranchs, the small apertures of the endolymphatic ducts which lead to the ear (see p. 42, fig. 45, e.d.). These apertures are near the middorsal line and slightly in front of a plane taken through the spiracles.

\footnotetext{
$1 \dot{\epsilon} \pi \tau \alpha$, seven; $\ddot{\alpha} \gamma \chi \omega$, with reference to compressed gill clefts.
} 
The paired fins of Heptanchus partake slightly of the enlargement characteristic of the forward part of the body; the pectorals (pt., fig. 15) are large, but the pelvies (ventrals, $p l$.) are much smaller. When considered in relation to other parts of the body the pectoral and pelvic fins appear close together but the distance between the two is considerable, the pelvic girdle being in the region of the fortieth spinal segment. The inner margin of each pelvic fin of the male is modified into a clasper, which extends backward (fig. 1t). The claspers, however, in the immature Heptanchus maculatus (see p. 288, fig. $251 \mathrm{~B}$, cls.) are small and inconspicuous. Between the inner margins of the pelvic fins and back of their bases is the cloacal opening through which products of excretion as well as the sex cells leave the body.

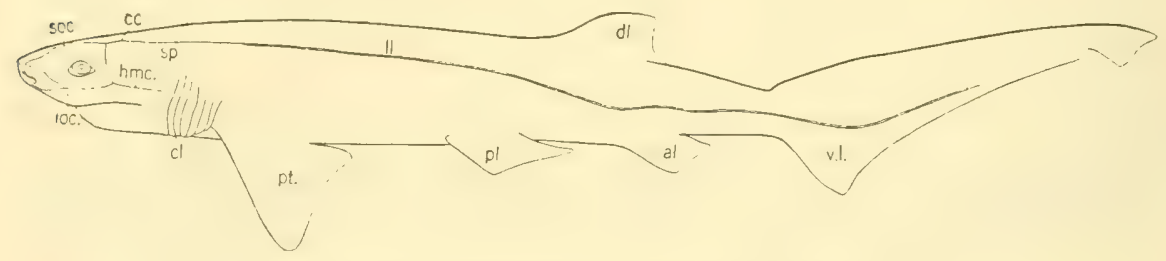

Fig. 15. Lateral view, Heptanchus maculatus.

$a l$. anal fin ; $c c$. , supracranial canal ; $c l$. , branchial clefts; $d l$, dorsal fin; $h m c$. , hyomandibular canal; ioc., infraorbital canal; $l l$., lateral line; $p l$., pelvic fin; pt., pectoral fin; soc., supraorbital canal; sp., spiracle; v.l., ventral lobe of caudal fin.

One of the most marked characteristies of Heptanchus is a single, unpaired dorsal fin ( $d l$., fig. 15). It is from this shapely fin that we get the term notidanus ( $\nu \hat{\omega} \tau o \nu$, the back; isavos, comely). The notidanids include both the heptanchid and hexanchid sharks. So far as this character is concerned it applies equally as well to Chlamydoselachus.

In Heptanchus this dorsal fin lies above and slightly back of the pelvies, having a position as far posterior as that oceupied by the second dorsal of many Elasmobranchs. The immense size of the caudal fin is due to the unusual extent of its lobes and to the width of the ventral lobe (v.l., fig. 15). In the ventral lobe the anterior dermal fin rays are especially well developed. These fin rays are followed by a shorter series back to a notch near the terminus of the lobe, behind which the dermal rays are again longer and extend in an almost horizontal direction to the tip of the tail. Between the ventral lobe and the cloacal opening is the smaller anal fin $(a l$.$) .$

The ground plan of coloration in Heptanchus maculatus (fig. 13) is an almost uniform drab above and light below. Scattered over the drab backoround is a motley pattern of spots from which comes the specific name, maculatus, spotted. These spots extend over the dorsal side of the paired fins and to the unpaired fins, and vary in size from minute dots to elumps of pigment larger than the pupil of the eye. Over the dorsal region of the body, where the pigment is most dense, they are less conspicuous; as growth proceeds many of them become hidden in the general color pattern. 
Overlying the coat of drab and the pattern of dots there is, in an adult, an armament of denticles, the so-called placoid scales, myriads of which go to make up the protective shagreen exoskeleton (see p.24, fig.27). 'This armament in the adult Heptanchus is made up of a vast number of closely set seales, many of which are more or less spade-shaped. In the more exposed parts of the body, however, which are subject to great wear, the scales often become modified and plate-like.

Another characteristic made out in external view is the lateral line $(l l$, fig. 15). In Heptanchus, this line is an open groove extending from the end of the tail along the side of the body to the pharyngeal region. This groove is connected with certain canals of the head, which, as closed tubes, are located deeper in the integument. Branching from the canals are small chimney-like tubes which retain connection with the surface by pores.

In the walls of this system of grooves and canals are groups of sense organs which we shall consider more fully in Chapter X.

In addition to these lines of pores there are other aggregates of pores (for example, p. 260, fig. $227 \mathrm{~A}$, soa.) in the region of the head, and pits which are located along the dorsal and anterior parts of the trunk. Each of these pores is the entrance to a tube which leads to an enlargement or ampulla of Lorenzini. The tubes are filled with a jelly-like mucus which, if pressure be put on the skin, may be made to exude from the pores. It is from this content that the pores of the ampullae of Lorenzini and those of the canal system are known as mucous pores. 


\section{EXTERNAL FORM OF ELASMOBRANCHS IN GENERAL}

A comparison of the adult in two types like Acanthias, the spiny dogfish, and Crolophus, the small sting ray (figs. 5 and 9), shows the two extremes of body form to which the Elasmobranch fishes have diverged. In Acanthias, which is beautifully adapted for cleaving the water in the running down and capture

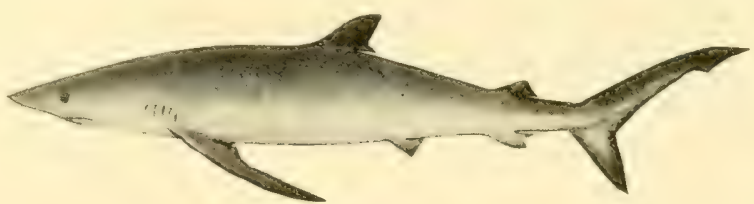

Fig. 16. Carcharias glaucus. (From Garman.)

of prey, the head is pointed, and the rounded body tapers gracefully into a powerful organ of locomotion, the caudal fin; while in Urolophus, which spends much of its time on the bottom, the head and body are depressed, carrying the branchial clefts to a rentral position, and the pectoral fins, extending

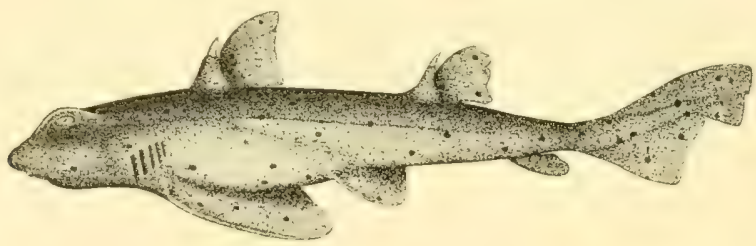

Fig. 17. Heterodontus francisci.

from the pelvic fins behind to the tip of the nose in front, have become the organs of effective locomotion.

It is by differences like these that the Elasmobranch fishes have been separated into two general groups (suborders). One of these, the Selachii, contains

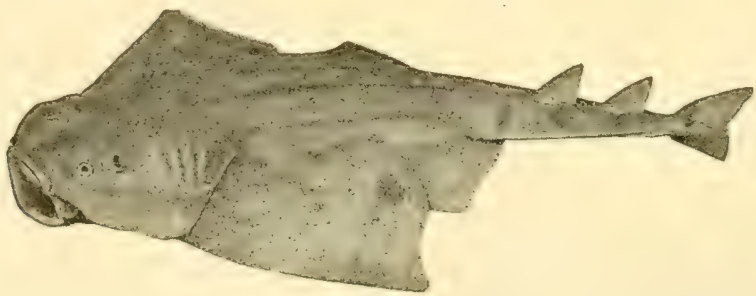

Fig. 18. Squatina californica.

the sharks; the other, the Batoidei, includes the rays. While this distinction between the Selachii and the Batoidei is of special service in separating forms like Acanthias from those like Lrolophus, yet between the two extremes there are types which link by link bridge the intervening gap. So effectively is this 
accomplished that on the border line between the two the characteristies of the one often resemble those of the other so closely that it is difficult to say this is a shark, that a ray. This will be made the more evident upon a consideration of a series of these forms.

\section{TransitionaL Series}

In such a series, Carcharias, the "man-eater" (fig.16), may be taken as a highly specialized type. The fusiform body, even more than that of Acanthias, is fashioned for cleaving the water; the caudal and pectoral fins are powerful; and the sharp pointed teeth are adapted for seizing and holding prey. In fact every line of its structure is an index of predacious perfection. To a less extent the same is true of Galeus. In Mustelus, although the body is highly specialized in this respect, the teeth, varying from the type, have generally become broad and flattened for erushing.

Heavier of body and clearly less graceful in form is the lamnoid type, Lamna cornubica, in which, although the teeth are long and fang-like, the body is relatively cumbersome and the pectorals are placed farther back. The lamnoids, however, retain their restless nature and are classed among the more predacious of the pelagic fishes.

In Heterodontus (fig. 17) we see a still less graceful type. In it the pectorals are expanded, suggestive of a less active nature, more given to foraging over the ocean floor in search of a shellfish diet. Furthermore, in Heterodontus the posterior teeth are of the erushing type adapted to such food (see p. 130, fig. 128). Yet it is worthy of notice that the most anterior of the teeth are prehensile showing that the grasping of food is possible.

Next in the series is Squatina, the angel fish (fig. 18), in which the body is greatly flattened. Furthermore, the pectorals extend forward and the dorsal fins have shifted to a posterior position. In all these respects Squatina is ray-like. But the gill clefts, although covered with a flap, open laterally, and other significant internal structures of fin and skull cling tenaciously to the shark type.

In Pristis, the sawfish (fig. 19), the anterior part of the body is still more flattened; but the caudal region is like that of a shark. The gill clefts of Pristis, however, are entirely ventral in position; and more important still its pectorals have fused to the sides of the head so that in essential respects it has passed over the batoid line and is clearly among the rays.

Slightly more ray-like is Rhinobatis productus, the guitar fish (fig. 7). But even here, although the head and body are depressed, the pectorals are relatively small and the tail is still the organ of active propulsion. From this sharklike ray to others singularly flattened in form are rays in great variety.

In the skate, Raia erinacea (fig. 20), the pectorals extend forward to the region of the nose, and the pelvics are large. Correlated with the greater development of the paired fins the caudal region, including the dorsal fins, is poorly developed, the dorsal fins having migrated still farther back on the tail. In this 
fish we see sufficient modification of form to insure a new mode of locomotion. Here the pectorals become the effective organs in propulsion, and the tail remains at a stage of development insufficient to propel the body. The skate is also an organism not only singularly adapted to its method of getting food, but equally effective in crouching on the ocean floor so as to evade its enemies.

Last in the series we may place the sting ray, Disceus thayeri (fig. 21), which even more than Urolophus undergoes profound depression of body. In

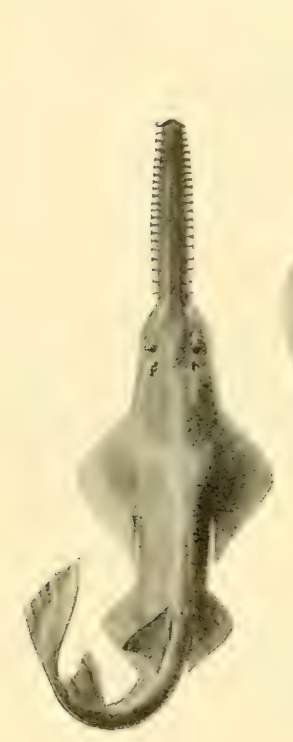

Fig. 19

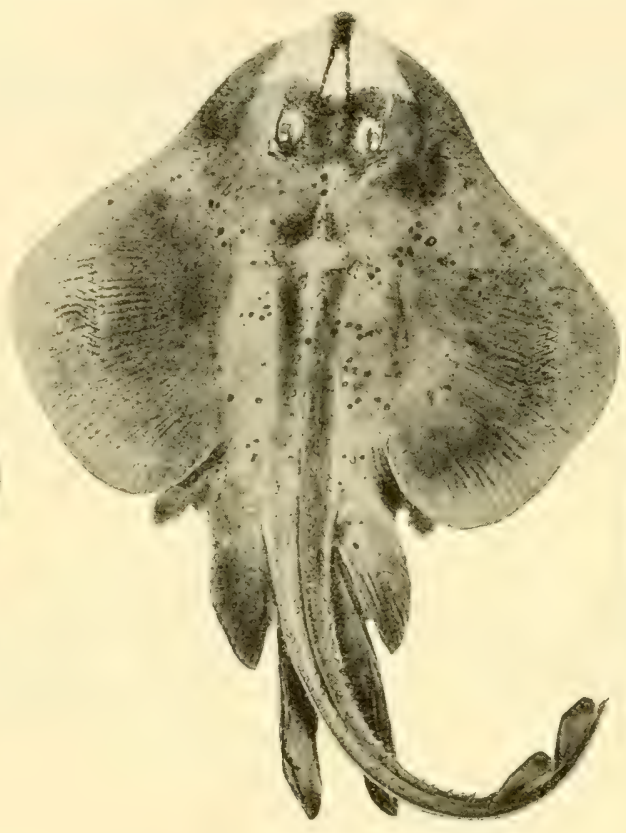

Fig. 20

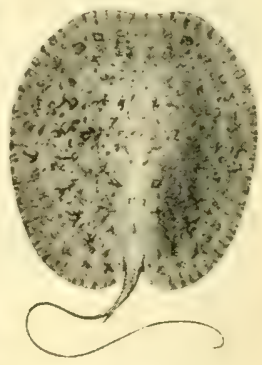

Fig. :21

Fig. 19. Pristis cuspidatum. (From Garman.)

Fig. 20. Raia erinacea. (From Garman.)

Fig. 21. Disceus thayeri. (From Garman.)

it the pectoral fins meet in front and behind so that the body is essentially disc-shaped. Like other rays of this type its tail is provided with a serrate sting, but unlike Urolophus the tail is whip-like and has but slight indication of fins or folds.

\section{External Form in Its Development}

The transition in external form which we have just considered in the series of sharks and rays may be similarly followed in a series of stages in the lifehistory of an individual ray. In other words, while a ray and a shark are very clissimilar in the adult, they are much alike in their earlier development. As growth proceeds, the ray gradually diverges from the shark-plan so that finally a fixed gulf separates the two. To illustrate this divergence we may again compare Acanthias and Urolophus. 
At an early stage there appears above the germinal disc a horseshoe-shaped mass of tissue, the closed end of which represents the head end, and the open end, the tail end. This mass of tissue then becomes spatulate (see p. 230, fig. 209). In a further stage, in which the body takes on definitive form, the two types are characteristically similar. In both, the optic vesicles stand out as prominent structures and the gill clefts, in breaking through, occupy about the same lateral position.

We may figure two stages (fig. 22A-D) which represent the parting of the ways. The first (A) and third (C) of these are of Acanthias; the second (B) and fourth (D) are of Urolophus. While in Urolophus (fig. 22B) the elefts still

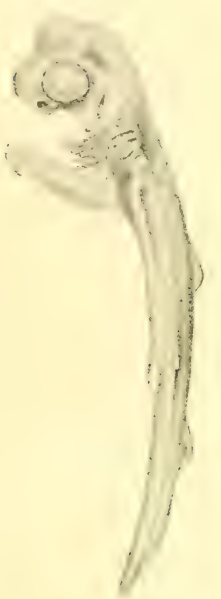

A

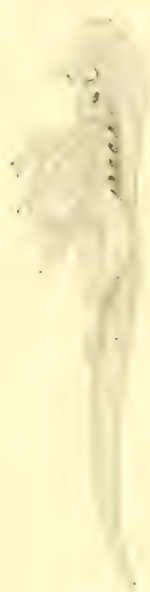

B

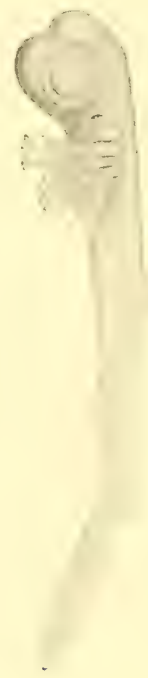

C

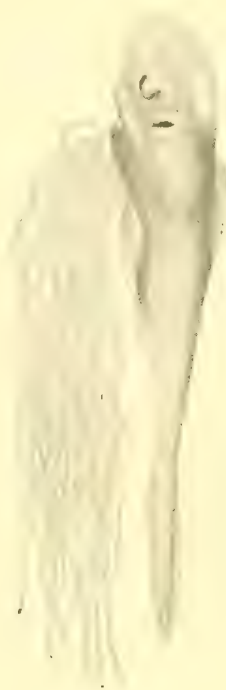

D

Fig. 22. Development of body form in Acanthias and Urolophus,

A. Stage in development of Squalus acanthias. (Length $20.6 \mathrm{~mm}$.) (From Seammon.)

B. Stage in development of Urolophus halleri. (Length $22 \mathrm{~mm}$.) (C. G. Potter, del.)

C. Older stage in development of Squalus acanthias. (Length $28 \mathrm{~mm}$.) (From Scammon.)

D. Older stage in development of Urolophus halleri. (Length $38 \mathrm{~mm}$.) (C. G. Potter, del.)

open on the sides, other changes are taking place which immediately characterize it as a ray. The most notable of these changes is the extension of the pectoral fin.

In the figures of Acanthias (c) and of Urolophus (D) both assume essentially the features of the adult. While Acanthias retains its slender form, Urolophus becomes greatly flattened, the disc-shape being the result largely of the growth of the pectoral fins. Each pectoral now takes the shape of a battle-axe, the blade of which extends outward. The posterior point of the blade projects toward the pelvic fin, while the anterior point extends over the branchial region. As the fin broadens, its anterior tip meets the growing antor- 
bital process and both anterior and posterior projections of the pectoral come in contact with, and fuse to the sides of the head and body. The fusion of the forward part thus profoundly modifies the branchial area, and the clefts take up a rentral position. As growth continues, the forward extensions of right and left pectorals meet in front, completing the dise of the adult body.

\section{Forir and Position of Adult Fins}

It was observed above that a determining factor in the external shape as a whole is the form and position of the fins. The pectorals are of first importance in such a determination. In fact sharks and rays could be separated with certainty by the character of the pectoral fin alone. In general the pectorals of the sharks are relatively small, while those in the rays are large. But a point of greater importance is the secondary fusion which, as we have just seen, the pectorals of the rays make with the head during derelopmental stages. Border types, like Squatina and Rhinobatis, which could not be separated by relative size of fins alone, could be distinguished with certainty by the presence or lack of such fusion.

The caudal fin, although of less value than the pectoral, may also be a determining factor in external form. The axis of the caudal in the sharks, although compressed, is more or less fleshy and the lobes of the fin both dorsally and ventrally are well developed. In adult and specialized rays, on the contrary, the entire tail may be in a more or less complete state of atrophy. In the skate (fig. 20), as an example, it is a long fleshy rod; in Mylinbatis, although it may reach an extreme length, it is slender and whip-like (fig. 8); and in Pteroplatea it never develops beyond the rudimentary stage. In transitional types of rays, howerer, especially among the Pristidae and Rhinobatidae, the axis of the tail is muscular, and the lobes of the caudal fin are pronounced structures, although they are less well developed than are those, sas, of Squatina (fig. 18).

Among the other fins the dorsals, which are usually ${ }^{2}$ correlated with the size of the tail, are more poorly developed in the rays than in the sharks. Furthermore, these fins in the rays, if present, generally take up a position relatively far posterior to the anal segment. Myliobatis as a type is exceptional in that the single dorsal fin takes a position just anterior to the sting. In the skates the dorsals are far out toward the tip of the tail. In fact, in some of the rays they may not inaptly be said to have migrated practically off of the end of the tail. An anal fin is always lacking in the rays; hence this would be of definitive value were it not wanting in a few of the sharks such as the Spinacidae and the Rhinidae.

\section{External Form of Fin and Its Bearing on Function}

If the pectoral fin be of sufficient extent it may perform the function of propulsion. But in the sharks propulsion is brought about largely by the caudal fin. Two general types of locomotion may be described for the Elasmobranchs.

\footnotetext{
2 Excepting in the second dorsal of Lamna, Alopias, ete.
} 
In one, forward movement is produced principally by the pectorals; in the other this function is performed chiefly by the caudal fin or tail. One of these types of locomotion we may therefore designate as pectoral, the other as

1
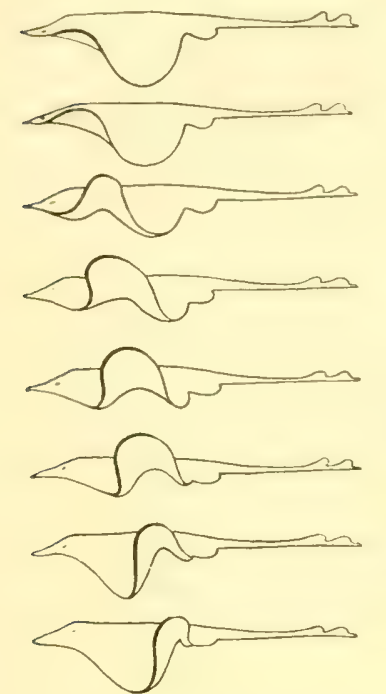

9

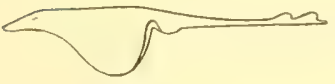

Fig. 23A. Diagram to illustrate the different phases (1-9) of pectoral locomotion in the skate. (From Marey.) candal. Pectoral locomotion among the Elasmohranchs is confined to the rays while the caudal type, so far as I know, is universal among the sharks. It is, howerer. by no means peculiar to them, since, as we have indicated, some transitional rays retain this method of swimming.

To illustrate pectoral locomotion Urolophus may first be considered. In Lrolophus progression is brought about by a synchronous wave movement in both pectorals. This wave begins at the anterior margin of the fin and passes backward, terminating at the posterior margin; thereupon another wave sets in and repeats this action. In the skate pectoral locomotion mar be seen to excellent advantage. In it (fig. 23A), as in trolophus, there is a wave motion which involves not only the margin, but also the greater width of the fin, throwing the pectoral into an inverted $\mathrm{U}$ with the sharper convexity directed forward. As this wave passes backward (1-9) it gains in size and evident momentum, serving as an effective pushing surface against the water. From this type of wave movement a beautiful gliding motion results. A further modification of the type is present in Cephaloptera, in which the stroke of right and left pectorals takes place alternately.

Transitional rays are instructive in that they have not yet attained the method of pectoral locomotion although the pectorals are well developed. In Rhinobatis these fins may be put to considerable use other than in directing the course, as may be seen upon grasping the tail and attempting to pull the fish out of the water.

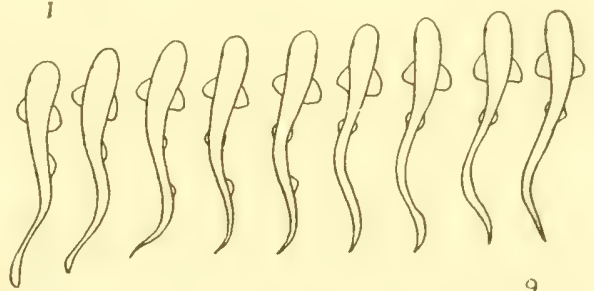

Fig. 23B. Diagram to illustrate the different phases (1-9) of caudal locomotion in the shark, Scyllium. (From Marey.)

In the sharks, in which caudal locomotion is employed, the body itself is thrown into undulations which also provide concave surfaces with which to push against the water (fig. 23B). The wave here begins in the body just back of the pectoral fins (1) and passes posteriorly and oft at the tip of the tail (9), and another undulation therenpon begins and repeats the course. At the same time and with the greatest effect the dorsal and ventral lobes of the caudal fin are directed by the strong muscles as a potent sculling organ. 
We have thus far spoken only of the fins which are propelling. In a type like Myliobatis (fig. 8), direction of the course is effected through the paired fins. In Urolophus (fig. 9) the horizontal course is also directed by the pectorals, but the vertical direction is controlled in large part by the caudal which is used effectively as a rudder.

In the sharks other fins are of service in directing the course. The use of the directive fins may made out by a series of experiments. If a rubber band is put over the pectorals of a young shark with the caudal fin free, there results a downward swimming of the fish, the pectorals functioning as organs for directing the horizontal course in the water. In function the pelvics are acces-

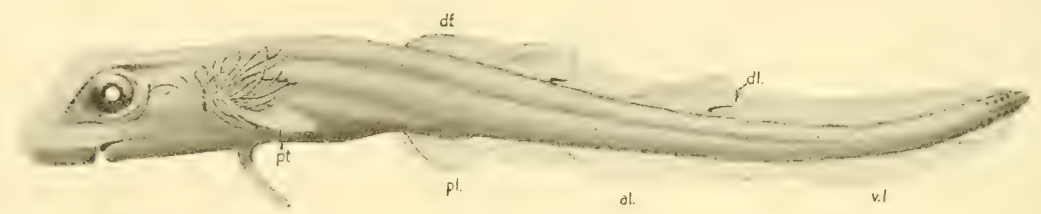

Fig. 24. Embryo of Scyllium canicula showing early epidermal fin-folds. (From Mayer.)

$a l .$, anal fin; $d f$. , dorsal fin-fold; $d l$., second dorsal fin; $p l$., pelvic fin; $p t$., pectoral fin; $v . l$, ventral fin-fold.

sory to the pectorals. Both the dorsals and the anal may be bound down without interfering seriously with propulsion. These fins are of service, however, in keeping the fish in a vertical plane.

\section{FORM OF FIN IN ITS BEGINNING}

It is evident that the form of the fin in present-clay Elasmobranchs differs from that of the ancestral type. And the question arises, What was the form of the ancestral fin? To this inquiry many answers have been given, few of which have gained a hearing. We may mention briefly two of the best known theories for the origin of the paired fins. One is the lateral fin-fold theory of Balfour and Thacher; the other is the gill-arch theory of Gegenbaur.

According to the fin-fold theory the ancestors of the present-day fishes are supposed to have possessed a median dorsal fold ( $d f$., fig. 24) which was continued over the tail as the dorsal lobe of the caudal fin and then forward to the anal region as the ventral lobe. (v.l.); anterior to the anal region the ventral lobe separated into right and left lateral folds not greatly unlike the metapleural folds of Amphioxus. In certain regions of the dorsal and the lateral folds greater development ensued than at the interspaces. These parts of the fin-fold hence increased in size and became the present umpaired and paired fins, while the intermediate parts finally dropped out.

The gill-arch theory of Gegenbaur holds that the framework of the girdles for the paired fins and of the fins themselves have been derived from the gill arches (g.a., fig. 25) and their attached branchial rays (b.r.). The arch itself represents the girdle and the formation of the skeleton of the fin proper was 
understood to have resulted from a fusion of the branchial rays at their bases into a main axis which by extension drew out the adjoining rays so that they arose from this main axis $(A-C)$.

When we consider that the pectoral girdle in form and position is much like a gill arch (see p. 49, fig. 54), and that the fin rays may be arranged both preand postaxially, Gegenhaur's theory appeals to us with much force. The application of the theory to the pelvic fin is more difficult, however, for the fin is assumed to have reached its present position by migrating from the branchial region. This assumption strikes one as far-fetched. Indeed, Dean (1902b) has studied the problem of migration of the fins and concluded for Heterodontus, at least, that there is no evidence of migration.

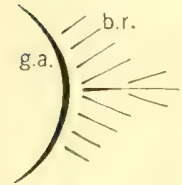

A

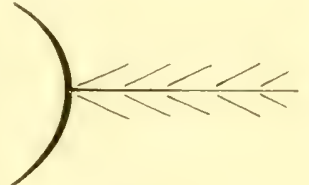

B

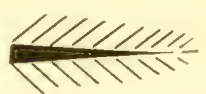

C

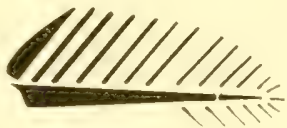

D

Fig. 25. Diagram A-D illustrating the gill-areh theory of Gegenbaur for the origin of paired fins. b.r., branchial ray; g.a., gill arch.

Further objections have been offered against the gill-arch theory. If the skeleton of the pectoral fin arose from the branchial rays of a single areh doubtless it at first occupied a dorsoventral position, a position disadvantageous to the fin as a directing organ. Moreover, if the pectoral arose as a modified gill arch, why are there so many segments involved in the fin? Again, paired fins both in their development and in their structure resemble in a remarkable degree unpaired fins. But unpaired fins certainly have not arisen as modified branchial arches. Still another objection which has been urged against the theory is that the branchial arches lie in the walls of the digestive tract (pharynx) and hence within the aortic arches of the blood system. The pectoral girdle, on the contrary, is superficial to both the arteries and nerves as is shown by the fact that it is perforated by these as they pass out to the fin (p. 78, fig. 84A). It is therefore difficult to see how the pectoral girdle could have reached its present position outside of blood vessels and nerves.

Evidence supporting the lateral fin-fold theory has been obtained from several sources. It has been shown by Dean (1909), for example, that in Cladoselachus (see p. 2, fig. 10), one of the most ancient sharks yet discovered, the paired fins are essentially lateral folds unconstricted at the base and with radial supports nearly parallel. From development also comes evidence for the lateral fin-fold theory. In a type like Scyllium (fig. 24) or Pristiurus or Torpedo there may be in the embryo an epiblastic fold along the back and over the tail, and in Torpedo embryonic lateral folds may extend from the pelvic region behind to the pectoral region in front. Furthermore, Dohrn has shown that the skeleton of the fin in Pristiurus arises as a series of parallel radials and that the girdle at the same time arises from a fusion of the bases 
of the anterior radials. Similarly Balfoux has demonstrated for Scyllium that the pectoral girdle arises secondarily. It may also be added that the blood system of the paired fins in a generalized type like Heptanchus and Hexanchus can most readily be interpreted in terms of a lateral fin-fold theory (see Bibliography, p. 195, Daniel, 1926). Other characters of musculature and nerve may be said to bear on this subject. To them we shall direct further attention when we consider these systems. 


\section{BIBLIOGRAPHY*}

\section{Chapter I}

GENERAL

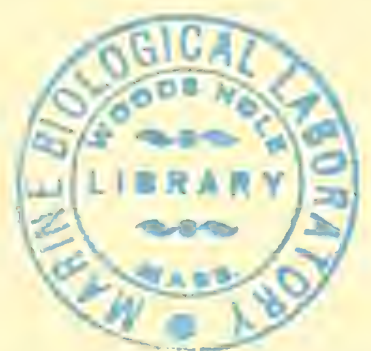

1833-43. Agassiz, I., Recherches sur les poissons fossiles. Vols. I-V, with atlas. Neuchâtel. 1878. BALFour, F. M., A Monograph on the Development of Elasmobranch Fishes. London.

1890. BEARD, J., The Inter-Relationships of the Ichthyopsida : a contribution to the Morphology of Vertebrates. Anat. Anz., Bd. 5, pp. 146-159, 179-188.

1879. Brehm, A. C., Die Fische. Leipzig. Thierleben, Bd. 8, pp. i-xvi + 1-426, 11 Taf., 145 text figs.

1904. Bripge, J. W., Fishes. The Cambridge Nat. Hist., London, Vol. 7, pp. 141-537, figs. $90-324.8^{\circ}$.

1828-45. Cuvier, G., and Valenciennes, A., Histoire naturelle des poissons. Paris, 'T. 1, pp. $14-424$, pls. 1-8.

1889. DAx, F., Fauna of British India. Vol. 1, Fishes. London.

1895. Dean, B., Fishes, Living and Fossil. The Macmillan Co., New York, pp. xiv +300 , 344 text figs.

1909. Dean, B., Studies on Fossil Fishes (Sharks, Chimaeroids, and Arthrodires). Mem. Amer. Mus. Nat. Hist., Vol. 9, Pt. 5, pp. 211-287, pls. 26-41, 65 text figs.

DEAn, B., Bibliography of Fishes. Amer. Mus. Nat. Hist., Vol. I, 1916; Vol. II, 1917 ; Vol. III, 1923.

DoHrN, A., Studien zur Urgeschichte des Wirbelthierkörpers. Numerous studies. Mitt. Zool. Stat. Neapel.

1865-70. DuMÉrIL, A., Histoire naturelle des poissons ou ichthyologie générale. T. 1, Elasmobranches, pp. 144-145, 663-697. Paris.

1913. Garman, S., The Plagiostomia. Mem. Mus. Comp. Zool. Harvard Col., Vol. 36, text and plates.

1909. Goodrich, E. S., in Lankester's 'Treatise on Zoology. Pt. 9, Fase. 1, Cyclostomes and Fishes, pp. 1-518. London.

1880. GứNTHER, A., An Introduction to the Study of Fishes. Pp. 12-48. Edinburgh.

1876-85. Hubrecht, A. A. W., Die Ordnungen der Fisehe. Bromn's Klassen u. Ordnungen, Bd. 5, 6; Abt. 1, Lief. I-IV. Leipzig.

1905. Jordan, D. S., Guide to the Study of Fishes. Pt. I, pp. vii + 624. Henry Holt.

1888. Marshall and Hurst, Junior Course in Practical Zoology. Smith, Elder Co, London.

1889. RabL, C., Theorie des Mesoderms. Morph. Jahrb., Bd. 15, pp. 113-252, pls. 7-10, 9 text figs.

1893. RabL, C., Theorie des Mesoderms. Morph. Jahrb., Bd. 19, pp. 65-144, pls. 4-7, text figs. 10-13.

1854. Stannius, H., Handbuch der Anatomie der Wirbelthiere (Buch I, Die Fische), pp. $1-279$.

1685. Willughber, Fr., Historia Piscium. Pp. 1-342 and append. 1-30. (Many interesting plates.)

1902. ZitTeL, K. A., Textbook of Palaeontology. (Translated by Eastman.) Vol. II, Selachii, pp. 17-49.

* To each chapter is appended a working bibliography. This may be greatly extended by the bibliography published by Dean and Eastman, of the American Museum of Natural History (1916-17 and 1923, see above). 


\section{EXTERNAL FORM}

190\%. BEAN, B. A., A Rare Whale Shark. Science (n. s.), Vol. 15, p. 353.

1905. BEAN, B. A., The History of the Whale Shark (Rhineodon typicus Smith). Smithsonian Mise. Col., Vol. 48, pp. 139-148.

1907. Bolívar, Ignatio, Indicación de algunos peces notables de la Corula. Bol. Soc. Españ. Hist. Nat., T. 7, pp. 206-209, 2 lám.

1909. Brohater, PAUL, Der Kopf eines Embryos von Chlamydoselachus und die Segmentierung des Selachierkopfes. Jena. Zeitschr. Naturwiss., Bd. 44 (N. F. 37), pp. 647 698 , pls. $34-37,15$ text figs.

1900. Burckhardt, R., Beiträge zur Anatomie und Systematik der Laemargiden. Anat. Anz., Bd. 18, pp. 488-492, 4 text figs.

1907. DEAN, B., Notes on Acanthodian Sharks. Amer. Jour. Anat., Vol. 7, pp. 209-226, 36 text figs.

189.. EigenmanN, Carl H., The Fishes of San Diego. Proc. U. S. Nat. Mus., Vol. 15, pp. 123-178, pls. 10-18.

Fitzinger, L. J. F. J., Bilder-Atlas zur wissensehaftlich-populären Naturgeschichte der Fische.

1874. Gardan, S. W., On the Skates (Rajae) of the Eastern Coast of the United States. Proc. Boston Soe. Nat. Hist., Vol. 17, pp. 170-181, 1 text fig.

1884. Garman, S. W., A Peculiar Selachian. Seience, Vol. 3, pp. 116-117, 1 text fig.

1884. Garman, S., New Sharks, Chlamydoselachus anguineus, Heptranchias pectorosus. Bull. Essex Inst., Vol. 16, pp. 47-57, 1 text fig.

1885. Garman, S., Chlamydoselachus anguineus Garm.-A Living Species of Cladodont Shark. Bull. Mus. Comp. Zool. Harvard Col., Vol. 12, pp. 1-35, pls. 1-20.

1899. Gararan, S., The Fishes (Deep Sea). Mem. Mus. Comp. Zool. Harvard Col., Vol. 24, pp. $21-45$, pls. I-VI.

1913. Garman, S., The Plagiostomia. Mem. Mus. Comp. Zool. Harvard Col., Vol. 36 (plates).

1888. Gegenbaur, C., Die Metamerie des Kopfes und die Wirbeltheorie des Kopfskeletes. Morph. Jahrb., Bd. 13, pp. 1-114.

1904. Gilbert, C. H., and Starks, E. C., The Fishes of Panama Bay. Mem. Calif. Acad. Sci., Vol. 4, pls. 1-33.

1862. Gul, Theo., On the Classifieation of the Families and Genera of the Squali of California. Proc. Acad. Nat. Sei. Phila., Vol. 14, pp. 483-501.

1564. Gill, Theo., Synopsis of the Eastern American Sharks. Proe. Acad. Nat. Sci. Phila., Vol. 16, pp. 258-265.

1902. GILL, THEo., The Whale-Shark (Rhineodon typicus) as an American Fish. Seience (n. s.), Vol. 15, pp. 824-826.

1905. GuL, Theo, On the Habits of the Great Whale Shark (Rhineodon typicus). Seience (n. s.), Vol. 21, pp. 790-791.

1917. Goodrich, E. S., On the Development of the Segments of the Head in Seyllium. Quart. Jour. Mise. Sci., Vol. 63, pp. 1-30, pls. 1-2, 1 text fig.

1915. Gudger, E. W., Natural History of the Whale Shark, Rhineodon typicus Smith. Zoologica: Sci. Contr. N. Y. Zool. Soc., pp. 349-389, text figs. 118-131.

1870. Günther, A., Catalogue of the Fishes in the British Museum. Pt. I. Chondropterygii. London. Vol. 8, 549 pp.

1894. His, W., Ueber die Vorstufen der Gehirn- und der Kopfbildung bei Wirbelthieren. Sonderung und Charakteristik der Entwickelungsstufen junger Selachierembryonen. Arch. f. Anat. u. Physiol. (Anat. Abt.), pp. 313-354, pl. 21, 32 text figs.

1894. Hofrinan, C. K., Zur Entwickelungsgeschichte des Selachierkopfes. Anat. Anz., Bd. 9 , pp. 638-653, 5 text figs.

1896. Jordan, D. S., and Evermann, B. W., The Fishes of North and Middle America. Bull. U. S. Nat. Mus., No. 47, Pts. 1-4. 
1903. Jordan, D. S., and Fow Japan. Proe. U. S. Nat. Mus., Vol. 26, pp. 593-674, pls. 26-27, 10 text figs.

1880. Jordan, D. S., and Grbert, C. H., Deseription of a New Species of Notidanoid Shark (Hexanchus corinus), from the Pacific Coast of the United States. Proc. U. S. Nat. Mus., Vol. 3, 1880, pp. 352-355.

1901. Jordan, D. S., and Snrder, J. O., A Preliminary Check List of the Fishes of Japan. Anno. Zool. Japonens., Vol. 3, Pts. 2 and 3, pp. 31-35. Tokyo.

1891. Killian. Zur Metamerie des Selachierkopfes. Anat. Anz., Bd. 5 (Verh.), pp. 85-107, 25 text figs.

1850. LEUCKART, R., Ueber die allmählige Bildung der Körpergestalt bei den Rochen. Zur Entwicklungsgeschichte von Torpedo marmorata. Zeitschr. wiss. Zool., Bd. 2, pp. 254-267, pl. 16.

1895. Locy, W. A., Contribution to the Structure and Development of the Vertebrate Head. Jour. Morph., Vol. 11, pp. 497-594, pls. 26-30, 11 text figs. (also thesis Univ. of Chicago).

1868. Macdonald, J. D., and Barron, Chas., Notes on Heptanchus indicus, ehiefly as regards Sexual Characters. Proc. Zool. Soc. Lond., 1868, pp. 371-373, pl. 33.

1879. Miklucho-Mactay, N. De, and Macleay, WM., Plagiostomata of the Pacifie. Pt. I. Fam. Heterodontidae. Proc. Linn. Soc. N. S. Wales, Vol. 3, pp. 306-334, 5 pls.

1883. Miklucho-Maclat, N. De, and Macleat, Wat., Plagiostomata of the Pacific. Pt. II (Heterodontus japonicus). Proc. Linn. Soc. N. S. Wales, Vol. 8, pp. 426-431, pl. 20.

1885. Miklucho-Maclay, N. DE, and Macheay, WM., Plagiostomata of the Pacific. Pt. III. Heterodontus zebra (Grey). Proc. Linn. Soc. N. S. Wales, Vol. 10, pp. 673-678, pls. $45-46$.

1839. Müller, J., Über den glatten Hai des Aristoteles, und über die Verschiedenheiten unter den Haifischen und Rochen in der Entwickelung des Eies. Abh. Akad. Wiss. Berlin, 1840, pp. 187-258.

1838-41. Müller, J., and Henle, J., Systematische Beschreibung der Plagiostomen. 60 Taf. Berlin. $4^{\circ}$.

1898. Neat, H. V., The Problem of the Vertebrate Head. Jour. Comp. Neurol., Vol. 8, pp. 153-161, 2 text figs.

1898. Nishikawa, T., Notes on some Embryos of Chlamydoselachus anguineus Garm. Anno. Zool. Japonens. Vol. 2, Pt. IV, pp. 95-102, pl. 4, 7 text figs. Tokyo.

1906. Regan, C. T., A Classification of Selachian Fishes. Proc. Zool. Soc. Lond., 1906, Pt. II, pp. 722-758, text figs. nos. 115-124.

1908. RegaN, C. T., A Synopsis of the Sharks of the Family Squalidae. Ann. Mag. Nat. Hist., Ser. 8, Vol. 2, pp. 39-57.

1908. Regan, C. T., A Synopsis of the Sharks of the Family Cestraciontidae. Ann. Mag. Nat. Hist., Ser. 8, Vol. 1, pp. 493-497.

1911. Scammon, R. P., Normal Plates of the Development of Squalus acanthias. Normentafeln z. Entwick, der Wirbeltiere, Heft 12, 4 plates, 26 text figs. (Excellent bibliography.)

1898. Setwertzoff, A. N., Die Metamerie des Kopfes von Torpedo. Anat. Anz., Bd. 14, pp. 278-282.

1829. Sirith, ANDrew, Contributions to the Natural History of South Africa. Zoological Journal, Tol. 4, Art. LIV, pp. 443-444.

1849. SMITH, ANDREw, Pisces, in Illustrations of the Zoology of South Africa. Plate XXVI and description. London.

1911. Sirith, H. M., Note on the Occurrence of the Whale Shark, Rhimeodon typicus, in the Philippine Islands. Proc. Biol. Soc. Washington, Vol. 24, p. 97.

1907. Starks, E. C., and Morris, E. L., The Marine Fishes of Southern California. Univ. Calif. Publ. Zool., Vol. 3, pp. 159-251, pl. 21.

1917. Starks, E. C., The Sharks of California. Calif. Fish and Game, Vol. 3, pp. 145-153, 13 text figs. 
1918. Starks, E. C., The Skates and Rays of California, with an account of the Rat Fish. Calif. Fish and Game, Vol. 4, pp. 1-15, 18 text figs.

1921. Stensio, E. A.: son., Triassic Fishes from Spitzbergen (Upsala).

1867. Storer, D. H., A History of the Fishes of Massachusetts. Mem. Amer. Acad. Art. and Sci. (n. s.), Vol. 9, pp. 217-256, pls. 36-39.

1902. WAItE, E. R., Studies in Australian Sharks (No. 2). Ree. Australian Mus., Vol. 4, pp. 175-178, 1 text fig.

1906. WaIte, E. R., Notes on Fishes from Western Australia (No. 3). Rec. Australian Mus., Vol. 6, pp. 55-82, 10 pls., 1 text fig.

1882. WIJHE, J. W. VAN (see p. 118).

1889-(95). Woodward, A. Santh, Catalogue of Fossil Fishes in the British Museum. Vols. I, II (and III). London.

1908. Ziegler, H. E., Die phylogenetische Entstehung des Kopfes der Wirbeltiere. Jena. Zeitschr. Naturwiss., Bd. 43, pp. 653-684, 23 pls., 11 text figs.

\section{DETAILED STUDY OF TYPES}

1811. Blainville, H. D., Mémoire sur le squale pèlerin. Ann. du Mus. Paris, T. 18, pp. 88135,6 text figs.

1899. Cunningham, R. O., On a Few Points in the Structure of Laborde's Shark (Euprotomicrus labordii). Proc. Zool. Soc. London, 1899, pp. 732-734.

1907. Gudger, E. W., A Note on the Hammerhead Shark (Sphyrna zygaena) and its Food. Science (n. s.), Vol. 25, pp. 1005-1006.

1933. Gudger, E. W., and Smiti, B. G., The Natural History of the Frilled Shark, Chlamydoselachus anguineus. Bashford Dean Memorial Volume. Art. V, pp. 245319 , pls. $1-5,31$ text figs.

1902. Helbing, H., Beiträge zur Anatomie und Systematik der Lämargiden. Anat. Anz., Bd. 21, pp. 658-668.

1904. Helbing, H., Beiträge zur Anatomie und Systematik der Lämargiden. Nova Acta Acad. Halle, Bd. 82, pp. 335-524, 2 Taf. Also: Inaug. Diss., Halle, pp. 9-135, pl. 1, 30 text figs.

1876. Huxlex, T. H., Contributions to Morphology. Ichthyopsida, No. 1. On Ceratodus forsteri, with Observations on the Classification of Fishes. Proc. Zool. Soc. Lond., 1876, pp. 24-59, 11 text figs.

1898. Jordan, D. S., Deseription of a Species of Fish (Mitsukurina Owstoni) from Japan, the Type of a Distinct Family of Lamnoid Sharks. Proc. Calif. Acad. Sci., Ser. 3, Vol. 1, pp. 199-202, pls. 11-12.

1909. Kellicott, W. E., The Growth of Parts in the Dogfish. Science (n. s.), Vol. 29, p. 437.

1847. KNeELAND, S., Dissection of Seymnus brevipinna. Boston Jour. Nat. Hist., Vol. 5, pp. $479-485$.

1785. Monro, Alfixander, The Structure and Physiology of Fishes explained and compared with those of man and other animals. Edinburgh. Many illustrations.

1866. Owen, Richard, On the Anatomy of Vertebrates. Vol. I. Fishes and Reptiles. London, Longmans, Green \& Co.

1882. PArker, T. J., Notes on the Anatomy and Embryology of Scymnus lichia. Trans. and Proc. N. Z. Inst., Vol. 15, Art. XXIX, pp. 222-234, pls. 31-32.

1884. PARKER, T. J., A Course of Instruction in Zootomy. Macmillan.

1887. PArker, T. J., Notes on Carcharodon rondeletii. Proe. Zool. Soe. Lond., 1887, pp. 2740, pls. 4-8.

1874. Pavesi, P., Contribuzione alla storia naturale del genere Selache. Ann. Mus. Civ. Storia nat. Genova, Vol. 6, pp. 5-72, tav. 1-3. Also: Extr.-Arch. sei. phys. et nat. Genève, T. 51, pp. 307-324. 
1891. Plate, Julia B., A Contribution to the Morphology of the Vertebrate Head based on a study of Aeanthias vulgaris. Jour. Morph., Vol. 5, pp. 79-106.

1904. Punnetr, R. C., Merism and Sex in Spinax niger. Biometrika. Cambridge. Vol. 3, No. 4, pp. 313-362, pl. 1.

1905. Rand, H. W., The Skate as a Subject for Classes in Comparative Anatomy. Amer. Nat., Vol. 39, pp. 365-379.

1874. 'Turner, W., Additional Observations on the Anatomy of the Greenland Shark (Laemargus borealis). Jour. Anat. Physiol., Vol. 8, pp. 285-290.

1906. Wooduand, W., On the Anatomy of Centrophorus ealceus. Proc. Zool. Soc. London, 1906 (2), pp. 865-886, pls. 57-62, 12 text figs.

\section{FINS AND THEIR ORIGIN}

1878. BALfour (

1887. Baur, G., Morphology and Origin of the Iehthyopterigia. Amer. Nat., Vol. 21, pp. $837-840$.

1906. Braus, H., Die Entwickelung der Form der Extremitäten und des Extremitätenskelets. Hertwig's Handb. vergl, u. expt. Entwick. Bd. 3, Teil 2, pp. 167-235.

1879. Davidoff, M., Beiträge zur vergleichenden Anatomie der hinteren Gliedmassen der Fische. Morph. Jahrb., Bd. 5, pp. 450-520, pls. 28-31, 1 text fig.

1896. Dean, B., Sharks as Ancestral Fishes. Nat. Sei., Vol. 8, pp. 245-253, 4 text figs.

1896. Dean, B., The Fin-Fold Origin of the Paired Limbs, in the light of the Ptychopterygia of Palaeozoic Sharks. Anat. Anz., Vol. 11, pp. 673-679, 8 text figs.

1902. DEAN, B., Historical Evidence as to the Origin of the Paired Limbs of Vertebrates. Amer. Nat., Vol. 36, pp. 767-776, 1 text fig.

1902b. DEAN, B., Biometric Evidence in the Problem of the Paired Limbs of the Vertebrates. Amer. Nat., Vol. 36, pp. 837-847, 1 text fig.

1884. DoHRN, A., Studien zur Urgeschichte des Wirbelthierkörpers. IV. Die Entwicklung und Differenzierung der Kiemenbogen der Selachier. Mitt. Zool. Stat. Neapel, Bd. 5, pp. 102-195, pls. 5-11.

1865. Gegexbaur, C., Die Brust-Flossen der Fische. Untersuch. z. verg. Anat. d. Wirbelth., Heft II.

1906. Goonrich, E. S., Notes on the Development, Structure, and Origin of the Median and Paired Fins of Fish. Quart. Jour. Mier. Sci., Vol. 50 (n. s.), pp. 333-376, pls. 10-14, text figs. 1-3. London.

1911. Gudger, E. W., The Finned-Tailed Larva of the Butterfly Ray, Pteroplatea maclura. Jour. Elisha Mitehell Seient. Soc., Chapel Hill, N. C., Vol. 27, p. 84.

1889. HAтSCHEK, Die paarigen Extremitäten der Wirbeltiere. Anat. Anz., Bd. 4 (Verh. Berlin), pp. 82-90, 4 text figs.

1860. KNER, RUdolph, Über den Flossenbau der Fische. Sitzber. der math.-naturwiss. Klasse, Vol. 41, pp. 807-824.

1893. MARey, M., Des mouvements de natation de la raie. C. R. Acad. Sei. Paris, Vol. 116, p. 77-81, 2 text figs.

1886. Mayer, Paul, Die unpaaren Flossen der Selachier. Mitt. Zool. Stat. Neapel, Bd. 6, pp. 217-285, pls. 15-19.

1879. Mivart (see p. 86).

1892. Moldier, S., Zur Entwickelung der Selachier Extremitäten. Anat. Anz., Bd. 7, pp. $351-365$.

1894. I. Mollier, S., Das Iehthyopterygium. Anat. Hefte, Bd. 3, pp. 1-160, pls. 1-8, 12 text figs.

1895. II. Moldier, S., Das Cheiropterygium. Anat. Hefte, Bd. 5, pp. 433-530, pls. 31-38, 7 text figs.

1909. MüLler, ERIK, Die Brustflosse der Selachier. Ein Beitrag zu den Extremitätentheorien. Anat. Hefte, Bd. 39 (Heft 118), pp. 471-601, pls. 27-46, 62 text figs. 
1907. Osburn, R. C., New Evidence from Primitive Sharks on the Origin of the Limbs of Vertebrates. Seience (n. s.), Vol. 25, pp. 729-730.

1907. Osburn, R. C., Observations on the Origin of the Paired Limbs of Vertebrates. Amer. Jour. Anat., Vol. 7, pp. 171-194, pls. 1-5.

1907. Osburn, R. C., The Origin of Vertebrate Limbs. Recent Evidence upon this Problem from Studies on Primitive Sharks. Ann. N. Y. Acad. Sei., Vol. 17, Pt. 2, pp. 415-436.

1906. Rennie, John, Accessory Fins in Raia batis. Anat. Anz., Bd. 28, pp. 428-431, 2 text figs.

1877. THACHER (

1892. Woodward, A. S., The Evolution of Fins. Nat. Sei., Vol. 1, pp. 28-35, 8 text figs. 


\section{IN'TEGUMENT}

\section{INTEGUMENT OF HEPTANCHUS MACULATUS}

One of the most characteristic structures observed in a study of the external form is the integument, in which is located the pigment pattern and from which project the shagreen denticles. The two layers of the integument of a young Heptanchus are shown in figure 26. The epidermis $\left(e_{0}\right)$ is relatively thin and the dermis or corium ( $\mathrm{cr}$. ) is considerably thicker.

The epidermis when examined in detail shows smperimposed strata of cells, the innermost layer of which, the basal or germinative layer $\left(g r^{\circ}\right)$, is of a columnar nature; while the outlying strata in which the cells are horizontal may be designated as the superficial layers of the epidermis. Between these two extremes are numerous intermediate cells which are irregularly stratified. These cells arise in development from the basal layer and pass outward toward the surface, becoming more flattened as they move outward.

At practically any level of the epidermis from the deep basal layer outward to the surface may be found large beaker or goblet cells (g.c.) of a glandular nature. Each of these cells arises as a modified cell divided off from a basal layer cell and comes to be essentially a large sac with the nucleus located near its base.

The dermis or corium (cr.) is composed of two more or less well defined layers in Heptanchus. The first or more superficial of these is made up of a dense mass of irregularly arranged cells; the second or deeper layer is com-

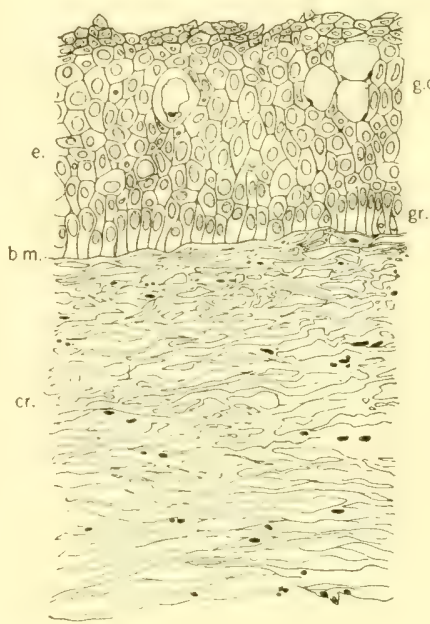

Fig. 26. Section through the buccal integument, Heptanchus maculatus.

b.m., basal membrane; cr., corium or dermis ; e., epidermis ; g.c., goblet or gland cell; gr., basal or germinative layer. posed of sparser cells which have protruding from them longer or shorter processes, which interlace into a network of supporting tissue.

In the upper layer of the corium and between it and the epidermis are located the pigment masses which are the causes of the color pattern. In the adult the pigment cells are black or greyish and are distributed more or less evenly over the back and sides, giving to the upper areas their drab hue. Over the drab background are scattered the irregular blotches of black which are produced by more deeply lying pigment. In the patches the cells are packed so closely together that it is impossible to pick them out individually. Pigment is absent from the integument on the ventral side, which is of a whitish, metallic color. 
The scales present in the integument of a shark like Heptanchus provide a relatively compact exoskeleton which, in a general way, serves to protect the organism against external injury. In form the scales vary considerably de-

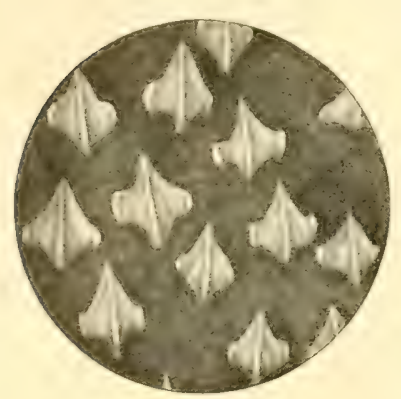

1

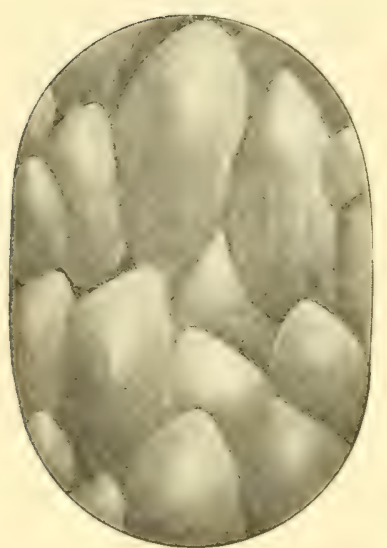

I3

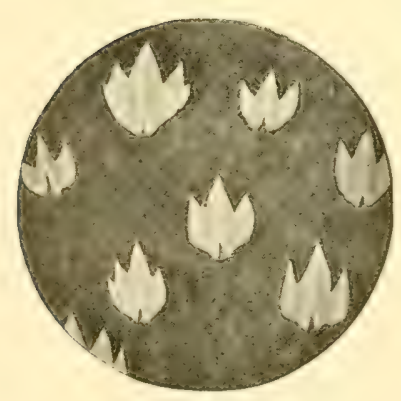

(

Fig. 27. Seale patterns, Heptanchus maculatus. A. From side of body. B. Modified seales from margin of fin. C. Stomodeal denticles from roof of mouth. pending upon their position. The first of these, represented by figure $27 \mathrm{~A}$, were taken from the side of the body just above the lateral line. They are therefore from a region which is not unduly exposed and which may be characterized as typical. By looking from the lower left- to the upper right-hand corner it will be observed that the seales are arranged more or less in oblique rows. The same is true, although less evident, if they be observed from the lower right- to the upper left-hand corner of the figure. If a larger piece of the integument be drawn and lines be ruled through the rows of scales, the lines will form a series of rhomboids, producing the diamond-shaped pattern. In such a pattern each scale normally points backward and is attached anteriorly and centrally.

The details of a single seale have been figured by Steinhard (1903) for Heptanchus cinereus (fig: 28). Here an anterior arm (a.a.) is well imbedded in the integument and a posterior spine $\left(s p .^{1}\right)$ projects more or less sharply upward and backward. Two lateral arms appear (l.a.) which, as a rule, eurve more or less upward and terminate in lateral spines $\left(s p .{ }^{2}\right)$. Passing along the middorsal line from the anterior arm to the tip of the posterior spine is the primary or axial erest $\left(c r .{ }^{1}\right)$. Located on the lateral arms and branching from the primary crests are the lateral erests $\left(c r^{2}\right)$. Other tertiary crests $\left(c r .{ }^{3}\right)$ connect primary and secondary crests, and a fourth $\left(\mathrm{cr}^{*}{ }^{ \pm}\right)$arises from the secondary erests to pass laterally around the sides of the scale. Lying deeply buried in the integument is the enlarged supporting base (ba.) which, in general, is rhomboidal in shape and is attached by a narrow neck or pedicel to the main body of the seale. Into the lower substance of the base enter strong fibers of connective tissue which anchor the scale to the integument.

Where the base may be broad, as in the scales over any of the exposed areas, many such supporting fibers may be present. 


\section{Monified Scales}

Scales located in a region that is more exposed may differ greatly from the typical ones which we have just described. The several areas in which the seales may become modified in Heptanchus are along the dorsal margin of the back and especially in front of the dorsal fin, around and in front of the eye, over the tip of the nose and the tip of the lower jaw; in fact, over any of the surfaces which are particularly exposed as the fish swims forward. An extreme example of modification is shown in figure $27 \mathrm{~B}$, the pattern of which was taken from the anterior margin of the pectoral fin. The crests and even the spines of the scales previously studied have here disappeared. In fact the entire form has become so greatly modified as to be hardly recognizable. Instead of having the regular spade-shape they have become enlarged nodules, the anterior and posterior parts of which ean be distinguished only with difficulty. Not infrequently such a scale in this exposed area reaches a size many times that of a protected scale.

A third type may be described briefly. Covering the lining of the buceal cavity and the pharyngeal box, excepting the posterior part of the roof, there are numerous modified scales which are designated as stomodeal denticles (fig. $27 \mathrm{c}$ ). These denticles

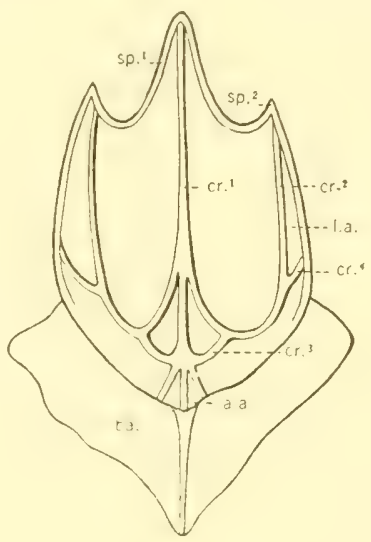

Fig. 28. Detail of placoid scale, Heptanchus cinereus. (From Steinhard.)

a.a., anterior arm; ba., base of scale; $c r^{1}{ }^{1}$, primary erest; $c r .{ }^{2}$, lateral erest; $c r .{ }^{3}$, tertiary crest; $c{ }^{*}{ }^{4}$, fourth crest; l.a., lateral arm; sp. ${ }^{1}$, posterior spine; $s p .^{2}$, lateral spine. resemble much more closely the normal scales previously described than they do those secondarily modified. Indeed, the stomodeal denticles, ocenpying a position which in the young is more protected than the normal type of scale, are sharply differentiated into parts. This is especially noticeable in their prominent lateral spines; in some even a second pair of laterals is present, making five spines in all. It will be observed that the stomodeal denticles closely resemble the lower teeth (see p. 122, fig. 121). 


\section{IN'TEGUMEN'T OF ELASMOBRANCHS IN GENERAL}

The deseription given for the layers of the integument in Heptanchus may serve to portray eonditions which are more or less general. There is, however, in the different Elasmobranchs considerable variation in the thickness of the integument, affecting one or both of the layers. In a type like Scymmus, for example, the upper or epidermal laver is thinner than that of Heptanchus, yet the corium of Heptanchus is relatively thin, so that its integument as a

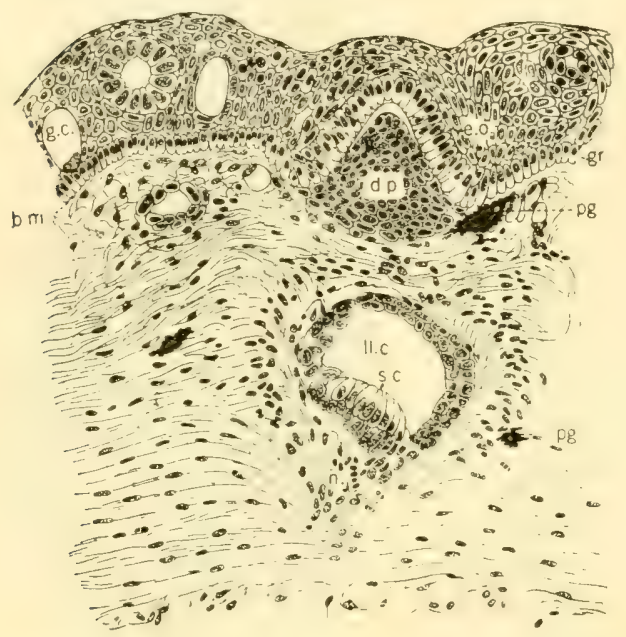

Fig. 29. Section of the integument of the Leopard shark, Triakis semifasciatus.

b.m., basal membrane; d.p., dermal papilla; e.o., enamel organ; y.c., goblet or gland cell; $g r .$, basal or germinative layer of epidermis; ll.c., lateral line canal; $n$., ramulus of vagus nerve; pg., pigment; s.c., sensory column. whole is of medium thickness. The thickening of the skin may be due to the addition of many cells to the corium as, for example, in Heterodontus, or it may be brought about as in Triakis (fig. 29), where the dermal cells, particularly in the superficial layer, are much less compact.

Color in the Elasmobranchs while varying considerably usually assumes a quiet hue, the brilliant reds or blues characteristic of the bony fishes rarely being present. The color may be a light drab as in Mustelus californicus, a deep blue as in the lamnoids, brown as in Torpedo (Tetronarce californicus), or black as in Torpedo occidentalis. It may be scattered over dorsum and venter alike as in the deep-sea forms,

Spinax of the Mediterranean and Etmopterus of Formosan waters; or it may be confined largely to the dorsum as in Galeus, Acanthias, and a host of other types; again, it may be collected in a remarkable pattern over a drab background as is characteristic of Cheiloscyllium and the Leopard shark, of Tigrinum and Rhinodon typicus. Whether the color be light or dark or variegated it is produced by chromatophores, several types of which are present.

The melanophore containing black or brown melanin is usually considered to be a connective tissue type of cell ${ }^{1}$ rhizopod in shape, and sometimes capable of amoeboid movement. Some of these cells in Heterodontus ( $p$ g., fig. 30) though typically rhizopod are capable of but slight change of form. Other melanophores, smaller in size, may have numerous processes which in extreme

1 There is evidence for the belief, however, that this cell is derived from a smooth muscle cell. 
ocenrences exceed in length many times the diameter of the hody of the cell. From the possession of great numbers of these processes expanded into a complex web, the extreme black of a form like Torpedo occidentalis results.

The golden cells or lipophores (lp., fig. 30) (Xanthophores) containing the fatty pignent, lipochrome, are beatifully shown in the young of Heterodontus. Here, with the brown melanophores, they give patches of a warm glossy yellow of remarkable beauty. In Cephaloscyllium (fig. 1) also, multitudes of lipophores produce the sulphur spots so characteristic of this form. In Rhinodon (fig. 3 ) the lipophores associated with reddish brown melanophores form the great orange spots or color patches.

In most of the Elasmobranchs, excepting the deep-sea types, pigment cells are absent from the venter. The metallic white here results from the presence of guanin, a waste product of metabolism, which impregnates the cells (leucophores) ventrally as do the pigment granules dorsally. The guanin granules although present are not visible dorsally, for in this location they are obscured by the melanin granules. Ventrally they are very numerous, and have much to do with the production of the light color. Contributing also to the formation of a light-colored venter is a certain concentration of tissues known as argentium. In this concentra-

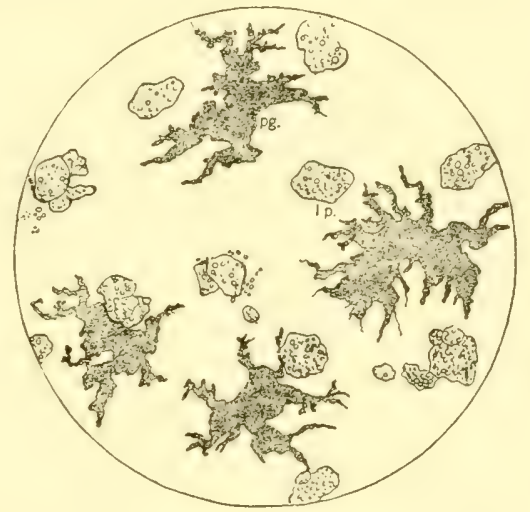

Fig. 30. Chromatophores of young Hetero. dontus francisci.

lp., golden cells containing granules; pg., melanophore filled with brown pigment.

tion the underlying tissues, through the deposition of calcic prisms, become so compact as to form a highly reflecting surface to which the silvery sheen characteristic of a fresh specimen is partly due.

The function of pigment has often been thought to be the protection of the more delicate underlying tissues against the rays of the sum. While this perhaps holds in general, such protection from the rays of the sun would not be necessary for those forms like Spinax or Etmopterus which inhabit the profound depths into which the light of the sun never penetrates. And it is the more singular that in such deep-sea Elasmobranchs pigmentation is not confined to the dorsum but is distributed over the ventral part of the body as well. It has been suggested that at depths at which the rays of the sum are unknown it may still be that pigmentation is in some way correlated with light; for pervading even the greatest depths there is present phosphorescent light, the source of which being diffuse would not result in pigment on the back alone but on the sides and venter as well. But the cause of pigmentation in deep-sea sharks is as yet not understood. It seems not improbable that the pigmentation is correlated not so much with light as with the lower temperature. 


\section{Gland Cells}

The integumentary beaker, or gland cell, as such (g.c., fig. 29) is produced entirely from the epidermis. In sections taken through the body of the embryo at different levels it is observed that these cells are distributed over the entire surface, with but few exceptions, like the cornea of the eye. They may likewise he found in the integument lining the buceal cavity (g.c., fig. 26) and the cloaca. these cavities being formed as invaginations from the surface. The first indication of the origin of such a gland cell is seen in the enlargement of

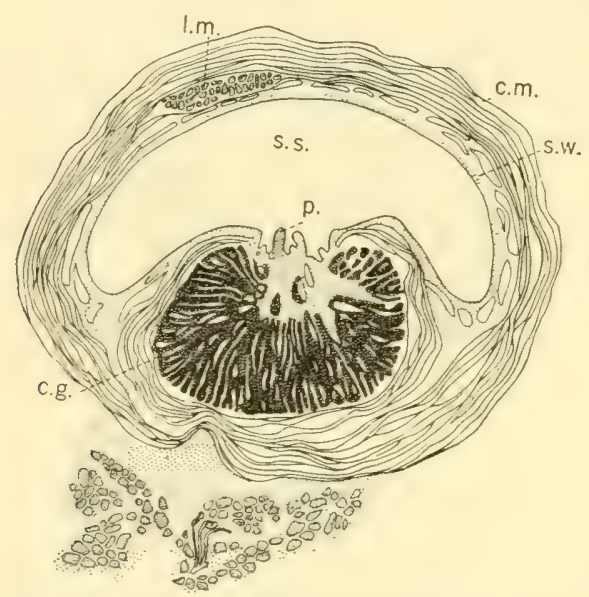

Fig. 31. Trainsverse section through siphon sae (s.s.), Raia circularis, to show clasper gland. (From Leigh-Sharpe.)

c.g., clasper gland; c.m., cireular muscle; l.m., longitudinal muscle; $p$. , papilla from gland; s.w., siphon wall. a cell derivative of the basal layer. This cell migrates through the intermediate layers to the surface as do the superficial cells, but instead of becoming flattened, as do the superficial cells, it becomes vesicular and reaches an enormous size. When it gains the surface a lumen forms, through which the gland pours out its product of excretion.

\section{Glands of Claspers}

In addition to the gland cells of the type just described there are in males of the Elasmobranchs numerous gland cells which are derived from the epidermis and which sink in at the base of the claspers. Such a gland in Squatina if examined under the microscope is seen to be essentially a series of enlarged goblet cells. In other forms as has been shown by Leigh-Sharpe (1920-21) the gland may fill up the siphon (Lamna) or it may be in only a part of its wall. In Raia circularis (fig. 31) the gland has been compared to a date stone, bilobed in appearance with a longitudinal groove running its entire length. Into the groove the papillae open to drain the different components of the gland.

\section{Poison Glands of Sting Ray}

Goblet or mucous cells which in the sting ray, Lrolophus, are present in great numbers at the root of and just under the sting, form what some believe to be a poison gland ( $p . g l$., fig. 32$)$. It is evident that these would secrete an abundant supply of mueus which might pass along the ventral groove into the wound made by the sting. It is doubtful, however, that this mucus is more toxic than is the acrid mucus of other glands. 


\section{Light Organs}

In deep-sea fishes, in general, gland cells have contributed to a most remarkable specialization: that is, they have become converted into light organs or photophores. Such organs have been found in various Selachians, prineipal among which are Spinax niger, Laemargus, and Etmopterus. In Etmopterus, Oshima (1911) has made out two types of light organs: (1) punctate, cupshaped organs which in the living specimen have a pearly luster; and (2) linear, semicylindrical organs which apparently result from a fusion of two or more punctate organs. In $E t$ mopterus these light organs are located in definite patterns, principally along the sides and ventrally, but they are present also on the dorsum.

Johann (1899) gives a section through a luminous organ of Spinax (fig. 33A) which shows that it is formed as a modification of cells in the germinative or basal layer of the epidermis $(g r$.). These cells enlarge and, as a cup, sink slightly into the corium. Two

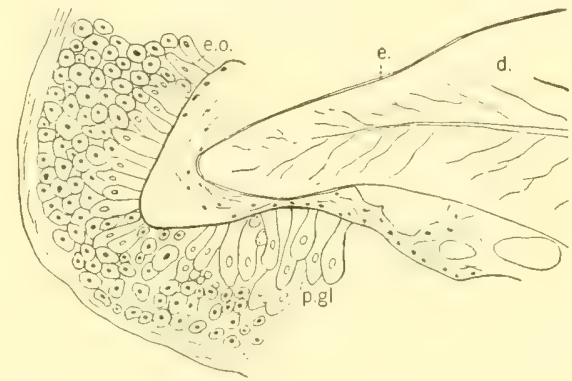

Fig. 32. Transverse section of sting, Urolophus halleri. (A. M. Paden, orig.)

e., enamel of sting; e.o., enamel organ; d., dentine of sting; $p \cdot g l .$, so-ealled poison gland.

types of cells are present, one, the lens cell (l.c.), the other, the light or photogenic cell (lt.c.).

The lens cells are few in number and are located toward the surface where they appear as enlarged mucous cells. In their beginning they arise from the basal layer and migrate outward, becoming large and granular. Upon coming in contact with the surface they pour out some or all of their contents and become the lens cells of the adult type. 'The light or photogenic cells (lt.c.) consist of a few cells (Spinax) or a number of them (Etmopterus) which occupy an irregular position at the base of the cup.

Under the basal membrane which supports the eup are blood sinuses (b.s.). Usually indenting the walls of these sinuses are masses of enclosing pigment. Figure 33B of Etmopterus shows the arrangement of pigment not given in figure 33A. This heavy band of pigment lines the bowl of the cup and extensions pass inward and practically cover the cup as the so-called iris ( $\mathrm{ir}$.$) .$

There is doubt as to how the organ thus described functions. It is possible, however, as in some of the bony fishes, that these basal cells, which are essentially mucous cells, form a luminous secretion, the oxidation of which produces the light. That the organ is effective in the production of light has been observed through the study of living specimens. Thus in Spinax, Dr. Theodor Beer has observed a strong phosphorescent light given off along the side and ventral region. The light was of variable intensity, glowing for a time and then 
decreasing in brilliancy. Oshima has also studied the luminosity, and has noted that in Etmopterus the light was never produced spontaneously but was emitted regularly upon the application of mechanical stimulation. Whether or not the pigmented iris through contraction and expansion regulates the light thus produced has not been sufficiently studied.

\section{Placoid Scales}

In figure 29, showing the layers of epidermis and corium, is also shown a developing placoid scale. The first indication of such a scale is the collection of a group of cells in the upper layer of the corium to form a dermal papilla (d.p.).

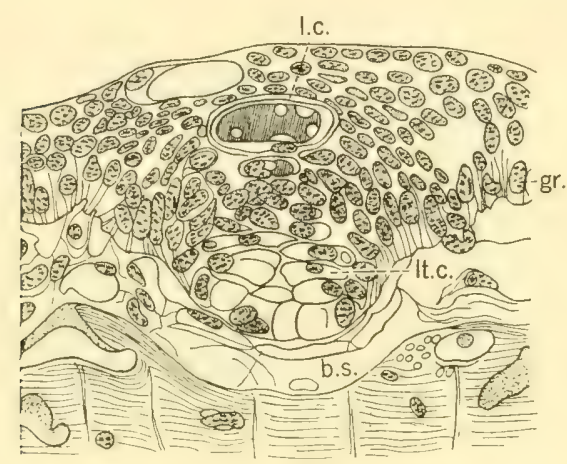

A

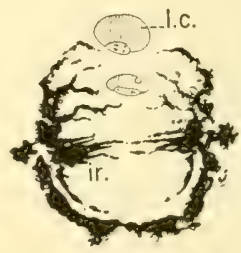

B

Fig. 33. A. Section through a light organ or photophore, Spinax niger. (From Johann.) B. Pigmentation of a photophore, Etmopterus. (From Oshima.)

b.s., blood sinus; gr., basal or germinative layer of epidermis; ir., iris; l.c., lens cell; 7t.c., light cell.

As the papilla grows upward it raises the basal layer of the epidermis, making of it a cap, the enamel organ (e.o.). By continuous growth the cells of the enamel organ assume the high eubical type with their nuclei located toward the outer margin.

The cells of the enamel organ form a layer of enamel over the tip of the papilla; while the odontoblasts of the dermal papilla which lie most superficially are the first to lay down dentine. The first layer covers the tip and sides of the papilla lying immediately under the thin layer of enamel. Then the odontohlasts which are located deeper send out processes around which dentine is deposited. The canals thus formed for the processes themselves are the beginning of the dentinal canals and into them the protoplasmic processes of those odontoblasts lying still deeper will later enter as the formation of the dentine continues. Thus it is that the dentine produced from without inward becomes thickened, finally crowding the core of the papilla into narrow compass.

When a scale like the one descrihed above reaches the surface the epidermal layers are rubbed off from the tip, and the body of the scale then erupts. In a more mature embryo than the one here described many such seales erupt at about the same time and come to take up a definite arrangement in patterns in 


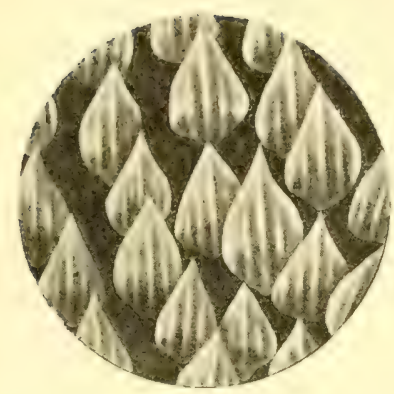

A

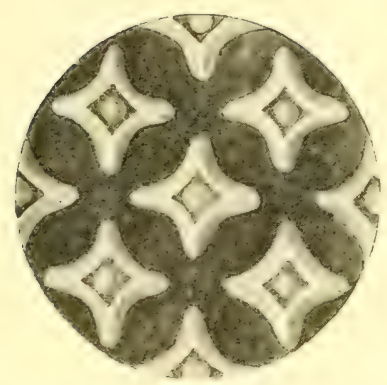

$\mathrm{B}$

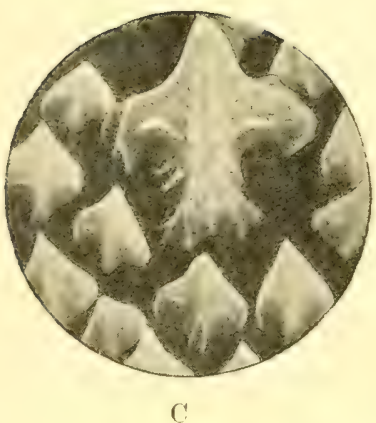

C

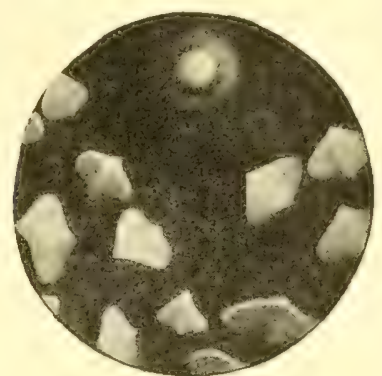

$\mathrm{D}$

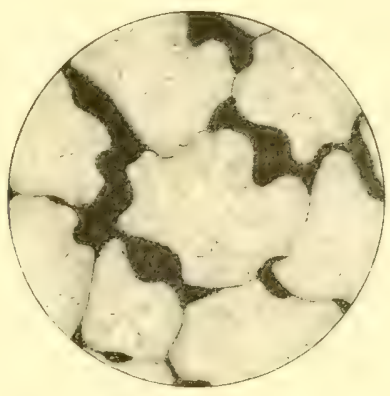

$\mathrm{E}$

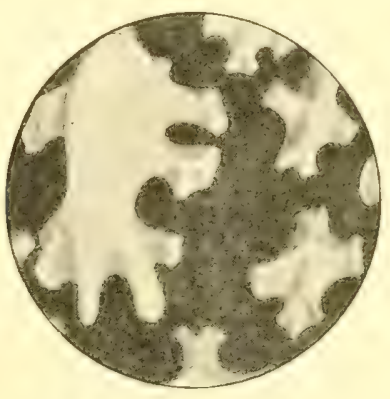

$\mathrm{F}^{*}$

Fig. 34. Scale patterns of Elasmobranchs. A. Mustelus californicus. (H. M. Gilkey, del.) B. Squaliolus. (From Smith.) C. Anchor scale. D. Stomodeal denticles. E. Flattened transitional seales. F. Nodules from fin margin. (C-F, Heterodontus francisci. Duncan Dunning, del.) 
general like that of Heptanchus. In some, however, a pattern exists only over limited areas. In others the scales may be confined to rows along the back, or, in addition to this arrangement, they may be scattered more or less promiscuously over the body, as they are in some of the rays. In other rays integumentary scales may be entirely lacking (Myliobatis, Trygon).

The individual placoid seale may bear but a single spine as in Mustelus californicus (fig. 34A), Carcharias, Pristiophorus. Or it may be tricuspate, multitudes of scales covering the surface as in Heptanchus (fig. 27 A), Scyllium, Zygaena, Pristiurus, and Pentanchus. The scales may be found in geometrical exactness and beauty as in Squaliolus (fig. 34B), or they may present various designs from a simple spade-shape to the anchor scale (fig. $34 \mathrm{c}$ ) or to the complex Greek cross of Heterodontus. The gross anatomy of the type described for Heptanchus may be taken as an example of more or less generalization.

\section{FINER ANATOMY OF SCALE}

A section through a placoid scale of Scymnus (fig. 35) illustrates the finer structure characteristic of the Elasmobranch scale. In such a section the erest surmounting the main body continues hackward to the spine. The base is rela-

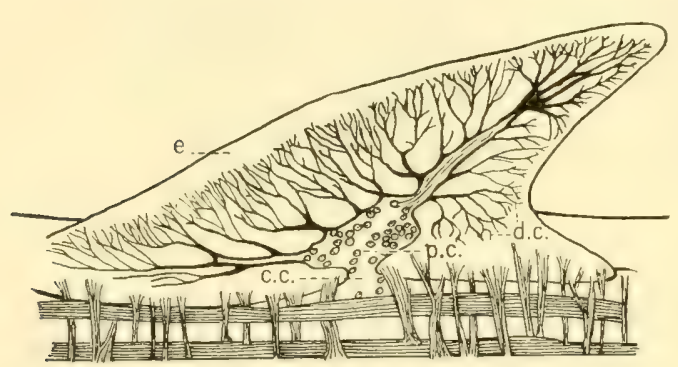

Fig. 35. Sagittal section showing finer anatomy of placoid scale, Scymnus lichia. (From O. Hertwig.)

c.c., central canal; d.c., dentinal canals; e., enamel; p.c., pulp cavity.

(d.c.) extend into the dentine. The enamel (e.) surrounding the exposed part and sinking slightly into the integument is much better developed anteriorly than it is posteriorly.

Considerable doubt has been raised as to whether or not the so-called enamel of the placoid scale and of the tooth of the Elasmobranchs is in fact comparable to the enamel of the teeth of higher forms. The studies thus far made show that the enamel formed in the Elasmohranch fishes presents a variety of trpes. In the rays it appears to be in all essential respects true enamel; in some of the sharks the evidence is not so clear. That the dentinal tubules in a type like Galeus may be traced far into the outer layer shows that there is here no clear demareation between dentine and enamel. For the present, then, we may think of the harder outer layer of the seale in some of the Elasmobranchs as composed of a substance just beginning to differentiate into true enamel. 


\section{MLODIFICATION OF SCALES}

By a peculiar hypertrophy modifications may arise which, although essentially like the primitive shagreen denticles in structure, greatly differ from them in form. Such hypertrophy may result in the production of a fin spine like that in Heterodontus (fig. 88) and the Spinacidae; a tooth like that in the sawfishes, Pristis (fig. 38) and Pristiophorus; a sting like that in the sting rays (fig. 42); or it may result in other variously modified structures, such for example as the branchial rakers in Cetorhims (fig. 44) and Rhinodon.

\section{Fin Spine}

In some of the types in which fin spines are present they are so rudimentary as to be but little larger than enlarged scales, as exemplified in Centroscymmus. In others, as in Heterodontus (fig. 88) and Acanthias, they are pronounced structures. In general, they are located just anterior to the dorsal fins, the posterior one (fig. 36 ) being longer than the anterior. For almost half its length the spine is buried in the integument. The buried part is designated as the root or base and the exposed portion the crown or spine proper.

If such a structure be removed and more closely studied, its deeply imbedded base is seen to be triangular in shape. The spine contains a large central cavity which when in place fits over a cartilage of the fin skeleton. The walls of the spine are made of dentine which in the crown consists of a double layer. The more superficial layer is bounded anteriorly and laterally by a layer of enamel, but enamel does not extend over the posterior groove which fits close

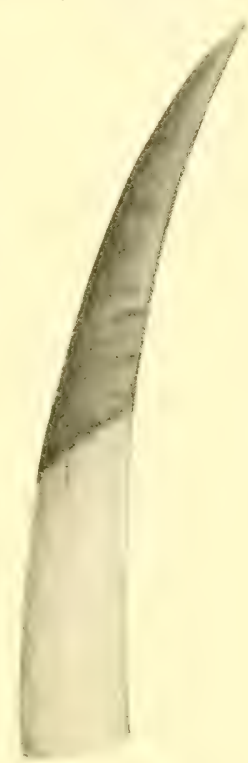

Fig. 36. Second fin spine, Squalus suchlii. up against the basal cartilage of the fin skeleton. A more or less compact layer: of pigment ( $\mathrm{pg}$., fig. 40) separates the enamel (e.) in front from the layer of dentiné $(d$.$) .$

The development of such a fin spine is of considerable interest. Figure $37 \mathrm{~A}$ represents a sagittal section of an early stage of Acanthius in which a mass of the epidermis (ep.) has sunk into the dermis, just in front of the dorsal fin. The bounding layer of this section becomes the enamel organ (e.o.). The formation of the enamel of the spine, and of a part of the dentine, is singularly modified by the peculiar position of this organ. It will be observed that the enamel organ here covers only the anterior upper part and sides of the developing spine, instead of forming a cap over the entire structure as it does in a placoid scale. As a result enamel is present only on the front and sides of the crown, little being produced posteriorly (e., fig. 40). The odontoblasts (od., fig. $37 \mathrm{~A}$ ) just under the enamel organ lay down dentine so that these two layers so far as they go are like the enamel and dentine of a common placoid scale, but the greater mass of dentine is formed back of this dentine. 
Markert (1896) says that in the formation of this secondary dentine certain long fibers ( $f s$., fig. $37 \mathrm{~A}$ ) grow down in a sheath posterior to the core of cartilage (ct.). These fibers penetrate deeply and near the base spread out, curve forward, and fuse anteriorly into a closed ring. Now this posterior sheath of fibers runs through the odontoblasts in such a way as to leave some of them in

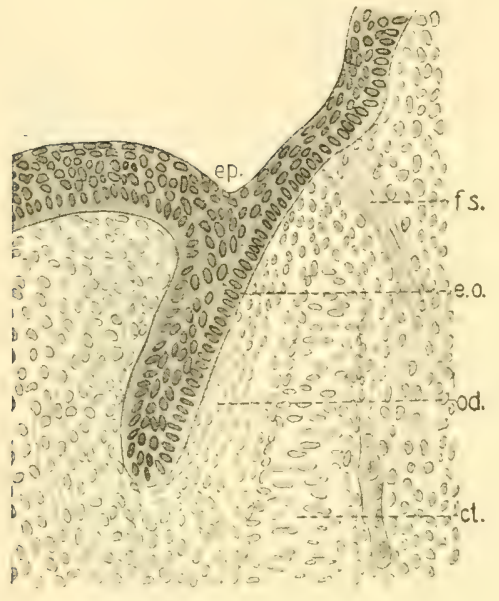

A. Young stage

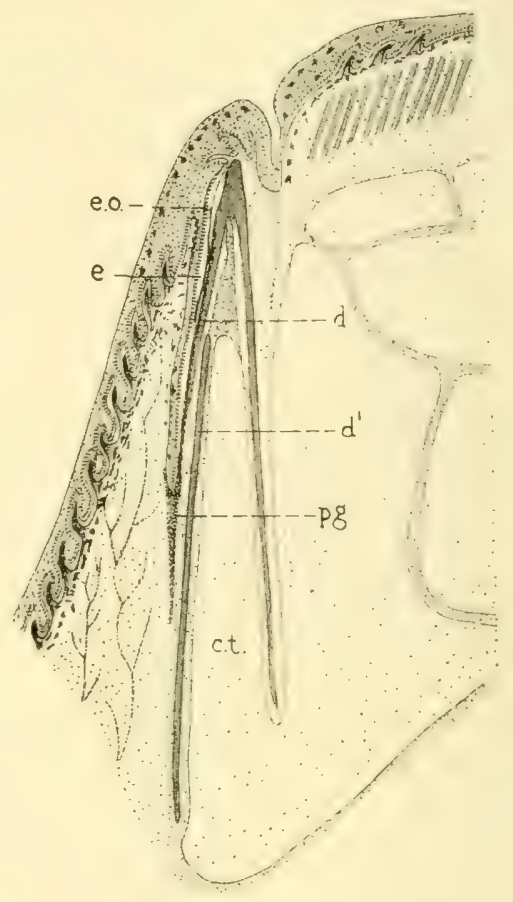

B. Older stage

Fig. 37. Development of fin spine, Acanthias. (From Markert.)

ct., core of cartilage; $d$. , primary dentine; $d$. , secondary dentine; e., enamel; e.o., enamel organ; ep., epidermis; $f s_{\text {. }}$, connective tissue fibers; od., odontoblast; pg., pigment.

front of it and others behind it. Both of these sets of odontoblasts lay down dentine so that the fibers $(f s$.$) come to lie between two layers of dentine.$ Finally the fibers themselves also give place to dentine. Hence a transverse section of this secondary dentine, taken at the base of the spine where the sheath of fibers is closed into a ring, shows a heavy circle of secondary dentine like the broad band around the core of cartilage ( $d^{1}$, fig. 40$)$; a similar transverse section taken toward the tip would indicate the layer of dentine as a crescent just back of the central core. 


\section{SAW 'T'OOTH}

A secondary form of hypertrophy is seen in the saw tooth of the sawfishes. Here the teeth are arranged along both edges of the saw (rostrum) as greatly modified scales. In the specimen from which figure 38 was taken the teeth were asymmetrical, 26 teeth being present on the left edge of the saw and 27 on the right. In the larger saws, some of which may reach a foot in width and six feet in length, the crown of the tooth may reach four inches in length and the teeth become most formidable organs of offense.

A sagittal section through an adult saw tooth according to Engel (1910) shows that the core of the tooth, unlike that of the spine, becomes converted into long columns of vasodentine, and a transverse section through this dentine near the tip also demonstrates numerous canals around which the dentine is formed and through which blood vessels pass (see section through tooth, p. 131, fig. 129).

A saw tooth erupting from the side of the rostrum (fig. 41) presents something of the appearance of a developing fin spine of Acanthias, but with one difference. The saw tooth arises directly through the mass of invaginated epidermis (ep.) and hence the posterior part is more completely surrounded by an enamel organ $(e .0$.$) . It follows that there is a layer of enamel$ over that part of the saw tooth just as there is over the placoid scale.

A transverse section through the saw tooth near its tip (fig. 39) shows that, like the fin spine of Acanthias, it is more or less flattened posteriorly. The central part of the immature tooth is occupied by the enlarged pulp cavity containing blood vessels and numerous odontoblasts. Just outside of the pulp eavity is the layer of dentine $\left(d .^{\prime}\right)$, superficial to which is the thimner

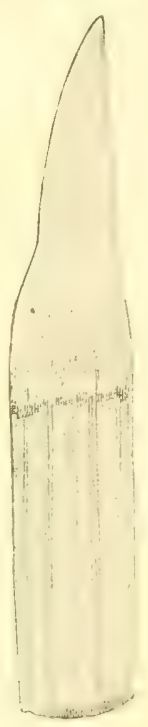

Fig. 38 .

Saw tooth of Pristis antiquorum band of enamel or vitrodentine $(e$.$) . The tissues outside of the enamel organ$ (e.o., fig. 41) do not take part in the production of the saw tooth. They are to be looked upon as the intermediate and superficial layers of the epidermis.

\section{STING}

A third form of hypertrophy occurs as the variously formed defensive organs of the sting rays (fig. 42). Here a spine arising from the dorsal part of the tail grows backward, varying greatly in size and in complexity. In the small sting ray Urolophus this spine is but two inches in length; while in the larger types. as in Myliobatis, it may reach a length of four or five inches. Usually the sting or spine is simple, but it may be compound, numerous spines arising one behind the other. Simple or compound, each spine is provided with a sharp point, and its sides have smaller and recurved hooks arising from them. 


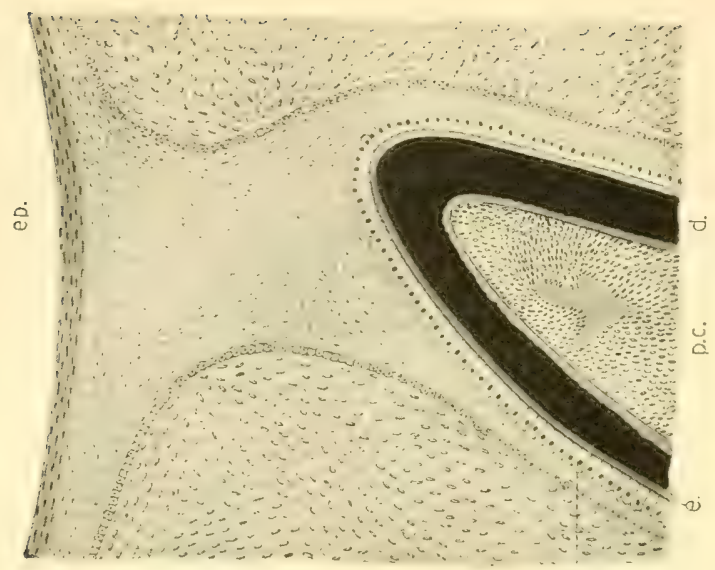

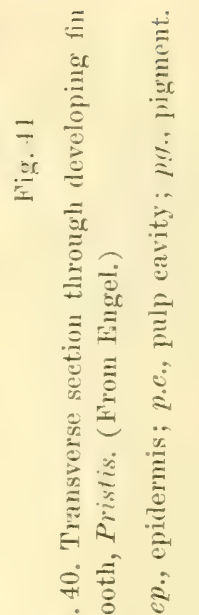
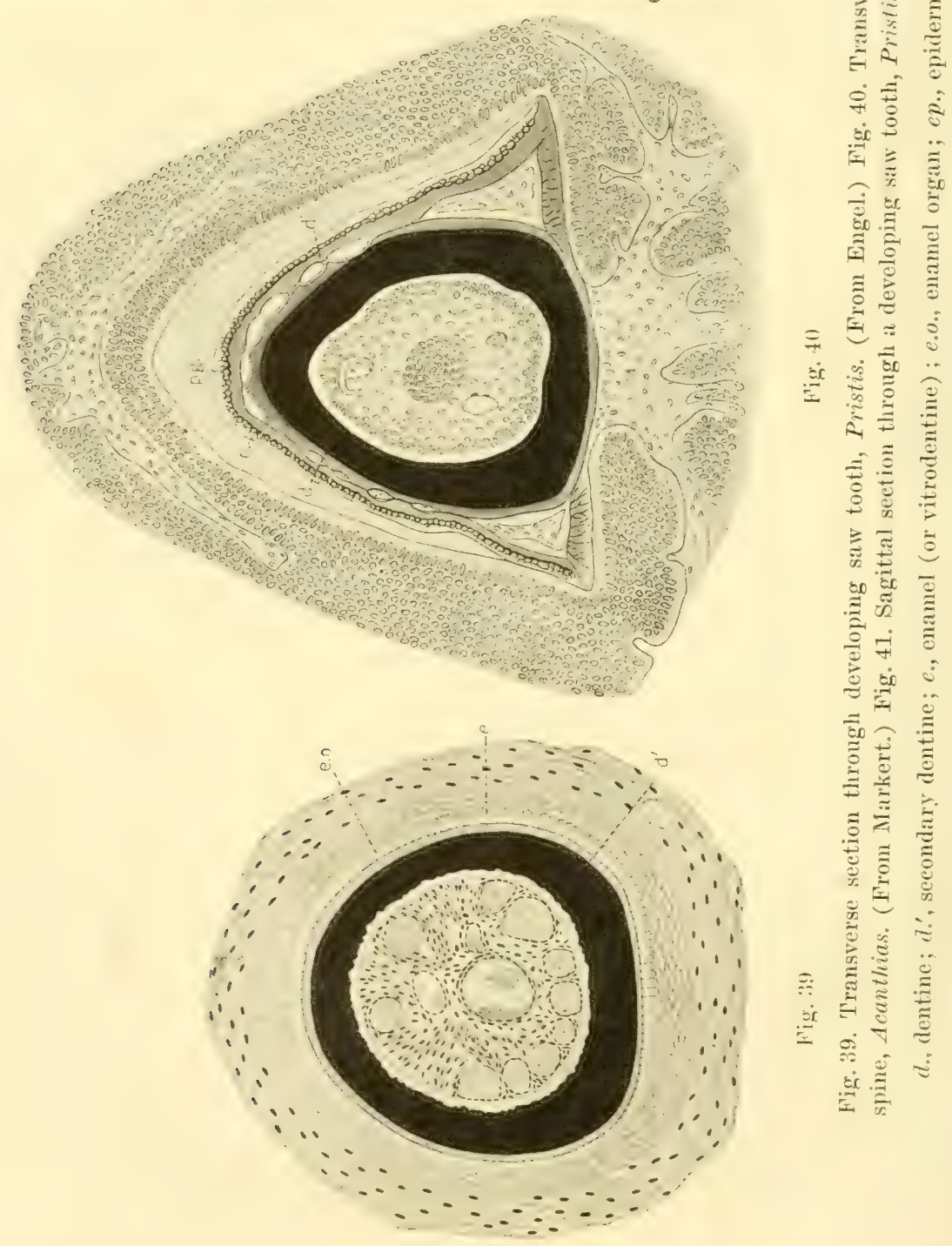
A transwerse section through the sting of Urolophus (p. 29, fig. 32) shows that it is convex dorsally. The ventral side consists of right and left plane surfaces separated by a median ventral ridge. Both the plane surface and the convex dolsal sides are covered with a thin layer of enamel (e.) under which is the thick dentine (d.). But the dentine here is arranged differently from that of the placoid scale.

Figure 43 is drawn from the dorsal side of a sting and represents it as a transparent object. In it may be observed numerous longitudinal and anastomosing canals (c.) surrounded by heavy dentine (d.). This arrangement of canals is much like that which we have observed in the saw tooth of Pristis.

The sting is clearly a protective structure. In those rays in which it is attached nearer the body, as in Myliobatis, it is more effective than in types like Dasyatis, in which it is located farther out on the tail. In either type, the sting is brought into action by thrusting the tail upward and forward orer the back. In the thrust the weapon is driven forward with precision and force, and is removed with great difficulty from the wound, the recurved hooks (sp.) forming a most painful tearing surface unless the sting can be pushed entirely through.

\section{Gill Rakers}

In some forms, structures located on the pharyngeal walls of the internal branchial arches have undergone modification into gill rakers, such, for example, as are seen in

Fig. 42. Squalus suchtii (p. 154, Sting of sting ray. fig. $147, g r$.$) . These gill$ rakers evidently serve as strainers to prevent food from passing out with the respiratory current. Structures somewhat like these in function but very unlike them in form have become remarkably specialized in Cetorhinus maximus (fig.4t) and in Rhinodon typicus, in which they form a highly complexstraining apparatus. Each raker in Cetorhinus arises from a semilumar base and extends as a long slender filament across the internal branchial aperture (figs. 44 and 148).

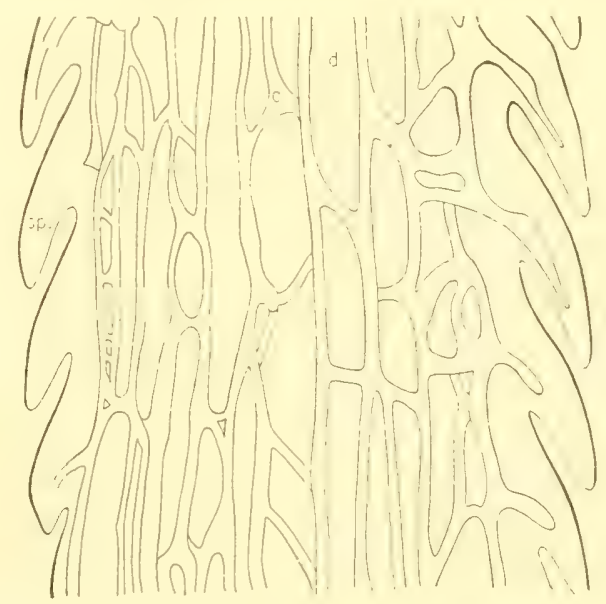

Fig. 43. Segment of sting, Urolophus halleri, seen as transparent object. Dorsal riew. (A. M. Paden, orig.)

$c .$, canals of sting; $d$., dentine; sp., recurved spine on sting.

It has long been known that one of these filaments with its adjoined base is structurally like a placoid scale. In a section through the base numerous den- 
tinal canals appear which are essentially like those of the scale. Superficially the filament is surrounded by a more compact layer, but structurally it is similar to the base. The central canal of the filament is surrounded by a "nonvascular dentine" in which there is a network of dentinal canals.

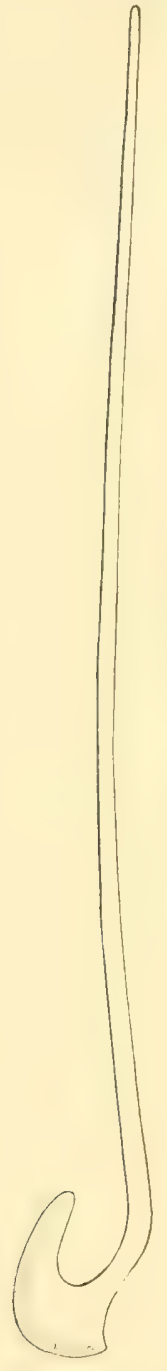

.Fig. 44.

Gill raker of Cetorhinus maximus.

(From Hendrieks.)

\section{Stomodeal Denticles}

The stomodeal denticles are also modified scales, although it may be more correct to speak of them as atrophied rather than hypertrophied. These denticles may be abundant over the larger part of the buccal and pharyngeal walls as well as over the branchial arches (Heterodontus, fig. 34D), or they may be present in the buccal cavity and restricted to the hyoid and first branchial arches (Squatina), or they may be confined to the pharyngeal margins of the branchial arches (Alopias vulpes). In certain types they are rudimentary (Squalus sucklii) and in others they have ceased to be developed altogether (Scyllium canicula).

It has been suggested that the denticles may serve to hold and to a slight extent to grind food, but it seems more probable that they are structures which, because of their location and origin, are without pronounced function, and hence are usually vestigial (see Chapter V). This is indicated by the fact, as Imms (1905) has suggested, that whether the food be hard or soft they develop equally well (as in Galeus, and Mustelus). Furthermore, like vestigial structures they often appear much later than do the seales of the body (Carcharias).

\section{Teeth as Modified Scales}

The most important structures, however, with which placoid scales are associated are the teeth. In a type like Acanthias, in which these are sharp pointed, superficial resemblance between the two is more or less pronounced. In a continuous section cutting through both the scales and the teeth it has been observed that the scales outside of the buceal region have their spines projecting backward, while those within the mouth may have their spines in a reverse direction, and still be pointing backward. Some of the transitionals between the two regions, however, possess both an anterior and a posterior spine, and hence are so generalized that the retention of the latter projection would result in a scale, its loss would result in the formation of a tooth.

In other Elasmobranchs, little outward similarity between tooth and scale is seen. Such is in part true of the immense tooth of Carcharodon (see p. 129, fig. 127); especially is it true of many of the plate-like crushing or pavement teeth like those of Myliobatis (p. 128, fig. 126в). Invariably, however, the two are essentially identical in nature. For a further consideration of the teeth, see Chapter V. 


\section{BIBLTOGRAPHY}

\section{Chapter II}

1874. Agassiz, L., Three Different Modes of Teething among Selachians. Amer. Nat., Vol. 8, pp. 129-135.

1875. Baliwill, F. H., Teeth of Sharks. Zoologist, Ser. 2, Vol. 10, pp. 43-45.

188. Benda, Carl, Die Dentinbildung in den Hautzähnen der Selachier. Areh. mikr. Anat., Bd. 20, pp. 246-270, Taf. 16.

1858. Brackel, Gregorius A., De cutis organo quorundam animalium ordinis Plagiostomorum disquisitiones microscopicae. Inaug. Diss., Dorpat, 1858, pp. 1-54, pl. 1.

1909. Brohl, Engeliert, Die sogenannten Hornfäden und die Flossenstrahlen der Fische. Jena. Zeitselır. Naturwiss., Bd. 45 (N. F. 38), pp. 345-380, Taf. 28-29, 5 text figs. Also: Inaug. Diss. Jena, pp. 1-36, 5 text figs.

1900. Burcifardt, Rud., On the Luminous Organs of Selaclian Fishes. Anm. Mag. Nat. Hist., Ser. 7, Vol. 6, pp. 558-568, 8 text figs.

1906. Burcknardt, Rud., Die Entwickelungsgeschichte der Verknöcherungen des Integuments und der Mundhöhle der Wirbeltiere. Hertwig's Handb. vergl. u. expt. Entwiek. d. Wirb., Bd. 2, Teil 1, pp. 349-462, text figs. 208-263.

1896. Cocco, Luigi, Studi sui denti dei Plagiostomi con Note palaeontologisehe. Atti Acad. Sci., Acireale (n. s.), Vol. 7, Classe Scienze, pp. 3-25.

1914. Daniel, J. Frank, The Anatomy of Heterodontus francisei. I. The Exoskeleton. Univ. Calif. Publ. Zool., Vol. 13, No. 6, pp. 147-166, pls. 8-9, 4 text figs.

1910. Engel, Heinrich, Die Zähne am Rostrum der Pristiden. Zool. Jalırb., Bd. 29 (Abt. Anat. u. Ontog.), pp. 51-100, pls. 3-6, 2 text figs. 1909, Diss. Giessen, pp. 1-47, 2 text figs.

1915. Fahrenholz, Curt, Ủber die Verbreitung von Zahnbildung und Sinnesorganen im Vorderdarm der Selachier und ihre phylogenetische Beurteilung. Jena. Zeitschr. Naturwiss., Bd. 53, pp. 389-444, Taf. 6-7, 7 text figs.

1904. Goodrich, E. S., On the Dermal Fin-Rays of Fishes-Living and Extinet. Quart. Jour. Mier. Sei., Vol. 47, pp. 465-522, pls. 35-41, 6 text figs.

1907. GooDrICH, E. S., On the Seales of Fishes, Living and Extinet, and their Importance in Classification. Proe. Zool. Soe. Lond., 1907 (2), pp. 751-774, pls. 43-46, text figs. $196-204$.

1868. Hannover, A., Recherches sur la structure et le développement des écailles et des épines chez les poissons cartilagineux. Ann. Sei. Nat. Zool., Sér. 5, T. 9, pp. 373-378.

1868. Hannover, A., Om Bygningen og Udviklingen af Skjael og Pigge hos Bruskfisk. Dansk. Vid. Selsk. Skr., Ser. 5, Vol. 7, pp. 483-529, tav. 1-4, 3 text figs.

1850. Harless, E., Ueber den Zahmbau von Myliobatis und dem verwandten Roehen Trikeras. Abh. math.-phys. Kl. Bayer Akad. Wiss., Bd. 5, Abt. 3, pp. 841-876.

1873. Heincke, F., Untersuchungen über die Zähme niederer Wirbelthiere. Zeitschr, wiss. Zool., Bd. 23, pp. 495-591.

1908. HeNDRICKs, K., Zur Kenntnis des gröberen und feineren Baues des Rausenapparates an den Kiemenbögen von Selache Maxima. Inaug.-Diss., Münster, pp. 3-89, pls. 18 19,5 text figs.

1874. Hertwig, Oscar, Ueber Bau und Entwickelung der Placoidschuppen und der Zähne der Selachier. Jena. Zeitsehr. Naturwiss., Bd. 8 (N. F. 1), pp. 331-404, Taf. 12-13.

1905. Ixms, A. D., On the Oral and Pharyngeal Denticles of Elasmobranch Fishes. Proc. Zool. Soc. Lond., Vol. 1905 (1), pp. 41-49, pl. III. 
1897. Jentsch, B., Beitrag zur Entwicklung und Struktur der Selachierzälıne. Diss. Leipzig, 38 pp., 2 Taf.

1899. Johand, L., Über eigenthümliehe epitheliale Gebilde (Leuehtorgane) bei Spinax niger. Zeitser. wiss. Zool., Bd. 66, pp. 136-160, Taf. 10-11.

1890. KuaAtsch, H., Zur Morphologie der Fischschuppen und zur Geschichte der Hartsubstanzgewebe. Morph. Jahrb., Bd. 16, pp. 97-202, Taf. 6-8, 209-258.

1894. Kuantsch, H., Ưber die Herkunft der Seleroblasten. Ein Beitrag zur Lehre ron der Osteogenese. Morph. Jahrb., Bd. 21, pp. 153-240, pls. 5-9, 6 text figs.

1901. KopPEN, HerManN, Ueber Epithelien mit netzförmig angeordneten Zellen und über die Flossenstacheln von Spinax̃ niger. Zool. Jahrb. (Abt. Anat. u. Ontog.), Bd. 14, pp. 477-522, pls. 38-40, 1 text fig.

1905. KwIETNiewski, C., Ricerehe interno alla struttura istologica dell' integumento dei Selachi. Padova, 156 pp., 6 tav.

1900. LaAser, PaUl, Die Entwickelung der Zahnleiste bei den Selachiern. Anat. Anz., Bd. 17, pp. 479-489, 8 text figs.

1903. LaAser, Paul, Die Zahnleiste und die ersten Zahnanlagen der Selachier. Jena. Zeitschr. Naturwiss., Bd. 37, pp. 551-578, Taf. 28, 13 text figs.

1852. LeYdig, Franz, Beiträge zur mikroskopisehen Anatomie und Entwicklungsgeschichte der Roehen und Haie (Leipzig), pp. 1-127, pls. 1-4.

1903. Lexdig, F., Bemerkung zu den Leuehtorganen der Selachier. Anat. Anz., Bd. 22, pp. 297-301.

1885. List, J. H., Über einzellige Drüsen (Becherzellen) in Cloakenepithel der Rochen. Zool. Anz., Bd. 8, pp. 50-51.

1885. List, J. H., Über einzellige Drüsen (Becherzellen) in der Oberhaut von Torpedo marmorata. Zool. Anz., Vol. 8, pp. 388-389.

1874. Lutken, Chr., Sur les différences dans la dentition que présentent, selon le sexe, les Raies (Raja) qui habitent les côtes du Danemark. Jour. Zool. (Gervais), T. 3, pp. 318321. Rerue: Arch. d. Zool. exper, et gén., Sér. 1, T. 3, pp. xxi-xxiii.

1896. Markert, F., Die Flossenstacheln von Acanthias. Ein Beitrag zur Kenntnis der Hartsubstanzgebilde der Elasmobranchier. Zool. Jahrb. (Abt. Anat. u. Ontog.), Bd. 9, pp. 665-722, pls. 46-49, 10 text figs.

1895. Maurer, F., Die Epidermis und ihre Abkömmlinge. Leipzig. 355 pp., pls. 1-9, 28 text figs. W. Engelmann.

1839. OWEN, R., Researehes concerning the Structure and Formation of the Teeth of the Squali, with a New Theory of the Development of the Teeth. London. $4^{\circ}$. Transl. in C. R. Acad. Sei. Paris, T. 9, pp. 784-788; Ann. Sei. Nat. Zool., Sér. 2, pp. 209-229.

1840-45. Otwen, R., Odontography. Vol. 1. London.

1911. Oshima, H., Some Observations on the Luminous Organs of Fishes. Jour. Coll. Sei. Tokyo, Vol. 27, Art. 15, pp. 1-25, pl. 1, 4 text figs.

1896. Ridewood, W. G., The Teeth of Fishes. Nat. Sci., Vol. 8, pp. 380-391, 22 text figs.

1900. Ritter, P., Beiträge zur Kenntnis der Stacheln von Trygon und Acanthias. Diss. Rostock. Inaug. Diss., Berlin. I-VI, pp. 1-56, pls. 1-6.

1894. Röse, C., Ueber die Zahnentwicklung der Fische. Anat. Anz., Bd, 9, pp. 653-662, 8 text figs.

1894. Röse, C., Ueber die Zahnentwicklung von Chlamydoselachus anguineus Garm. Morph. Arb., Bd. 4, pp. 193-206.

1898. Röse, C., Ueber die versehiedenen Abänderungen der Hartgewebe bei neideren Wirbeltieren. Anat. Anz., Bd. 14, pp. 33-69, text figs. 4-28.

1908. RYNBERK, G. van, Sur une disposition particulière dans le squelette cutané de quelques Sélaciens. Arch. Ital. Biol., T. 49, pp. 203-212, 12 text figs. 
1908. RYNBERK, G. VAN, Di una disposizione particolare nello scheletro eutaneo di alemi Selacei. Rend. Accad. Lincei Roma, Ser. 5, Vol. 17, pp. 137-146, 12 text figs.

1906. Spengel, J. W., In Beziehung auf Mund- und Sehlundzähne der Elasmobranchier. Zool. Anz., Bd. 29, pp. 332-333.

186i1. Steenstrup, M., Sur la différence entre les poissons osseux et les poissons cartilagineux au point de rue de la formation des écailles. Ann. Sei. Nat. Zool., Sér. 4, T. 15, p. 368 .

1913. Steinhard, Otto, Über Placoidsehuppen in der MIund- und Rachen-Höhle der Plagiostomen. Arel. f. Natur., Jahr 69, Bd. 1, pp. 1-46. Also: Inaug. Diss. Bern, 1902, pp. 1-50, Taf. 1-2.

1906. StudničKA, F. K., Ueber kollagene Bindegewebsfibrillen in der Grundsubstanz des Hyalinknorpels, im Dentin und im Knochengewebe. Anat. Anz., Bd. 29, pp. 334-344, 10 text figs.

1909. Studnǐ̌Ka, F. K., Zur Lösung der Dentinfrage. Anat. Anz., Bd. 34, pp. 481-502, 2 text figs.

1576. Touses, C. S., On the Development of the Teeth of Fishes. (Elasmobranehii and Teleostei.) Phil. Trans. Roy. Soe. Lond., Vol. 166 (1), pp. 257-267, pl. 31.

1594. Toxes, C.S., Upon the Structure and Development of the Enamel of Elasmobranch Fishes. Phil. Trans. Roy. Soc. Lond., Vol, 190B, pp. 443-464, pls. 17-18.

1898. Tonres, C. S., Upon Röse's Proposed Classification of the Forms of Dentine. Anat. Anz., Bd. 14, pp. 343-348.

1896. Treuenfels, Paul, Die Zähne von Myliobatis aquila. Inaug. Diss., Univ. Basel, pp. 1-34, pls. 1-2.

1849. Williamson, IV. C., On the Mieroseopic Structure of the Scales and Dermal Teeth of Some Ganoid and Placoid Fish. Phil. Trans. Roy. Soc. Lond., 1849, Pt. 1, pp. 435475 , pls. $40-43$.

1851. Willianson, W. C., Investigations into the Structure and Development of the Seales and Bones of Fishes. Phil. Trans. Roy. Soc. Lond., 1851, Pt. II, pp. 643-702, pls. $28-31$.

1892. Woopward, A. S., The Evolution of Sharks' Teeth. Nat. Sei., Vol. 1, pp. 671-675, 12 text figs.

1893. Woodward, A. S., On the Dentition of a Gigantic Extinet Species of Myliobatis from the Lower Tertiary Formation of Egypt. Proc. Geol. Soc. Lond., pp. 558-559, pl. 48. 


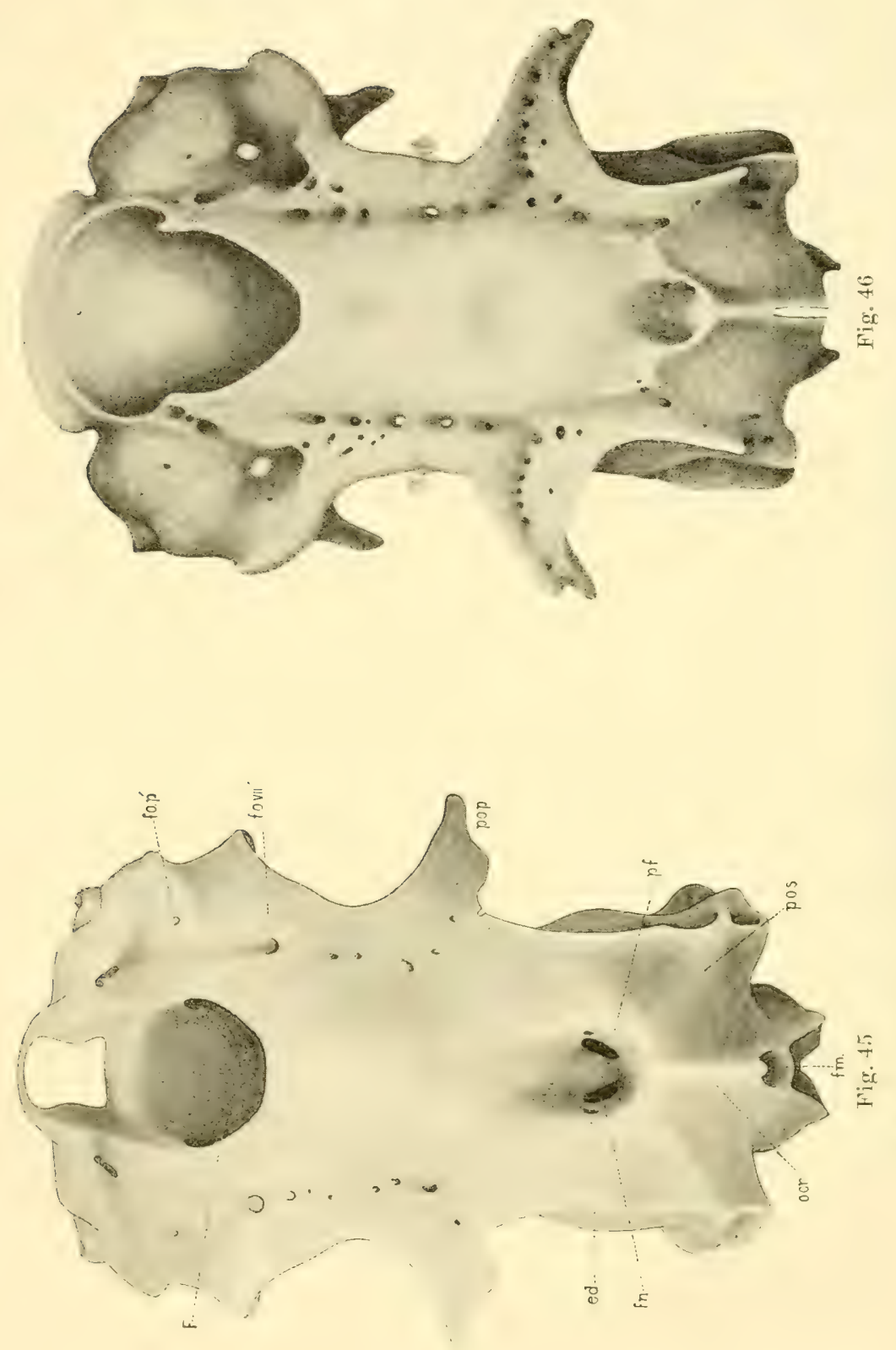




\section{ENDOSKELETON}

\section{ENDOSKELETON OF HEPTANCHUS MIACUATUS}

The endoskeleton in Heptanchus maculatus consists of a framework of relatively simple cartilage which serves as a protection for the various internal organs and at the same time acts as a support for the attachment of the musculature of the body. The cartilage of the axial part, the skull and the spinal column, is essentially like that of the appendages in that it has but little calcium deposited in it.

\section{Axial Śkeleton}

\section{SKULL}

The skull of Heptanchus maculatus is composed of (1) a relatively thin-walled cranium or brain case to which in the adult are fused the nasal and auditory capsules, and (2) a series of cartilaginous visceral arches which support the mouth and the pharyngeal region.

The cranium in dorsal view (fig. 45 ) is like a violin box, broadly pointed in front and almost square at the posterior margin. At the sides it is constricted, and back of these constrictions are the heavy postorbital processes (po.p.). In the middorsal line at the posterior margin of the cranium is a ridge, the occipital erest $(o . c r$.$) which lies posterior to a pit, the parietal fossa \left(p . f_{\circ}\right)$; from the bottom of the fossa the foramina for the endolymphatic duets $(e d$.$) and$ the fenestrae $(f n$.) lead to the ear. Inclosing the parietal fossa and pointed backward is faintly indicated a $\mathrm{V}$ produced by the two anterior oblique semicircular canals. This $\mathrm{V}$, together with a similar $\mathrm{V}$ produced by the posterior oblique semicircular canals (see p.o.s.) and inclosing the occipital crest posteriorly, roughly forms an hourglass. In front of the parietal fossa the roof is slightly convex and extends to a large dorsally placed opening, the anterior fontanelle $(F$.$) .$

On each side of the anterior fontanelle is a small foramen for the ophthalmicus profundus nerve $\left(f . o . p .^{1}\right)$, and at the sides of the posterior part of the fontanelle are two (or one) large openings (f.o.VII $I^{1}$ for the ophthalmic branch of the seventh cranial nerve. Running on a line posterior from this large opening and parallel to the margins of the indenture is a row of smaller foramina on each side, through which twigs of the same nerve pass.

It will be observed that the cranium of Chlamydoselachus in dorsal view (fig. 46) is much like that of Heptanchus.

In side view (figs. 47 and 48) projecting forward there are the elongated cartilaginous smpports for the rostrum, at the sides of which is the olfactory capsule (ol.c) for the nasal apparatus. The cartilages of the capsules are 
exceedingly thin-walled and open to the exterior by the nasal apertures. Surrounding the aperture is the arch-like nasal cartilage (n.c.). The optic capsule does not fuse with the cranium.

On each side at the posterior third of the cranium is the auditory capsule (a.c., fig. 47 ) in which the semicircular canals and the organs of hearing are located. Between the auditory and the nasal capsule is the large orbit for the eye. Overhanging this is the supraorbital crest (s.o., fig. 48), the anterior projection of which is the preorbital $\left(p r^{\circ} .0.\right)$, and the posterior one the postorbital process (po.o.). Ventral to the posterior part of the orbit the cranium bends sharply downward forming the basal angle (b.a., fig. 47). On the anterior face of the basal angle is a flattened articular surface against which the orbital process of the upper jaw plays. Anterior to the basal angle and extending from the margin of the cranium is an antorbital process (a.pr., fig. 47). This process is called by Allis (1923) and by others the ectethmoidal process.

Numerous foramina through which nerves and blood vessels course perforate the walls of the cranium. The first of these between the orbit and the nasal capsule is the anterior opening of the orbitonasal canal (o-n.), its posterior opening $\left(o-n .^{1}\right)$ lying in the anterior angle of the orbit. Above this opening is a smaller foramen for the anterior cerebral vein (f.a.c.). Ventrally and at the middle of the orbit is the large optic foramen $(f . I I)$ through which the second cranial nerve reaches the brain. Directly above it is the ophthalmic foramen through which the superficial ophthalmic branch of the seventh nerve $(f . o . V I I)$ leaves the orbit. A short distance ventral and anterior to this is a small opening through which the deep branch of the fifth nerve leaves the orbit. Posterior to the ophthalmic is the small trochlear foramen $(f . I V)$ for the fourth cranial nerve which passes to the superior oblique muscle of the eye. Behind the optic and below and slightly back of the tip of the postorbital process is the large orbital fissure (o.f.) ; through this the fifth, and a part of the seventh cranial nerves pass. The sixth nerve enters the orbit through its own foramen in the anteroventral margin of the orbital fissure. Below and slightly posterior to the orbital fissure is the facial foramen $\left(f . V I I^{3}\right)$ for the hyomandibular branch of the seventh nerve. On a line between the facial and the optic foramina are two perforations, the larger and posterior of which is for the interorbital canal (i.o.) by means of which the blood sinuses of the two orbits communicate. The other of these perforations $(f . r . a$.$) is for the entrance$ of the ramus anastomoticus artery. Above this is the small opening $(f . I I I)$ for the exit of the third cranial nerve to muscles of the eye.

\section{VISCERAL SKELETON}

The visceral skeleton is composed of a series of cartilaginous arches which more or less completely surround the buceal cavity and the pharynx. The mumber of these in Heptanchus (nine) exceeds that of any other present-day Elasmobranch. The arches may be divided into two groups. The first group comprises the mandibular and the hyoid arches, each of which is made up of two segments. The second group consists of seven hranchial arches which support 


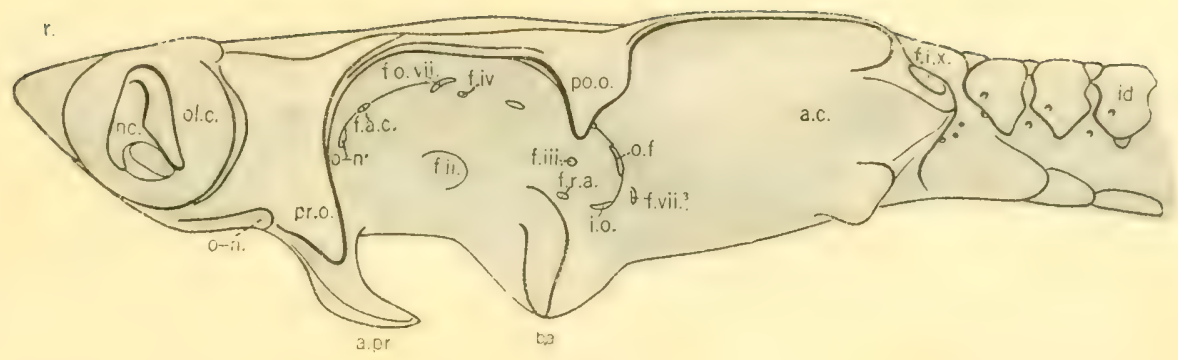

Fig. 47. Lateral view of cranium. Heptanclus maculatus.

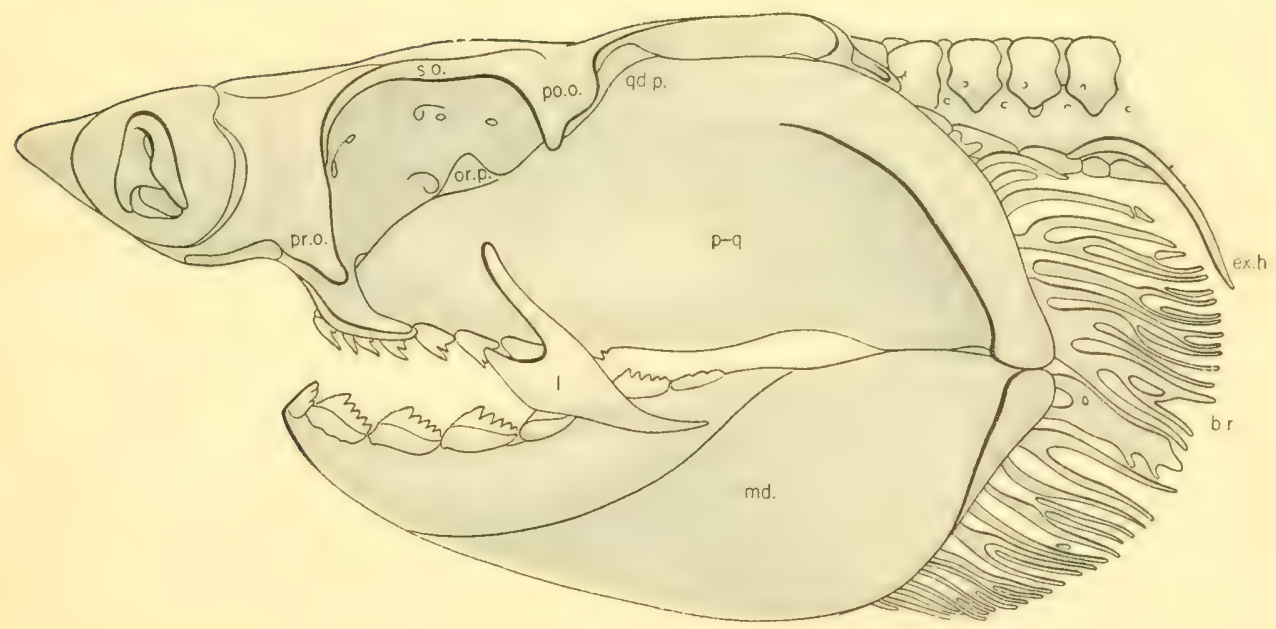

Fig. 48. Lateral view of skull, with branchial arches removed, Heptanchus maculatus. (Duncan Dunning, del.)

a.c., auditory capsule; a.pr., antorbital process; b.a., basal angle; b.r., branchial rays; ex.h., extrahyoid cartilage; f.II, optic foramen; f.III, foramen for oculomotor nerve; f.IV, trochlear foramen; $f . V I I^{3}$, foramen for hyomandibular branch of facial nerve; f.IX, foramen of glossopharyngeal nerve; f.a.c., foramen of anterior cerebral vein; f.o.VII, foramen for ophthalmicus superficialis nerve (leaving orbit) ; f.r.a., foramen for ramus anastomoticus artery; i.o., interorbital canal; $l$., labial eartilage ; md., mandible ; n.c., nasal cartilage; o.f., orbital fissure; $0-n$., anterior opening of the orbitonasal canal; $0-n .{ }^{1}$, posterior opening of the orbitonasal canal; ol.c., olfactory capsule; $p-q$. , palatoquadrate cartilage; po.o., postorbital process; pr.o., preorbital process; qd.p., quadrate process; s.o., supraorbital erest. 


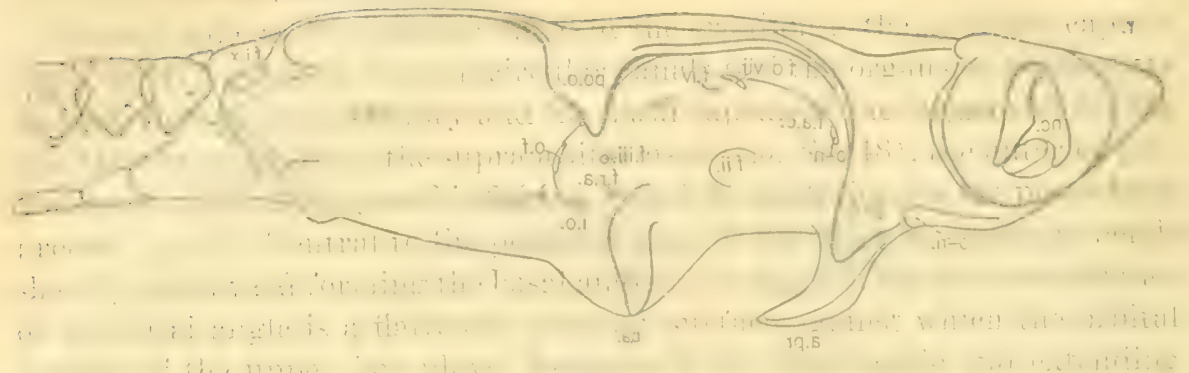

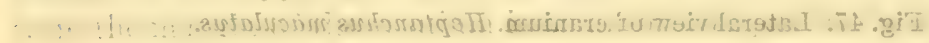

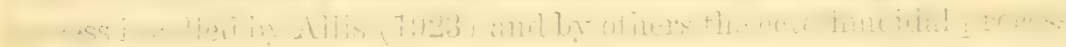

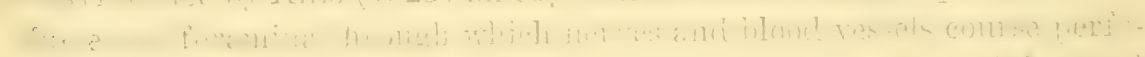

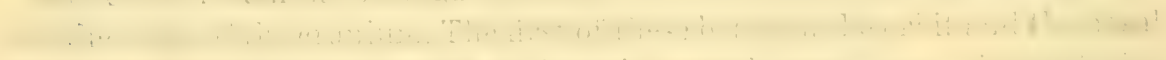

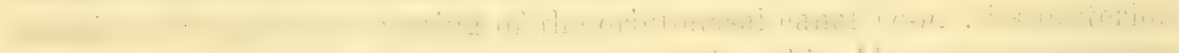

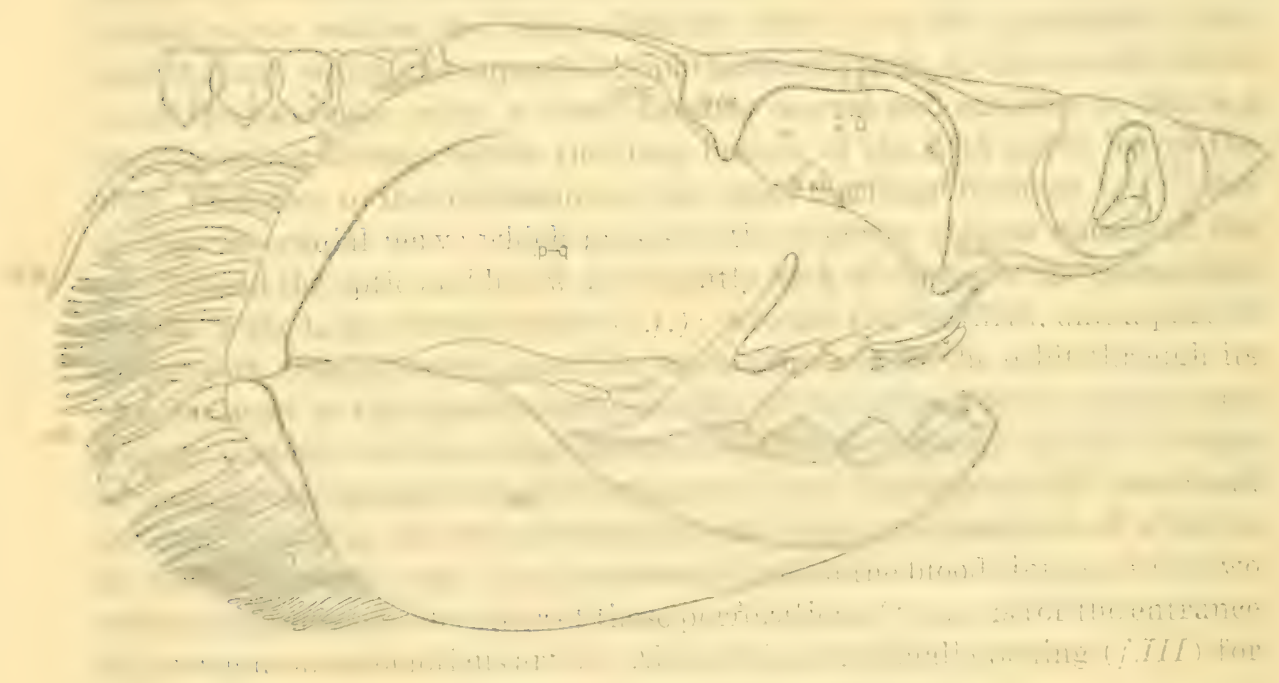

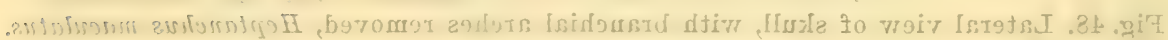

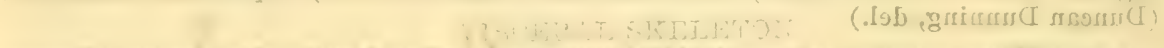

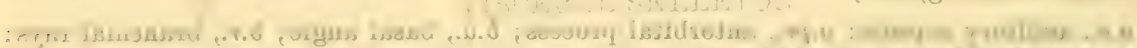

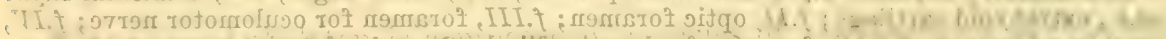

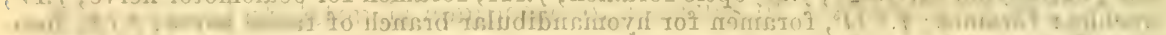

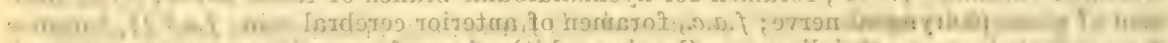

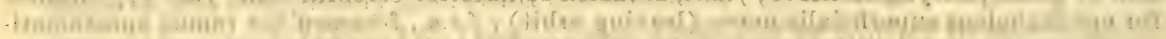

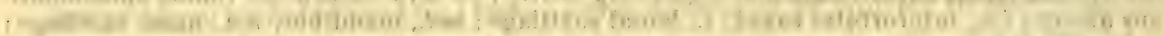

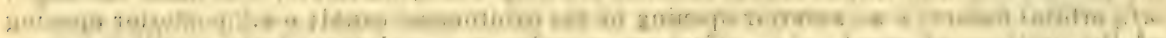

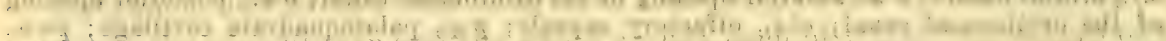

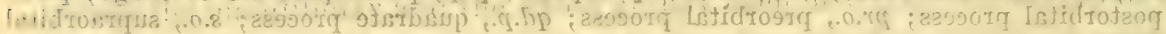
... 


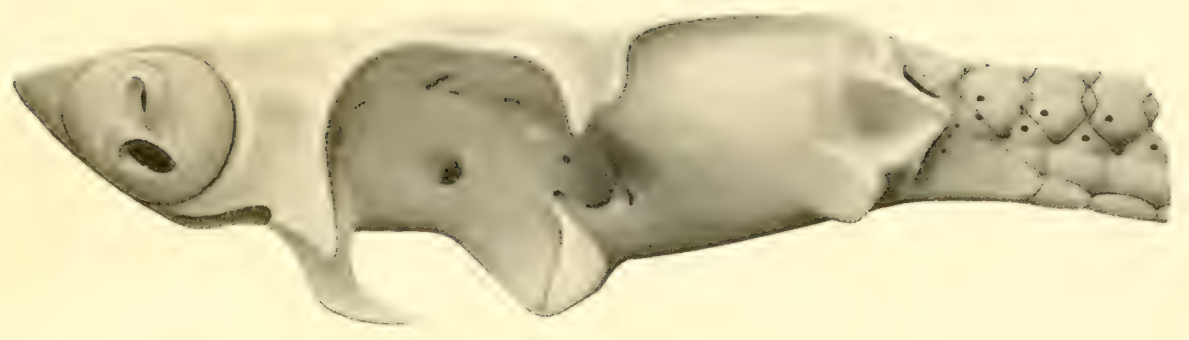

Fig. 4

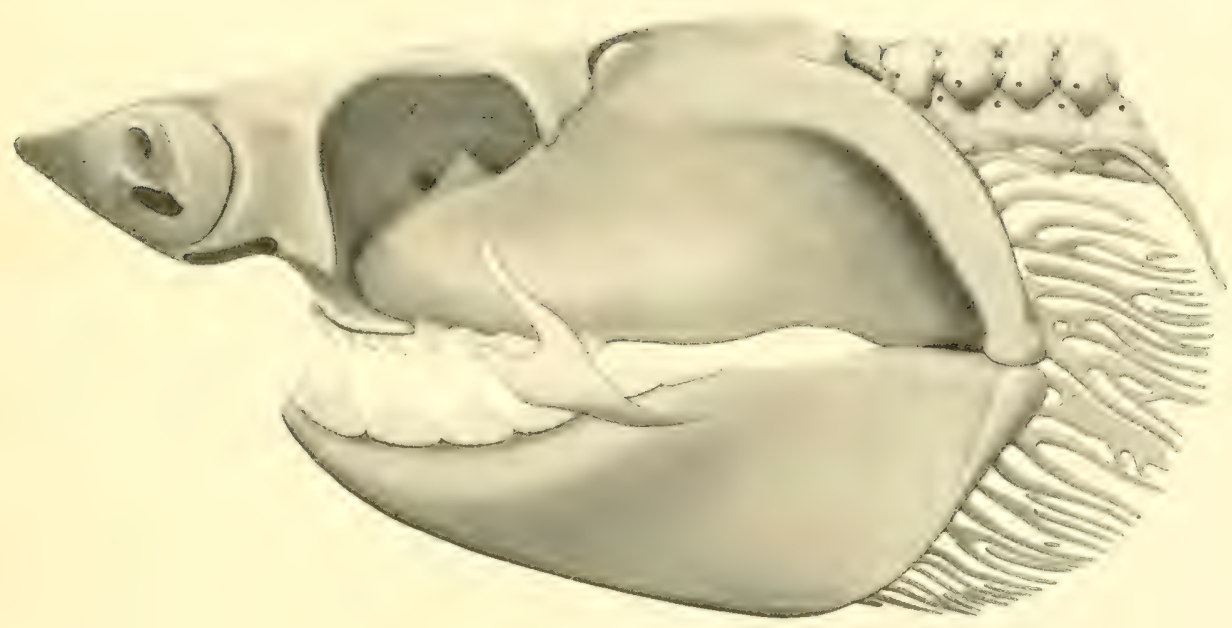

Fig. 48 

the walls of the pharynx. In plan the branchial arches are essentially similar to the first two, but in the branchial arches there are typically four segments to every arch; these segments differ among themselves in minor details.

The mandibular or first arch upon which the teeth are borne has become the most highly specialized of all the visceral arches. The massive upper palatoquadrate (pterygoquadrate) segment ( $p-q$. , fig. 48) of this arch is as large as the lower mandibular segment or Meckel's eartilage (md.). This arch in Heptanchus, unlike that in most sharks, is closely bound to the cranium in two places, giving the amphistylic type of attachment (amphi, both; stilar, pillar). Anteriorly this union with the cranium is effected by the orbital process of the quadrate coming in contact with the sides of the basal angle (b.a., fig.47). Posteriorly the union is produced by a strong quadrate process ( $q$ d.p., fig. 48) joining the postorbital process of the cranium (po.o.). The upper and lower segments of the left side are connected in front with similar segments of the right side, but this articulation in Heptanchus is loosely made. Posteriorly the upper and lower segments are joined to each other by a simple double joint, and made fast medially by pronounced ligaments.

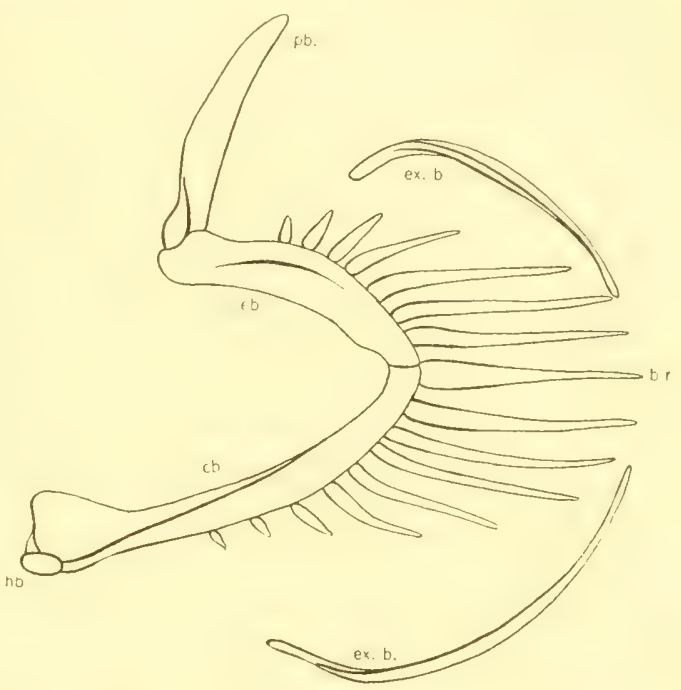

Fig. 49. First branchial arch, Heptanchus maculatus. b.r., cartilaginous branchial ray; $c b$, ceratobranchial; eb., epibranchial segment; ex.b., extrabranchial cartilage; $h b$., hypobranchial; $p b$., pharyngobranchial segment.

The hyoid or second visceral arch is, as we have said, composed of two segments. In Heptanchus these segments are slender and are entirely hidden in side view by the mandibular arch. The upper segment, unlike that in more highly specialized Elasmobranchs, is not a suspensorium for the mandibular arch; the lower segment is long and slender. Connecting the two ceratohyoids of opposite sides in the midventral line is an additional unpaired piece, the basihyal cartilage (bh., fig. 50A).

Both segments of the hyoid are provided with numerous cartilaginous rays (b.r., fig. 48) which support the main respiratory structures. These rays on the hyoid are considerably more complex than are similar cartilaginous rays found on the branchial arches.

The first branchial arch (fig. 49) may be taken as a type. Its segments, from the dorsal to the ventral side, are: (1) the pharyngobranchial $(p b),.(2)$ the epibranchial $(e b),.(3)$ the ceratobranchial $(c b$.$) , and (4) the small hypo-$ branchial $(h b$.$) , respectively. These segments slant obliquely forward and$ 
downward, the pharyngobranchial and ceratohranchial lying almost parallel to each other. All the branchial arches, except the last, are similar to the first. They differ from it, however, in that their hypobranchial segments are better developed. In the last areh a functional hypobranchial is lacking and the pharyngobranchial has fused dorsally with that of the sixth arch.

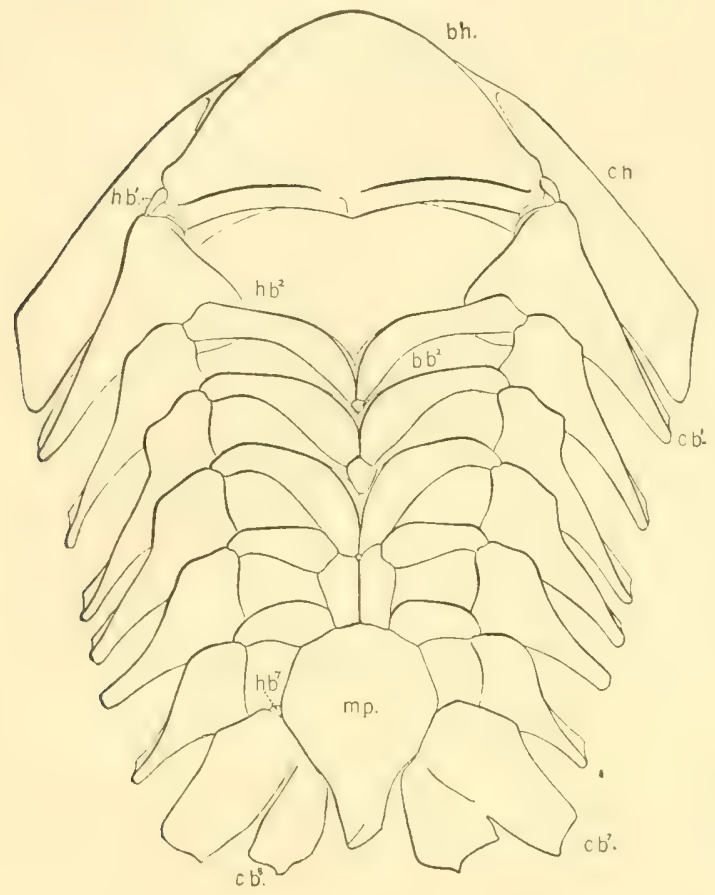

A

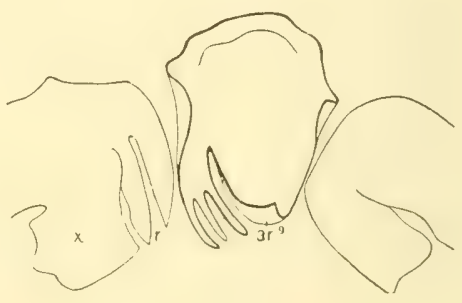

B

Fig. 50A. The median branchial cartilages, Heptanchus maculatus, dorsal view. (H. M. Gilkey, del.)

Fig. 50B. Area of rudimentary arehes, Heptanchus maculatus, ventral view.

$a r_{.}{ }^{9}$, ninth arch; $b b_{.}{ }^{2}$, second basibranchial; $b h$. , basihyoid; $c b$. , ceratobranchial; $c h .$, ceratohyoid; $h b .$, hypobranehial; $m p$. , median piece; $r_{.}$, rudimentary rays; $x$. , part of eighth arch.

In the midventral line of the branchial basket is a series of unpaired pieces which unite the arches of opposite sides. The first of these is the basihyoid previously mentioned ( $b h$., fig. 50A). A first basibranchial piece is lacking, but basibranchials are present on the second to the fourth arches following $\left(b b^{2-4}\right)$. A large median piece posteriorly ( $m p$.) serves for the attachment of the fifth and sixth hypobranchials and the seventh ceratobranchial $\left(c b .^{7}\right)$.

All these arches, except the last, have cartilaginous branchial rays on their epi- and ceratohranchial segments. These branchial rays, though simpler than those on the hyoid arch (b.r., figs. 48 and 49), serve the same function of supporting the gill septa.

The visceral arches are further provided with superficially placed piees, the extravisceral cartilages. Those accompanying the first or mandibular arch 
are the so-called labial cartilages (see fig. $48, l$.), a single one of which is found in Heptanchus maculatus. 'This is an irregular cartilage, interesting particularly because of its unusual development in this species. An extravisceral is present dorsally on the hyoid areh (ex.h., fig. 48), but none is present ventrally. Similar cartilages are found both dorsally and ventrally on all branchial arches except the last. The extrabranchial cartilages (ex.b., fig. 49) curve around the tips of the branchial rays as a protection and a support for the outer margins of the gill septa.

In addition to the arches above described there are, especially in some of the young specimens of Heptanchus, supernumerary rudiments of still other

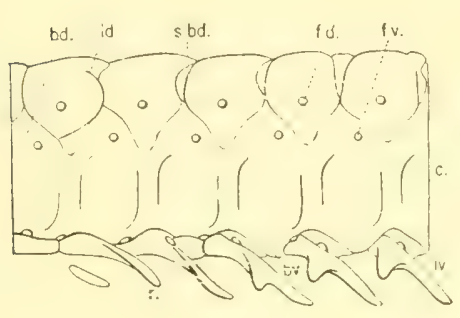

Fig. 51

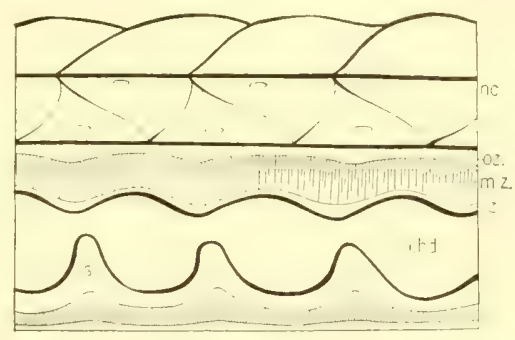

Fig. 52

Fig. 51. Fifth to eighth segments of the spinal column, Heptanchus maculatus.

Fig. 52. Sagittal section through sixth to eighth segments of the column.(H.M.Gilkey, del.)

$b d_{.}$, dorsal basal (basidorsal) plate; $b v$. , ventral basal (basiventral) plate; $c$. , central column; chd., unconstricted part of notochord; $f . d$., foramen for dorsal root nerve; $f . v$., foramen for ventral root nerve; h.a., haemal arch; $i d$. , dorsal interealary (interdorsal) plate; $i v$., ventral intercalary piece; $i z$. , layer immediately around the gelatinous notochord: m.z., middle layer in sheath of notochord; n.c., neural canal; oz., eartilage; $r .$, rib; s., septum constricting notochord; s.bd., so-called neural spine.

branchial arches. An eighth appears directly back of the last functional arch $\left(c b .{ }^{8}\right.$, fig. 50A $)$ and even a ninth arch may be indicated nearer the middle line $\left(a r^{9}\right.$, fig. 50B ), (Daniel, 1916).

\section{Spinal Columin}

The spinal column in Heptanchus, because of its simplicity, is especially interesting. Unlike that of the higher Elasmobranchs, it consists of a long central column (c., fig. 51) which is essentially the enlarged sheath of the notochord. Anteriorly the column is more or less continuous with the oceipital region of the cranium (see fig. 47) and posteriorly it extends to the tip of the tail. Above this central column there is a series of neural arches formed for the protection of the spinal cord; below it, in the region of the tail, is a similar series of haemal arches (h.a., fig. 53) for the protection of the caudal artery and vein.

A segment of the column in the so-called neck region shows the central part well developed. Above this central part are the neural plates making up the neural arch. Each arch is composed of a dorsal plate (bd., fig. 51) and a dorsal 
intercalary piece $(i d$.$) . Both of these cartilages are more or less triangular in$ shape, the former having its base on the centrum, the latter with apex pointing toward the centrum. Ahove the dorsal plate there may be pieces segmented off $(s . b d$.$) to form the so-called neural spines, and in the most anterior part of$ the column two such pieces may be present one above the other (fig. 47). Each dorsal plate in the anterior region is further perforated by a ventral root $(f . v$. ) of the spinal nerve, and each dorsal intercalary by the dorsal root ( $f . d$. of the same nerve.

In this region and ventral to the central column are also ventral plates (bv., fig. 51). On the third and succeeding vertebrae back to the forty-fifth, ribs $(r$.$) are present. The eighth to twenty-fourth ribs in Heptanchus, like$ some of those in Laemargus (Helbing, 1904, cited on p. 72), are divided into

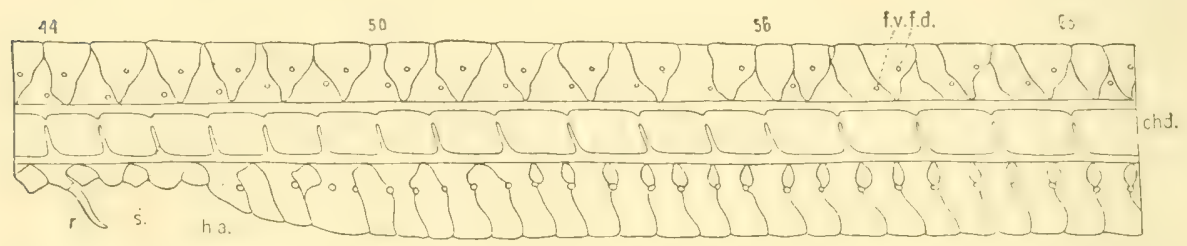

Fig. 53. Lateral view of spinal column in transitional area. Drawn as transparent object. (Katharine Rogers, orig.) (For explanation see fig. 52.)

an anterior and a posterior part, the former of which is a curious plate-like process projecting forward and downward. Between two ventral plates there is interpolated a small ventral intercalary piece ( $i v$.).

A sagittal section through this region (fig. 52) shows the central column composed of three concentric layers in the notochordal sheath. These layers surround the notochord (chd.) and constrict it at intervals into a bead-like chain. The outermost of these layers is relatively thin and consists of cartilage; within this cartilage is a second and lighter broad area (m.z., fig. 52) which appears to be made up of transverse fibers. Within this second layer and bounding the notochord is a third layer $(i z$. ) of a white tissue. At regular intervals the third layer forms septa $(s$.$) which produce the regular constric-$ tions in the central part of the notochord. It will be observed that the septa are more pronounced ventrally than dorsally and that they pass intracentrally.

In the midbody the central column assumes its simplest form. Here it consists essentially of a heavy and but slightly constricted sheath which if it be allowed to dry slightly gives greater evidence of constrictions. At about the fiftieth segment of this region (fig. 53) some of the dorsal plates extend entirely to the top of the arch so that no neural spines are present. Following these plates, and heginning at about the fifty-sixth segment two types of dorsal plates obtain, one of which is high, the other much lower. The higher is perforated by the ventral root of the nerve; the lower is imperforate. The higher plate is followed by a dorsal intercalary plate, perforated by the foramen for the dorsal root nerve. In the region beyond the fifty-fifth segment it will be 
observed that to each segment two neural arehes are present, and that a similar condition obtains in the haemal arches (h.a.) even farther forward. Such a condition is incomplete diplospondyly.

\section{Appendicular Skeleton}

The appendicular skeleton is the framework for the fins and the girdles to which these, if paired, are attached.

The pectoral girdle (fig. 54) in Heptanchus is a slender arch open dorsally, to which the framework of the pectoral fin is attached. It is composed of right

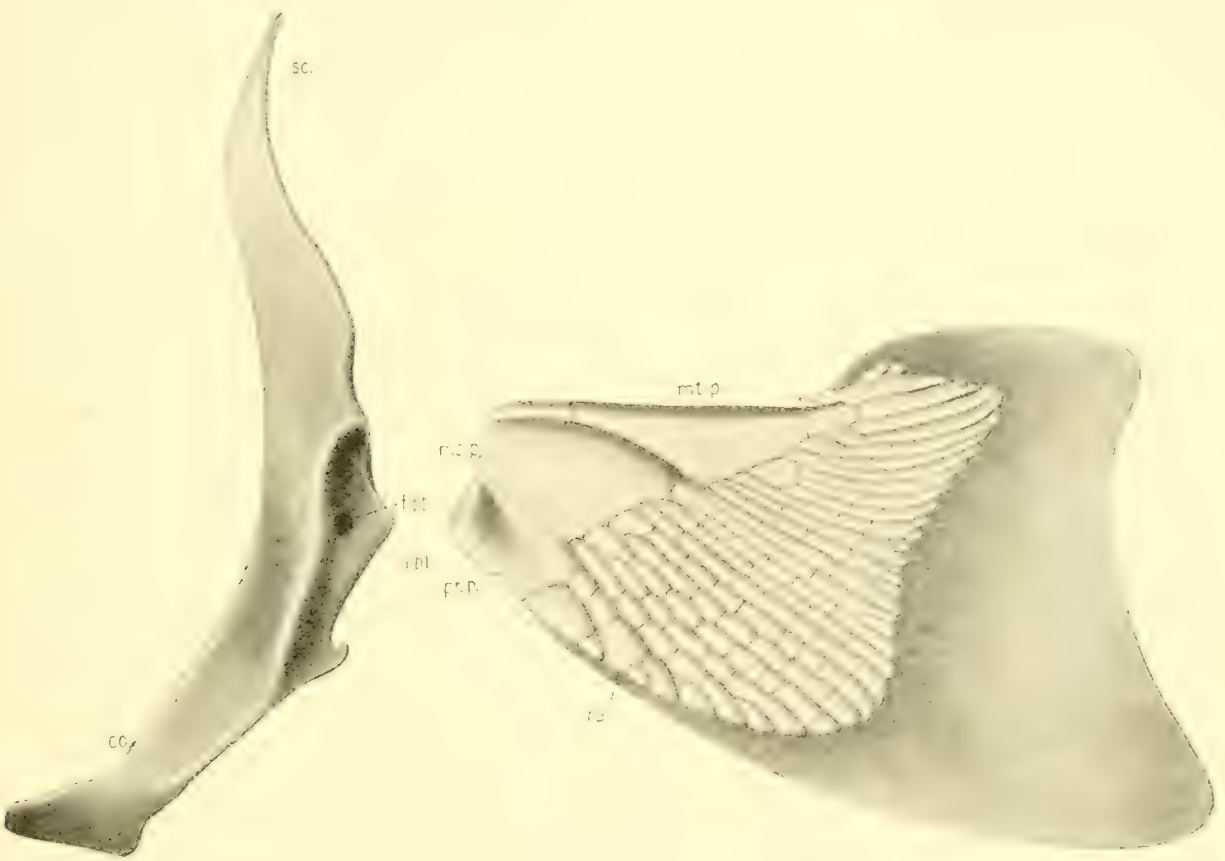

Fig. 54. Lateral view of the skeleton of the pectoral fin and girdle, Heptanchus maculatus. (Duncan Dunning, del.)

a.pl., process for articulation of pectoral fin; co., coracoid; f.pt., foramen for nerves and blood vessel; ms.p., mesopterygium; mt.p., metapterygium; pr.p., propterygium; ra., radials; sc., scapula.

and left cartilaginous halves which are united in the middle line below by means of an unpaired median piece. The part of the girdle extending the more dorsalward is the scapula (sc.), tipped by the suprascapula; that part which, by means of the median piece, joins a similar part from the opposite side below is the coracoid portion (co.). At the middle and posterolateral part of each half of the girdle there is an irregular surface for articulation with the pectoral fin (a.pl.). In front of and below this projection is a broad surface for the attachment of the ventral muscles of the fin. Perforating the girdles in this surface is a large foramen ( $f . p t$.) through which the brachial artery and nerves pass to supply the fin. 


\section{Skeleton of Paired Fins}

The skeleton of the pectoral fin (fig. 54) is fan-shaped; the proximal part consists of three hasal cartilages, propterygium, mesopterygium, and metapterygium; from the last two, numerous rows of radials radiate.

The propterygium ( $p r \cdot p$.$) in Heptanchus maculatus is a small nodule of$ cartilage located upon the mesopterygium. It is followed by four or five large

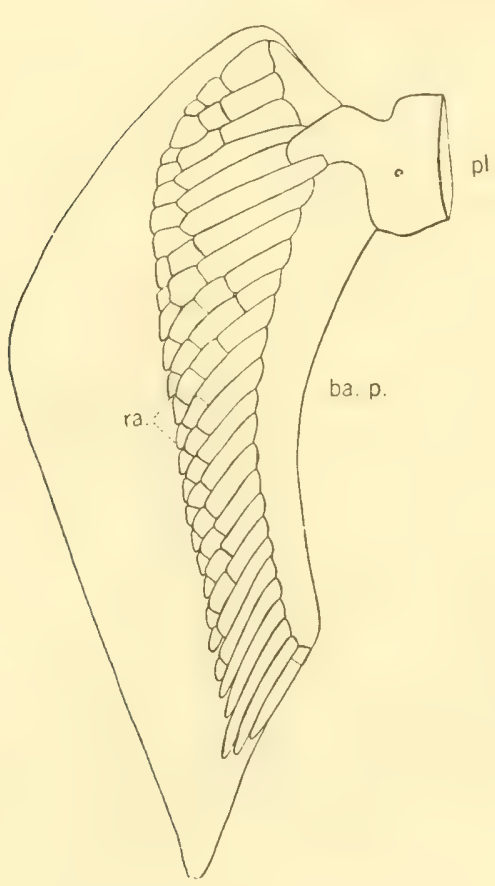

A. Female

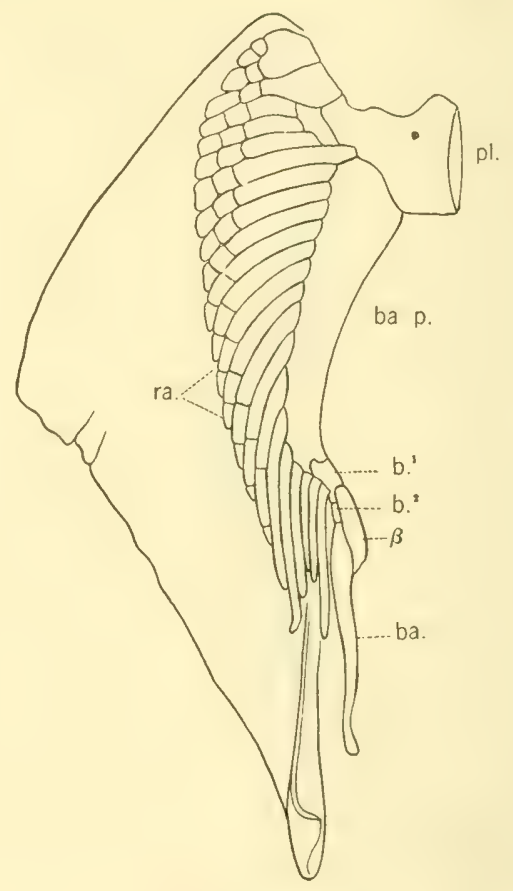

B. Male

Fig. 55. The skeleton of the pelvic fin and girdle, Heptanchus maculatus. (Ruth Jeanette Powell, del.)

$\beta$, beta cartilage; $b 0^{1-2}$, first and second connecting segments; $b a$. , basal or axial cartilage ; ba.p., basipterygium; $p l$, pelvie girdle; ra., radials.

radials, the first of which may fuse with the mesopterygium. The mesopterygium (ms.p.) is a stout cartilage, from the enlarged distal end of which extend ten or twelve rows of radials ( $r a$.$) , depending upon the amount of$ fusion which has taken place proximally. The most anterior row is composed of large and irregular plates, hut the remaining rows are broken up into small segments. The metapterygium (mt.p.) is a large triangular cartilage, the base of which points ventrally. It is segmented both proximally and distally and is then continued into the most distal radial. From the metapterygium diverge numerous rows of preaxial radials, in addition to which there are clearly marked postaxial radials. 
The pelvic girdle ( $p l$, fig. 55 ) is a flattened band of cartilage, slightly coneave dorsally and enlarged at the ends. Perforating the terminal parts of the girdle are from one to three foramina (see p. 95, fig. 96) through which nerves pass to the pelvic fin. At the termini of the girdle are the articular processes, each consisting of two protuberances which fit into depressions (fossae) of the pelvic fin skeleton. These are not well shown in figure 55.

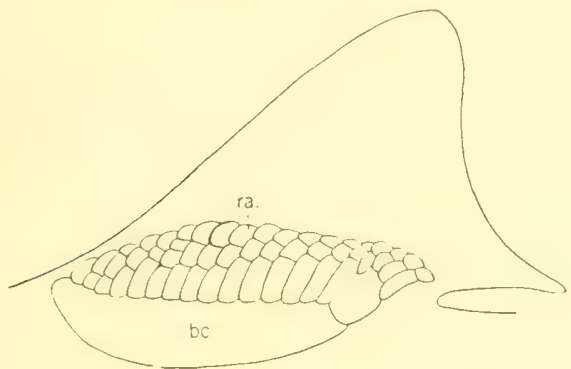

Fig. 56

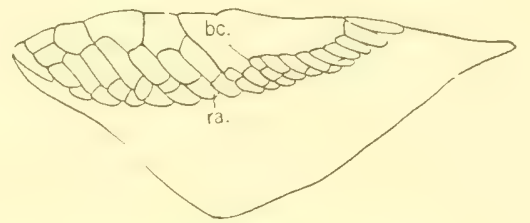

Fig. 57

Fig. 56. Dorsal fin, Heptanchus cinereus. (From Mivart.)

Fig. 57. Anal fin, Heptanchus cinereus. (From Mirart.) bc., basal eartilage; ra., radial.

The framework of the pelvic fin proper consists of a long posteriorly projecting basal cartilage, the basipterygium (ba.p.) which bears one or two small terminal segments. From this cartilage in the female proceed 21 or 22 radials ( $r a .$, fig. $55 \mathrm{~A}$ ), all of which, except the last five, are segmented. Anteriorly, a much enlarged plate meets the basal piece, forming an obtuse angle. From this run three rows of radials. At the proximal ends of this enlarged plate and the basal piece, are the two fossae with which the protuberances on the pelvic girdle above described articulate.

In the male the long basipterygium (ba.p.) is continued by the basal or axial cartilage of the claspers $(b a$.$) . Where the two join there are two segments$ $\left(b \cdot^{1-2}\right)$, and dorsal to them is the so-called beta cartilage $(\beta)$.

\section{Skeleton of Unpaired Fins}

DORSAL FIN

Extending over the forty-ninth to the fifty-fifth segment of the vertebral column is the thin basal cartilage of the dorsal fin (see Heptanchus cinereus, fig. 56, bc.). From this plate in Heptanchus maculatus arise seventeen or eighteen radial cartilages $(r a$.$) , one of which, the anterior, is unsegmented and$ a few of the posterior radials may or may not be fused into a single piece.

\section{CAUDAL FIN}

The segments of the tail show a characteristic diplospondyly in the arches both above and below the central column, although the pseudosegments of the central column itself are not doubly constricted. The ventral rays of the caudal 
fin (see fig. 53) are an integral part of the axial skeleton, being the prolongations of haemal spines under the haemal arches (h.a.). These consist of a series of rays, two of which correspond to a segment. The dorsal lobe of the fin is also supported by rays which begin back of the segment shown in figure 53. These dorsal rays are more than twice as numerous as the segments present.

\section{ANAL FIN}

The base of the anal fin (bc., fig. 57) ends anteriorly at about the fifty-third centrum of the spinal column. The basal piece, barring the fact that it is segmented in front, is remarkably similar to that of the dorsal. From it, however, the radials ( $r a$. ) proceed in a less definite fashion. 


\section{ENDOSKELE'OON OF ELASMIOBRANCHS IN GENERAL}

T'he endoskeleton in the Elasmobranchs in general varies a great deal in its composition. While in all it is formed of cartilage and never of bone, yet this cartilage differs greatly as to its rigidity. In a shark like Heptanchus maculatus the cartilage is usually of a clear hyalin type and relatively soft. In $H$. cinereus, on the contrary, it is strengthened by a deposit of ealcium. In some of the more specialized forms calcification is so abundant and so arranged that the cartilage is almost as strong as bone.

Cartilage as such in Elasmobranchs is composed of cartilage cells and ground substance. The ground substance consists of a muein-like substance in which are cologen fibers. In certain forms elastic fibers may also be included in the cartilage, and calcification is present in many Elasmobranchs (see Roth, 1911).

\section{Axial Skeleton SKULL}

The skull in the Elasmobranchs varies considerably in shape. In the rays it is depressed dorsoventrally, while in the sharks in general it is similar in plan to the skull as described for Heptanchus. In all Elasmobranchs the skull includes the cranium, the capsules for the organs of special sense, and the visceral arches.

\section{CRANIUM}

The cartilaginous cranium or brain case in the Elasmobranchs is unlike the bony

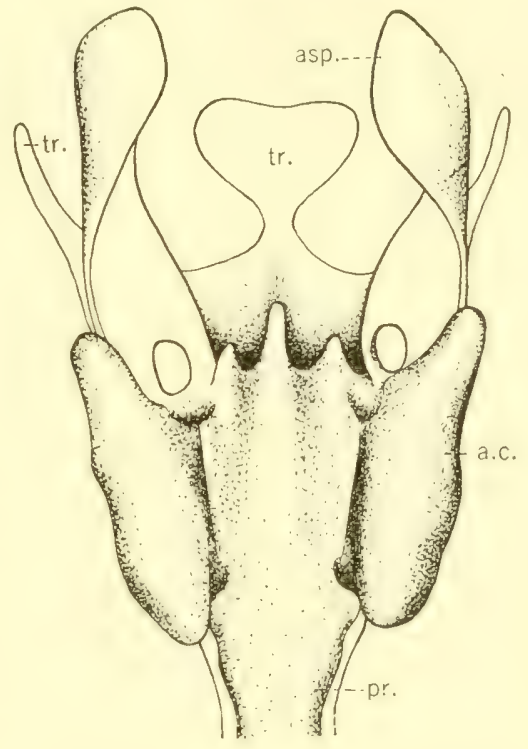

Fig.58. Development of cranium, Acanthias (Modified from Sewert. zoff.)

a.c., auditory capsule; asp., alisphenoidal cartilage; pr., parachordal plate; tr., trabecular cartilage. cranium of higher forms in that its sides, roof, and floor are welded into a single piece of cartilage. Joined to it also are the auditory and olfactory capsules for organs of special sense. The cranium is perforated by nerves and blood ressels which enter or leave the brain. Below the orbit the cranium may project outward as an infraorbital plate (most sharks) or such a plate may be absent (rays).

The rudiments for the brain case are laid down in the embryo of Acanthias according to Sewertzoff (1897) as three pairs of cartilages (see figs. 58 and $70)$. These are (1) the parachordal plates $(p r$.$) which lie at the sides of the$ notochord and posterior to the internal carotid foramina; (2) a pair of alisphenoidal cartilages (asp.); and (3) a pair of trabecular eartilages $(t r$. anterior to the internal carotid foramina. The parachordal and trabecular 


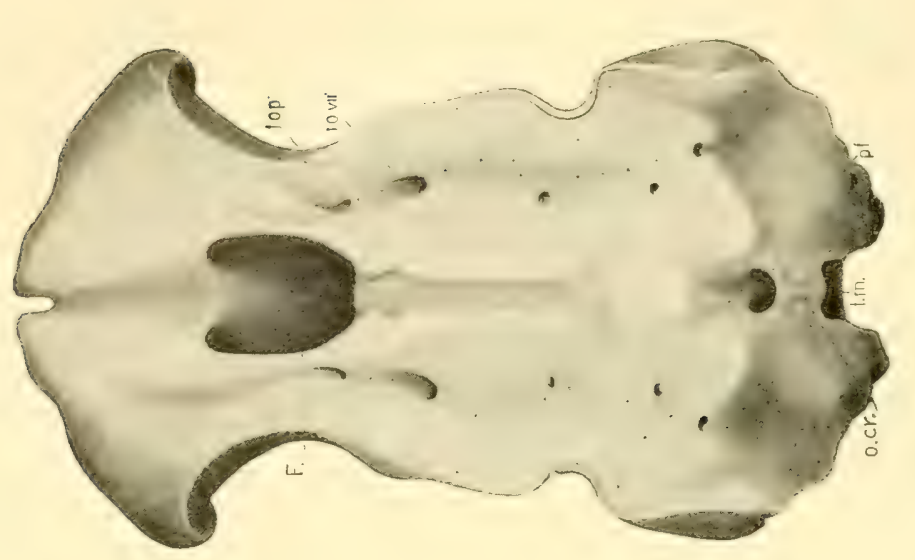

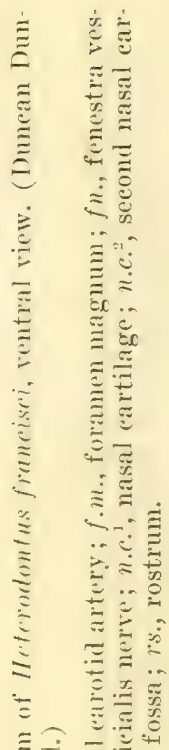

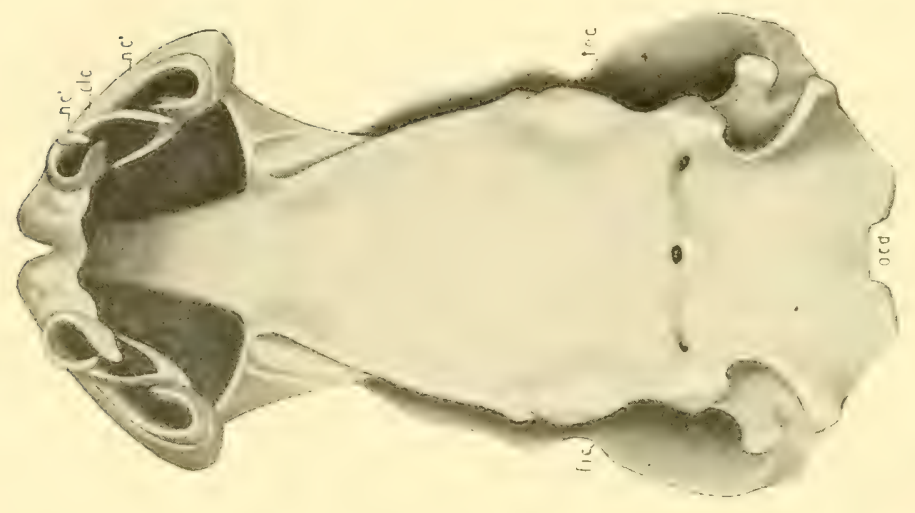

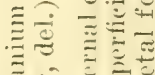

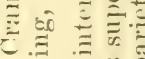

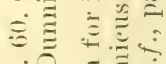

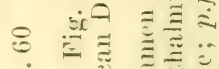

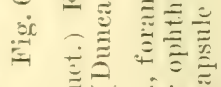

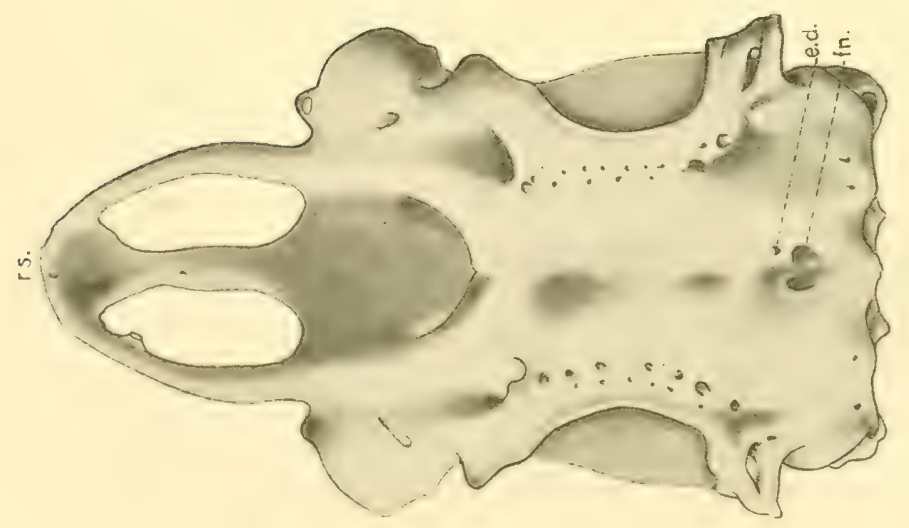

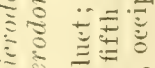


rudiments by growth extend medially, forming the floor of the cranium; the trabeculae bend to form the basal angle, and then project forward in the region of the rostrum, giving rise to the rostral plate. 'The alisphenoidals produce a large part of the sides of the eranium and extend dorsally, to form the roof of the cranium. 'To these three pairs of cartilages the sense capsules fuse. The nasal capsule joins the trabecula (rostral); the otic or auditory capsule joins the parachordal; while the optic capsules, when present, remain free.

In the adult sharks and rays, as we shall see, the extent to which the plates increase in size and the modifications to which they are subject vary greatly. Indeed, in various species of the same group these differences often produce entirely unlike crania. An example of this variation may be seen in Zygaena, the hammerhead (fig. 65), in which the cranium in the region of the eye is so modified as to be unlike that of the nearly related Galeus. The modification, or, better, the progressive development of the cranium is best understood by considering first the simpler and more generalized, and then the more highly specialized Elasmobranchs.

In dorsal view the adult Elasmobranch cranium may be said to take the shape of an hourglass (figs. 59, 61, 62). In this hourglass the basal segment is formed by the enlarged otic or auditory capsules; the middle part of the indentation contains the orbits for the eyes; and the top segment is produced by the olfactory capsules. Upon this as an apex may arise longer or shorter rostral cartilages $(r s$.$) .$

In more generalized forms, as, for example, Heptanchus or Chlamydoselachus, the positions of the semicireular canals of the ear are evident as superficial ridges on the surface of the auditory capsule.

The ridge for the posterior canal runs from the parietal fossa or pit outward and backward to the foramen for the ninth cranial nerve, while the ridge for the anterior canal rises at the parietal fossa and runs forward at right angles to the posterior canal. In more highly specialized types, where the parietal fossa is shallower, external evidence of the canals is less distinct (fig. 62).

From the bottom of the parietal fossa certain apertures lead to the ear. Two of these are for the endolymphatic ducts (e.d., fig. 59) and two other accessory apertures are the fenestrae $(f n$. $)$, for the perilymphatic spaces. In some forms the parietal pit may be deep and the endolymphatic foramina may be separated only by a short space, as in Heptanchus. Again it may be shallow, whereupon these foramina are farther apart (Scyllium). In still other forms, the pit is only a slight depression and the endolymphatic foramina are more widely removed from each other (Rhinobatis, fig. 62; Raja clavata; Trygon; Myliobatis). The fenestrae are apertures of much larger size than are the foramina for the endolymphatic ducts, and have at times been confused with them. In a type like Heterodontus (fig. 61) the parietal pit is deep and hence the fenestrae are difficult to see. They are evident, however, in Psendotriacis ( $f n$. fig. 59) and in Rhinobatis (fig. 62). In a specimen of Galeorhinus, six feet in length, and in a large Myliobatis californicus, they were relatively of immense size. 


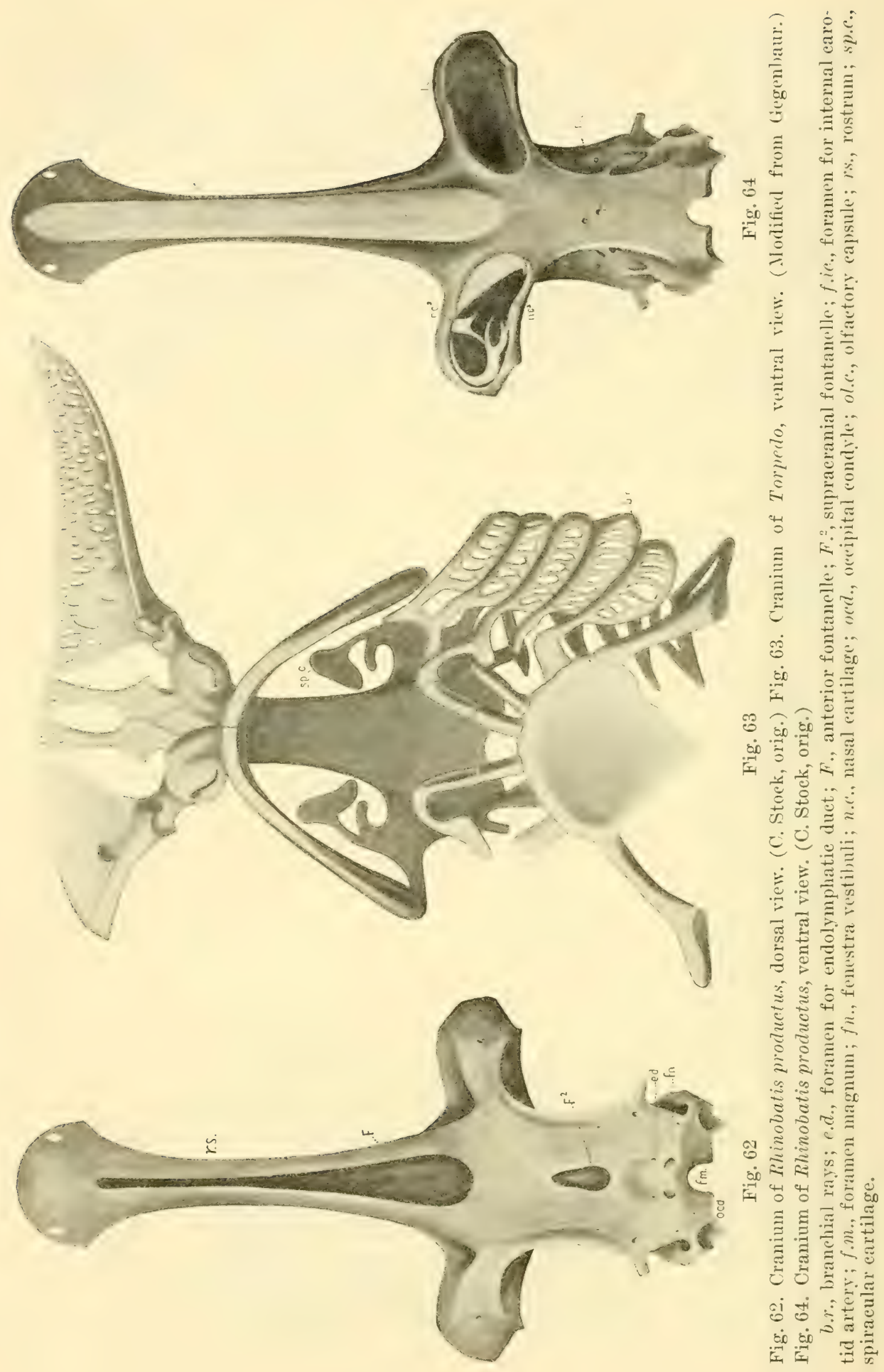


The middle region varies greatly in dorsal view. While it is typically constricted, secondarily this constriction may be obseured by the expansion of the supraorbital crests (Heterodontus, fig. 61), or the constriction present in the young may be entirely lost in the adult, as in Carcharodon rondeletii (T. J. Parker, 1887). In the rays a supracranial fontanelle is usually present in the middorsal line. 'This fontanelle is small in Trygonorhina, but large in Rhinobatis (F.2, fig. 62) and Raja clavata.

The olfactory capsules (ol.c., fig. 60) which represent the uppermost segment of the hourglass are in most Elasmobranchs more or less well developed. In some of the sharks they may be relatively of immense size, as for example in Zygaena where they are drawn far out with the preorbital processes of the cranium (fig. 65). But the capsules are normally smaller as in Pseudotriacis (fig. 59). In Rhinobatis (fig. 64) and many other rays they are large wing-like expansions to which heavy antorbital pieces are attached. In the middorsal line of this median segment there is present in all sharks and rays the anterior fontanelle $(F$.$) , which in some is confluent with the supracranial fontanelle$ (Mliobatis).

The rostral pieces which may form an apex to the hourglass may be flat and divergent, as in Heterodontus (fig. 61) and Crossorhimus, or blunt and convergent as in Scymmus and Laemargus; or there may be two long dorsolateral bars which unite forward with a ventral bar as in Psendotriacis microdon ( ${ }^{*} s$., fig. 59), Mustelus, Galeus, and many others. In Acanthias the ventral cartilage is broad and spoon-shaped and the dorsolateral bar is rudimentary, each bar being joined to the nasal capsule by a double cord of comnective tissue (Wells, 1917). In some of the rays (Myliobatis) a rostrum is lacking, but this is the exception. In the majority of this group it is a long single piece (Rhinobatis, fig. 62), and in some it is of great length, as for example in Pristis the saw ray.

In a ventral view of the cranium (figs. 60, 63, and 64) a similar hourglass shape is apparent. The auditory region at the base is a broad expansion of the parachordal cartilage of the embryo to which the auditory capsules have fused. In the most posterior region of the midventral line is the notch separating the two occipital condyles (ocd., fig. 60); by means of the condyles the spinal column articulates with the cranium. In primitive sharks like Heptanchus the column is more or less completely fused with the cranium so that no true articulation exists. In the rays the condyles are well developed, but here a secondary fusion takes place which affects the occipitovertebral articulation and the anterior part of the column (see p. 70, fig. 76B). Posteriorly and between the two condyles is the foramen magnum ( $f$.m., fig. 61) through which the spinal cord joins the brain.

The middle segment in ventral view is characteristically different in the sharks and rays. In the adult of most of the sharks right and left infraorbital plates broaden out into wing-like processes which form a floor for the orbits, and consequently obscure the constriction. In the rays the form of the hourglass is very evident, for in them, as in Heptanchus, an extension of these plates is characteristically absent. 
In the olfactory region the capsules are seen in their relation to the elliptical nasal cartilages (n.c., figs. 60, 63, and 64) surrounding the nasal aperture. Projections from the anterior and posterior margins of the ellipse meet and cross, usually forming of it a figure 8. A second anterior accessory process may be added as in Heterodontus (n.c. ${ }^{2}$, fig. 60), or may be more completely developed as in $S c y l l i u m$. In the rays the ellipse may be broken into segments. In Rhinolutis (fig. 6t) the anterior and posterior projections forming the bridge are relatively slender cartilages. In Myliobatis numerous accessory projections are present.

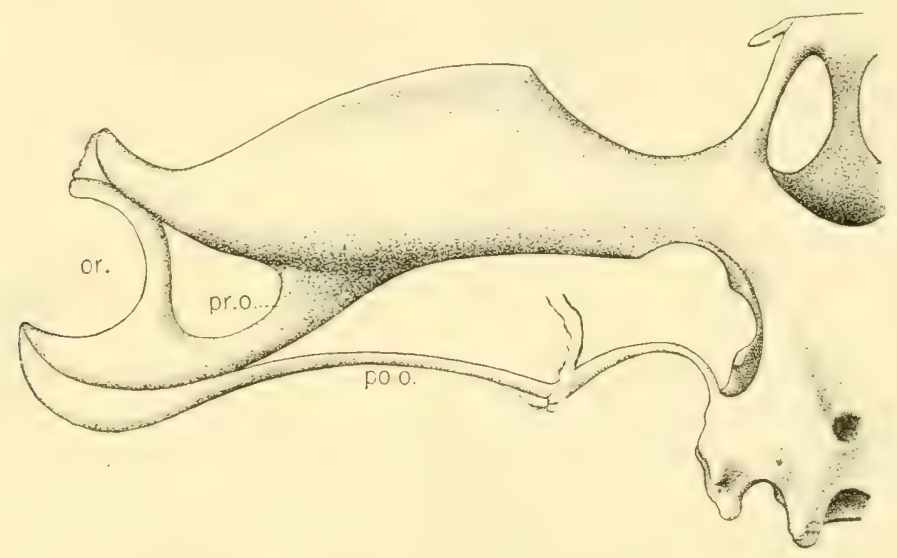

Fig. 65. Dorsal riew of cranium, Zygaena, left side. (Modified from Gegeubaur.) or., orbit; po.o., postorbital process; pr.o., preorbital process.

In a side view (figs. 66 and 68 ) the auditory, optic, and olfactory regions of the cranium are seen to advantage. With the exception of Chlamydoselachus and the notidanids the auditory region is greatly modified superficially for the attachment of the hyoid arch. In most of the recent sharks the articulation is made by means of a deep pit (as is present in Heterodontus, fig. 66). In some of the rays a special part from the hyoid arch makes an extended articulation with this part of the eranium.

Anterior to the auditory region is the enlarged orbit in which the eyeball rests. Its roof is usually formed by a supraorbital erest, modified posteriorly into a postorbital process (po.o.), and anteriorly into a preorbital process $\left(p r^{\circ}\right.$ o. $)$.

In the sharks the postorbital process is rarely extended. Exception must be made, however, of Zygaena, the hammerhead (po.o., fig. 65) and its near ally, the bonnet shark, where it may be prolonged outward to meet the posterior part of the preorbital process. Exception should be made also of Chlamydoselachus and the notidanids in which the postorbital process serves in suspending the upper jaw. In the rays, except those bearing stings, this process is characteristically small or absent.

The preorbital process in Zygaena (pr.o., fig. 65) arises far out on the cranium and is divided into anterior and posterior parts. The anterior part 


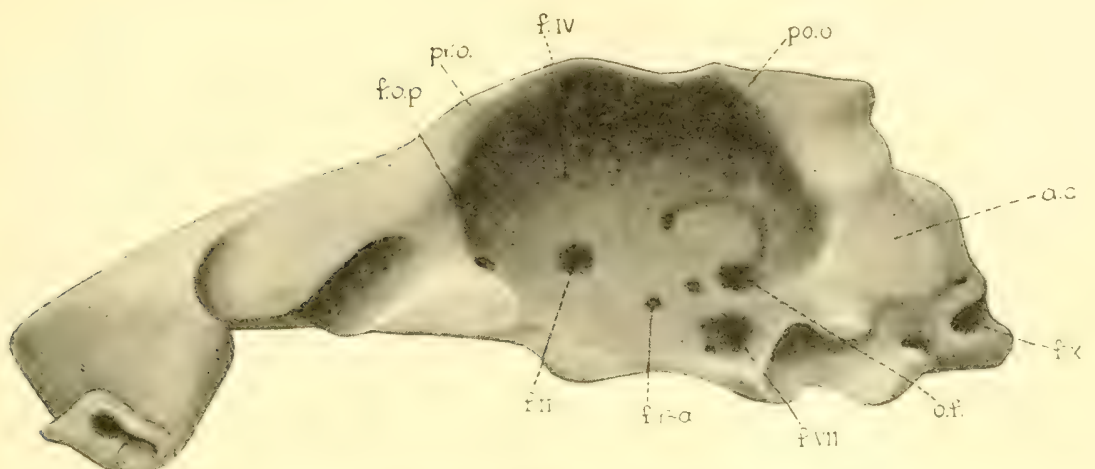

Fig. 66. Cranium of Hetroutontus francisci, lateral view. (I)umean I)umning, del.)

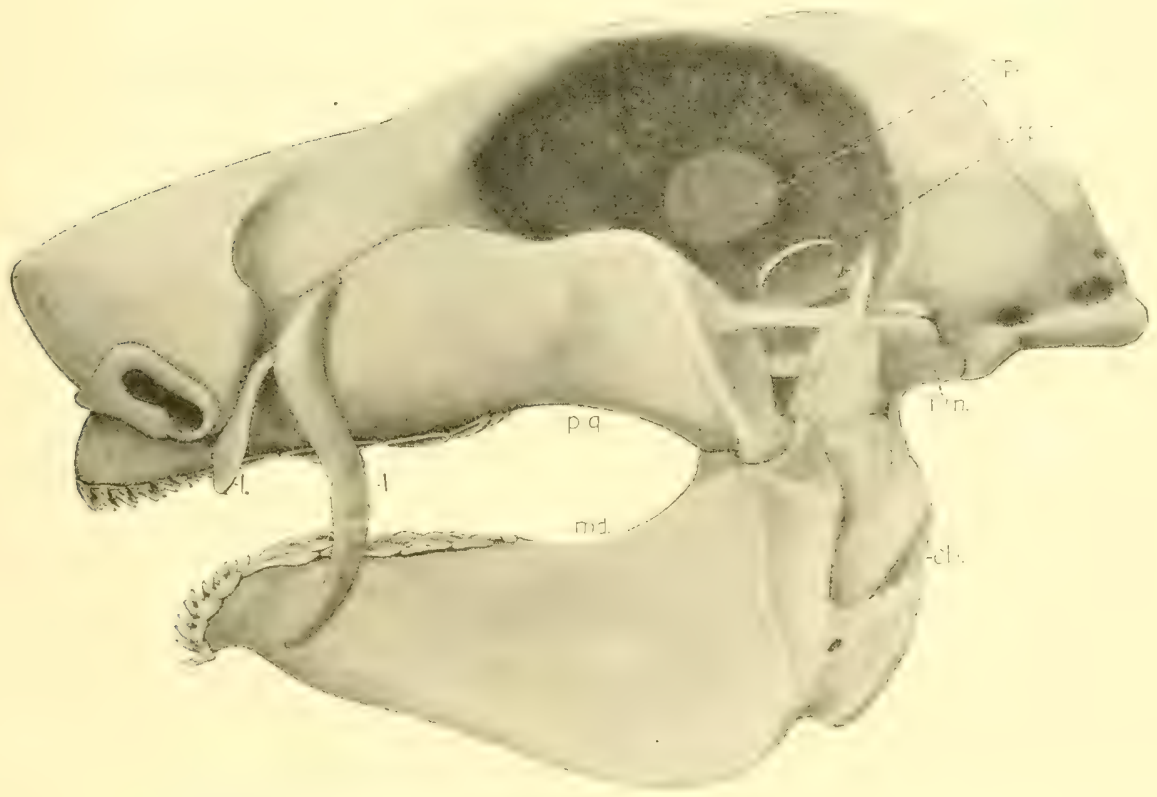

Fig. 67. Skull of Heterodontus francisci (articulate). (Duncan Dumning, del.)

a.c., auditory eapsule; $c h$. , eeratohyoid; $l$., labial cartilage; f.op., foramen for profundus nerve; $f . x^{*} a$., foramen for ramus anastomoticus artery; $f . I I$, optic foramen; $f . I V$, trochlearis foramen; $f . V I I$, foramen for hyomandibularis branch of facial nerve; $f . X$., foramen for tenth nerve; $h m$. , hyomandibula; ma., mandible; o.f., orbital fissure; o.p., optic pedicel; po.o., postorbital process; $p$-q., palatoquadrate cartilage; pr.o., preorbital process; sp.c., spiracular cartilage. 
joins the nasal capsule and the posterior part extends back to the postorbital process (po.o.). Between anterior and posterior parts is located the secondary orbit (or.).

In the notidanid sharks, in Chlamydoselachus, and in the rays there is a posterior projection from the preorbital region, the antorbital process (figs. 69 and $47, a . p r$.$) . In the notidanids and Acanthias this serves for the attach-$ ment of one of the superior labial muscles. In the rays it unites the pectoral fin skeleton to the cranium.

The eyeball is held out from the cranial wall by a rod, the optic pedicel (Heterodontus, fig. 67,o.p.) ; this pedicel in some of the sharks has a terminal expansion into which the eyeball fits. In Chlamydoselachus (fig. 46) it further serves as a place of origin for the rectus muscles. In the rays the pedicel is plate-like and may be fixed to the eyeball (Torpedo).

The apertures which perforate the orbital region for the cranial nerves and blood vessels vary considerably in size and position from those given for Heptanchus. Ordinarily the optic foramen ( $f . I I$, fig. 66) is relatively large and oceupies a central position in the orbit, but in types like Rhinobatis (fig. 68) it is well forward. In the embryo (Acanthias) this foramen separates the alisphenoid from the trabecular cartilage. The oculomotor and the trochlearis foramina take positions respectively behind and above the optic; but the trochlearis is variable. In the rays (Rhinobatis, fig. $68, f . I V ;$ Myliobatis) it is above but posterior to the aperture for the optic nerve. The orbital fissure (o.f.) usually gives exit to the fifth and a considerable part of the seventh cranial nerves, and in a type like Rhinobatis is of unusual size. In this type it is not unlike the large fissure which early forms a separation of the alisphenoids from the parachordal cartilages in the embryo of Acanthias. In Mustelus henlei, where there are special foramina for the superficial division of the seventh nerve and the profundus division of the fifth nerve, the fissure is reduced in size. The foramen for the sixth nerve usually opens separately at the base of the orbital fissure. The facial foramen for the hyomandibular branch of the seventh nerve may be located posterior to the orbit, as in Heptanchus ( $f . V I I^{3}$, fig. 47), in Scymmus, and in other forms; or it may be in the posteroventral angle of the orbit (Heterodontus, fig. 66, f.VII; and others). In the upper anterior angle of the orbit is the ophthalmic foramen (or foramina) which gives exit to the ophthalmicus superficialis of the seventh nerve. In Heterodontus, as is general for the Elasmobranchs, the profundus nerve (f.op.) leaves the orbit by an extra foramen ventral to that for the ophthalmicus superficialis.

Anterior to the orbit is the ethmoidal region in which is situated the nasal or olfactory capsule. The capsules in the simpler forms are more or less terminal in position, while in the highly specialized rays, as for example Myliobatis, the region is bent sharply downward so that the apertures are entirely ventral in position. The olfactory cups are usually more or less surrounded by cartilage, learing their apertures as relatively small openings. These openings are visible in side view in the sharks only. The nasal cartilages surrounding the openings have been described. 


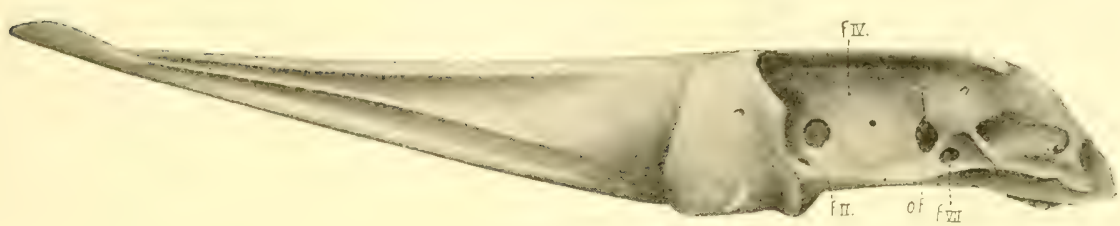

Fig. 68. Cranium of Rhinobatis productus, lateral view. (Chester Stock, orig.)

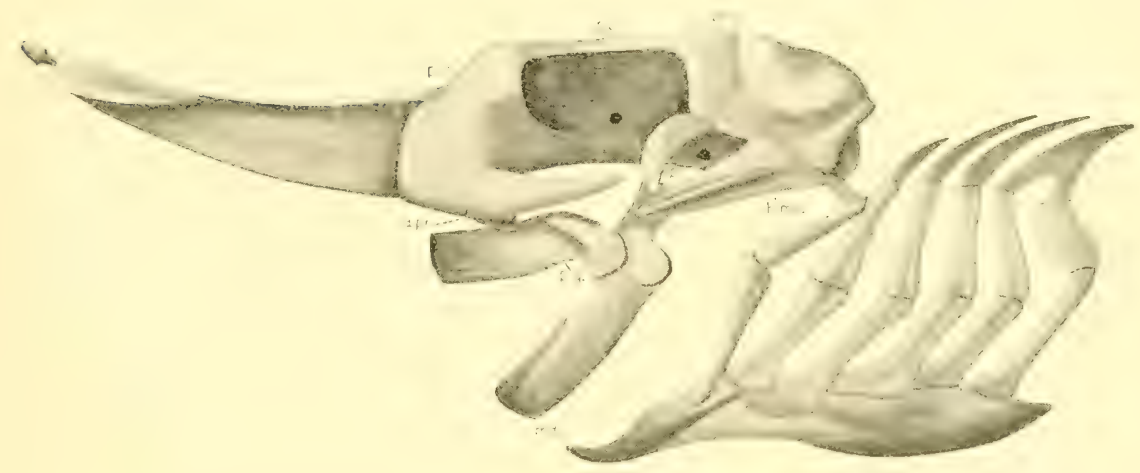

Fig. 69. Skull of liaju clavata (articulate). (Modified from W. K. Parker.)

a.pr., antorbital process; $f . I I$, optic foramen; $f . I V$, trochlear foramen; $f . V I I$, foramen for hyomandibular branch of facial nerve; h.md., hyomandibula; md., mandible; o.f., orbital fissure; po.o., postorbital process; $p$-q., palatoquadrate; pr.o., preorbital process; s.o., supraorbital crest; sp.c., spiracular cartilage. 


\section{VISCERAL SKELETON}

The cartilaginous risceral skeleton in the Elasmolnranchs usually consists of seven visceral arches: the mandihular, the hyoid, and five branchial arches. In Chlamydoselachus and the notidanids, however, there are additional branchial arches making a total of eight visceral arches in Hexanchus and Chlamydoselachus and, as we have seen, nine in Heptanchus.

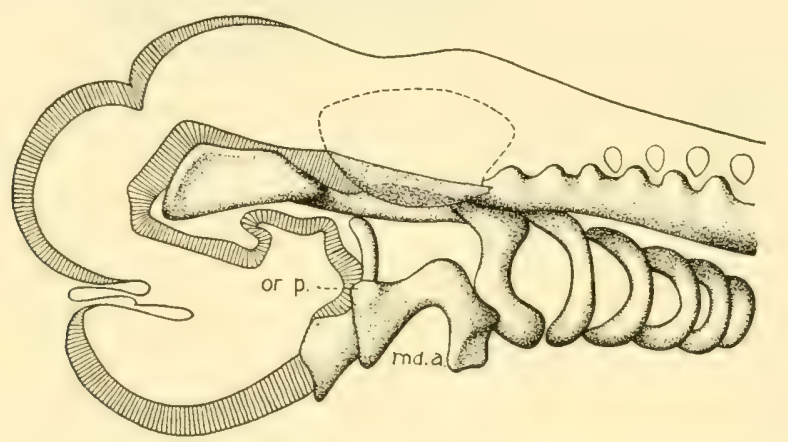

Fig. 70. Development of embryonic visceral arches in Acanthias. (From Sewertzoff.) ma.a., mandibular or first arch; or.p., orbital process.

The visceral arches of the adult are more easily understood if we first study their early arrangement in the embryo. In a reconstruction made by Sewertzoff of the embryo of Acanthias (fig. 70), all the arches appear as bent cartilaginous bars which as yet have not divided into segments. The first or mandibular arch (mc.a.) takes the form of an inverted U. On the upper (anterior) limb of the arch is a process which abuts against the trabecular cartilage, and, in the adult, forms the orbital process (or.p.) for articulation with the cranium. The second or hyoid arch at this stage is sigmoid in shape, and even here joins the cranium in the region of the auditory capsule. The remaining five branchial arches, third to seventh viscerals, are erescentic in shape and like the preceding arches show no signs of segmentation at this stage.

The mandibular arch in all adult Elasmobranchs, as in Heptanchus, is divided into (1) an upper palatoquadrate (pterygoquadrate) segment ( $p$ - $q$.) and (2) the mandibular segment or Neckel's cartilage (md., figs. 67 and 69). In simple types like the notidanids the palatoquadrate may have two fairly well defined regions, an anterior palatine (pterygoid) and a posterior quadrate. In more specialized forms, however, it is impossible to distinguish these segments other than hy position. On the anterior part of the quadrate segment may he present an orhital (palatohasal) process which articulates with the median wall of the orbit (Chlamydoselachus, Scymmus, Acanthias); or it may be wanting, as for example in Heterodontus (fig. 67) and Raja (fig. 69) where the mandibular arch is shoved forward. The palatoquadrate cartilage unites in front with a similar segment from the opposite side, as does also the mandible. 
The union of the right and left cartilages may be loosely made (notidanids) or it may be firmer as in most forms; that of the mandibular cartilage, while firm in the rays, is loose in most sharks except Squatina and Heterodontus.

The articulation of the upper and lower jaws may be by a joint in all respects similar to that of Heptanchus; such is the articulation in Chlamydoselachus and Hetcrodontus. Or the joint may be slightly more specialized as in Scyllium. A highly specialized type found in the Elasmobranchs is that in Raja (fig. 69), where a single ball and socket joint prevails. The joint may be bound simply by short ligaments, or it may be firmly held by a most complex ligamentous arrangement, as in Heterodontus francisci (figs. 67 and 128).

Following the mandibular arch, and above the quadrate segment, is the spiracular cartilage (sp.c., figs. 67 and 69 ) which supports the filaments in the anterior wall of the spiracle, where such exist. This cartilage may be composed of sereral segments (three in Centrophorus, two in Acanthias), or it may consist simply of a single piece. In other sharks where the spiracle is minute the cartilaginous support may be absent (Lamna). In the rays (Torpedo, fig. 63; Raja, fig. 69; Myliobatis) it is well developed, and serves as a framework for the support of the spiracular valve. It follows a true prespiracular ligament.

The hyoid or second visceral arch, which is simple in primitive sharks, is subject to great modification when the Elasmobranchs in general are considered. This arch in its generalized condition (Heptanchus) is composed of a dorsal segment which suspends a ventral segment. Under such conditions the hyoid does not function, or functions but slightly, in suspending the first or mandibular arch. The proximal end of the dorsal segment consequently is attached loosely by ligaments and hence indents the auditory capsule but slightly as in Heptanchus cinereus. In other types it may indent the capsule by only a part of its surface (Hexanchus, Chlamydoselachus). When this oecurs the distal end of this segment suspends the ventral segment of the hyoid and the latter is bound by ligaments to the mandible.

In general, an attachment of the second arch to the mandibular may be made by a ligament at the joint and elsewhere. In Chlamydoselachus the form of attachment is very simple. While the lower segment depends slightly upon the mandible, the latter begins also to depend upon the upper segment for support. In other words, the dorsal segment is on its way to become a hyomandibula or suspensorium. Where it is a true hyomandibula, as in most sharks, this upper segment of the hyoid arch is of service primarily to the first arch. As a suspensorium it becomes stronger and its articulation with the cranium becomes deeper; furthermore, its ligamentous attachment to the mandibular arch may be most complex (Heterodontus francisci, fig. 67; see Daniel, 1915).

When the upper segment of the hyoid has assumed the secondary function of suspending the mandibular arch, that is, where it becomes hyomandibular, it may still continue to suspend the lower part of its own arch also. This is indeed characteristic of the sharks. But the lower segment may lose connection more and more with the upper (hyomandibular) segment. Instead of being suspended from the distal end of the hyomandibula, it may be joined 
posteriorly to the middle portion of the hyomandibula (Torpedo, fig. 63). Such a union results from the method of growth of the hyomandibula. A process extends from the anterior angle of the upper segment which, in the adult Torpedo, forms the suspensorium or hyomandibula. This part suspends the mandibular arch while the lower segment is attached to the posterior part of the hyomandibula (fig. 69). In some of the other rays the lower segment may not be attached at all to the hyomandibula, but may be united with the poste-

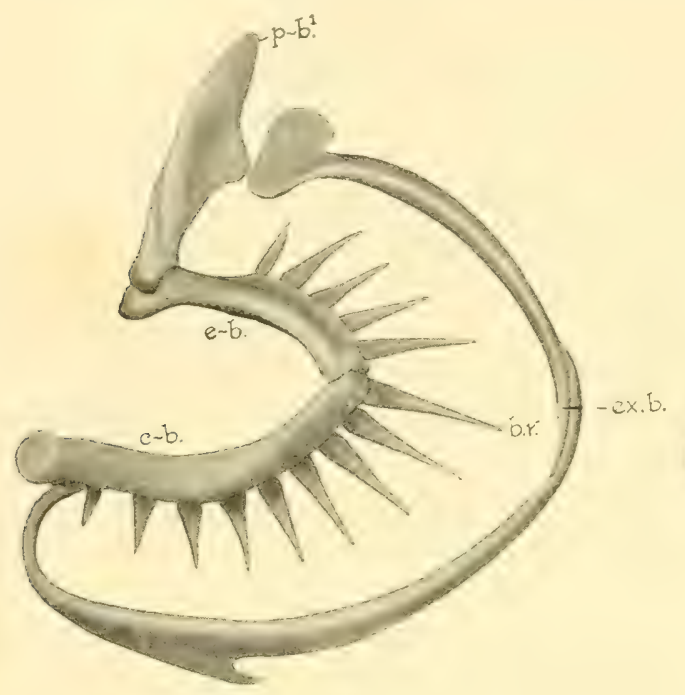

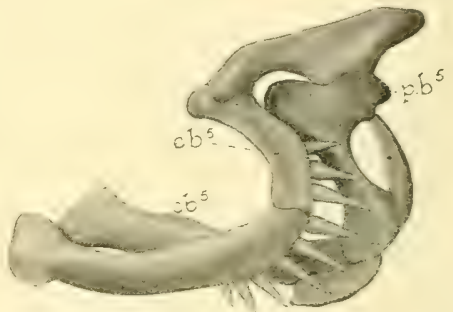

Fig. i:

Fig. 71

Fig. 71. First branchial areh, Heterodontus francisci. (Duncan Dunning, del.)

Fig. 72. Fourth and fifth branchial arches, Heterodontus francisci. (Duncan Dunning, del.)

b.r., branchial ray; $c b$. , ceratobranchial; eb., epibranchial; ex.b., extrabranchial cartilage; $p b$. , pharyngobranchial.

rior part of the cranium (Urolophus). In a still more specialized form it may have no union either with the hyomandibula or with the cranium, but may be bound to the tip of the first branchial (third visceral) arch, as in Rhinobatis and Myliobatis. In some such occurrences the lower arch may be further segmented.

The branchial arches in general are typically made up of four segments (fig. 71, Heterodontus) which from dorsal to ventral, as was given for Heptanchus, are: (1) the pharyngobranchial $(p b),.(2)$ the epibranchial $\left(e_{0} b.\right),(3)$ the ceratobranchial $(c b$.$) , and (4) the hypobranchial ( h b$. , fig. 73 ) segments.

The pharrngohranchials are usually flattened cartilages which lie dorsal to the pharynx. In sharks they are usually attached by strong connective tissues (ligaments) to the roof of the pharynx or to the sides of the spinal column but not to the pharyngobranchials of the opposite side, as is the first in Heptanchus and Scyllium. In the rays, the pharyngobranchial segment of the first hranchial arch, as we have said, may join the cranimm (Rhinobatis, Trygon). 
The most posterior pharyngobranchial, as a usual thing, in both sharks and rays is fused with the one preceding, hence it may lose much of its characteristic shape (Heterodontus, fig. 72).

The epi- and ceratobranchials are the ray-bearing segments of the arches. In all, except the most posterior arches, these segments are similar. In the last arch, hoth of these segments are more or less modified. Generally this modification takes the form of a thickening of the ceratobranchial (sharks) and an atrophy of the epibranchial because of its fusion with its pharyngobranchial cartilage.

The hypobranchials, although perhaps more regular in a type like Chlamydoselachus (fig. 73A) than in Heptanchus, are generally more variable than are any of the other segments. In the sharks the first, if present, is usually small and is located between the distal end of the first ceratobranchial and the hyoid cartilage (Heterodontus, fig. $73 \mathrm{~B}, h b^{1}{ }^{1}$; Laemargus). The second may fuse with a similar one from the opposite side across the midventral line (Scymnus, Laemargus); or the two may join a median unpaired cartilage, the second basibranchial, as in Acanthias, Trygon, Heterodontus (bb., fig. $73 \mathrm{~B}$ ) ; or they may arch backward to join the enlarged median piece ( $m p$. ) as in Torpedo (fig. 63) and Rhinobatis. Generally the third and fourth hypobranchials of pentanchid forms, except in some of the rays, are well developed and are attached to the large median unpaired piece. In general, except Heptanchus (fig. 50), hypobranchials on the most posterior arch are lacking or are fused with the unpaired median piece to which the third and fourth hypobranchials are attached. In the rays these segments may be present as platelike cartilages attached to the mpaired median piece (Rain crimacea, fig. 74B).

In the midventral line unpaired basal elements join the arches of the right and left sides. The element connecting the two halves of the hyoid arch is the basihyoid ( $b h$. fig. 73 ) and those connecting the branchials are the basibranchial cartilages ( $6 b$.$) . The basihyal cartilage may be a broad plate, per-$ forated by the thyroid foramen (Chlamydoselachus, fig. $73 \mathrm{~A}, 6 h$.) ; or it may bear an anterior glossal projection as a support for the tongue (Heterodontus, fig. 73в, g.p.; Scyllium). Again it may be a narrow band as in Acanthias or as in Raia erinacea (fig. 7413); or it may be incomplete as in Torpedo (fig. 63). Basibranchials are present as distinct irregular pieces of cartilage anteriorly, but posteriorly they may fuse into a single mass. Generalized forms are characterized by numerous basal elements. The first of these may be a peg-like structure attached to the basihyoid (Chlamydoselachus), or it may lie free behind the basihyoid (Laemargus). The second basibranchial is usually free and the third, when present, is often attached to the larger posterior median piece which may or may not be segmented. In the rays only the posterior median piece is present (Rhinobatis, and Torpedo, fig. 63).

In the embryo of some forms well marked rudiments of still other branchial arches persist, as we have seen in Heptanchus. Such rudiments are also present in Chlamydoselachus, where a seventh arch has been described, and in Heterodontus and in some of the rays, where a sixth arch may occasionally be 
found. The rudimentary arch in the embryo of Heterodontus consists of at least two segments, which in the adult may still be seen, welded more or less closely to the fifth hranchial arch (fig. 72). Rudiments of such structures are of interest in forms like Heptanchus and Chlamydoselachus in which an unusual number of arches becomes functional in the adult. That still other rudiments are present in the embryo indicates that ancestral forms possessed a number of arches exceeding that of present-day types.

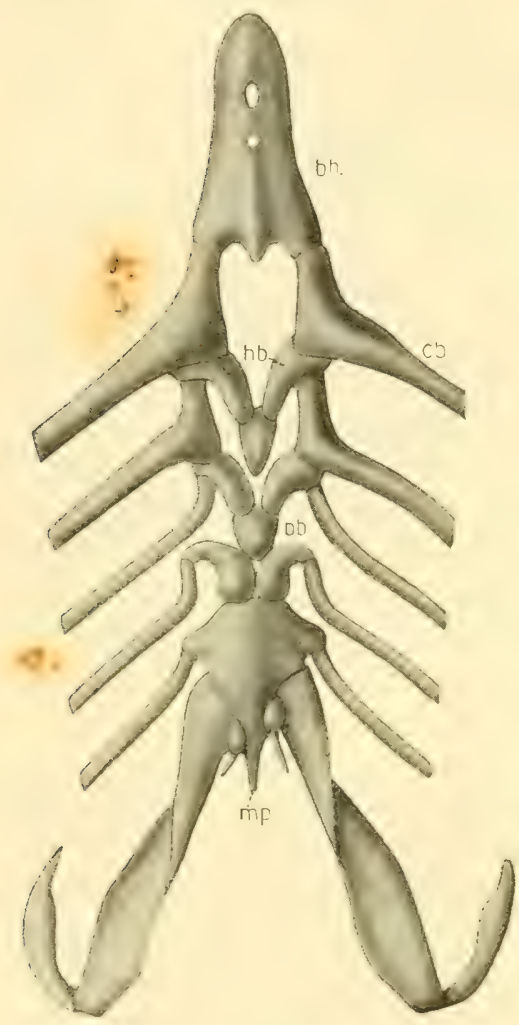

A

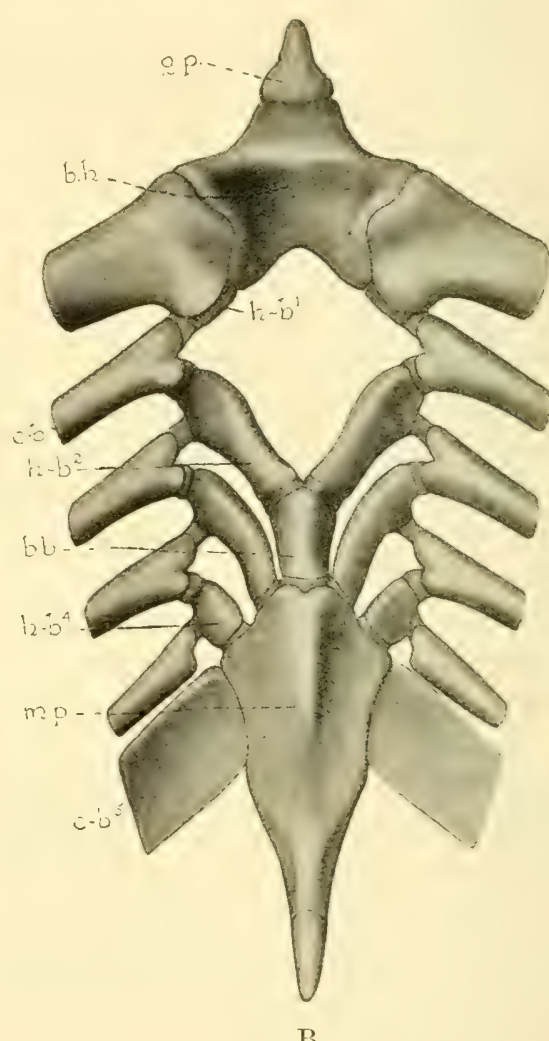

B

Fig. 73. Median ventral basibranchial cartilages. A. Chlamydoselachus. (From Goodey.) B. Heterodontus francisci.

bb., basibranchial; $b h .$, basihyoid; $c b .$, ceratobranchial; g.p., glossal process; $h b .$, hypobranchial; $m p$. , median piece.

Figure 50B represents the area of rudimentary arches in Heptanchus maculatus. It will be observed that a slight asymmetry is shown which gives a somewhat greater development of the midventral region on the right than on the left side. Through this asymmetry the rudimentary areh and adjoining area on the right side are more highly developed than on the left.

Upon examination of the ventral side of the rudimentary arch on the right side I found certain round and pointed rays ( $r$, fig. 50 B) arising from the 
seventh ceratobranchial practically at right angles to its long axis. These rays extend posteriorly between the plate $x$ and the median piece as clear pieces of hyalin cartilage. Whether they represent rudimentary branchial rays on the seventh areh like those deseribed by Gegenbaur (1872, pl. 12, fig. 5) on the anterior margin of the fifth arch for Scyllium, or have to do with the rudimentary arch following, is not certain.

On the middle piece a similar arrangement is found. Here there are three pieces which are successively longer toward the middle line. They are essentially identical in appearance with the rays above described on the seventh ceratobranchial segment, but they are attached along their whole dorsal length as flattened lamellae. Terminally the median two look very much like the rays above described and they are much like them also in that they are of clear hyalin cartilage. Farther toward the median line on the middle piece there is clear evidence of still another similar group, except that it is not reparated into rays or lamellae. This group is also of clear hyalin cartilage differing distinctly from the median piece, which, in the specimen, is of a dark color. I have interpreted this group as a remnant of a ninth arch $\left(a r^{9}\right)$, although I am not certain what part it represents.

The condition found in this specimen is suggestive as to the method of formation of the enlarged median piece so characteristic of the Elasmobranchs. It would appear that in this region the rudimentary arches are forced more and more to take a longitudinal direction nearer the middle line, and that the median piece represents in its most posterior part the fusion of these archeis from side to side.

Extending from all the visceral arches, except the first (mandibular) and the last, is a series of cartilaginous branchial rays for the support of gills. These supporting rays are confined to the epi- and cerato-segments. The branchial rays may be complex and branched, the termini fusing into arches on the hyoid (sharks), or they may be comparatively simple and straight (rays). In Torpedo a curions modification of the branchial rays occurs in the form of terminal dises (b.r., fig. 63 ), each of which is almost circular in shape. These cartilaginous rays, although fewer the more posterior the arch, may be exceedingly numerous anteriorly as in Lamna, or relatively sparse as in Laemargus. The central ray, the one between the epi- and the ceratobranchial, may exceed all others in length. This ray may be postulated as the main axis of the fin skeleton according to the gill-arch theory for the origin of paired fins.

\section{EXTRAVISCERAL ARCHES}

Outside of the deep intermal visceral arches are the extravisceral cartilages. These may be divided into the labials ${ }^{1}$ of the mandibular arch, the extrahyals of the hyoid, and the extrabranchials of the branchial arches. Normally each

\footnotetext{
1 The labial segments are often interpreted as representing arches formerly present between the mandibular and hyoid arches.
} 
of these arches is made up of two segments, one dorsal, the other ventral in position.

Three labial cartilages are usually present on a side in sharks, two dorsal, the so-called premaxillary and the maxillary cartilages on the palatoquadrate, and one ventral on the mandible. Of the dorsal segments the anterior is the shorter. When well developed the labials serve to reduce the gape of the mouth.

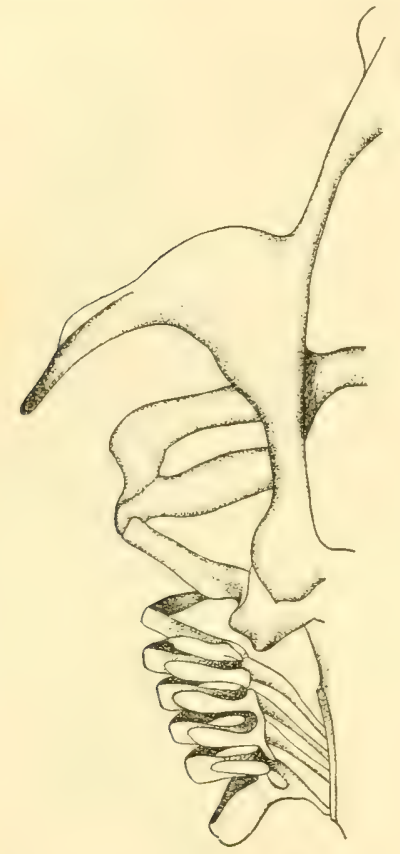

A

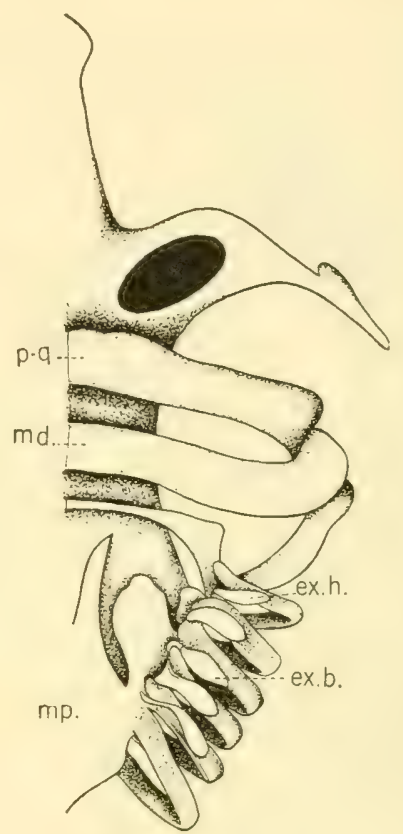

B

Fig. 74. Extrabranchial cartilages of Raia erinacea. (From Foote.) A. Dorsal riew. B. Ventral view.

$e x . b$. , extrabranchial cartilage; $e x . h .$, extrahyoid cartilage; md., mandible; mp., median piece; $p$-q., palatoquadrate (pterygoquadrate) cartilage.

An interesting series may be followed in the specialization of these cartilages from the simple condition of a single cartilage to the tripartite condition just mentioned. Heptanchus cinereus has a single labial located dorsally, which because of its small size long escaped observation (Fürbringer, 1903). In Heptanchus maculatus ( $l$., fig. 48) there is a single cartilage, shaped like a tuming fork, which extends across the gape of the mouth and ends dorsally in two horns. It gives no evidence, however, of segmentation. In Hexanchus, the labial extends across the gape of the mouth and according to Gegenbaur (1872) is more or less divided into an anterior and a posterior division. In the noticlanids, then, we have practically a complete transition from the single rudiment to the condition found in more specialized forms.

It may be said of transitional rays that the labial cartilages are poorly developed (Rhinobatis). 
Since the extrahyoids and extrabranchials both serve the same purpose the two types may be deseribed together. 'These structures support the free margins of the gill septa and hence run parallel with the deeper visceral arches to which the septa are attached. They may be present on the hyoid and on all the branchial arches except the last, as in Acanthias and in Raia erinacea (ex.b., fig. 74). In others, while the extrahyoid is lost dorsally it may persist ventrally, making five inferior and only four superior cartilages (Heterodontus francisci). In still others, both segments of the extrahyoid arch may be absent, and ret a full complement of extrahranchial arehes on the first four branchials may be present (Trygon). In a reduction of the number of extrabranchials the posterior cartilages are the first to be absent. A fourth extrabranchial may be lacking ventrally, leaving three below and four above (Scyllium).

While the extrahyal segments present are normally small, the extrabranchials over the branchial arches may be well developed. Occasionally the tips of the dorsal and ventral segments of the anterior arches overlap as in Hetero-

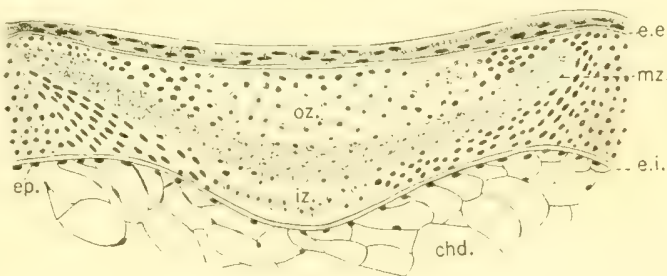

Fig. 75. Sagittal seetion through a developing rertebra, Scyllium canicula. (From Schauinsland.)

$c h d .$, notochord; e.e., elastica externa; $e . i .$, elastica interna ; $e p$. , chordal epithelium ; $i z .$, inner zone; mz., middle zone; oz., outer zone.

dontus (fig. 71). In most forms, however, the dorsal and ventral segments fail to touch (Acanthias), and in many they are relatively insignificant structures (Raia erinacea, fig. 74).

We have said above that the extravisceral arch is normally composed of a superior and an inferior segment. In a number of species an interesting condition is found in which lateral pieces, extraseptalia, are also added. These may be present as flattened bands of cartilage between the external clefts (Torpedo; Raja clac ata) or they may be flattened plates lying underneath the forward projection of the propterygial segment of the fin skeleton as this passes over the region of the gills (Myliobatis). In Cephaloptera, the devil ray, they are relatively large plates bound under the propterygium.

\section{Spinal Column}

The spinal column in Elasmobranch fishes shows great variation, from a simple cartilaginous tube around the notochord, as in Heptanchus maculatus, to the highly segmented and calcified column common to many forms. In general, it consists of a central axis made up of centra upon which is a series of neural arches, which extend throughout the body. In the region of the tail, haemal arches, under the centra, furnish protection for the haemal or blood vessels. A vertebra includes a centrum and its neural and haemal arches. The vertebrae vary greatly in numbers. In a type like Heterodontus there are only a few more than a hundred in the whole column, while in Alopias there are more than twice that number in the tail alone. 
In Elasmobranchs the column is particularly instructive because of its relation to the still more primitive notochord fomd in the prechordata and in the embryo of all vertehrates. This new cartilaginous column arises around and in the sheath of the notochord as a secondary and more effective support. Its mode of development may be noticed briefly.

In the embryo, cells proliferate from the sclerotome or inner part of the somite (see p. 96, fig. 97, scl.) and migrate inward to a position around, above, and below the notochord. Those which collect at the upper and lower levels form four cogs with the notochordal sheath as the center. These cells lay down cartilage for the neural and haemal arches and around the notochord.

Many of the cells around the notochord, however, may perforate its external

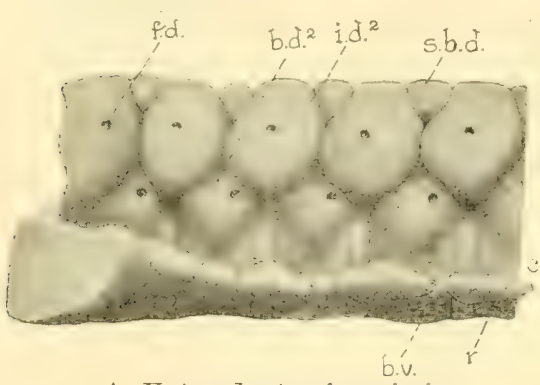

A. Heterodontus francisci. wall (elastica externa) and deposit cartilage within the notochordal sheath. A sagittal section through a vertebra of Scyllium canicula is shown in figure 75. The sheath between the outer (e.e.) and inner (e.i.) layers in which cartilage is deposited may be divided into outer (oz.), median (mz.), and inner (iz.) zones. The median zone is the one in which calcium is ustually deposited.

The central column, in

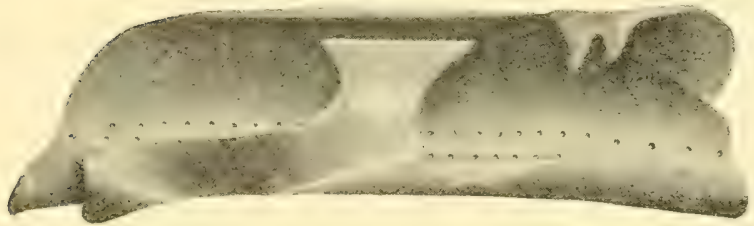

B. Rhinobatis productus. (Chester Stock, orig.)

Fig. 76. Cervical vertebrae.

$b d$. , dorsal basal plate (basidorsal); $b v$., ventral basal plate; $c$., centrum; f.d., foramen for dorsal nerve; id., dorsal intercalary (interdorsal plate) ; $r$., rib; $s b d$. , neural spine.

described for Amphioxus by Von Ebner (1895). As to the layer which is designated " $i z$." in figure $52 \mathrm{I}$ am not sure whether this represents the inner zone of more specialized Elasmobranchs or is a part of the elastica interna.

In types only a little more specialized than Heptanchus maculatus (Chlamydoselachus and Heptanchus cinereus), a slightly greater amount of calcification may be present in the column; and in still more specialized forms, where the column becomes a stronger support than that just deseribed, calcification is a pronounced feature. But different regions vary greatly in the amount of calcification. For convenience of description the column may be divided into three regions. The first of these, the anterior section, joins the head; the second is in the area of the trunk; and the third we may designate simply as the caudal segment of the column. 
The anterior section of the column differs in the various Elasmobranchs in its relation to the eranium. In the notidanids, as we have seen, the two are more or less continuous. 'This continuity is further emphasized in all generalized forms by the fact that this fused region is perforated by a number of occipitospinal nerves which arise between the vagus and the first spinal nerve. In a type like Acanthias in which there are a dorsal and two lateral ridges continuing directly from the column to the cranium, the relation of the two

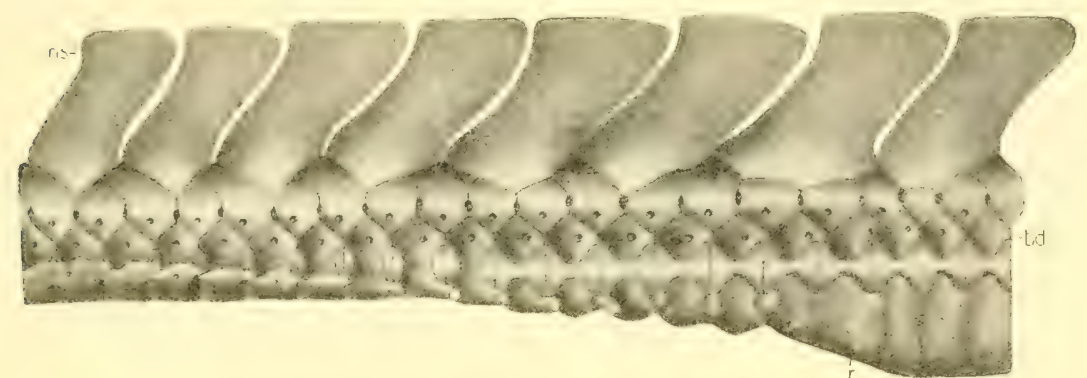

A. Rhinobatis productus. (Cliester Stock, orig.)

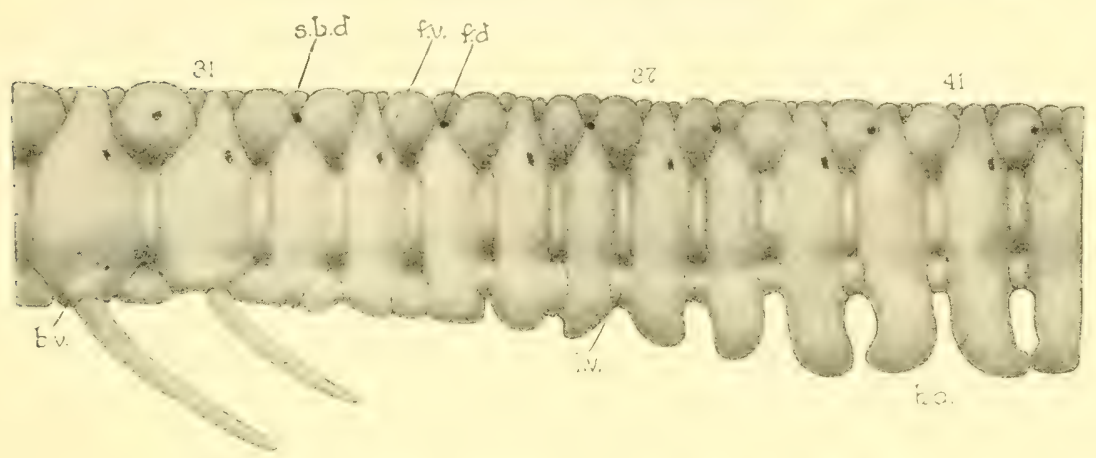

B. Heterodontus francisci. (Dunean Dumning, del.)

Fig. 77. Transitional vertebrae.

$b c$., dorsal basal (basidorsal) plate; bv., ventral basal plate; f.l., foramen for dorsal root nerve; f.v., foramen for ventral root nerve; iv., ventral intercalary; n.s. (and) sbd., neural spine; $r$, rib.

regions is not so clear; while in still more specialized forms the column is more or less elearly separated from the eranium, attachment of the two being made by processes of the cranium and the column (rays).

This segment of the column (fig. 76A, Heterodontus), unlike that of Heptanchus, is usually clearly divided into centra $(c$.). In practically all forms the relation of the dorsal and ventral arches to the centra is equally clear. In a type like Pseudotriacis, however, the segmentation is irregular, both in the centra and in the neural arches of the column. This irregularity is especially marked in the most anterior vertebra which has fused into a solid ring. In the rays (Rhinobatis, fig. 76B) the larger part of this anterior region has secondarily fused into a solid vertebral plate, the segmentation of which is made out only through a study of the foramina and certain lateral processes. 
The trunk vertebrae lie between the pectoral and pelvic regions and their dorsal and rentral plates are usually distinct and regular. In some types, however, as for example Laemargus borealis, the dorsal intercalary plates represent the maximum of change in that each plate is subdivided into two or more parts. A similar segmentation in the ventral intercalary plates may be present in this area.

The anterior vertebrae of this region are rib-bearing but there is great variation in the number of ribs present. In Laemargus borealis ribs are present on only a few vertebrae, while in other forms ribs may extend almost to the

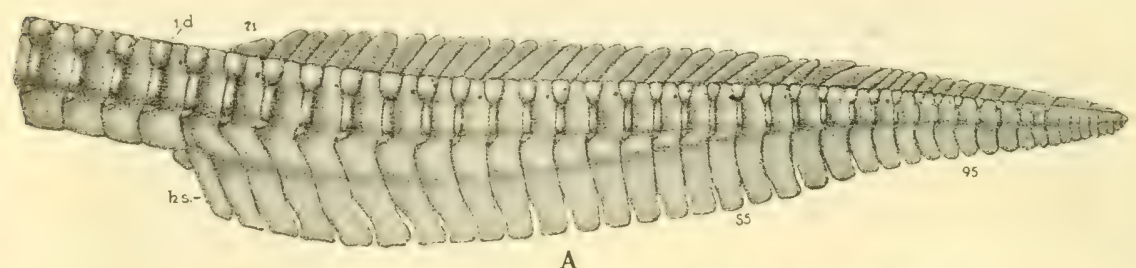

A

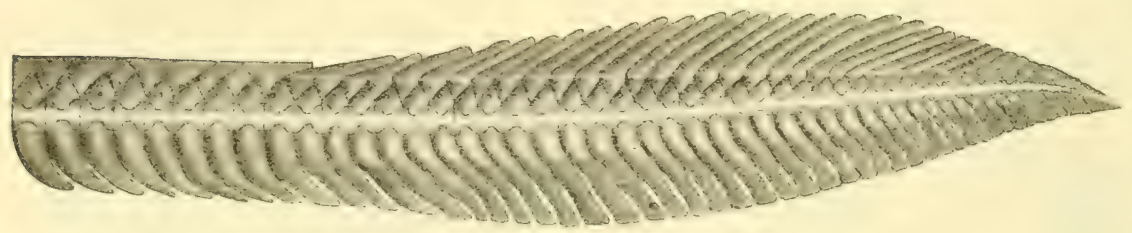

B

Fig. 78. Caudal vertebrae.

A. Heterodontus francisci. (Duncan Dunning, del.)

B. Rhinobatis productus. (Chester Stock, orig.)

$h . s .$, haemal spine; $i d$., dorsal interealary plate.

posterior limits of the trunk area. The posterior part of the trunk segment offers great variation in the different elements of the column and is of particular interest because of diplospondyly or doubling of the segments, which is present here.

Diplospondyly may begin immediately after the last rib-bearing centrum (Heterodontus, fig. 77B), or a series of vertebrae may intervene before the diplospondylous vertehrae are reached. In Scyllium, according to Ridewood (1899), a hrief area of transition follows the rib-bearing segments in which the stages from monospondyly to diplospondyly may be traced. The first indication of the change is seen in the slight shifting backward of the dorsal intercalary plate of the first vertebra behind the last one bearing a rib, so that one of the neurals rests directly upon the dorsal basal plate. In the vertebra following, this condition is further accentuated and results in diplospondyry. which is also seen in succeding vertebrae. In a type like Rhinobatis (fig. 77 A) the rib-bearing segments $(r$ ) extend far posteriorly and are separated from the true diplospondylous segments by only a few vertebrae. In this type, also, the spines are of large size and rest between two or more of the irregular intercalary pieces. 

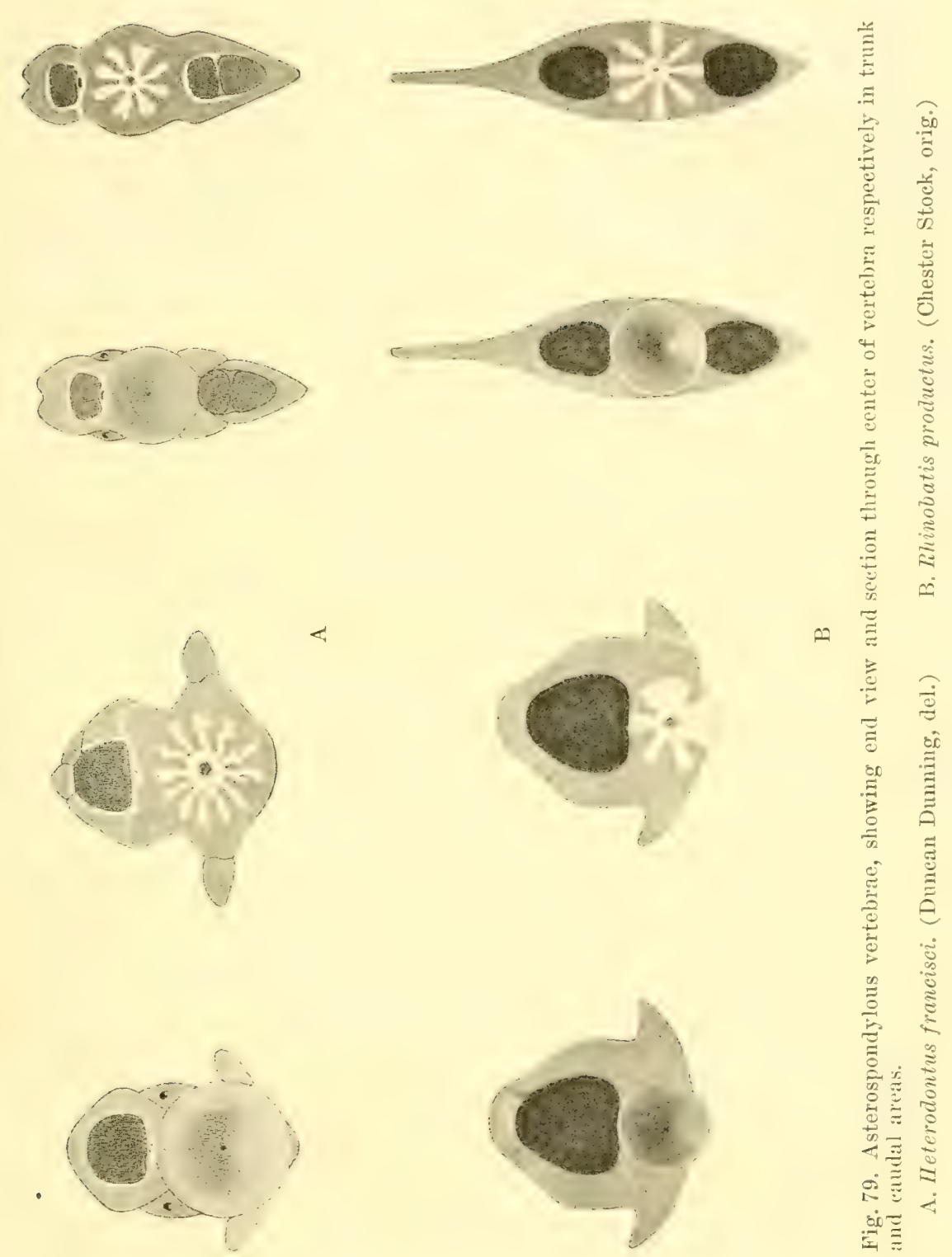
The doubling probably is to be interpreted as meaning that there is need for greater freedom of movement in the active area preceding the caudal fin. In this area where the most severe strain is imposed upon the column it is important, as Ridewood has suggested, that greater strength and at the same time greater freedom of movement be obtained. Strength is given by the increased calcification, and freedom of movement is brought about by increasing the number or decreasing the size of the segments; that is, by diplospondyly. Diplospondyly may extend practically to the tip of the tail (Acanthias) or the terminal segments may be irregularly segmented (heterospondylic).

As a usual thing the vertebrae in the caudal segment of the column present marked regularity in their centra and arches. In Heterodontus (fig. 78A) the radials are more numerous than are the vertebrae. In Lamna the dorsal radials are inconspicuous, while those having a ventral position are usually large. In this type we see the extreme of heterocercy, in which the axis of the body turns sharply upward into the dorsal lobe of

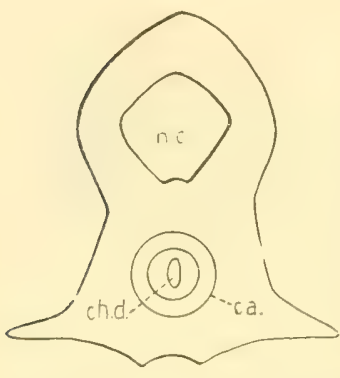

Fig. 80. Cyclospondylous rertebra, Squalus sucklii.

ca., calcification; chd., notochord; n.c., neural canal. the caudal fin. In Rhinobatis (fig. 7SB) the caudal segment is unlike that of the sharks especially in that the vertebral column is here practically straight, and dorsal and ventral radials of the caudal fin skeleton are of practically equal length. Such a trpe is more nearly diphycercal than heterocercal.

Helbing (1904) has shown for Lacmaryus that there is a tongue of cartilaginous segments in the area between the ventral lobe of the caudal fin and the pelvic fin. This tongue is attached to the haemal process of one of the vertebrae posteriorly and extends anteriorly. While the basal plates of the neural arches are uniform in size, the intercalary pieces are variable. In the anterior part of this area (fig. 78B ) they may segment irregularly, while more posteriorly they are continuous with the dorsal radials. At the most posterior tip the intercalaries and radials represent an irregular mass.

In various regions of the column the calcification takes up different localities, forming diverse and eurious designs. Probably the simplest design is that in which a single ring of calcium is produced in the middle zone of the notochord sheath (fig. 75). A cross-section through a centrum thus calcified shows the ring, of large or small diameter depending upon whether it is cut near the end or at the middle of the centrum. A sagittal section would show it as a broad $V$ above and as an inverted broad $V$ below within the centrum. the two V's being separated at their apices by the notochord. Such a type of vertebra has been designated by Hasse as cyclospondylous (fig. 80, Squalus suchlii).

Another design formed by the calcification is a further addition to the cyclospondylous type. In this, two or more concentric rings of calcium are formed in the sheath of the notochord. The inner ring is thick like that of the 
eyclospondylous type, but the outer circle is usually a thin sheet. Such a type of ealeification is known as tectospondyly. A modification of the tectospondylous type may add still other outer circles, as, for example, in Squatina. A sagittal section through this type would show the heavy inner circles as V's above and below, which are concentrically surrounded by sections of other circles, appearing as more or less straight lines.

A most interesting and varied type of ealcification is arranged around the immer zone of the notochordal sheath as a central hub from which spokes or rays diverge in a star-like fashion through the onter zone (asterospondyly).

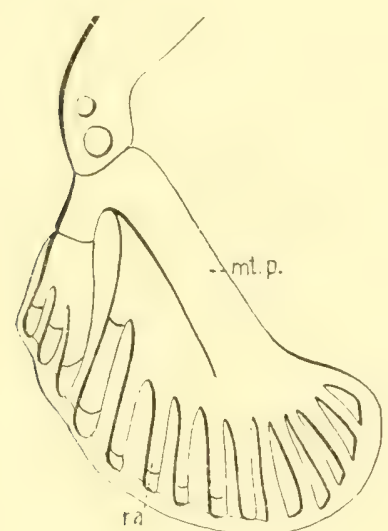

A

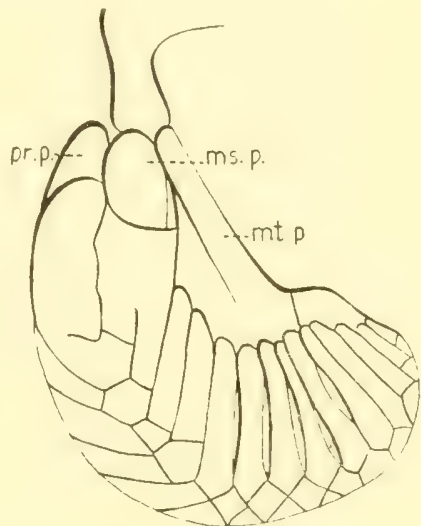

B

Fig. 81. A and B. Stages in development of the pectoral fin of Scyllium canicula. (From Balfour.)

$m s . p$. , mesopterygium; mt.p., metapterygium; pr.p., propterygium; ra., radial.

Few calcified rays may be present as in Galeus, or they may be more numerous as in Heterodontus (fig. 79A) and Rhinobatis (fig. 79B). In Alopias more than twenty rays are present.

So characteristic are the above types of calcification that Hasse has used them as a basis for classification. Under such a classification exceptions must be made, however, for many variations are to be found.

\section{Appendicular Skeleton}

\section{SKELETON OF PAIRED FINS AND OF FIN GIRDLES}

\section{PECTORAL FIN SKELETON}

The skeleton of the pectoral fin, as noted in Heptanchus, consists of a more or less horizontal framework of cartilage attached to a vertical girdle. The cartilages making up the framework of the pectoral fin itself are: (1) a set of basal cartilages from which projects (2) a series of median cartilaginous 


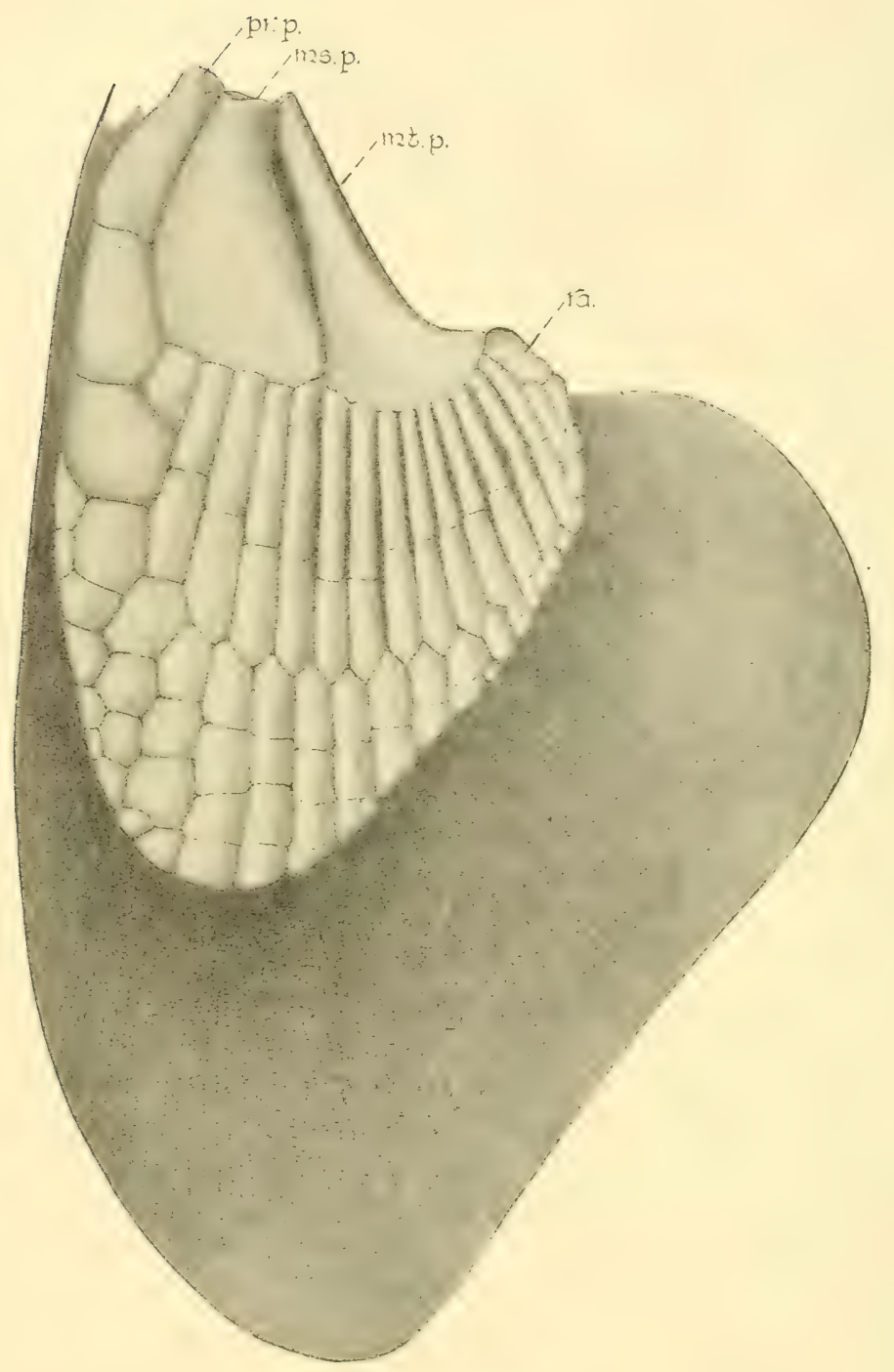

Fig. 82. The adult pectoral fin, Heterodontus francisci. (Duncan Dunning, del.) ms.p., mesopterygium; mt.p., metapterygium; pr.p., propterygium; ra., radials. 
radials ( $r$., fig. 82). In some forms there may also be found (3) a series of distal plate-like radials (IItevodontus) between upper and lower dermal rays.

A knowledge of the development of such a skeleton is helpful to an understanding of the adult framework. In Scyllium canicula (fig. 81) Balfour (1881) has shown that the pectoral skeleton arises as a horizontal bar or plate of cartilage from which radials (ra., fig. 81) extend. These radials by fusion at their outer tips form a rim from which plate-like distal radials pass well out into the fin. As growth progresses the original bar of cartilage becomes the main axis of the fin skeleton, the metapterygium (mt.p., fig. 81A) to which numerous radials are attached. Anterior to the metapterygium, the socalled median piece or mesopterygium (ms.p.) arises secondarily; fewer radials project from it. There is next segmented off from the anterior part of the mesopterygium a piece, the propterygium ( $p r . p$. , fig. $81 \mathrm{~B}$ ), which bear's a single plate-like radial. As for the pectoral girdle, it is formed secondarily from the anterior tip of the horizontal bar.

In the adult shark the simplicity of plan characteristic of this embryonic fin is rarely retained (Chlamydoselachus), yet the fundamental plan here laid down is the same, even in the most specialized of peetorals. Propterygium, meso-, and metapterygium are usually present. The propteryginm may be fused with the mesopterygium, as in the adult

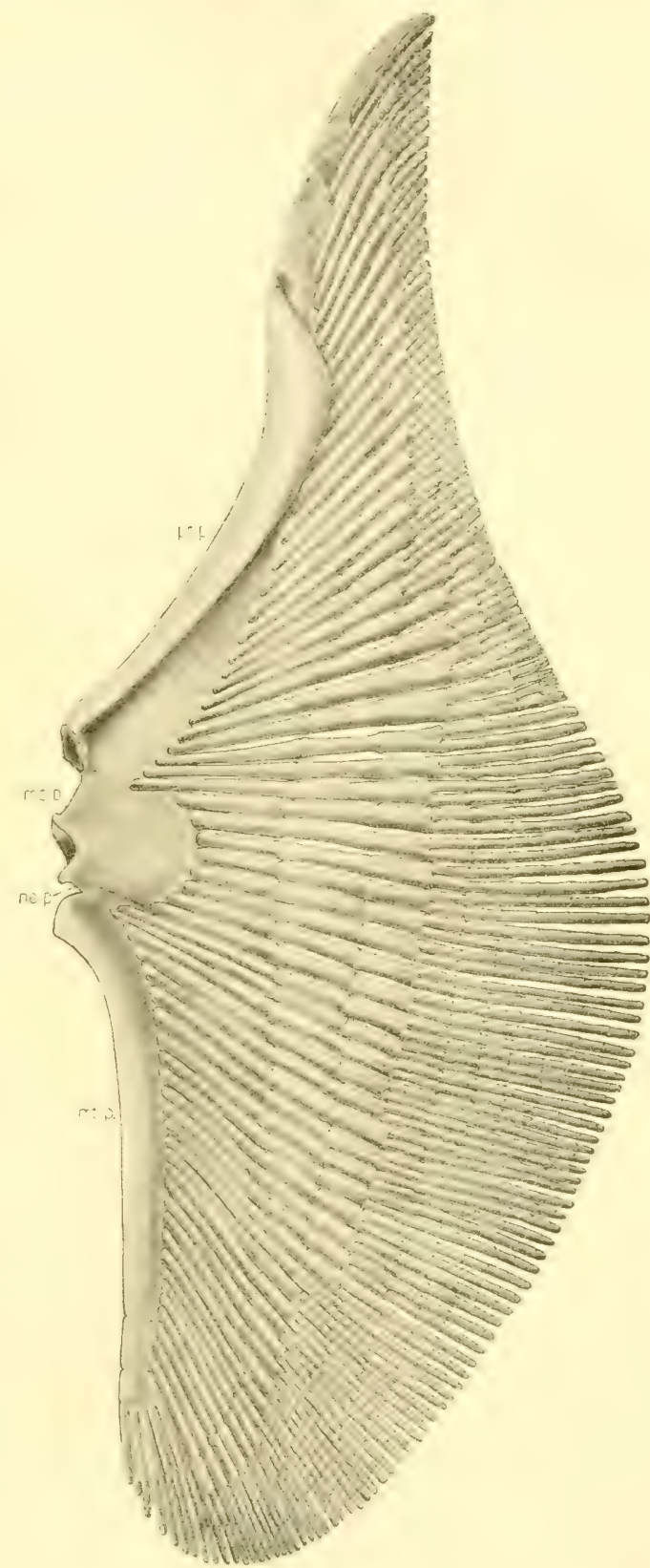

Fig. 83. The adult pectoral fin, Rihinobatis productus. (Mildred Bennett, del.)

ms.p., mesopterygium; mt.p., metapterygium; ne.p., neopterygium; pr.p., propterygium. 
IIeterodontus phitippi, although this does not oceur in Heterodontus francisci (fig. 82). The mesopterygium is usually an independent piece, but it may be masked by fusion as in Pristiophorus japonicus. A considerable change from the embryonic plan of the basals is found in Scymnus lichia, in which only a single basal cartilage is present. It is supposed that the missing basal cartilages have secondarily fused in the adult.

The form of the fin in the rays differs greatly from that of a shark like Heptunchus in that the hasal cartilages are modified in keeping with the dorsoventral depression and the great extent, anteroposteriorly, to which the fins are expanded. The pectoral of Squatina, although shark-like in its articulation,
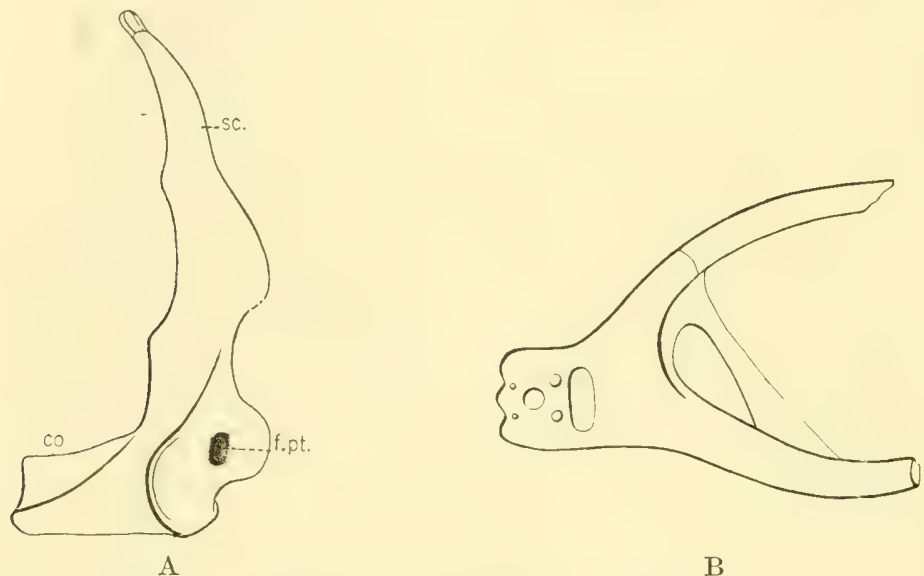

$\mathrm{B}$

Fig. 84. Pectoral girdles. A. Heterodontus francisci. B. Torpedo. (Modified from Gegenbaur.)

$c o$. , coracoid; f.pt., aperture for nerve and blood vessels to pectoral fin; sc., scapula.

is like that of the rays in extent; it has, however, a much heavier mesopterygium than have the rays. Usually the propterygium of the rays is divided into a number of segments which extend forward to join the antorbital process (Rhinobatis, fig. 83, pr.p.; Raju, Myliobatis), or even to the tip of the ethmoid region where the two from the opposite sides unite (Urolophus). The mesopterygia of the rays are very variable. In sone forms a mesopterygium is absent whereupon the radials extend to the girdle. In other types there is a considerable mesopterygial plate, as in Rhinobatis (ms.p., fig. 83). In others still, a second plate back of the mesopteryium may be formed, as in Pteroplatia. The metapterygium of the rays, like the propterygium, is greatly developed, passing backward to the region of the pelvic fin.

The proptery gial radials of the sharks are usually few in number. They may form a single line of segments which may be of more or less regular plates, as in Heptanchus or Heterodontus francisci (fig. 82). In others the rows may be more numerous. In the rays there are many rows of such propterygial radials, some of which are made up of great numbers of segments (Rhinobatis, fig. 83).

The radials attached to the mesopterygium in the sharks are more numerous 
than those of the propterygium. In the rays these are of unusual interest. In addition to those extending from the mesopterygial cartilage there are certain other radials posterior to this cartilage, as we have said, which extend to the girdle. Five such oceur in Raja clavata, two or three in Squatina, a shark, and a larger number in some other forms. The most interesting thing about these extraradials is that in some of the rays they produce, as Howes (1890) has shown, a fourth basal, the neopterygium (ne.p., fig. 83), indicated in Rhinobatis and well formed in Pteroplatea.

In the rays the metapterygial radials are similar to those of the propteryg-
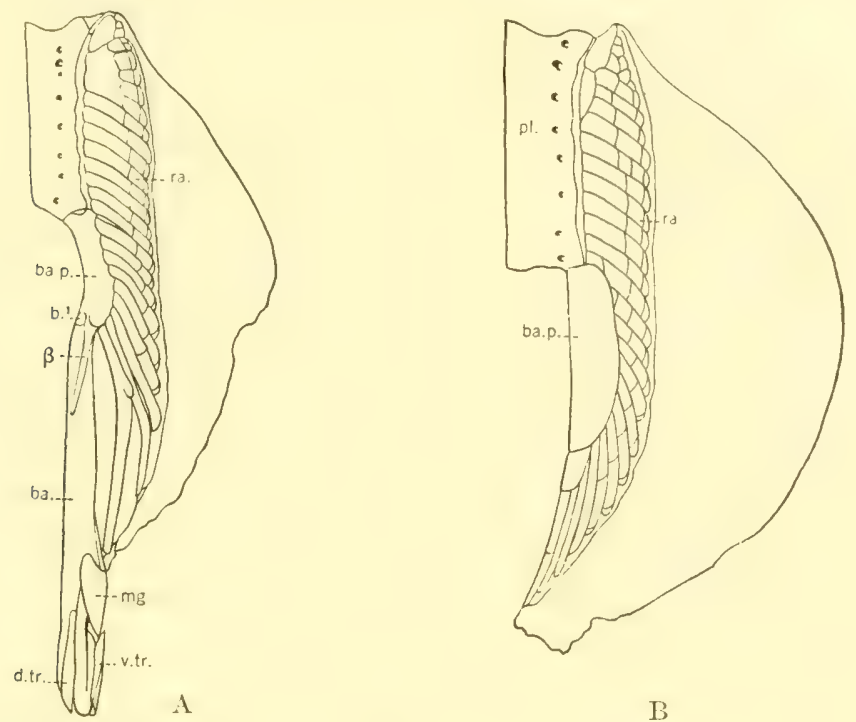

Fig. 85. Pelvic fin and girdle, Chlamydoselachus (A ठ, B ㅇ). (From Goodey.)

For explanation see fig. 86 .

iim. In the sharks these normally are found in the adult on the anterior side of the main metapterygial axis. Not infrequently, however, postaxial radials are well developed in the embryo (Acanthias, Carcharias, and many others). The significance of postaxial radials has been pointed out by investigators seeking a solution of the early form of the paired limb. Those who hold that the early type of limb was like that of the present-day lungfish, Ceratodus, with a central axis and anterior and posterior rays, think that the postaxial rays of sharks are remnants of a past condition.

\section{PECTORAL GIRDLE}

The right and left limbs of the girdle are incomplete dorsally except in the rays, in which the upper tips may be firmly joined to the spinal column or to each other. Each half of the girdle is composed of two pieces, one dorsal, the scapula (sc., fig. 84), another ventral, the coracoid (co.). The scapula varies 
a great deal in the direction which it takes. In Heptanchus it slopes very obliquely backward. while in Heterodontus and especially in the rays it stands more nearly vertical. In general it is capped by a suprascapular cartilage.

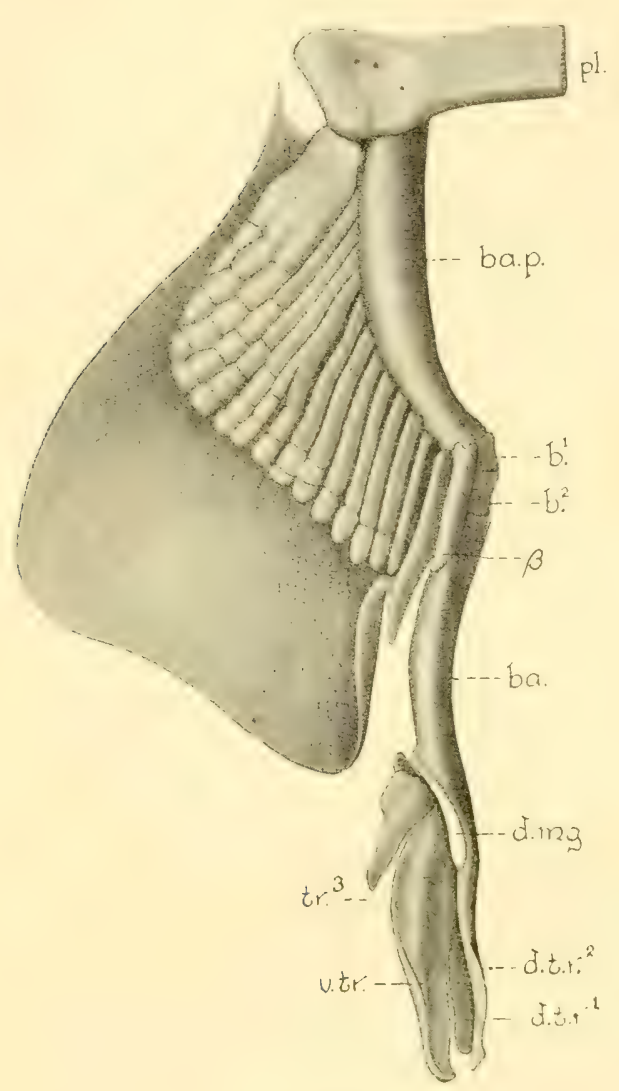

A

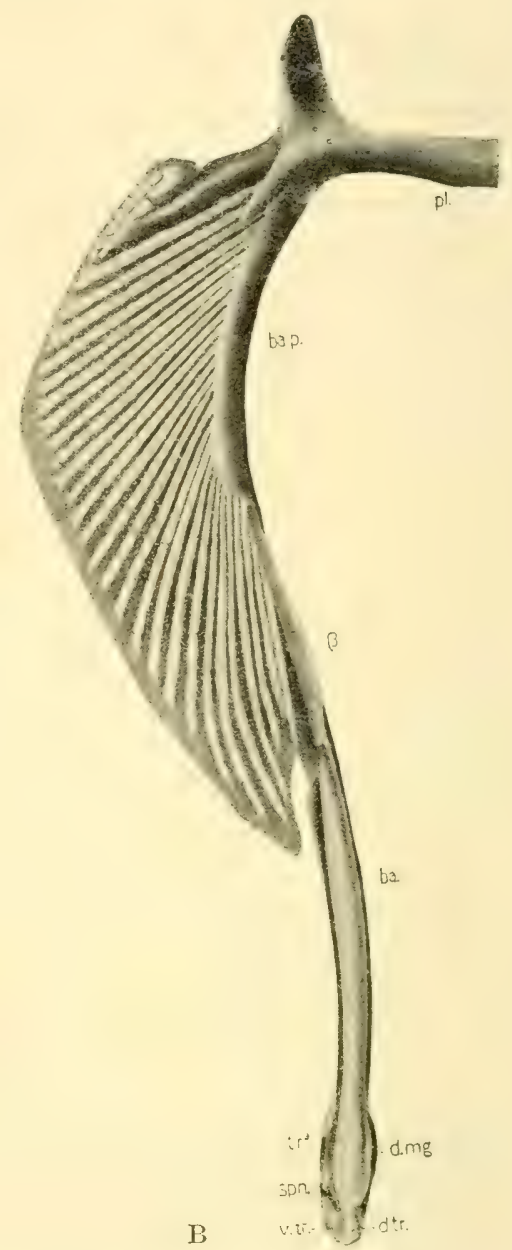

Fig. 86. Pelvic fin and girdle of male. A. Heterodontus francisci. B. Rhinobatis productus. (Chester Stock, orig.)

$\beta$, beta cartilage; $b .^{1-2}$, intermediate segments; $b a$. basal or axial cartilage; $b a . p$. basipterygium; d.mg. and $m g$. (fig. 85), dorsal marginal; $d . t r_{0}{ }^{1-2}$, first and second dorsal terminal cartilages; $p l$., pelvic cartilage; $r a$. (fig. 85), radials; spn., spine; $t r_{.}^{3}$, accessory terminal; v.tr., ventral terminal.

Near the union of the coracoid and scapular pieces, but on the coracoid, is the articular process. This area of articulation in the sharks is directed vertically or obliquely and consequently is usually composed of two convex surfaces (Squatina). The surface in the rays differs from that in the sharks in that it is longitudinal in position and much greater in extent. Torpedo (fig. 84B) has a type of articulation intermediate between sharks and rays. 
There is a foramen entering the median side of the girdle for the brachial artery and for nerves going to the pectoral fin. 'The canal leading through the girdle from this foramen separates into a dorsal and a ventral part so that laterally there are two foramina leaving the girdle.

The coracoids from the opposite sides may be separated by a special $m$ paired sternal piece (Heptanchus maculatus). Usually, however, they are joined ventrally in the sharks; in Heterodontus and Squatina they are firmly welded together. In the rays this region is firm excepting in Torpedo.

\section{PELVIC FIN SKELETON}

'The skeleton of the pelvic (ventral) fin is made up of at least two basal cartilages, the basipterygium (ba.p., figs. 85-86) and the anterior basal. From

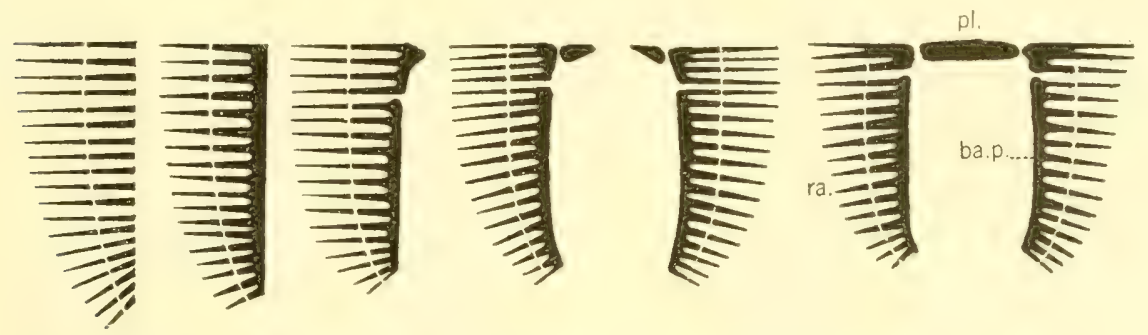

Fig. 87. Diagram to illustrate the probable origin of the pelvic girdle. (From Mivart after Thacher.)

ba.p., basipterygium; pl., pelvie girdle; ra., radial.

these two basal pieces the radials proceed. The basals are supported by a girdle which in the Elasmobranchs is not in contact with the axial skeleton. The structure of the adult pelvic fin is much simpler than that of the pectoral, but in the embryo the two are built on the same fundamental plan. 'The basipterygium (ba.p.) is comparable to the metapterygium of the pectoral. This is normally a single piece, but posteriorly it may be broken into three or four segments (Centrophorus, Heterodontus, fig. 86A; Rhinobatis, fig. 86B). The anterior basal is somewhat like the propterygium. It apparently represents a fusion of the basal parts of the anterior radials, from the distal part of which the radials extend freely. In Heptanchus (fig. 55) a segment may join the girdle between the anterior basal and the basipterygium which in position is like the mesopterygium. 'The radials belonging to the basipterygium proper are more or less segmented anteriorly, but posteriorly, in both male and female, they are usually unsegmented.

'The skeleton of the clasper' of the male is a continuation in the median axis of the basipterygium of the fin, the two being connected by short segments $\left(b .^{1}\right.$ and $b .^{2}$, fig. 86A) as in Heptanchus. The terminal part of the basal or axial cartilage assumes different degrees of complexity in the various Elasmobranchs. In some, the basal or axial cartilage $(b a$. $)$ is provided with a single accessory cartilage. In others there are present distally an outer marginal and a ventral and a dorsal terminal accessory cartilage (Chlamydoselachus, 
fig. 85A.) A still more complex type (fig. 86A) has one or two dorsal terminals $\left(d . t r \cdot{ }^{1-2}\right)$ and a ventral terminal $(v . t r)$, and along the furrow leading to the terminal groove there is an accessory terminal $\left(t r^{3}\right)$, and a dorsal marginal (mg. and d.mg.) (Heterodontus, Mustelus, Scyllium, Carcharias, Raja).

\section{PELVIC GIRDLE}

The pelvic girdle is probably built on a generalized plan in Chlamydoselachus (fig. 85). Here it is an unusually wide cartilage which is perforated by no fewer than six to eight nerves. In most other types the adult girdle is a narrow band which points backward in the middle line.

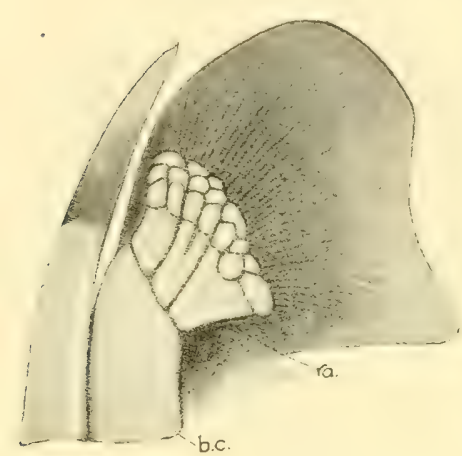

A

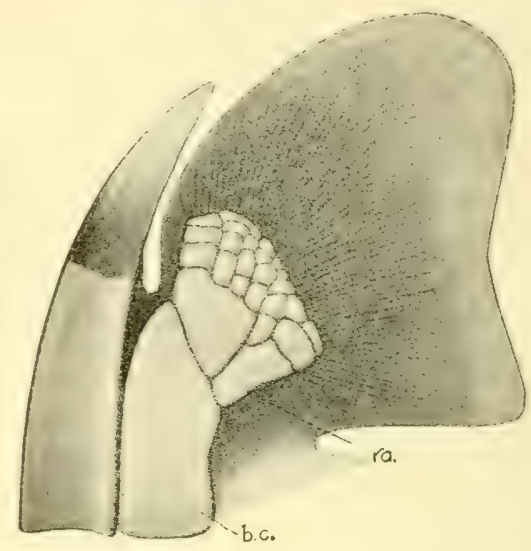

$\mathrm{B}$

Fig. 88. Dorsal fins of Heterodontus francisci, showing fin spines. (Dunean Dunning, del.) A. Second dorsal. B. First dorsal.

b.c., basal cartilage; ra., radial.

Figure 87 is a diagram showing the origin of the pelvic girdle as postulated by Thacher (1877). This indicates that the anterior fin radials fuse and the fusion joins a similar fusion from the opposite side to form a bar which becomes the girdle $(p l$.$) ; the fusion of the tips of the rays back of this becomes$ the basipterygium (ba.p.).

\section{SKELETON OF UNPAIRED FINS}

The first indication of the unpaired fins in the embryo of Pristiurus, Dohrn (1884) found to be the development of a median longitudinal ridge in which cartilage is laid down as a series of parallel rods. In adult Elasmobranchs these cartilaginous rods are usually more or less completely segmented into: (1) basal (b.c., fig. 89), (2) median (b.c. $\left.{ }^{1}\right)$, and (3) distal segments $\left(b . c^{\circ}{ }^{2}\right.$ ). The first are proximal or nearest the body axis, and the third often run a considerable distance into the fins between the two rows of dermal fin rays.

In the dorsal fins all these types may be present as single segments of the radials (. Mustelus antarcticus, fig. 89A, or Z ugaena). In some forms the distals 
may he further segmented ( ringlymostoma) or they may be absent (s'quatina, fig. $89 \mathrm{~B}$ ); or, finally, all the basal segments may fuse into a single basal plate (Heptanchus, Heterodontus, fig. 88). In certain forms the basals may come in contact with the column. Such a condition occurs in Squatina (fig. 89B), Rhinobatis, and Pristis, in which numerous segments in front of the fin may be present joining the neural spines.

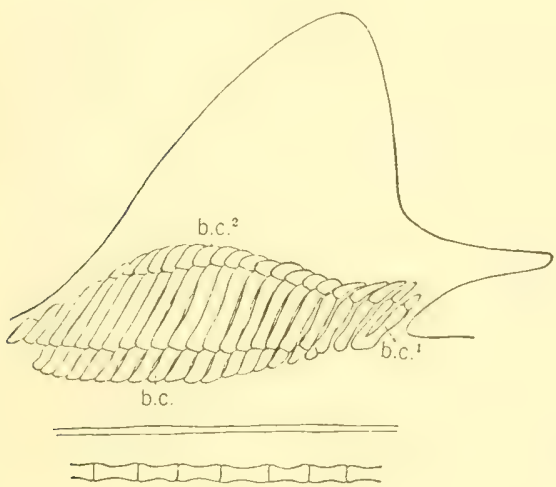

A

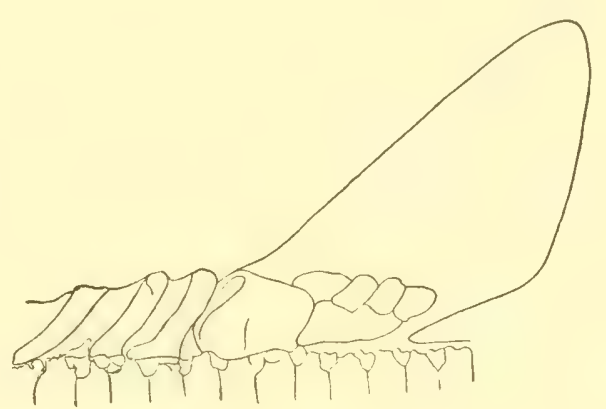

B

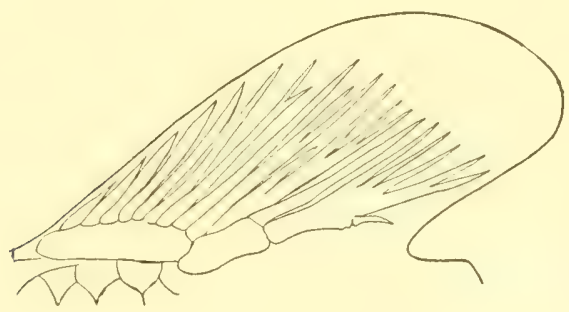

C

Fig. 89. Dorsal fin skeleton of Elasmobranchs. (From Mivart.) A. Mustelus antarcticus. B. Squatina. C. Raja.

b.c., basal cartilages; $b . c .^{1}$, median segments; $b . c^{2}$, distal segments.

The skeleton of the anal fin, like that of the other unpaired fins, is made up of two or three different types of segments, which, in general, show modifications similar to those in the dorsals. 


\section{BIBLIOGRAPHY}

\section{Chapter III}

1923. Allis, E. P., The Cranial Anatomy of Chlamydoselachus anguineus. Acta Zoologica, Bd. 4, pp. 128-221, pls. 1-23.

1926. Aluis, E. P., On Certain Features of the Orbito-ethmoidal Region in the Cyclostomata, Plagiostomi and Telostomi. Jour. Anat., Vol. 60, pp. 164-172.

1\$81. Baffour, F. M., On the Development of the Skeleton of the Paired Fins of Elasmobranchii, considered in relation to its Bearings on the Nature of the Limbs of the Vertebra. Proc. Zool. Soe. Lond., 1881, pp. 656-671, pls. 57-58, 2 text figs.

1901. Braus, H., Über neuere Funde versteinerter Gliedmassen-Knorpel und Muskeln von Selachiern. Verh. d. phys.-med. Ges. Würzburg (N. F.), Bd. 34, pp. 177-192, 8 text figs.

1906. Braus, H., Die Entwickelung der Form der Extremitäten und des Extremitätenskelets. Hertwig's Handb. vergl. u. expt. Entwick. d. Wirb., Bd. 3, Teil 2, pp. 167338, text figs. 178-266.

1906. Braus, H., Ueber den embryonalen Kiemenapparat ron Heptanchus. Anat. Anz., Bd. 29 , pp. 545-560, 2 text figs.

1874. Bunge, A., Ueber die Nachweisbarkeit eines biserialen Archipterygium bei Selachiern und Dipnoërn. Jena. Zeitsehr. Naturwiss., Bd. 8 (N. F. 1), pp. 293-307, pls. 8-9.

1875. CARTiER, O., Beiträge zur Entwickelungsgeschichte der Wirbelsäule. Zeitschr. wiss. Zool., Bd. 25, Suppl., pp. 65-76, Taf. 4.

1811. Chevreul, M., Expériences chimiques sur le cartilage du Squalus maximus. Nour. Bull. Sci. Soc. Philom, T. 2, pp. 318-320.

1854. Cope, E. D., The Skull of a Still Liring Shark of the Coal Measures, Amer. Nat., Vol. 18, pp. 412-413.

1915. Daniel, J. Frank, The Anatomy of Heterodontus francisci. II. The Endoskeleton. Jour. Morph., Vol. 26, No. 3, pp. 447-493, 8 pls.

1916. Daniel, J. Frank, The Anatomy of Heptanchus maculatus. The Endoskeleton. Univ. Calif. Publ. Zool., Vol. 16, No. 18, pp. 349-370, pls. 27-29, 8 text figs.

1879. Davidoff, M. v., Beiträge zur vergleichenden Anatomie.der hinteren Gliedmassen der Fische. Morpl. Jahrb., Bd. 5, pp. 450-520, pls. 28-31, 1 text fig.

1539. Davy, JoHn, On the Male Organs of Some of the Cartilaginous Fishes. Phil. Trans. Roy. Soc. Lond., Vol. 129, pp. 139-149.

1889. Döderlein, L., Das Skelet von Pleuracanthus. Zool. Anz., Bd. 12, 1889, pp. 123-127, 1 text fig.

1884. DoHrN, A., Studien zur Urgeschichte des Wirbelthierkörpers. IV. Die Entwicklung und Differenzirung der Kiemenbogen der Selachier. Mitt. Zool. Stat. Neapel, Bd. 5, pp. 102-151. VI. Die paarigen und unpaarigen Flossen der Selachier, pp. 161-195, Mitt. Zool. Stat. Neapel, Bd. 5, pp. 152-195, Taf. 5-9.

1886. DoHRN, A., Studien zur Urgeschiehte des Wirbelthierkörpers. VII. Entstehung und Differenzirung des Zungenbein und Kieferapparates der Selachier. Mitt. Zool. Stat. Neapel, Bd. 6, pp. 1-48.

1895. EBner, V. von, Ueber den Bau der chorda dorsalis des Amphioxus lanceolatus. Sitzber. d. k. Akad. d. math.-nat. Wiss. Wien, Bd. 104, pp. 199-228, 4 Taf.

1897. EBner, V. von, Die chorda dorsalis der niederen Fische und die Entwickelung des fibrillaren Bindegewebes. Zeitschr. wiss. Zool., Bd. 62.

1897. Foote, Exherwyn, The Extrabranchial Cartilages of the Elasmobranchs. Anat. Anz., Vol. 13, pp. 305-308, 4 text figs. 
1903. Fürbringer, KarL, Beiträge zur Kenntnis des Visceralskelets der Selachier. Morph. Jałırb., Bd. 31, pp. 360-445, Taf. 16-18.

1903. Fürbringer, Kard, Nachtrag zu meiner Ablandlung Beiträge zur Kenntnis des Visceralskelets der Selachier. Morph. Jahrb., Bd. 31, pp. 620-622.

1896. Fürbringer, MLAx, Ueber die mit dem Viseeralskelet verbundenen spinalen Muskeln bei Selachiern. Jena. Zeitsehr. Naturwiss., Bd. 30, pp. 127-135.

1903. Fürbringer, Max, Notiz über die oberflächliehe Knorpelelemente im Kiemenskelet der Rochen (Extraseptalia), zugleich nach ron J. Ed. Stumpf gemachten Beobachtungen, Morph. Jahrb., Bd. 31, pp. 623-627, 4 text figs.

1888. GaDow, HaNs, On the Modifications of the First and Second Visceral Arehes, with especial reference to the Homologies of the Auditory Ossieles. Plil. Trans, Roy, Soe. Lond., Vol. 179B, pp. 451-485, pls. 71-74.

1895. Gadow, H., and ABвotr, Miss E. C., On the Evolution of the Vertebral Column of Fishes. Phil. Trans. Roy. Soe. Lond., Vol. 186B, Pt. 1, pp. 163-221, 13 text figs.

1900. GaUPP, E., Alte Probleme und neuere Arbeiten über den Wirbeltiersehädel. Ergebn. d. Anat. u. Entwick., Bd. 10, pp. 847-1001, 5 text figs.

1865. Gegenbaur, C., Untersuchungen zur vergleiehenden Anatomie der Wierbelthiere. Pts. I-II. Leipzig.

1870. GegeNBaUR, C., Ueber das Skelet der Gliedmassen der Wirbelthiere im allgemeinen und der Hintergliedmassen der Selachier inbesondere. Jena. Zeitsehr. Naturwiss., Bd. 5 , pp. 397-447, Taf. 15-16, 7 text figs.

1870. Gegenbaur, C., Ueber die Modifieationen des Skelets der Hintergliedmassen bei den Männchen der Selachier und Chimären. Jena. Zeitsehr. Naturwiss., Bd. 5, pp. 448-458, pl. 16, figs. 15-24.

1872. Gegenbaur, C., Untersuchungen zur vergleichenden Anatomie der Wirbelthiere. Pt. III. Das Kopfskelet der Selachier, ein Beitrag zur Erkenntnis der Genese des Kopfskelets der Wirbelthiere, pp. 1-316, pls. 1-22. Leipzig.

1873. Gegenbatr, C., Ueber das Arehipterygium. Jena. Zeitsehr. Naturwiss., Bd. 7, pp. 131-141, Taf. 10.

1887. Gegenbaur, C., Ueber die Oecipitalregion und die ilır benachbarten Wirbel der Fische. Sonder-Abdruck a. d. Festehr. f. Albert ₹. Kölliker. Leipzig, pp. 35-48, Taf. 2.

1895. Gegenbaur, C., Das Flossenskelet der Crossopterygier und das Archipterygium der Fische. Morph. Jahrb., Bd. 22, pp. 119-160, 5 text figs. Review, Zool. Centralbl., Vol. 3, 1896, pp. 706-708.

1895. Göppert, E., U๋utersuchungen zur Mrorphologie der Fisehrippen. Morph. Jahrb., Bd. 23, pp. 145-217, pls. 13-16, 21 text figs.

1910. Gooder, T., A Contribution to the Skeletal Anatomy of the Frilled Shark, Chlamydoselachus anguineus Garm. Proc. Zool. Soc. Lond., 1910, pp. 540-571, pls. 42-46.

1878. HASSE, C., Das natürliche System der Elasmobranehier auf Grundlage des Baues und der Entwicklung der Wirbelsaüle. Zool. Anz., Bd. 1, 1878, pp. 144-148, 167-172.

1878. Hasse, C., Die fossilen Wirbel. Morphologische Studien. Die Cestracionten. Morph. Jahrb., Bd. 4, Heft 2, pp. 214-268, pls. 12-14.

1879. Hasse, C., Ueber den Bau und über die Entwickelung des Knorpels bei den Elasmobranchiern. Zool. Anz., Bd. 2, 1879, pp. 325-329, 351-355, 371-374.

1879-85. HASSE, C., Das natürliche System der Elasmobranchier auf Grundlage des Baues und der Entwicklung ihrer Wirbelsaüle. Eine morphologische und palaeontologisehe Studie. Jena, Fischer, 1879.

1893. Hasse, C., Die Entwicklung der Wirbelsaüle der Elasmobranchier. (Dritte Abhandlung über die Entwicklung der Wirbelsaüle.) Zeitsehr. wiss. Zool., Bd. 55, pp. 519-531, Taf. 21. 
1881. Haswell, W. A., Studies on the Elasmobranch Skeleton. Proe. Linn. Soc. N. S. Wales, Vol. 9, pp. 71-1I7, pls. 1-2.

1906. Hawkes, Mrs. O. A. M., The Presence of a Vestigial Sixth Branchial Arch in the Heterodontidae. Jour. Anat. Physiol., 1905-06, Lond., Vol. 40, pp. 81-84, 2 text figs.

1899. HAy, O. P., Dr. Gadow and Miss Abbott on the Vertebral Column of Fishes. Zool. Bull., Vol. I, pp. 131-141.

1913. Hoffmann, Ludwig, Zur Kenntnis des Neurocraniums der Pristiden und Pristiophoriden. Zool. Jahrb. (Abt. Anat.u. Ontog.), Bd. 33, pp. 239-360, pls. 13-24, 8 text figs.

1809. Home, Everard, On the Nature of the Intervertebral Substance in Fish and Quadrupeds. Phil. Trans. Roy. Soe. Lond., Vol. 99, 1809, pp. 177-187, pl. 5.

1887. Howes, G. B., On the Skeleton and Affinities of the Paired Fins of Ceratodus, with Observations upon those of the Elasmobranchii. Proc. Zool. Soc. Lond., pp. 3-26, pls. 1-3.

1890. How es, G. B., Observations on the Pectoral Fin-Skeleton of the Living Batoid Fishes and of the Extinct Genus Squaloraja, with especial reference to the Affinities of the Same. Proc. Zool. Soc. Lond., pp. 675-688, 10 text figs.

1901. Huber, O., Mitteilungen zur Kenntnis der Copulationsglieder bei den Selachiern. Anat. Anz., Bd. 19, pp. 299-307. Also: Zeitschr. wiss. Zool., Bd. 70, pp. 592-674, pls. 27-28, 12 text figs.

1905. JAQUeT, M., Deseription de quẻlques parties du squelette du Pseudotriacis microdon Capello. Bull. Mus. Ocean. Monaco, 1905, No. 36, pp. 1-28, pls. 1-8.

1899. Jungersen, H., On the Appendices Genitales in the Greenland Shark, Somniosus microcephalus and Other Selachians. Danish Ingolf-Exped., Vol. 2, Pt. 2, pp. 1-88, pl. 6, 28 text figs.

1893. KlaAtsch, Herm., Beiträge zur vergleichenden Anatomie der Wirbelsaüle. I. Über den Urzustand der Fischwirbelsaüle. Morph. Jahrb., Bd. 19, pp. 649-680, pl. 26, 1 text fig. II. Über die Bildung knorpeliger Wirbelkörper bei Fischen. Bd. 20, pp. 143-186, pl. 7, 6 text figs.

1895. Klaatsch, Herm., III. Zur Phylogenese der Chordascheiden und zur Geschichte der Umwandlungen der Chordastruktur. Ibid., Bd. 22, pp. 514-560, pls. 22-23.

1897. KIAATSCH, H., Zur Frage nach der morphologischen Bedeutung der Hypochorda. Morph. Jahrb., Bd. 25, pp. 156-169, Taf. 10.

1860. Kölliker, Professor AlberT, "On the Structure of the Chorda Dorsalis of the Plagio. stomes and Some other Fishes, and on the Relation of its Proper Sheath to the Development of the Vertebrae." Verh. d. phys.-med. Ges. Würzburg, Bd. 9, pp. 193-242, Tafs. 2-3.

1860. Kölliker, Albert, Ueber den Anteil der Chordascheide an der Bildung des Schädelgrundes der Squalidae. Würzburg. Naturwiss. Zeitschr., Bd. 1, pp. 97-105.

1909. Lubosch, W., Anpassungserscheinungen bei der Verkalkung des Selachierknorpels. Anat. Anz., Bd. 35, pp. 1-8, 8 text figs.

1880. Metschnikoff, Olga, Zur Morphologie des Becken- und Schulterbogens der Knor-: pelfische. Zeitschr. wiss. Zool., Bd. 33, pp. 423-438, Taf. 24.

1879. Mivart, St. George, Notes on the Fins of Elasmobranchs, with Considerations on the Nature and Homologues of Vertebrate Limbs. Trans. Zool. Soc. Lond., Vol. 10, pp. 439-484, pls. 74-79, 6 text figs.

1887. Parker, T. J., Notes on Carcharodon rondeletii. Proc. Zool. Soe. Lond., pp. 27-40, pls. 4-8.

15.(0. Parker, T. J., On the Presence of a Sternum in Notidanus indicus. Nature, Vol. 43, p. 142, 1 text fig. 
1S79. PARKer, W. K., On the Strueture and Development of the Skull in Sharks and Skates. Trans. Zool. Soe. London, Vol. 10, pp. 189-234, pls. 34-42.

1877. PArker, W. K., and BettanX, G. T., Morphology of the Skull. London, Macmillan.

1994. RABL, C., Ueber die Herkunft des Skelets. Anat. Anz., Bd. 9, pp. 163-169. (Verh., Strassburg.)

1497. Ridewood, W. G., Note on the Extrabranchial Cartilages of Elasmobranch Fishes. Anat. Anz., Bd. 13, pp. 499-501.

1899. Ridewood, W. G., Note on the Basibranchial Skeleton of Echinorhinus spinosus. Anat. Anz., Bd. 15, pp. 346-348, 1 text fig.

1899. Ridewood, W. G., Some Observations on the Caudal Diplospondyly of Sharks. Jour. Limm. Soe. Zool. Lond., Vol. 27, pp. 46-59, 2 text figs.

1884. Rosenberg, Emil, Untersuchungen über die Occipitalregion des Cranium und den Proximalen Teil der Wirbelsaüle einiger Selachier. Festschr. Dorpat, Vol. 4, pp. 1-26, pls. 1-2.

1886. Rosenberg, Wa., Ueber das Kopfskelet einiger Selachier. Sitzber. Naturf. Ges. Dorpat, Bd. 8, pp. 31-34.

1911. Roth, Wilhels, Beiträge zur Kenntnis der Strukturverhältnisse des Selachier-Knorpels. Morph. Jahrb., Bd. 42, pp. 485-555, pls. 5-8, 18 text figs.

1902. Ruge, ERnst, Die Entwicklungsgeschichte des Skelets der vorderen Extremitäten von Spinax niger. Morph. Jahrb., Bd. 30, pp. 1-27, 1 Taf., 13 text figs.

1903. SABATIER, ArMAND, Sur les mains seapulaires et pelviennes chez les poissons ehondropterygiens. C. R. Acad. Sei. Paris, T. 137, pp. 1216-1219.

1906. Schauinsland, H., Die Entwicklung der Wirbelsaüle nebst Rippen und Brustbein. Hertwig's Handb. vergl. u. expt. Entwick., Bd. 3, Teil 2, pp. 339-572, text figs. 166-322.

1911. Secérov, Slavko, Über die Entstehung der Diplospondylie der Selachier. Arb, zool. Inst. Wien, T. 19, pp. 1-28, pls. 2, 5 text figs.

1925. Senna, Angeto, Contributo alla conoscenza del cranio della Selache (Cetorhinus maximus Gunn.). Areh. Ital. anat. e emb., Vol. 32, pp. 84-122, pls. 9-10, 4 figs. in text.

1895. Sewertzoff, A. N., Die Entwicklung der Oecipitalregion der niederen Vertebraten im Zusammenhang mit der Frage über die Metamerie des Kopfes. Bull. Soe. Impér. des Nat. Moseou, pp. 186-284, pls. 4-5, 4 text figs.

1897. Sewertzoff, A. N., Beitrag zur Entwicklungsgeschichte des Wirbeltierschädels. Anat. Anz., Vol. 13, pp. 409-425, 4 text figs.

1899. Sewertzoff, A. N., Die Entwicklung des Selachierschädels. Ein Beitrag zur Theorie der korrelativen Entwicklung. Festsehr. z. Carl v. Kupffer, Jena, pp. 281-320, Taf. 29-31, 4 text figs. (Text and atlas.)

1911. Sunier, A. L. J., Les premiers stages de la différentiation interne du Myotome et la formation des éléments sclérotomatiques chez les Acraniens, les Sélaciens et les Téléostéens. Onderz. Zool. Lab. Groningen, 1911, pp. 1-102, pls. 1-6.

1877. Thacher, J. K., Median and Paired Fins. Trans. Connecticut Acad., Vol. III, pp. 281310 , pls. $49-60,4$ text figs.

1917. Wells, Grace H., The Skull of Acanthias vulgaris. Jour. Morph., Vol. 28, pp. 417444 , pls. $1-3$.

1892. Whiте, Pн. J., 'The Skull and Visceral Skeleton of the Greenland Shark, Laemargus microcephalus. Trans. Roy. Soc. Edinburgh, Vol. 37, Pt. 2, pp. 287-306, pls. 1-2.

1896. White, PH. J., A Sternum in Hexanchus griseus. Anat. Anz., Bd. 11, pp. 222-224, 2 text figs.

1896. White, PH. J., Note on the Extra-branchial Cartilages of Scyllium canicula. Anat. Anz., Bd. 12, p. 158. 
1896. White, Pн.J., The Existence of the Skeletal Elements between the Mandibular and Hyoid Arches in Hexanchus and Laemargus. Anat. Anz., Bd. 11, pp. 57-60, 3 text figs. 1892. Wiedersheim, R., Das Gliedmassenskelet der Wirbelthiere. Jena, pp. 1-266, pls. 1-17, 40 text figs.

1904. WiJHE, J. W. vaN, Ueber die Entwicklung des Kopfskelets bei Selachiern. C. R. 6me Congr. internat. zool., Berne, 1904, pp. 319-322.

1922. WiJнe, J. W. VAN, Frühe Entwicklungsstudien des Kopf- und Rumpfskelets von Acanthias vulgaris. Dijd Dierk., Afl. 22, pp. 271-298, pl. 11, 4 text figs.

1886. WoodWARd, A. S., On the Relations of the Mandibular and Hyoid Arehes in a Cretaceous Shark (Hybodus dubrisiensis, Mackie). Proc. Zool. Soc. Lond., pp. 218-224, pl. 20. 


\section{MUSCULA'TURE}

\section{IIUSCULATURE OF HEPTANCHUS MACULATUS}

The muscles in Heptanchus may be divided into two groups. In one the fibers are short, reaching from one connective tissue septum (myoseptum) to another; in the other they are more or less extended and are not confined within myosepta. The muscles of the body are of the short type; while those of the eyeball, of the hypobranchial region, and of the claspers in the male are of the long type.

In a side view the muscles of the body of Heptanchus maculatus are divided at the lateral line $(l l$, fig. 90) into dorsal bundles (d.b.) which attach to the cranium, and ventrolateral bundles which attach to the pectoral girdle. Both the dorsal and the ventrolateral muscles extend to the tip of the tail. In these bundles the myosepta (ms.) are bent into zigzag shape. Above the lateral line one of the columns has the apices of its myosepta directed forward, the other backward. Below the line there appears to be a single column with apex pointed posteriorly. Some of the anterior

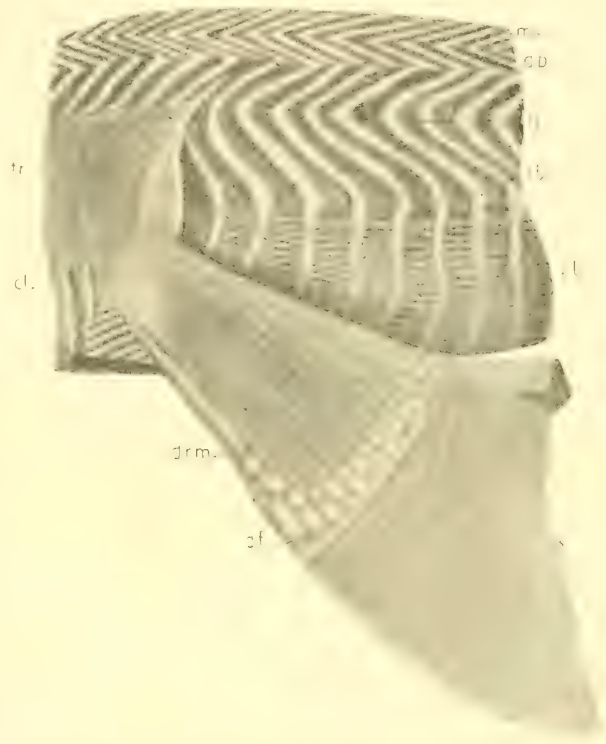

Fig. 90. Lateral riew of body musculature in pectoral region, Heptanchus maculatus. (Evelyn Forsythe, orig.)

$c l$. , gill eleft; $a . b .$, dorsal bundle; $d . f .$, dermal fin-rays; d.r.m., dorsal radial muscles of pectoral fin; $l . b$. . lateral bundle; $7 l$., lateral line; ms., myoseptum; tr., trapezius muscle; $r . b$., ventral median muscle.

fibers of the ventral bundle are specialized as the pectoral muscles of the pectoral fin. Of the long muscles we may consider those of the eyeball first.

\section{Muscles of THE Eye}

Two groups of muscles are present in the orbit. The first group is placed anteriorly and consists of the superior oblique (s.o., fig. 91) and inferior oblique (i.o.) museles. These muscles extend from the anterior part of the orbit outward and backward to be inserted on the eyeball. The second group consists 
of the four rectus muscles, all of which arise from the posterior surface of the orbit around the base of the optic pedicel (o.p.). The most dorsal of the rectus muscles is the superior rectus $\left(s . r_{0}\right)$, the most ventral the inferior rectus $\left(i . r_{0}\right)$, the most posterior the external or posterior rectus ( $p . r$.$) , and the most ante-$ rior the internal or anterior rectus (a.r.). They pass outward and forward, also to be inserted on the eyeball.

\section{Buccal and Pharyngeal Muscles}

The muscles in the region of the mouth and pharynx may be separated into four groups. The first group includes the superficial constrictor muscles; the

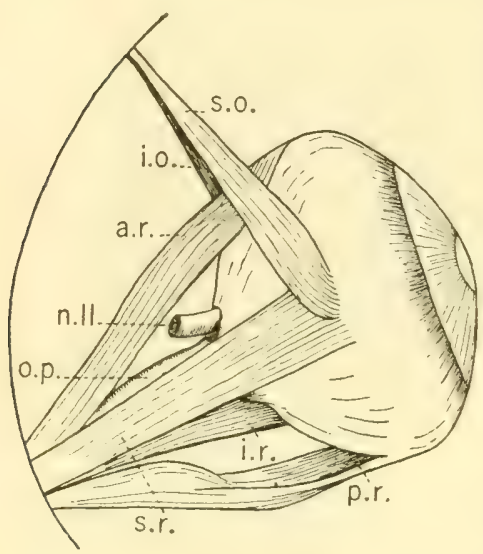

Fig. 91. Muscles of the eye, Heptanchus maculatus, dorsal view.

a.r., anterior or intemal rectus; $i . o$, inferior oblique muscle; $i . r$., inferior rectus; $n . I I$, optic nerve; o.p., optic pedicel; p.r., external or josterior rectus; S.o., superior oblique; $s . r$, superior rectus.

above, and the $2-3,3-4$, etc., are separated by the cleft following. The last of these superficial muscles lies in front of the last eleft.

\section{DORSAL CONSTRICTORS}

The first dorsal constrictor ( $c s d .{ }^{1}$ ) arises from the occipital part of the cranimm and from heary comnective tissue (fascia) surromnding the dorsal longitudinal bundles. As a thin slip of muscle it passes downward and slightly backward around the anterior border of the spiracle to be inserted on the inner and upper margin of the palatoquadrate cartilage $(p-q$.$) . Dorsally and$ anteriorly the first dorsal constrictor is difficult to separate from the levator maxillae muscle; furthermore the two have a common line of origin and of insertion. 
The second dorsal constrictor ( $\left.c s d .^{2}\right)$ is a very broad band lying between the spiracle and the first branchial cleft. It arises also along the fascia of the dorsal bundle, its anterior margin in Heptanchus maculatus being continuous with the first dorsal constrictor. In Heptanchus cinereus it is overlapped by the first constrictor. From its place of origin it extends downward and its anterior and more superficial fibers are inserted on the quadrate; the fibers lying underneath the superficial fibers join the upper segment of the hyoid; while those fibers lying back of them pass over to join the fibers of the ventral constrictor. In Heptanchus maculatus, where the dorsal constrictor meets the ventral there is superficially a heavy connective tissue septum.

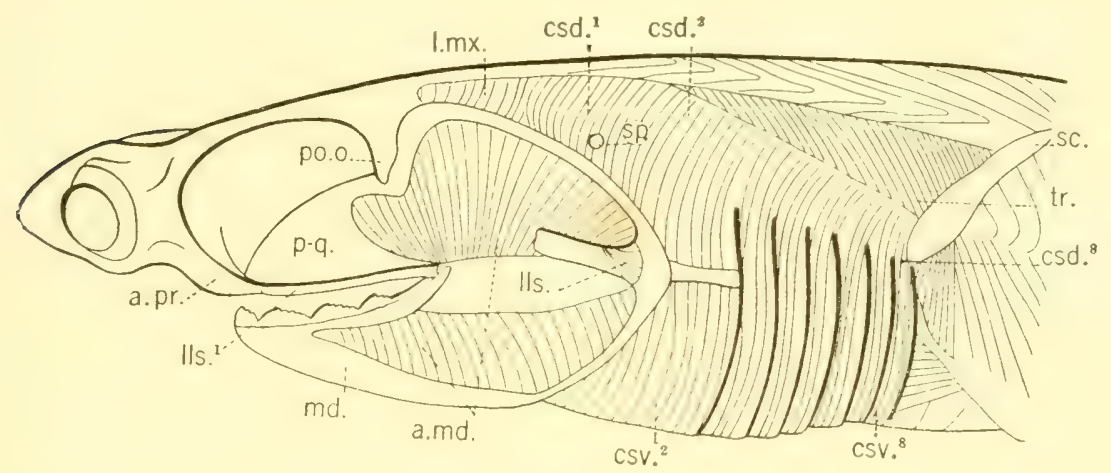

Fig. 92. Lateral view of the constrictor museles, Heptanchus maculatus. (From Daridson.)

a.md., adductor mandibulae; a.pr., antorbital process; cscl. ${ }^{1-8}$, first to eighth dorsal constrictors; $c s v .^{2-8}$, second to eighth ventral constrictors; $l l s$. , medial levator labialis; $l l s .^{1}$, lateral levator labialis; l.mx., levator maxillae; ma., mandible; po.o., postorbital process; $p$-q., palatoquadrate (pterygoquadrate); sc., scapular cartilage; sp., spiracular cleft; $t r .$, trapezius muscle.

The third to the eighth $\left(c s d .^{8}\right)$ dorsal constrictors are more slender and have their origin largely from the dorsal fascia and by tendons through the trapezius muscle $(t r$.$) . The superficial fibers pass over into those of the ventral$ constrictors, while deeper fibers, acting as interbranchial muscles (see p. 149, fig. $143, i b . d$.), lie just anterior to the eartilaginous branchial rays. In a section eutting through the dorsal constrictor between two gill clefts, the dorsal constrictors $(c s d$.$) are the thicker bundles lying over the margin of the septum;$ and the deeper fibers (ib.l.), comparable to the interbranchial muscle of the more specialized Elasmobranchs, extend inward as thimner bands.

\section{VENTRAL CONSTRICTORS}

The ventral constrictors of Heptanchus cinereus are seen in figure 93. They have their origin from a seam of connective tissue in the midventral line. The superficial, posterior fibers pass over into the dorsal constrictors, but the deeper ones are inserted on the ceratobranchial segment sof the risceral arches. 
In Heptanchus maculatus a first ventral constrictor is closely united with the second, which as an immense sheath passes from the midventral line to be inserted on the mandibular and hyoid arches. By removing a V-shaped segment from the anterior third of the mandible and hyoid, it will be seen that

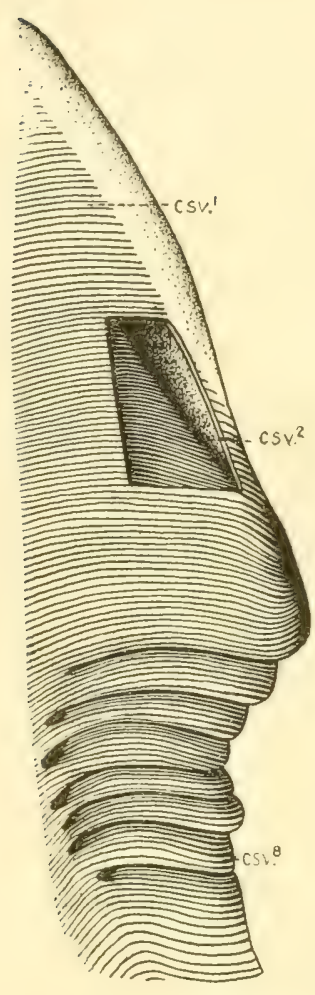

Fig. 93. The ventral constrictors, Heptanchus cinereus. (From Vetter.)

$\operatorname{csv} .^{1-2-8}$, first, second, and eighth ventral constrictor muscles. this bundle is separated into superficial fibers to the mandible and deeper fibers to the hyoid cartilage.

The third to the eighth ventral constrictors arise similarly from the midventral, triangular seam. Their superficial fibers are continuous with those of the third to the eighth dorsal constrictors (fig. 92). The deeper slips or interbranchial parts of these muscles pass through the coracobranchial muscles and are inserted on the neck of the ceratobranchial cartilages (ibv., fig. 95).

The trapezius muscle ( $t r$., fig. 92 ) arises from the side of the dorsal longitudinal bundle and passes backward and downward between this bundle and the dorsal constrictors. A small slip of it is attached to the upper part of the last arch, but most of its fibers are inserted on the scapula which it draws forward.

\section{INTERARCUALES}

The interarcuales (fig. 94) are deep muscles which bind the branchial arches together. Two systems of these are present, one of which is dorsal $\left(i a \cdot d .^{1-5}\right)$ and the other lateral $\left(i a . l .^{1-6}\right)$ in position. The dorsal interarcuales consist of bands which bind the pharyngobranchial cartilages together. In Heptanchus maculatus the first or anterior interarcualis is large and extends from the first to the second pharyngobranchial cartilage. The following dorsal interareuales decrease in size and bridge succeeding pharyngobranchials.

There is present in Heptanchus the so-called subspinalis (s.sp., fig. 94) which, unlike the dorsal interarcuales, takes its origin from the posterior part of the cranium, from the spinal column, and from the ventral fascia of the longitudinal bundle. Like the dorsal interarcuales it is inserted on pharyngobranchial cartilages, but, unlike them, it is inserted by a double tendon on the tips of the first and second pharyngobranchials.

The lateral interarcuales (ia.l., fig. 94), except the sixth (ia.l. ${ }^{6}$ ), are double bands, the anterior of which in each pair bridges the angle between pharyngohranchial and epibranchial cartilage of the single arch; while the posterior one extends from the following pharyngobranchial to a common insertion with the anterior muscle on the upper and posterior surface of the epibranchial. 
There are in Hoptanchus maculatus two levator labiales muscles. One of these (lls. ${ }^{1}$, fig. 92) arises from the median side of the antorbital process, passes backward over the angle of the jaw, and as a fibrous band divides the adductor mandibulae into dorsal and ventral parts. The other labialis (lls.) arises from the cranium in front of the antorbital process and nearer the midventral line as a wide and loose band of connective tissue; it passes under the orbit, and over the adductor mandibulae to be inserted at the angle of the jaw.

\section{ADDUCTORS}

The adductor mandibulae ( $a . m d .$, fig. 92) is an immense and complex muscle which closes the jaws. Superficially it is divided into a dorsal and a ventral part by the insertion of the first labialis muscle. 'The fibers of the adductor mandibulae arise from the quadrate and are inserted in two groups : first, a smaller deep posterior group is inserted directly on the mandible;second, a major group joins the tendon of the labialis, and fibers are then continued from the labialis tendon ventrally to insert on the mandible. The insertion in general is somewhat ob. seured by a fibrous capsule over the ventral part of the muscle.

An adductor is absent

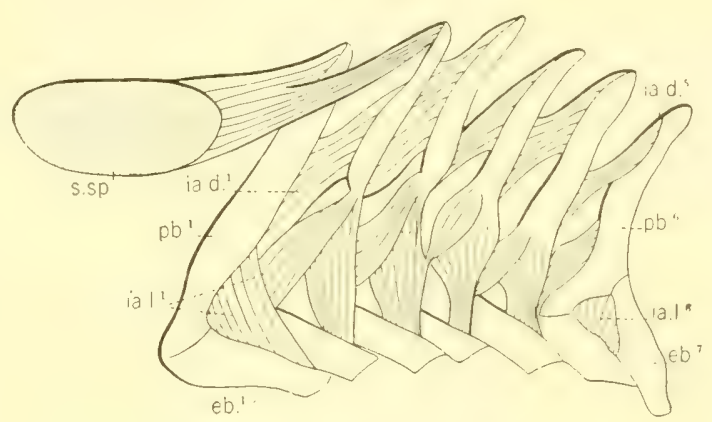

Fig. 94. Interarcuales muscles, Heptanchus maculatus. (From Davidson.)

$e b .^{1-7}$, first to seventh epibranchial cartilages; $i a . d 0^{1-5}$, first to fifth dorsal interarcuales; ia.l. ${ }^{1-6}$, first to sixth lateral interarcuales; $p b 0^{1-6}$, first to sixth pharyngobranchial cartilages; s.sp., subspinalis musele. from the hyoid, but adductors similar to the deep posterior part of the adductor mandibulae are present on all the branchial arches. These muscles have their origin in a groove on the inner side of the epibranchial (see p. 149, fig. $143, a d$.$) and join the ceratobranchial cartilage. They act in closing the bran-$ chial arch and hence in spreading the cartilaginous branchial rays to enlarge the gill pocket.

\section{Ventral Longitudinal Muscles}

The last group of muscles to be considered in the region of the pharynx is composed of the hy pobranchial or ventral longitudinal muscles. These are forward continuations of the ventral body muscrlature, the segmental nature of which is seen in a series of myosepta in the coracoarcuales (c.ar., fig. 95). The arcuales communes take origin from the coracoid cartilage and are inserted on the heavy connective tissue which forms the floor of the pericardial cavity.

The coracomandibularis (c.md.) arises from fascia above and between the anterior projection of the arcuales and passes forward as a large band to be 
inserted at the symphysis of the mandible. The paired coracohyoideus muscles (c.hy.) continue forward from the coracoarcuales as a layer just dorsal to the sides of the coracomandibularis. They are relatively broad muscles in Heptanchus and are inserted on the hasi- and ceratohyoid cartilages (ch., fig. 50A). only a few of the fibers reaching the base of the ceratohyoid cartilage. Dorsal

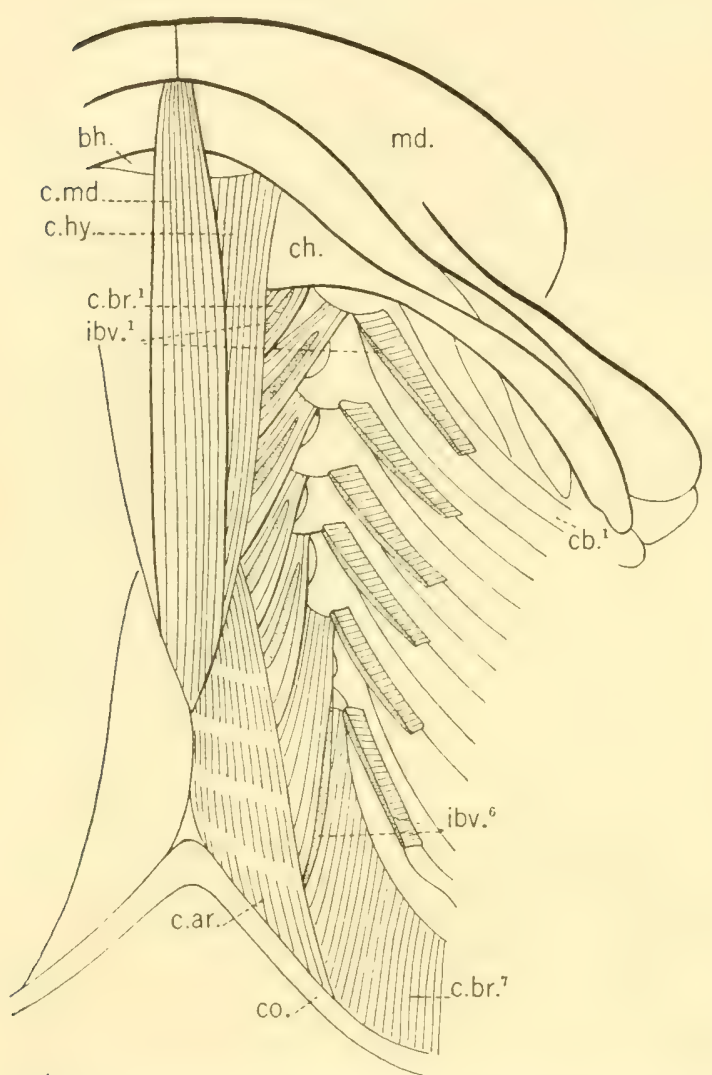

Fig. 95. Ventral longitudinal or hypobranchial muscles, Heptanchus maculatus. (From Davidson.)

$b h$. basihyal cartilage; c.ar., coracoarcualis muscle; $c b{ }^{1}$, first ceratobranchial eartilage; $c . b r_{0}{ }^{1-\tau}$, first to seventh coracobranchial muscles; ch., ceratohyal cartilage; $c . h y$., coracohyoideus; $c . m d$., coracomandibularis muscle; co., coracoid cartilage; $i b v .^{1-4}$, first to sixth interbranchial slips; md., mandibular cartilage. to the region of the coracohyoideus muscle is the third group, the coracobranchiales muscles $\left(c . b r \cdot{ }^{1-7}\right)$. The first six of these arise from the heavy connective tissue dorsal to the coracoarcuales and pass forward, upward, and outward as narrow slips to be inserted on the hypobranchial cartilages. The last or seventh $\left(c . b r^{7}\right)$ arises in two parts; one part is continuous with the sixth, and the other originates directly from the coracoid cartilage. This muscle inserts as a wide band along the whole length of the last ceratobranchial cartilage and a part of the median piece. Slips of the ventral constrictor (interbranchial, ibv. ${ }^{1-6}$, fig. 95) muscles pass through the ceratobranchial muscles.

\section{Muscles of the Fins}

The muscles on the dorsal side of the pectoral fin (d.r.m., fig. 90) take origin from the posterolateral margin of the scapula, and from the basal and, in part, from the radial cartilages of the fin skeleton. The radial muscles are distinct in the central part of the fin, but on the posterior margin the separation into definite bundles is not so evident. The muscles run toward and are attached to the heavy sheet of connective tissue continuous with the dermal fin-rays $(d . f$.$) . The radials$ while appearing to be long are, according to Davidson, made up of short fibers. The ventral radial muscles arise from the posterior side of the coracoid and 
from the hasal and radial cartilages, and extend outward to be attached to the connective sheath of the ventral side of the fin.

The muscles governing the claspers of the fins in the male are in bundles specialized from dorsal and ventral radial muscles. We may first examine them on the dorsal side of the pelvic of the male (fig. 96). Here they are continued from the myomeres to the fin, parallel with the radials, and are firmly attached to the peripheral part of the fin skeleton. The first of these muscles is the adductor $(a d$.$) , which arises from$ the posterior border of the pelvic girdle and is inserted on the distal end of the basipterygium (see p. 50, fig. 55B, ba.p.). The external flexor muscle (f.e., fig. 96), which has its origin along the inner margin of the basipterygium (ba.p.), is inserted on the "beta" cartilage ( $\beta$, fig. $55 \mathrm{~B}$ ). In Heptanchus the internal flexor $(f . i$.) arises in common with, but deeper than the external flexor on the basipterygium and on the "beta" cartilage and is inserted on the segment $b^{2}$ (fig. 55) and on the proximal part of the basal cartilage (ba.). On the dorsal side are also to be seen the dilator ( $d l$.) and the compressor ( $c p$. ) muscles. The dilator arises on the proximal end of the basal cartilage (ba.) and is inserted distally with the connective tissue covering the tip of the basal cartilage. The compressor muscle $(c p$.) has its origin from the "beta" cartilage ( $\beta$, fig. 55B), and passes backward and outward to be inserted on the last radial cartilage. One of the museles associated with the clasper, which is not seen in dorsal view, is the constrictor of the sac. Its fibers arise from the segments $b .{ }^{1-2}$, and from the proximal end of the basal

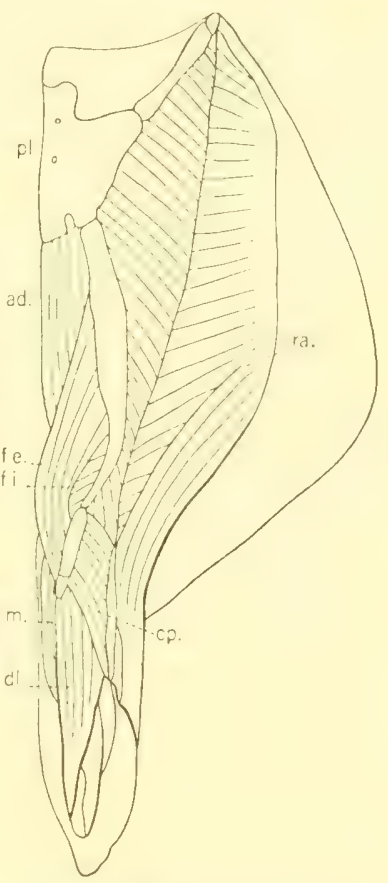

Fig. 96. Muscles of the pelvic fin of male, Heptanchus maculatus, dorsal view. (From Davidson.)

ad., adductor muscle of clasper; cp., compressor of the sac; dl., dilator muscle; f.e., external flexor musele; $f . i .$, internal flexor; $p l$., pelvic girdle; ra., radial muscles; s.m., muscle of sac. cartilage. Its dorsal fibers are inserted on the curved radial and its ventral fibers form the wall of the pterygopodial sac. 


\section{MUSCULATURE OF ELASMOBRANCHS IN GENERAL}

In a consideration of the musculature of Elasmobranchs in general we may first notice the primitive segments or somites which in the embryo are arranged in series from the region back of the ear to the tip of the tail. A transverse section through the trunk (fig. 97) shows the somite to be made up of

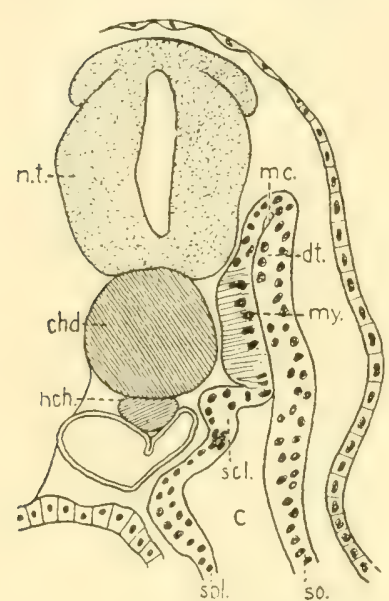

Fig. 97. Transverse section through developing somite, Pristiurus. (From Rabl.)

c., coelom; chd., notochord; dt., dermatome; hch., hypochorda; mc., myocoele; my., myotome or muscle plate; n.t., neural tube; scl., sclerotome; so., somatic layer mesoderm; spl., splanchnic layer mesoderm. forms the peritoneal lining of the body cavity, and gives rise to comnective tissue cells.

The cells of the myotome, the myoblasts, elongate and attach themselves both anteriorly and posteriorly to the connective tissue septa (myosepta) separating somites (fig. 98). Such a muscle cell or fiber furthermore becomes differentiated into longitudinal fibrils and is crossed by a series of transverse stripes or bands. In the body of the adult Elasmobranch the fibers generally retain the simple plan of attachment to myosepta. But the myosepta in the adult have secondarily changed their course, always, or at least generally, so as to take a zigzag direction.

The myotome next extends its boundaries dorsally to the middorsal line, and ventrally it grows toward the midventral line. The fibers formed dorsally between the dorsal septum and the lateral line septum compose the dorsal Iongitudinal bundles (d.b., figs. 100 and 112) which extend from the occipital 
region of the skull to the tip of the tail. These fibers universally take a horizontal direction. Those fibers between the lateral line septum and the midventral line are divided into a lateral $(l . b$.$) and a ventral (v . b$.$) region. The lateral$ muscle $(l . b$.$) is readily recognized by the fact that it lies just ventral to the$ lateral line and is of a dark color. Between pelvic and pectoral regions this bundle is folded in in such a way (figs. 99 and 100) as to be overlapped by the ventral bundle $(v . b$.$) . Anterior to the pelvis the fibers in the lateral bundle$ may take an almost horizontal direction (l.b., fig. 112) but they usually take an oblique direction of anterior and upward (fig. 100); while posterior to the pelvic area the fibers of this bundle run more or less horizontally.

The ventral bundle ( $v . b$.,figs. 100 and 112 ) is highly specialized and its fibers take a characteristic anteroventral direction. In some of the Elasmobranchs, as in Zygaena, the ventral bundle is further specialized into a rectus abdominis at the midventral line (r.a., fig. 100).

Figure 99 is a model for Squalus sucklii of all muscle fibers between two myosepta in the region of the first dorsal fin. Dorsally it will be seen that the septa run posteriorly elose together

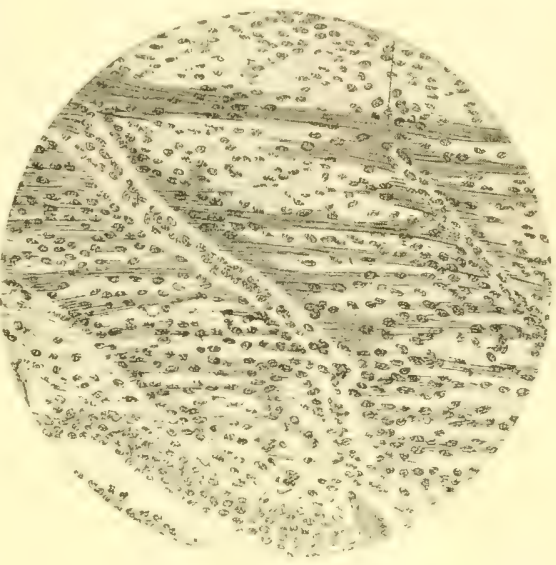

Fig. 98. Showing the finer anatomy of developing muscle. (Modified from Erik Miiller.)

and almost parallel with the middorsal line. They then turn anteriorly and run forward. Next they bend on an acute angle and curve backward; and then they turn forward and downward to the lateral line, where they fold inward and are carried forward. When the septa emerge from the fold they are displaced backward so that as they pass through the lateral bundle they are fully a half-segment posterior to the same myosepta above the lateral line. In the lateral bundles the septa curve downward and backward and then turn forward where they fold inward and backward to emerge in the ventral bundle $(v . b$.$) . In the ventral bundle they run sharply downward and slightly forward.$ T'hey then turn backward, and finally run forward to the midventral line.

In a transverse section of the tail of Lamna the various muscle cones appear in their relation to one another (fig. 101). The rows here are so arranged that a dorsomedian $\left(d m_{0}\right)$, a dorsolateral $(d l$.$) , and a lateral row (l.b.) lie above$ the lateral septum which extends from the spinal column to the skin in the region of the lateral line (not drawn in the figure). The ventrolateral $\left(v l_{\text {. }}\right.$ ) and ventromedian ( $v m$.) rows are below the septum. The bundles are made up of concentric lamellae, the concentricity of which is due to the projection of the apex of one cone into the angle of the V's in front of or back of it. The dorsolateral and ventrolateral bundles are small, the dorsomedian and ventromedian bundles are large, and the lateral bundle, composed of nine concentric 


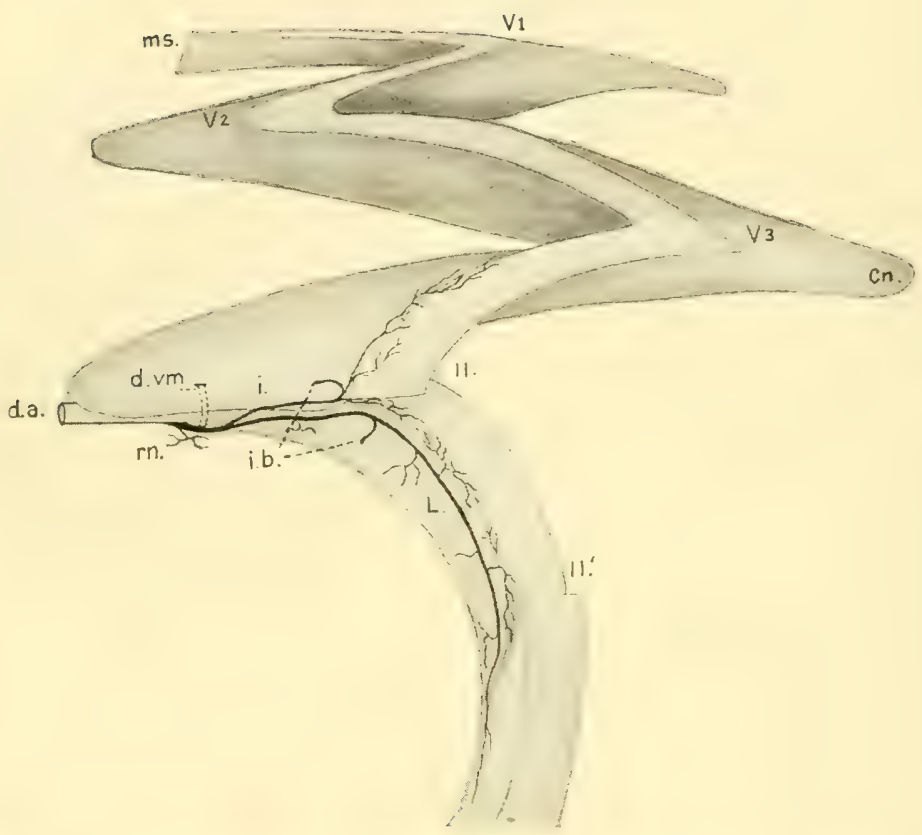

Fig. 99. Model of muscle fibers between two myosepta, Squalus sucklii. (From Coles.)

cn., extension of myosepta forming cone; d.a., dorsal aorta; d.vm., dorsal vertebromuseular artery; $i$., intercostal artery; $i . b$., intercostal branches to preceding segments; $L_{\text {. }}$ lateral bundle; $1 l$., lateral line fold; $l_{.}$, fold between lateral and ventral musculature; ms., myosepta ; $r n$., renal artery; $V_{1}, V_{2}, V_{3}$, bends in myosepta. 
lamellae, is of immense size. In side view the V's would appear very long and acute, many of them being cut in transverse section.

We may next consider the specialized or long muscles of the adult which are present in the head and in the pharyngeal region.

\section{Muscles of the Eye}

The muscles of the eye originate from head somites (fig. 102) which in a way are like the body segments or somites previously described. The first or premandibular somite, the second or mandibular, and the third or hyoidean somite, all take part in the formation of these muscles. It will be observed

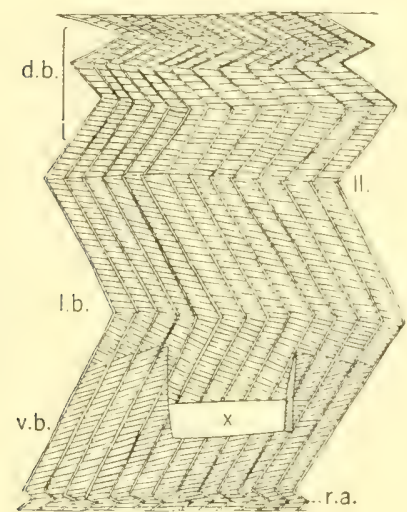

Fig. 100

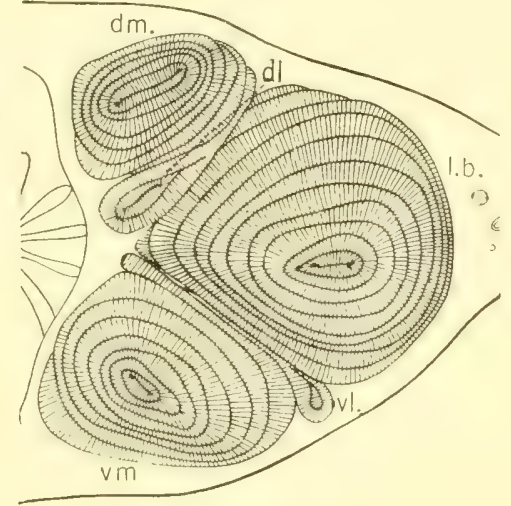

Fig. 101

Fig. 100. Trunk museulature, Zygatna side view. (From Maurer.)

Fig. 101. Transverse section, muscle bundles of tail, Lamna. (From Ewart.)

$d . b$. , dorsal bundles; $d l$., dorsolateral bundle; $d m$. , dorsomedian bundles; $7 . b$. , lateral bundle; $l l$. , lateral line; r.a., rectus abdominis; $v . \bar{b}$., ventral bundle; $v l$, ventrolateral bundle; vm., ventromedian bundle; $x$, part of ventral bundle removed to show overlapping of lateral bundle.

from the figure that somites four, five, and six, which are in the region near the enlarging ear capsules, degenerate and consequently take no part in the formation of eye muscles.

The most anterior of these head somites, the premandibular, ${ }^{1}$ gives rise to four of the six muscles of the eye. The first muscle to bud off from this somite, arising ventrally as shown by the ruled lines in figure 103 (Lamb, 1902) is the inferior oblique (i.o.). Following this the inferior rectus (i.r.) arises also from the ventral part of the somite. From the dorsal side the internal or anterior rectus $\left(a . r_{0}\right)$ and the superior rectus $\left(s . r_{0}\right)$ are budded off. The second or mandibular somite divides into two parts, a small upper part and a larger lower part. From the upper part the superior oblique muscle (s.o.) arises. The cells which form this muscle first take a longitudinal direction; later, as they become muscle fibers, they lie more in a dorsoventral direction. From the ventral part of the second somite a part of the rectus externus arises (Neal).

\footnotetext{
1 In front of the premandibular has been described (Platt, 1891) still another somite (Acanthias).
} 
The third or hyoidean somite is simpler than the rest, and from its lower part the remainder of the external or posterior rectus muscle $(p . r$.) arises. The relations of the muscles to the somites and nerve supply are tabulated by Neal as follows:

\begin{tabular}{|c|c|}
\hline \multirow{2}{*}{ Myotome } & Mruscle \\
\hline & $\int$ Rectus superior \\
\hline & Reetus internus \\
\hline $1 \nabla$. & Rectus inferior \\
\hline & Obliquus inferior \\
\hline $2 \pi \ldots$ & $\begin{array}{l}\text { Obliquus superior } \\
\text { Rectus externus? }\end{array}$ \\
\hline $3 \mathrm{v} \ldots$ & Rectus externus \\
\hline
\end{tabular}

Innervated by

Oculomotor nerve III

Oculomotor nerve III

Oculomotor nerve III

Oculomotor nerve III

Trochlearis nerve IV

Abducens nerve VI

The position occupied by the inferior oblique muscle of the adult varies somewhat in different forms. In Heptanchus the inferior oblique is attached to the orbit practically against the superior oblique, while in Acanthias the two may be slightly apart. In the saw shark, Pristiophorus, an interesting condi-

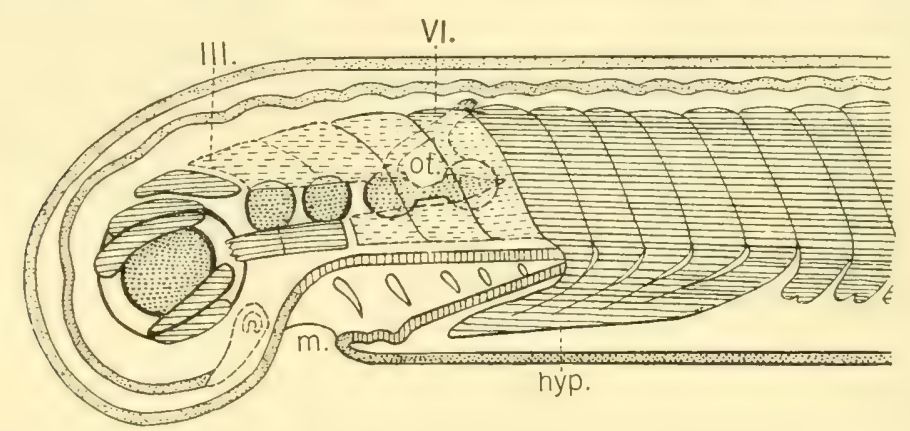

Fig. 102. Diagram showing the head somites in relation to the body somites in Squalus acanthias. (From Neal.) The eye muscles are derived from the first three somites.

hyp., hypobranchial (hypoglossus) museulature; m., mouth ; ot., otic eapsule; III and $F I$, third and sixth head somites.

tion obtains in which a second strip of the inferior oblique is attached along the infraorbital plate. This is evidently a forermner of the condition present in the rays, in which the whole of the muscle has its attachment as a broad band ventral to the orbit (Rhinobatis, Raja). In this respect, then, Pristiophorus is a transitional form between the sharks and the rays.

\section{Muscles of Visceral Arches}

The levator labii superioris muscle in a type like Acanthias (lls., fig. 104) consists of a single muscle on each side, which has its origin on the interorbital space ventral to the cranium. The muscle passes backward and outward along the upper jaw and over the dorsal labial cartilages. At the angles of the mouth it becomes tendinous and is inserted on the mandible. In all probability; this muscle is comparable to lls. of Heptanchus. In Torpedo (fig. 105A) (see Tiesing, 1896), the muscle is divided into two parts, a median (lls. ${ }^{1}$ ) and a 
lateral levator $\left(l l s^{2}{ }^{2}\right)$. The lateral levator labii has its origin behind the angle of the ethmoidal region and is inserted on the process of the quadrate. The median head arises as a broader muscle near the preorbital process and passes as a tendon around the angle of the mouth to join the mandibular muscle as in Acanthias.

A more complex condition is reached in Rhinobatis and in Raja. In the former there are four (or even five) parts to the muscle, and in the latter five parts are characteristically present. In Raja (fig. 107B) the first division of the muscle $l l s^{1}{ }^{1}$ represents the median division of the muscle in Torpedo. There is a second muscle (fig. $\left.107 \mathrm{~B}, l l s_{{ }^{2}}\right)$ which is large in Raja and which holds a peculiar position in Rhinobatis, being surrounded at its base by the mandibular muscle soon to be described. A third slip $\left(l l s^{3}\right)$ is isolated, and a fourth and a fifth(?) join the mandibular muscle.

The levator maxillae superioris muscle in Acanthias (l.mx., fig. 104) has its origin from the postorbital processes and supraotic erest, and passes downward in common with the first dorsal constrictor, the fibers of the latter lying directly against the spiracle and the fibers of the former (levator maxillae) being those of the anterior group. The levator maxillae is inserted on the palatoquadrate. In Carcharias, how-

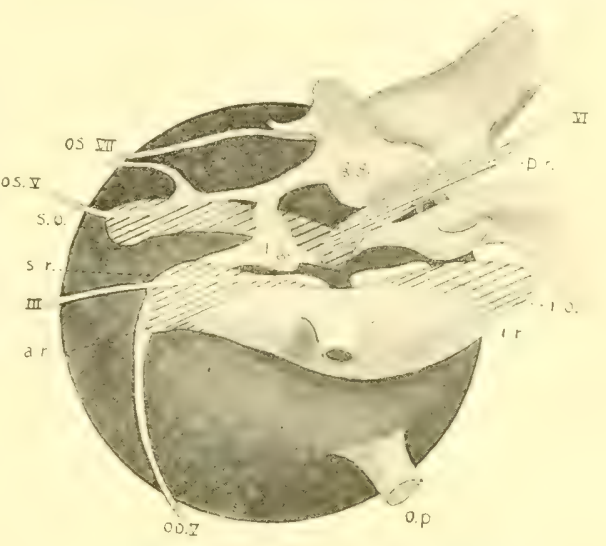

Fig. 103. Development of the muscles to the eye, Acanthias, right, median view. (From I.amb.)

a.r., anterior rectus; cl.g., ciliary ganglion of fifth nerve; g.g., gasserian ganglion; i.o., inferior oblique; i.r., inferior rectus; o.p., optic pedicel; op., , ophthalmicus profundus; p.r., external or posterior rectus; s.o., superior oblique; os. $V$ and $V I I$, ophthalmicus superficialis branches of the firth and seventh nerves; s.r., superior rectus; $I I I$ and $V I$, oculomotor and abducens nerves respectively. ever, in addition to its postorbital relations, it extends its origin anteriorly along almost the whole of the supraorbital erest. In the rays, this muscle and the first dorsal constrictor are distinct and separate. In Torpedo (l.mx., fig. $105 \mathrm{~A}$ ) the levator maxillae is well defined and runs far forward to be inserted on the median palatal part of the palatoquadrate. In Rhinobatis it is much broader than in Torpedo and is inserted still farther forward. In Raja ( l.mx., fig. 105B) it arises by two heads, a superior and an inferior; the fibers of the two unite anteriorly, whereupon insertion is made on the palatine part of the palatoquadrate cartilage.

\section{Superfictal Constrictors of Pharynx}

The superficial constrictor muscles vary considerably from those studied in Heptanchus. These museles in pentanchid Elasmobranchs are six in number. 
In the rays, the fihers of the dorsal constrictors are not continuous with those of the ventral constrictors, the two sets being separated by a horizontal tendon.

\section{DORSAL CONSTRICTORS}

The first dorsal constrictor in Acanthias (fig. 104), as has been said, is separated from the levator maxillae only at the ventral part of the spiracle where its fibers curve posteriorly around the base of the spiracle to be attached to

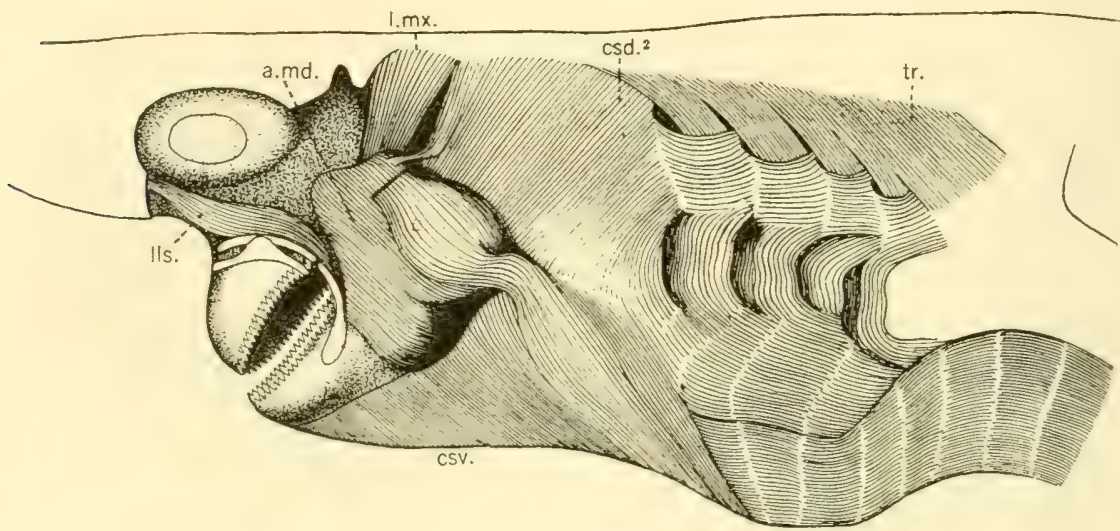

Fig. 104. Lateral pharyngeal muscles, Acanthias. (From Vetter.)

a.md., adductor mandibulae; $c s d .{ }^{2}$, second dorsal constrictor; $c s v$. , ventral constrictor; $l l s .$, levator labii superioris; $l . m x$. , levator maxillae; tr., trapezius.

the quadrate. In a boiled specimen of Mustelus californicus the first dorsal constrictor can readily be distinguished from the levator maxillae by a difference in its color. Furthermore its anterior ventral margin folds in under the levator maxillae. In the rays (fig. 105) the first dorsal constrictor is a clearly marked band which forms a crescent in front of the spiracle.

In Elasmobranchs which have a nictitating membrane the muscles controlling that membrane are derivatives of the first dorsal constrictor. The nictitator in Mustelus californicus may here be described with the other accompanying muscular slips. It has its origin posterior to that of the first dorsal constrictor and under the second dorsal constrictor. From its origin it passes anteriorly and downward in front of the spiracle ( $n t$., fig. 106) to be inserted on the nictitating membrane $(n$.$) . Crossing the nictitator almost at right$ angles is a deeper muscle, the depressor $\left(d_{p}\right.$. $)$ of the upper eyelid, which takes origin somewhat posterior and dorsal to the spiracle and over the second constrictor. This passes forward and upward to be inserted at the tail of the eye on the upper eyelid. Arising in the common mass with the depressor of the upper lid but superficially, is a rudimentary retractor palpebrae superioris $(r . p$.$) which ends anteriorly against the nictitator so that the nictitator oper-$ ates between it and the depressor. Arising from the anterodorsal margin of 
the spiracle is the dilator ( $d l$.) of the spiracle, which passes anteriorly and upward between the retractor and depressor finally to join the nictitator. Surrounding the spiracle $(s p$.$) superficially is the constrictor spiraculae (c.s.).$

The second dorsal constrictor (csd. ${ }^{2}$, fig. 104) in the sharks extends from the supraotic crest of the cranium back to and even perforating the anterior end of the trapezius $(t r)$; other fibers arise from the seam dorsal to the cleft. The

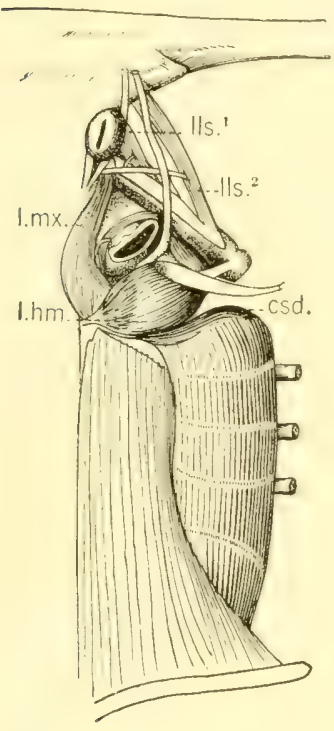

A

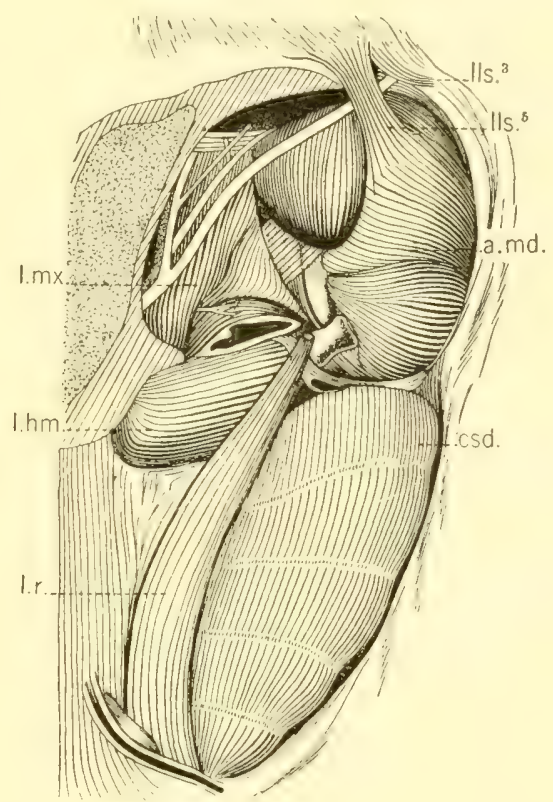

$\mathrm{B}$

Fig. 105. Dorsal pharyngeal museles. (From Tiesing.) A. Torpedo. B. Raja.

a.md., adductor mandibulae; csd., dorsal constrictor musele; l.hm., levator hyomandibularis; $7 l s_{{ }^{1-5}}$, first to fifth slips of levator labiales; l.mx., levator maxillae; l.r., levator rostri.

insertion of this muscle in Acanthias is interesting. Part of its fibers tonch the hyomandibula and a number of other fibers impinge on the ceratohyoid; while still a third set joins a horizontal tendinous hridge, separating dorsal and ventral constrictors. Back of this tendon other fibers are continuous with the ventral constrictors.

Those fibers inserted on the hyoid in Heterodontus and Squatina are separated into a kind of levator hyomandibularis. In the rays the levator hyomandibularis (l.hm., fig. 105) is a muscle of great importance. It may be inserted on the hyomandihula at the angle (Torpedo, fig. 105 $\mathrm{A}$, l.hm.; Raja (fig. $105 \mathrm{~B})$, or on the lower part as in Rhimobatis. In the rays those fibers back of the levator hyomandibularis and in front of the first eleft form the second dorsal constrictor proper. These fibers run practically in a horizontal direction.

The remaining dorsal constrictors are similar to the second. A point or two, however, may be added. From the third to the fifth constrictors in the sharks 
(Acanthias), the fibers dorsally arise largely from the seam above the cleft and from the extrabranchial cartilages. These fibers pass downward and those more anterior are inserted on the seam in front and on its underlying extrabranchial cartilage (fig. 104). The posterior fibers pass on and are continuous with the ventral constrictors. The sixth dorsal constrictor in addition has some of its fibers arising from the scapular part of the pectoral girdle.

In the rays there is present a levator rostri (l.r., fig. 105). This muscle has its origin dorsally in the fascia of the longitudinal muscle, near the posterior

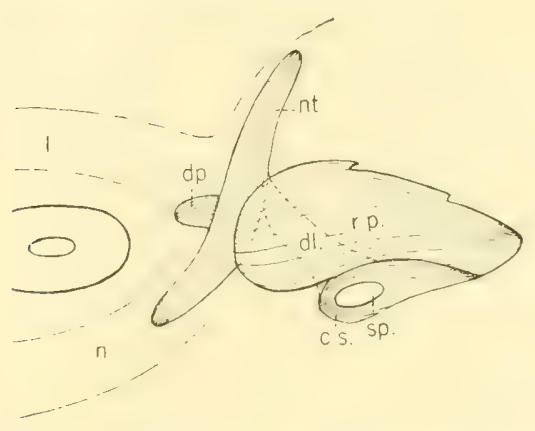

Fig. 106. Museles to the nictitating membrane and associated parts, Iateral view, Mustelus californicus.

c.s., constrictor spiraculae; $71 .$, dilator spiraculae; $d p$., depressor of upper lid; l., upper eyelid; n., nictitating membrane; $n t$., nietitator muscle; r.p., superficial fibers which do not reach upper lid; $s p$., spiracle. seam at the sides of the dorsal constrictor, and extends to the margin of the rostrum (Rhinobatis) where it is inserted on heavy tissue.

The trapezius, which is not a part of the constrictor system, may here be considered. In sharks it arises from the fascia of the dorsal bundles, and from the cranium above and at the sides of the ninth foramen (Acanthias), its origin extending almost from the cranium to the region of the scapula. In Acanthias ( $t r$., fig. 104) it is perforated by slips of the dorsal constrictors and has its insertion largely on the scapula.

In the rays several slips of muscle are found in the location of the trapezius, hut it is not certain that these are comparable with the trapezius of the sharks.

\section{VENTRAL CONSTRICTORS}

In Acanthias, according to Marion (1905) there may be two parts to the first rentral constrictor, the more anterior of which is the smaller and bridges the anterior symphysis of the lower jaw. The more posterior part is much wider and is like that in Heptanchus. These parts take origin from a midventral seam and are inserted on the posterior margin of the mandible. In the rays the second part acts as a depressor mandibulae (d.md., fig. 107в).

The second ventral constrictor in the sharks is similar to that in Heptanchus. This also arises from the midventral seam and is inserted on the border of the hyoid cartilage. In the rays the second ventral constrictor is divided into an anterior and a posterior part. The anterior part acts as a depressor hyomandibuluris (d.hm., fig. 107B), a muscle antagonistic to the levator hyomandibularis previously mentioned as derived from the second dorsal constrictor. The more posterior and narrower ventral part is the second ventral constrictor.

Each of the remaining ventral constrictors in the rays (fig.107B) consists of two parts, a large outer and a small inner portion. 
Superficial to this ventral region in the rays, arising from the fascia of the ventral longitudinal muscle (the coracomandibularis), is a depressor rostri (d.r., fig. 107). 'This is inserted far forward between the end of the propterygium and the tip of the rostrum (Raja). It has a balancing effect on the levator rostri (see fig. 105, l.r.) previously described.

\section{Deeper Muscles of Pharynx}

The interbranchials of more specialized Elasmobranchs are usually more completely separated from the constrictors into distinct bundles than are

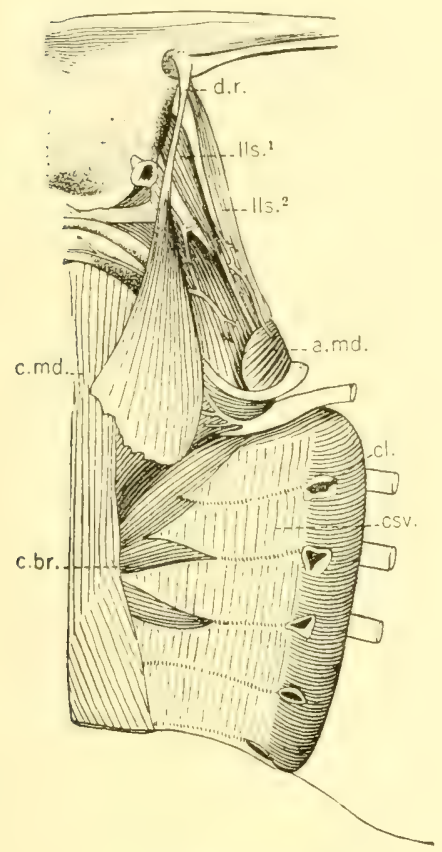

A

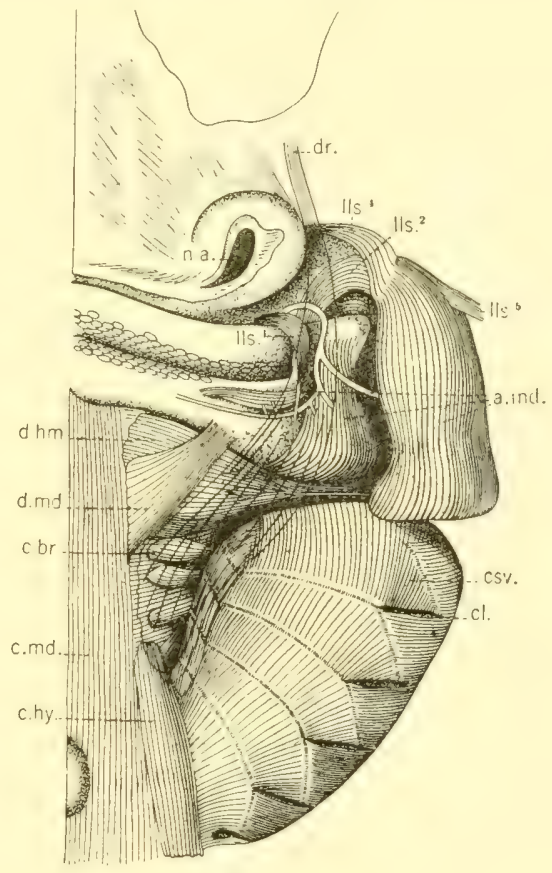

B

Fig. 107. Ventral pharyngeal museles. (From Tiesing.) A. Torpedo. B. Raja.

a.mc., adductor mandibulae; $c l$, first gill cleft; $c . b r$, coracobranchial muscle; $c . h y .$, cora cohyoideus; c.md., coracomandibularis; $c s v$., ventral constrictor muscle; $d . h m$., depressor hyomandibularis; d.md., depressor mandibulae; d.r., depressor rostri; $l l s_{.}{ }^{1}$, median levator labii; $7 l s^{2}{ }^{2}$, lateral levator labii; $l l s .^{4-5}$, fourth and fifth slips of levator labii ; n.a., nasal aperture.

those of Heptanchus. In Acanthias (fig. 108A), as is true in general, they lie between the demibranchs, in front of and against the branchial rays of all the whole gills. The dorsal fibers arise from the seams, separating the dorsal constrictors above the eleft, and from the dorsal extrabranchial cartilages. The shorter, inner fibers are attached to the outer margin of the epibranchial segment of the branchial arch, while the outer fibers pass over to ventral interbranchial fibers (sharks). The rentral fibers of the interbranchials arise from the fascia around the coracomandibularis muscle and from the ventral extra- 
branchial cartilages. The shorter or inner fibers join the ceratobranchial cartilage, and the outer fibers in the sharks pass into the dorsal interbranchial fibers.

In the rays the interbranchials are somewhat like those of the sharks. Here, however, the dorsal and ventral fibers do not form a continuous muscle even at the outer margin. The fibers both dorsally and ventrally arise as in the sharks. The inner dorsal fibers are inserted also on the epibranchial ( $c b$., fig.

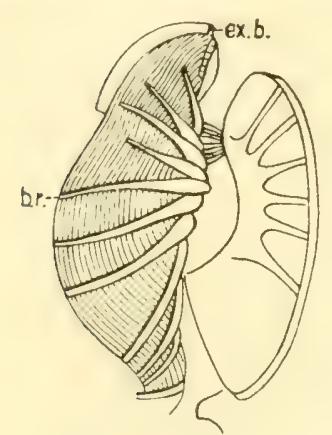

A

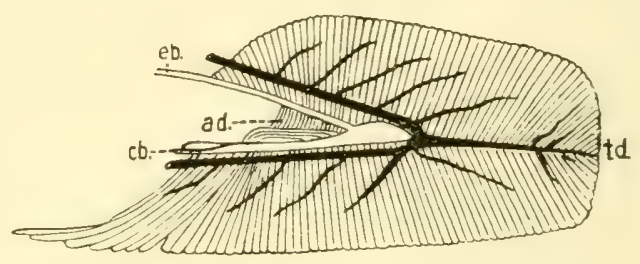

B

Fig. 108. Interbranchial museulature.(From Marion.) A. Acanthias. B. Raia erinacea. $a d .$, adduetor musele; $b r$., branchial ray; $c b$., ceratobranchial eartilage; $e b$. , epibranehial eartilage; $e x . b$., extrabranchial cartilage; $t d$., longitudinal tendon.

$108 \mathrm{~B})$ and the imner ventral fibers on the ceratobranchial cartilages $(c b$.). The onter fibers are attached to the cartilaginous branchial ray which proceeds outward at the angle between the epibranchial and ceratobranchial segments. Some of the most median fibers ventrally take origin from the fascia of the coracomandibularis muscle.

\section{INTERARCUALES}

The interarcuales, as in Heptanchus, are divided into two systems, a dorsal (medial of Marion) and a lateral system. The subspinalis, which is considered by some as the first of the dorsal systems, arises from the base of the cranium, the ventral side of the vertebrae, and the fascia ventral to the longitudinal bundle, and tapers back to be inserted near the tip and laterally usually on the first pharyngobranchial cartilage. In Scyllium, as in Heptanchus, the subspinalis is divided into two bands; in squatina it is very slender; and in scymnus and in the rays it is generally absent.

The true dorsal interarcuales (ia.d., fig. 109) unite succeeding pharyngobranchial segments. The dorsal interareuales vary in number; five in Heptanchus, four in Hexanchus, three in Acanthias and Heterodontus, and two in Raja. In $S c y m m$ s the tips of the pharyngobranchial segments are bound by strong ligaments to a sheet of connective tissue ventral to the spinal column.

In Acanthias (fig. 109 $\mathrm{A}$ ), as in Heptanchus and many other sharks, the lateral interarcuales system (ia.l.) consists of V-shaped museles, one limb of 
the $T$ arising on the posterior side of the hase of the first pharyngohanchial, and the other limb, on the anterior side of the base of the following pharyngobranchial. The fibers of the two limbs of the $\mathrm{V}$ pass ventrally and anteriorly and unite before they are attached on the posterior side of the epibranchial cartilage. 'The first to the third interarcuales of the lateral system in pentachid sharks are alike, but the fourth is undivided in its origin.

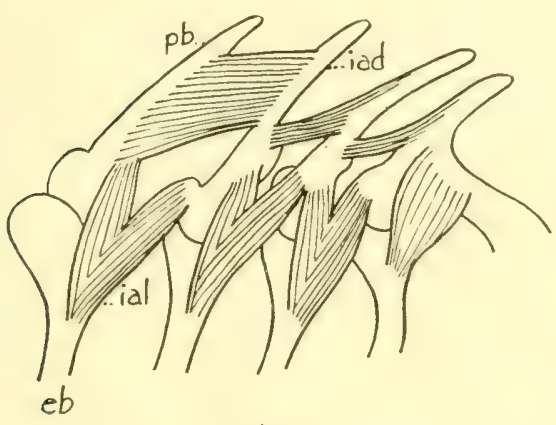

A

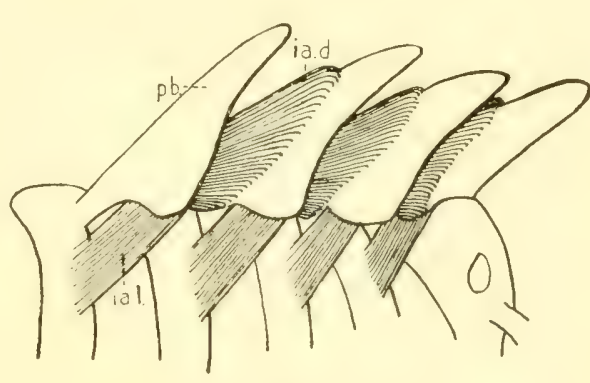

B

Fig. 109. Interarcuales museles. A. Acanthias. (From Vetter.) B. Heterodontus francisci. (Lucile Graham, orig.)

eb., epibranchial cartilage; ia.d., dorsal interarcuales muscles; ia.l., lateral interarcuales; $p b$., pharyngobranchial cartilage.

In Heptanchus maculatus (p. 93, fig. 94) the second or posterior branch of the first lateral interarcualis is seen to be closely related to the dorsal system; while in the second to the fifth, the lateral interarcuales come to be more and more widely separated from the dorsal system. In Heterodontus (fig. 109B) the dorsal system consists of very broad bands, and the lateral system is also composed of wide bands, the inserting heads of which are not divided.

\section{ADDUCTORES ARCUS}

Under this head are included the adductor mandihulae and the branchial adductors. The adductor mandibulae in a type like Acanthias (a.md., fig. 104) may be described as a mass of muscle at the outer angle of the jaw, which arises from the quadrate and passes over to the whole of the side of the posterior part of the mandible. According to Vetter a small slip of the adductor mandibulae in Acanthias may also pass downward and join the ventral constrictor already described. In a form like Heterodontus the adductor is of unusual size. In Torpedo (a.md., fig. 107A) it is divided into a large median and a smaller lateral part; and in Raja (fig. 107B) and Rhinobatis the median part is small and the outer part is subdivided into a large inner and an immense outer division.

Adductors are present on all the gill-bearing arches, except the hyoid. They arise from grooves on the inside of the epibranchials, and are inserted on similar grooves inside of the ceratobranchials (fig. 108B, ad.). In the branchial 
region of Chlamyd.oselachus the adductors diminish in size from hehind forward, so that, in addition to the absence of one from the hyoidean areh, there is but slight evidence of a first branchial adductor.

\section{Hypobranchial Musculature}

The hrpohranchial or rentral longitudinal muscles extend from the coracoid cartilage forward under the branchial basket, and consist of the arcus communes which continue forward from the pectoral girdle, the coracomandi-

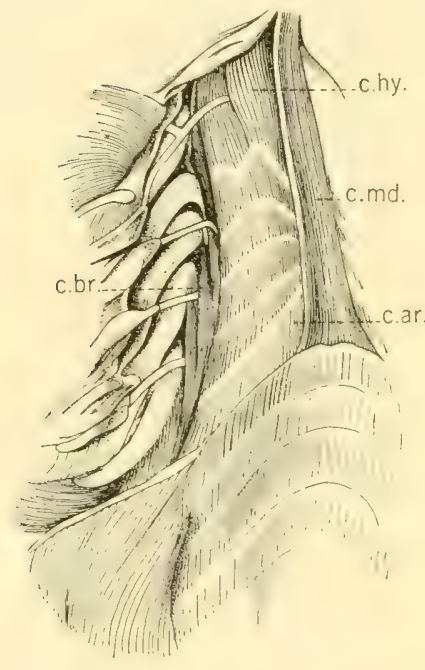

A

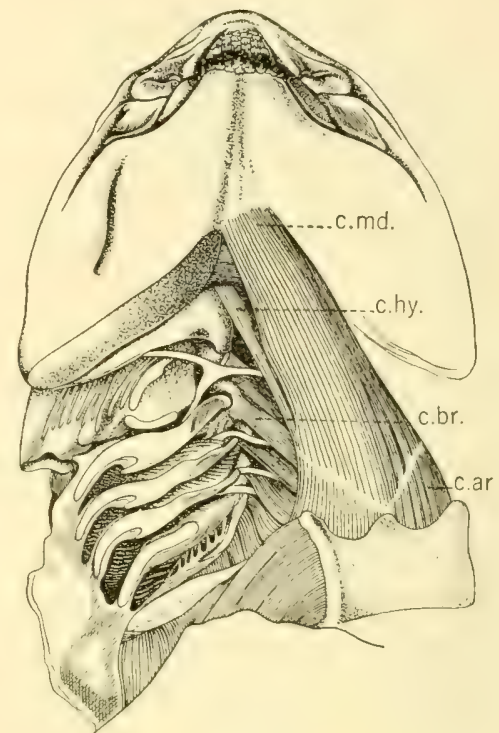

13

Fig. 110. Hypobranchial museles. (From Max Fürbringer.) A. Scymnus. B. Heterodontus philippi.

c.ar., coracoareualis muscle; $c . b r$, coracobranchialis; $c . h y .$, coracohyoideus muscle ; $c . m d$. , coracomandibularis.

bularis, lying in the middle line, the coracohyoideus at the sides of the coracomandibularis, and the deeper coracobranchiales extending to all the branchial arches. All these muscles except the coracobranchials arise from the first five trunk myotomes (fig. 102) as buds which migrate forward and mediad and take up their position under the branchial and buccal areas. The coracobranchiales in Scyllium, according to Edgeworth (1903), are developed from head myotomes. In the sharks the hypobranchials usually come to be heavy round muscles, while in the rays they are more or less flattened.

The arcus communes (see coracoareualis, c.ar., fig. 110) are separated by myosepta (scriptores tendiniae), much like other ventral bundles, into a varying number of segments in different forms. In Heterodontus philippi (fig. 110B), for example, a single segment is produced, in Raja two, and in Scymmus (fig. 110 ) and a number of other types, fire are present anterior to the girdle. 
The coracomandibularis (c.md.) in the shark is seen upon removing the skin and the first and second ventral constrictors. In the rays it lies directly under the skin. In Scymmus (c.md., fig. 110A) it is an unpaired muscle which originates directly from the coracoid cartilage and is inserted near the mandibular symphysis. That the muscle is of a paired nature, however, is shown by its being innervated by paired nerves. In Raja its paired condition is indicated anteriorly, and in Actobatis the two muscles are entirely separate.

The coracohyoideus inuscle (c.hy., fig. 110) is seen lying at the sides of the coracomandibularis (Heterodontus, fig. 110B). It arises from the fascia around the areus communes and is inserted on the basihyoid and lower part of the hyoid arch. In Scymmus (fig. 110A) it passes more directly forward from the most anterior areual segment than it does in $\mathrm{Hep}$ tanchus. In Raja (see fig. 107B) the coracohyoideus is small and lies more or less over the coracomandibularis. It is inserted on the ventral part of the basihyal segment.

The coracobranchiales $\left(c, b r^{\circ}\right)$ are the deepest of the hypobranchial muscles and support the floor of the pericardial cavity. They consist of five separate parts in pentanchid sharks, six in Hexanchus, and seven in Heptanchus. In the rays they arise in a common mass. The first coracobranchialis (c.br.) is large in Scymnus; and the remaining muscles, except the last which is the largest, are smaller. They are normally inserted on the ceratobranchial segment of the branchial arches.

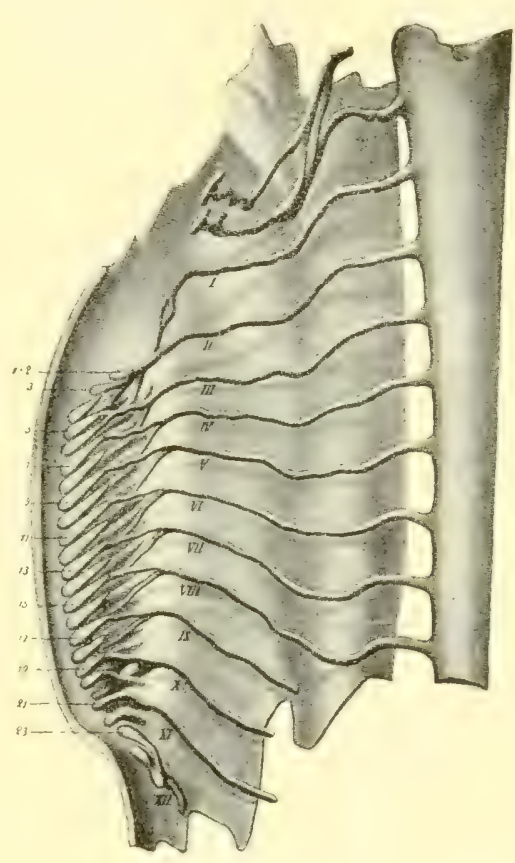

Fig. 111. Development of the museles to the pectoral fin, Acanthias. (From Erik Müller.)

1-23, muscle buds; $I-X I I$, nerves.

In Elasmobranchs the muscles of the paired fins arise in the embryo as buds from the ventral downgrow th of the myotome. Varying numbers of these buds take part in the formation of the fins in different species of Elasmobranchs. After the dorsal somite is separated off from the lateral plates its myotome grows rapidly both dorsally and ventrally. As the ventral downgrowth passes the fin area it gives off the muscle buds as lateral growths. The muscle bud separates into an anterior and a posterior primary bud, each of which in turn divides into an upper and a lower secondary bud so that from one myotome four buds arise. The two of these buds which are dorsal in position go to make up dorsal fin muscles, while the two ventral in position compose the ventral musculature of the fin (fig. 111). 
It is evident that the number of segments that take part in the formation of buds for the pectoral fin is ferer in the sharks than in the rays. This fact is clear when we consider two types like Mustelus and Torpedo, in the former of which the fin is relatively narrow and in the latter is of great extent. According to Maurer (1912), in the embryo of Mustelus only ten segments contribute to the formation of the musculature of the pectoral fin; while in Torpedo there are twenty-six such segments.

The further course of the development of these buds in two forms like the

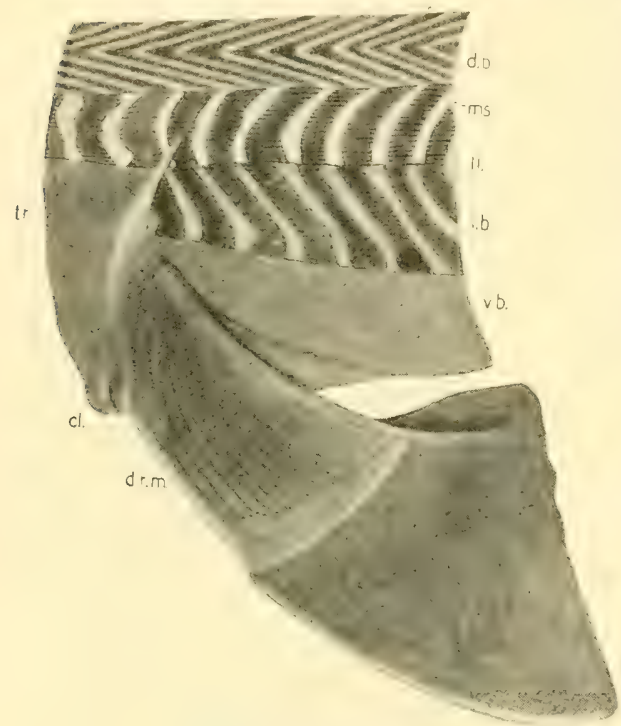

Fig. 112. Adult pectoral muscles, Squalus suclitii. (Evelyn Forsythe, orig.)

cl., gill eleft; d.b., dorsal bundle; d.r.m., dorsal radial muscle of pectoral fin; $1 . b$., lateral bundle; $l l$., lateral line; ms., myoseptum; $t r .$, trapezius muscle; v.b., ventral median muscle. above has been studied in great detail because of the bearing which such development has on the lateral fin-fold theory. That in a type like Mustelus segments (myotomes) anterior to the pectoral fin and between the pectoral and pelvic fins form buds which atrophy without entering the fin is taken by those who accept the lateral fin-fold theory to mean that the fin previously had a much greater anteroposterior extent than at present; and it is hence in agreement with what would be expected from that theory.

MLuscles of the unpaired fins are formed in essential respects like those of paired fins. As the myotome grows dorsally to the middorsal line it gives off buds in the regions of the dorsal fins and the dorsal lobe of the eaudal fin. Each bud for the unpaired fins divides into an anterior and a posterior bud but no further division takes place since the buds from opposite sides unite to form the musenlature of the unpaired fins. Ventral buds arise from the tip of the tail forward to the anal region. The more posterior of these supply the ventral lobe of the caudal fin, while those in the region of the anal fin, in forms in which an anal fin develops, provide musculature for that fin.

\section{MUSCLES OF THE CLASPERS}

The muscles which control the claspers are usually more complex than those deseribed for Heptanchus. In Chlamydoselachus, however, few points of modification are shown. The principal change is noted in the area of the adductors. While the adductor in the notidanids is a long muscle, in Chlamydoselachus (ad., fig. 113) it is relatively broad and fan-shaped. Here, too, the external 

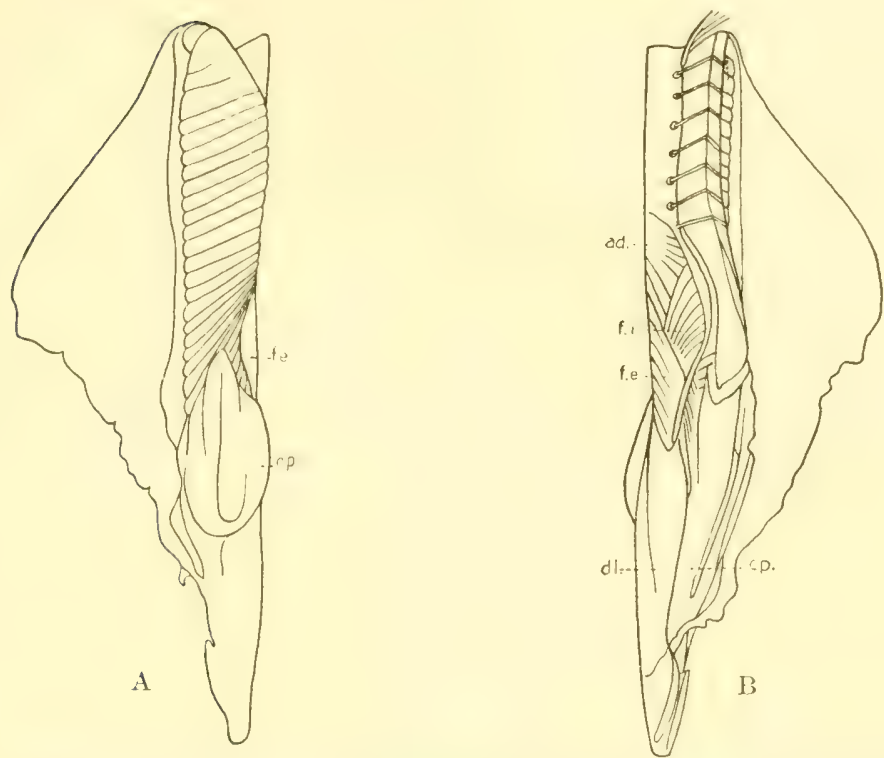

Fig. 113. Muscles of the claspers, Chlamydoselachus. A and B, ventral and dorsal views. (From Goodey.) ad., adductor; $c p$. , compressor; dl., dilator; f.e., external flexor; f.i., internal flexor.
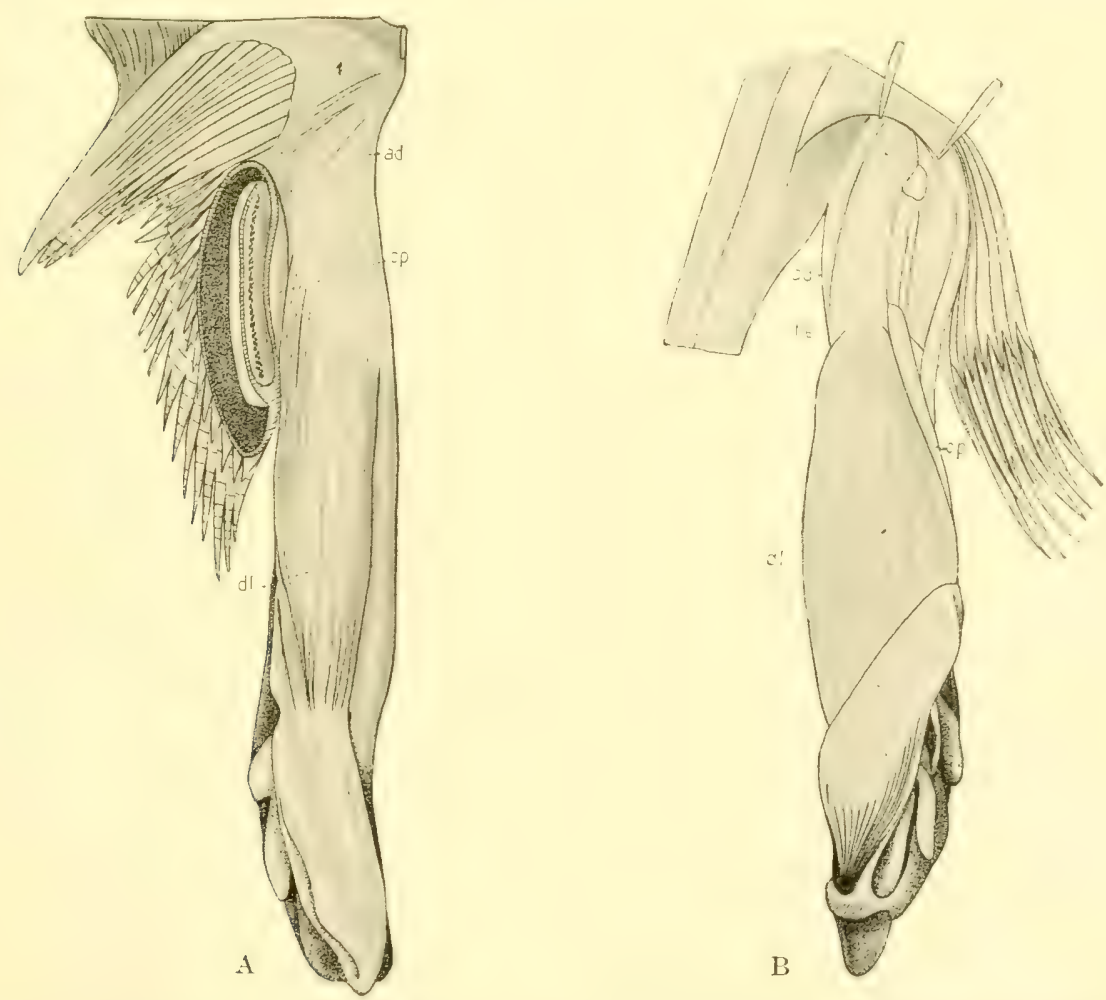

Fig. 114. Muscles of the elaspers, Raja. (From Bachman.) A and B, ventral and dorsal views. $a d$., adductor; $c p$., compressor; al., dilator; f.e., external flexor. 
flexor (f.e.) differs in that its point of origin is far removed from that of the internal flexor $\left(f . i_{0}\right)$.

In the rays, where the skeleton of the fin is much more complex, the muscles have undergone a relatively high degree of specialization. In figure $114 \mathrm{~A}$ of Raja clavata the adductors ( $a d$.) are shown on the ventral side as diverging fibers passing toward the sac. Surrounding the sac is the large compressor, a part of which also appears in dorsal view ( $c p$. fig. 114B). The large dilator $(d l$.$) in the same view is divided into a ventral and a dorsal part, the latter$ heing very heary. Continuing from this muscle on the dorsal side is the large external flexor (f.e.) and at its sides is the margin of the adductor seen also in ventral view.

\section{ELECTRIC ORGAN IN ELASMIOBRANCHS}

One of the most highly specialized organs found in the animal kingdom is present in the rays. This is the electric organ by means of which electric shocks can be generated. While this organ is found in its perfected form in Torpedo,

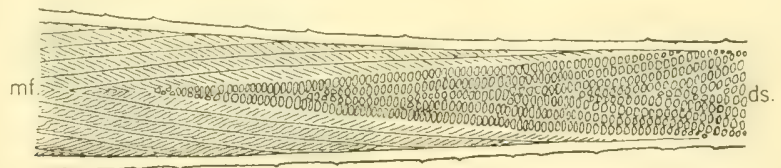

Fig. 115. The relation of the electric organ to the muscles, Raia batis. (From Ewart.) $d s$, electric dises; $m f$., musele fibers.

it is also present in the genus Raja. In Torpedo it consists of vertically placed dises located on the dorsal part of the pectoral fin. In the rays, on the other hand, it is made up of a series of cones located in the tail.

\section{Electric Organ of Rays}

The electric organ of the ray is spindle-like and extends throughont the greater length of the tail. It is spindle-shaped, however, only in part. While it tapers gradually at both ends, in the middle region it is not always cylindrical, since it is subject to pressure from the surrounding ligaments, muscles, and the vertebral column, resulting often in deep grooves in the organ. (Ewart.)

Figure 115 shows the relation of the electric organ of the ray to the surrounding muscular tissue. From this it is seen that the organ is continuous with the lateral row of muscle cones. In fact it is clear that the organ itself is formed as a series of cones altogether similar to those of the muscle, with the single exception that the direction of the muscle fibers ( $m f$.) in the muscle is more oblique to the myosepta than are the discs $(d s$.$) of the electric organ.$ 


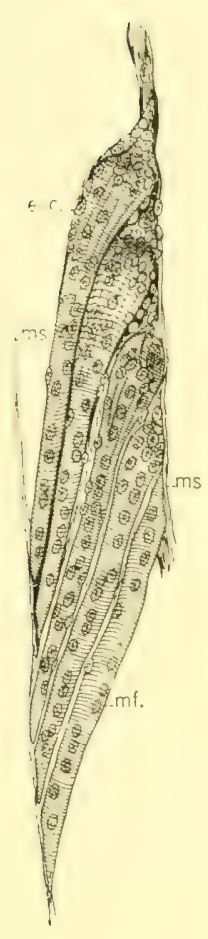

A

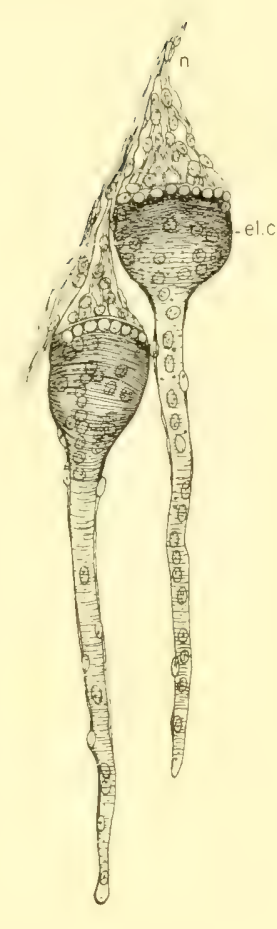

B

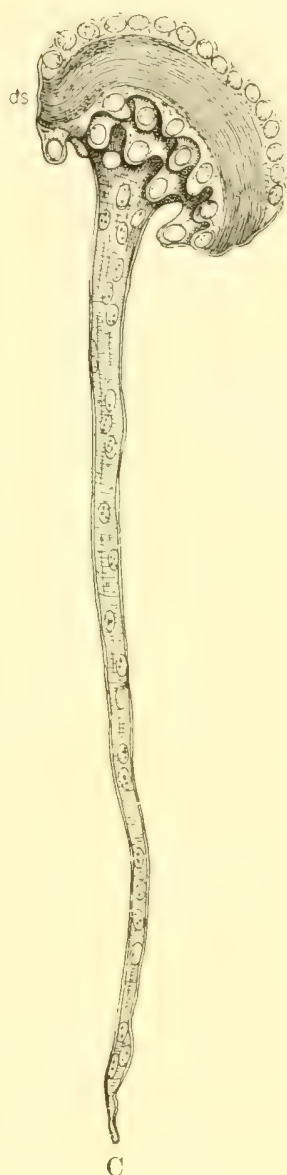

Fig. 116. Development of electrie organ of Raia batis. Stages A-C. (From Ewart.) ds., electric dise; el.c., electric club; $m f$., musele fiber; ms., myoseptum; n., nerve. 
The electric dises $(d s$.$) , although directed more at right angles to their con-$ nective tissue septa, have otherwise the same general relations as the fibers of the muscle. Like them they are smaller and less regular at the tip and base of

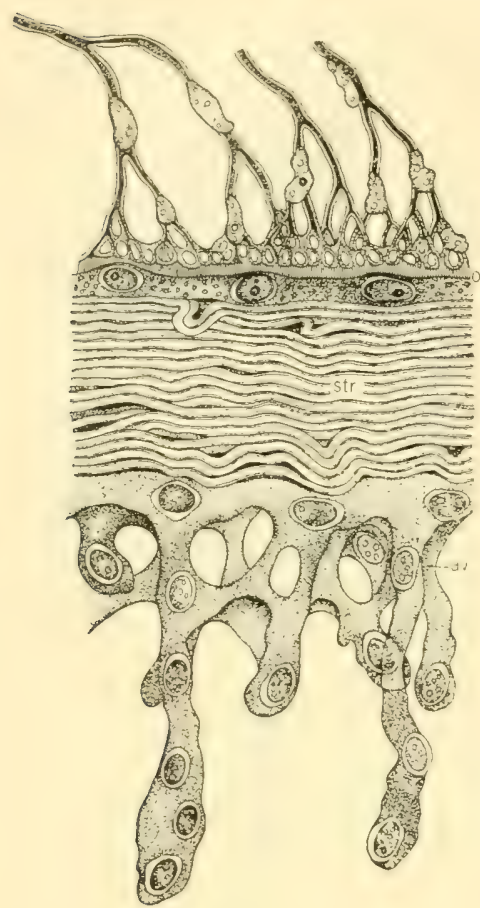

Fig. 117. Finer structure of electric dise. (From Ewart.)

av., alveolar layer; o.e., outer electric layer; str., striate layers. the cone. They are, however, much larger than the muscle fibers. As individual units they are more or less quadrangular in shape, their walls being formed of connective tissue. A glance will show that there are a great number in a single organ. It has been estimated that as many as 20,000 dises are present in an adult Raia batis.

One of the most interesting things about the electric organ is the fact that, whether it be in Raja or in Torpedo, it is formed as a series of metamorphosed muscle fibers. The organ as deseribed by Ewart in Raia batis first appears when the embryo is about an inch long. Here it is confined to the tail and only those muscle fibers are affected which belong to the lateral bundles, as described for Lamna (fig. 101). These fibers undergo complete change of form and assume an entirely secondary functional rôle.

A group of such fibers (fig. 116A) shows the beginning stages in this metamorphosis. The anterior fibers, near their attachment to the myoseptum, are beginning to enlarge into elub-shaped structures (el.c.), while the posterior fiber ( $m f$.) is still of the muscle type. By further growth and differentiation each incipient electric club comes to assume the form of a cone, in the enlarged end of which in time a concavity forms. A nerve entering this concavity breaks up into many branches (n., fig. $116 \mathrm{~B}$ ). At this stage, striation characteristic of the muscle fiber has decreased on the cups, but striations are still present on the body of the cone. In a later stage (fig. 116c) the organ has acquired essentially the adult characteristics. In this stage it is seen that the dise ( $d s$.) has greatly enlarged and that the terminal part of the cone has lost something of its muscle-like appearance. From a somewhat more mature organ we may study the detail of its finer structure.

\section{FINER ANATOMY OF ELECTRIC ORGAN}

'The disc may be divided into three well defined layers (fig. 117), an outer electric layer (o.e.), a middle striated layer (str.), an inner alveolar layer $(a v$.$) . 'The outer layer is in fact composed of two layers, the more superficial$ of which is made up of a net of nerves, and the next layer is characterized by 
the presence of cells with enormous nuclei. 'The middle striated layer consists of fibers probably of connective tissue which take a transverse and wave-like course. In this, muelei are rarely seen. 'The inner or alveolar layer is at first composed of granular tissue which later gives rise to long, backward directed projections. At the base of these three layers is a thick eushion of gelatinous tissue which is contained in the comnective tissue walls of the cone.

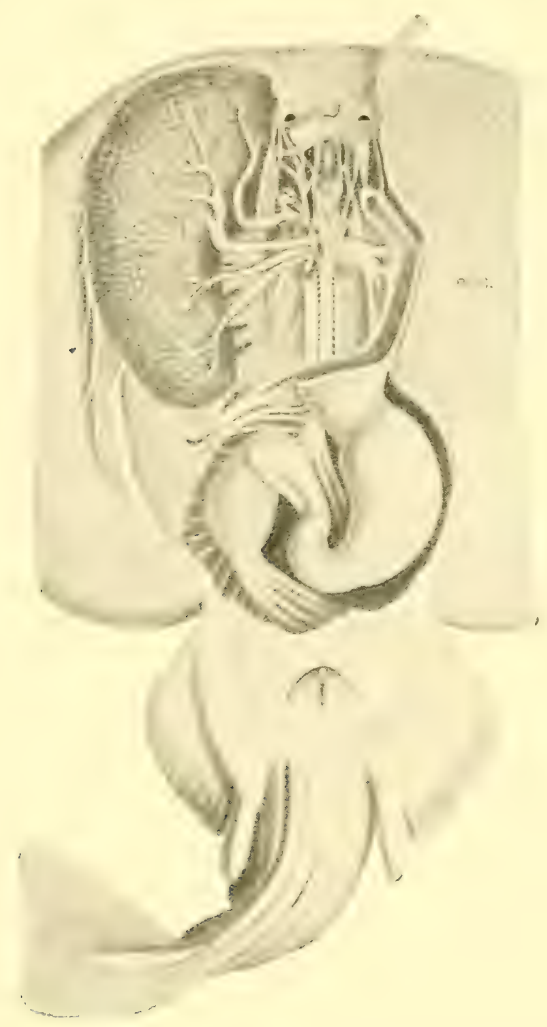

Fig. 118. Electric organ, Torpedo. (After Schimkevitsch from Krupski's atlas.) el.c., electric columns.

In the adult organ of Torpedo, the dises, as previously noted, are located in the body in the region of the pectoral fins. Removal of the skin from this area (el.c., fig. 118) shows the organ to be made up of multitudes of hexagonal columns resembling the cells in honeycomb. Each column further consists of a series of dises piled one upon another, ten to twelve of these being present in each column. Each dise may be considered as having two surfaces, one ventral, the other dorsal. The ventral surface bears a negative charge of electricity while the dorsal is positively charged.

'The innervation of the electric organ will be considered in Chapter IX. 



\section{BIBLIOGRAPHY}

\section{Chapter IV}

MUSCULATURE

1899. Allis, E. P., JR., An Abnormal M[usculus Obliquus Superior in Carcharias. Anat. Anz., Bd. 16, pp. 605-607, 1 text fig.

1901. Allis, E. P., Jr., The Lateral Sensory Canals, the Eye-Museles and the Peripheral Distribution of Certain of the Cranial Nerves of Mustelus laevis. Quart. Jour. Mier. Soe. (1. s.), Vol. 45, pp. 87-236, pls. I1-12.

1899. Braus, H., Beiträge zur Entwicklung der Muskulatur und des peripheren Nervensystems der Selachier. Morph. Jahrb., Bd. 27, pp. 415-496, pls. 19-21, 6 text figs. I. Theil. Die metodischen Urwirbel und spino-occipitalen Nerven. II. Theil. Die paarigen Gliedmassen, pp. 501-629, pls. 22-25.

1595. Corning, H. K., Ueber die Entwickelung der Zungenmuskulatur bei Reptilien. Anat. Anz. (Verh. Basel), Bd. 10, pp. 165-175.

1902. Conding, H. K., Über die vergleichende Anatomie der Augenmuskulatur. Morph. Jahırb., Bd. 29, pp. 94-140, pls. 5-6.

1915. Davidson, Pirie, The Musculature of Heptanchus maculatus. Univ. Calif. Publ. Zool., Vol. 18, pp. 151-170, 12 text figs.

1902. DEAN, BASHFord, The Preservation of Muscle-Fibers in Sharks of the Cleveland Shale. Amer. Geologist, Vol. 30, pp. 273-278, pls. 8-9.

1884. Dohrn, A., Studien zur Urgeschichte des Wirbelthierkörpers. Mitt. Zool. Stat. Neapel, Bd. 5, pp. 102-195, Taf. 5-11. (See the part on museulature.)

1903. Edgeworth, F. H., The Development of the Head Museles in Seyllium canicula. Jour. Anat. and Physiol., Vol. 37, pp. 73-88, pls. 4-10.

1899. Harman, N. B., The Palpebral and Oculomotor Apparatus in Fishes. Jour. Anat. and Physiol., Vol. 34, pp. 1-40, pls. 1-6.

19:23. Howell, A. Brazier, The Arehitecture of the Pectoral Appendage of the Dogfish. Jour. Morph., Vol. 54, pp. 399-413, 4 text figs.

18S5. Hurecht, A. A. W., and SAgemehr, M., Miskulatur Bronn's Klassen und Ordnungen des Thier Reichs, Bd. 6, Abt. 1, Pisces, Lief. 4, p. 87.

18i2. Huniphrex, Professor, The Muscles of the Smooth Dogfish (Mustelus levis). Jour. Anat. and Physiol., Vol, 6, pp. 271-278, pl. 13.

1Sy.2. TAestaner, S., Ueber die allegemeine Entwickelung der Rumpf und Schwanzmusculatur bei Wirbelthieren. Mit besonderer Berücksichtigung der Selachier. Arch. f. Anat. u. Physiol. (Anat. Abt.), Bd. 1892, pp. 153-222, pls. 9-12.

1910. KNAUER, KarL, Die Bauchmuskulatur der Fische. Abt. Zool. Inst. Wien, T. 18, Heft. 3, pp. 207-226, Taf. 1-3, 6 text figs. (Selachians, fig. 1, pp. 5-8.)

1902. Lanib, A. B., The Development of the Eye Muscles in Acanthias. Amer. Jour. Anat., Vol. 1, pp. 185-202, 9 text figs. Also: Tufts College Studies, No. 7, Vol. 1, pp. 275-292, 9 text figs.

1904. Lavgelane, J. W., On the Form of the Trunk-Myotome. (Proc.) Sci. Akad. Amsterdam, Vol. 7, Pt. 1, pp. 34-40, 7 text figs.

1909. Luther, Alex., Untersuchungen über die von n. trigeminus innervierte Muskulature der Selachier (Haie und Rochen) unter Berücksichtigung ihrer Beziehungen zu benachbarten Organen. Acta Soe. Sei. fenn., T. 36, No. 3, pp. 1-176, Taf. 1-5, 23 text figs. 
1909. Luther, ALEx, Beiträge zur Kenntnis von Muskulatur und Skelet des Kopfes des Haies Stegostoma tigxinum Gm., und der Holocephalen mit einem Anhang über die Nasenrinne. Acta Soc. Sci.fenn., T. 37, No.6, pp. 1-60, 36 text figs.

1905. Marion, G. E., Mandibular and Pharyngeal Muscles of Acanthias and Raia. Amer. Nat., Vol. 39, pp. 891-924, 15 text figs.

1892. MAUrer, F., Der Aufbau und die Entwicklung der ventralen Rumpfmuskulatur bei den urodelen Amphibien und deren Beziehung zu den gleichen Muskeln der Selachier und Teleostier. Morph. Jahrb., Bd. 18, pp. 76-179, pls. 4-6, 6 text figs.

1906. MAUrer, F., Die Entwickelung des Muskelsystems und der elektrischen Organe. Hertwig's Handb. vergl. u. expt. Entwick. d. Wirb., Bd. 3, Teil I, pp. 1-80, 41 text figs.

1912. MAURer, F. Die ventrale Rumpfmuskulatur der Fische (Selachier, Ganoiden, Teleostier, Crossopterygier, Dipnoer). Jena. Zeitschr. Naturwiss., Bd. 49, pp. 1-118, Taf. 1-2, 6 text figs. (on Elasmobranchs).

1911. MÜLLER, ErIK, Untersuchungen über die Muskeln und Nerven der Brustflosse und der Körperwand bei Acanthias vulgaris. Anat. Hefte, Bd. 43, pp. 1-147, pls. 1-26, 11 text figs.

1834. MÜLler, J., Vergleichende Anatomie der Myxinoiden. Abh. Akad., Berlin.

1897. NEAL, H. V., The Development of the Hypoglossus Musculature in Petromyzon and Squalus. Anat. Anz., Bd. 13, pp. 441-463, 2 text figs.

1918. Neal, H. V., The History of the Eye Museles. Jour. Morph., Vol. 30, pp. 433-453, 20 text figs.

1891. Platt, Julia B. (See Bibliography, Chap. I.)

1899. Riderrood, W. G., On the Eyelid-Muscles of the Carchariidae and Seyllium. A contribution to the Morphology of the Nictitating Membrane of Sharks. Jour. Anat. and Physiol., Vol. 33, pp. 228-242, 7 text figs.

1897. RUGe, G., Ueber das peripherische Gebiet des nervus facialis bei Wirbelthieren. Festschr. f. Gegenbaur, Vol. 3, pp. 195-348, 76 text figs.

1896. Tiesing, Berthold, Ein Beitrag zur Kenntnis der Augen-Kiefer und Kiemenmuskelatur der Haie und Rochen. Jena. Zeitschr. Naturwiss., Bd. 50 (N. F. 23), pp. 75-126, pls. 5-7.

1874. VeTTeR, B., Untersuchungen zur vergleichenden Anatomie der Kiemen- und Kiefermusculatur der Fische. Jena. Zeitschr. Naturwiss., Bd. 8 (N. F. 1), pp. 405-458, pls. 14-15.

1882. WiJhe, J. W. vaN, Ueber die Mesodermsegmente und die Entwickelung der Nerven des Selachierkopfes. Verh. d. k. Akad., Amsterdam, Deel 22, pp. 1-41, Taf. 1-5.

\section{ELECTRIC ORGAN}

1876. BABUchin, A., Uebersicht der neuen Untersuchungen über Entwickelung, Bau und physiologische Verhältnisse der elektrischen und pseudoëlektrischen Organe. Arch. f. Anat. u. Physiol., Bd. 1876, pp. 501-542, Taf. 11-12, 2 text figs.

1893. Baliowitz, Emil, Ueber den Bau des elektrischen Organes von 'Torpedo mit beson. derer Berücksichtigung der Nervenendigungen in Demselben. Arch. mikr. Anat., Bd. 42 , pp. $459-568$, Taf. $29-31$.

1.99-. Ballowitz, E., Ueber die Uebereinstimmung des feineren Baues der elektrischen Organe bei den starkelektrischen und schwachelektrisehen Fischen. Anat. Anz., Bd. 13, pp. 124-126.

1897. Ballowitz, E., Über den feineren Bau des elektrischen Organs des gewöhnlichen Rochen (Raja clavata L.). Anat. Hefte, Bd. 7, pp. 283-375, Taf. 19-29.

1873. Boll, F., Beiträge zur Physiologie von Torpedo. Arch. f. Anat. u. Physiol., Bd. 1873, pp. 76-102. 
1874. BolL, F., Die Struetux der elektrischen Platten von Torpedo. Areh. mikr. Anat., Bd. 10, pp. 101-121, Taf. 8.

1876. Bous, F., Neue Untersuchungen über die Structur der elektrischen Platten von 'Torpedo. Areh. f. Anat. u. Physiol., Bd. 1876, pp. 462-479, T'af. 8.

1898. Crevatin, F., Ueber das sogenamnte Stäbchennetz im elektrischen Organ der Zitterrochen. Anat. Anz., Bd. 14, pp. 243-250, 2 text figs.

1849. Ecker, A., Einige Beobachtungen über die Entwicklung der Nerven des electrisehen Organs von Torpedo galvanii. Zeitsehr. wiss. Zool., Bd. 1, pp. 38-47.

1888. EWART, J. C., The Eleetric Organ of the Skate. On the Development of the Electric Organ of Raia batis. Phil. Trans. Roy. Soc. Lond., Vol. 17913, pp. 399-409, pl. 68.

1888. EwarT, J. C., The Electric Organ of the Skate. On the Structure of the Electric Organ of Raia circularis. Phil. Trans. Roy. Soc. Lond., Vol. 179B, pp. 410-416, pl. 68.

1888. EwarT, J. C., The Electric Organ of the Skate. The Electric Organ of Raia radiata. Phil. 'Trans, Roy. Soc. Lond., Vol. 179B, pp. 539-552, pls. 79-80.

1892. Ewart, J. C., The Electric Organ of the Skate-Observations on the Structure, Relations, Progressive Development, and Growth of the Electric Organ of the Skate. Phil. Trans. Roy. Soc. Lond., Vol. 183B, pp. 389-420, pls. 26-30.

1883. Fritsch, G., Berieht über , lie Fortsetzung der Untersuchungen an plektrisehen Fischen. Beiträge zur Embryologie von 'Torpedo. Sitzber. Akad. Berlin, I, pp. 205209 , pl. 4.

1883. Fritsch, (i., Die dektrischen Fische in Lichte der Descendenzlehre. Samm. gemein. Wissen. Vortr., Bd. 18, Ser. 1, pp. 835-898, 7 text figs. (Virehow Holtzendorff Vorträge.)

1801. GeOfFror, E., Mémoire sur l'anatomie comparée des organes électriques de la Raie torpille, du Gymnote engourdissant, et du Silure trembleur. Ann. du Mus., 'T. 1, pp. $392-407, \mathrm{pl} .26$.

1845. Goodsin, J., Ol)servations on Electric Organs (Ray). Ann. Mag. Nat. Hist., Ser. 1, Vol. 15, p. 122 .

1887. GoTCm, Francis, The Electromotive Properties of the Electrieal Organ of Torperlo narmorata. Phil. Trans. Roy. Soe. Lond., Vol. 178B, pp. 487-537, 4 text figs.

488. (отсн, F., Further Observations on the Electromotive Properties of the Electrical (rgan of Torpedo marmorata. Phil. Trans. Roy. Soe. Lond., Vol. 179B, pp. 329-363, is. 51-52, 3 text figs.

1861. IARTMANn, RoBT., Bemerkungen ïber die elektrisehen Organe der Fisehe. Arch. f. Anat. u. Physiol., Bd. 1861, pp. 646-670, Taf. 16.

1911. LaGuesse, E., Un Exemple bien net d'architecture lamellaire du tissu conjonctif lache. C. R. Soc. Biol. Paris, 'T. 71, pp. 328-329.

1861. M'DONNELL, R., On an Organ of the Skate which appears to be a Homologue of the Electrical Organ of the Torpedo. Nat. Hist. Review, pp. 57-60.

1906. Portier, P., Les Poissons électriques. Bull. Mus. Ocean. Monaco, No. 76, 1906, pp. $1-23,18$ text figs.

1873. Reichenheim, Max, Beiträge zur Kenntnis des elektrischen Centralorgans von Torpedo. Arch. f. Anat. u. Physiol., Bd. 1873, pp. 751-759, Taf. 15-16.

1856. RemaK, R., Ueber die Enden der Nerven im elektrischen Organ der Zitterrochen. Areh. f. Anat. u. Physiol., Bd. 1856, pp. 467-472.

1898. Retzius, G., Ueber die Endigung der Nerven im elektrischen Organ ron Raja clavata und Raja radiata. Biol. Untersuch. (n. s.), Bd. 8, pp. 83-93, pls. 19-21.

1846. Roвin, CH., Recherches sur un organe particulier qui se trouve sur les poissons du genre des Raies (Raia cuv.). C. R. Acad. Sci. Paris, T. 22, pp. 821-822. 
1865. RoвıN, CH., Mémoire sur la démonstration expérimentale de la production d'électrieité par un appareil propre aux poissons du genre des Raies. Jour. de l'Anat. et Physiol., T. 2, pp. 507-535, pls. 33-35.

1888. Sanderson, J. B., and Goтсн, Francis, On the Electrical Organ of the Skate. Jour. Physiol., Vol. 9, pp. 137-166, 5 text figs.

1889. SANderson, J. B., and Goтch, Francis, On the Electrical Organ of the Skate. Part II. Jour. Physiol., Vol. 10, pp. 259-278, pl. 22, 1 text fig.

1858. Schultze, Max, Zur Kenntnis des den electrischen Organen verwandten Schwanzorganes von Raja clavata. Arch. f. Anat. u. Physiol., Bd. 1858, pp. 193-214, Taf. 9.

1906. Schulze, O., Zur Frage von dem feineren Bau der elektrischen Organe der Fische. Biol. Centralbl., Bd. 26, pp. 640-656. Festschr. f. J. Rosenthall, Leipzig, pp. 101-118.

1845. Stark, Dr., On the Existence of an Electrical Apparatus in the Flapper Skate and Other Rays. Ann. Mag. Nat. Hist., Vol. 15, p. 121. 


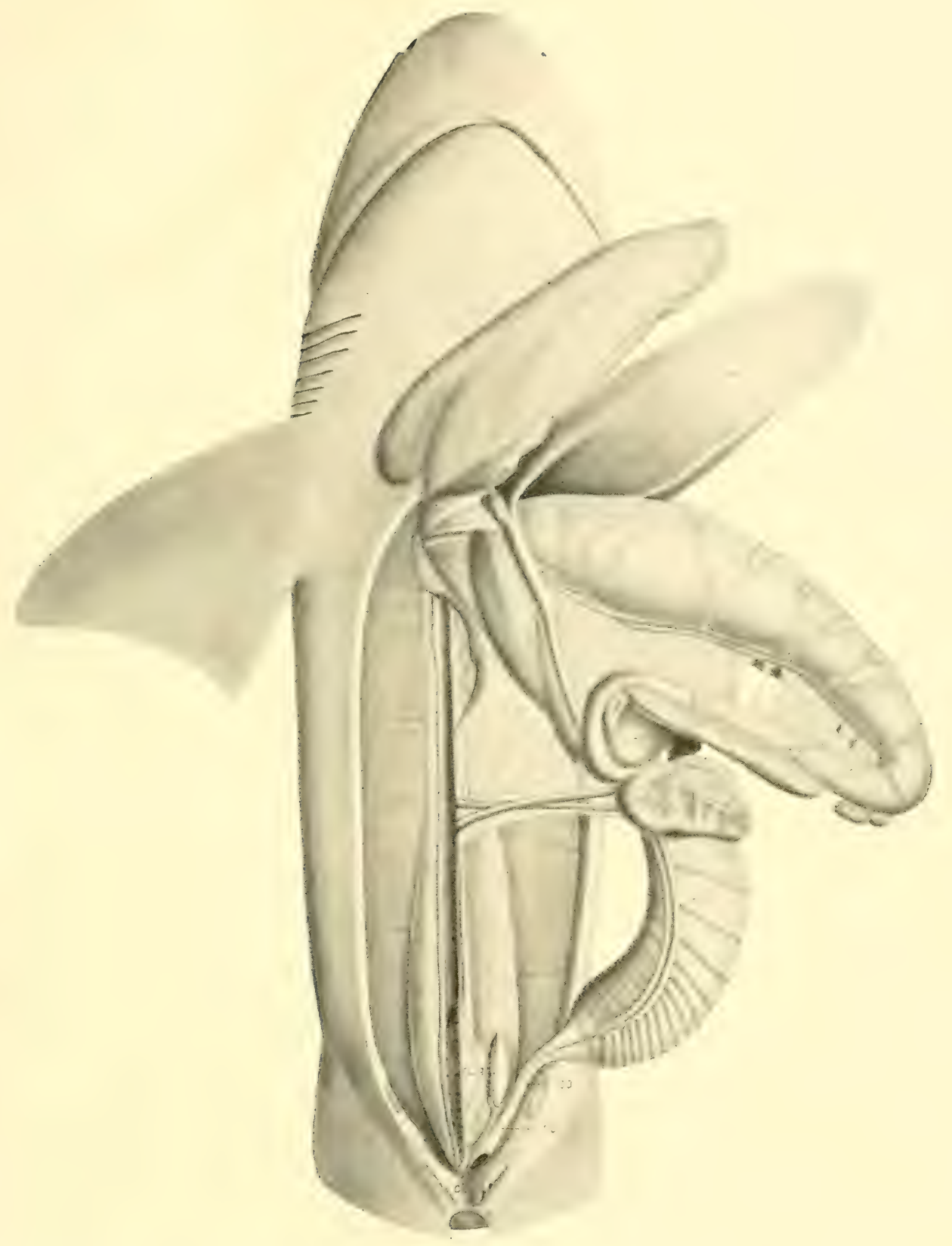

Fig. 119. Body cavity opened to show viscera, Heptanchus maculatus. (C. G. Potter, orig.) cl., cloaca; co., colon; c.s., cartiae stomach; $7 v$., liver; $p u^{1-2}$, dorsal and ventral lobes of pancreas; p.s., pyloric stomach; rc., rectum; rc.g., rectal gland; sp.i., valvular intestine. 


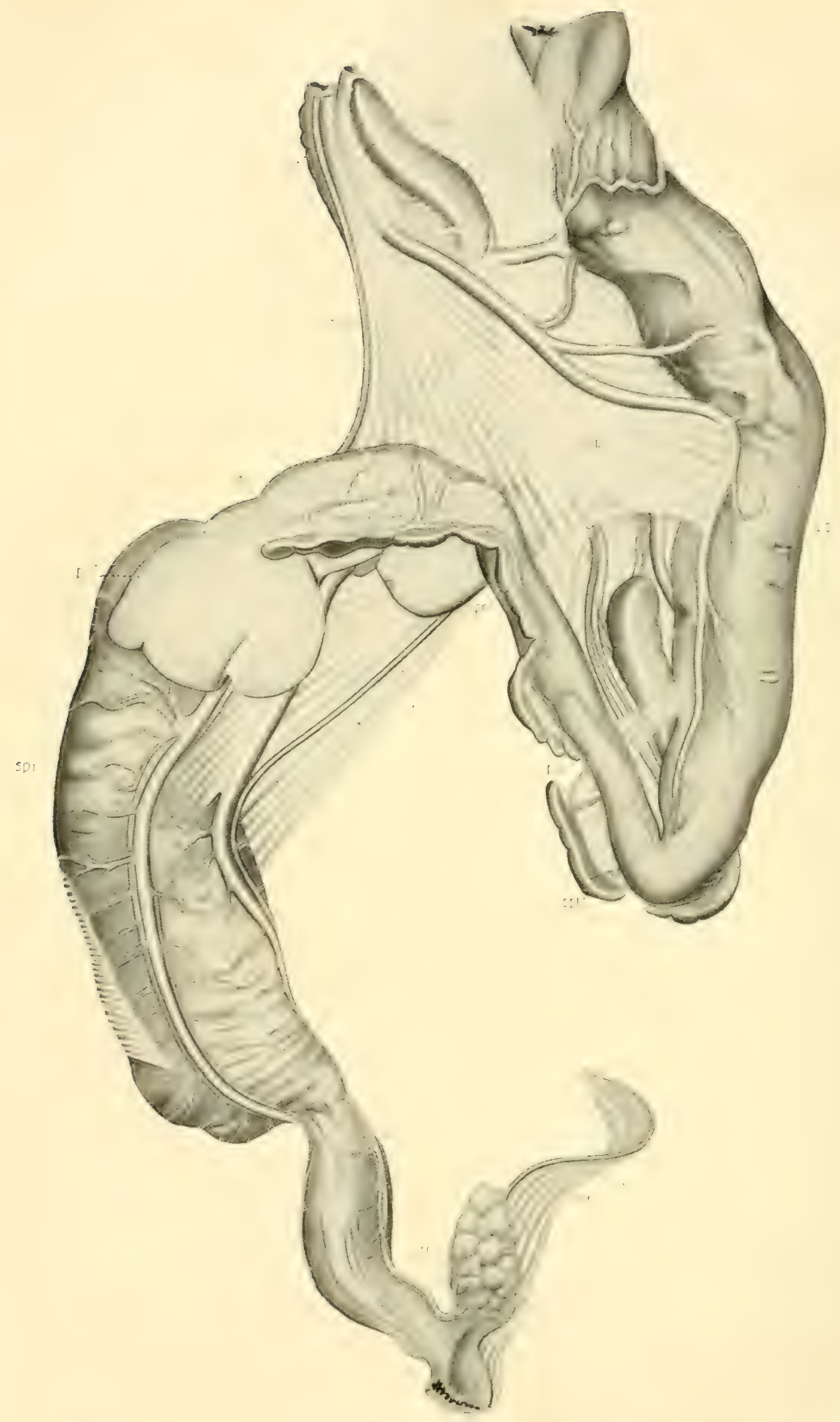

Fig. 120. Digestive tract and its mesenteries, Heptanchus maculatus. (Ruth Jeanette Powell, del.)

co., colon; c.s., cardiae stomach ; d.ch., bile duet; du., duodenum; h.p., hepatic portal rein; m.p., median fold of mesentery (omentum); mr., mesorectal mesentery; oe., oesophagus; $p n^{1-2}$, dorsal and ventral lobes of pancreas; $p . s ., p y l o r i e ~ s t o m a c h ; ~ r . f$., right fold of mesentery ; re, rectum; rc.g., reetal gland; sp.i., spiral intestine; spl., spleen; spl. ${ }^{1}$, anterior extension of spleen. 


\section{DIGESTIVE TRAC'T}

\section{DIGESTIVE 'TRAC'T OF HEP'TANCHUS MACULATUS}

\section{Miesenterial Structures}

The digestive tract of Heptanchus (figs. 119 and 120) is suspended from the dorsal body wall by mesenteries, which are present in two general areas, an anterior and a posterior (fig. 120). The anterior mesenteries are somewhat complex; while those which suspend the posterior part of the tract are simpler. For convenience of description the mesentery in the anterior region may be considered as made of a right, a median, and a left fold. The right fold of the mesentery ( $r . f .$, fig. 120) passes from the middorsal line and from the right suspensory ligament to the hepatic portal vein (h.p.) and to the spiral intestine $(s p . i)$, the extent of its origin, in other words, being along the middorsal line from the liver in front, back to the region of the superior mesenteric artery. Since the anterior part of the right mesentery is attached along the hepatic portal rein and back to the suspensory ligament of the spiral intestine, it is largely hidden in figure 120.

The second or median division extends from the right suspensory ligament of the liver and the ligament along the hepatic portal vein, across to the oesophagus and down the lesser curvature of the stomach to the proximal tip of the duodenum. The larger part of this is shown in figure 120 (m.p.) with a portion removed to show underlying organs. The left mesentery extends from the middorsal line to the dorsal side of the oesophagus and the stomach. Along its line of origin the left fold lies against the right and the two are firmly fused together. Remnants of this part of the mesentery appear on the outer angle of the stomach separating the stomach from the spleen ( $\mathrm{spl}$.) and from the pancreas $\left(p n .^{2}\right)$.

T'hese three parts of the mesentery may be considered as loosely enveloping the digestive tract and extending from the middorsal line on the right side to the suspensory ligament and hepatic portal vein. From here the middle segment (omentum) stretches across to the lesser eurvature of the stomach; the left segment continuing around is attached to the middorsal line on the left.

The posterior mesentery or mesorectum ( $m$.) extends from the middorsal line to the rectal region; it suspends the rectal or digitiform gland, and reaches forward to the posterior mesenteric artery.

\section{Buccal Cavity}

'The mouth or entrance to the buceal cavity is ventral in Heptanchus. If seen from below (fig. 119) it presents the appearance of a large erescentic slit with regular margins, except near the angles where there are enlarged folds. The 
mouth and nasal pits in Heptanchus are not connected by oronasal grooves characteristic of some of the Elasmobranchs. The buceal cavity proper is large and spacious. Its floor is lifted up by the basihyal cartilage, forming a skeleton for the so-called tongue. The mucous membrane lining the mouth is provided hoth dorsally and ventrally with numerous stomodeal denticles (see p. 24, fig. 27c) which, as we have seen in a study of the integument, are modifications of placoid scales. In the region just within the erescent of teeth the lining of the mouth is thrown into heavy folds, which lie over the concentric rows of tooth buds.

The teeth of Heptanchus (see fig. 48, facing p. 44) consist of a heavier lower series and a cuspidate upper series. The first tooth in the lower row of Hep-

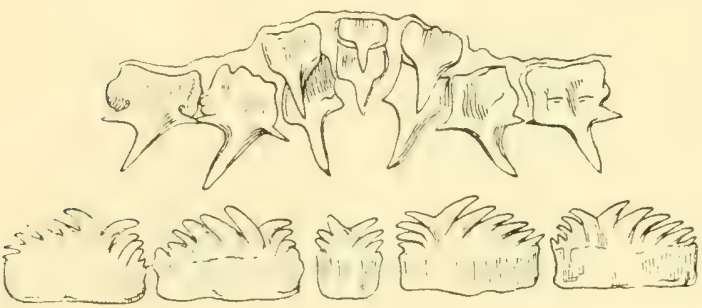

Fig. 121. Teeth of Heptanchus indicus. (From Maedonald and Barron.) tanchus maculatus, like that for $H$. indicus (fig. 121), is unpaired and without a median cusp. On either side of it are seven teeth, the most posterior of which is cuspless and is followed by several rows of smaller flat nodules not shown in figure 48. The first of the large teeth is provided with a se-

ries of three conules on the median margin and usually six larger conules on the lateral margin. Other lower teeth inchuding the sixth, though differing in size, are essentially like the first paired tooth. Unlike Heptanchus indicus (fig. 121) there is usually no unpaired upper tooth in Heptanchus maculatus. The first paired tooth above bears a long fang which is directed downward; at its sides are small basal denticles like those in Heptanchus indicus. The second tooth and the ones following, although larger, differ from the first only in that they possess median conules and outer cusps, several of which are present on each tooth.

\section{Pharynx and Associated Structures}

The pharyngeal part of the tract is wide from side to side and depressed or flattened dorsoventrally. Throngh its rentrolateral walls are perforations, the internal branchial openings by means of which the respiratory current reaches the gill pockets (see fig. 142, facing p. 148). These openings are of interest in a consideration of the respiratory system. The lining of the pharynx, like that of the buccal cavity, is provided with denticles, but these on the roof in the posterior part are confined to a narrow strip just above the internal branchial clefts. The pharynx narrows toward the region of the oesophagus, which is closed except during the passage of food. By this closure of the oesophagus the buceal cavity and pharynx form a relatively large room.

In connection with the pharynx are the thymus and thyroid glands. The thymus in Heptanchus, figure 122, lies dorsal to the first six gill clefts and takes the form of bunches of grapes. Van Wijhe has made the remarkable dis- 
covery that in the young embryo of $H$. cinereus the thymus is not a ductless gland. In this type ducts lead from the first six lobes of the thymus into the pharynx. The thyroid gland is located at the symphysis of the lower jaws between the coracomandibularis and coracohyoideus muscles (see p. 200, fig. $184, t h$.). It is a mass of semitransparent glandular tissue slightly erescentic in shape and surrounded by a capsule of connective tissne.

\section{OESOPHAGUS}

The digestive tract is continued posteriorly from the pharynx by a short, thick-walled portion, the oesophagus (oe., fig. 120). The lining of the oesophagus is thrown into whitish longitudinal folds, some of which may be continuous with those of the stomach. The oesophagus is distinguished from the stomach, however, by the character of its folds, the folds of the latter being much more pronounced. The epithelium of the oesophagus differs from that of the pharynx in that it does not contain stomodeal denticles.

\section{Stomach}

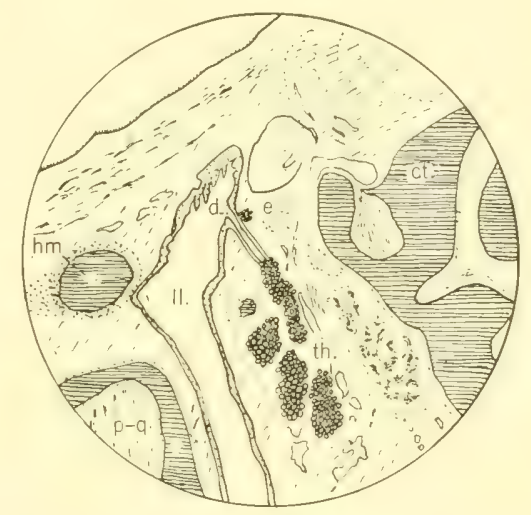

The stomach of Heptanchus is Ushaped, the larger left limb heing the cardiac end (c.s., fig. 120), and the smaller right limb, the pyloric division (p.s.). Superficially the cardiac portion of the stomach appears as a more or less distended bag, while the pyloric

Fig. 122. Section through thymus glanil of $63 \mathrm{~mm}$. embryo He pitanclins cinereus. (From Van Wijhe.)

d., duct of thymus; e., epithelial body; hm., Iryomandihnlar cartilage; ot., otic area; $p$-q., palatoquadrate cartilage; the, thymus nodules; II, second gill cleft.

division is thick-walled. Within the cardiac stomach is usually found a considerable amount of undigested food material in the form of pieces of fishes, the shell and claws of crabs, and the like.

Internally the pronounced folds of the cardiac stomach continue in a more or less longitudinal direction from its union with the oesophagus throughout two-thirds of its length where they become more or less tortuous. At the distal end of this part of the stomach there is present a blind sac in which some of the folds terminate. Some of the small folds abut against a circular fold which in a way separates the cardiac from the pyloric division. The pyloric lumen of the stomach is long and narrow, and its folds are not especially marked at the proximal end. As the terminus of the pylorus is reached, however, they become much higher. Three-fourths of an inch from the termination of the pyloric limb there is a slightly enlarged portion which opens into the duodenum through the pyloric valve. 
SPLEEN

The spleen $(s p l$.) although unconnected with the digestive tract may be considered here. In Heptanchus this organ, when its relation to that in other forms is studied, is very instructive. It consists of a long, more or less lobate band extending from the rentral lobe of the pancreas over the greater (outer) angle of the stomach. It then crosses over the stomach dorsally and is continued in the lesser curvature, one of its branches extending as far forward as the tip of the cardiac portion (spl. ${ }^{1}$, fig. 120).

\section{Duodenum or Middele Intestine}

The part of the digestive tract immediately following the pylorus, the duodenum or middle intestine, is well defined in Heptunchus. In figure 120, this segment $\left(d u_{\circ}\right)$ is covered in part by the ventral lobe of the pancreas $\left(p n_{\circ}{ }^{2}\right)$. As in several other forms, the valve of the spiral intestine extends forward throughout the length of the middle intestine and touches the pyloric valve. Into this segment of the intestine the ducts of the liver and the pancreas empty.

The liver ( $l v$. fig. 119) consists of a right and a left lobe between which is a small caudate lobe, not shown in the figure. In the caudate lobe is located the gall bladder which is emptied by a long duct (d.ch., fig. 120) into the duodenum.

The entrance of the duct into the duodenum is of interest. It reaches and enters the wall on the dorsal side only a short distance from the pyloric terminus of the stomach. It then runs in the wall backward and outward on a line almost at right angles to the attachment of the first whorl of the spiral valve. After having encircled about one-fourth of the duodenal circumference it empties into the duodenum a short distance from the first loop of the valvular intestine.

The pancreas is composed of two compact and connected lobes. The smaller of these is dorsally placed ( $p n_{0}{ }^{1}$, fig. 120), while the more compact lobe lies ventrally on the angle between the pyloric division of the stomach and the duodenum $\left(p n 。^{2}\right)$. The two lobes empty by a common duct which leaves the ventral lohe and, passing through the duodenal wall, runs almost parallel with the first ammular artery. As it passes hackward and outward it approaches the first fold of the valvular intestine and finally empties into the duodenum only a short distance to the left of (dorsally to) a line drawn from the entrance of the bile duct at right angles to the first fold of the valvular intestine.

\section{VALvUlar Intestine}

The most interesting part of the intestine (figs. 120, sp.i., and 123) is the spiral valve contained within its cavity. The attachment of the valve to the intestine may be seen from the outside as a series of annular folds traversed by blood ressels, seventeen or eighteen turns of which are present in Heptanchus maculatus. By making a window in the valvular intestine (fig. 123) it may be 


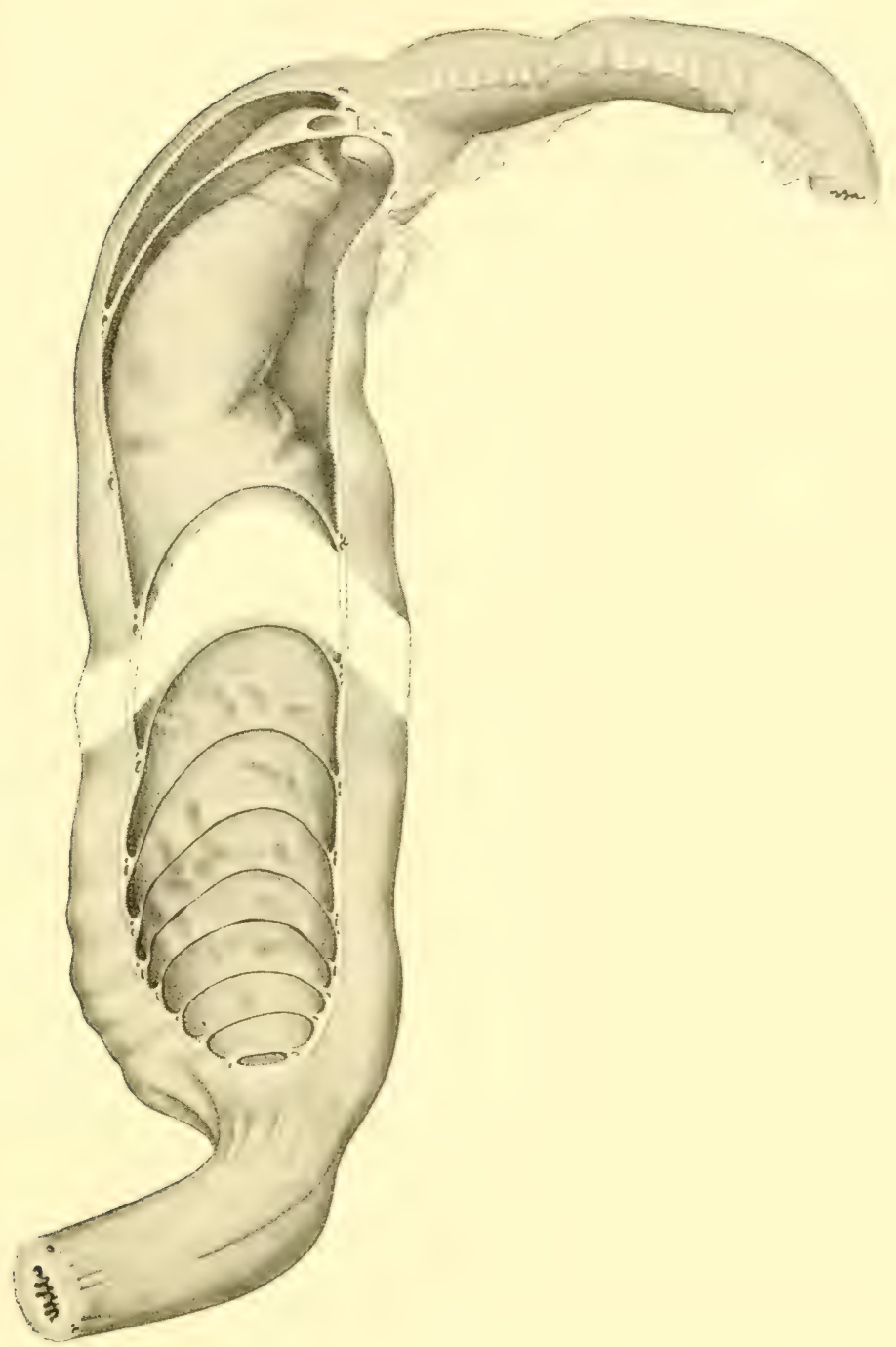

Fig. 123. Valvular intestine, with middle segment omitted, Heptanchus maculatus. (Duncan Dunning, del.) pv., pyloric valve. 
observed that the folds are far apart anteriorly and very much closer together posteriorly. The valye is formed as an ingrowth into the intestine and extends from the duodenum throughout the large intestine to the region where the opening of the rectal gland enters the intestine posteriorly. This fold is considerably broader than the diameter of the intestine and is thrown into a series of cones having their apices pointing anteriorly. The surface of the valve, if seen under the microscope, shows numerous finger-like villi which serve for the absorption of digested food.

\section{Colon and Rectum}

The part of the large intestine immediately following the valve is known as the colon (co., fig. 120). It is a muscular segment and superficially appears as slightly bulbous. Its lining, together with that of the part succeeding it, the rectum $\left(r^{\circ} \mathrm{c}.\right)$, is thrown into longitudinal folds. In the most posterior part, however, the walls of the rectum are smoother. The line of demarcation be-

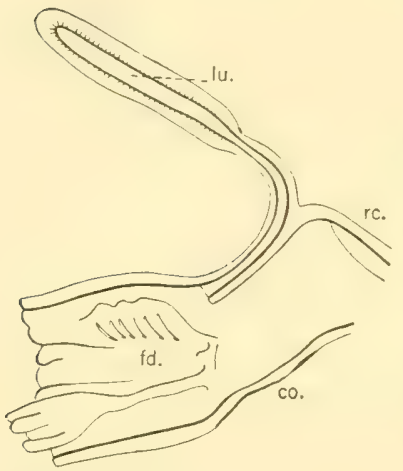

Fig. 124. Sagittal section through rectal gland, Heptanchus. (From Howes.)

$c o .$, colon; $f d$., fold of spiral intestine; lu., lumen of gland; rc., rectum.

tween the colon and the rectum is formed by a lumen from the rectal or digitiform gland.

\section{RECTAL GIAAND}

The rectal or digitiform gland (rc.g., fig. 120 and fig. 124) in Heptanchus is a finger-like structure which is composed of multitudes of gland cells and which empties by a central lumen into the intestine. It is so arranged, however, that the lumen does not enter immediately at the point at which it reaches the intestine, but passes sharply forward and downward emptying on a level with the terminus of the spiral valve.

\section{CLOACA}

The rectum empties into an enlarged room, the cloaca, which is lined with a smooth mucous membrane (see fig. 252, facing p. 290). Into the anterior part of the cloaca empty the products from the digestive, the urinary, and the genital systems, and in its posterior part are two finger-like processes, the cloacal papillae $(p$.$) .$

\section{ABDOMINAL PORES (PORI ABDOMINALES)}

As a usual thing the cloacal papillae in Heptanchus are imperforate. Occasionally, however, as on the left side in figure 252 , they are perforate, forming the so-called pori abdominales. These pores connect the abdominal cavity or coelom with the exterior. 


\section{DIGESTIVE TRACT OF ELASMOBRANCHS IN GENERAL}

The digestive tract constitutes a tube in which food is digested and through the walls of which it is absorbed into the eirculatory system. In the adult, as we have seen in Heptanchus, the tract is folded upon itself so that when seen in ventral view it takes the form of an ?. A median line parallel to the body axis may bisect the oesophagus and cloaca leaving the stomach to the left and the spiral intestine to the right.

\section{Mesenteries}

The mesenteries of Heptanchus are generalized when the Elasmobranchs as a group are considered, but they are more specialized than are those described

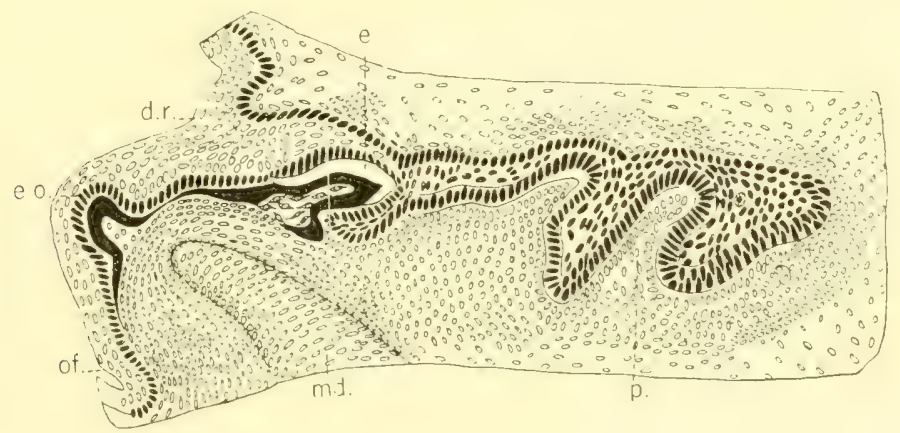

Fig. 125. Development of teeth in lower jaw of Spinax niger. (From Laaser.)

d.r., dental ridge; e., enamel; e.o., enamel organ; ma., mandibular cartilage; o.f., onter furrow; $p$., tooth papilla.

by Howes (1890) for Hypnos subnigrum, the Australian torpedo. In Hypnos, which has the most generalized type of any adult Elasmobranch with which I am acquainted, the mesentery extends as an almost unbroken sheet along the entire digestive tract. Only in the region of the spleen and of the rectal gland are there any indications of a break in the folds. In the adult of most other Elasmobranchs, however, there is a more pronounced tendency than in Heptanchus toward a loss of parts of the folds. In Acanthias, for example, relatively small parts of the folds which we have described as right and leftremain.

In its development the digestive tract of the Elasmobranch fishes is a more or less simple tube. It consists of a median segment which is put into communication with the outside: (1) by an anterior invagination which finally, as the stomodeum, breaks through to join the middle segment, and (2) by a posterior pit which also reaches the middle segment as the proctodeum. There is thus formed a tube including three parts: (1) the anterior stomodeum, lined with the outside ectoderm, which in the adult becomes the buceal and 
pharyngeal (?) regions; (2) a long middle portion lined with entoderm which includes in the adult the segments from the oesophagus to the end of the rectum, and finally (3) a posterior proctodeum or cloacal area also lined with

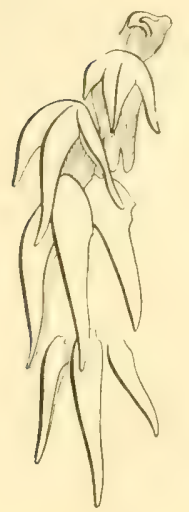

A
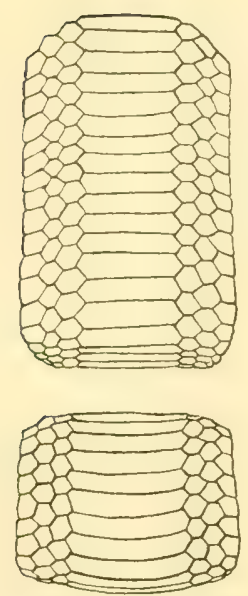

$\mathrm{B}$

Fig. 126. Tooth patterns. A. Chlamy. doselachus. (From Röse.) B. Myliobatis. (From Garman.) ectoderm. From these simple beginnings the complex traet results. As growth proceeds a series of dilations and constrictions divides the tract into parts characteristic of the adult. These we shall next consider in order.

\section{Buccal Cavity}

The mouth in Elasmobranchs is a large crescent which is usually ventral, although in certain types it is terminal, in position. It is bounded by membranous folds or lips and leads into a voluminous buceal cavity.

The floor of the buceal cavity is raised up into a heavy fold, the "tongue," which in some forms (Lamna) is well developed; in others it is less pronounced. The buceal cavity is lined with a smooth or papillated mucous membrane (Mustelus, Scyllium, Chlamydoselachus), the cells of which secrete mucin; but it is devoid of all glands which are characteristically present in higher forms. Perforating the lining of the cavity are two structures which, although differing in form, are essentially identical : the stomodeal denticles and the teeth. The former we have considered in Chapter II, page 38. The latter may be discussed here more in detail.

\section{TEETH}

The teeth ${ }^{1}$ characteristic of the Elasmobranchs are of two types: sharp or prehensile teeth and pavement or crushing teeth. Between these extremes multitudes of patterns, more or less complex, occur. In the early stages the two types are essentially alike, but as development proceeds each takes on its specific character. The general mode of development we may examine before considering the types further.

A sagittal section made through the lower jaw of Spinax niger by Laaser (fig. 125) shows the ectoderm sinking in to form a dental ridge $\left(d . r^{\circ}.\right)$. In this ridge several tooth germs are developing, and cells are collecting at the papilla $(p$.$) to form still another tooth. In the tooth germs which are$ more mature than those just mentioned the papillae have grown outward carrying caps of epidermis, the enamel organ (e.o.), over them. In their formation the teeth are much like the saw tooth already studied (p. 35).

Teeth thus formed in other Elasmobranchs may be long and fang-like, ${ }^{1}$ For bibliography on the teeth, see Chap. II. 


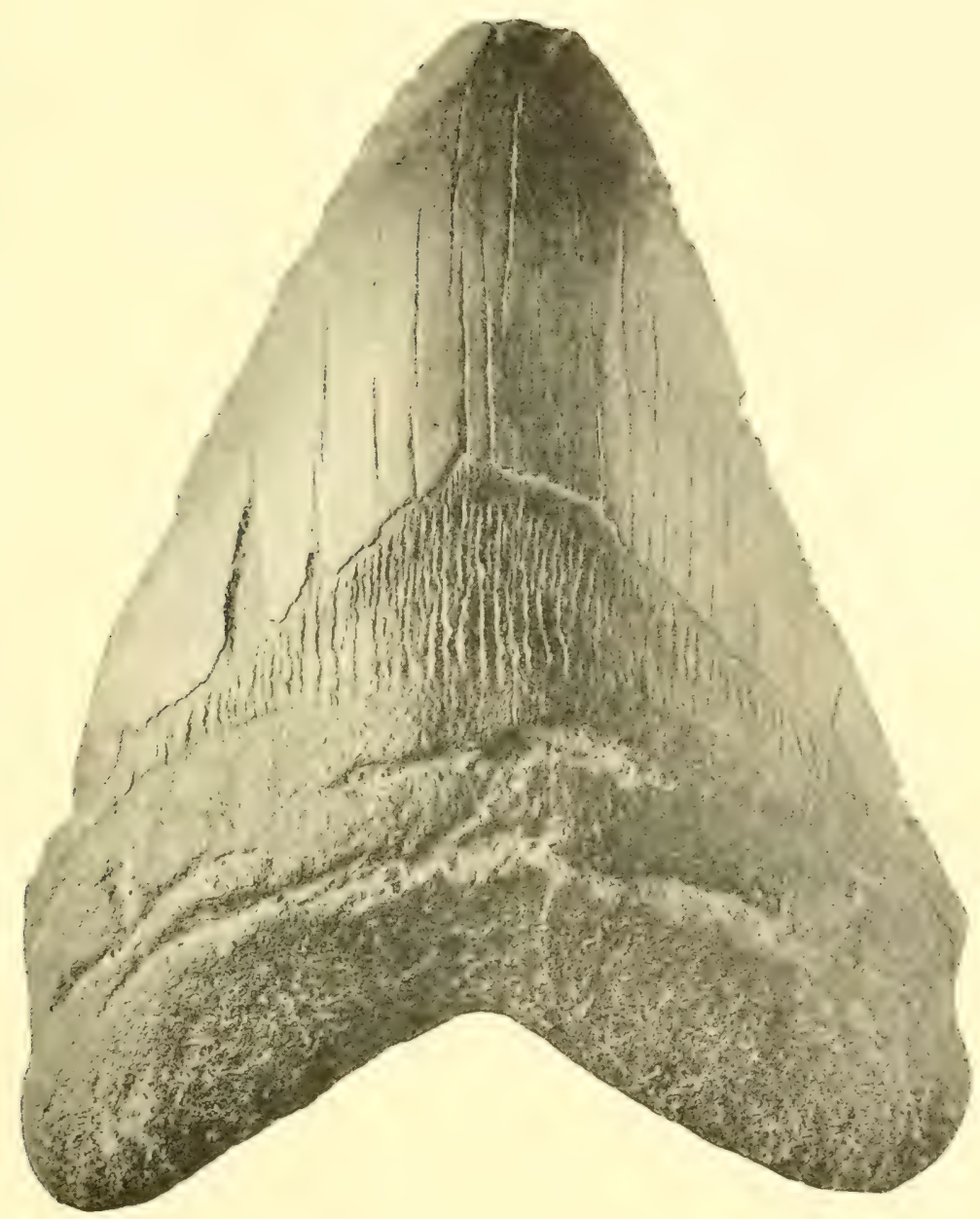

Fig. 127. Tooth of extinet Carcharodon. (Photograph natural size.) 
resulting from a single narrow papilla, of which several may fuse at the base into a simple triconodont tooth as in Chlamydoselachus (fig. 126A); or in the rays a most complex arrangement of large median and smaller lateral hexagonal plates as in Myliobatis (fig. 126B) may result in pavement or crushing teeth; or the plates may reach from side to side in an unbroken line as in detobatis. The teeth of Heterdontus (fig. 12s) are particularly interesting in that they represent both anterior prehensile and posterior crushing teeth. Furthermore, in the area between these two, transitional teeth are present

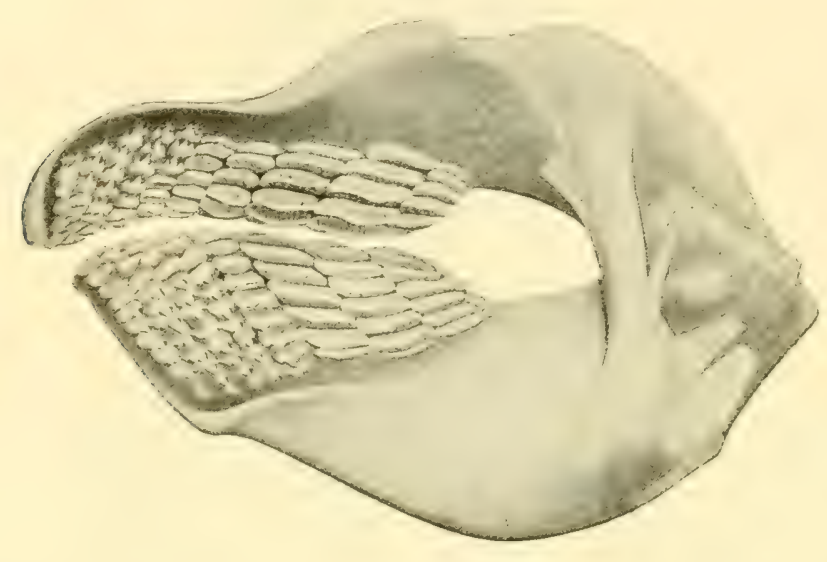

Fig. 128. Median view of teeth in jaws, Heterodontus francisci.

(Duncan Dunning, del.)

which have characteristies of both. The teeth in the sixth row from the front are flattened out and are provided with cusps essentially like the parement teeth of Mustelus henlei.

The finer structure of a tooth (fig. 129) is somewhat similar to that of a scale. In both there is an outside harder cap usually of structureless enamel (e.) over a heavier inside layer of dentine. The enamel in some teeth is of a coarse grain, closely resembling dentine and by some held to be identical with it. The dentine $(d$.$) is of the tubular type formed by the odontoblasts of the$ dentinal papilla. In the connective tissue cells at the base of the tooth vasodentine $(v d$.$) is formed, which is somewhat softer than dentine proper. In the$ adult Myliobatis the whole core of the tooth becomes filled with dentine as does the core in the tooth of the saw (Pristis), leaving only central canals from which run numerous dentinal canals (d.c.).

It is generally held that enamel results from the basal layer of the epidermis. with the exception that in Carcharias, according to Tomes (1898) it arises from a special amelioblastic layer formed by the corium. All agree that dentine is produced in and by the corium. Here the odontoblasts send out processes along which are deposited the lime salts which harden as dentine. The processes become surrounded and are retained within dentinal canals (d.c., fig. 129) which ramify throughout the dentine. In some forms the dentinal 
tubes end in enlarged islands continnous with the enamel (Galeus). In others the tubules penetrate far outward into the enamel and either divide into branches (Carcharias) or are lost as fine single tubules (Lamna).

\section{REPLACEMENT OF TEETH}

Teeth which have been injured or lost are replaced by new ones. To gain a notion of the provision made for repairing injury or loss it is only necessary to examine the mouth of a form like Carcharias, or Heterdontus (fig. 128). In
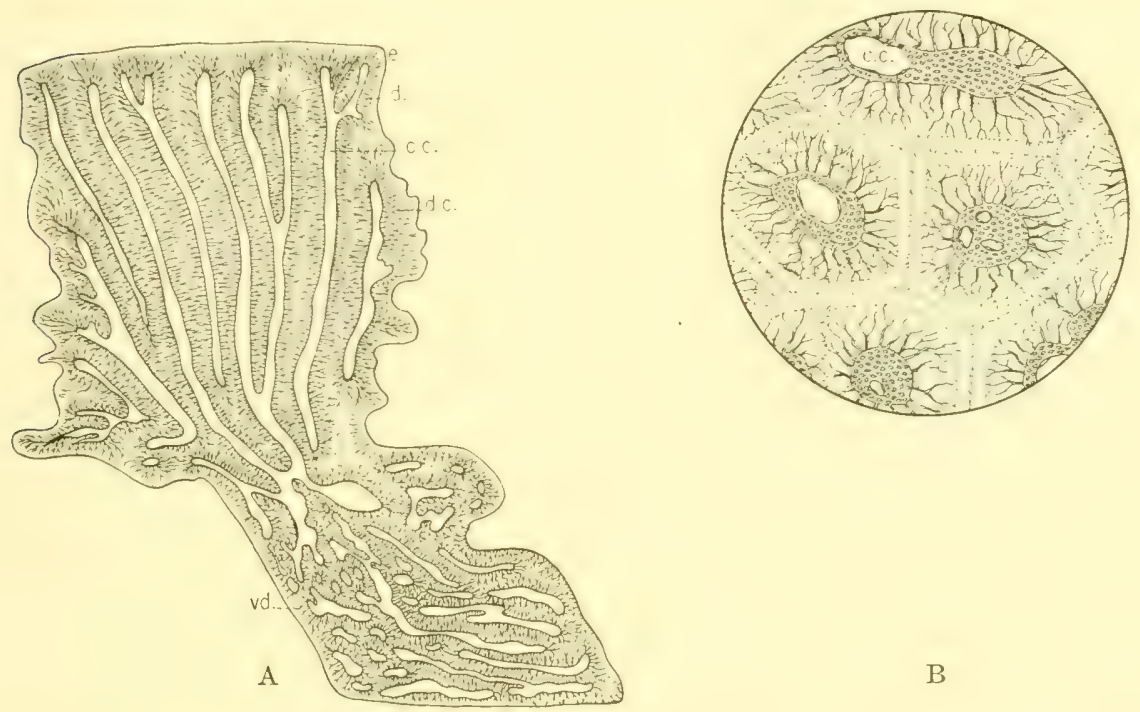

Fig. 129. Finer structure of a tooth, Myliobatis. (From Röse.) A. Sagittal section of whole tooth. B. Transverse section eutting a few eanals; highly magnified.

c.c., central canals; d., dentine; d.c., dentinal canals; e., enamel layer; vd., vasodentine.

these forms the teeth are arranged horizontally in crescentic rows, several of the outer rows functioning at the same time; upon injury or loss the outermost teeth are replaced by others which migrate outward over the jaw to take their places. It may thus happen that the teeth in several rows may be lost in encounter or in capture of food. In such an event, provision has been made for their replacement, for at the base of the innermost row are other deeply buried and less mature teeth ranging in development down to flabby tooth-buds.

\section{Pharynx}

The pharynx is that part of the tract which leads from the buccal cavity and which is characterized hy hranchial perforations or clefts opening through its walls. In addition to the spiracle seven such apertures perforate the pharynx in Heptanchus, six in Hexanchus and Chlamydoselachus, and five in pentanchid Elasmobranchs. In the adult the spiracle opens into the hyoidean pocket and is of small size. The remaining perforations are large but de- 
crease in size posteriorly. The lining of the pharynx is a continuation of that of the buccal cavity, being made up of a deeper layer of connective tissue and a superficial epithelium; in the latter are located the mucous cells. Special interest attaches to the pharyngeal region because of two structures associated with it, the thymus and the thyroid glands.

The thrmus gland is an embryonic structure appearing as a series of nodules connected into a chain above the gill pockets. We have seen that six such

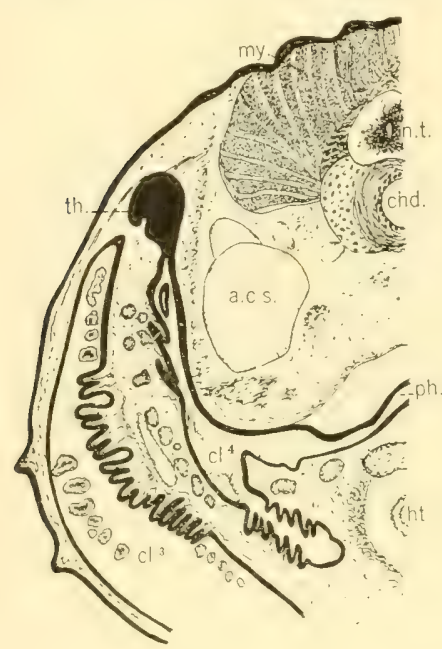

A.

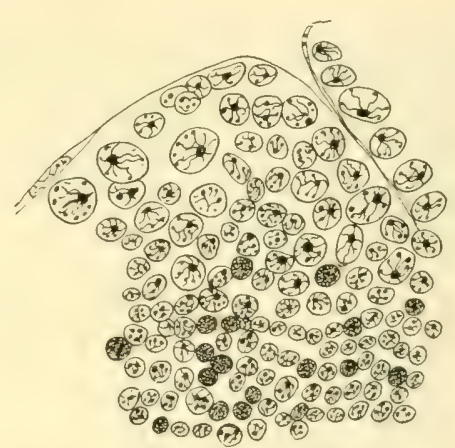

Is

Fig. 130. Developing thymus gland, Spinax. (From Fritsche.) A. Transverse section. B. Section of gland magnified.

a.c.s., anterior cardinal sinus; chd., notochord; $c l . .^{2-4}$, third and fourth clefts; ht., heart; my., myotome; n.t., neutral tube; ph., pharynx; th., thymus gland.

nodules may be present in Heptanchus. In Spinax, Acanthias, Mustelus, and Scyllium four of these, corresponding to the first four branchial clefts, are present, and, in the embryo of Spinax, transitional thymus buds have also been found over the spiracular and the fifth clefts. In the rays thus far studied a similar number is present lying back of the spiracle and between the gill pockets and the lateral line. Figure 22D gives a dorsal view of the embryo of Urolophus in which the nodules of the thymus are seen between the gill pockets and the lateral line canal.

In development the thymus arises as an anterodorsal thickening of the epithelium of the gill pouches ( $t h$., fig. 130A). These thickenings as we have said may represent the spiracular and the five branchial pockets in pentanchid Elasmobranchs, but the first and the last never pass the rudimentary stage.

Figure 122 of Heptanchus cinereus shows that each thymus nodule has the form of a bunch of grapes.

A highly magnified section through the thymus of spinax (fig. 130в) shows two types of cells, one outer and larger, and the other a more deeply located, small, round cell. Among them are to be found oceasional lymphocytes, and it has been questioned whether the smaller cells of the thymus are not trans- 
formed directly into lymphocytes. It is generally believed, however, that the function of the thymus, whatever it may be, is not that of a lymphoid organ (Fritsche, 1910).

T'hat the thymus possesses a duct in Heptanchus, as has been demonstrated

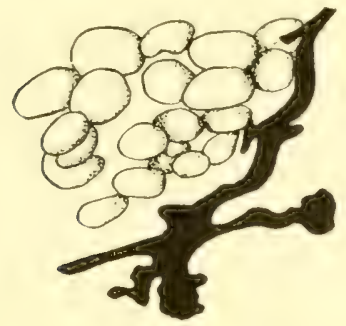

A

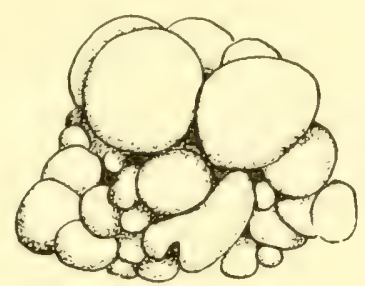

B

Fig. 131. Thyroid follicles making up the gland. (From Ferguson.) A. Carcharias littoralis. B. Raia erinacea.

by Van Wijhe, is an unusually interesting fact, although the significance of the duct has not yet been made out.

The thyroid" gland in the Elasmohranch fishes is a gelatinous mass of tissue surrounded by a connective tissue capsule. In the sharks it is located in the region behind or below the basihyal cartilage, between the coracomandibular and the coracohyoideus muscles. It may be crescentic in shone or it may be more or less irregular (Acanthias). Where the basihyal cartilage is broad it occupies its ventral side, resting in a depression (Acanthias, Mustelus) or in a deep groove (Carcharias littoralis). It occupies the space between the basihyoid and the bifureation of the ventral aorta. Where the eartilage is narrow as in Raia erinacea the thyroid may lie farther posterior on the terminal bifurcation of the ventral aorta.

Upon removal of the connective tissue capsule from the thyroid it is seen to be made up of groups of follicles of various forms. They may be small (Carcharias, fig. 131A; Mustelus; Squatina) or large (Raia, fig. 131B). A section through an individual follicle shows an outer wall of epithelium enclosing a mass of colloidal substance (Ferguson, 1911).

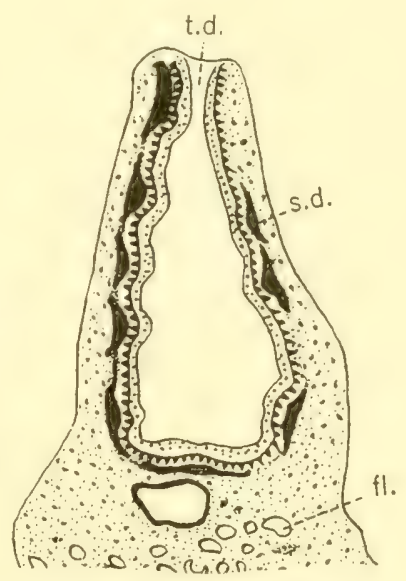

Fig. 132. Sagittal section through the thyroid gland of Chlamydoselachus anguineus. (From Groodey.)

fl., follicle; s.d., remnant of stomodeal denticle; t.d., thyroid duct.

The history of the thyroid in forms lower than the Elasmobranchs is of interest. In Amphioxus, the Ascidians, and Ammocoetes, there is present in the floor of the pharynx a median groove, the ciliated endostyle, the walls of which

2 Thyreoid. 
possess groups of cuneiform secreting cells. By the beating of the cilia, food caught in the mucous secretion is directed into the intestine.

Marine (1913) has shown for Ammocoetes of the brook lamprey that the groups of cumeiform secreting cells degenerate at the time of metamorphosis, and that the follicles of the thyroid gland arise from certain areas in the walls surrounding these columns.

In the embryo of the Elasmobranchs the thyroid arises similarly as an eragination of the pharyngeal floor, or as a solid block of cells in which a lumen may form (Acanthias). Either way, in development, it sinks deeper. While it may retain its connection with the pharynx practically until the period of birth, later than this all relation with the pharynx is usually lost and the thyroid becomes a "ductless gland."

Especially significant in this regard is the discovery by Gooder (1910) that in Chlamydoselachus the duct (t.d., fig. 132) retains its connection with the pharynx. In this form the aperture of the duct enters the pharynx, through a perforation in the basihyal cartilage, and is lined with the pharyngeal epithelium as is the endostyle of Amphioxus. Within this invaginated lining of Chlamydoselachus numerous seale-like structures are present, the remmants of stomodeal denticles $(s . d$.$) .$

\section{Oesophagus}

In most of the Elasmolranchs the segment of the digestive tract known as the oesophagus (oe., figs. 173 and 175) is short. In some forms it is easily distin-

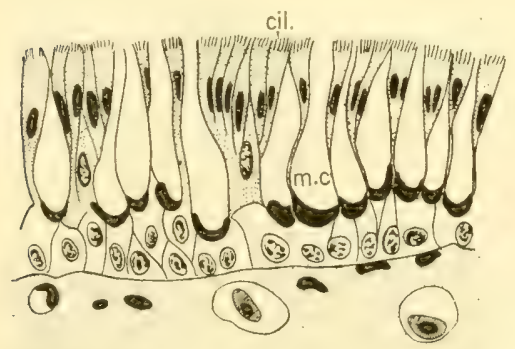

Fig. 133. A section through the lining of the oesophagus of Squatina (From Petersen.)

cil., long ciliated cell; m.c., mucous cell. guished from the stomach by its smaller size, but in others it is wide and passes almost imperceptibly over into the stomach. Denticles which may be present on the pharyngeal lining cease more or less abruptly at the beginning of the vesophagus. 'The mucous membrane lining the oesophagus may be covered with long. fingerlike papillae as in Acanthias, but usually it is thrown into numerous folds. Anteriorly these folds are low and regular; posteriorly they may run transversely marking a boundary between the oesophagus and the stomach. Anteriorly, too, the mucous membrane is similar to that of the pharynx, but posteriorly it consists mainly of ciliated and goblet cells.

A section of the membrane lining the oesophagus of Squatina, by Petersen (1908), shows the two main types of cells (fig. 133). One of these is of long ciliated cells (cil.), among which are scattered the mucous cells (mc.). The mucous cells are extremely large and vacuolated, and each has its nuclens well toward the basal end of the cell. 


\section{STOMACH}

The stomach of Elasmobranchs when seen in ventral view is a U-or J-shaped tube (for types see figs. 173 to $175, c . s$. and $p . s$. ), the left arm of which, as in Heptanchus, is the cardiac and the right arm the pyloric division. The great variety in shape of the stomach found among the Elasmohranchs is due largely to variation in the relative length of the pyloric arm. In some, although the pyloric division is small in diameter, in length it is practically equal to the cardiac (leopard shark, fig. $173 \mathrm{~A} ; \operatorname{Raja}$ ) ; in other's this arm is less than one-half the length of the cardiac, so that the shape of the stomach in these is better described as a J (Acanthias). In still others the pyloric limb is only a small projection from the cardiac division of the stomach (Scymmus lichia, fig. 135B; Laemargus rostratus, fig. 136B). In the latter there is a so-called "blind sac" $\left(s c^{2}\right)$ at the angle.

The mucous lining of the adult stomach is thrown into folds which, as we have said, may be continuous with those of the oesophagus. The folds on the walls of the cardiac division are high and may extend in part as the finer folds into the pyloric limb, but those of the two regions are usually distinet.

A section through the mucosa of the stomach of Squalus acanthias according to Ringoen (1919; fig. 134) shows a gland as long and flask-shaped. The superficial epithelial cells (ep.) are somewhat like those found in the oesophagus, that is, they are columnar or pyramidal cells, the upper part of which contains a plug of mucus $(p l$.). The cells lining the median part of the crypt are large and their nuclei are vertical in position. In the deeper crypts are the gastric cells that are peculiar to the

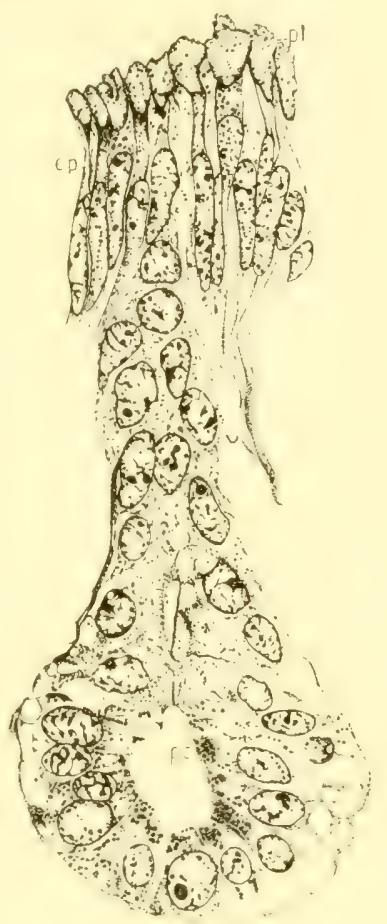

Fig. 134. Section through lining of the stomach, squalus acanthias. (From Ringoen.)

ep., epithelial cell ; pc., peptic cells; $p l$, mucous plug. cardiac stomach. They lie at the base of the crypts and are large and gramular and of a polygonal shape with their nuclei taking a more or less horizontal position. These are the true peptic cells $(p c$.), which secrete the digestive substances.

The function of gastric juice, which contains hydrochloric acid and a ferment, pepsin, is the digestion of protein matter. Such digestion takes place at a much lower temperature in the stomach of the shark than in the stomach of a higher animal. While, in the latter, digestion is carried on at body temperature $\left(37^{\circ} \mathrm{C}\right)$, in the former it takes place at $10^{\circ}$ to $15^{\circ} \mathrm{C}$, although the pepsin may also be active at as high as $40^{\circ} \mathrm{C}$. 
At the terminus of the pyloric division of the stomach is a circular band of muscle fiber, the pyloric valve, separating the pyloric stomach from the duodenum or middle intestine. This valve varies considerably in extent in different forms. In some types it shows only slight signs of constriction, as for example in Heterodontus, where it may allow food of considerable size to pass into the spiral intestine. In Heptanchus we have seen that it projects as a well defined circular band into the duodenum; and in Laemargus the valve is greatly extended.

In some of these forms an interesting condition obtains in which a room, the bursa entiana, may be formed and into which the pylorus may empty. This

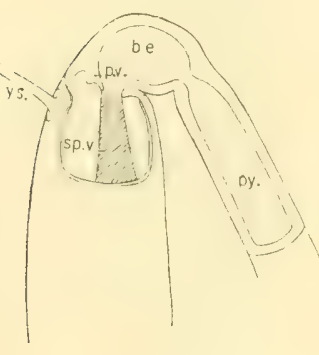

A

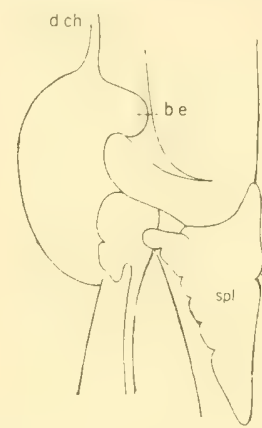

B

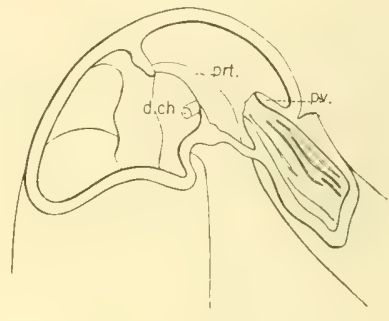

C

Fig. 135. Relation of the terminal part of the pylorus to the next segment, the duodenum. A. Galeus. (From Redeke.) B. Scymnus. (From Helbing.) C. Hypnos. (Australian torpedo.) (From Howes.)

b.e., bursa entiana; d.ch., bile duct; prt., intraintestinal partition; p.v., pyloric valve; py., pylorus; spl., spleen ; sp.v., spiral valve; y.s., yolk stalk.

occurs in Galeus (b.e., fig. 135A) and in Cetorhinus. In Scymnus (fig. 135B) such an enlargement is formed in a different way. Here the pylorus enters a special room the upper part of which is the bursa entiana, and the lower is continued into the intestine as a valve-free portion. In the Australian torpedo Hypnos (fig. 135c) there is an interesting modification of this plan. The enlarged room is separated into an anterior and a posterior chamber by an intraintestinal partition ( $p r t$.). Into the former the pylorus ( $p y_{0}$ ) empties and into the latter the ductus choledochus (d.ch.) enters.

\section{Duodenum or Middie INTEstine}

The duodenum may be encroached upon by the spiral valve through its entire course, as in Heptanchus, or it may be free as in a few of the sharks and rays. In a type like Spinax niger (fig. 136A) the valve-free portion is long. This segment is present in Rhinobatis, but, of all the rays, it is best developed in Trygon. In the great majority of types, however, the valve has so encroached upon the pylorus that no free portion exists (Galeus, fig. 135A, Carcharias, Lamnidae, Notidanidae, Scyllidae, Rhinidae, and some of the Rajidae).

The proximal part of the duodenum shows different stages of complexity. 'T'his may be illustrated by Spinax niger, where the pyloric tip is small and 
enters the duodenum in such a way as to form two miniature blind sacs $\left(s c{ }^{1-2}\right)$. In Laemargus rostratus (fig. 136B) the blind sac is divided so that the proximal part of the intestine appears as a bilobed strueture. Into one of the lobes the pylorus enter's.

The ducts from the liver (d.ch., fig. 137 B) and pancreas ( $p . d$. .) enter this middle or duodenal part of the intestine as in Heptanchus, and their entrance

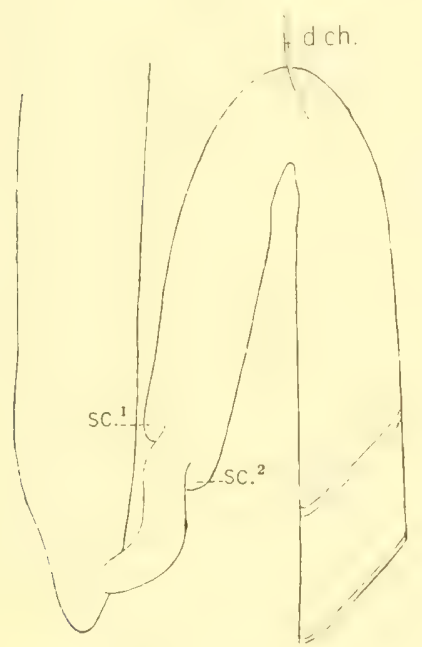

A

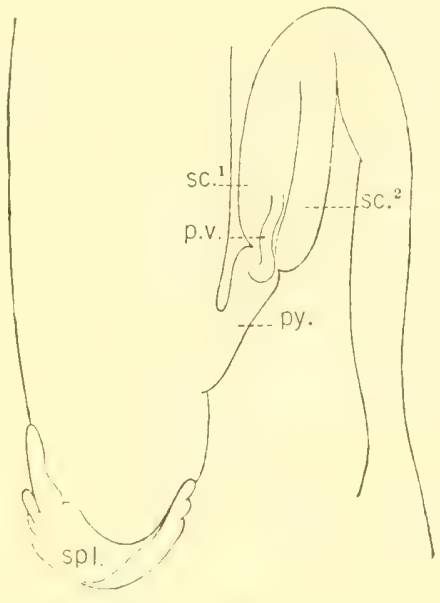

I3

Fig. 136. The duodenum. A. Spinax niger. (From Redeke.) B. Laemargus rostratus. (From Helbing.)

d.ch., bile duct; p.v., pyloric valve; py., pyloric stomach; sc. ${ }^{1-2}$, first and second blind saes; spl., spleen.

marks the region from which the liver and the pancreas arose in the embryo, the length of the ducts in the adult showing how far the two organs have become separated from their place of origin.

\section{LIVER}

The liver in the adult consists of a right and a left lobe, connected solidly anteriorly as in Heptanchus (see fig. 119). From the posterior part of the union of the two lobes a caudate lobe may arise. In this or in either of the other lobes the gall bladder may be located. The main lobes of the liver are characteristically large in the sharks and may extend the entire length of the coelom. In some of the larger sharks (Cetorhinus) as much as five barrels of oil are reported to have been obtained from the liver of a single specimen. In the rays the lobes are less well developed, but here, too, they are often large.

Bile secreted by the liver is collected by a series of tubules some of which empty into the gall bladder. The gall bladder is drained by a duct which, joined with other ducts from the liver, is the ductus choledochus. This duct in Squalus sucklii (d.ch., fig. 137B) reaches the intestine at its proximal part 
and on the dorsal side, but unlike that of Heptanchus it passes backward within the intestinal wall, making a half-loop before it empties into the ventral side of the duodenum. In its course it becomes thrown into a series of ridges much like the ridges in the seminal vesicles of some Elasmobranchs.

\section{PANCREAS}

The pancreas (fig. 137) in the adult consists of two lobes. One of them, the dorsal lobe $\left(m \mathrm{r}^{1}\right)$, runs parallel with and over the terminal part of the cardiac stomath and near its middle part sends a bridge over the pylorus to join the ventral lobe $\left(p n .^{2}\right)$ which is closely bound to the rentral surface of the proxi-

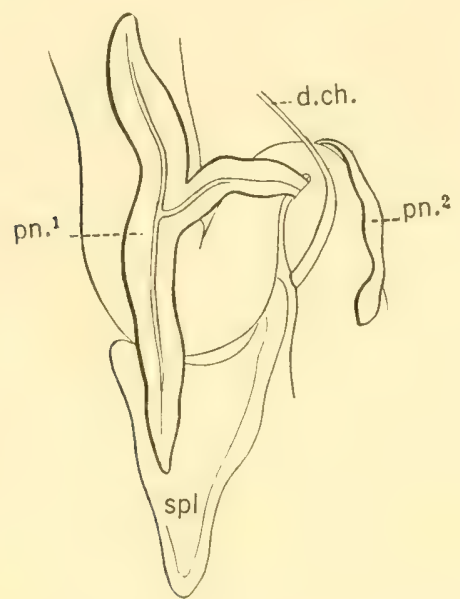

A

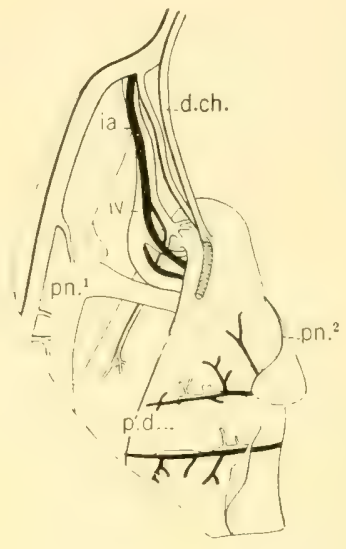

$\mathrm{B}$

Fig. 137. The pancreas and associated structures. A. Acanthias, dorsal view. (From Kantorowicz.) B. Squalus suchlii, dorsal view. (Chester Stock, orig.)

d.ch., bile duct or duetus choledochus from the liver; ia., intraintestinal artery; iv., intraintestinal vein; $p n .^{1}$, dorsal lobe of panereas; $p n_{.}{ }^{2}$, ventral lobe of panereas; $p . d$. pancreatic duct; spl., spleen.

mal part of the middle intestine. In all specimens which I have examined the pancreatic duct ( $p . d$., fig. 137B) empties into the duodenum much as was described for Heptanchus (p. 124).

\section{SPLEEN}

The spleen, although not comnected by ducts leading to the digestive tract, is located in the mesentery and may be regarded as an organ made up of cells specialized from the connective tissue of the mesentery. In sharks it is often triangular in shape and its characteristic position ( $s p l .$, fig. 137A) is on the greater curvature of the stomach, that is, on the outer angle between the cardiac and pyloric divisions. In the rays ( see p. 187, fig. 175, spl.) it is a lobular or round structure located in the angle of the lesser curvature of the stomach. In Heptanchus we have observed that the spleen takes a generalized form in which it extends along the outer angle of the stomach and across the 
mesentery into the lesser angle. In other words, in addition to the type of spleen on the outer angle characteristic of sharks, IIeptanchus also has splenic tissue on the inner angle of the stomach like that of the rays.

\section{VAlivular Intestine}

The valvular intestine receives its name from the fact that it contains within its lumen a membranous fold or valve. This fold as a general thing in the

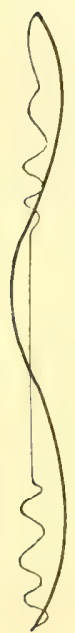

A

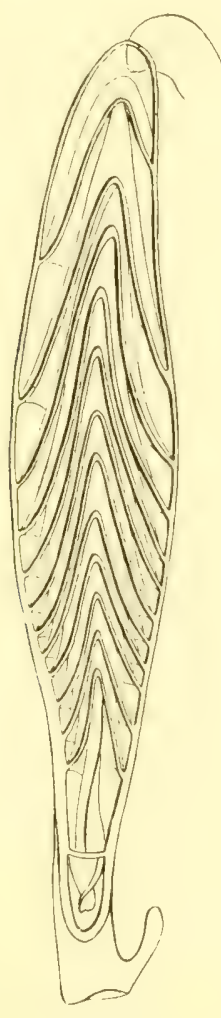

$\mathrm{B}$

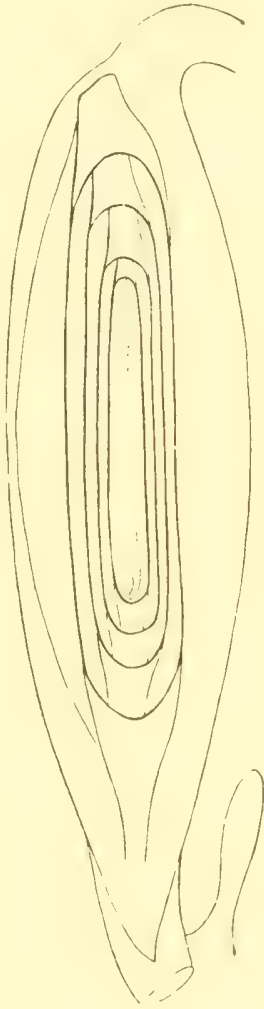

C

Fig. 138. Valvular intestine. (From T. J. Parker.) A. Attachment in Zygaena. B. Talve in Scyllium. C. Valve in Zygaena.

Elasmobranchs is spiral in nature, and produces a spiral valve. In a few forms. however (Zygaena), it is of the scroll type, with the line of attachment along the wall of the intestine only slightly curved (fig. 138 A). This valve in $Z y$ gaena (fig. 138c) is rolled up within the intestine and has a width two-thirds of its length.

Seen from the outside the spiral valve presents the aspect of a screw over the threads of which has been wrapped some thin suhstance through which the threads are evident superficially. But such a likeness would be correct only if the threads grew from and were a part of the outer covering. 
In development the valve first appears as a ridge or fold of the intestinal mucosa along the intestinal wall. Whether the increase in the width of the valve is due to the growth of the mucosa pulling the tissue within the folds as in Ammocoetes (Daniel, 1931), or to the growth of connective tissue which forces the mucosa downward as a cap, is not clear. The likelihood is that both of these processes take place. This fold in a young Zygaena hangs down as a simple longitudinal plate which, upon reaching the opposite side of the

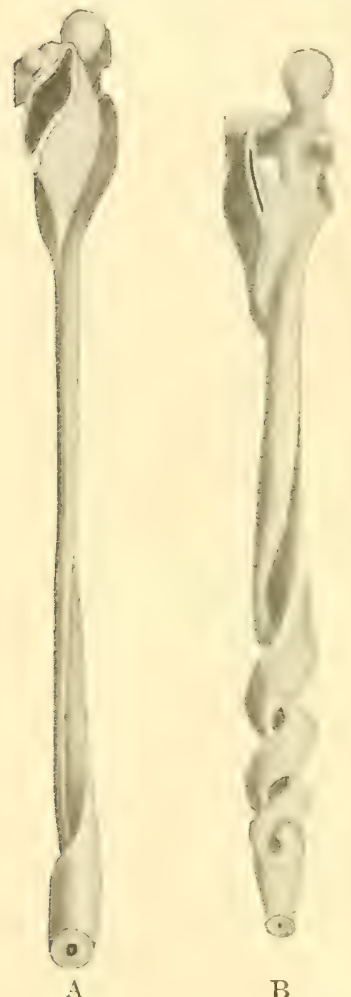

Fig. 139. Two stages A-B to show the development of the spiral valve, Pristiurus. (From riiickert.) lumen, rolls up into a scroll valve as would a sheet of paper similarly dropped down. In the spiral valve, however, another factor enter's. Here a torsion occurs in the lining of the intestine which throws the scroll into a spiral. Figure 139 from Rückert (1896) represents the mucosa of the intestine in the formation of the spiral. The turns in figure $139 \mathrm{~B}$ are more numerous in the posterior region, and the intestine in the older stage is seen to be relatively shorter.

The number of turns of the valve in the adult varies greatly among the Elasmobranchs. In fact. slight variation in the number within a single species is common. In some the number is as low as four (Prionace), or eight (Raja), or ten (Mustelus). In others it is increased but slightly (twelve in Heterodontus). In some, however, great numbers are present, twenty in Lamna and forty-five in Alopias.

In width the valve in the adult may approach or extend beyond the middle of the lumen (Heptanchus). When it is less than one-half the width of the intestine there appears in end view a canal which would represent the core of the screw. If it exceeds one-half the diameter of the intestine the free edge representing the core of the screw rolls up so as to appear from side view as a series of concentric cones pointing anteriorly or posteriorly

(Scyllium, fig. 138B). In some forms the valve anteriorly may thus be thrown into cones, while posteriorly the free edge does not reach the middle line. Hence an end view from the posterior would present a central lumen (Raja, fig. 140).

The lining of the valvular intestine from the duodenum to the end of the spiral valve consists of cylindrical and goblet cells (Carcharias, Mustelus) and is thrown into multitudes of tiny points or villi (fig. 140). From the type of lining it is apparent that the function of the spiral valve, in addition to prerenting the too rapid passage of food, is the absorption of digested substances. 


\section{Colon and Rectum}

The segments of the intestine succeeding the valvular intestine, the colon and the rectum, usually differ in their lining from the valvular intestine in the absence of villi. Separating these two areas and emptying into the dorsal side of the digestive tract is the rectal gland.

The rectal or digitiform gland varies in size from a tiny structure one-half an inch long, as in some of the rays, to one three or four inches long in some of the larger sharks. It is a compound, tubular structure, the secreting cells of which are surrounded by a strong, fibromuscular layer. These cells empty their secretion through tubules into a median lumen which, as we have seen in Heptanchus, enter's the intestine between the colon and the rectum. In some of the rays the lumen is large, that part at which it enters the intestine being especially expanded (Raja, fig. 141B). In most of the sharks, however, the gland is constricted at its base, and its lumen is small. As a general thing the lumen is prolonged forward so that the entrance to the intestine is anterior to the position of the gland (Zygaena, fig. $141 \mathrm{~A}$ ). Although the rectal gland has been studied in a great number of forms, its function has not yet been made out.

\section{CLOACA}

The cloaca is the common receptacle into which the digestive tract and the urinary and genital systems empty. It is generally an enlarged room, the walls of which are more or less loosely folded. In some types, transverse crescentic folds from the dorsal wall of the cloaca separate it into an anterior and a posterior division on each side. In the anterior division two types of structure may be

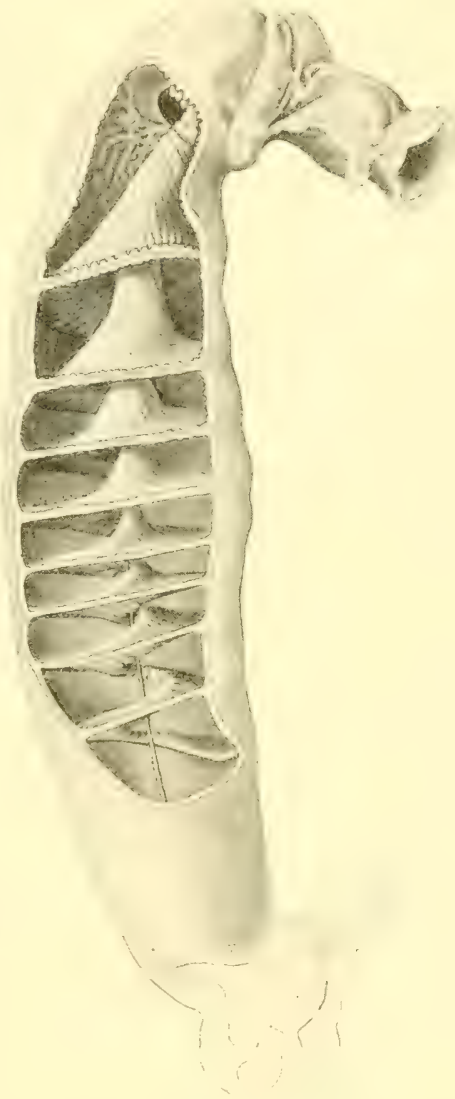

Fig. 140. Valvular intestine of Raja. (From Paul Mayer.) found. One of these is a pair of finger-like papillae (see fig. 252, p., facing p. 290); the other is a pair of cloacal pits. The papillae, when present, usually contain prolongations of the lining of the body cavity. The cloacal pits are often located lateral and posterior to the papillae. In some forms both the pits and the papillae are present. In connection with the pits or with the papillae may oceur apertures, the abdominal pores, which put the abdominal cavity into connection with the outside. 


\section{ABDOMINAL PORES}

The abdominal pores in the Elasmobranchs may perforate the tips of the papillae or, as was just said, they may pass through the cloacal pits. Some of the types having perforated papillae are Triakis semifasciatus, Carcharias glaucus, Zygaena, Mustelus. In some the papillae are imperforate (Squatina). The slit-like type of abdominal pores is in connection, not with the papillae, but with the cloacal pits. This type is especially common among the rays.

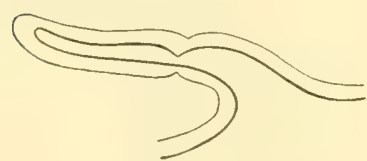

A

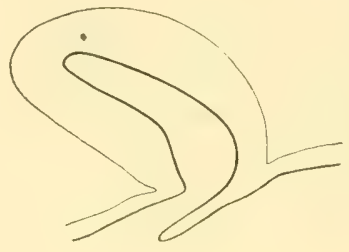

B

Fig. 141. Sections through rectal gland. (From Howes.) A. Zygaena. B. Raja.

The abdominal pores vary so greatly in different species and in fact in different individuals of the same species as to suggest that they are vestigial structures. In the Cyclostome fishes they function as apertures through which the sex cells leave the body; but in the Elasmobranchs, if the pores have ever been thus used, this function has been lost upon the appropriation of special channels formed for the passage of the sex cells. It hence becomes a question whether or not in the Elasmobranchs the openings subserve any particular function at the present time. 


\section{BIBLIOGRAPHY}

\section{Chapter V}

1919. Allis, E.P., The Lips and the Nasal Apertures in the Gnathostome Fishes. Jour. Morph., Vol. 32, pp. 145-205, pls. 1-4.

1892. AntrPA, GR., Ueber die Beziehungen der Thymus zu den sog. Kiemenspaltenorganen bei Selachiern. Anat. Anz., Bd. 7, pp. 690-692, 1 text fig.

1888. Beard, J., The Old Mouth and the New. A Study in Vertebrate Morphology. Anat. Anz., Bd. 3, pp. 15-24.

1900. BEARD, J., A Thymus-Element of the Spiracle in Raja. Anat. Anz., Bd. 18, pp. 359-363.

1900. BEARD, J., The Source of Leucocytes and the True Function of the Thymus. Anat. Anz., Bd. 18, pp. 550-573.

1902. BEARD, J., The Origin and Histogenesis of the Thymus in Raja batis. Zool. Jahrb. (Anat. u. Ontog.), Bd. 17, pp. 403-480, pls. 5-10, 8 text figs.

1878. BlanchaRd, RAPHAËL, Recherches sur la structure et le développement de la glande superanale (digitiforme) des poissons cartilagineux. Jour. de l'Anat. et Physiol., T. 14, pp. 442-450.

1882. BLANCHARD, RAPHAËL, Sur les fonctions de la glande digitiforme ou superanale des Plagiostomes. C. R. Acad. Sci. Paris, T. 95, pp. 1005-1007. Also: Bull. Soc. Zool. Paris, T. 7, pp. 399-401.

1897. Bles, EDWARD J., On the Openings in the Wall of the Body-Cavity of Vertebrates. Proc. Roy. Soc. Lond., Vol. 62, pp. 232-247.

1898. BLES, ED. J., The Correlated Distribution of Abdominal Pores and Nephrostomes in Fishes. Jour. Anat. and Physiol., Vol. 32, pp. 484-512, 6 text figs.

1907. Bottazzi, Filippo, Grassi e glucogeno nel fegato dei Selacii. Accad. dei Lincei, Roma (5), Vol. 16, Sem. 2, pp. 514-517.

1896. Brachet, A., Recherches sur le développement du paneréas et du foie. (Sélaciens, Reptiles, Mammifères). Jour. de l'Anat. et Physiol., T. 32, pp. 620-700, pls. 18-20.

1879. Bridgf, T. Wrr., Pori Abdominales of Vertebrata. Jour. Anat. and Physiol., Vol. 14, pp. 81-100, 7 text figs.

1887. Catraneo, G., Note d'istologia comparata. I. Ulteriori ricerche sulla struttura delle glandule peptiche dei Selaci, Ganoidi e Teleostei. II. Sul significato fisiologico delle glandule da me trovate nello stomaco delle Storione e sul valore morfologico delle loro cellule. Boll. Scientifico, Nos. 3 and 4, 16 pp., Pavia.

1903. CAvalié, M., La vésicule biliaire et sa circulation artérielle chez Torpedo galvani, chez Galeus canis, et chez Scyllium eatulus. Soc. Sei. d'Areachon Stat. Biol., T. 7, pp. 23-28, 5 text figs.

1899. Crawford, J., On the Rectal Gland of the Elasmobranchs. Proc. Roy. Soc. Edinburgh, Vol. 23, pp. 55-61, pl. 1.

1931. Dantel, J. Frank, Features in the Development of Ammocoetes. Univ. Calif. Publ. Zool., Vol. 37, pp.41-52, 5 text figs.

1886. Dohrn, A., Studien zur Urgeschichte des Wirbelthierkörpers. XII. Thyreoidea und Hypobranchialrinne, Spritzlochsack und Pseudobranchialrinne bei Fischen, Ammocoetes und Tunicaten. Mitt. Zool. Stat. Neapel, Bd. 7, pp. 301-337, Taf. 4-5.

1905. Drzewina, AnNa, Contribution à l'étude du tissu lymphöide des Ichthyopsidés. Areh. de Zool. expér. et gén., Sér. 4, T. 3, pp. 145-338, pl. 7, 9 text figs.

1906. Drzewrna, AnNA, Sur les hyperplasies tissulaires à l'ablation de la rate des Ichthyopsidés. Bull. de la Soc. des Sciences de Krakovie. 
1835. Eschrichi, D. F., and MÜLLer, Ueber die Wundernetze am Darmkanal des Squalus rulpes L. Abh. Akad. Wiss. Berlin, pp. 325-328.

- 1911. Ferguson, J. S., The Anatomy of the Thyroid Gland of Elasmobranehs, with remarks upon the Hypobranchial Circulation in these Fishes. Amer. Jour. Anat., Vol. 11, pp. 151-210, 20 text figs.

1909. Fritsche, E., Die Entwicklung der Thymus bei Spinax niger. Zool. Anz., Bd. 35, pp. 85-93, 6 text figs.

1910. FrITsche, E., Die Entwicklung der Thymus bei Selachiern. Jena. Zeitsehr. Naturwiss., Bd. 46 (N. F. 39), pp. 77-112, 18 text figs.

1885. Gegenbaur, C., Bemerkungen über die Abdominalporen der Fische. Morph. Jahrb., Bd. 10, pp. 462-464.

1892. Gegenbaur, C., Über Cöcalanhänge am Mitteldarm der Selachier. Morph. Jahrb., Bd. 18, pp. 180-184, 1 text fig.

1894. Gegenbaur, C., Zur Phylogenese der Zunge. Morph. Jahrb., Bd. 21, pp. 1-18, 5 text figs.

1909. Goodall, J. S., and EARLE, H. G., The Structure of the Pancreas in Relation to Funetion. Brit. Med. Jour., 1909, Pt. 2, pp. 681-684, 4 text figs.

1910. Goodex, T., Vestiges of the Thyroid in Chlamydoselachus anguineus, Scyllium catulus, and Scyllium canicula. Anat. Anz., Bd. 36, pp. 104-108, 4 text figs.

1893. Hansarar, J.A., Einige Plattenmodelle zur Beleuchtung der früheren embryonalen Leberentwickelung. Arch. f. Anat. u. Entwick., 1893, pp. 121-156, pls. 11-12.

1911. Hammar, J. A., Zur Kenntnis der Elasmobranchier-Thymus. Zool. Jahrb. (Abt. Anat.), Bd. 32, pp. 135-180, pls. 9-11, 6 text figs.

1907. HAwkes, Mrs. O. A. M., On the Abdominal Viscera and a Vestigial Seventh Branchial Arch in Chlamydoselachus. Proc. Zool. Soc. Lond., 1907, Pt. 2, pp. 471-478, 2 text figs.

1903. Helbing, Hermann, Ueber den Darm einiger Selachier. Anat. Anz., Bd. 22, pp. 400407, 3 text figs.

1900. HochsteTter, F., Ưber die Entstehung der Scheidewand zwischen Pericardial- und Peritonealhöhle und über die Bildung des Canalis pericardiaco-peritonealis bei Embryonen von Acanthias vulgaris. Morph. Jahrb., Bd. 29, pp. 141-168, Taf. 7, 12 text figs.

1897. Holm, J. F., Ueber den feinern Bau der Leber bei den niedern Wirbelthieren. Zool. Jahrb., Bd. 10 (Abt. Anat. u. Ontog.), pp. 277-286, pls. 24-25.

1917. Hoskins, E. R., On the Development of the Digitiform Gland and the Postvalvular Segment of the Intestine in Squalus acanthias. Jour. Morph., Vol. 28, pp. 329-368.

1890. Howes, G. B., On the Visceral Anatomy of the Australian Torpedo (Hypnos subnigrum), with especial reference to the Suspension of the Vertebrate Alimentary Canal. Proc. Zool. Soc. Lond., 1890, pp. 669-675, pl. 57.

1890. Howes, G. B., On the Intestinal Canal of the Iehthyopsida, with especial reference to its Arterial Supply and the Appendix Digitiformis. Jour. Linn. Soc. Lond. (Zool.), Vol. 23, pp. 381-410, pls. 1-2.

1897. Kantorowicz, R., Ueber den Bau und Entwicklung des Spiraldarms bei Selachier. Zeitschr. Naturw., Halle, Bd. 70, pp. 337-364, Taf. 4, 3 text figs.

1907. Kolster, R., Über die Magenschleimhaut von Centrophorus granulosus. Anat. Hefte, Bd. 33, pp. 491-511, Taf. 35-39, 15 text figs.

1878. Krukenburg, C. F. W., Versuche zur vergleichenden Physiologie der Verdauung mit besonderer Berücksichtigung der Verhältnisse bei den Fischen. Untersuchungen d. physiol. Inst. der Universität Heidelberg, Bd. 1, pp. 327-340, Taf. 2.

1890. Laguesse, E., Recherches sur le développement de la rate chez les poissons. Jour. de l'Anat., Paris, Vol. 26. Deuxième partie, Rate des Sélaciens, pp. 425-495, pls. 12-13, 4 text figs. 
1894. Laguesse, E., La Rate, est-elle dorigine entodermique ou mésodermique? Bibliog. Anatomique, 1894 , T. 2, pp. 22-27, 6 text figs.

1894. Laguesse, E., Développement du pancréas chez les Sélaciens. Bibliog. Anatomique, T. 2, pp. 101-109, 4 text figs.

1903. LAguesse, E., Sur l'histogénèse de la fibre collagène et de la substance fondamentale dans la capsule de la rate chez les Sélaciens. Arch. d'Anat. mier., T. 6, pp. 99-169, pl. 5, 16 text figs.

1903. LAguesse, E., Sur la structure de la capsule de la rate chez l'A canthias. O. R. Soc. Biol. Paris, T. 55, pp. 1107-1108.

1913. MARINE, DAVID, The Metamorphosis of the Endostyle [Thyroid gland of Ammocoetes branchialis, Larval Land-locked Pertomyzon marinus (Jordan) or P. dorsalis (Wilder) ]. Jour. Exp. Med., Vol. 17, pp. 379-395, pls. 66-70.

1897. MAYer, Paul, Úber den Spiraldarm der Selachier. Mitt. Zool. Stat. Neapel, Bd. 12, pp. 749-754, Taf. 33.

1897. MAYr, Jos., Über die Entwickelung des Pankreas bei Selachiern. Anat. Hefte, Bd. 8, pp. 75-151, pls. 11-18.

1886. Meuron, P. DE, Recherches sur le développement du Thymus et de la glande thyroïde. Ree. zool. Suisse, Vol. 3, pp. 517-628, pls. 23-27, 1 text fig.

1867. Mrklucho-Maclax, N. von, Ueber ein Schwimmblasenrudiment bei Selachiern. Jena. Zeitschr. Naturwiss., Bd. 3, pp. 448-453, Taf. 10.

1898. Neuvilue, H., A propos des termes par lesquels on désigne les formes diverses de la rate des Sélaciens. Bull. Mus. Hist. Nat. Paris, 1898, pp. 201-202.

1918. Norris, E. H., The Morphogenesis of the Thyroid Gland in Squalus acanthias. Jour. Morph., Vol. 31, pp. 187-223, pls. 1-2, 16 text figs.

1898. OppeL, A., III. Verdauungs-Apparat; Mundhöhle mit Zunge; Speicheldrüsen; Schlund; Magen; Darm; Brunnersche Drïsen; Bauchspeicheldrüse; Leber. Ergebn. d. Anat. u. Entwick., Bd. 8, pp. 124-190.

1880. Parker, T. J., On the Intestinal Spiral Valve in the Genus Raia. Trans. Zool. Soe. Lond., Vol. 11, pp. 49-61, pls. 10-11.

1908. Petersen, Hans, Beiträge zur Kenntnis des Baues und der Entwickelung des Selachierdarmes. Teil I. Oesophagus. Jena. Zeitschr. Naturwiss., Bd. 43, pp. 619-652, pls. 20-22, 4 text figs.

1909. Petersen, Hans, Beiträge zur Kenntnis des Baues und der Entwickelung des Selachierdarmes. Teil II: Magen- und Spiraldarm. Jena. Zeitsehr. Naturwiss., Bd. 44, Hefte 1, pp. 123-148, pls. 4-6, 18 text figs. Also: Diss. Jena, 1908, pp. 1-28, 18 text figs.

1885. Phisalix, C., Recherches sur l'anatomie et la physiologie de la rate chez les Iehthyopsidés. Arch de Zool. expér. et gén., Sér. 2, T. 3, pp. 369-464, pls. 18-22.

1890. Pilliet, A., Recherches sur la structure du foie des Sélaciens. C. R. Soc. Biol. Paris, T. 42 (or Sér. 9, T. 2), pp. 690-694.

1900. Redeke, H. C., Die sogenannte Bursa Entiana der Selachier. Anat. Anz., Bd. 17, pp. $146-159,3$ text figs.

1900. REDEKE, H. C., Aanteekeningen over den bouw van het maagdarmslijmvlies der Selachier. Tijdschr. Nederland, Dierk. Ver., Leiden, Ser. 2, Deel 6, pp. 284-303, pl. 12.

1878. Richet, Ch., Sur l'acide du sue gastrique (Lophia, Seyllium et Raja). C. R. Acad. Sei. Paris, T. 86, pp. 676-679.

1919. Ringoen, A. R., The Development of the Gastric Glands in Squalus acanthias. Jour. Morph., Vol. 32, pp. 351-377, 1 text fig., 3 pls.

1896. RückeRT, J., Ueber die Entwickelung des Spiraldarmes bei Selachiern. Areh. f. Entwickelungsmeeh., Bd. 4, 1897, pp. 298-326, pl. 15, 1 text fig. 
1896. RÜCKERT, J., Ueber die Spiraldarmentwiekelung von Pristiurus. Anat. Anz., Bd. 12 (Verh. Berlin), pp. 145-148.

1888. SANFELICE, F., Intorno all' appendice digitiforme (glandola sopranale) dei Selaci. Boll. Soc. Nat. Napoli, Vol. 3, pp. 1-23, pls. 1-3.

1889. SANFétCE, F., Sur l'appendice digitiforme (glande suranale) des Sélaciens. (Résumé.) Arch. Ital. Biol., T. 12, pp. 222-223.

1899. Sellier, J., Recherches sur la digestion des poissons. Soc. Sci. d'Arcachon. Stat. Zool. (Trar. d. labor. 1899), Ann. 4, pp. 93-102.

1902. Sellier, J., De l'action favorisante du sue intestinal sur la digestion paneréatie des matières albuminoides chez les poissons cartilagineux. C. R. Soc. Biol. Paris, T. 54, pp. 1405-1407.

1911. Slyke, D. D. VAN, and White, G. F., Digestion of Protein in the Stomach and Intestine of the Dogfish. Jour. Biol. Chem., Vol. 9, pp. 209-217.

1907. Sullivan, M. X., The Physiology of the Digestive Traet of Elasmobranchs. Bull. Bur. Fish., Vol. 27, pp. 1-27. Also: Brown Univ. Contrib., Vol. 6, No. 87, pp. 1-27, pl. 1.

1873. Turner, Professor War, A Contribution to the Visceral Anatomy of the Greenland Shark (Laemargus borealis). Jour. Anat. and Physiol., Vol. 7, pp. 233-250, 3 text figs.

1879. T'urner, WM., On the Pori Abdominales in Some Sharks. Jour. Anat. and Physiol., Vol. 14, pp. 101-102.

1907. VinCENT, S., and Thompson, Florence D., The Islets of Langerhans in the Elasmobranch Fishes (Prelim. Comm.), Jour. Physiol, London, Vol. 35, pp. xlv-xlvi.

1901. Weinland, Ernst, Zur Magenverdauung der Haifische. Zeitschr. f. Biol., Bd. 41 (N. F., Bd. 23), Hft. 1, pp. 35-68, Taf. 1, Hft. 2, pp. 275-294.

1895. Yung, ÉmாE, Sur les phénomènes de la digestion chez les Squales. Arch. des Sci. phys. et nat., T. 34, pp. 464-468.

1898. Yung, Fmile, De la digestion gastrique chez les Squales. C. R. Acad. Sci. Paris, T. 126, pp. 1885-1887.

1898. Yung, Émlle, Sur les fonctions du paneréas chez les Squales. C. R. Acad. Sci. Paris, T. 127, pp. 77-78.

1899. YUnG, ÊmuE, Recherches sur la digestion des poissons. (Histologie et physiologie de l'intestin.) Arch. de Zool. expér. et gén., Sér. 3, T. 7, pp. 121-201, pl. 9. 


\section{RESPIRATORY TRACT}

\section{RESPIRATORY TRACT OF HEPTANCHUS MACULATUS}

Heptanchus is characterized by having the greatest number of gill clefts or external branchial apertures of any known Elasmobranch. In fact it is from the number of clefts, as we have said, that it has received its name. These perforations in Heptanchus are lateral in position and lie between the cranium and the pectoral fin. The first branchial cleft, not the spiracle, is the largest of the series, while the one farthest from the cranium is the smallest. By opening one of the clefts both dorsally and ventrally we may study the structures of the gill pouch or pocket.

\section{Gill Pouch or Pocket}

If the second gill pocket of Heptanchus (fig. 142, facing p. 148) be opened as suggested above, the cavity is seen to be shaped somewhat like a funnel flattened from side to side, with the apex pointing inward and opening into the pharynx as the internal branchial aperture. The internal branchial aperture of the second pocket is supported by the first branchial areh anteriorly and by the second branchial arch posteriorly. On the margin of the first arch, and pointing backward, are one or two low projections which resemble incipient gill rakers. On the anterior branchial arch are also numerous elevations, the bases of the cartilaginous branchial rays $\left(6 . r^{*}\right)$, which support the gill septum. The tips of these cartilages are visible on the posterior surfaces. The walls of the pocket, both anteriorly and posteriorly, are covered with numerous radiating gill filaments or folds $(f t$. ), the effective organs of respiration.

The remaining pockets, excepting the seventh, are essentially similar to the first. The seventh external branchial cleft has the same fumel-shaped arrangement with its smaller apex connecting with the pharynx. On its anterior wall filaments similarly appear although these are fewer in number than in the preceding pockets. The posterior wall, however, is perfectly smooth, all semblance of gill filaments being entirely wanting.

\section{SPIRACLE}

The spiracular pocket upon being opened is found to be similar to the last pocket, that is, it bears filaments only on the anterior wall. But it differs from the others in the reduction in size of both its external and intermal apertures and in the reduction in the number of its filaments.

The spiracle in Heptanchus is not a straight tube, but as Ridewood (1896) says, it bears diverticula on its walls. The most important of these diverticula 
is located dorsally and extends inward until it meets and joins the cartilage of the auditory capsule. A second smaller diverticulum also extends dorsally from the spiracular walls near their union with the pharynx.

\section{Gill or Holobranch}

A holobranch consists of the tissue between two gill pockets; for example, the tissue hetween the second and third pockets constitutes the second gill or holohranch. This second holohranch hence includes all filaments on the posterior wall of the second pocket, and those on the anterior wall of the third gill pocket, as well as the supporting structures between the two. The filaments on the anterior and posterior sides of a whole gill are also designated as the anterior and posterior demibranchs. Thus the filaments on the posterior side of the second pocket form the anterior demibranch of the second gill, and the filaments on the anterior side of the third pocket constitute the posterior demibranch of the second gill.

With this understanding of a gill there are thus present in Heptanchus six whole gills, located between pockets $1-2,2-3,3-4,4-5,5-6,6-7$. In addition there is present on the anterior wall of the first pocket a half-gill, the hyoidean demibranch. It is often more convenient to consider the number of demibranchs rather than the number of holohranchs. Thus there are present in addition to the first mpaired hyoidean demibranch, a second and third, a fourth and fifth, a sixth and seventh, an eighth and ninth, a tenth and eleventh, and a twelfth and thirteenth branchial demibranch, these pairs representing the first, second, third, fourth, fifth, and sixth gills or holobranchs, respectively.

The gill filaments of the adult differ from certain external filaments present in the embryo. The external filaments of the embryo arise from the tissue on the posterior part of the hyoidean and branchial arches, and in Heptanchus are of particular interest because of their great numbers, a mark of a generalized condition. Those filaments arising on the hyoid in Heptanchus cinereus, according to Braus (1906), consist of 14 filaments; those from the first branchial opening, 39 ; from the second to the fifth. 29 each; from the sixth, 26 , and from the last, 18.

\section{Gill Supports}

The arches supporting the gills of the adult (see fig. 48, facing p. 44, and fig. 49, p. 45) are the hyoidean and all the branchial arches except the last. From epi- and ceratobranchial segments of all the visceral arches, except the mandibular and the last branchial, cartilaginous branchial rays (b.r.) extend outward toward the integument. The branchial rays on the hyoidean arch (fig.48) are often branched and complex, but on the other visceral (branchial) arches they are simple unbranched rods. In the latter they are separated from the gill filaments anteriorly by the interbranchial musculature and extend as supports beyond the ends of the filaments.

The septum of each holobranch, or wall between two sets of filaments, ex- 


tends from the visceral skeleton outward and is attached to the integument; it is further secured in its outer margin by the dorsal and ventral extrabranchial cartilages, where such exist. These extrabranchials (see p. 45, fig. 49, $e x . b$.$) extend around the margin of the septum ronghly at right angles to the$ branchial rays. At their dorsal and most ventral angles the extrabranchials pass posteriorly across the pockets so that in the opened pocket their transected ends show on both sides of the incision $(e x, b$., fig. $142)$.

\section{Gill Fillaments}

The respiratory membrane is formed of the series of folds or filaments ( $f$. $)$ attached to the anterior and posterior sides of the septum of each whole gill. Anteriorly these folds compose the respiratory surface of the anterior demihranch; posteriorly, that of the posterior demihranch. The filaments of the posterior demibranch in Heptanchus maculatus extend considerably farther distally on the septum than do those of the anterior set, but they also arise farther out from the base. In both they consist of a series of plates flattened from side to side. The longest of these plates is located medially and from this point they get shorter and shorter until at both the dorsal and ventral angles of the pocket they are relatively minute. Above and below the epi- and ceratobranchial segments filaments are absent.

A section taken at right angles to the internal branchial arch and eutting through the epibranchial segment, parallel with an

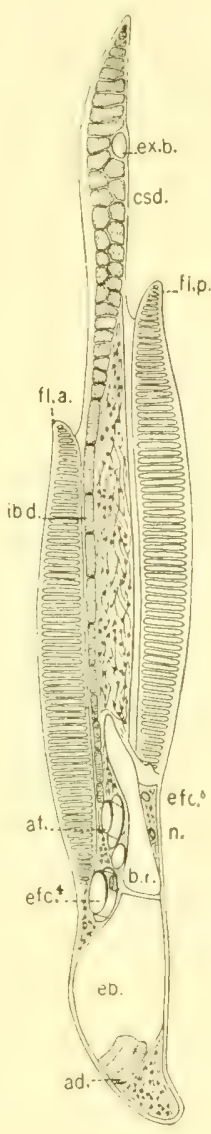

Fig. 143. Section cutting parallel to branchial filaments througl second holobranch, Heptanchus maculatus. (H. M. Gilkey, (leI.)

ad., adductor muscle; af.,third afferent artery; b.r., liranchial ray eut short: csd., fourth dorsal constrictor muscle; eb., epibranchial segment of internal branchial arch; cf $c^{4-5}$, fourth and fifth efferent-collector arteries; ex.b., ex trabranchial car tilage; fl.a., an terior filament; fl.p., posterior filament; ib.d., dorsal inter. branchial musele; n., posterior division of the branchial nerve. anterior and a posterior filament, is seen in figure 143. In this, the fourth dorsal constrictor muscle ( $\csc d_{0}$ ) is thickened toward the margin of the septum, where it is supported by the extrabranchial cartilage (ex.b.). It is continued toward the internal branchial aperture as an interbranchial muscle (ib.d.) directly in front of the cartilaginous branchial ray (b.r.), the upper part of which in figure 143 has been eut off. Anterior to the branchial ray is the third afferent artery (af.) which is surrounded by the nutrient vein (sinus) of the arch, and anterior to the union of the branchial ray with the internal branchial arch is the large anterior efferent-collector artery $\left(e f c_{\circ}^{4}\right)$; just posterior to this efferent-collector is the pretrematic division of the branchial nerve (crosshatched), and below the posterior filament is the small posterior efferentcollector artery $\left(e f c .^{5}\right)$. 


\section{RESPIRATORT TRAC'T OF ELASIIOBRANCHS IN GENERAL}

The respiratory tract or passageway through which the water current passes in bathing the gills of Elasmobranchs, unlike the tract in higher forms in which the respiratory current may enter external nares, begins with the month and terminates with the external branchial clefts. The following parts are included in the respiratory tract : the buccal cavity, the enlarged pharynx, and, in the wall of the pharynx, the gill pockets. The gill pockets, as in Heptanchus, are reached from the pharynx by the internal branchial apertures and open to the exterior through the external branchial apertures or clefts. We shall describe first the external branchial apertures.

Many of the Elasmobranchs are of the pentanchid type, that is, those possessing five gill clefts; only Chlamydoseluchus and those sharks belonging to the notidanids exceeding this number. Record is also made of a greater number occasionally oceurring in other forms. In Chlamydoselachus and in Hexanchus six elefts are present and in Heptanchus, as we have seen, there are seren, the greatest number known for any gnathostome or jaw-possessing vertebrate.

The position of the external branchial apertures or clefts has long been used in separating the sharks from the rays. Characteristic of the former the elefts are lateral in position, while in the latter they are ventrally located. In the rays, however, there enters the element of time, for while a ventral position of the clefts is characteristic of the adult, the position for a considerable period of time in the embryo is lateral (see p. 11).

The external branchial apertures in the sharks vary greatly in relative size. In a type like Acanthias (fig. 5) they extend as slits practically one-half the height of the body. In Heterodontus (fig. 17) the first cleft is large, but the last is so small as to be of slight functional value. Many other forms are like Heterodontus in this regard. In some of the other sharks the clefts are of immense size. This condition is found especially in the lamnoids and in Cetothims and Rhinodon (fig. 3), in all of which the apertures are practically the height of the pharyngeal diameter. In the rays the clefts are relatively of a much smaller size.

The first cleft to open and one of the most important in the embryo is the spiracle. As growth proceeds, however, the spiracle fails to keep pace with the other clefts, so that at its maximum development in types like Acanthias (see p. 11, fig. 22) and Squatina it is relatively small. In others, as for example Lamna and Carcharias, the spiracle of the adult is often minute; and in still others all superficial trace of it may be lost. In the rays, on the contrary, it has assumed a secondary function and hence has become enlarged.

\section{Gill Pouch or Pocket}

In shape the gill pockets of the sharks are generally like those of Heptanchus. In types like Lamna, Cetorhimus, or Rhinodon, however, the external clefts are so large that the normal form of the closed pocket is more like that of the 
opened pocket in Heptanchus. In the rays the pocket is somewhat like an inverted $U$, in which the internal and external branchial apertures are represented by the tips of the $U$ elose together.

The first indication of a pocket in the embryo appears as an evagination or outpocketing of the pharyngeal wall toward the exterior ( $g p$. , fig. 144). As this approaches the surface it meets a slight pitting in from the outside, and the wall between the two breaks through to form the external branchial cleft or aperture.

In pentanchid types six of these pouches, including the spiracular, are formed; but accessory pockets are often indicated. Thus in Acanthias a small pouch on the left side (or a pair of pouches) is produced as an evagination from the floor of the pharynx just back and mediad of the sixth pouch. This pouch does not reach the outside layer but comes in contact with the roof of the pericardial cavity. Here it forms numerous tubules and becomes the so-called postbranchial or suprapericardial body. These bodies have also been described for Scyllium, Galeus, Pristiurus, and Raja.

In figure 144 the anterior clefts have thus broken through. Between the pockets are columns, from which all the tissues of the holobranchs are later produced including their supporting cartilages and musculature. On the posterior wall of the hyoidean cleft will appear a little later the beginnings of the embryonic or external gill filaments.

The whole column from the internal branchial arch toward the exterior lengthens out and the central core becomes a plate, the septum or diaphragm of the gill. This plate supports the filaments or respiratory membrane, and is peculiar in the Elasmobranchs in that it extends outward beyond the filaments which are attached to it. It is

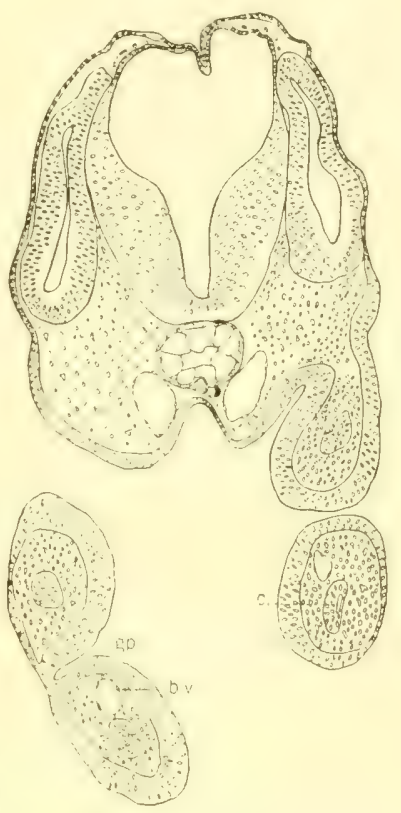

Fig. 144. Horizontal section through pharynx to show formation of the gill pockets, Iletrouloutus fiancisci. (Marshall Williamson, del.)

b.v., blood vessels; $c$., cavity; $g p .$, gill poeket. from the peculiar attachment of the filaments to the septa that the Elasmo-

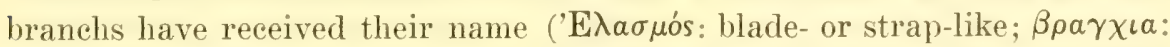
gilled). The septum may be said to attach internally on the internal visceral arches, and to extend outward to the lower layer of the integument. Each septum is limited anteriorly and posteriorly by a heavy layer of tissue which is continuous with the mucous membrane of the pharynx. Terminally the anterior and posterior plates of this tissue run parallel and are separated only by the interbranchial musculature, connective tissue, and cartilaginous branchial rays (Heptanchus) which support the septum.

The interbranchial muscles ( $i b . m .$, fig. 145 ) are located on the anterior sur- 
face of, and run at right angles to, the cartilaginous branchial rays of each whole gill. These muscles form thin sheaths dorsally and ventrally by which attachment is made to the fascia and to the extrabranchial cartilages; medially a part of the interhranchial joins the epi- and ceratohranchial segments of the internal branchial arches. Some of the outer fibers in their course are attached to eartilaginous hranchial rays. but in the sharks most of them are continuous above and below. In the rays these museles are regularly attached to the branchial rays (see p. 106, fig. 108B). They are thus able by contraction to decrease the size of the pocket.

The filaments of the adult gill are to be distinguished from those of the early embryo which we may first consider. Upon the breaking through of the external clefts in the embryo of all Elasmobranchs a series of nodules arises from the posterior margins of the hyoidean and the branchial arches. These grow outward as long external gill filaments which sometimes exceed the entire body in length (Urolophus, fig. 22D); in others they are shorter (Acanthias, fig. 22c). Such filaments are characteristically more numerous in the more generalized types. In Heptanchus we have seen the greatest number known in Elasmobranchs. In Acanthias they are more numerous than in Scyllium, and in Scyllium they exceed in number those of most rays.

These filaments in the living embryo are particularly noticeable from the fact that they are kept constantly in motion and are filled with blood, giving to them their striking color. Under the microscope the circulation of blood can here be seen to remarkable advantage. Each embryonic filament is a more or less flattened plate with a blood vessel encircling it near its outer border. The whole tissue of the filament acts as the respiratory membrane.

External branchial filaments thus developed in the embryo are early absorbed, giving place to permanent or internal filaments. In some forms the filaments of the adult may be of great length reaching practically to the outer margin of the septum (Lamna). In many others, however, they are of medium length (Scyllium); while in a few they are relatively short (Squatina). Tsually in the Elasmobranchs the filaments of the posterior demibranch are longer than those of the anterior; and those of the middle of the septum are the longest of the series.

Sections through the septum parallel to the filaments give a clear notion of the structure of a gill. Dröscher (1882) gave such a section through a holobranch of Torpedo (fig. 145) which shows that here the filament of the posterior demibranch, like that in Heptanchus, is longer than that of the anterior, and that both extend only two-thirds the length of the septum. Running transversely through the central part of the septum, from the internal branchial arch toward the exterior is the interbranchial muscle; back of this is the cartilaginous branchial ray. It is observed further that the filaments, instead of being round as in face view, are flattened from side to side. A section of the filaments of Torpedo, so far as considered, is essentially like the one studied of Heptanchus. It differs from it somewhat in the position of its blood and in its nerve supply. 
The finer strueture of the gill of Torpedo shows that the relation of the blood system to the gill is much like that of Mustelus and Heptanchus. Passing through the base of the septum, and anterior to the cartilaginous branchial ray $\left(b . r_{0}\right)$, is an afferent branchial artery (af.). From this an arteriole $\left(a . b .^{1}\right)$ passes to the anterior filament and another $\left(a . b^{2}{ }^{2}\right)$ to the posterior filament. These arterioles give off smaller branches which break up into a net of capillaries which, in turn, form a complex web over the larger part of the surface of the filament. The capillaries are continued to efferent branchials $\left(e . b .^{1}\right.$ and $\left.e . b .^{2}\right)$ as efferent arterioles which carry the oxygenated blood down the filament into the efferent-collectors (efc.), an anterior and a posterior of which are present at the base.

In the spiracular pocket as in branchial pockets the anterior wall is usually also provided with filaments. These are numerous in the rays but few in number in the sharks, as in Heterodontus. In a type like Carcharias, in which the spiracle is minute or wanting, they are entirely absent.

From the anteromedial wall of the spiracular pocket and dorsally located there is an evagination which may reach the auditory capsule and be attached to it above the postorbital groove (dc., Scyllium, fig. 146, Mustelus, Gaelus, Squatina, Rhinobatis, Zygaena). At its beginning the diverticulum may be practically closed (Galeus), but as it approaches the auditory capsule it becomes enlarged. In Squalus acanthias, Norris and Hughes (1920) have recently shown that this evagination may be divided into two or three diverticula each of which is supplied with a branch of the ramus oticus VII nerve. The organ is considered to be a

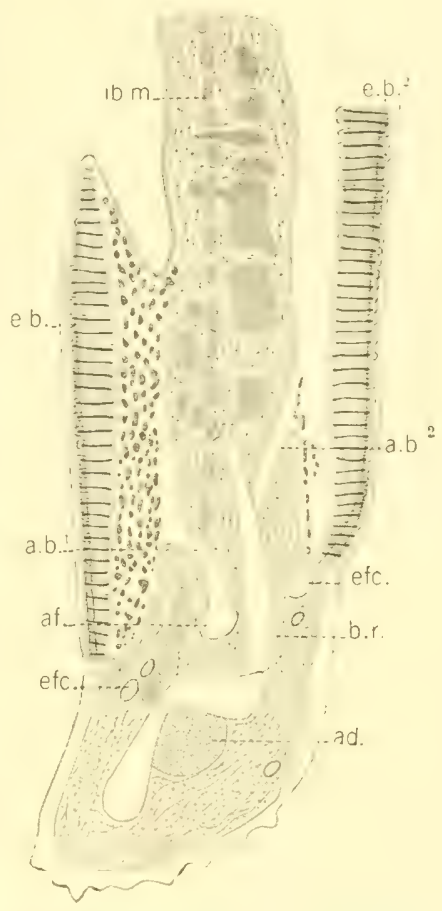

Fig. 145. Section of branchial filaments, parallel to branchial ray, Torpedo. (From Dröscher.)

$a . b .^{1-2}$, afferent branchial arterioles from afferent artery; ad., adductor muscle; af., afferent artery; b.r., branchial ray; $e . b .^{1-2}$, efferent branchial arterioles to efferent-collectors; efc., efferent-collector; $i b . m$., interbranchial musele. modified ampulla of Lorenzini. A second diverticulum on the anteromedial wall of the spiracular pocket is located ventrally near the union of the pocket with the pharynx. This in Scyllium is shallow, but in some of the other Selachians it is connected to the spiracular pocket by a neck. In the spiracle of rays there is a well developed valve on the anterior side of the cleft. It is composed of a stiff crescentic fold of comnective tissue which is constantly opened and closed in respiration. Serving as a support for the fold is the strong crescentic spiracular cartilage which at each end is fixed by ligament. The closure of the spiracle is due to the contraction of the first 
dorsal constrictor muscle. A similar valve, although less well developed, occurs in some of the sharks, as for example in Acanthias and Mustelus.

The internal branchial apertures of the branchial pockets may be simple slits or the aperture may be modified by the presence of certain gill rakers. The gill rakers in squalus suctilii ( $g r$, fig. 147 ) form a series of processes from the pharygeal arches across the internal branchial apertures. On the first

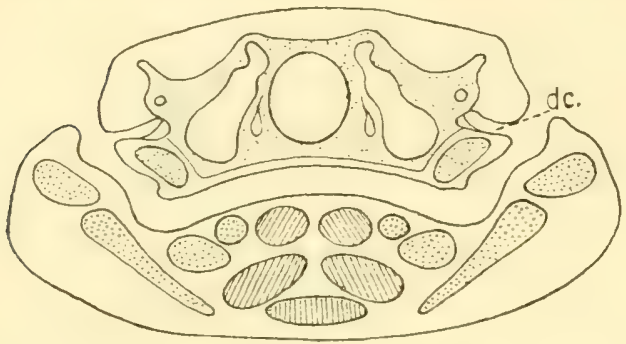

Fig. 146. Transverse section through spiracles, Scyllium. (From Ridewood.) dc., dorsal caecum. two branchial arches they project only from the anterior surface of the arch, while on the third and fourth they extend from both the anterior and the posterior surfaces. These projections are covered with caps of the mucous lining, on which stomodeal denticles are present, and are supported internally by cartilages, the anterior ones of which practically touch the internal branchial arch and the posterior ones are directed outward from the adductor muscle (ad.).

In Cetorhinus a straining apparatus is differently formed. As we have remarked (p.37) the gill rakers in Cetorhinus and Rhinodon are modifications of placoid scales which arise from semilunar bases and are continued as long filaments across the internal branchial aperture. Upon opening a gill pocket in Cetorhinus (fig. 148A) myriads of these rakers or filaments (g.r.) are seen to be attached to the internal branchial arches and to extend inward so that those from the arch in front of the pocket overlap those from the areh behind it (fig. $148 \mathrm{~B}$ ). There is thus formed of these rakers a V-shaped strain-

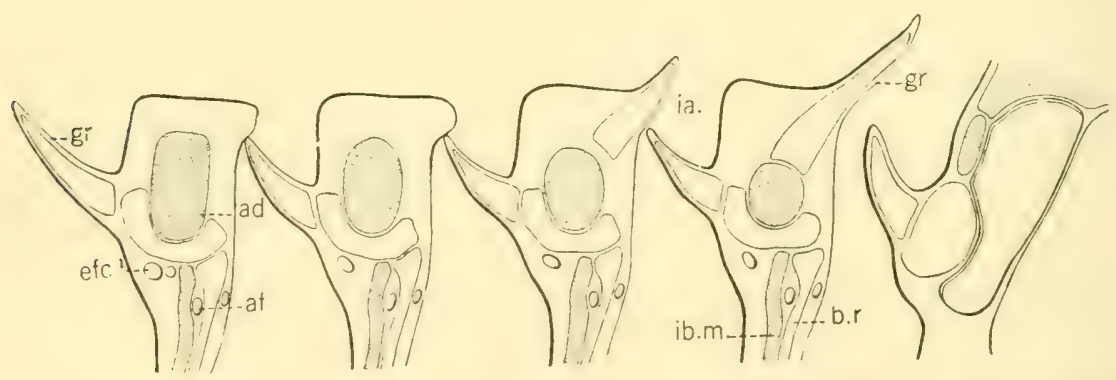

Fig. 147. Horizontal section cutting through the gill pockets to show gill rakers, Squalus sucktii. (H. M. Gilkey, del.)

$a d$. adductor muscle; af., afferent artery; b.r., branchial ray; $e f c{ }^{1}$, anterior efferentcollector; gr., gill rakers; $i a$., internal branchial aperture; ib.m., interbranchial muscle.

ing apparatus which points into the pharynx and completely covers the internal branchial aperture. By means of this strainer small organisms. prevented from passing out with the respiratory current, are collected in great numbers and passed down the digestive tract as food. 


\section{PRODUCTION OF RESPIRATORY CURRENT}

For the sharks and rays in general the respiratory eurrent is produced by the interaction of the complicated series of buceal and pharyngeal muscles which insure that when the current enters the mouth the external clefts close and when the clefts open, the mouth closes. In general the action is as follows: By the contraction of the rentral, longitudinal, or hypobranchial musculature

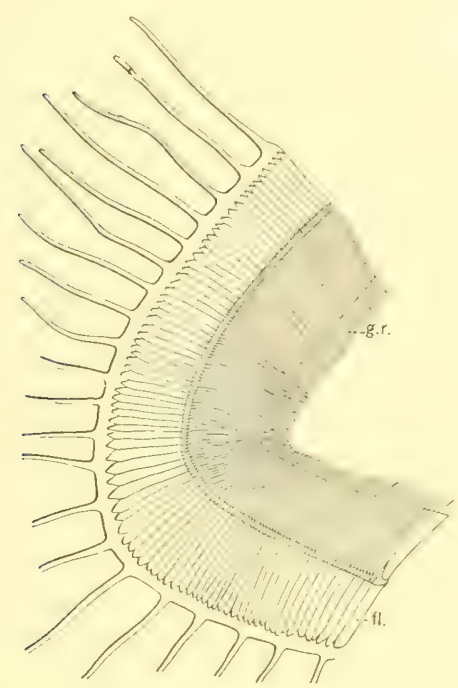

A

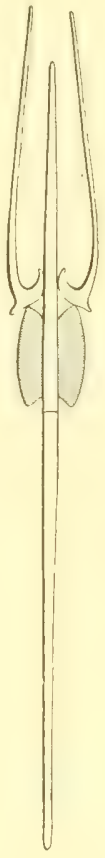

B

Fig. 148. A. Part of a gill pocket of Cetorhinus. (From Paresi.) B. Diagram of a section parallel to the gill rakers.

b.r., branchial ray; fl., filaments; g.r., gill rakers; g.p., gill pocket; ia., internal branchial aperture.

the floor of the mouth and pharynx is lowered, thus enlarging the buceal and pharyngeal rooms, at the same time that the mouth is opened. Into this cavity the water rushes. The adductors then act, closing the mouth and at the same time flexing the epi- and ceratobranchial segments of the arches, thereby spreading apart the cartilaginous branchial rays and causing the pockets to enlarge. The water now enters the pockets and is then forced out through the external clefts by the contraction of the constrictor and interbranchial muscles. By this action of the muscles a rhythm is produced which under conditions of rest is about thirty-five respirations a minute (Heterodontus francisci). 


\section{DIRECTION OF RESPIRATORY OURRENT}

In the free-swimming sharks the current enters the mouth, from which it passes through the pharym and into the gill pockets, the external clefts, including the spiracle, at the same time remaining closed. The mouth then closes, the external clefts open, and the water is forced out.

In the rays, which spend most of their time on the bottom and hence often in mud or sand, there is an interesting change in the direction of the current. In these the greater part of the current enters through the spiracle and but little through the mouth. The valve of the spiracle then closes and the water is forced out rentrally through the external branchial clefts. At the expulsion of the water the month does not entirely close, but only a little of the current
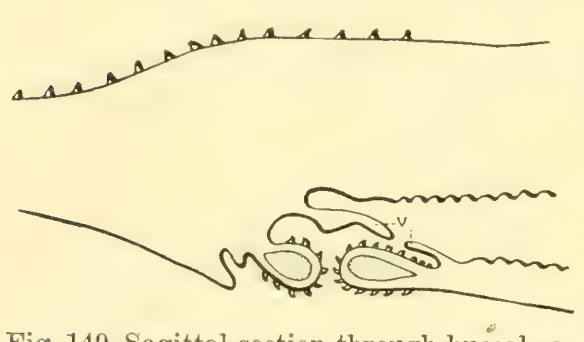

Fig. 149. Sagittal section through buecal cav ity of Raia erinace a to show valves $(v$.). (From Rand.) is able to gain exit through it because of valves which are located on its roof and floor ( $v$., fig. 149).

In rays there often occurs a reversal of the current, by which the water is spouted outward through the spiracle. Rand (1907) has shown that this may be brought about experimentally in several ways. In the first place spouting may be produced by putting the ray into water overcharged with carbon dioxide, or it may be the result of fatigue as is shown by compelling the ray to keep in rapid motion for a period of time. Again, spouting may be produced by putting a soft substance, as for example sea moss, into the spiracle. To any of these experiments the ray responds by ejecting a columm of water through both spiracles. Rand has shown further that by striking the margin of the spiracle or of the eye on a single side, spouting may be produced by a single spiracle on the side thus irritated.

While spouting is characteristic of the rays it is not confined to them. In Squatina, a form which spends much time on the bottom, I have also found spouting to occur. But in this type it is not so much an indication of a reversal of the current. Here as in other sharks water enters the mouth and passes out through the clefts. To study the spouting behavior and to note the direction of the current, I have observed Squatina (a shark) and Rhinobatis (a ray) in the same large aquarium. Under such conditions both are seen to spout occasionally. With exercise the spouting occurs more frequently. If now the water in the aquarium is let off so as to expose the spiracular clefts, Rhinobatis becomes greatly agitated while Squatina is little disturbed. These observations show that the spiracle in Squatina is not, as it is in the rays, the principal intake. Darbishire (1907) says for Squatina, however, that carmine liberated in the region of the spiracle enters, and furthermore, that it enters not rhythmically but in a constant stream. This regularity of the current is produced by a rhythmic action of the free margins of the gill septa. In the 
experiments on Squatina, above mentioned, I have also observed the phenomenon of the outgoing current, but that the spiracle is not of great importance as an aperture for the intake of the current is shown by my experiment.

Something of the same rhythmic enrent occurs in the rays, although it may be produced differently. In specimens of the small sting-ray, Crotophus, which are buried in the sand with only the spiracular clefts and the outline of the body discernible, the spiracular elefts open and close regularly. The only evidence of the outgoing current, however, is seen in a regular geyser of sand grains arising to an inch or two in height at the anterior margin of the pectoral fin.

\section{CIRCULATION OF BLOOD IN FILAMENTS}

In a later study of the blood system (Chapter VII, p. 161) it will be found that the afferent arteries bear non-oxygenated blood from the heart to all the demibranchs and give off to them smaller branches which run outward toward the tips of the filaments; the branches in turn give off thin-walled arterioles which in their course break up into capillaries. It is in these capillaries that the exchange of oxygen and carbon dioxide takes place. From the eapillaries efferent branchial arterioles convey the oxygenated blood toward the base of the filaments into either an anterior or a posterior efferent-collector (efc.). By means of these collectors oxygenated blood is removed from the region of the gills. In other words, while a single afferent artery supplies both anterior and posterior series of filaments with non-oxygenated blood, two efferent-collectors, one at the base of each demibranch, carry away the blood which has been oxygenated.

\section{RESPIRATION OR THE EXCHANGE OF' GASES}

The respiratory current thus brought into the gill pockets is separated from the blood contained in the capillaries of the filaments only by the thin capillary wall. The free oxygen of the water passes by osmosis through this wall into the blood to be distributed to the body, and the carbon dioxide brought to the capillaries from the body tissues passes outward into the water to be eliminated by the respiratory current. The exchange of gases takes place with extreme rapidity as is evident from the fact that the blood makes its complete transit of the capillaries in a very short time. 


\section{BIBLIOGRAPHY}

\section{Chapter VI}

1840. Alesandinini, Antonil, Observationes super intima branehiarum structura piscium cartilagineorum. Novi Comment. Acad. Bonon., Vol. 4, pp. 329-344.

1886. BEMMELEN, J. F. VAN, Über vermuthliche rudimentäre Kiemspalten bei Elasmobranchiern. MIitt. Zool. Stat. Neapel, Bd. 6, pp. 165-184, pls. 11-12.

1818. Blainville, H. D., U̇ber den Bau der Kiemen bei den Foetus der Haifisehe. Areh. f. Physiol, Bd. 4, pp. 275-296.

1906. Braus, H., Ueber den embryonalen Kiemenapparat ron Heptanchus. Anat. Anz., Bd. 29 , pp. 545-560, 2 text figs.

1917. Caxp, W. E., The Development of the Suprapericardial (Post-branchial, Ultimobranchial) Body in Squalus acanthias. Jour. Morph., Vol. 28, pp. 369-415, pls. 1-2, 29 text figs.

1857. Cornatia, Emilo, Sulle branchie transitorie dei feti Plagiostomi. Gior. dell' I. R. Istit. Lombardo (n. s.), T. 9, pp. 256-258.

1870. Cornish, Thomas, On a Shark Captured in Mount's Bay on June 11, 1870, Supposed to be Identical with the Basking Shark of Pennant and the Broadheaded Gazer of Couch. Zoologist, August, 1870, pp. 2253-2260.

1907. Darbishire, A. D., On the Direction of the Aqueous Current in the Spiracle of the Dogfish: together with some observations on the Respiratory Mechanism in other Elasmobranch Fishes. Jour. Linn. Soc. Lond., Vol. 30, pp. 86-94, 3 text figs.

1886. DohrN, A., Studien zur Urgeschichte des Wirbelthierkörpers. XI. Spritzlochkieme der Selachier, Kiemendeckelkieme der Ganoiden, Pseudobranchie der Teleostier. Mitt. Zool. Stat. Neapel, Bd. 7, pp. 128-176, Taf. 2-5.

1882. Dröscher, WILHELM, Beiträge zur Kenntnis der histologischen Struktur der Kiemen der Plagiostomen. Diss. Leipzig, 1881, pp. 12-176, pls. 9-12.

1890. Etrart, J. C., On the Spiracles of the Porbeagle Shark (Lamna cornubica). Jour. Anat. and Physiol., Vol. 24 (n. s., Vol. 4), pp. 227-229.

1909. Hyde, IDA H., A Study of the Respiratory and Cardiac Activities and Blood Pressure in the Skate following Intravenous Injections of Salt Solutions. Kansas Univ. Sei. Bull., Vol. 5, No. 4, pp. 29-63, pl. 10, 49 text figs.

1836. LEUCKART, F. S., Untersuchungen über den äusseren Kiemen der Embryonen von Rochen und Haien. Ein Beitrag zur Entwicklungsgeschichte der Abtheilung der Knorpelfische angehörenden Plagiostomen. Stuttgart, pp. 1-44, pls. 1-5.

1880. M'KendRICK, J. G., On the Respiratory Movements of Fishes. Jour. Anat. and Physiol., Vol. 14, pp. 461-466, pl. 28.

1894. Mayer, P., Über die vermeintliche Sehwimmblase der Selachier. Mitt. Zool. Stat. Neapel, Bd. 11, pp. 475-478, 1 text fig.

1920. Norris, H. W., and Hughes, SAlly P., The Spiracular Sense-Organ in Elasmobranchs, Ganoids and Dipnoans. Anat. Ree., Vol. 18, pp. 205-209, 1 text fig.

1874. PAvesi, P., Contribuzione alle storia naturale del genere Selache. Ann. Mus. Cir. Storia nat., Genova, Vol. 6, pp. 5-72, pls. 1-3.

1911. Polmanti, Osw., Über den Beginn der Atmung bei den Embryonen von Seyllium (Catulus Cuv., Canicula L.). Zeitsehr. Biol., Bd. 57, pp. 237-272, 2 text figs.

1904. Quinton, René, Communication osmotique chez le poisson Sélacien marin, entre le milieu vital et le milieu extérieur. C. R. Acad. Sci. Paris, T. 139, pp. 995-997. 
1907. Rand, H. W., The Funetions of the Spiracle of the Skate. Amer. Nat., Vol. 41, pp. 287-302, 3 text figs.

- 1896. Ridewood, W. G., On the Spiracle and Associated Struetures in Elasmobranch Fishes. Anat. Anz., Bd. 11, pp. 425-433, 2 text figs.

1875. Schenk, S. L., Die Kiemenfäden der Knorpelfisehe während der Entwickelung. Sitzber. Akad. Wien, math.-naturwiss. Klasse, Vol. 71, pp. 227-238, Taf. 1.

1875. TURner, WM., On the Presence of Spiracles in the Porbeagle Shark (Lamna cornubica). Jour. Anat. and Physiol., Vol. 9, pp. 301-302.

1579. TuRner, WM., The Strueture of the Comb-like Branchial Appendages and of the Teeth of the Basking Shark (Selache maxima). Jour. Anat. and Physiol., Vol. 14, pp. 273$286, \mathrm{pl} .12$.

1898. VIRCHow, H., Ueber Oberflächenbilder von Selachierkiemen und Mesodermursprungs. zone. Anat. Anz. (Verh.), Bd. 14, pp. 43-49, 4 text figs.

1876. Wright, E. P., The Basking Shark. Nature, Vol. 14, pp. 313-314, 2 text figs. 


\section{CIRCULATORY SYSTEM}

\section{CIRCULATORY SYSTEM OF HEPTANCHUS MACULATUS}

The heart in Heptanchus (fig. 150) is located over, and in front of, the sternal symphysis of the pectoral areh in the region between the gills, and is retained within a relatively large pericardial cavity. It is made up of two rooms proper, an auricle (atrium) (au.) and a ventricle (vn.), into the former of

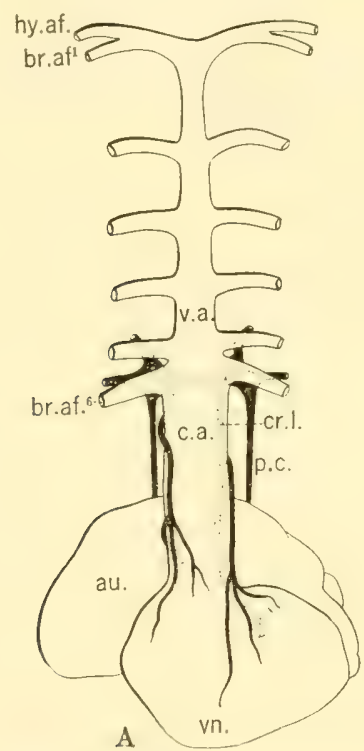

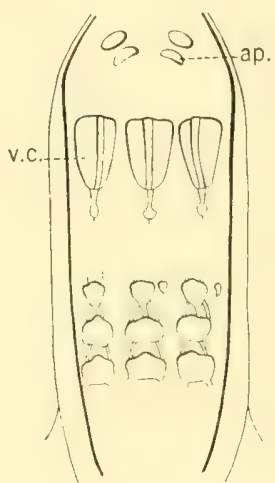

B

Fig. 150. A heart of Heptanchus maculatus. (Marie Weldt, orig.) B. Valves of conus, ventral view. (From Garman.)

ap., aperture of last afferent artery ; $a u$. , auricle (atrium) ; br.af.$^{1-6}$, first and sixth branchial afferent arteries; c.a., conus arteriosus; $c r . l$. , left coronary artery; $h y . a f .$, hyoidean afferent artery; p.c., pericardial; v.a., ventral aorta; v.c., valves of conus; vn., ventricle.

which the blood enters from the sinus venosus (see p. 203, fig. 188, s.v.), and from the latter of which it is expelled through the conus arteriosus (c.a., fig. 150).

The auricle, or atrium, is a greatly enlarged, thin-walled sac which lies dorsally over the ventricle. Connecting it with the sinus venosus is the sinuauricular opening. At the sides of this opening are the two sinu-auricular valves ( $s a$, fig. 188), which prevent the backward flow of the blood into the sinus venosus upon the contraction of the auricle. Connecting the auricle with the ventricle is an auriculoventricular opening guarded by valves of the same name attached to the ventricular walls.

The more or less triangular ventricle forces the blood by way of the conus arteriosus through the gill capillaries and as a consequence of the strain 
imposed upon it, its walls have become greatly thickened. Inside, the lining has become thrown into numerous irregularities and is richly provided with supporting chordac tendineae stretched from the walls of the ventricle to the auriculoventricular valves. These tendinous cords prevent the valves from being forced into the auricle upon the contraction of the ventricle.

The conus arteriosus connects the ventricle and the ventral (ascending) aorta $\left(v a_{0}\right)$. Its walls are museular so that it serves to keep the blood sent out from the ventricle at a more constant pressure. A longitudinal section through the comus of Heptanchus shows its thickened walls and, on the sides of the lumen, a series of pocket-like valves (v.e., fig. 150B), which prevent blood from reëntering the ventricle. These are arranged in three longitudinal rows, one dorsal and two ventrolateral in position. 'The anterior and much larger valves in each row are located just back of the exit of the most posterior afferent branches of the ventral aorta. Following these are other small valves, behind which are three valves of medium size, in each row.

\section{ARTERIES}

\section{Ventral Aorta}

The ventral aorta (v.a., fig. 150A) continues forward from the conus and, in the region back of the mandibular symphysis, divides into right and left halves. Along its course it gives off paired branches, the afferent arteries (hy.af., and br.af. ${ }^{1-6}$, fig. 150A) which distribute blood to the gills.

\section{AFFERENT ARTERIES OF ADULT}

In Heptanchus these branches are seven in number. An anterior pair, consisting of the hyoidean afferent (hy.af.) and the first branchial afferent (br.af. ${ }^{1}$ ), arises from a common trunk formed by the bifurcation of the anterior end of the ventral aorta. The first or hyoidean supplies the hyoidean demibranch, entering in front of the first gill pocket. The second enters the first whole gill between the first and second pockets, supplying both of its demibranchs. Following these on each side are given off the second to the sixth branchial afferents, the last two of which arise close together from the ventral aorta (fig. $150 \mathrm{~B}$, ap.). The second to the sixth branchial afferents enter and supply the fourth-fifth, sixth-seventh, eighth-ninth, tenth-eleventh, and twelfth-thirteenth demibranchs. Branches from the afferents break up into smaller and smaller arterioles and finally as capillaries supply the filaments of all the gills.

\section{EFFERENT'COLLECTORS}

From the capillaries the blood passes down the filaments into efferent-collectors. If the most anterior gill pocket of an injected specimen be opened, as is the second pocket in figure 142, an efferent-collector artery would be seen to drain the demibranch in front of the cleft, the hyoidean demibranch (see also 
fig. 151), and another, the one hehind the eleft. These two arteries, the first and second efferent-collectors, unite both rentrally and dorsally, forming a loop around the cleft (fig. 151). The third and fourth efferent-collectors encircle the second pocket as the first and second encircle the first pocket, but the one forming the anterior part of the loop, which is the posterior efferent-collector of the first holobranch, is small and has an irregular course. As it passes ven-

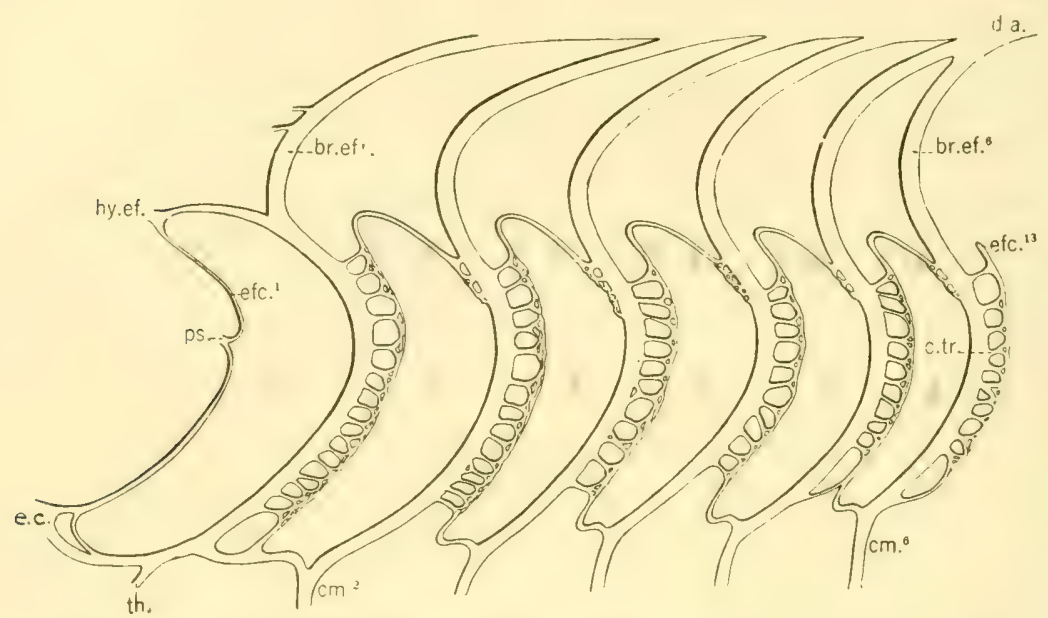

Fig. 151. Efferent-collector arteries, Heptanchus maculatus. (R. T. Trotter, orig.)

br.ef. ${ }^{1-6}$, first and sixth branchial efferent arteries; $\mathrm{cm}^{2-6}$, second and sixth commissural arteries; c.tr., cross-trunk; d.a., dorsal aorta; $e . c$. , external carotid; ef $c_{.}^{1-13}$, first and thirteenth efferent-collector arteries; hy.ef., hyoidean efferent; $p s$. , pseudobranchial artery; th., posterior thyroid artery.

trally it may increase somewhat in size and is comnected with the efferentcollector in front of it hy numerous cross-trunks. Tentrally it joins the larger efferent-collector behind the cleft, the anterior efferent-collector of the second holobranch, and dorsally it loops back also making comnection with the same ressel. Similar efferent-collector's encircle the remaining pockets, except the last, where a complete loop is not formed due to the lack of gill filaments on the posterior wall of the pocket. The hlood from the last (thirteenth) efferentcollector is drained by means of cross-trunks (c.tr.) into the twelfth efferentcollector through the greater part of the holobranch; and ventrally the last efferent-collector joins the one in front of it directly.

\section{Branches of Efferent-Collectors}

\section{HYPOBRANCHIAL ARTERIES}

From the ventral angles of the second to the fifth (or sixth) efferent-collector loops in Heptanchus, large commissural arteries (cm. ${ }^{-6}$, figs. 151 and 15:3) pass inward toward the middle line. Near their origin they are usually conneeted by small vessels which, joined together, may be called the lateral hypo- 
branchial artery (l.hb., fig. 153); or the lateral hypobranchial vessels may arise from the ventral parts of the efferent-collector loops; or again a lateral hypobranchial segment may be incomplete between certain of the commissurals. Just hetore reaching the miclventral line the commissurals of each side form a larger longitudinal vessel, the median hypobranchial ( $m . h b$.), the right and left median hypobranchials being connected by several small connectives (cn.) which may or may not unite right and left pairs of commissurals. The two median hypobranchial trunks are continued posteriorly above the peri-

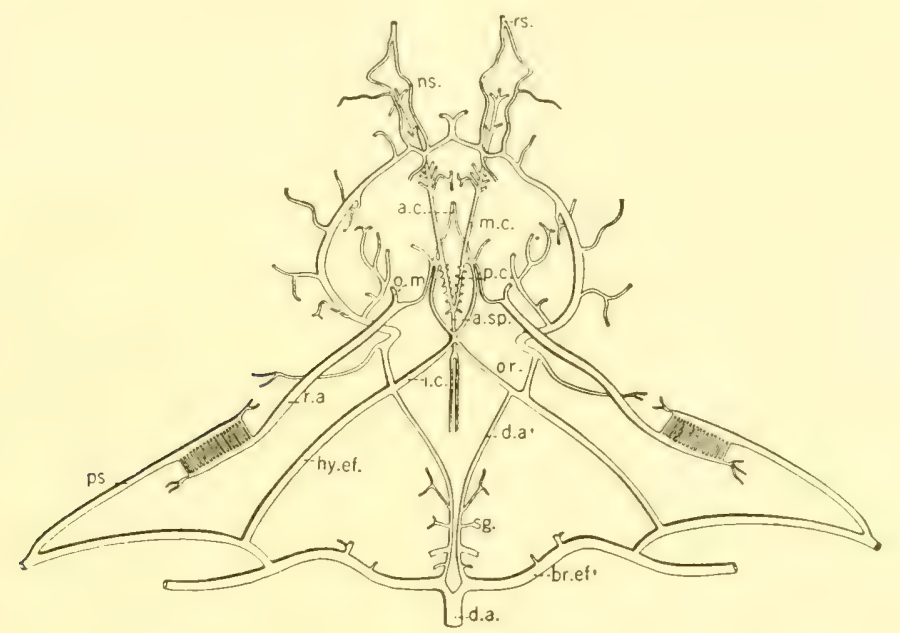

Fig. 152. Arterial branches of first efferent-collector, Heptanchus maculatus. (Marie Weldt, orig.)

a.c., anterior cerebral ; a.sp., arteria spinalis; $b r . e f .^{1}$, first branchial efferent; $a . a_{0^{1}}$, paired dorsal aorta; d.a., dorsal aorta; hy.ef., hyoidean efferent; i.c., internal carotid; m.c., median eerebral; ns., nasal artery; o.m., ophthalmica magna; or., orbital artery; p.c., posterior cerebral; ps., pseudobranchial artery; r.a., ramus anastomoticus; rs., rostral artery; $s g$. , segmental artery.

eardial roof as the two large pericardial arteries $(p c$.$) . The pericardials may$ be of essentially the same size or the right one may be the better developed (see fig. 154, r.pc.). The epigastric artery (epg., fig. 154), which supplies branches to the oesophagus and the stomach, is a branch off of the pericardial or is the direct continuation of the right one.

A large vessel is given off from the median hypobranchial between commissures two and three, or three and four, which passes to the midventral line and joins a similar artery from the opposite side. 'This united trunk extends posteriorly, and at the sixth commissural divides into the right and left coracoid arteries (co.a.), which join the subclavian arteries. Similarly, near the sixth commissural, an artery arises from the median hypobranchial on each side to pass posteriorly and toward the midventral line. This artery, however, does not reach or fuse with its fellow from the opposite side, but continues as the coronary artery (cr.l., figs. 153 and 150) to the heart.

In Heptanchus maculatus the left coronary (cr.l., fig. 150A) runs along the dorsal and left side of the comus arteriosus, supplying it and the dorsal side of 
the ventricle. About midway of the conus it sends a branch to the ventral side of the ventricle. The right coronary passes around to the ventral side of the conus, supplying branches to the tissues on the right side and to the ventral and dorsal parts of the ventricle and to the auricle. A posterior coronary
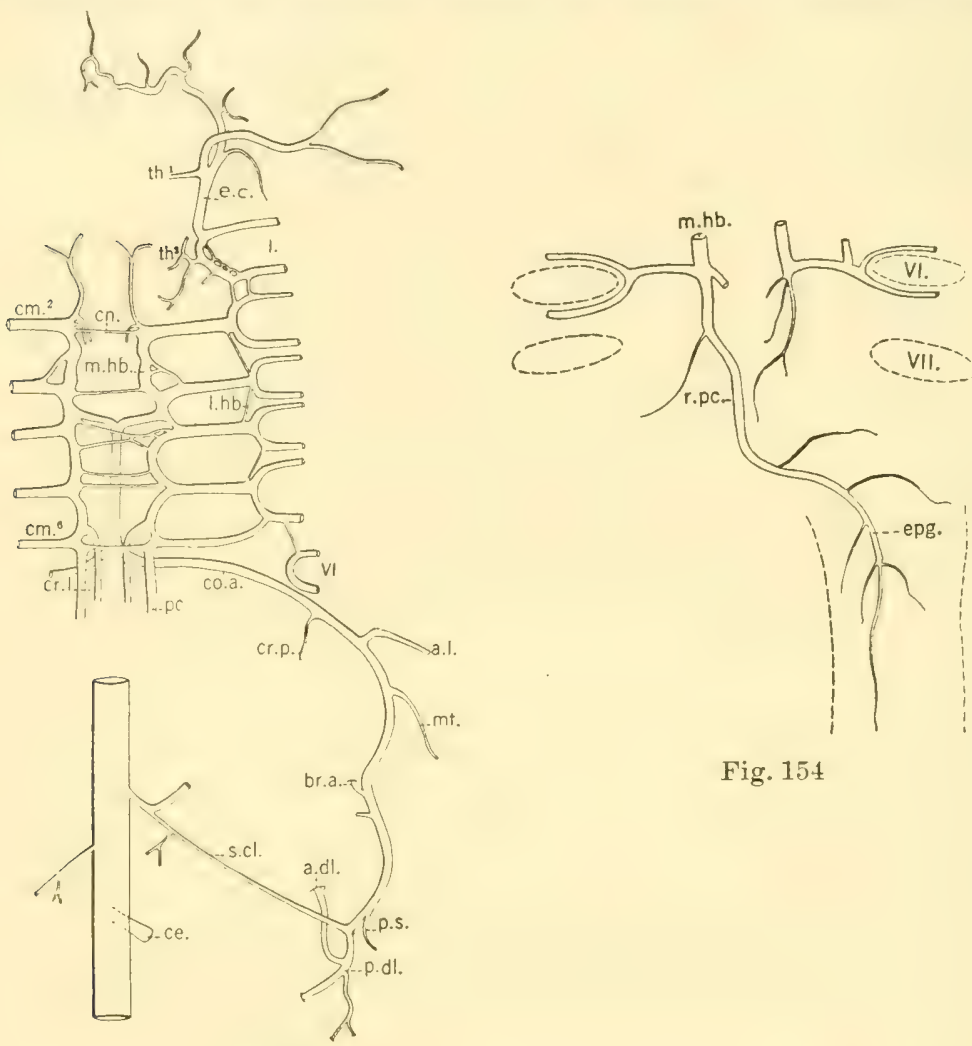

Fig. 154

Fig. 153

Fig. 153. Hypobranchial arteries, Heptanchus maculatus, dorsal view. (Marie Weldt, orig.) a.dl., anterior dorsolateral artery; a.l., anterior lateral artery; br.a., brachial artery; $c e$. , coeliac axis; $\mathrm{cm}^{2-6}$, second and sixth commissural arteries; cn., connective; co.a., coracoid artery; cr.l., left coronary artery; cr.p., posterior coronary artery; e.c., external carotid; $l . h b$., lateral hypobranchial; $m . h b .$, median hypobranchial; $m t$., metapterygial artery ; pc., pericardial artery; p.dl., posterior dorsolateral artery; p.s., posterior scapular; s.cl., subelavian artery; th. ${ }^{1-2}$, anterior and posterior thyroid arteries; $I-V I$, first and sixth branchial clefts.

Fig. 154. Epigastric artery (epg.), Heptanchus maculatus, ventral view. (Cecil Rowe,orig.) $m . h b$., median hypobranchial; r.pc., right pericardial; $\nabla I-V I I$, sixth and seventh branchial clefts.

(cr.p., fig. 153), arising from each coracoid artery, passes inward to supply the sinus venosus.

From the ventral angle of the first efferent-collector loop a posterior thyroid ( $t h .^{2}$, fig. 153) is given off which in general position takes the place of a first commissural. From about the same position or a little more anterior than the posterior thyroid the large external carotid artery (e.c., figs. 151 and 153) passes forward and the stem then divides, one part passing inward to the sym- 
physis of the lower jaw and giving branches to the coracomandibularis muscle; and the other upward between the hyoid and mandibular cartilages to supply the structures around the mandibular and hyoid regions. The external carotid or one of its branches gives off a small branch $\left(t \hbar^{1}{ }^{1}\right.$, fig. 153$)$ which supplies the anterior part of the thyroid gland.

From the upper third of the first efferent-collector another large artery, the pseudobranchial ( $p s$. , figs. 151 and 152), runs forward to break up into a number of strong branches in the spiracle. From the spiracle this artery is continued inward and forward as the ramus anastomoticus (r.a., fig. 152), which passes through a foramen in the orbit (see fig. 47, f.r.a., facing p. 44) to join the internal carotid artery inside the cranial wall. Before entering the orbit, however, this ramus gives off the ophthalmica magna (o.m., fig. 152) to the eye region.

\section{EFFERENT ARTERIES}

The first efferent artery, the hyoidean efferent ( $h y . e f .$, fig. 152), extends as a contimution of the first efferent-collector from the anterodorsal angle of the first efferent-collector loop forward and mediad to the paired dorsal aorta $\left(d \cdot a \cdot{ }^{1}\right)$. The remaining efferents, branchial efferents (br.ef. ${ }^{1-6}$, fig. 151) similarly arise from the dorsal angles of efferent-collector loops, but they, as continuations of the anterior efferent-collector, extend backward and inward to join the umpaired dorsal aorta. In Heptanchus five of these efferents, above the first to the fifth holobranchs, reach the umpaired dorsal aorta and a sixth joins the fifth.

Near the mion of the hyoidean efferent and the paired dorsal aorta an orbital (stapedial) artery (or., fig. 152) is given off. laterally and extends forward through the orbit. The paired dorsal aorta is continued forward as the internal carotid (i.c., fig. 152) which enters the cranium from the midventral line to supply the brain. After perforating the cartilage the right internal carotid joins the left and the two run for a short distance as a common trunk. They then separate and pass forward and slightly outward where they are joined by the right and the left ramus anastomoticus, respectively ( $r \cdot a$., fig. 152). Given off after the union of the ramus anastomoticus and internal carotid are the three cerebral arteries to the brain. The anterior cerebral (a.c., fig. 152) passes anteriorly between the hemispheres of the brain and is usually joined to its fellow from the opposite side by an intercommunicating artery. The median cerebral (m.c.) passes forward to supply the olfactory tract and bulb. The posterior cerebral (p.c.) passes backward, and its two branches join to form the arteria spinalis (a.sp., fig. 152) which extends down and ventral to the spinal cord. There is thus formed by the union of the anterior and the posterior cerebrals a complete circle around the ventral part of the brain.

\section{Dorsal AORTA}

The dorsal aorta (fig. 152) is composed of a short anterior paired part (d.a. ${ }^{1}$ ) and a long posterior unpaired part $\left(d_{\text {. }} a_{0}\right)$. The paired part receives the hyoidean efferent, and the unpaired part receives the first four pairs of efferents 
and the united trunk of the fifth and sixth efferents. The umpaired dorsal aorta then passes backward ventral to the spinal column, becoming in the tail region the candal aorta. In its course through the body it gives off arteries to the digestive tract and its appendages, to the extremities, and to the body musculaure and deeper structures.

\section{ARTERIAL SUPPLY TO DIGESTIVE TRACT}

The arteries given off from the dorsal aorta to the digestive tract consist of three large trunks, the coeliac axis, the anterior mesenteric, and the posterior. mesenteric arteries.

\section{COELTAC AXIS AND ITS BRANCHES}

In Heptanchus maculat us the coeliac axis (ce., fig. 155) arises as a single trunk from the ventral side of the dorsal aorta, only a short distance posterior to the union of the last efferents. It passes downward and backward as a relatively long artery and at the place where it strikes the portal vein it divides into: (1) a very short gastrohepatic which bifureates into a small hepatic branch (h., fig. 155) to the liver and a large gastric branch to the stomach, and (2) a large anterior intestinal artery (a.i.a.) which is continued along the ralvular intestine as the ventral intestinal artery.

The gastric artery separates into two main divisions, the anterior gastric $(a . g$.$) and ventral gastric (v . g$.$) arteries. The anterior gastric sends a branch$ to the ventral union of oesophagus and stomach and also supplies a branch to the dorsal side of the anterior part of the cardiac stomach. The ventral gastric artery $(v . g$.$) , which is the posterior of the gastric divisions, passes down the$ ventral side of the cardiac stomach and at the angle between the cardiac and the pyloric arms of the stomach breaks up into numerous branches some of which pass along the pylorus and anastomose with a posterior gastrosplenic artery.

The hepatic artery $(h$.$) passes toward the liver, and after giving branches$ to the anterior segment of the spleen, bifurcates. giving off a smaller artery to the left lobe of the liver and a larger branch to the right lobe. These tro hepatic divisions follow the course of the larger hepatic reins almost to the tip of the liver, giving off numerous branches as they go.

The anterior intestinal division of the coeliac axis (a.i.a., figs. 155 and 156) runs posteriorly and strikes the anterior part of the dnodenum. Before entering the duodenum as the intraintestinal artery (see fig. 156, i.a.) it gives off: (1) a posterior gastro-pancreaticosplenic artery (p.gps.), (2) the ventral intestinal artery (v.i.a.), and (3) the gastroduodenal artery (gd.). The posterior gastro-pancreaticosplenic supplies a short hranch to the distal part of the pylorus (py.a.) and a long branch which after supplying branches to the pancreas $(p n$.$) and spleen passes along the pyloric arm as the posterior gastro-$ splenic (p.gs., fig. 155). This branch finally reaches the posterior side of the prlorus where it gives off splenic branches and receives certain anastomosing 


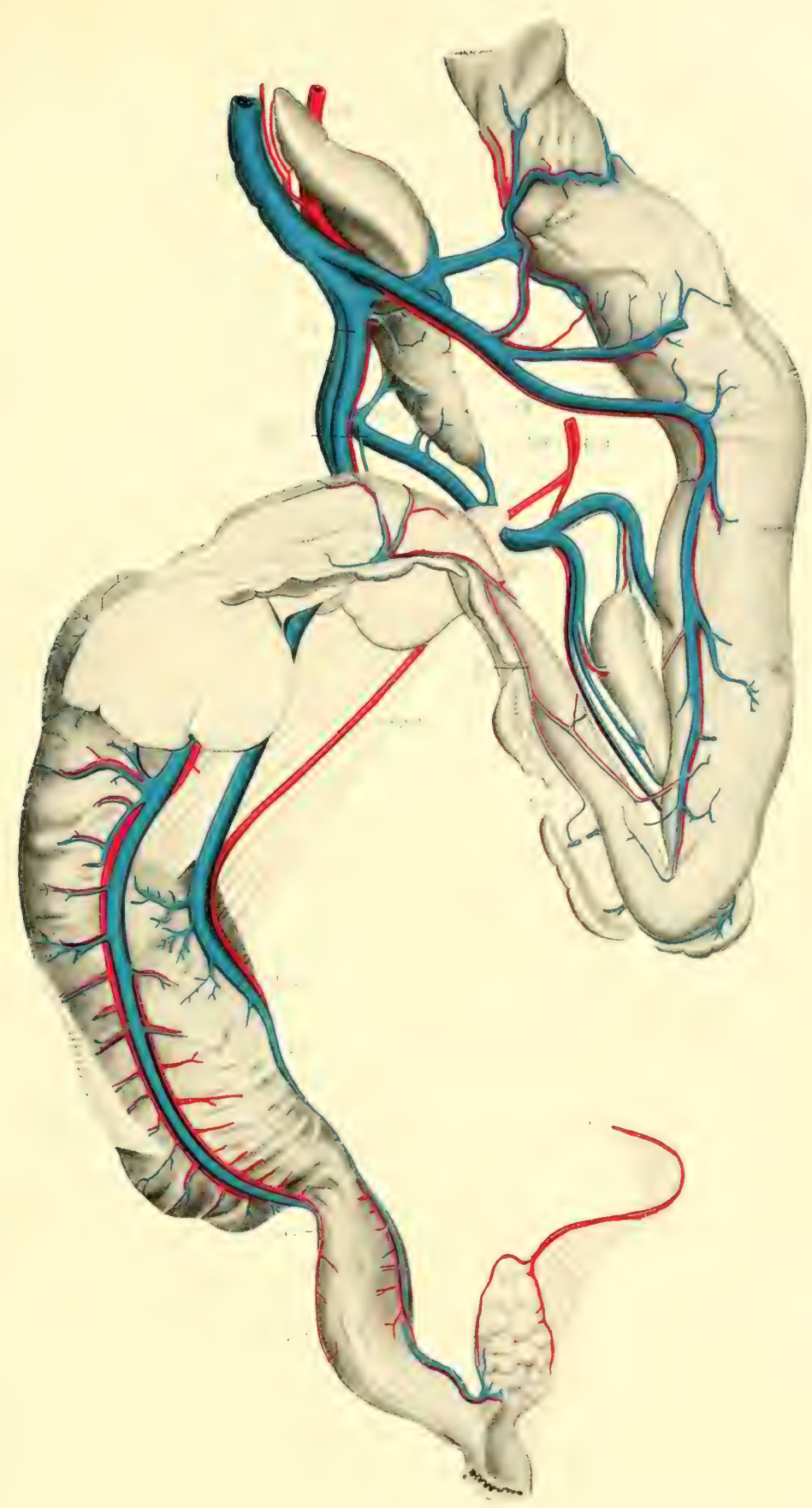

Fig. 155. Vaseular supply to the digestive tract, Heptanchus maculatus. (Duncan Dumning, del.) (Dorsal and ventral intestinal arteries and veins draw relatively elose together in order that they may be seen.)

a.g., anterior gastrie artery; a.gps, anterior gastro-pancreaticosplenic artery; a.gps.v., anterior gastro-pancreaticosplenic rein; a.i.a., anterior intestinal artery; a.i.v., anterior intestinal vein; ce., coeliae axis; d.i.a. and d.i.v., dorsal intestinal artery and rein; $h_{\text {., he- }}$ patic artery; h.p., hepatic portal rein; i.m., inferior mesenteric; p.gs., posterior gastrosplenic artery; p.gs. $x$, posterior gastrosplenie rein; p.i.a., pusterior intestinal artery ; p.i.v., posterior intestinal vein ; $r$., rectal artery ; $v . g$. , ventral gastrie artery; v.g.v., ventral gastric vein; v.i.a., and v.i.v., ventral intestinal artery and vein. 

branches from the rentral gastric artery. It then extends to the cardiac stomach where it anastomoses with the anterior gastrosplenic artery which supplies a more anterior segment of the stomach.

The ventral intestinal artery (v.i.a.) passes over the distal end of the pylorus and the ventral lobe of the pancreas, to appear on the ventral side of the valvular intestine. (On the intestine it supplies the distal part of the duodemm and furnishes the rentral side of the valvular intestine with numerous paired annular branches which run on the attached edge of the spiral valve more or less nearly encircling the intestine (see fig. 155).

The gastroduodenal artery ( $g d$., fig. 156) in addition to supplying the proximal part of the duodenum sends a short branch to the tip of the pylorus.

\section{SUPERIOR (ANTERIOR) MESENTERIC AND ITS BRANCHES}

The superior mesenteric artery (s.m., fig. 157) as such is usually absent in Heptanchus maculatus and when present it is never more than a short stem given oft from the dorsal aorta a little more than one-half the way back in the body eavity. (In figure 155 the superior mesenteric branches [a.gps. and p.i.a.] have heen displaced forward.) It immediately divides into: (1) an anterior gastro-pancreaticosplenic (a.gps., fig. 155) and (2) a posterior intestinal (p.i.a.).

The anterior gastro-pancreaticosplenic

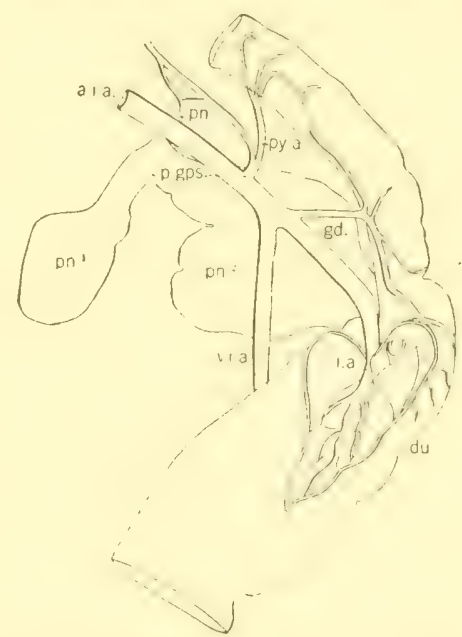

Fig. 156. Arterial supply to the duodenum. Dorsal view, Heptanchus maculatus. (Marie Weldt, orig.)

a.i.a., anterior intestinal artery; $a u_{.}$, duodenum; gd., gastroduodenal artery; i.a., intraintestinal artery; $p n$., pancreatic branch; $p n .^{1-2}$, dorsal and ventral lobes of panereas; p.ops., posterior gastro-panereaticnsplenic artery; py.a., pyloric artery; v.i.a., ventral intestinal artery.

(a.gps.) sends branches to the dorsal and distal parts of the cardiac stomach, to the dorsal lobes of the pancreas, and to the spleen in and on the angle of the stomach.

The posterior intestinal artery runs back over the mesentery to the valvular intestine which it joins at about the middle of its length. Then, as the dorsal intestinal (d.i.a.), the artery continues backward to supply the dorsal posterior half of the spiral valve with annular branches. Some of these branches anastomose with similar anmular branches from the ventral intestinal artery. Finally the dorsal intestinal artery traverses the region of the colon and terminates in the rectal gland where it joins branches of the inferior mesenteric.

\section{INFERIOR (POSTERIOR) MESENTERIC ARTERY}

'The inferior mesenteric artery (i.m., figs. 157 and 155) arises as a single trunk a few segments behind the superior mesenteric region. It runs along the anterior margin of the mesorectal mesentery to the anterior part of the rectal 
gland where it divides, the anterior branch joining the dorsal intestinal artery to which reference has been made. The posterior part supplies numerous

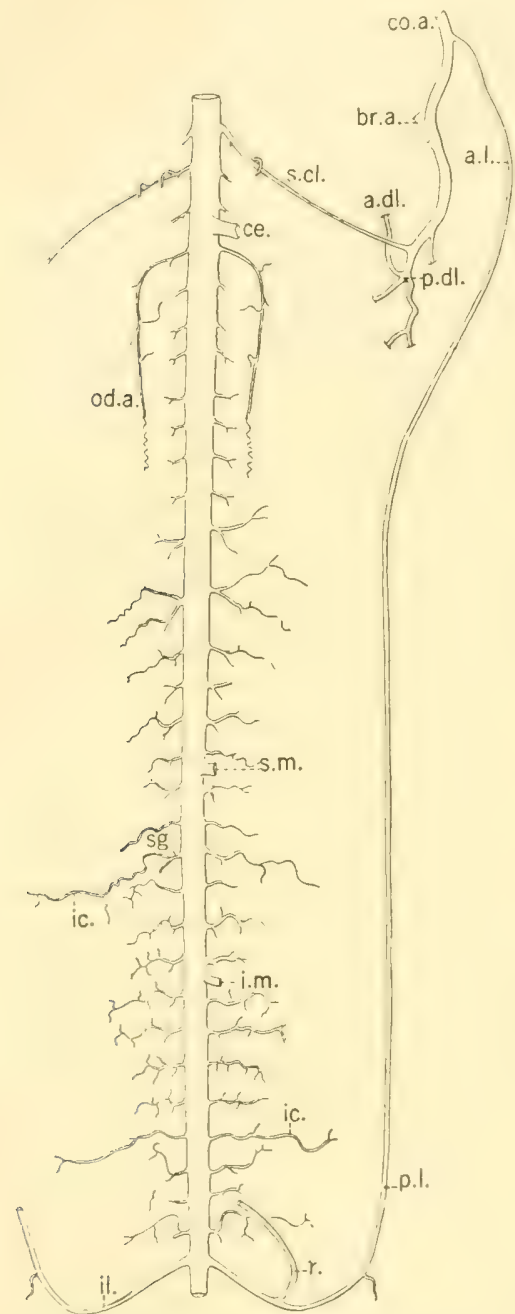

Fig. 157. The dorsal aorta and its branches, Heptanchus maculatus. (Marie Weldt, orig.)

a.dl., anterior dorsolateral artery; a.l., anterior part of lateral artery; br.a., brachial artery; ce.. coeliac axis; co.a., coracoid artery; $i c$. intercostal artery; $i l$. , iliae artery; $i . m$. , inferior mesenteric; od.a., oviducal artery; $p . d l$, posterior dorsolateral artery; p.l., posterior part of lateral artery; $r$., asymmetrical rectal artery; s.cl., subclavian artery ; sg., segmental artery; s.m., superior mesenteric artery. branches to the rectal gland and rectum.

\section{ARTERIAL SUPPLY TO EXTREMITIES}

The arterial supply to the extremities includes a pair of subclavian arteries (s.cl., fig. 157) carrying blood to the pectoral fins, and a pair of iliac arteries (it.) leading toward the pelvic fins.

The subelavian arteries in Heptanchus maculatus are unusual in that they often are no better developed than are the common intercostals (ic.). They pass from the dorsal aorta near the union of the last efferents and out toward the pectoral region. A short distance out each subclavian gives off a dorsolateral artery, one relatively large division of which passes forward (a.dl., fig. 157) and one backward $(p . d l$.$) . From about this point a smaller$ artery passes dorsally supplying the area posterior to the scapula. The brachial artery (br.a.) leaves the subelavian and continues through a foramen in the pectoral girdle to the pectoral fin. From the brachial foramen the subelavian is continued forward by a larger brachioscapular vessel (see also bsc., fig. 169) to join the coracoid artery (co.a., fig. 153) at a place where it meets the lateral (abdominal) artery (a.l.). The coracoid in turn joins the median ventral unpaired artery (see fig. 153), described with the hypobranchial system.

Arising from the brachioseapular ressel is a branch ( $m$ t., fig. 153), which passes along the metapterygium of the pectoral fin. The lateral artery (a.l., figs, 153 and 157 ) is a continuation of the coracoid; it passes backward, hidden by the lateral abdominal vein, to join the iliac artery (il.) from the posterior region. Also leaving the coracoids, but farther anterior than the origin of the lateral, is the posterior coronary artery (cr.p., fig. 153), which has been previously described. 
The iliac artery arising from the dorsal aorta in the pelvic region is larger than the subclavian. 'The first branch of the iliac on the left side, the rectal, is asymmetrical and passes forward to supply the wall of the rectum (see r., figs. 155 and 157 ). Before the iliac, as the femoral, passes through a foramen in the pelvic girdle to supply the pelvic fin, it joins the posterior part of the lateral $\operatorname{artery}(p l$.$) .$

ARTERIAL SUPPLY TO DEEPER STRUCTURES

The third set of paired arteries arising from the dorsal aorta consists of segmental arteries ( $s g$. fig. 157). The first of these segmentals may arise from the paired dorsal aorta ( $s g$. fig. 152) throughout the pharyngeal region and perforate the deeper musculature around the spinal column.

In the region between the subelavians and iliaes about thirty pairs of regularly arranged segmental arteries leave the aorta. Each segmental sends a branch dorsally around the spinal column supplying a median branch to the spinal cord and lateral branches to the musculature, and is continued by a superficial intercostal branch $(i c$.) which runs along the peritoneum bounding the body cavity. These intercostals extend outward to supply the interseptal musculature and are often of great length. Occasionally, however, some of these are lacking, and the interseptal spaces, especially in the region of the mesonephros or kidney, may be supplied by neighboring arteries.

The renals are the most ventral branches of the segmentals. They are more irregular along the anterior prolongation of the kidney, but in the posterior region where the kidney is enlarged they are regular in position and of large size.

The oviducal arteries in Heptanchus (od.a., fig. 157) arise from the third pair of segmentals back of the subelavians. These arteries run posteriorly, and at about the eighth segment behind the subclavians become tortuous in their course ending in segment nine or ten.

\section{Caudal norta}

The dorsal aorta, as the caudal artery, traverses the haemal canal to the tip of the tail giving off segmentals similar in general to those of the trunk. These pass from the caudal aorta laterally throngh interhaemal spaces and branch into ventral and dorsal divisions; the ventral branches go to the ventral muscles and the dorsal branches pass upward and around the body of the centrum. From the dorsal part, spinal arteries are given off which enter the neural canal to supply the spinal cord. 


\section{CIRCTLATORY SISTEM OF ELASMIOBRANCHS IN GENERAL}

The circulatory apparatus in the Elasmobranchs in general consists of four structures, all formed first as simple tubes. These structures are (1) a relatively simple two-roomed heart, the walls of a part of which have become thickened for pumping; (2) arteries, which bear blood from the heart and from the gills; $(.3)$ a series of terminal thin-walled capillaries which comnect the arteries

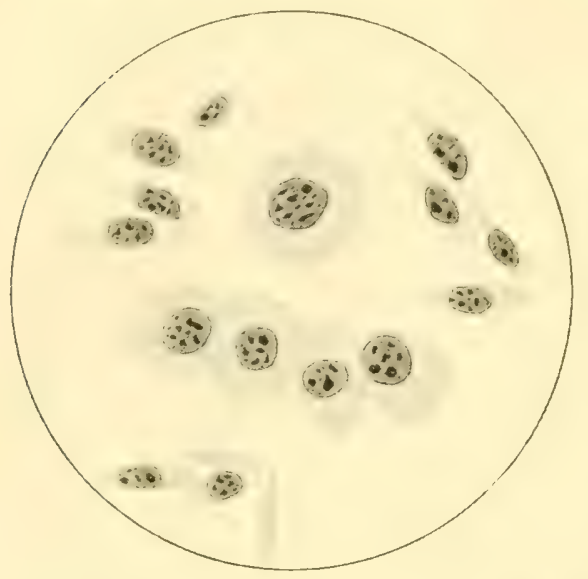

Fig. 158. Red blood corpuscles of Squalus sucklit. (M. C. Williamson, orig.) with (4) the veins. The veins in Elasmobranchs are relatively large and return the blood to the heart.

As is true for vertebrates in general, the arteries and veins are distinguished by two or three well defined characteristics. Both are made up of layers from the inside out as follows: a thin lining, the intima, around which is the muscularis or muscular layer. Surrounding the muscular layer is the serosa. But in the artery the muscular laver is much thicker than it is in the vein. It is this layer in the artery which keeps the blood under more constant pressure and forces it through the capillaries and reins back to the heart. $A$ second distinction between the two is that the veins possess valves. These valves are numerous and are especially large at the ends where the vessels empty. They are so arranged that blood can pass freely towards the heart, but its passage in the opposite direction is precluded.

The blood stream in the Elasmobranchs, as in other vertebrates, is made up of a relatively large amount of plasma in which is contained a small amount of serum. The erythrocytes or red corpuscles (fig. 158) contain only a small amount of haemoglobin or red coloring matter and are nucleated cells much greater in diameter than are the red corpuscles of man. The white corpuscles are also nucleated and may be filled with granules.

\section{HEART}

The heart in the Elasmobranchs, as was seen in Heptanch us, does not undergo the differentiation characteristic of the more complex heart of higher animals. As a usual thing, it is composed of a thin-walled auricle (atrium) (au., fig.159) and a thick-walled ventricle $(v n$.). The auricle receives the non-oxygenated blood from the sinus venosus (s.v.) and the the ventricle sends it forward through the conus (truncus) arteriosus (c.a.). 
The simus venosus may in general be described as a delta-shaped collecting sac, the apex of which leads to the auricle and the base of which is posterior in position ( terior part of the roof of the pericardial eavity; laterally each angle of the delta extends to the right or left as the duct of cuvier. 'The principal change in the form of the sinus venosus from that just described is found in some of the rays (see p. 209, fig. 194B) in which the lateral angles are drawn out into the elongated ducts of Cuvier.

Conneeting the sinus venosus with the auricle is the sinu-auricular aperture which, as in Heptanchus, is guarded by the sinu-aurieular valves. These valves are nothing more than double folds of the endothelial lining of the auricle

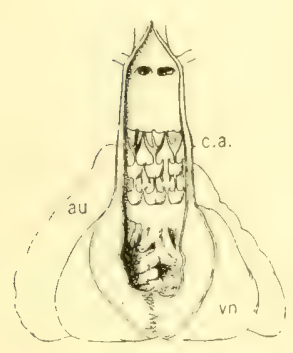

A

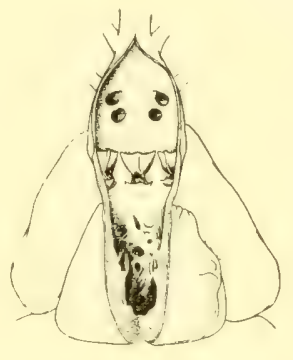

$\mathrm{B}$

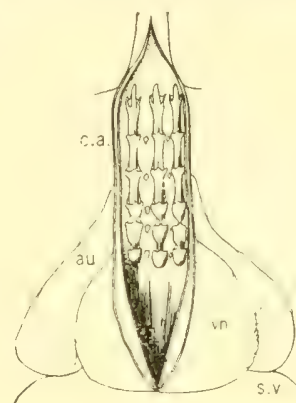

$\mathrm{C}$

Fig. 159. The heart opened to show valves. (From Garman.) A. Isurus. B. Cephaloscyllium. C. Mobula.

au., auricle (atrium) ; c.a., conus arteriosus; s.v., sinus venosus; vn., ventricle.

projecting into the sinus venosus. They are so arranged as to permit the free passage of blood into the auricle, but a flow in the opposite direction is prevented by their closure.

The auricle (atrium) in the Elasmobranchs in general is thin-walled and lies over the ventricle. The walls of the sac, however, may be folded and may even give the appearance of possessing two rooms. Internally the auricle in practically all Elasmobranchs is smooth, that is, it rarely possesses tendinous supporting cords which pass across the cavity from one wall to the other. The auriculoventricular opening may be shifted sharply to the left, so that the communication between the auricle and ventricle is visible in ventral view. 'The auriculoventricular valve consists of two pocket-like flaps, the concavities of which are directed toward the ventricle.

The ventricle is relatively small in all the Elasmobranchs, although in the rays it may be relatively thick. It may be described as a pyramid with the base posterior, two faces directed ventrally and outward, and the other dorsally in position. A section through the ventricle shows its greatly thickened walls ( $v n$., fig. 159). The lining, unlike that of the auricle, is often exceedingly rough and irregular. The tendinous cords (chordae tendineae) present in the ventricle of the Elasmobranchs are muscular at one end and drawn out into longer or shorter tendons at the other. The ends are attached to opposite walls and prevent the vessel from spreading beyond its eapacity. 
The apex of the ventricle is continued anteriorly by the conus arteriosus (c.a.), a short and narrow tube, the lumen of which is triangular and the walls muscular. Internally the conus of the Elasmobranchs is universally provided with three longitudinal rows of semilunar valves, corresponding to the faces of the triangle, one row dorsal and the other two ventrolateral in position. Figure 159 shows several types of valves. As a rule, in the sharks the number of tiers in each longitudinal row decreases in the more highly specialized forms. A somewhat generalized condition was seen in Heptanchus (fig. 150B) in which four or five tiers occur, and a fairly general condition is that of Isurus (fig. $159 \mathrm{~A}$ ). Much greater specialization is present in Cephaloscyllium (fig. 159B), in which only two tiers of valves are present. A decrease in the number of tiers does not necessarily indicate specialization in the rays, as is shown by the fact that several tiers are present in Mobula (fig. 159c), which is a highly specialized form. In most sharks the valves of the anterior row are best developed and often cover practically the entire lining of this section of the conus. The valves in the succeeding tiers usually decrease in size the farther they are located posteriorly. Not infrequently the lips of the valves are held in position by chordae tondineae and chordae may also extend from the fold of a valve posteriorly (fig. 159A). Among the regular valves, furthermore, are often found smaller or accessory valves (see fig. $159 \mathrm{c}$ ).

\section{ARTERIES}

Ventral or Ascending Aorta

The ventral aorta ( $v$.a., fig. 167) in the adult passes forward as a continuation of the short conus arteriosus. In all the Elasmobranchs this, also, is a relatively short trunk and divides anteriorly into right and left halves. The ventral aorta is smaller in caliber than the conus and its walls are thimner. As in Heptanchus, it gives off afferent arteries which carry the blood to the gill region to be oxygenated.

\section{AFFERENT ARTERIES OF ADULT}

In all Elasmobranchs the hyoidean afferent (hy.af., fig. 166в) and the first branchial afferent on each side $\left(b r \cdot a f^{1}{ }^{1}\right)$ arise from a common trunk, this being a bifureation of the ventral aorta above mentioned. In many sharks (Squalus, fig. 161; Mustelus antarcticus, fig. 166A) the last two afferents also arise from a common trunk, but when this oceurs the trunk is short. In some forms the last two arise separately, as in Heptanchus (ap., fig. 150в) and Chlumydoselachus (fig. 160). The second hranchial afferent arises as a single outgrowth from the ventral aorta between the common trunk of the hyoidean and first branchial afferents and that of the last two afferents in pentanchid Elasmobranchs (Mustelus, fig. 166). This is also the condition in at least one of the rays, Dasyatis dipterura (fig. 167). In rays in general, however, the 


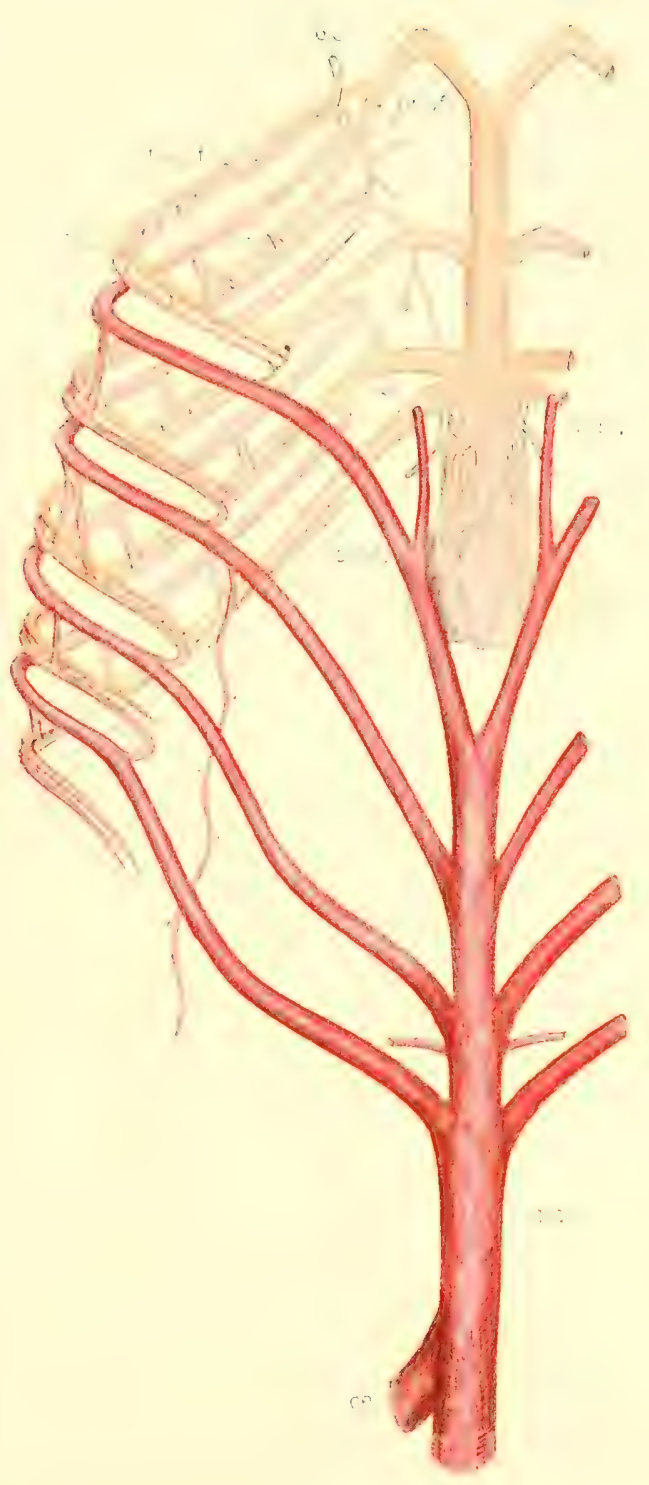

Fig. 161. Dorsal riew of afferent and efferent arteries, Siqualus suchlii. (Elizabeth Christiansen, orig.)

br.af.$^{1}$, first branchial afferent artery ; br.cf., branchial efferent artery; $c . t r$. , cross trunk: $c e .$, coeliac axis; $d_{0 .}{ }^{1}$, paired dorsal aorta ; d.a., unpaired dorsal aorta ; e.c., external carotid artery; hy.af., hyoidean afferent; p.s., pseudobranchial artery. 

second branchial afferent joins the common trunk of the last two so that, in them, only two stems leave the ventral aorta.

Each afferent continues around the base of the cartilaginous gill arch in front of the branchial rays, giving oft smaller afferent arterioles both to the anterior and to the posterior filaments of a gill (Squalus sucklii, fig. 161, braf.). In their course upward the afferents grow smaller and smaller and terminate in the dorsal part of the branchial region. An interesting arrangement is reported by Allis (1911) for Chlamydoselachus (fig. 160) in which the afferent arteries, except the hyoidean and last branchial, instead of ending dorsally, bifurcate, one branch $\left(a f_{.^{a}}\right)$ passing over the cleft anteriorly to join

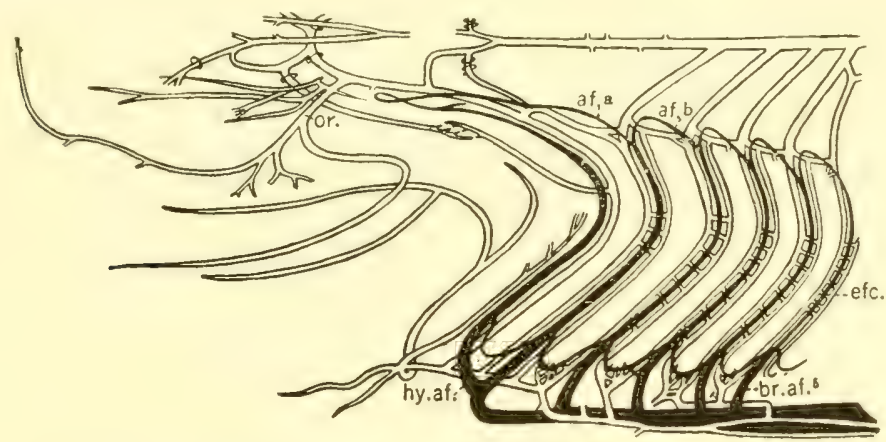

Fig. 160. Branchial arteries of Chlamydoselachus. (From Allis.)

$a f_{. "}$, anterior division of afferent; $a f_{. b}{ }^{b}$, posterior division of afferent; $b r_{\text {. }} f^{j}$, fifth branchial afferent; efc., efferent-collector; hy.af., hyoidean afferent artery; or., orbital artery.

the afferent in front, the other $\left(a f^{b}{ }^{b}\right)$ passing dorsally and back over the succeeding cleft to join the following afferent. In this arrangement, which is not greatly unlike that of Squalus, the afferents are connected into a series of closed loops around all the clefts.

\section{CAPILLARIES}

The capillaries in the gill filaments or folds connect the arterioles of the afferents (see fig. 145,a.b.) with a similar series of efferent arterioles (e.b.) leaving the gills. They form a net so complex that it is impossible to trace an individual capillary. The wall of each capillary is made up of a single layer of cells, forming the effective membrane through which the exchange of gases is made. If a longitudinal section could be made through the entire length of a single capillary it would begin where the thicker walled afferent arteriole ends and end with another thicker walled arteriole, the beginning of the efferentcollector type of vessel.

\section{EFFERENT-COLLECTORS}

Blood brought to the gills by the afferents passes into the capillaries of the gill filaments. Here it is oxygenated and is then sent down the gill filaments (e.b. ${ }^{2}$, fig. 145) into efferent-collectors (efc.) lying at their bases. The efferent- 
collector which forms the anterior part of the loop, however, is a posterior efferent-collector, for it drains the posterior demibranch of a whole gill; and the efferent-collector posterior to the cleft is the anterior efferent-collector of the following gill. To make this clear, if the area between two pockets, for example between the first and second pockets, be considered (fig. 161), its anterior efferent-collector (the second) drains the demibranch just behind

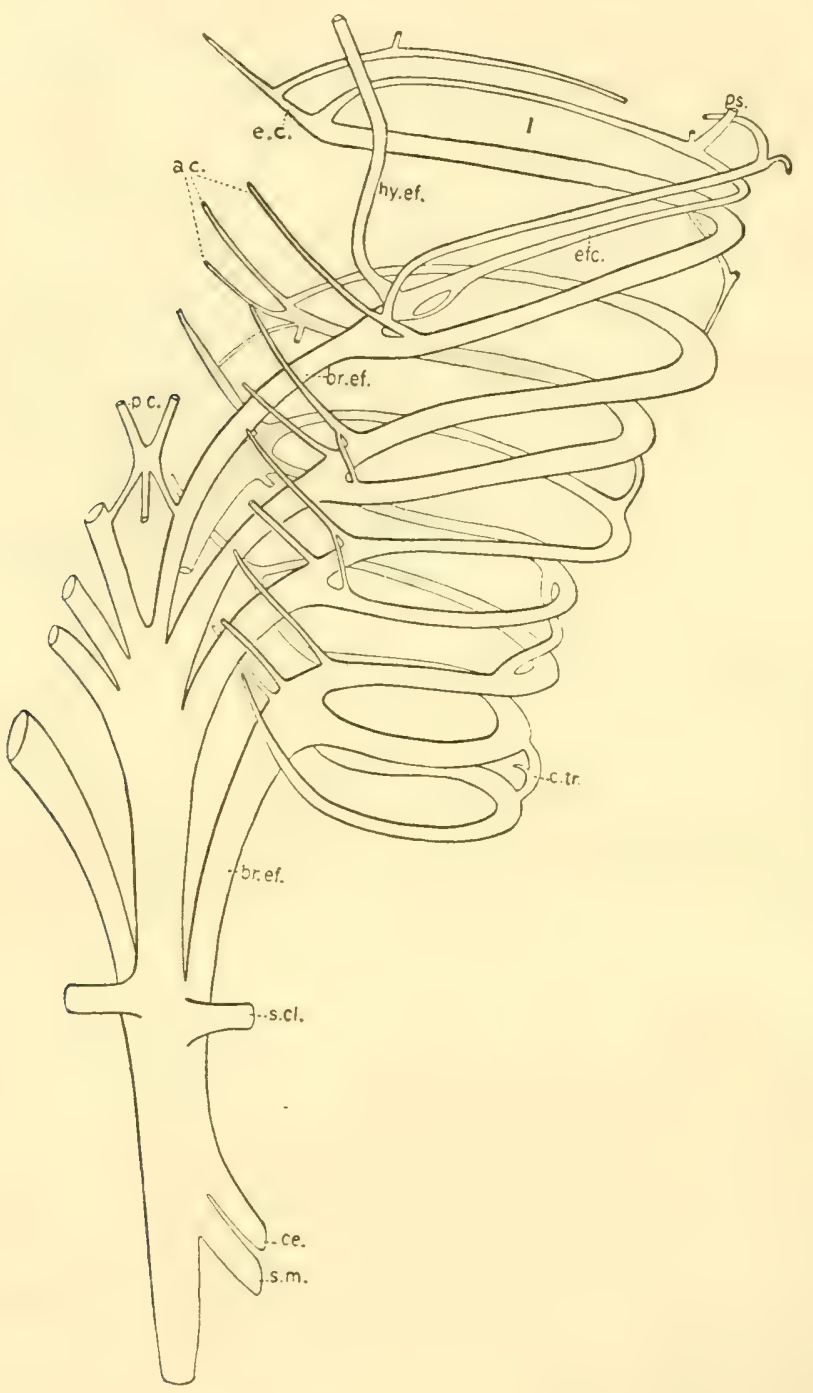

Fig. 162. Dorsal view of afferent and efferent arteries, Dasyatis dipterura. (Blanche Lillibridge, orig.)

$a c$. , accessory branchial arteries; br.ef.; branchial efferent arteries; c.tr., cross-trunk; ce., coeliac axis; efc., efferent-collector; e.c., external carotid; hy.ef., hyoidean efferent; p.c., posterior cerebral artery; $p s$. , pseudobranchial artery; s.cl., subelavian artery; s.m., superior mesenteric; $I$, first gill cleft. 
the first pocket, and the posterior efferent-collector (the third) drains the area in front of the second pocket. The anterior efferent-collector, by its connection through cross-trunks (c.tr., fig. 161) with the posterior collector back of it and by its ventral continuation with the collector in front of it, reeeives a considerable amount of blood and is a much larger vessel than is the posterior efferent-collector of the same gill. It is the anterior efferent-collector which is continned directly outward to the dorsal aorta as the branchial efferent proper (see fig. 161, br.ef.). All the efferent-collector loops posterior to the one just deseribed are similarly made up of posterior and anterior efferent-collectors, and all are emptied into the unpaired dorsal aorta similarly through branchial efferents (br.ef.) which are the direct continuation of the anterior efferentcollectors.

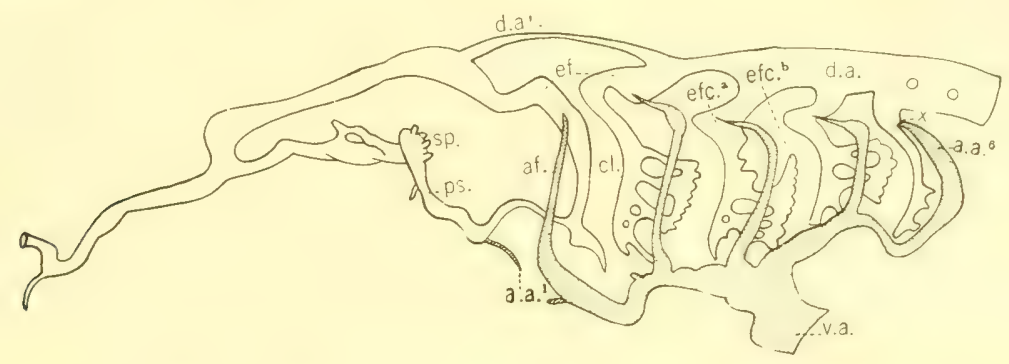

Fig. 163. The developing branchial arteries, Squalus acanthias. (From Seammon.)

a. $a^{3-6}$, first and sixth embryonic aortic arches; af., first afferent artery; $c l$., gill eleft; d.a. ${ }^{1}$, paired dorsal aorta; d.a., dorsal aorta; ef., efferent artery; efc. $a$, anterior efferentcollector; $e f c_{.}{ }^{\circ}$, posterior efferent-collector; $p s$. , pseudobranchial artery; $s p$. spiracle; v.a., ventral aorta; $x$. , where break in primary arch will take place.

We may briefly consider the formation of the afferent and efferent systems in the embryo of Squalus as described by Scammon (1911). The arterial system here consists of (1) a ventral aorta (v.a., fig. 163) running forward from the heart under the gill region, (2) a dorsal aorta (d.a.) extending backward above this and dorsal in position, and (3) six aortic arches $\left(a . a^{1-t^{-i}}\right)$ comnecting dorsal and ventral aortae in the pharyngeal or branchial region. Upon the formation of the gill filaments a new branch $\left(c f c .^{a}\right)$ is budded off which collects the blood from the newly formed gill tissues. The origin of this collector from the embryonic aortic areh marks the place where the embryonic arch later separates (see last arch at $x$ ) into two parts, the upper becoming the efferent $(e f$.$) which joins the dorsal aorta, and the lower the afferent$ (a.f.), which joins the ventral aorta. The collector (efc. ${ }^{a}$ ) (efferent-collector) next sends cross-trunks hackward to the posterior demibranch and a posterior efferent-collector ( $\left.e f c{ }^{b}\right)$ is formed. In the last arch it will be observed that the posterior efferent-collector has not as yet formed. In a general way it may be said that for every embryonic aortic arch, except the first and second, two efferent-collectors thus arise. One of them is formed for the anterior demibranch $\left(e f c_{v^{a}}\right)$, the other for the posterior $\left(e f c^{b}\right)$. The two collectors then continue to grow downward and the tip of the posterior efferent-collector now joins the 
collector behind it. Soon the gill cleft is surrounded ventrally by these ressels, but dorsally the loop is not yet completed around the cleft. A second important change then takes place. A branch from the posterior efferent-collector passes backward above the cleft and connects with the anterior efferent-collector following. There is thus completed an efferent-collector loop around the entire cleft eharacteristic of the adult.

In certain forms, even in the adult, the posterior efferent-collector may re-
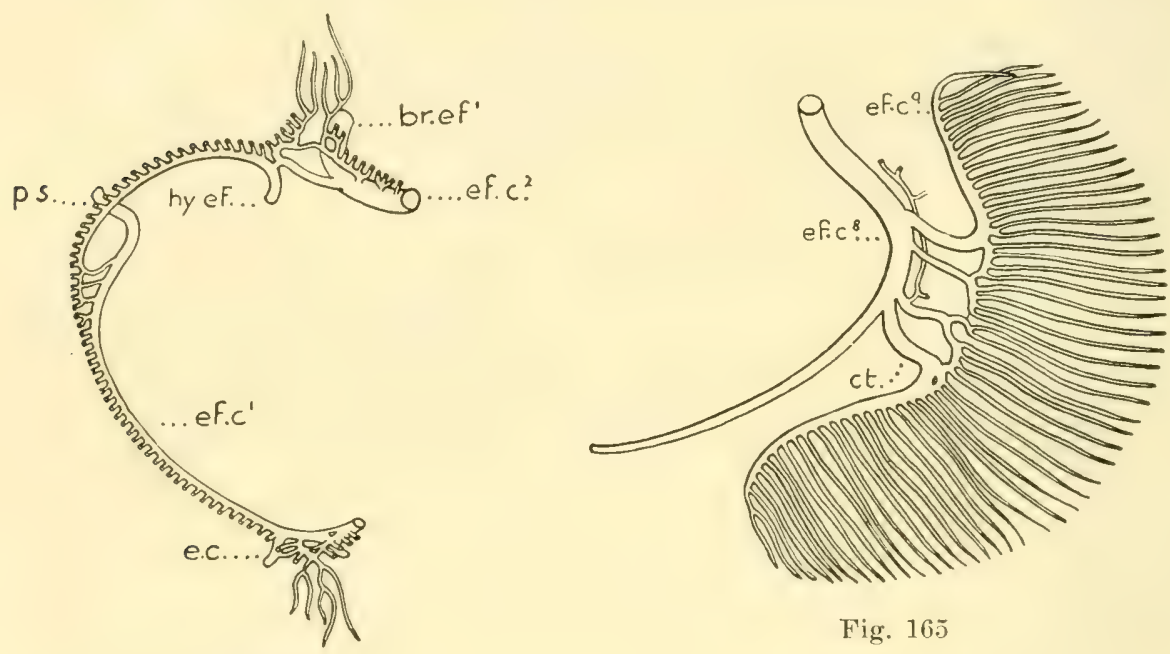

Fig. 165

Fig. 164

Fig. 164. Arteries derivative of the first efferent-collector, Squalus sucklii. (L. H. Bennett, orig.)

$b r . e f .{ }^{1}$, first branchial efferent; e.c., external carotid; ef.c..$^{1-2}$, first and second efferentcollector arteries; hy.ef., hyoidean efferent; $p s$., pseudobranchial artery.

Fig. 165. Cross-trunks from eighth to ninth efferent-collectors, Squalus sucklii. (L. H. Bennett, orig.)

ct., cross-trunk; ef.c. ${ }^{8-9}$, eighth and ninth efferent-collectors.

tain a dorsal commissural connection with the anterior efferent-collector of the same gill. This interesting condition obtains in the adult Chlamydoselachus (fig. 160). In this form the posterior efferent-collector sends a branch to join the efferent-collector back of it, but it also retains an embryonic attachment with the anterior efferent of its own holobranch. Usually, however, the branch connecting it to the suceeding efferent-collector becomes so important that the original connection of the posterior efferent-collector to its own efferent anteriorly is entirely lost in the adult. In any event there results in the adult a complete efferent circuit around the gill cleft, each circle being composed of the posterior efferent-collector of one gill and the anterior efferent-collector of the gill following. Around all the clefts (except the last) and the spiracle, complete loops are formed as thus described.

Since there are no demibranchs posterior to the last eleft no efferent-collector lies back of this cleft and hence a circuit is incomplete around it. The last posterior efferent-collector, that one in front of the last cleft, is usually 
separated from the anterior efferent-collector dorsally, and its blood reaches the anterior efferent-collector in front of it only by means of cross-trunks (c.tr., figs. 162 and 165). It is by means of such cross-trunks that the last efferent-collector is relieved of its blood. In fact, the posterior collector of

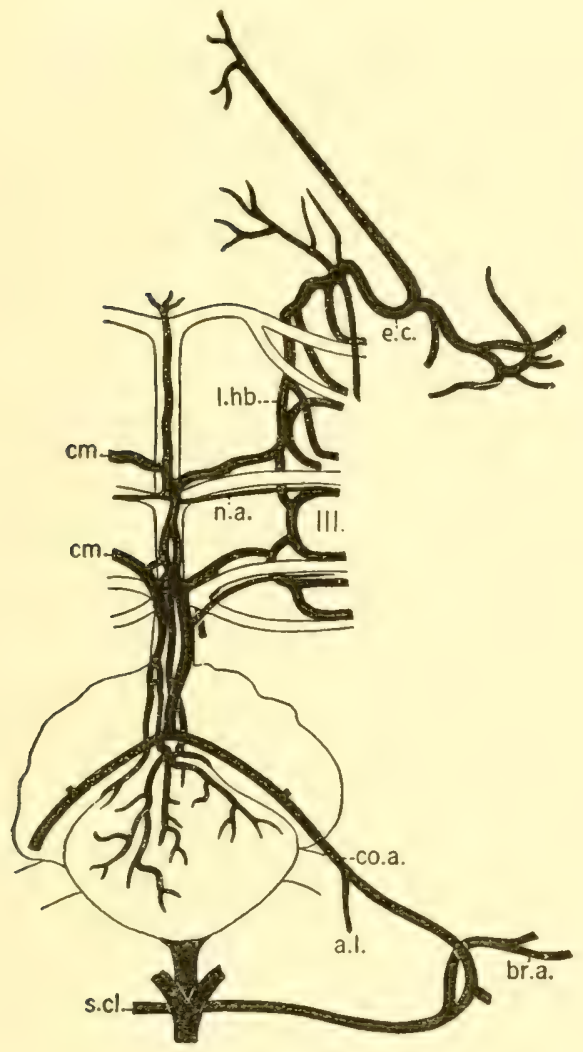

A

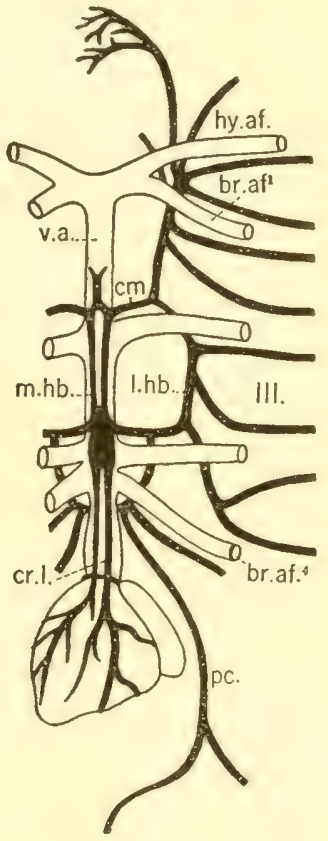

B

Fig. 166. Hypobranchial arteries. A. Mustelus antarcticus. (From T. J. Parker.) B. Mustelus canis. (From Ferguson.)

a.l., anterior lateral (lateral abdominal) artery; br.a., brachial artery; $b r . a f .{ }^{1-4}$, first and fourth branchial afferent arteries; co.a., coracoid artery; $\mathrm{cm}$., commissural artery; $c r . l .$, left coronary artery; er.p., posterior coronary; e.c., external carotid; hy.af., hyoidean afferent; $l . h b$., lateral hypobranchial; m.a., mandibular artery; m.hb., median hypobranchial; n.a., nutrient artery; $p c$., pericardial; s.cl., subclavian; v.a., ventral aorta; $I I I$, position of third gill eleft.

each gill empties a considerable amount of its blood into the anterior efferent-collector of its own gill by similar cross-trunks. These trunks may be numerous as in Heptanchus maculatus, few as in Squalus, or they may be single as in Dasyatis (c.tr., fig. 162).

The circuits made by the efferent-collectors, as we have said, are drained into the dorsal aorta by means of the efferent arteries. These arteries we shall consider after discussing certain branches given off by the efferent-collectors. 


\title{
BRANCHES OF EFFERENT-COLLECTORS
}

\author{
HYPOBRANCHIAL ARTERIES
}

The hrpolnanchial arteries in Elasmobranchs form a most complex system of ressels in the ventral walls and floor of the pharyngeal area. In general the ventral ends of the different efferent-collector loops may be more or less completely connected by a longitudinal vessel which, following Parker and Davis, I have termed in Heptanchus the lateral hypohranchial artery (l.hb., fig. 15:3).

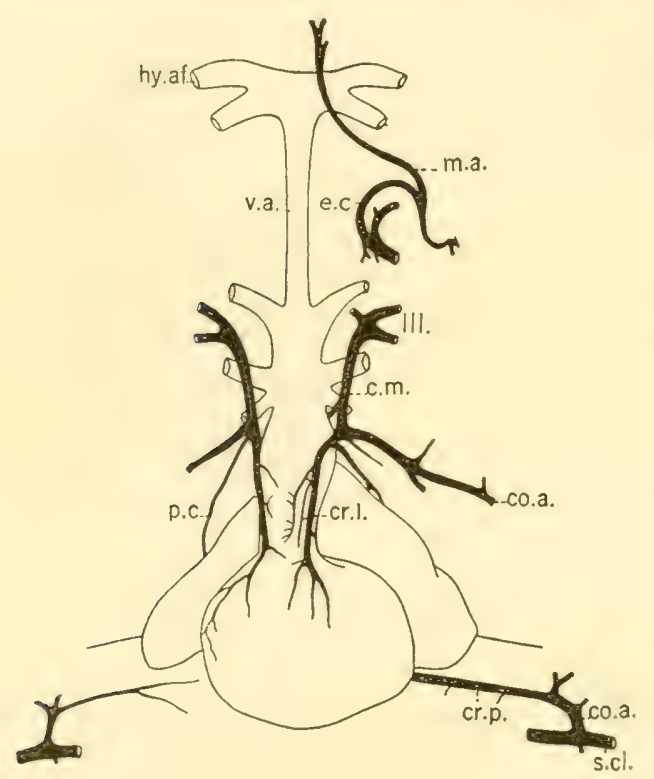

Fig. 167. Hypobranchial arteries, Dasyatis diptcrura. (Blanche Lillibridge, orig.) (For explanation see fig. 166.)

This vessel sometimes forms a continuous ventral chain on each side from the first to the fourth efferent-collector loop (Mustelus, fig. 166). In Raia erinacea, and sometimes in Carcharias littoralis, according to Parker and Davis (1899), the lateral hypobranchial may even include the fifth loop, but there is considerable irregularity about this. Whatever connections the loops may make with the lateral hypobranchials, however, the tendency is to make them in the region of the second and third branchial arehes rather than from the first or last loops. In other forms the lateral hypobranchial line is incomplete ( Raja clavata), and in still others a lateral hypobranchial is absent (Dasyatis dipterua, fig. 167).

Commissural arteries (cm.) may arise from the hypobranchial, at or posterior to the angles of the efferent-collector loops, and pass toward the midventral line anterior to the third and fourth afferent arteries (Mustelus antarcticus, fig. 166A); or only a single one may be present as is usual for Squalus sucklii. The commissurals passing from the lateral hypobranchials medially may meet paired median hypobranchials as in Heptanchus maculatus (fig. 153 and Hexanchus corinus, fig. 169). Some evidence of paired median ressels is also seen in Mustelus ( $m . h b .$, fig. 166). In certain forms the commissural may join an umpaired median hypobranchial as in Carcharias littoralis.

The commissures may be of a dorsal or a ventral type. In the former type the artery passes to the median line above the ventral aorta, while in the latter it passes below the ventral aorta. In Mustelus canis (fig. 166B) both commissures are of the ventral type; in Scyllium catulus both are of the dorsal 


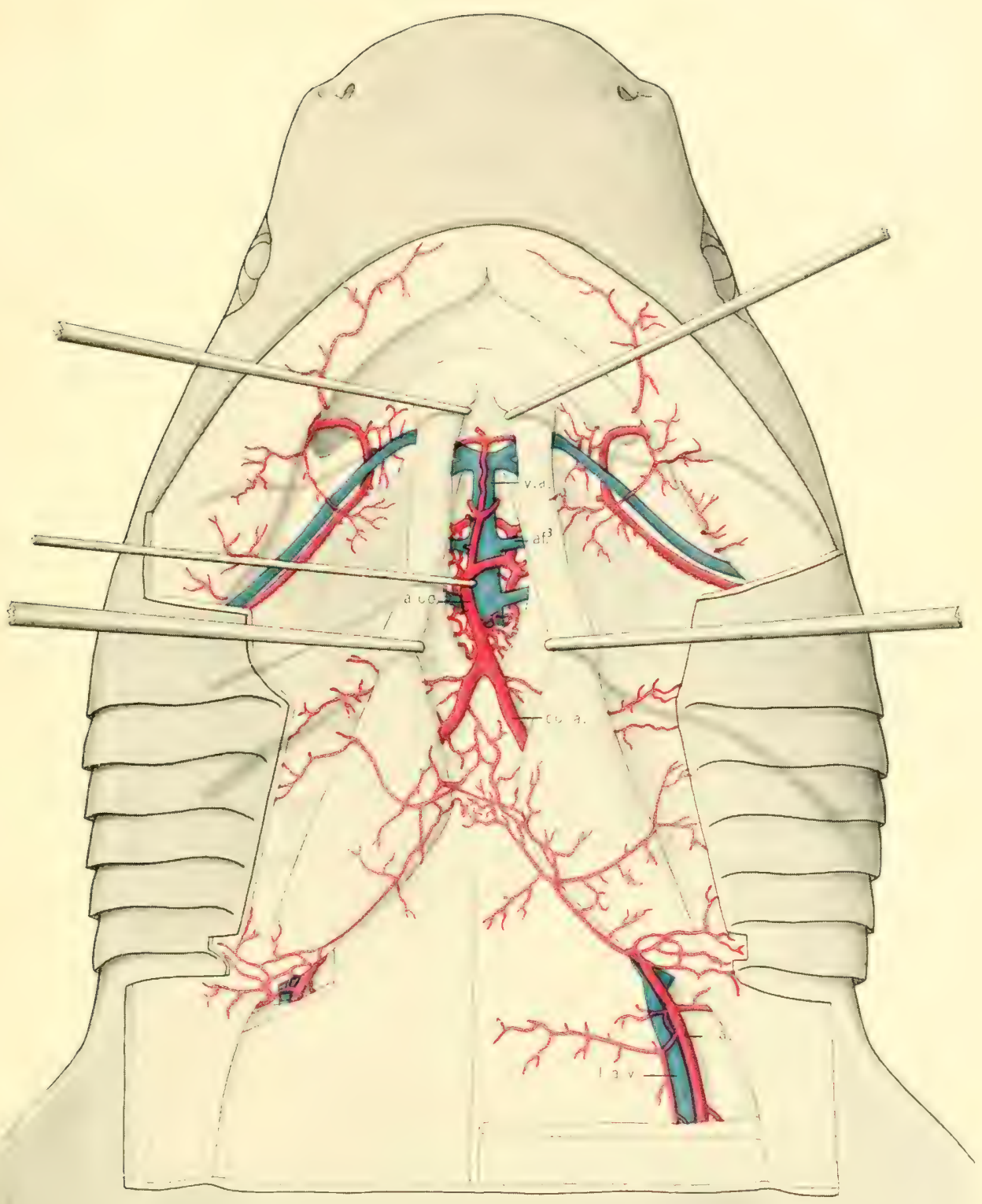

Fig. 168. Hypoloranchial arteries, Hexanchus corinus, ventral view. (From Keys.) a.co., median coracoid artery; af. ${ }^{3}$, third afferent artery ; co.a., coracoid artery ; l.a.. lateral (abdominal) artery ; l.a. ., lateral abdominal vein; p.cr., posterior coronary artery; v.a., ventral aorta. 

type. In Carcharias littoralis one is dorsal and the other ventral. In Zygaena two are ventral and a third is dorsal.

In Hexanchus corinus the median stem of the coracoid artery (co., fig. 169) arises from the left median hypobranchial and is continued posteriorly by the coracoid artery $\left(c o^{\prime}\right)$. 'The coracoid is continued as the lateral (abdominal) artery which follows the course of the lateral abdominal vein. From the lateral (abdominal) artery the brachioseapular artery (bsc., fig. 169) carries a large supply of blood to the pectoral area and joins the subclavian at a point where the brachial artery $\left(b r^{\circ}\right)$ is given off to the fin.

From the median hyprobranchials, or from the last commissural, the pericardial ( $p c$, fig. 1668) and the coronary arteries (cr.l.) may arise, and near the origin of pericardials and coronaries in the rays, the coracoid artery (co.a.) joins the last commissural (Dasyatis, fig. 167). In Carcharias littoralis a branch, designated by Parker and Davis as the epigastric, arises from the median unpaired hypobranchial.

The pericardial, as in Heptanchus, goes to supply the dorsal pericardial wall, and to furnish branches to the nesophagus and one or more epigastric arteries to

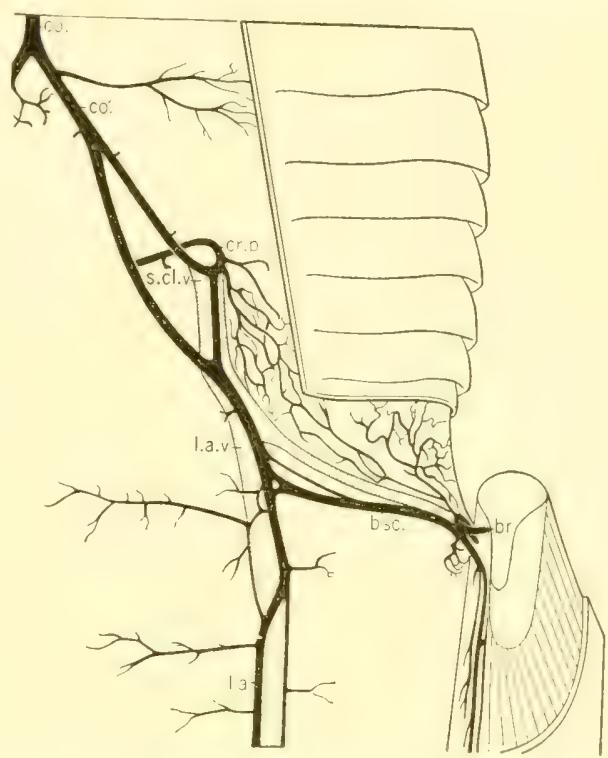

Fig. 169. Relations of coracoid to lateral (abdominal) artery, Hexanchus corinus, ventral view. (From Keys.)

co., median stem of coracoid artery ; co.', coracoid artery; br., brachial artery; bsc. brachioscapular artery; cr.p., posterior coronary artery; l.a., lateral (abdominal) artery; 7.a.r. latiral aldominal vein; s.el.e.. sulcelavian rein. the dorsal side of the stomach. An interesting condition obtains in Lamna cormubica (Burne, 1923) in which the pericardials, after having traversed the "supra-hepatic retia," supply practically the whole of the blood to the digestive tract.

The coronary arteries (cr.l., figs. 166B and 167) in the Elasmobranchs are unusually well developed. They may consist of a median ventral artery arising from the rentral type of commissure and a single dorsal arising from the dorsal type as in Carcharias littoralis. Or they may consist of a pair of ressels, the left one of which may go to the ventral side of the conus and ventricle, and the right to the dorsal side. In Heterodontus two pairs of coronaries are present, one of which is dorsal, the other ventral. In the rays, as in Heptanchus, a posterior pair of coronaries (cr.p., fig. 169) arises from the coracoid arteries and runs forward to the sinus venosus and ventricle. These coronaries are especially interesting in Dasyatis. While the right posterior artery extends 
only to the sinus venosus, the larger left one passes across the ventricle to unite with the right (dorsal) coronary forming a strong continuous vessel. A branch arising from this trunk on the ventricle passes across the conus to the left ventral coronary.

It will be observed that at the ventral angles of the efferent-collector loops are certain smaller nutrient vessels (n.a., fig. 166A) which supply arterial

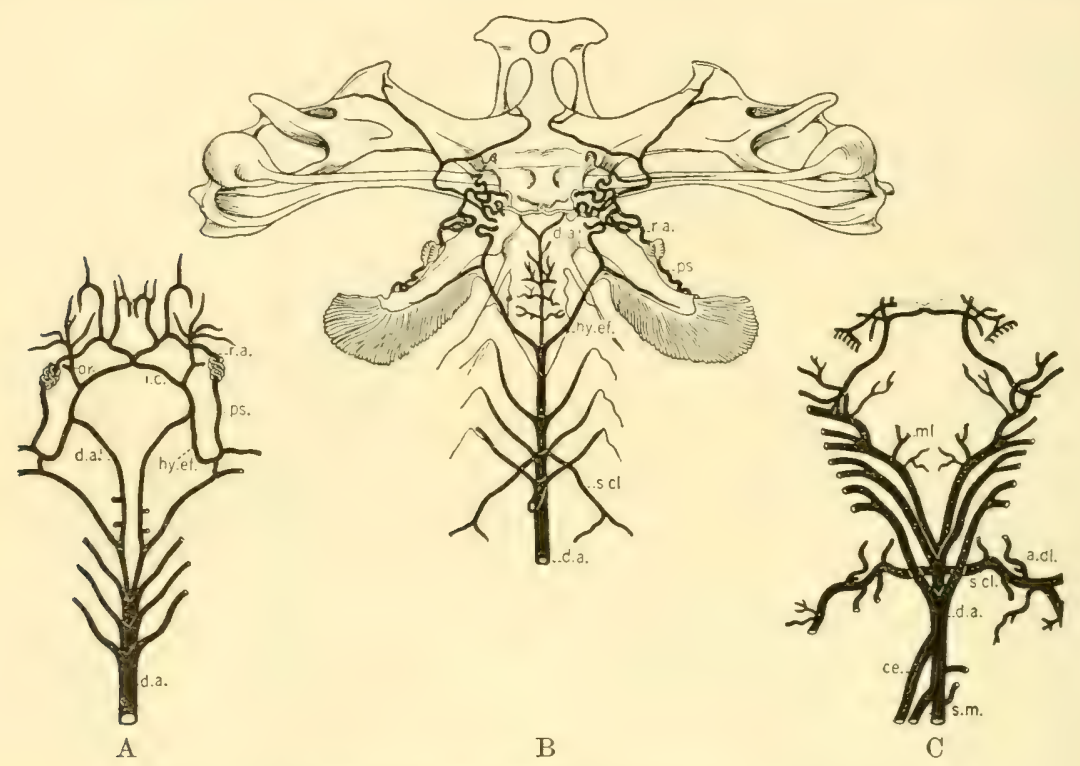

Fig. 170. The carotids and associated arteries. (From Hyrtl.)
A. Acanthias.
B. Zygaena.
C. Raja.

a.dl., anterior dorsal artery; ce., coeliae axis; d.a., unpaired dorsal aorta; d.a. ${ }^{1}$, paired dorsal aorta "vertebral artery"; hy.ef., hyoidean efferent; i.c., internal carotid; ml., myeIonal artery to cord; or., orbital (stapedial) artery; ps., pseudobranchial artery; r.a., ramus anastomoticus; s.cl., subelavian; s.m., superior mesenteric.

blood to the gills and surromding tissue. In Dasyatis arteries are well developed both at the ventral and the dorsal angles of the loops. Here they are accessory efferent-collectors ( $a c$, fig. 162) from accessory gills.

\section{AR'TERIAL SUPPLY TO HEAD}

In the Elasmobranchs in general the two branches from the first efferentcollector to the head are essentially like those noted in Heptanchus. They often differ, however, in extent of distribution. The first, the external carotid artery (e.c., figs. 164 and 166A), arises from the ventral angle of the hyoidean efferentcollector and its branches are similarly distributed, as in Heptanchus. The mandibular artery (m.a., fig. 167) extends toward the symphysis of the lower jaw and supplies structures in this area. The hyoid artery runs upward between the hyoid and the mandibular arch, giving off twigs along its course.

The second branch, the pseudobranchial, arising from the middle of the first efferent-collector, differs greatly in the sharks and rays (ps., fig. 164). Only in 
the sharks may it be spoken of as a true anastomoticus. In a type like Scyllium it courses by the spiracular region almost uninterruptedly and passes through a foramen in the orbit to join the internal carotid. In some of the other forms (Acanthias, Zygaena, fig. 170) instead of being straight it may pursue a most tortuous course. In these, and in many other forms it is interrupted at the spiracle. In Cetorhinus (fig. 171B), for example, it forms the so-called "won-
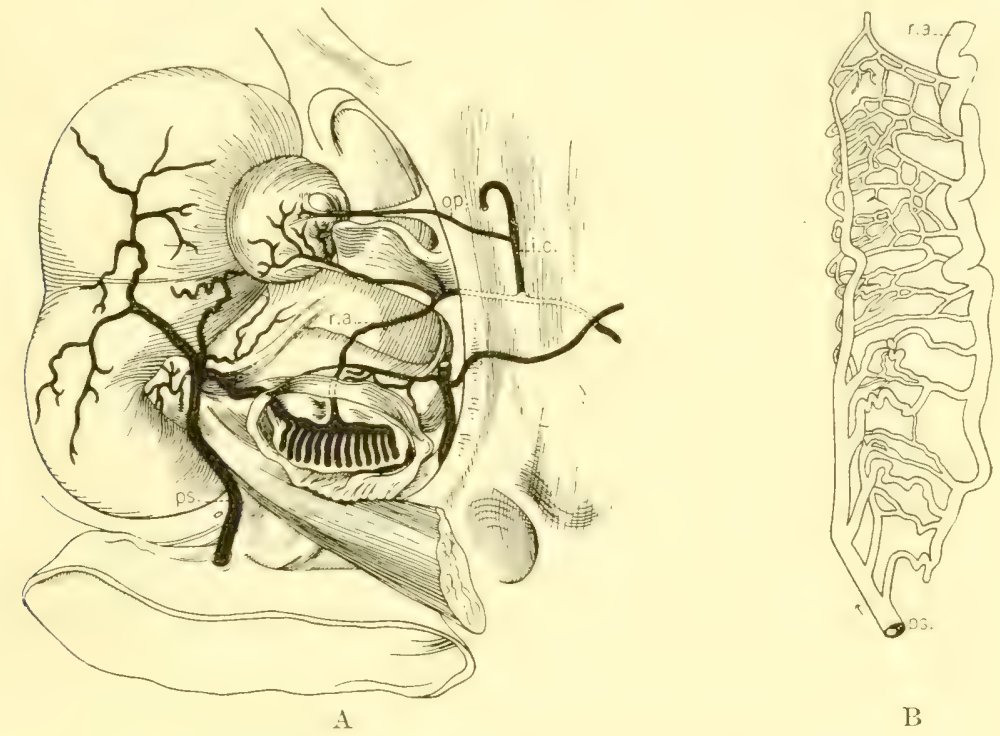

Fig. 171. Arteries associated with the spiracle.

A. Raja. (From Hyrtl.) B. Cetorhinus. (From Carazzi.)

i.c., internal carotid artery; op., optic artery; $p s$. , pseudobranchial artery; $r . a$. , ramus anastomotieus.

der net," the wonder net being composed of a coil of arteries comnecting the part going to the spiracle with the part leaving it.

A different condition is found in this artery in the rays. In these the spiracle is usually large and the blood supply to the filaments is better developed than in the sharks. The artery here takes its origin similarly from the first efferentcollector and as a large vessel ( $p s$. fig. 171A) passes toward the pseudobranch. Before reaching the latter, however, it gives off a large branch to the adductor mandibularis muscle. At the pseudobranch it separates into numerous filamentous arteries, and then continues as a smaller artery (r.a.) to join the internal carotid artery (i.c.), as in the sharks. On its way it gives off the ophthalmica magna to the eye.

Much attention has been given to the function of the ramus anastomoticus. In some of the sharks in which the spiracle is closed and in which the artery passes almost directly from the collector to the internal carotid, it is a true ramus anastomoticus. But in the rays it is composed of an afferent and an efferent part. It has been urged by Hyrtl (1858) that in the rays the branch connecting the internal carotid and the spiracular gill is the afferent branch 
to the spiracular pseudobranch and that it carries, at least in part, non-oxygenated blood from the eye; and further that the branch extending from the psendobranch to the first efferent-collector is the true efferent pseudobranchial.

In the embryo of Squalus acanthias the pseudobranchial (ps., fig. 163) is seen in relation to the remnant of the first embryonic arch, which at this stage has broken, and the segment from the ventral aorta is only a nodule $\left(a . a^{1}{ }^{1}\right)$. The psendohranchial itself is somewhat like a cross-trunk in that it is attached to the posterior efferent-collector, but it crosses a relatively long span through the posterior demibranch of the hyoidean gill and through what would be the anterior demibranch of the hyoidean gill and the posterior demihranch of the spiracular gill were such demibranchs present.

\section{EFFERENT ARTERIES}

We may now continue the description of the efferent arteries (see figs. 161162 ). In the large majority of forms five efferent arteries are present (pentanchid sharks). These represent the dorsal parts of the second to the sixth embryonic aortic arches and consist of the hyoidean and four branchial efferents. The hyoidean efferent artery passes forward and inward to join the paired dorsal aorta when such persists, or is continued into the head by the orbital (stapedial) artery (Heptanchus, fig. 152). In the embryo of Squalus acanthias (fig. 163) this vessel is relatively large where it joins the paired dorsal aorta. The four branchial efferents may reach the aorta as four arteries on each side (Selachians); or the first may fuse with the second so as to give only three pairs of branches (most rays, fig. 170c). In Hexanchus and in Chlamydoselachus (fig. 160) the fifth branchial efferent joins the fourth before entering the aorta just as, in Heptanchus, the sixth branchial joins the fifth.

The orbital (stapedial) artery may arise at the union of the hyoidean efferent and paired dorsal aorta (or., fig. 152) or it may arise near or anterior to this union (fig. 170A). When the latter condition obtains there is formed a common stem from which the orbital and the internal carotid spring. In the adult rays where the paired dorsal aortae may be absent the hyoidean efferent may continue directly into the common stem.

The orbital (stapedial) artery may reach the orbit without perforating the basis eranii as in Heptanchus, or it may enter by a foramen in the margin of the foramen through which the hyomandibular nerve enters (Heterodontus, p. 59, fig. 66). The orbital gives off one or two branches (Chlamydoselachus, fig. 160) which supply the muscles of the eye, and a second important branch which passes backward to the hyoid area where it may anastomose with the external earotid system. The main stem then passes forward under the eyeball and leaves the orbit through the orbitonasal canal. This stem gives oft a buccal artery which turns downward and backward to supply the adductor mandibulae muscle and finally the stem divides into the nasal and rostral arteries.

The internal carotid (i.c., left side, p. 163, fig. 152), which may be considered as the direct continuation of the paired dorsal aorta, enters the cranium 
through a foramen or pair of foramina in or near the middle line. Within the cranium it may be joined to the corresponding internal carotid of the opposite side by a cross-connective, as in Squatina; or the two may run for a short distance as a fused common trunk. 'The internal carotid then passes forward, and after receiving the ramus anastomoticus, gives off the optic artery (op., fig.

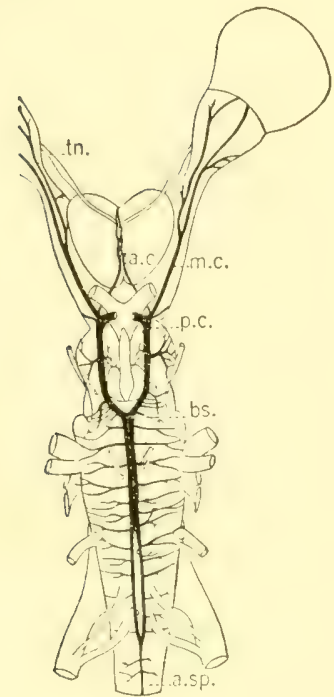

A

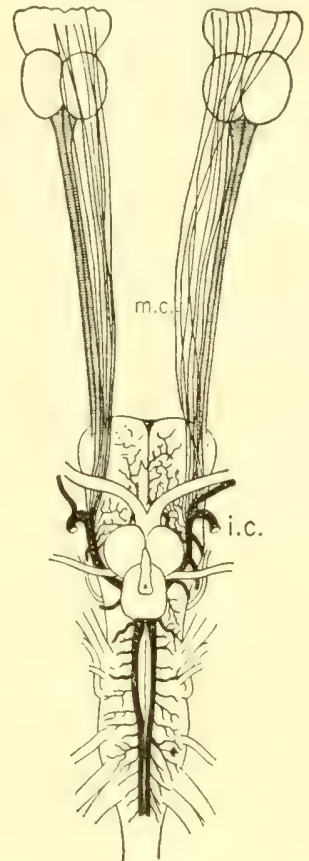

B

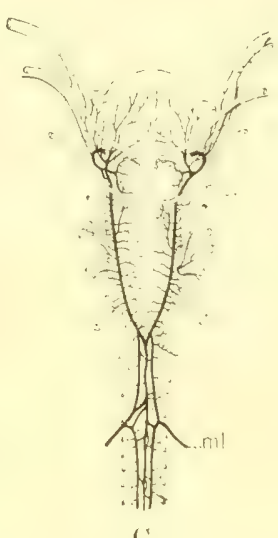

Fig. 172. Cerebral arteries. A. Squalus sucklii. (E. H. Barbera, orig.) B. Cetorhinus. (From Carazzi.) C. Raja clavata. (From Hyrtl.)

a.c., anterior cerebral artery; $a . s p .$, spinalis artery; $b s$. basal artery; i.c., internal carotid artery; m.c., median cerebral; ml, myelonal artery; p.c., posterior cerebral; tu., terminal nerve.

171A), which runs with the optic nerve to the eye. Each internal carotid then turns upward, as in Heptanchus, and divides into the three cerebral arteries which vary considerably in the different Elasmobranchs.

The cerebral arteries, consisting of an anterior, a median, and a posterior pair of arteries are, as we have seen in Heptanchus, derivatives of the right and left internal carotids. The anterior cerebral arteries (a.c., fig. 172A) pass forward ventrally around the lobi inferiores of the brain and over the optic chiasma; in front of this, right and left arteries may be put into communication by a cross-trunk. From here forward great variation ensues. In some types these arteries pass as single strands between the right and left divisions of the telencephalon. In others they extend forward as numerous branches (Heterodontus, rays). The median cerebrals (m.c.) extend under the telencephalon and along the olfactory tracts as fairly simple vessels (Squalus 
sucklii, fig. 172A). In certain forms they may extend forward in a number of strands (Cetorhinus, fig. 172B). The posterior cerebrals in Squalus (p.c., fig. $172_{A}$ ) loop around the inferior lobes of the brain and fuse into a single strand. By the union of right and left posterior cerebrals behind and the anterior cerebral in front a circle of Willis is formed somewhat like that in man. Further-

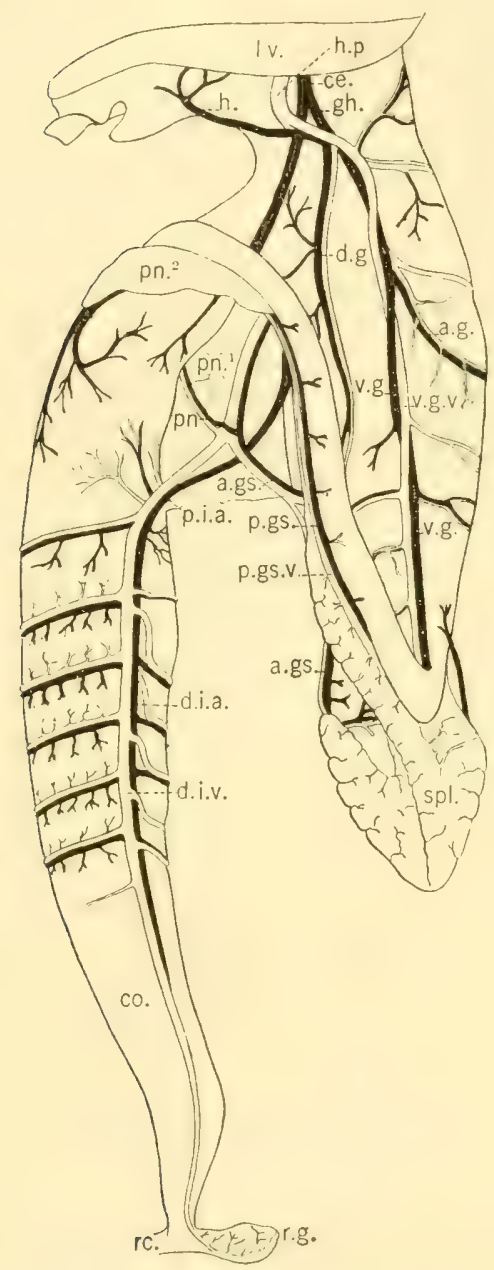

1

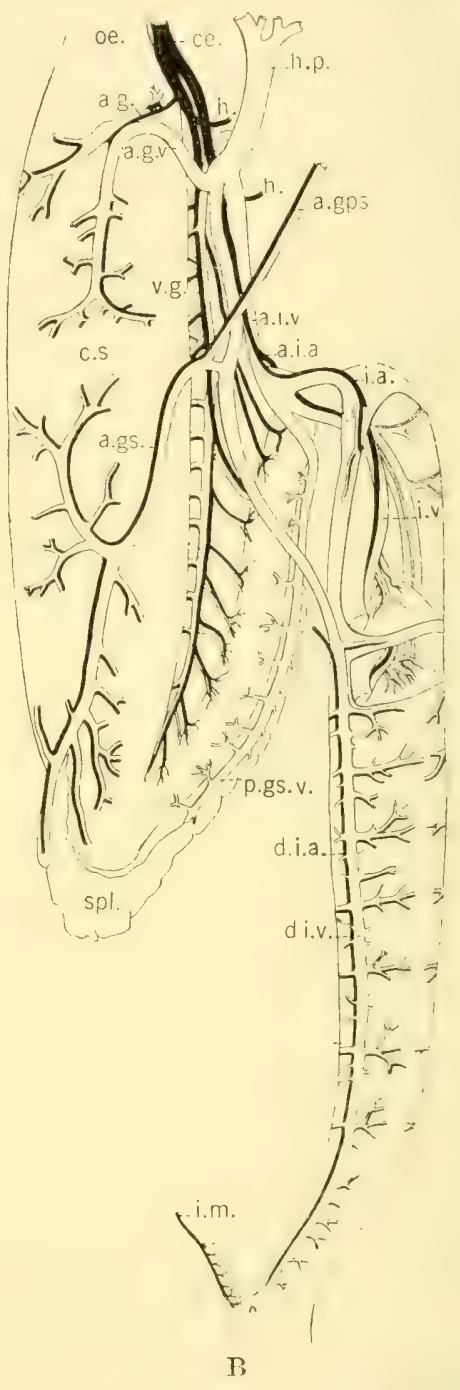

B

Fig. 173. Vascular supply to the digestive tract. A. Triakis semifasciatus, ventral riew. (Elizabeth Christiansen, orig.) B. Mustelus antarcticus, dorsal view. (From T. J. Parker.)

a.g., anterior gastric artery; a.g.v., anterior gastric vein; a.gps., anterior gastro-panereaticosplenic artery; $a . g s$. , anterior gastrosplenic artery; a.i.a., anterior intestinal artery; $a . i . v$., anterior intestinal vein; ce., coeliac axis ; co., colon; c.s., cardiae stomach; d.g., dorsal gastric artery; d.i.a., dorsal intestinal artery; d.i.v., dorsal intestinal vein; gh., gastrohepatic artery; $h$. , hepatic artery; h.p., hepatic portal vein; i.a., intraintestinal artery; i.v., intraintestinal vein; i.m., inferior mesenteric artery; $l v$., cut end of liver; oe., oesophagus ; p.gs., posterior gastrosplenic artery; p.gs.v., posterior gastrosplenic vein; p.i.a., posterior intestinal artery; $p n$., pancreatic artery; $p n .^{1-2}$, dorsal and ventral lobes of pancreas; $r c$., rectum; spl., spleen; v.g., ventral gastric artery; v.g.v., ventral gastric vein. 


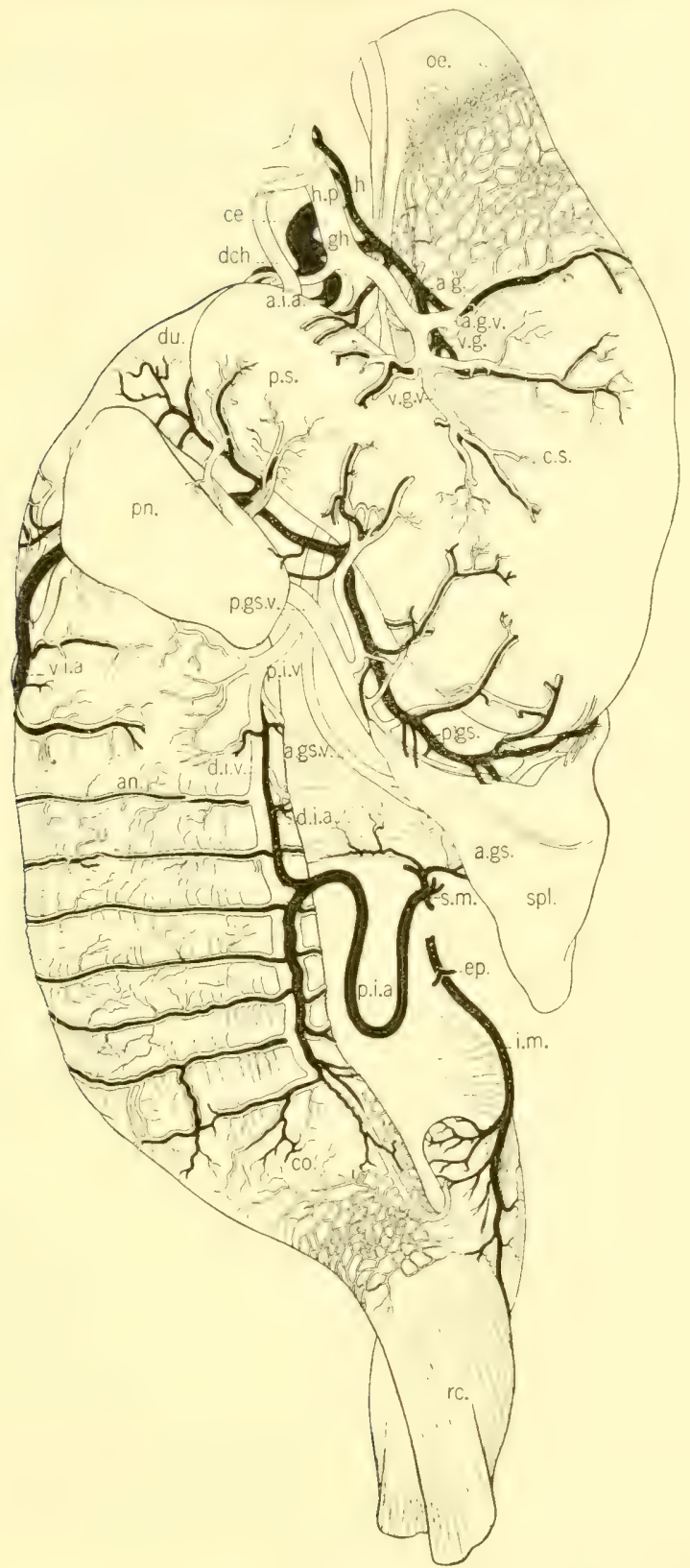

Fig. 174. Vascular supply to the digestive tract, Heterodontus francisci. (Duncan Dunning, del.)

a.g., anterior gastric artery; $a . g . v$., anterior gastric vein; a.gs., anterior gastrosplenic artery; a.gs.v., anterior gastrosplenic vein; a.i.a., anterior intestinal artery; an., annular artery; ce., coeliac axis; co., colon; c.s., cardiac stomach; dch., ductus choledochus; d.i.a., dorsal intestinal artery ; $d_{. i} . v_{\text {. }}$, dorsal intestinal vein; $d u$., duodenum ; ep., epigonal artery; $g h .$, gastrohepatic; $h$. , hepatic artery; $h . p$. , hepatic portal vein; $i . m$. , inferior mesenteric; oe., oesophagus; p.gs., posterior gastrosplenic artery; p.gs.v., posterior gastrosplenic vein; p.i.a., posterior intestinal artery; p.i.v., posterior intestinal vein; pn., pancreatic artery; p.s., pyloric stomach; rc., rectum; s.m., superior mesenteric artery; v.g., ventral gastric artery; v.g.v., ventral gastric vein; v.i.a., ventral intestinal artery. 
more, upon the posterior fusion of right and left cerebrals a midventral artery, the basilaris $\left(b_{s}\right.$ ), is produced, which supplies the medulla of the brain and as the spinalis (a.sp., fig. 172A) continues ventrally down the spinal cord. The spinalis will again he considered in our deseription of the arteries of the spinal cord. In Raja (fig. 172C) the posterior cerebrals form broad arches on the brain stem before uniting. Here the spinalis is made up of several strands. According to Hyrtl it receives the myelonal vessel ( $m l$.) from the united first and second efferents, as was seen in figure $170 \mathrm{c}$.

\section{Arterial Supply to Trunk}

\section{DORSAL AORTA}

The dorsal aorta in all the Elasmobranchs is supplied with blood from the branchial efferent arteries; it extends through the body and is continued into the tail as the caudal aorta. It arises in the embryo as a pair of arteries. Evidence of this condition may be absent in the adult, but in forms like Acanthias and Zygaena the anterior part of the aorta, "the vertebral," to which the second embryonic aortic arch is attached, indicates the paired condition. In Acanthias the paired aortae ( $\left(a{ }^{1}{ }^{1}\right.$, fig. 170$)$, as widely separated arteries, pass forward and are joined by the hyoidean efferents; while in Zygaena (fig. $170 \mathrm{~B}$ ) the two are fused far forward. In the adult ray, on the contrary (fig. $170 \mathrm{C}$ ), all indication of the paired aortae is lacking. In the region of the trunk the paired embryonic aortae early fuse into a single median dorsal aorta, which is the source from which many vessels arise. These arteries, as in Heptanchus, spring from the aorta either as paired or as unpaired vessels.

\section{UNPAIRED ARTERIES}

The unpaired arteries in anteroposterior direction are the coeliac axis (ce., figs. 173-175), the superior mesenteric ( $s . m$.), and the so-called inferior mesenteric $(i . m$.$) arteries. When a fourth is present, as is usual in the sharks, it$ is due to a failure to form a superior mesenteric, the two branches of which arise separately from the dorsal aorta.

\section{COELTAC AXIS AND ITS BRANCHES}

The coeliac axis (ce., figs. 173-175) arises posterior to the union of the fourth branchial efferents and behind the paired subclavians. In some forms this is a relatively short trunk (Mustelus), while in others it is long (Acanthias). Normally as in Heterodontus (ce., fig. 174) it supplies the gonad and then divides into two parts, one of which, the gastrohepatic ( $g h$.), supplies the stomach and the liver; the other, the anterior intestinal.(a.i.a.), passes backward to the region of the intestine.

The gastrohepatic may be a fairly well developed segment as in Triakis (fig. 173A). It is, however, usually a short trunk as in Acanthias; or it may be en- 
tirely absent (Dasyatis, fig. 175). The gastric arteries follow much the same plan in the Elasmobranchs generally as has been described for Heptanchus. In certain forms, however, a dorsal gastric may be well developed.

The hepatic artery may arise as a single trunk, Heptanchus, or a hepatic branch may be given off from the anterior intestinal artery, as in II ustelus antarcticus (fig. 173B). Occasionally a second hepatic branch may be given off from the ventral gastric in Triakis. The hepatic artery (or arteries) supply twigs to the ductus choledochus, to the gall bladder, and to the liver.

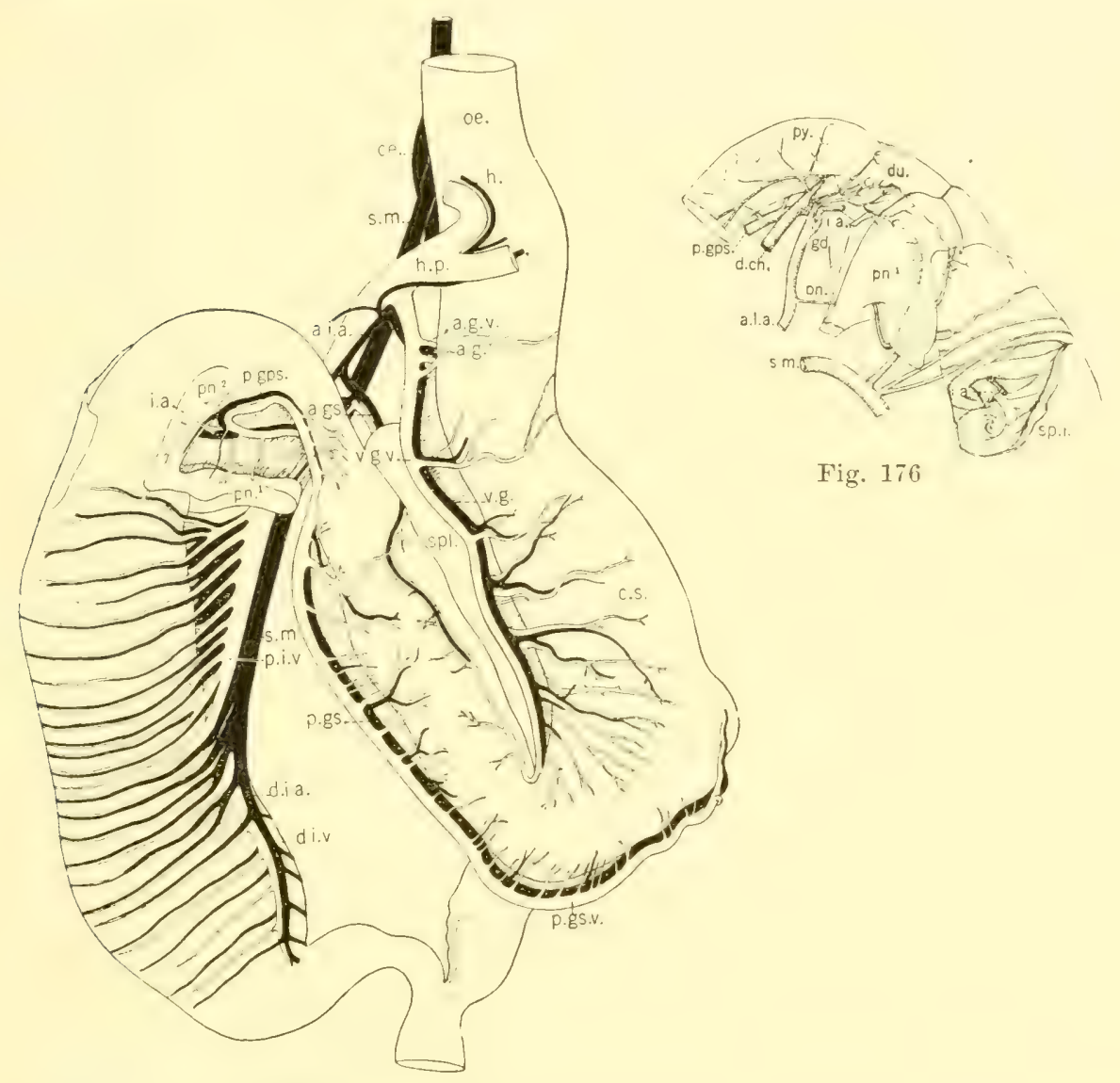

Fig. 175

Fig. 175. Arteries to the digestive tract, Dasyatis dipterura, ventral view. (Blanche Lillibridge, orig.)

Fig. 176. Duodenal supply, Dasyatis dipterura, dorsal view. (Blanche Lillibridge, orig.) a.g., anterior gastric artery ; a.g.v., anterior gastrie vein; a.gps., anterior gastro-pancreaticosplenic artery; a.gs., anterior gastrosplenic artery; a.i.a., anterior intestinal artery; $c e$, coeliac axis; c.s., eardiac stomach; d.i.a., dorsal intestinal artery; d.ch., ductus choledochus; d.i.v., dorsal intestinal vein; $d u$., duodenum; gd., gastroduodenal artery; $h$. , hepatic artery; h.p., hepatic portal vein; i.a., intraintestinal artery; oe., oesophagus; p.gps., posterior gastro-pancreaticosplenic artery; p.gs., posterior gastrosplenic artery; p.gs.v., posterior gastrosplenic vein; p.i.v., posterior intestinal vein; $p n$. , pancreatic branch; $p n_{.}{ }^{1-2}$, dorsal and ventral lobes of pancreas; $p y$. , pylorus; s.m., superior mesenteric artery; sp.i., valvular intestine; $v . g$., ventral gastric artery; $v . g . v$, ventral gastric vein. 
The anterior intestinal artery (a.i.a., figs. 173 and 174) is a relatively large vessel in the sharks, while in the rays it is usually less important. In both it is continued as the intraintestinal (i.a.) along the free edge of the spiral valve. In sharks before it enter's the intestine as the intraintestinal it gives off the rentral intestinal artery which rums along the ventral side of the valvular intestine to which it gives numerous annular branches. In the rays a ventral intestinal artery is characteristically absent.

In Dasyatis the anterior intestinal gives off an anterior gastro-pancreaticosplenic artery (a.gps., fig. 175), which in sharks is given off from the dorsal aorta. In Rhimobatis and Raja this artery is a branch from the superior mesenteric artery. This artery sends a strong branch to the dorsal lobe of the pancreas (fig. 175), and then, as the anterior gastrosplenic (a.gs., fig. 173B) dirides, supplying the spleen and the dorsal side of the cardiac stomach. Just hefore the anterior intestinal disappears as the intraintestinal it gives off a posterior gastro-pancreaticosplenic ( $p . g p s$ s, fig. 176), which artery after supplying pancreatic branches to the ventral lobe of the pancreas passes in the gastrosplenic omentum around the onter margin of the pyloric stomach as the posterior gastrosplenic artery ( $p . g s$., fig. 175). In the rays, where there is no spleen on the angle of the stomach, all the branches of this artery go to the stomach. A second branch, the gastroduodenal artery $(g d$.$) , is given off at$ about the same place or farther posteriorly (Raja) from the anterior intestinal artery. This supplies the duodenum and may also supply the dorsal side of the pyloric arm of the stomach as did a similar artery in Heptanchus.

There is usually considerable anastomosing of the branches on the pyloric angle of the stomach. Branches of the anterior gastrosplenic join with those from the posterior gastrosplenic as also do branches from the ventral gastric artery.

\section{SUPERIOR MESENTERIC ARTERY}

The superior or anterior mesenteric artery is variable as to its place of origin. It may arise in the midbody far removed from the coeliac axis, as in Heterodontus (s.m., fig. 174), or it may more nearly approach the coeliac as in Scyllium, Galeus, Triakis (fig. 173A). In the rays the superior mesenteric and the coeliac are often in close proximity (Raja clavata; Dasyatis, fig. 177в). The office of the superior mesenteric in the sharks is to supply blood to two general areas. The main artery to one of these areas is the anterior gastro-pancreaticosplenie (fig. 173B), which supplies the distal part of the eardiac stomach (a.gs.), the pancreas, and the spleen. The other is the posterior intestinal (p.i.a.), which is continued along the dorsal wall of the valvular intestine as the dorsal intestinal artery (d.i.a.).

A superior mesenteric, as just described, is present in Heterodontus (sm., fig. 174) and may oceasionally he found also as a short trunk in Acanthias (out of 500 specimens examined in Squalus suclilii seven had short superior mesenteric trunks). In this form, then, while a short trunk is oceasionally present, in the majority of occurrences the branches of the superior mesenteric arise sepa- 
rately from the dorsal aorta. In such, the posterior intestinal arises anterior to and crosses over the anterior gastro-pancreaticosplenic. 'This condition is characteristic of many types of which it should be said that no true superior mesenteric artery exists.

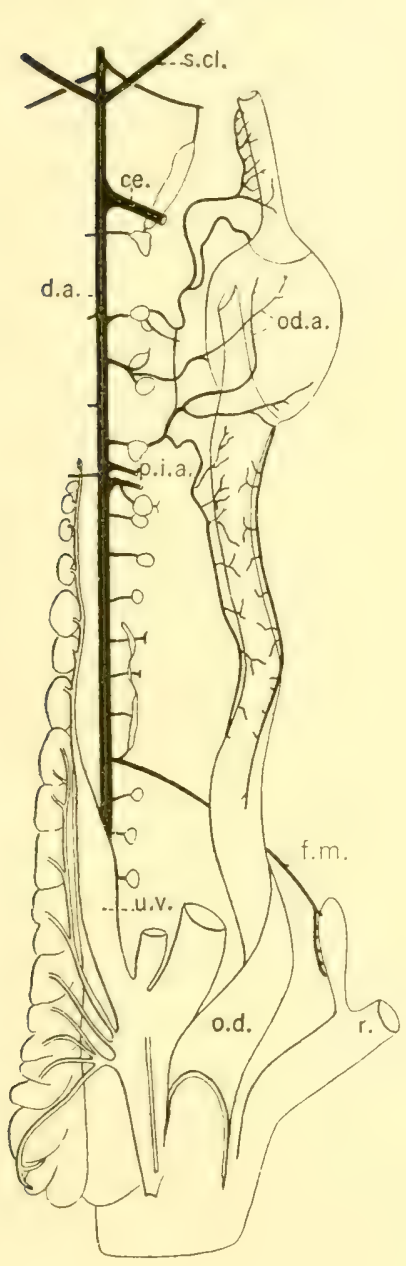

A

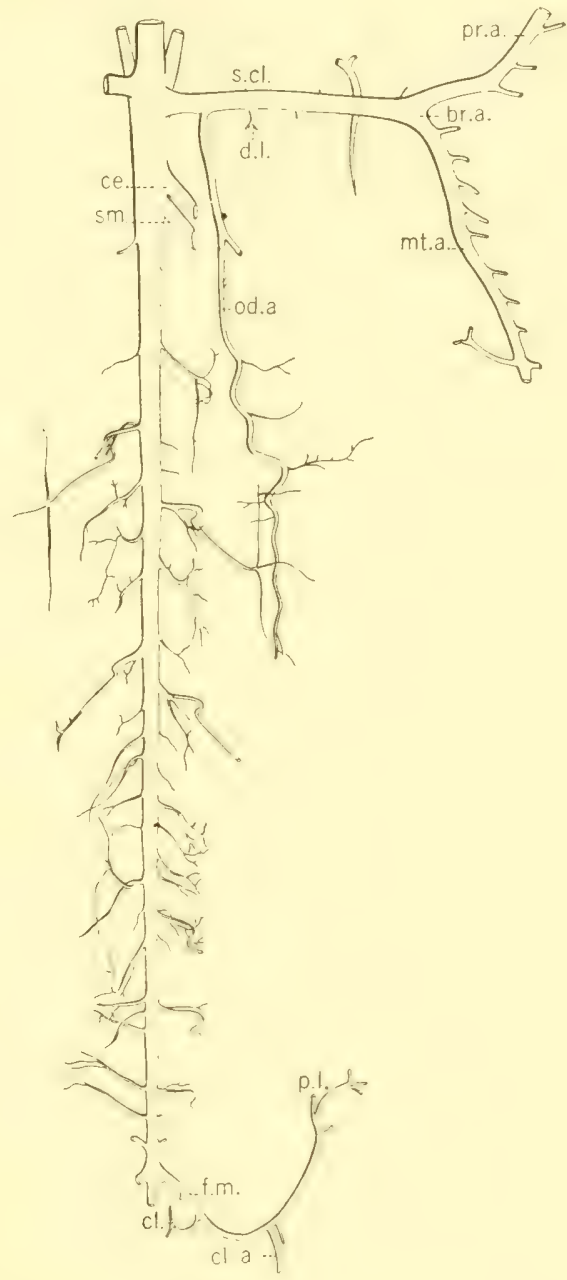

$\mathrm{B}$

Fig. 177. Dorsal aorta and its segmentals. A. Scyllium. (From Carazzi.) B. Dasyatis. (Blanche Lillibridge, orig.)

br.a., brachial artery; ce., coeliae axis; cl., cloacal branch; cla., branch to elasper; d.a., dorsal aorta; d.l., dorsolateral artery; f.m., iliae artery; mt.a., metapterygial artery; $0 . d$. oviduct; od.a., oviducal artery; p.i.a., posterior intestinal artery; p.l., posterior lateral artery; pr.a., propterygial artery; r., rectum; s.cl., subclavian artery; s.m., superior mesenteric; $u . v$., urinary vesicle.

The anterior gastro-pancreaticosplenic (a.gps.) is contrasted with the posterior gastro-pancreaticosplenic (p.gps.), previously described, by its supplying a more anterior (proximal) segment of the digestive tract. While, as we have seen, the posterior artery of this name is in relation to the pyloric part 
of the stomach, the anterior gastro-pancreaticosplenic supplies the cardiac stomach. Its gastric part divides into two branches which supply the dorsal and distal halves of the cardiac stomach. The branch supplying the dorsal half may anastomose with twigs from the dorsal gastric artery which in Wus-

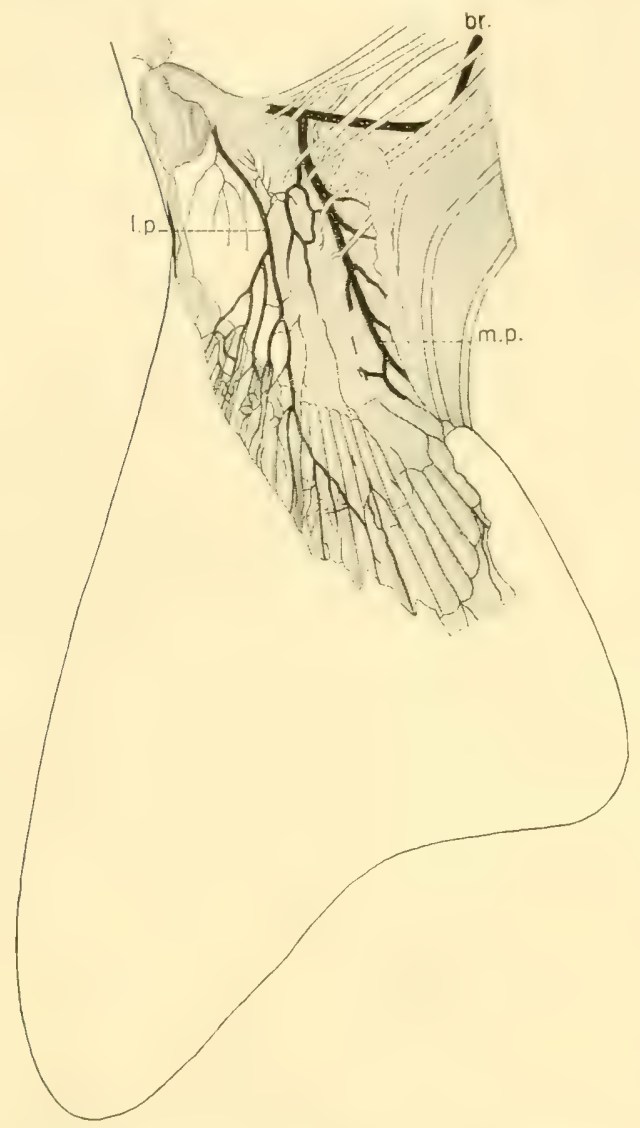

Fig. 178. Arteries of the pectoral fin, Acanthias, dorsal view. (From Erik Müller.)

br., brachial artery; l.p., lateral pterygial artery; m.p., median pterygial. coeliae, that is, the anterior gastro-pancreaticosplenic which in sharks, as a branch of the superior mesenteric, arises from the anterior intestinal artery, which is a derivative of the coeliac axis.

\section{INFERIOR MESENTERIC ARTERY}

The inferior or posterior mesenteric artery (i.m., figs. 173 and 174) usually arises as a single vessel, except occasionally as in Acanthias (see fig. 179), and is more or less removed from the anterior mesenteric. It supplies branches to the epigonal organ or non-functional part of the sex gland in forms in which such exists (Heterodontus, fig. 174, ep.; Triakis, and Mustelus antarcticus), 
and then runs to the rectal gland and the surrounding parts of the digestive tract, where it breaks up into a network of vessels. Unlike Heptanchus, however, it does not usually anastomose with the dorsal intestinal artery.

Occasionally median vessels arise from the dorsal aorta posterior to the origin of the inferior mesenteric. They are characterized by passing directly downward to the region of the rectum and, oceasionally, to the oviducts. Such ressels may be present in Acanthias and one or several of them may be present in Raja. These vessels have been held by Howes (1891) to represent the true inferior mesenteric comparable to that in mammals.

\section{Paired Branches of Aorta}

\section{SUBCLAVIANS AND ILIACS}

The subclavians of the more specialized Selachii are similar in position to the same arteries in Heptanchus (s.cl., fig. 157) and Hexanchus (fig. 169). Considerable variation in the origin of the subclavians may occur. As a rule they are given off from the dorsal aorta at the region between the third and fourth pairs of efferent arteries, but they may arise farther back at the base of the fourth pair of efferents (Dasyatis, fig. $162, s . c l$.$) . While their origin is usually sym-$

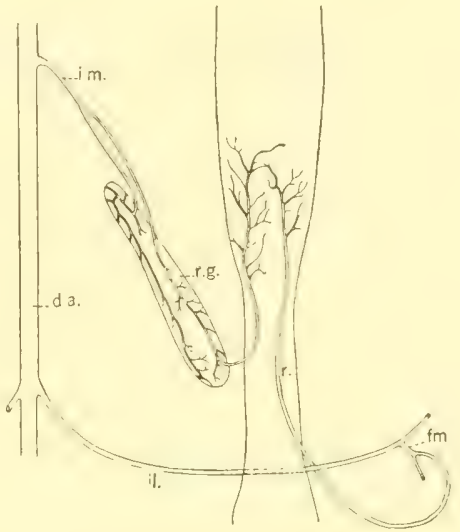

Fig. 179. Relations of rectal artery, Squalus sucklii. (C. E. Bird, orig.)

d.a., dorsal aorta; fm., femoral artery; il., iliac artery; $i . m$., inferior mesenteric; $r$, rectal artery; $r . g$., rectal gland. metrical, sometimes right and left arteries, as Monroe (1785) long ago claimed for the ray, arise asymmetrically. Such a condition is found in Dasyatis (fig. 177B).

The subelavians (fig. 166A) are usually much stronger vessels than are those of Heptanchus where they take little blood from the dorsal aorta. In some specimens of Heptanchus twigs given off from the subclavians indicate that the blood is flowing toward the dorsal aorta. In other types, as the subclavians pass outward along the pectoral girdle they give off important branches which differ considerably in the sharks and the rays. Usually in both, after the dorsolateral (a.dl., fig. 170c) is given off it divides into a relatively large branch which passes forward across the scapula, and another which passes backward between the bundles of muscles. The brachial leaves the subclavian and enters the foramen of the pectoral girdle. As it passes through the girdle it follows the ventral canal and consequently enters the fin on the ventral side (Squalus).

In the fin of Acanthias the brachial artery separates into a median pterygial (m.p., fig. 178) and a lateral pterygial artery (l.p.). In the rays the brachial separates into a strong branch to the propterygium and another to the metapterygium. From these branches numerous smaller arteries run to the radial muscles of the fin. 
The subclavian is continued ventrally along the coracoid segment of the girdle by the coracoid artery (co.a., fig. 166A), which at the ventral part of the girdle gives off posteriorly the anterior lateral artery (a.l.) which is the anterior part of the lateral (abdominal) artery. This artery, as in Heptanchus, runs under the walls of the lateral abdominal vein and continues posteriorly past the iliac artery. As the coracoid is followed forward and inward it is seen to meet its fellow from the opposite side in the midventral line and to give off the posterior coronary (cr.p., figs. 153 and 169) to the heart. By the union of right and left coracoids a median stem is formed. This stem joins the commissurals from the ventral efferent-collector loops.

The iliaes have the same form and take the same direction as the renal arteries but their terminal parts extend into the pelvic fins as the femoral arteries. The iliac artery arises from the posterior part of the lateral (abdominal) artery (p.l., figs. 157 and $f . m,, 177_{\mathrm{B}}$ ). In the rays Parker has figured renal arteries arising from the iliacs. These renal arteries apparently are not comparable to the rectal artery in Heptanchus. A rectal (hypogastric) artery in Squalus sucklii (r., fig. 179) may arise from the femoral or from the iliac. As in Heptanchus maculatus it runs to the digestive tract and anastomoses with the posterior intestinal. The iliac is continued to the pelvic fin as the femoral which distributes smaller arteries both to the dorsal and the ventral sides of the fin.

\section{SEGMENTALS}

For convenience the segmentals may be divided into three groups. One group consists of the musculospinal arteries (fig. 170A), anterior to the subclavian arteries; the second group is situated between the subclavians and the iliaes; and the third set is posterior to the iliaes in the region of the tail.

The musculospinal arteries are usually paired, but sometimes they are more or less irregularly arranged. The first pair of these in Heterodontus passes upward and around the spinal column and through small canals in the posterior walls of the cranium (see p. 54, fig. 61). The intereostal branches of these segmentals may divide just over the pharynx as in Zygaena (fig. 170B), or they may be regular as in Acanthias (fig. 170A). In Raja the myelonal artery ( $m l$., fig. $170 \mathrm{c}$ ) supplies the spinal cord.

A trunk segmental sends a large vertebromuseular branch dorsally around the vertebra and up the dorsal septum to the middorsal line. As seen in a transverse section of Squalus sucklii (d.vm., fig. 180) this artery gives rise to a number of branches, the most dorsal of which (dms.) passes upward along the myoseptum to supply the musculature of the dorsomedian bundle. In the region of the dorsal fins large branches of this artery extend into the fins. The next branch given off, the vertebrospinal artery, passes mediad through the neural arch to supply the spinal cord. Inside of the neural canal this artery divides into a dorsal branch, the ramus dorsalis (Acanthias, fig. 181, d.r.), and a ventral branch, the ramus ventralis $\left(v . r_{0}\right)$. The smaller ramus dorsalis forms the tractus arteriosus lateralis $\left(t_{.} l_{\text {. }}\right)$, which passes both backward and for- 
ward on the cord. The ramus ventralis passes to the midventral line where it enters the arteria spinalis (a.sp.). Branches, especially from the tractus lateralis, enter the substance of the cord and terminate in large part around the grey matter (Nterzi, 190t). Other branches given off laterally from this dorsal branch of the segmental pass outward in a spiral direction along the myoseptum dorsally and laterally to the muscle bundles.

The segmental, as the intercostal (i., fig. 180), is continued laterally to supply the musculature encircling the peritoneum. The intercostals in all recent Elasmobranchs are reduced in number (fig. 177). While in Heptanchus there are about thirty pairs, in the rays they may be reduced to only a few pairs, and those remaining may present great irregularities in size and position. This irregularity is especially noticeable in the trunk region where there is a considerable crowding of the viscera.

The most ventral branch of the segmental, the renal artery ( $\left.r n_{0}\right)$, turns ventrally and enters the tissue of the kidney. In the posterior region where the kidney is enlarged the vessels come to be strong trunks which pass downward, then sharply backward, to break up into numerous branches.

The renal divisions of the segmental artery may be modified as the oviducal arteries. In Scyllium several pairs of the segmentals just posterior to the subclavians (od.a., fig. 177A) pass to the oviduct and shell glands. The fourth to the sixth are the main ones, which pass to the oviduct and along the greater part of its length. In Heterodontus francisci two sets of these arteries are present. An anterior set arises from the eleventh and twelfth segmentals, and a posterior set from the nineteenth and twentieth segmentals. The oviducals anastomose on the oviduct and in viviparous types send arteries to the inner lining of the uterus to supply the villi. In those forms in which the young are carried for a considerable time the oviducal

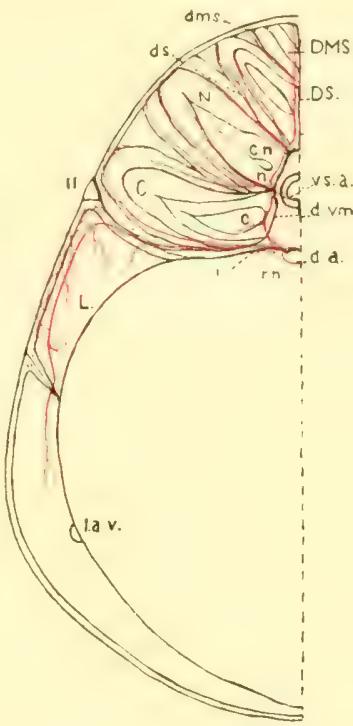

Fig. 180. Transverse section through trunk region, Squalus sucklii, showing branches of a segmental artery. (From Coles.)

C., central muscle bundle; c., artery to central bundle; d.a., dorsal aorta; DMS., dorsomedial septal bundle of museles; dms., dorsomedial septal artery; $D S$. , dorsal septal bundle; ds., dorsal septal artery; d.vm., dorsal vertebromuscular artery; $i$, intercostal artery; $L$., lateral bundle; la.v., lateral abdominal vein; $l l$., lateral line; $N$., neural muscle bundle; $n$., artery to neural bundle; $n$. renal artery; vs.a., vertebrospinal artery. arteries may be remarkably developed (Acanthias, see p. 306, fig. 267A; Rhinobatis).

\section{CAUDAL SEGMENTALS}

The segmentals in the region of the tail differ somewhat from those of the body just described. The principal change is the result of the haemal arch. The segmental, in addition to sending a vertebromuscular branch upward, sends 
a similar rertebromuscular branch downward to supply the segment at the sides of the haemal arch. Branches from this ventral artery supply the ventral muscles in the caudal region. From the ventral branch of the vertebromuscularis, the anal fin, where such is present, and the rentral lobe of the caudal fin

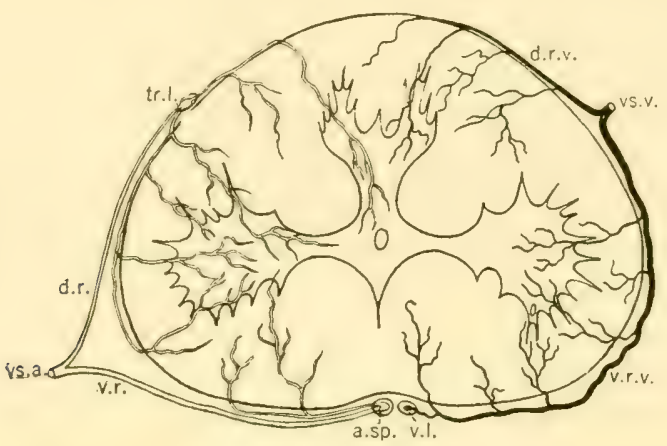

Fig. 181. Arteries and veins of the spinal cord, Acanthias. (From Sterzi.)

a.sp., arteria spinalis; d.r., ramus dorsalis artery; d.r.v., dorsal ramus vein; tr.l., tractus lateralis; v.l., vena limitans; v.r., ramus ventralis artery; v.r.v., ventral ramus vein; vs.a., vertebrospinal artery; vs.v., vertebrospinal vein.

are supplied with arterial blood. The ventral branches in the region of the fins are better developed than are those of the dorsal series. In a type like Squatina where a dorsal fin is located on the tail the dorsal branches similarly supply this fin as well as the dorsal lobe of the caudal fin. 


\section{BIBLIOGRAPHY}

\section{Chapter VII}

1908. Alits, E. P., Jr., The Pseudobranchial and Carotid Arteries in the Gnathostome Fishes. Zool. Jahrb. (Abt. Anat. u. Ontog.), Bd. 27, pp. 103-134, pl. 9.

1911. Aluis, E. P., Jr., The Pseudobranchial and Carotid Arteries in Chlamydoselachus anguineus. Anat. Anz., Bd. 39, pp. 511-519, 2 text figs.

1912. Allis, E. P., Jr., The Branchial, Pseudobranchial and Carotid Arteries in Heptanchus (Notidanus) cinereus. Anat. Anz., Bd. 41, pp. 428-492, 2 text figs.

1889. Ayers, H., The Morphology of the Carotids, based on a study of the Blood-Vessels of Chlamydoselachus anguineus. Bull. Mus. Comp. Zool. Harvard Col., Vol. 17, pp. 191-223, 1 pl.

1909. BuiJtendis, F. J. J., On the Changes in the Blood Serum of Sharks after Bleeding. (Proc.) Akad. Wet. Amsterdam, Vol. 12, pp. 377-380.

1923. Burne, R. H., Some Peculiarities of the Blood-vascular System of the Porbeagle Shark (Lamna cornubica). Philos. Trans. Roy. Soc. Lond., Vol. 212, B, pp. 209257, pls. 9-10, 16 text figs.

1904. CARAzzI, D., Sulla circolazione arteriosa cardiaca ed esofagea dello Scyllium catulus (stellare). Monit. Zool. Ital. Firenze, Vol. 15, pp. 147-148.

1905. Carazzi, D., Sul. sistema arterioso di Selache maxima e di altri Squalidi (Acanthias vulgaris, Mustelus vulgaris, Scyllium catulus, S. canicula, Squatina vulgaris). Anat. Anz., Bd. 26. pp. 63-96, 124-134, 24 text figs.

1928. Coles, Esther M. The Segmental Arteries in Squalus sucklii. Univ. Calif. Publ. Zool., Vol, 31, pp. 93-110, 10 text figs.

1930. Corrington, J. D., Morphology of the Anterior Arteries of Sharks. Acta Zoologica, Bd. 11, pp. 185-261, 24 text figs.

1918. Daniel, J. Frank, The Subelavian Vein and Its Relations in Elasmobranch Fishes. Univ. Calif. Publ. Zool., Vol. 18, No. 16, pp. 479-484, 2 text figs.

19:5. DANLEL, J. FrANK, La Signification de l'artère coraco-latérale chez les poissons Élasmobranches primitifs. Bull. Soc. Zool. France, T. 50, pp. 94-95.

1926. Daniel, J. Frank, The Lateral Blood Supply of Primitive Elasmobranch Fishes. Univ. Calif. Publ. Zool., Vol. 29, pp. 1-7, 1 text fig.

1938. Daniel, J. Frank, The Elasmobranch Fishes. Univ. Calif. Press (ed. 2, Chap. VII).

1909. Diamare, V., Sui rapporti della vena porta e delle arterie splanchiche in Seyllium catulus e Torpedo marmorata. Anat. Anz., Bd. 34, pp. 552-559, 2 text figs.

1910. DiAmare, V., I vasi splanenici e loro relazioni topografiche in Seyllium eatulus e Torpedo marmorata. (Contributo all' anatomia splancnica negli Elasmobranchi.) Memoria I, Arch. zool. Napoli, Vol. 4, pp. 437-488, 1 tav. Also: 1916, Publ. Stat. Zool. Napoli, pp. 209-217, tav. 5.

1884. DoHrN, A., Die Entwicklung und Differenzirung der Kiemenbogen der Selachier. Mitt. Zool. Stat. Neapel, Bd. 5, pp. 102-192, Taf. 5-11.

1886. DoHrN, A., Entstehung und Differenzirung des Zungenbein- und Kieferapparates der Selachier. Mitt. Zool. Stat. Neapel, Bd. 6, pp. 1-92, pls. 1-8.

1835. Duvernox, G. L., Sur quelques particularités du système sanguin abdominal et du canal alimentaire de plusieurs poissons cartilagineux. Ann. Sci. Nat. Zool., Sér. 2, T. 3, pp. 274-281, pls. 10-11.

1911. FERGuson, J. S., The Anatomy of the Thyroid Gland of Elasmobranehs, with remarks upon the Hypobranchial Cireulation in these Fishes. Amer. Jour. Anat., Vol. 11, pp. 151-210, 20 text figs. 
1866. Gegenbaur, C., Zur vergleichenden Anatomie des Herzens. I. Ueber den Bulbus arteriosus der Fische. Jena. Zeitschr. Naturwiss., Bd. 2, pp. 365-375.

1891. Gegenbaur, C., Über den Conus arteriosus der Fische. Morph. Jahrb., Bd. 17, pp. $596-610,7$ text figs.

1903. Greil, Ueber die Entwickelung des Truncus arteriosus der Anamnier. Anat. Anz., Bd. 23 (Verh.), pp. 91-105, 11 text figs.

1929. Grodzinski, Z., Entwicklung der Blutgefässe bei Seyllium conieula. Mémoire Bull. l'Acad. Polonaise Sci. et Litt., (Sér. B Math.-Natur.), pp. 417-454, pls. 26-28, 3 text figs.

1902. GrynfeltT, Ed., Vascularisation des corps surrénaux chez les Seyllium. C.R. Acad. Sei. Paris, T. 134, pp. 362-364. Also: C.R. Soc. Biol. Paris, T. 54, pp. 144-146.

1902. GRYNFELTT, ED., Les corps suprarénaux chez quelques Squales et leurs rapports avec le système artérial. IV e Congrès de l’Assoc. des Anat. Montpellier, Nancy, pp. 31-34.

1845. Gullot, Natalis, Sur un réservoir particulier que présente l'appareil de la circulation des Raies. C.R. Acad. Sci. Paris, T. 21, pp. 1179-1180.

1906. Hochstetter, F., Die Entwickelung des Blutgefässystems. Hartwig's Handb. vergl. u. expt. Entwick., Bd. 3, Teil 2, pp. 21-115.

1892. HofrmanN, C. K., Ưber die Entstehung der endothelialen Anlage des Herzens und der Gefässe bei Hai-Embryonen (Acanthias vulgaris). Anat. Anz., Bd. 7, pp. 270-273, 3 text figs.

1893. HofruanN, C. K., Zur Entwicklungsgeschichte des Herzens und der Blutgefässe bei den Selachiern. Ein Beitrag zur Kenntnis des unteren Keimblattes. Morph. Jahrb., Bd. 19 , pp. 592-648, pls. 22-25, 6 text figs.

1900. HofFmanN, Max, Zur vergleichenden Anatomie der Gehỉrn- und Rückenmarksarterien. Zeitsehr. Morph. Anthropol., Vol. 2, pp. 247-322, pls. 7-10, 7 text figs.

1813. Home, Everard, Additions to an Account of the Anatomy of Squalus maximus, contained in a former paper; with observations on the Structure of the Branchial Artery. Phil. Trans. Roy. Soc. Lond., Pt. I, pp. 227-241, pls. 16-22.

1891. Howes, G. B., On the Intestinal Canal of the Ichthyopsida, with especial reference to its Arterial Supply and the Appendix Digitiformis. Jour. and Proc. Linn. Soc. Lond., Vol. 23, pp. 381-410, pls. 1-2.

1858. Hrrtu, Joseph, Das arterielle Gefäss-system der Rochen. Denkschr. Akad. Wiss. math.-naturw. Wien, Bd. 15, pp. 1-36, Taf. 1-5.

1872. Hyrtu, JosepH, Die Kopfarterien der Haifische. Denkschr. Akad. Wiss. math.-naturw. Wien, Bd. 32, pp. 263-275, Taf. 1-3.

1845. Jones, T. W., 'The Blood-Corpusele considered in Its Different Phases of Development in the Animal Series. Phil. Trans. Roy. Soc. Lond., Vol. 136, 1846, pp. 63-102, pls. 1-2.

1868. Jourdain, S., Coup d'oeil sur les systèmes veineux et lymphatique de la Raie bouclée. Ann. Acad. la Rochelle, T. 8, pp. 21-34.

1928. Keys, Ancel B., The Derivatives of the Hypobranchial Arteries in Hexanchus corinus. Univ. Calif. Publ. Zool., Vol. 31, pp. 111-130, pls. 5-8, 5 text figs.

1898. Lafite-Dupont, Note sur le système veineux des Sélaciens. Soc. Sei. d'Arcachon Stat. Zool., Ann. 3, pp. 86-93.

1887. MAYfr, PaUl, Úber die Entwicklung des Herzens und der grossen Gefässtämme bei den Selachiern. Mitt. Zool. Stat. Neapel, Bd. 7, pp. 338-370, Taf. 11-12.

1888. MAYER, P., Über Eigenthümlichkeiten in den Kreislaufsorganen der Selachier. Mitt. Zool. Stat. Neapel, Bd., 8, pp. 307-373, pls. 16-18.

1894. MAyer, P., Ueber die ersten Stadien der Gefässe bei den Selachiern. Anat. Anz., Bd. 9, pp. 185-192. 
1912. Maxmow, Alexander, Untersuchungen über Blut und Bindegewebe. V. Über die embryonale Entwieklung der Thymus bei Selachiern. Arch. mikr. Anat., Bd. 80 (Abt. 1), pp. 39-88, Taf. 4-8.

1903. Müller, E., Morphologie der Gefässtämme. Anat. Hefte, Bd. 22, pp. 379-568, 'Taf. $17-36,24$ text figs.

1597. Neuvlle, H., Sur les vaisseaux intra-intestinaux des Sélaciens. Bull. Mus. d'Hist. Nat. Paris, No. 3, p. 317.

1901. Neuviute, H., Contribution à l'étude de la vascularisation intestinale chez les Cyclostomes et les Sélaciens. Ann. Sci. Nat. Zool., Sér. 8, T. 13, pp. 1-115, pl. 1, 22 text figs.

19:8. O'Donoghue, C. H., and Aввотт, Eileen, The Blood-raseular System of the Spiny Dogfish, Squalus acanthis Linné, and Squalus sucklii Gill. Trans. Roy. Soc., Edinburgh, Vol. 55, pp. 823-890, 20 text figs.

1886. Parker, T. J., On the Blood-Vessels of Mustelus antarcticus: a contribution to the Morphology of the Vaseular System in the Vertebrata. Phil. Trans. Roy. Soc. London, Vol. 177B, Pt. 2, pp. 685-732, pls. 34-37, 2 text figs.

1899. Parker, G. H., and Davis, F. K., The Blood Vessels of the Heart in Carcharias, Raja, and Amia. Proc. Boston Soc. Nat. Hist., Vol. 29, pp. 163-178, pls. 1-3.

1874. Pavesi, P., Contributione alla storia naturale del genere Selache. Ann. Mus. Cir. Storia nat. Genova, Vol. 6, pp. 5-72, tav. 1-3.

1905. Pitzorno, Marco, Richerche di morfologia comparata sopra le arterie succlavie ed ascellare, Pt. III, Selaei. Monit. Zool. Ital. Firenze, Vol. 16, pp. 94-103, 3 text figs.

1882. Pouchét, G., Terminaisons vasculaires dans la rate des Sélaciens. Jour. de l'Anat. et Physiol., T. 18, pp. 498-502, pl. 28.

1592. RaBL, C., Ueber die Entwicklung des Venensystems des Selachier. Festschr. Rudolf Leuckart, pp. 228-235, 3 text figs.

189.. Raffafe, F., Ricerehe sullo sviluppo del systema rascolare nei Selacei. Mitt. Zool. Stat. Neapel, Bd. 10, pp. 441-479, tav. 29-31.

1367. RoBIN, CH., Mémoire sur l'anatomie des lymphatiques des Torpilles comparée a celle des autres Plagiostomes. Jour. de l'Anat. et Physiol., T. 4, pp. 1-34, pls. 1-3.

1900. Rodrer, E., Sur la pression osmotique du sang et des liquides internes chez les poissons Sélaciens. C.R. Acad. Sci. Paris, T. 131, pp. 1008-1010.

1590. RösE, C., Beiträge zur vergleichenden Anatomie des Herzens der Wirbelthiere. Morph. Jahrb., Bd. 16, pp. 27-96, Taf. 4-5.

1388. Rückert, J., Ueber die Entstehung der endothelialen Anlagen des Herzens und der ersten Gefässtämme bei Selachier-Embryonen. Biol. Centralbl., Bd. 8, pp. 385-399, $417-430,18$ text figs.

1927. SEWERTzoFF, A. N., Études sur l'évolution des vertébrés inférieurs. Structure primative de l'appareil viscéral des Elasmobranches. Publ. Stat. Zool. Naples, Vol. 8, pp. 475-554, pls. 29-31.

1929. Sewertzoff, A. N., Directions of Evolution. Acta Zoologica, Bd. 10, pp. 59-141, 9 text figs.

1904. SterzI, G., Die Blutgefässe des Rückenmarks. Untersuchungen über ihre vergleichende Anatomie und Entwickelungsgeschichte. Anat. Hefte, Bd. 24, pp. 1-364, Taf. $1-4,37$ text figs.

1576. StöHr, P., Ueber den Klappenapparat im Conus arteriosus der Selachier und Ganoiden. Morph. Jahrb., Bd. 2, pp. 197-228, pls. 12-13.

1879. Trois, E. F., Sopra la singolare disposizione della Carotide esterna nella Oxyrrhina (Lamna) spallanzanii. Atti R. Instit. Veneto, Vol. 5, pp. 257-262.

1895. Virchow, H., Die Entwicklung des Gefässbezirkes auf dem Selachier-Dottersacke. Sitz. Ges. nat. Freunde Berlin, No. 5, pp. 98-103. 


\section{CIRCULATORY SYSTEM (Continued)}

\section{CIRCULATORY SYSTEM OF HEPTANCHUS MACULATUS}

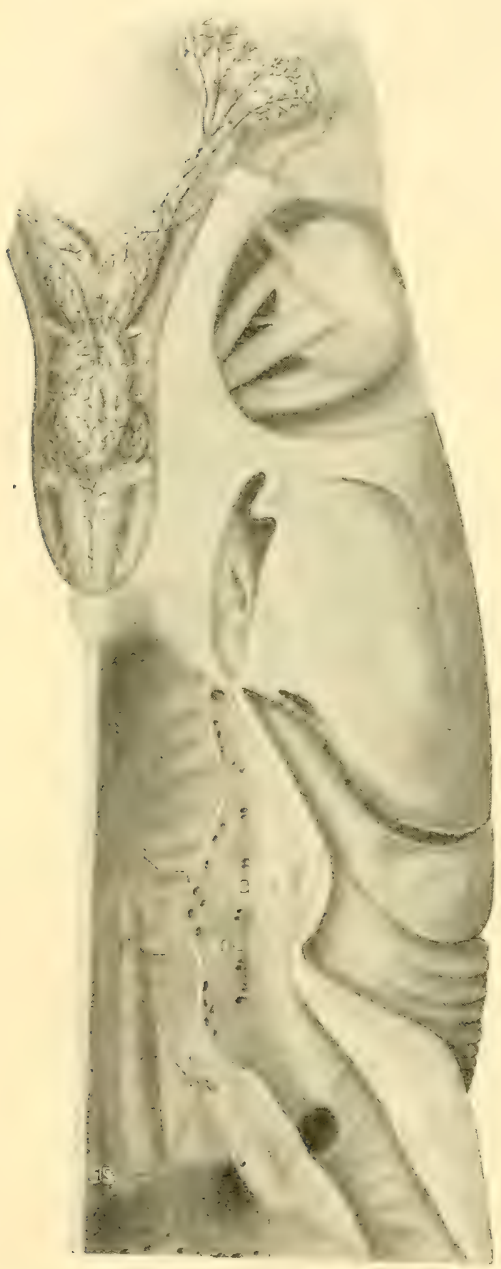

Fig. 182. Anterior cardinal sinus, Heptanchus maculatus. (Mast Wolfsohn,

a.c.s., anterior cardinal sinus; $d . s$. , Danielian sinus; $n u$, nutrient vessel; o.s., orbital sinus. orig.)

VEINS

Blood distributed by the arteries is returned to the heart by several important systems of veins. We shall consider these vessels for Heptanchus maculatus in the particular regions which they oceupy.

\section{VEINS OF HEAD}

The anterior cardinal sinus (a.c.s., figs. 182 and 183) drains the blood from the region around the eye, and as a large vessel passes backward dorsal to the gills. At the pectoral girdle it drops downward and enters the duct of Cuvier. The vessel may be thought of as arising from two terminal vessels, the anterior cerebral and the anterior facial veins.

The anterior cerebral vein (see fig. 182) collects blood from the forward part of the brain by two main branches; the anterior branch runs over the telencephalon receiving numerous venules; the posterior division drains the dorsal part of the diencephalon and receives a few branches from the optic lobes. The anterior facial or orbitonasal vein returns the blood from the nasal region (see fig. 190, a.f.v.). Both the anterior cerebral and the anterior facial vessels empty into the large orbital sinus (o.s.) back of the eyeball. Connecting the two orbital sinuses is the interorbital vein which passes through the eranium by way of the interorbital canal (see fig. 47, i.o., facing $\mathrm{p}$. 44).

From the orbital sinus the anterior cardinal passes backward through the postorbital groove and, in the region of the hyoidean arch, broadens out as the anterior cardinal sinus proper (a.c.s., fig. 183). In the pharyngeal region it receives certain nutrient reins ( $n$ u., figs. 
182-18t) from the hyoidean demibranch and from all the holohranchs. Posteriorly, the anterior eardinal sinus drops suddenly downard into the duret of Cuvier (d.c., fig. 183).

A second vessel, dorsal to the branchial region but nearer the middle line, is the Danielian sinus (d.s., figs. 182 and 183) discovered by Mast Wolfsohn. Anteriorly this sinus extends almost to the vagus foramen and posteriorly it reaches practically to the end of the anterior cardinal sinus. The anterior extremity ends in a blind sac (bs.) and similarly the posterior extremity may end blindly. The Danielian sinus is connected with the anterior eardinal by mumerous openings (ap., fig. 183) the most anterior of which is near the en-

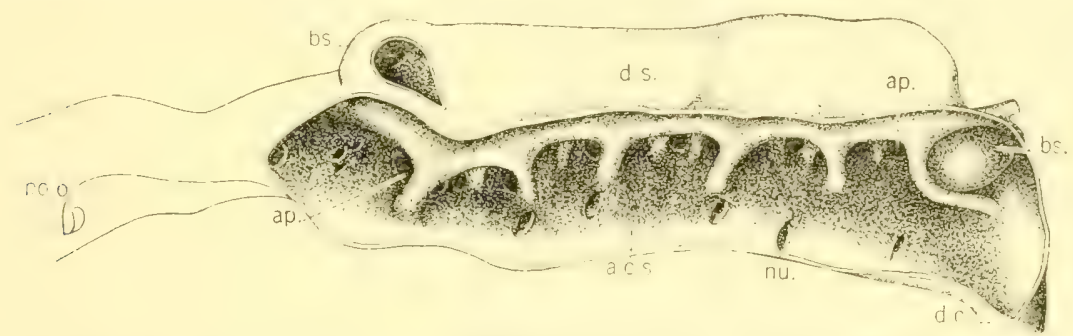

Fig. 183. Danielian sinus, Heptanchus maculatus. (Ruth Conrad, orig.)

ap., apertures comnecting anterior cardinal (a.c.s.) and Danielian sinuses (d.s.); bs.. blind sacs leading from Danielian sinus; $d . c$., entrance to duct of Cuvier; nu., nutrient vessels; po.o., posiorbital process.

trance of the hyoidean rein. Other openings (ap.) between the anterior cardinal and Danielian sinuses, posterior to this point, are arranged more or less segmentally as may be seen by lifting up the vagus nerve.

The inferior jugular vein (i.j., fig. 184) drains the ventral area of the pharynx and extends as an enlarged vein or sinus back to the heart. Anteriorly it receives a tributary from the symphysis of the lower jaw (smt.) and another from the thyroid region (th.v.). It next receives the hyoidean vein or simus (h.s.) and, at regular intervals back of this, ventral nutrients ( $n u$.) which are continuous with the dorsal nutrients of the anterior cardinal. Notwithstanding the fact that it receives veins from all the holobranchs, the inferior jugular decreases in caliber in its course backward. Near its termination it eurres laterally and then passes backward to enter the duct of Cuvier just mediad of the entrance of the subclavian vein (fig. 188).

\section{VEINS OF TAIL}

The caudal vein (cd.v., fig. 185) passes forward in the haemal canal of the tail, and back of the cloaca divides into the renal portal veins $(r \cdot p$. ). It receives branches from the dorsal and posterior ventral cutaneous veins (fig. 189) and numerous segmental veins from the tail; other segmentals join the renal portals as they pass along the dorsolateral margins of the kidney. The ventral rami of the segmental veins receive the blood from the musculature of the ventral lobe of the caudal fin, and each dorsal ramus collects venous blood from dorsal musculature and from the spinal cord. The renals finally break up) into a net in the tissues of the kidney. 


\section{VEINS FROM KIDNEY OR MESONEPHROS}

Blood is returned from the kidneys and the hack by the two large postcardinal reins (p.c., fig. 185) which run along the sides of the spinal column just under the lining of the body cavity. The right one of these veins may be traced as a single ressel from the posterior tip of the kidney forward to the region of

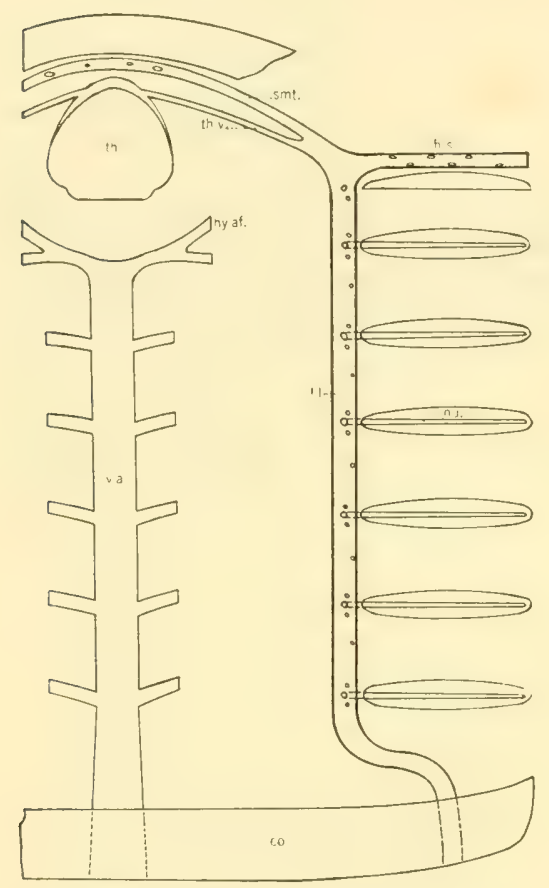

Fig. 184. Diagram of inferior jugular vein, Heptanchus maculatus. (Mast Wolfsohn, orig.)

co., coracoid cartilage; h.s., hyoidean vein or sinus; hy.af., hyoidean afferent artery; $i . j$. , inferior jugular vein; $n u$, nutrient vein; smt., submental vein; $t h$., thyroid gland; th.v., thyroid vein; v.a., ventral aorta. the inferior mesenteric artery, where it is joined by the left posteardinal. Just behind the origin of the posterior intestinal artery the two postcardinals in Heptanchus are joined by two or more cross-trunks (c.tr.).

The postcardinals receive numerous revehentes ( $v$., fig. 186B) from the kidney, which have collected the blood distributed by the advehentes (av., fig. $186 \mathrm{~A}$ ) of the renal portal veins. As the two postcardinals pass forward they receive segmental veins from the body wall and before reaching the heart increase in size to form the enlarged postcardinal sinuses (p.c.s., fig. 185). The walls of right and left sinuses freely intercommunicate posteriorly and anteriorly and are held in place by multitudes of tendinous cords. The posterior cardinals enter the duct of Cuvier (d.c., fig. 183) posterior and mediad of the aperture for the anterior cardinal sinus.

\section{VEINS EROM DIGESTIVE TRACT}

Venous blood is returned from the digestive tract to the heart by the hepatic portal system of veins (see fig. 155, h.p., facing p. 166). The prineipal veins making up this system in Heptanchus are : the posterior intestinal, the intraintestinal, the anterior intestinal, the gastrics, the portal, and the hepatic veins.

The posterior intestinal vein, as the dorsal intestinal (d.i.v., fig. 155), drains the rectal gland and passes forward along the colon and valvular intestine. At about the place where the posterior intestinal artery (p.i.a.) reaches the valvular intestine the vein, as the posterior intestinal proper, leaves the intestine and passes over the hridge of the pancreas. Fefore joining the anterior intestinal vein it receives the large anterior gastro-pancreaticosplenic vein formed by a gastric branch from the dorsal side of the cardiac stomach, splenic 
branches from the spleen on and in the angle of the stomach, and smaller pancreatic veins. As it passes the anterior segment of the spleen it receives one or more additional strong branches.

The anterior intestinal vein is a forward continuation of the intraintestinal vein and, as such, drains the free margin of the valve within the valvular intestine. Near the place where it leaves the intestine the anterior intestinal vein receives several branches. The first of these branches is the ventral intestinal vein (v.i.v., fig. 155) which arises on the rectum and passes over the colon and along the ventral side of the valvular intestine parallel with and not far from the dorsal intestinal vein. At the distal part of the valvular intestine the ventral intestinal vein is usually comnected by a transverse vessel with the dorsal intestinal vein (d.i.v.), and along the valvular intestine it receives annular branches. The ventral intestimal in continuing over the ventral lobe of the pancreas receives certain branches from the pancreas. It next receives a long gastrosplenic branch (p.gs.v.) which drains the posterior side of the pyloric stomach along which it travels from the cardiac division where it receives splenic branches. The anterior intestinal may next be joined by the large anterior branch of the gastric which drains the most anterior part of the cardiac stomach and, in part, the main division of the anterior segment of the spleen; or the anterior gastric vein may join the ventral gastric and empty with it into the portal.

After the union of the anterior and the posterior intestinal veins the large ventral gastric $\left(v \cdot g \cdot v_{0}\right)$ joins the stem of the hepatic portal system (h.p.). The hepatic portal vein extends a short distance forward and divides into right and left halves to the lobes of the liver. The blood thus distributed to the liver is finally collected by right and left hepatic trunks which enter the sinus venosus of the heart a short distance from the middle line (h.v., fig. 188).

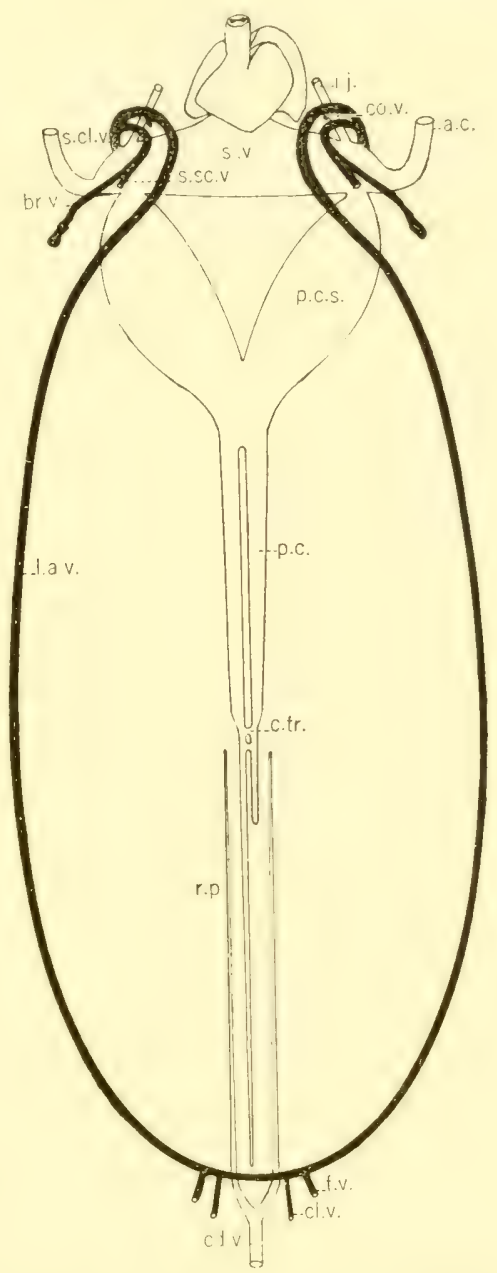

Fig. 135. General view of veins in $H e p$ tanchus maculatus. (C. G. Potter, orig.)

a.c., anterior cardinal; br.v., brachial vein; c.tr., cross-trunk; $c d . v$. , caudal vein; cl.v., cloacal vein; co.v., coracoid rein; f.v., femoral vein; $i . j$, inferior jugular vein; l.a.v., lateral abdominal vein; p.c., postcardinal vein; p.c.s., postcardinal sinus; r.p., renal portal; s.cl.v., subelavian vein; s.sc.v., subseapular vein; s.v., sinus venosus. 


\section{VEINS OF BODY WALL}

The reins of the hody wall empty into the lateral abdominal system, the chief vessels of which are the lateral abdominal veins (l.a.v., fig. 185) which run along the sides of the body just under the lining of the body cavity. In the region of the cloaca, right and left lateral abdominal veins are continuous across

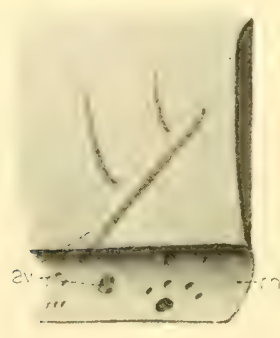

A

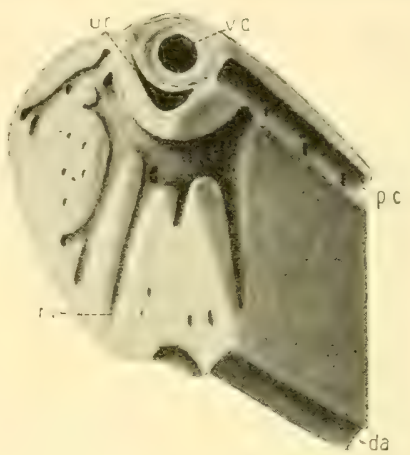

B

Fig. 186. Finer vessels in kidney, Heptanchus maculatus. (C. G. Potter, orig.) A. Segment of kidney showing renal rein and advehentes. B. Section of the kidney showing revehentes entering the postcardinal.

$a v$. , advehentes; da., dorsal aorta; p.c., posteardinal vein; $r n$. , renal vein; $r v$. , rerehentes; ur., ureter; va., vas deferens.

the midventral line. Each lateral abdominal receives a cloacal vein (cl.v.) from the rectal region and a femoral vein $(f . v$. ) from the pelvic fin. Between the pelvic and the pectoral regions the lateral abdominals receive numerous tributaries from the thinner musculature of the body wall, which are not shown in figure 185 . In the pectoral region it receives the brachial vein (br. $v$, fig. 187) from the pectoral fin, the subscapular (s.sc.v.), including the lateral

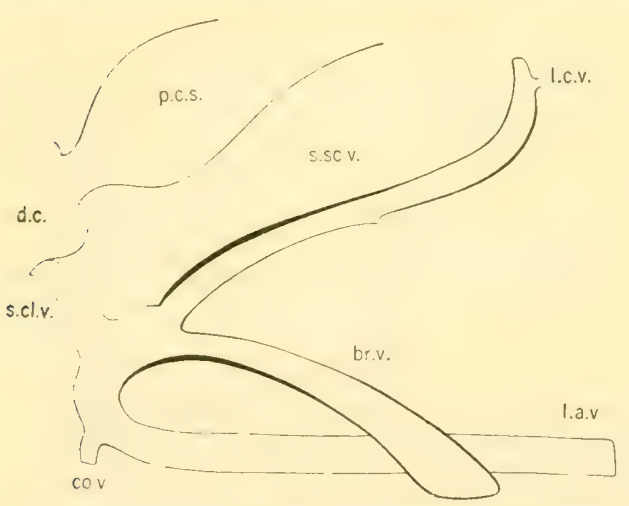

Fig. 187. The subelavian vein and its relations, Heptanchus maculatus, lateral view.

br.v., brachial vein; co.v., coracoid vein; d.c., duet of Cuvier; l.a.v., lateral abdominal vein; l.c.r.. lateral cutaneous rein; p.c.s., posteardinal sinus; s.cl.v., subclavian vein; s.sc.v., subseapular vein. cutaneous vein (l.c.v., fig. 187), and the coracoid vein (co.v.) from the ventral part of the girdle; the last-named vessel receives the ventral cutaneous vein from the skin. As the subclavian vein, the lateral abdominal turns sharply upward and enters the duet of Cuvier (s.cl.v., fig. 187).

\section{VEINS OF SKIN}

The dorsal cutaneous vein in Heptanchus maculatus (p.d.c., fig. 189) runs in the connective tissue of the skin along the middorsal line. For convenience of description it may be divided into a posterior and an anterior 
part. The posterior part is first found ahout halfway between the pectoral and pelvic segments and continues from this point posteriorly almost to the tip of the tail. In the region of the dorsal lobe of the eandal fin the dorsal cutaneous vein is double, and around the dorsal fin right and left dorsal cutaneous veins form a loop from which a strong intereommunicating branch passes to join the lateral cutaneous vein. From the unpaired vein just back of the loop a medium

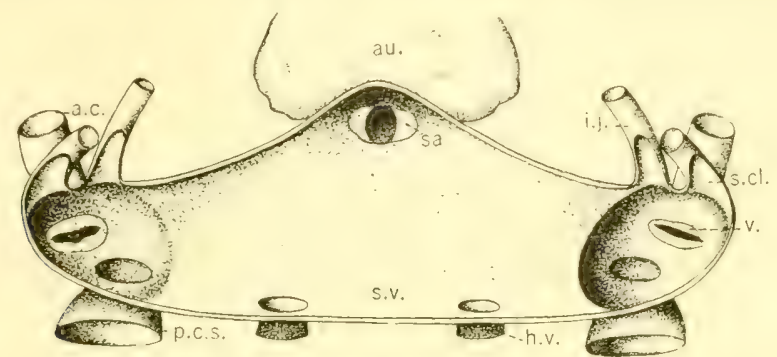

Fig. 188. Sinus venosus opened, Heptanchus maculatus. (Ruth Jeanette Powell, del.)

a.c., anterior cardinal; au, auricle; h.v., hepatic vein; $i . j$. , inferior jugular vein; p.c.s., posteardinal sinus; sa., sinu-auricular valve; s.cl., subclavian vein; s.v., sinus venosus; v., valves of anterior eardinal sinus.

deep vein $(m . v$.$) passes to the right of the spinal column to join the caudal$ vein $(c d . v$.). The anterior part of the dorsal cutaneous vein ends anteriorly in a $V$-shaped sinus over the brain case.

The lateral cutaneous vein (l.c.v., fig. 189) runs directly under the skin, parallel with and ventral to the lateral line groove. It extends from the middle region of the caudal fin forward, and joins the subscapular sinus near its tip (fig. 187). In its course forward it receives numerous segmentally arranged cutaneous branches, and in the region of the dorsal fin it has strong intercommunicating branches which join the cloacal vein (cl.v.) of the lateral abdominal system.

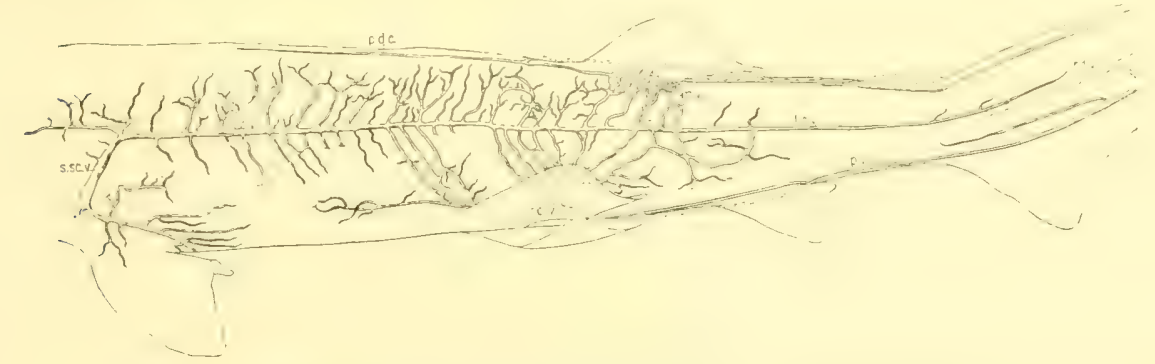

Fig. 189. Cutaneous veins, Heptanchus maculatus. (Helen Hopkins, orig.)

$c d . v$. , caudal vein; cl.v., cloacal vein; l.c.v., lateral eutaneous vein; m.v., median unpaired vein; p.d.c., posterior dorsal cutaneous vein; p.v.c., posterior ventral cutaneous; s.sc.v., subscapular vein.

The ventral cutaneous vein lies in the subcutaneous tissue in the midventral line. In the region of the anal fin it forms a loop and like a $\mathrm{V}$ its right and left branches run backward on the caudal fin. The posterior part of the vessel empties into the cloacal vein (cl.v.) and the anterior segment of this vein joins the coracoid vein (co.v., fig. 187). 


\section{CIRCELATORY SITEEM OF ELASMOBRANCHS IN GENERAL}

Blood which has been distributed by the arteries to the capillaries of the tissues is collected and returned to the heart by the veins. The veins, as we have said, differ as a rule from the arteries in possessing thinner walls. In section this is seen to be due especially to a lack in the muscular layer. A backward flow of blood, which in the arteries is prevented by the muscular elasticity of the larger proximal arteries and by the rhythmic action of the heart, is prevented in the veins by valves. These valves are present at irregular intervals throughout the course of some of the veins and are especially marked at the junction of principal trunks, as for example at the entrance of the anterior cardinal to the duct of Cuvier ( $v$., fig. 188). The valves are formed by the lining of the veins as loose erescentic folds, the concavity of which is directed toward the heart. These permit a free course of the blood toward the heart but prevent its backward flow by filling with blood and thus blocking the lumen.

The Elasmobranch reins frequently become greatly enlarged sinuses. An incision through the posteardinal sinus shows that its walls, though similar in other respects to those of the veins, differ from them especially in two ways. In the first place if they possess any musculature it is exceedingly thin, and secondly they have, passing from wall to wall, numerous tendinous supporting cords. Many such enlarged sinuses are present in the Elasmobranchs especially in the region of the head and in the proximal part of the veins near the heart.

\section{VEINS}

For convenience of description the veins of the Elasmobranchs in general may be grouped into seven systems as follows: (1) those which return blood from the head, the anterior cardinal system; (2) veins which bring blood from the caudal region to the kidney, the renal portal system; (3) the vessels draining the kidneys along the dorsal body wall, the posterior cardinals; (4) the veins which carry the hlood from the digestive tract and its appendages to the liver, the hepatic portal system; (5) those veins which return blood from the extremities and sides, the lateral abdominal system; (6) a system of veins draining the walls of the heart; and (7) the cutaneous veins or veins of the skin.

\section{ANTERIOR CARDINAL SYSTEM}

The anterior cardinal system consists of the anterior cardinal or jugular reins and the inferior jugulars together with their tributaries. The anterior cardinal vein (a.c.s., fig. 190), like that of Heptanchus, passes from the orbital sinus (o.s.) back over the branchial basket. The orbital sinus receives the anterior facial (a.f.v.) or orbitonasal and the anterior cerebral veins (a.c.v., fig. 191), together with certain cutaneous reins of the head. Right and left orbital sinuses 
are comnected by the interorbital vein which traverses the interorbital canal ( see fig. 47, facing 1 ). 44). The blood thus collected in the orbital sinus passes through the postorbital groove and then backward in the enlarged anterior cardinal sinus over the pharyngeal region. The sinus receives nutrients from the gills. At the level of the most posterior gill arch the anterior cardinal drops down and enters the duct of Cuvier or the posteardinal sinus (Scyllium, fig. 190B, a.c.s.). The branches to the anterior cardinal may be considered further.
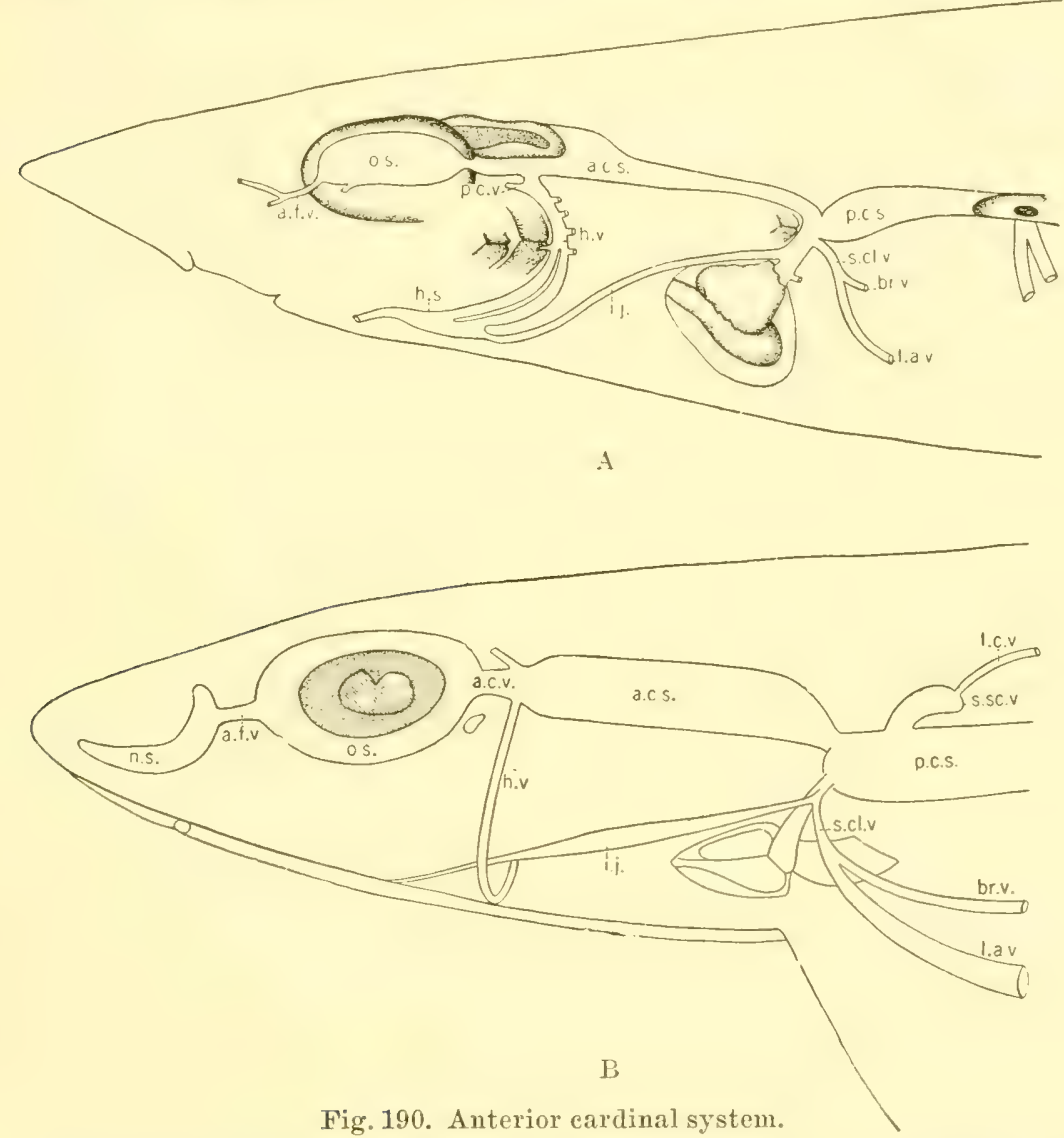

A. Mrustelus. (From T. J. Parker.)

B. Scyllium. (From O'Donoghue.)

a.c.s., anterior cardinal sinus; a.c.v., anterior eardinal vein; a.f.v., anterior facial vein; $b r . v$., brachial vein; $h_{. s}$., hyoidean sinus; $h . v$., hyoidean vein; $i_{. j}$., inferior jugular; l.a.v., lateral abdominal vein; l.c.v., lateral cutaneous; n.s., nasal sinus; o.s., orbital sinus; p.c.s., posteardinal sinus; p.c.v., posterior cerebral vein; s.cl.v., subclavian vein; s.sc.v., subseapular vein.

A supraorbital vein (so.v., fig. 192A) collects blood from the skin and the jelly-like tissue overlying the cranium, and passes forward from the segment of the parietal fossa ( $p . f$.) over the dorsal surface of the nasal capsule. At the place where the superficial ophthalmicus nerve (fo.VII, fig. 192A) perforates the cartilage the left supraorbital receives a small dorsomedian rostral vein (dm.v.). 
The supraorbital then extends forward, receiving a dorsolateral branch $(d l . v$.$) , and then passes through the foramen in the roof of the olfactory$ capsule and continues as the nasomaxillary (nm.r.). As this vein eurves downward within the capsule and along its posterolateral aspect it receives a fairly large branch ( $n . v$., fig. 192B), which is the result of a remarkable leash of vessels coming from the folds of the olfactory organ. Just after the nasomaxillary

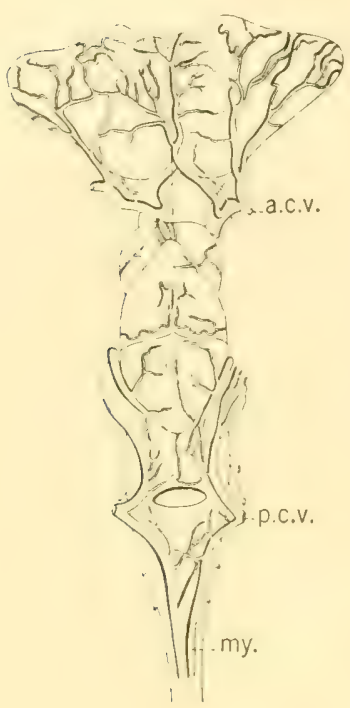

A

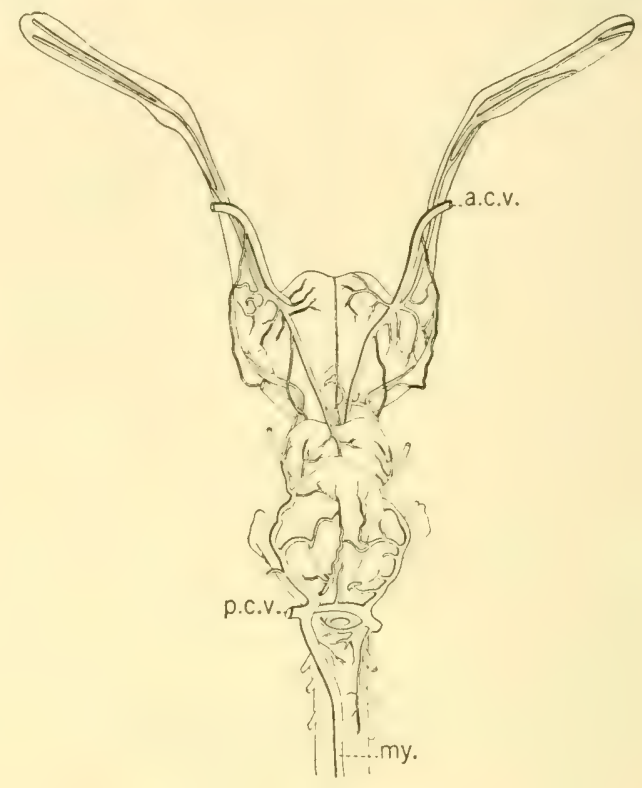

B

Fig. 191. Cerebral veins. (From Rex.) A. Scyllium catulus. B. Raja asterias, a.c.v., anterior cerebral vein; my., myelonal vein; p.c.v., posterior cerebral vein.

enters the cartilage in the posteroventral region of the capsule it is joined by the orbitonasal (on.v.) or anterior facial vein (a.f.v., fig. 190), which serves to connect the veins under discussion with the orbital sinus (o.s., fig. 190). The nasomaxillary vein next emerges from the nasal cartilage just laterad of the point where the maxillary nerve first passes under the basal fenestra ( $f n$., fig. 2, Wells, 1917). Here it receives twigs from the skin and tissue outside of the capsule, and a subrostral vessel $(s r . v$. ) from the tip of the snout. In the posterior part of its course the nasomaxillary vein swings mediad in front of the superior labialis muscle $\left(l l s_{\text {. }}\right)$ to join its mate from the opposite side to form a dorsal sinus (s.). From the sinus (s.) the buccopharyngeal veins (bp.v., fig. 19: $\mathrm{B}$ ) lead backward, and at the basal angle of the eranium, right and left vessels swing outward following the margin of the orbits. At the postorbital process each buccopharyngeal receives one or two lateral tributaries from the sides of the upper jaw, and then right and left vessels take an almost parallel course posteriorly finally to empty into the anterior cardinal sinus.

The anterior cerebral vein (a.c.v., fig. 191A), which, as we said above, enters the orbit as the principal vein from the anterior part of the brain, may vary 
considerably from the condition seen in Heptanchus. It is formed by an anterior vessel on the olfactory bulb which receives a branch from the olfactory lobe, a median branch from the ventral olfactory and diencephalic areas, and a posterior vein which in the middorsal line joins a similar vein from the opposite side as the mesencephalic vein. In other words, the first branch of

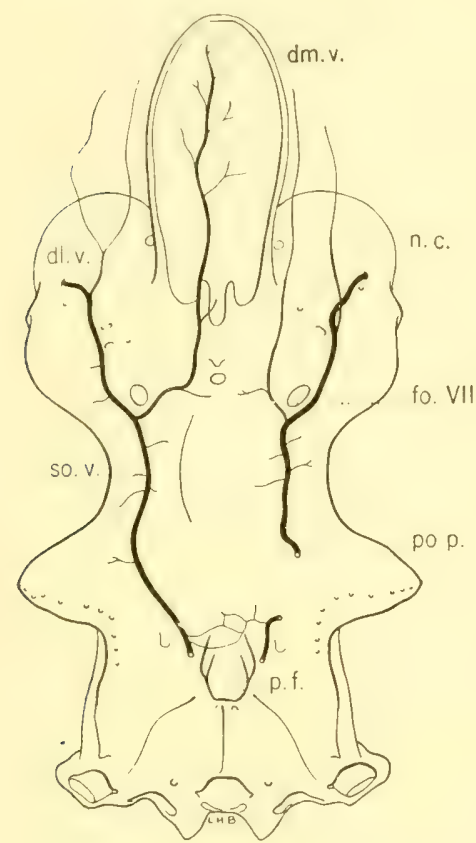

Fig. 192A. Veins dorsal to roof of cranium, Squalus sucklii.

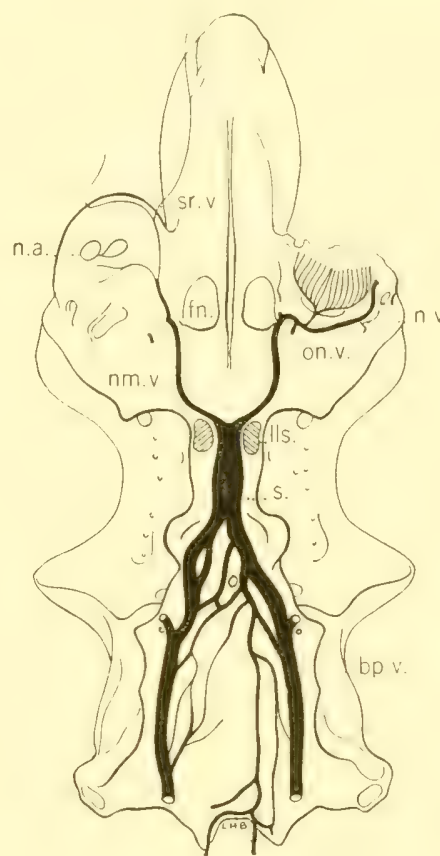

Fig. 192B. Veins in roof of buccal cavity, Squalus sucklii.

$b p . v$. , buccopharyngeal vein; dl.v., dorsolateral rostral vein; dm.v., dorsomedian rostral vein; $f n$., basal fenestra; fo. VII, exit of superficial ophthalmic nerve; lls., attachment, superior levator labialis muscle; n.a., nasal aperture; n.c., nasal capsule; $n m . v$, nasomaxillary vein; n.v., nasal vein; on.v., orbitonasal (facial) vein; p.f., parietal fossa; po.p., postorbital process; s., sinus; so.v., supraorbital vein; sr.v., subrostral vein.

the anterior cerebral drains the olfactory lobe and tract, the second the whole of the ventral area back to the optic chiasma, and the third the whole of the remaining dorsal region anterior to the cerebellum. It is through the lastnamed vessel that the roof of the third ventricle is drained.

The anterior cardinal sinus (fig. 190) receives the hyoidean vein and the nutrients (not shown) from all the holobranchs. These nutrients, as in Heptanchus, are contimuous with ventral nutrients.

The posterior cerebrals (p.c.v., fig. 191) from the brain enter the anterior cardinal sinus. In a type like Scyllim (fig. 191A) they collect the blood from the cerebellum and medulla and pass it posteriorly in large right and left dorsal veins through the foramina with the vagus nerves. In Raja asterias (fig. 191B) the posterior cerebral is usually a single vessel. Continuing pos- 
terior from this ressel in both Seyllium and Raja is the dorsal myelonal vein (my.). This vein is absent, however, in Acanthias (fig. 181). A ventral myelonal vein, arising posterior to the optic chiasma, drains the vascular saes and passes on down the cord.

The hyoidean vein in Mustelus enlarges ventrally into the hyoid sinus. Each sinus (h.s., figs. 190 and 193) is triangular and of large size, the base of the

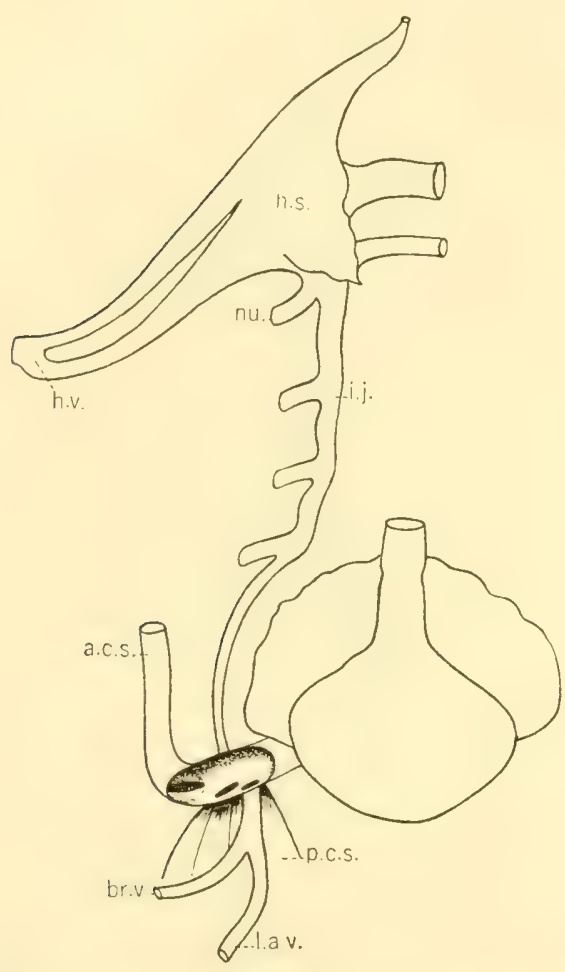

Fig. 193. Veins ventral to pharynx, Mus. telus antarticus. (From T. J. Parker.)

a.c.s., anterior cardinal sinus; $b r . v$. , brachial vein; h.s., hyoid sinus; h.v., hyoidean vein; i.j., inferior jugular; l.a.v., lateral abdominal vein; nu., nutrient; p.c.s., posteardinal sinus. tends from the tip of the caudal fin through the haemal canal to the cloaca. It represents the stem of a $\mathrm{Y}$, the arms of which pass to the sides of the cloaca as the renal portal veins (r.p., fig. 194A). Each renal portal continues forward and upward dorsal to and along the lateral margin of the kidneys, giving to each numerous advehentes.

In its course as a single median vessel, the caudal receives dorsal and ventral segmental reins on each sicle, which are of large size at the place where the dorsal and ventral lobes of the fin are deepest. The two renal portals also receive segmental veins from the hody wall in the region of the kidneys and from 
the oviduct of the female. In certain forms, as we shall see later, the tips of the oviducal veins are in communication with other veins in the cloacal region.

\section{POSTERIOR CARDINAL VEINS}

The posterior cardinal veins in the Elasmobranchs in general are two enlarged vessels located at the sides of, and ventral to, the spinal column and ventrolateral to the dorsal aorta. In some types right and left postcardinals may

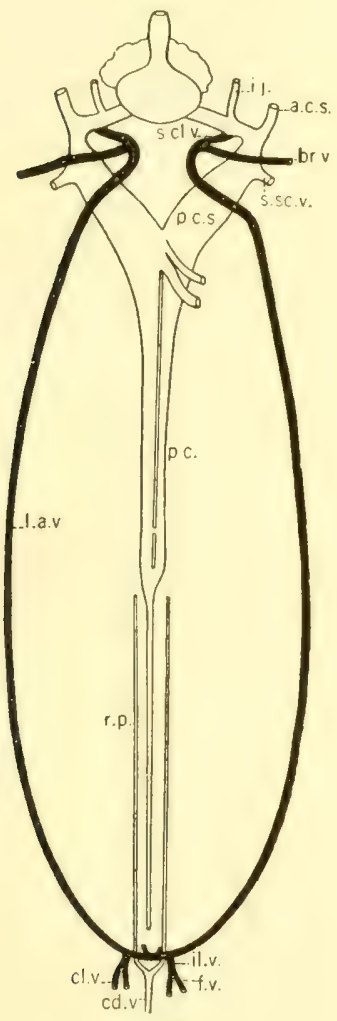

A

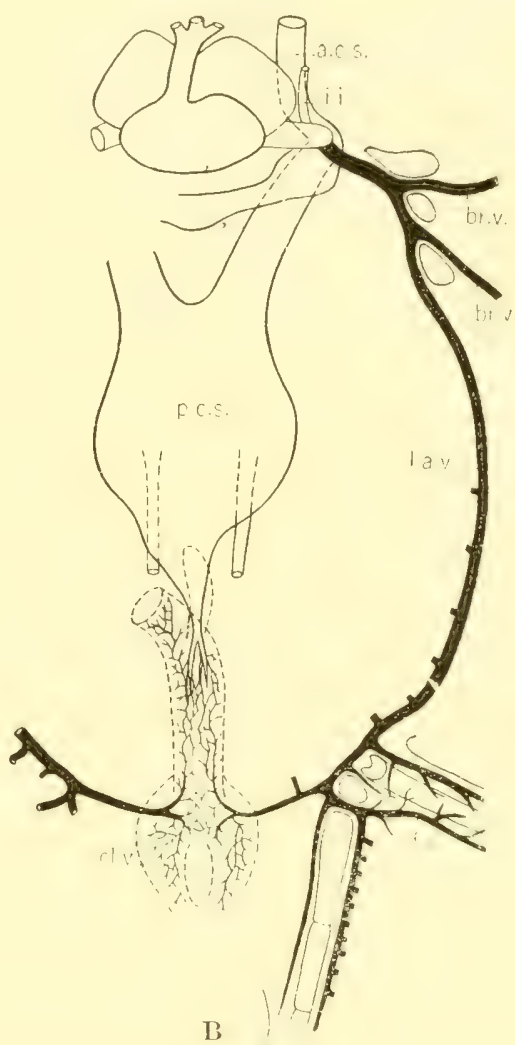

B

Fig. 194. General view of veins of body.
A. Mustelus antarcticus. (From T. J. Parker.)
B. Raia erinacea. (From Rand.)

a.o.s., anterior cardinal sinus; br.v., brachial vein; $c d . v$, eaudal vein; $c l . v$., cloacal vein ; $f . v$., femoral vein; $i . j$., inferior jugular vein; $i l . v$., iliae vein; l.a.v., lateral abdominal vein; p.e., posteardinal vein; p.c.s., postcardinal simus; $r . p$. , renal portal vein; $s . s c . v$. , subscapular vein; s.cl.v., subclavian vein.

form a fused vessel posteriorly (Scyllium and Raja). In others the postcardinals extend as separate vessels from the posterior tip of the kidney behind to the sinus venosus in front. As a usual thing, however, only the right one extends backward the whole length of the kidney, while the left is attached to the right (Mustelus, fig. 194A, p.c.).

In the sharks the anterior third of the posterior cardinals forms the enlarged 
postcardinal sinuses, the two usually being freely intercommunicating. At the middle of the postcardinals in the rays (fig. 194B) a spacious sinus (p.c.s.) is formed which is prolonged backward by a narrower outpocket toward the rectal gland. In most forms the thin walls of the sinuses are strengthened by the unusual development of the trabeculae.

The postcardinals may enter the posterior inner angle of the duct of Cuvier a considerable distance from the entrance of the hepatic veins, as in Heptanchus, or they may empty as in Mustelus (fig. 190A).

The first and most posterior branches received by the posterior cardinals are the revehentes draining the kidneys; while the tributaries from the anterior region are usually the large genital sinus draining the gonads, and the subscapular vessel coming from under the scapula. Between these two areas and throughout the greater part of their course forward they receive segmental veins from the body walls. The ventral branches of the segmentals drain the blood from the interseptal spaces, and the dorsal branches the blood from the deep musculature of the back. Into the dorsal rami the veins (vs.v., fig. 181) from the spinal cord enter.

In a type like Acanthias the vertebrospinal veins leave the neural canal through the foramina of the dorsal nerve roots. Within the canal each vein divides into a dorsal ramus $(d . r . v$. ) which drains the dorsal part of the cord and a ventral ramus $(v . r . v$. ) draining the ventral part. The ventral ramus is also connected with a vena limitans which extends longitudinally along the ventral side of the cord. In Scyllium the dorsal rami of each side of the cord form plexuses of reins each of which is more or less united into a longitudinal dorsolateral tract. In the rays, longitudinal tracts form a dorsal spinal vein of large size which as we have seen joins the posterior cerebrals anteriorly.

\section{HEPATIC PORTAL SYSTEMI}

Blood which has been distributed to the digestive tract by the coeliac axis and the mesenteric arteries is returned from the tract by branches of the hepatic portal system. Two such branches in both the sharks and the rays are of special interest. These are the intraintestinal, including the anterior intestinal vein, and the posterior intestinal or mesenteric reins. To these branches should be added the gastric veins mentioned for Heptanchus.

The intraintestinal vein (see fig. $173 \mathrm{~B}, i v$.) represents a part of the anterior segment of the subintestinal rein of the embryo. It was discovered first on the free margin of the scroll valve of Zygaena where it is of so large a size that Duvernoy (1833) deseribed it as a "venous heart." Such, however, is not its nature. As it emerges from the anterior end of the valvular intestine it is continued as the anterior intestinal vein.

The anterior intestinal vein (see p. 184, fig. 173B, a.i.v., and figs. 174 and 175 ) is usually well developed in the sharks, but is small or relatively insignificant in the rays. As it continues forward from the intraintestinal vein it is joined by the ventral intestinal which arises on the ventral side of the valvular intestine, and receives anmular branches from the attached side of 
the valve. At the anterior end of the valvular intestine it receives branches from the lobes of the pancreas and the posterior gastro-pancreaticosplenic vein (p.gs.v., fig. 173в).

The posterior gastro-pancreaticosplenic is continued in the mesentery (omentum) between the spleen and the stomach as the gastrosplenic vein (p.gs.v., figs. 173-175). While in Heptanchus it is relatively small, although a long vessel, in most of the other sharks it is well developed, and in the ray (Dasyatis, fig. 175) is of relatively immense size. Here, in the absence of a spleen on the greater curvature of the stomach, it drains only the stomach and pancreas.

The anterior intestinal then passes forward to join the posterior intestinal. The segment of the anterior intestinal vein as it passes forward to join the posterior intestinal varies greatly in length. In Scyllium it is exceedingly short, but in Acanthias and Mustelus (fig. 173B) it is a relatively long segment.

The posterior intestinal vein is the direct continuation of the dorsal intestinal vein (d.i.v., fig. 173) which arises within the tissue of the rectal gland, from the tip of the gland (leopard shark, fig. 173A), or from a sinus which runs longitudinally along the lumen of the gland to its base (Acanthias, Mustelus, fig. 173B). The dorsal intestinal passes along the dorsal side of the valvular intestine, receiving annular branches. In some forms the posterior intestinal vein leaves the intestine at the place where the posterior intestinal artery strikes it, that is, at about the middle of the intestine (Acanthias, Dasyatis, fig. 175), or it may leave it farther forward (Heterodontus, fig. 174; Triakis, fig. 173). It extends forward by the spleen, from which it receives the anterior gastrosplenic vein (Squalus sucklii; Heterodontus, fig. 174, a.gs.v.). The posterior intestinal vein then proceeds forward to join the anterior intestinal vein to form the portal.

The anterior gastro-pancreaticosplenic vein, which is an important vessel in Heptanchus, is much simpler in Mustelus (fig. 173B) and in Scyllium. In all types it is divided into gastric and splenic parts, and as in Triakis (fig. $173 \mathrm{~A}$ ) it usually receives a branch from the dorsal lobe of the pancreas.

The portal or hepatic portal is formed by the union of the posterior intestinal vein, anterior intestinal trunk, and one or more gastries. It passes to the liver usually as a vessel of large size, receiving on its way the large ventral gastric (v.g.v., figs. 174 and 175), two or more branches of which drain the ventral surfaces of the cardiac and pyloric stomach. Upon reaching the liver the portal divides into two branches, one to each of the lobes. These branches extend to the tips of the lobes, giving off in their course numerous other branches which break up into a net.

The blood thus distributed to the liver by the hepatic portal vein and by the hepatic arteries is re-collected by the hepatic veins and taken to the heart. The hepatic veins may empty near the median line by a right and left vein, as in Acanthias; or these veins may break up into a more or less complex net before entering the sinus venosus (Lamna). In other forms the two hepatic vessels join and enlarge in the anterior part of the liver, forming immense hepatic 
sinuses. Where the two vessels fuse together the walls between the two sides are more or less broken down and the remaining walls are supported by trabeculae. These hepatic sinuses may empty by relatively small apertures near the middle line into the sinus venosus (Scyllium). In certain types the hepatic veins enter the outer tips of the duct of Cuvier (Torpedo, Raja).

\section{DEVELOPMENT OF HEPATIC PORTAL SYSTEM}

In the embryo, the vitelline veins from the yolk sac ( $v . v$. , fig. 195) are among the first vessels to appear. These are followed by the subintestinal vein (s.i.), previously mentioned, which unites with the vitelline to form an omphalo-

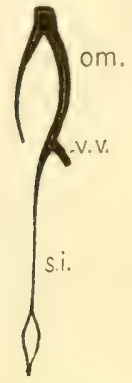

A

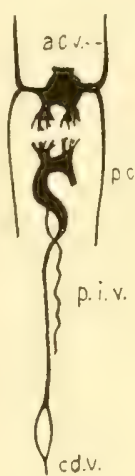

B

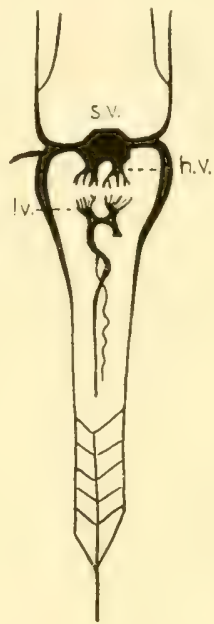

C

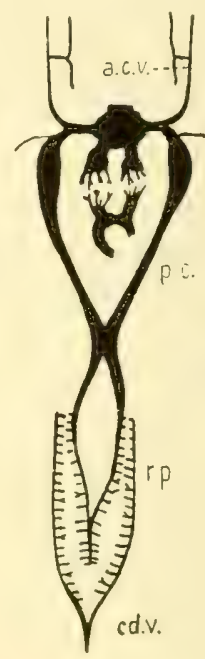

$\mathrm{D}$

Fig. 195. Diagram of development of hepatic portal system in Elasmobranchs, ventral view. (From Rabl, modified.)

a.c.v., anterior eardinal vein; $c d . v$. , caudal vein; $h . v$. , hepatic vein; $l v$., liver capillaries; om., omphalomesenteric vein ; p.c., posteardinal; p.i.v., posterior intestinal vein; r.p., renal portal vein; s.i., subintestinal (intraintestinal) vein; $s . v$, sinus venosus; $v . v$, vitelline vein.

mesenteric. The right vein remains rudimentary, but the left omphalomesenteric becomes an important vessel $(\mathrm{om}$.). When the developing liver comes in contact with the omphalomesenteric the latter vessel sends branches into the tissue of the liver and divides into two parts, each of which forms a series of capillaries in the liver ( $l v$. fig. $195 \mathrm{c})$. After the absorption of yolk, and the consequent loss of the vitelline veins, the main stem of the hepatic portal system is along the subintestinal line. This vein in the adult is carried in with the developing valve into the valvular intestine, as the intraintestinal, to drain the free margin of the valve. 'There is next formed the posterior intestinal or' mesenteric vein (p.i.v., fig. 195B-C). Blood now empties by the united subintestinal and posterior intestinal into the hepatic portal and this empties into the liver. From the liver the blood is collected and passes to the sinus venosus 
(s.v., fig. $195 \mathrm{c}$ ) by the hepatic veins (h.v.), which were previously the anterior ends of the vitelline veins. In figure $195 \mathrm{c}$ and $\mathrm{D}$ the cardinal and renal systems are also well developed.

\section{LATERAL ABDOAINAL SYSTEM OF VEINS}

The lateral abdominal veins (l.a.v., fig. 194) extend from the pelvic to the pectoral segments of the body just under the peritoneum in the sides of the body wall. Posteriorly each vein may arise from a net of fine veinlets on the side of the rectal and cloacal walls (Ra.ja, fig. 194B) ; or right and left veins may be continuous across the pelvic eartilage (Mustelus antarcticus, fig. 194A; Scyllium canicula). Posteriorly a rectal branch joins the lateral abdominal of Scyllium near the midventral line. The first important tributary (or tributaries) to the lateral abdominal system of veins is the iliac, resulting from a fusion of the cloacal and femoral veins from the cloacal and pelvic areas, respectively (Mustelus, fig.194A). In certain forms the cloacal and femoral veins join the lateral abdominal independently, as in Heptanchus. In Raja an aceessory femoral vein also empties into the lateral abdominal (fig. $194 \mathrm{~B})$. The femoral veins ( $f . v$. are formed in the pelvic fin from numerous veinlets, while the cloacal veins $\left(c l . v_{0}\right)$ drain the sides of the cloacal region.

Blood collected from the deeper structures in the posterior region,

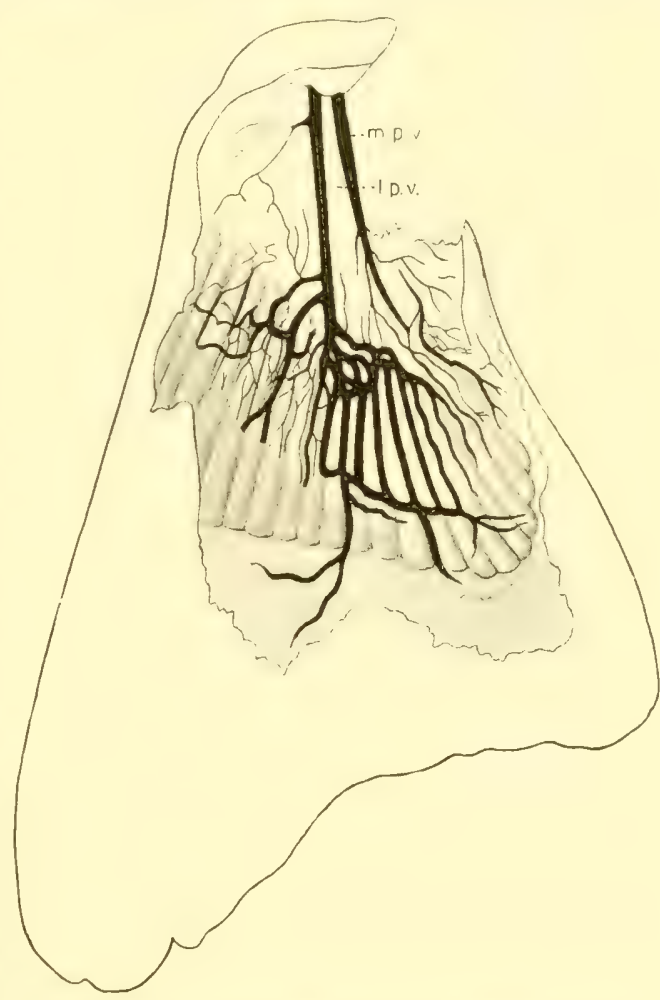

Fig. 196. Veins of peetoral fin, Acanthias. (From Erik Müller.)

l.p.v., lateral pterygial vein; m.p.v.. medial pterygial rein. then, whether from the cloaca or the pelvic fin, is carried forward by the lateral abdominal ressel. As this vessel passes anteriorly many veins from the body wall enter it.

At the pectoral girdle the lateral abdominal vein receives important tributaries. The first of these is the brachial vein. In the sharks the brachial arises from the union of a dorsal, a median pterygial (m.p.v., fig. 196), and a lateral pterygial vein (l.p.v.) of the fin. In rays where the pectoral fin is large in extent, a much larger median pterygial branch is present and is joined by the smaller lateral, ventral vein. In addition a large anterior branch from the 
propterrgium joins the lateral abdominal vein independent of the brachial (Raia erinacea, fig. 194B). In Raja nasuta two independent brachial branches join the lateral vein.

In Heptanchus it was seen that the subseapular vein (s.sc.v., fig. 187) is an important tributary of the lateral abdominal, emptying, in common with the brachial as a brachioseapular vessel, blood from the pectoral girdle and from the lateral cutaneous vessel. In Mustelus henlei a short subseapular trunk joins the brachial but all blood from the lateral cutancous reaches the heart

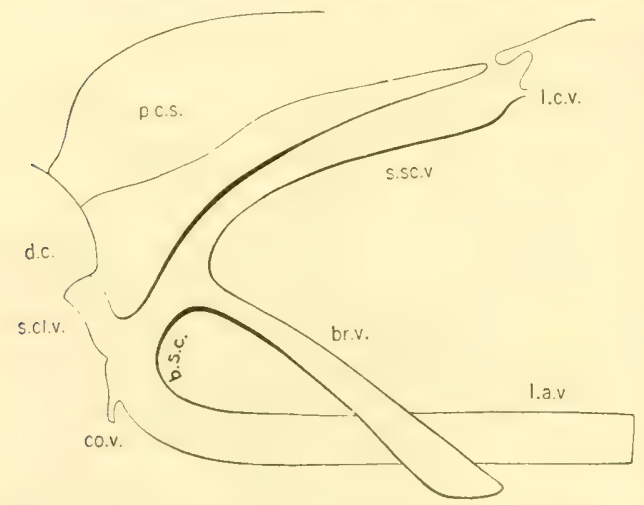

Fig. 197. Diagram of relations of postcardinal to lateral abdominal system, Squalus suchlii.

$b r . v$. , brachial vein; b.s.c., brachioscapular; co.v., coracoid vein; d.c., duet of Cuvier; l.a.v. lateral abdominal vein; l.c.v., lateral eutaneous vein; p.c.s., posteardinal sinus; s.cl.v., subclavian vein; s.sc.v., subseapular. through the posteardinal.Squalus sucklii is of interest as a type which actually bridges these two extremes. In it the lateral abdominal (l.a.v., fig. 197), just before entering the duct of Cuvier, receives the brachioscapular trunk which includes the subscapular vein (s.sc.v.). Now the subseapular vein dorsally comes in contact with, and has an opening into, the postcardinal sinus (p.c.s.). The lateral cutaneous vein (l.c.v.) empties into the subscapular near the nuion of the subscapular with the postcardinal sinus, so that the blood from the lateral cutaneous vein after entering the subscapular may pass dorsally into the posteardinal sinus or ventrally into the lateral abdominal vein. In other words, if the subseapular vein of squalus suctilii had no connection with the postcardinal sinus, Squalus would be in all essentials of the type of Heptanchus. If, however, that segment of the subseapular between the entrance of the lateral cutaneous (l.c.v., fig. 197) and the brachial vein (br.v.) were dropped out, then the lateral cutaneous would be independent of the lateral abdominal system and the type would be like that of Mustelus or Scyllium.

After receiving the brachioseapular trunk (brachial and subscapular), the lateral abdominal vein as the subclavian (s.cl.v.) turns sharply upward in the pericardio-peritoneal wall and across the scapular cartilage to empty into the duct of Cuvier (d.c.) as in Heptanchus.

The history of the lateral abdominal system is of interest. In origin it is one of the earliest of the systems to appear. Furthermore it occupies a position which would have been of particular value had a lateral fin-fold been present, for such a vessel would have drained this fold directly as it does those parts of the fold which remain, that is, the paired fins.

The lateral abdominal vein has often been considered in relation to the rentral abdominal vein of the amphibians which in its anterior and posterior sections drains the paired appendages, but in the middle region is a single 
ventral vessel. Anteriorly, in the embryonic amphibian, it enters the duct of Cuvier, but later, by secondary twigs, it comes to empty directly into the liver. From these characteristics it appears likely that the ventral abdominal in Amphibia is homologous with the lateral abdominal of Elasmobranchs.

\section{VEINS OF HEART}

Three sets of vessels return blood, distributed by the colonary arteries, from the heart itself. These are a small right coronary, a median cardiac vein, and a larger left coronary vein. These veins enter the sinus venosus, near the sinuauricular opening, usually by two or more apertures. The right and left systems in Acanthias, however, join and empty into the sinus venosus by a single large aperture.

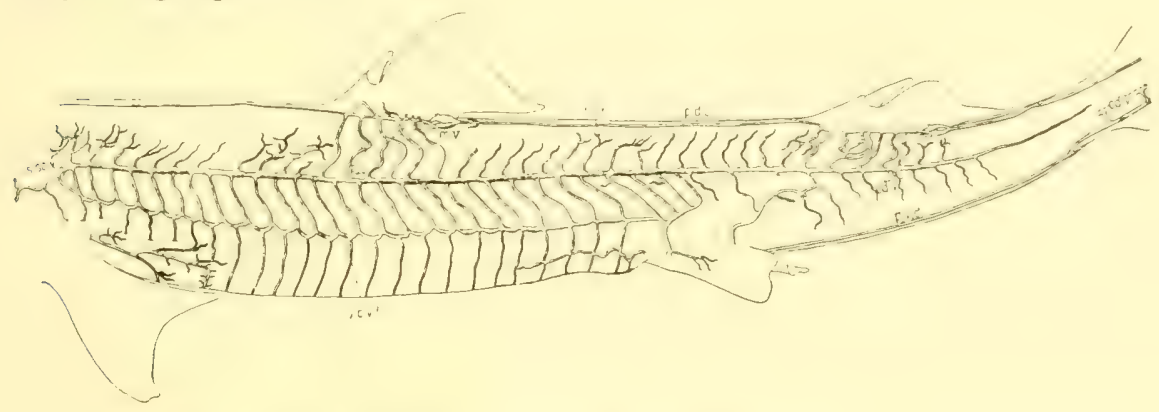

Fig. 198. Cutaneous system of veins, Squalus sucklii. (Helen Hopkins, orig.)

cd.v., caudal vein; l.c.v. and l.c.v. ${ }^{1}$, superior and inferior lateral cutaneous veins; $m . v$, median vein; p.c., posteardinal vein; p.d.c., posterior dorsal cutaneous vein ; p.v.c., posterior rentral eutaneous; s.sc.v., subscapular veïn.

The right coronary may drain the right side of the ventricle and the dorsal side of the conus (Carcharias littoralis), emptying into the sinus venosus by its own aperture at the right side of the sinu-auricular opening; or the right may arise as two vessels on the dorsal and ventral sides of the conus and on the ventral side of the ventricle. These two continue separately and open independently (Raia erinacea). The left coronary in Raia erinacea is of considerable size and drains the ventral and lateral parts of the ventricle. In other forms it is a vessel of importance (Carcharias littoralis, Cetorhinus, Scyllium), draining the ventral and lateral parts of the ventricle.

The cardiac veins drain the dorsal part of the ventricular wall. They may form as a double vessel and unite to enter the sinus venosus with the left coronary (Carcharias littoralis), or they may empty independently into the sinus venosus by a half-dozen smaller mouths (Raja rubens). In Raia erinacea numerous vessels receive blood from the large triangular area lying parallel to the posterior margin of the sinus venosus and empty it directly into the sinus venosus.

The vessels of Thebesius in the Elasmobranchs, according to Parker and Davis (1899), are deep in the walls of the heart and are connected with the coronary veins. They may be detected by immersing the heart in water and 
then inflating the left coronary vein with a blow pipe, whereupon bubbles of air emerge from the left atrial wall into the atrium (Acanthias). No bubbles, however, appear upon the inflation of the right coronary vein. The same may

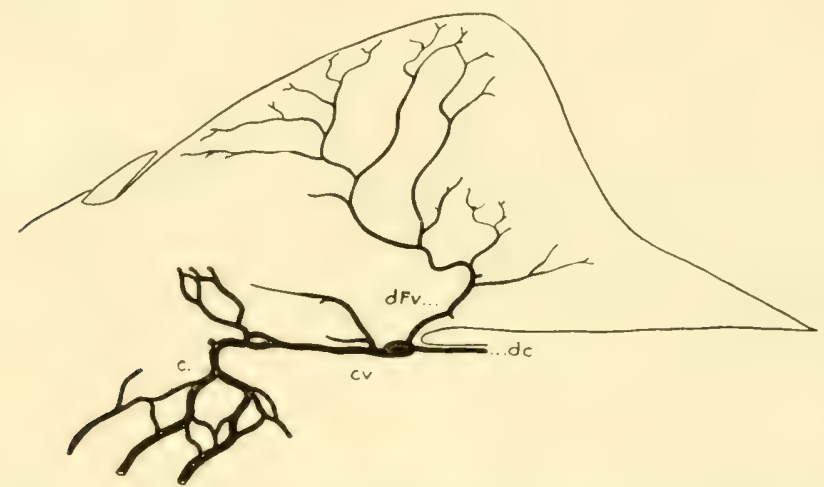

Fig. 199A. Veins of, and in the region of, first dorsal fin, Squalus sucklii. (L. H. Bennett, orig.)

$c$. , vein connecting dorsal and lateral cutaneous systems; c.v., vena circularis; d.c., dorsal cutaneous vein; dfv., vein draining dorsal fin.

be demonstrated in the coronary arteries but with more diffieulty. In Raia erinacea hy inflating either right or left vein a similar bubbling oceurs from the inner surface of the atrium, although none occurs from the ventricle. In

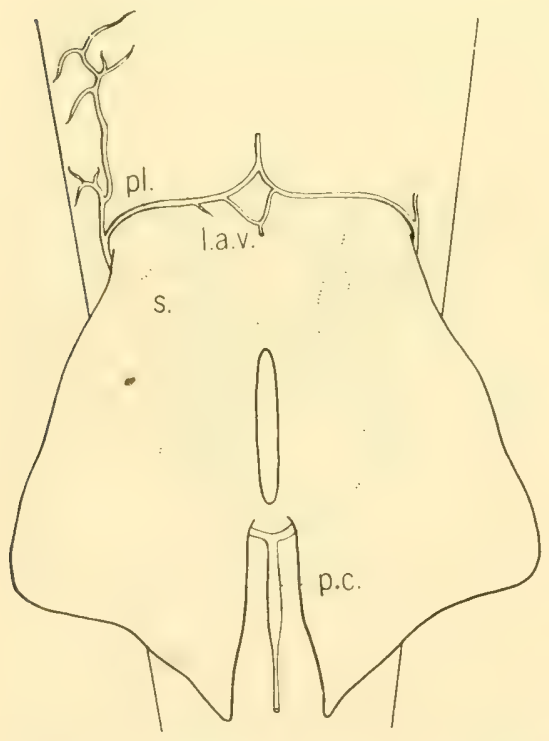

Fig. 199B, Cutaneous veins in region of cloaca, Squalus suchlii. (Edith Stoker, orig.)

l.a.v., lateral abdominal vein; p.c., postcloaeal segment of ventral cutaneous; $p l$., pelvic vein from ventral cutaneous to sinus (s.). the Elasmobranchs, then, the superficial veins of the heart empty into the sinus venosus and the deeper Thebesian vessels enter the atrium direct.

\section{CUTANEOUS SYSTEM OF VEINS}

The cutaneous veins consist of the dorsal, ventral, and lateral vessels of the skin.

The dorsal cutaneons vein collects blood from the skin on the back (Squalus sucklii, fig. 198, p.d.c.). It extends along the middorsal line from the caudal fin to the endolymphatic duets, and surrounds both dorsal fins in closed loops (c.v., fig. 199A). Posterior to the loop surrounding the first dorsal in Mustelus antarcticus according to T. J. Parker (1886) a median vein passes downward to the left of the column to join the left renal portal. This is essentially the condition found in squalus except that this deep vessel arises as a 
double vein the parts of which later unite to form the vena profunda of Mayer. Further, in Squalus the vena profunda joins the posteardinal vein. In Mustelus henle $i$ if the deep vessel passes to the right of the column it breaks up in a leash of vessels and may join the renal portal vein. In Heptanchus maculatus a similar vessel in the region of the single dorsal fin, which is comparable to the second dorsal fin of Squalus, passes to the right of the column and joins the caudal vein. The vena profunda of the second dorsal loop in Squalus and in Mustelus henlei joins the eaudal vein.

The lateral cutaneous veins (l.c.v., fig. 198) aceompany the lateral line system, the main trunk of the lateral eutaneous passing just mediad of and ventral to the lateral line. They collect blood from dorsal and ventral branches to the corium and underlying connective tissue and empty anteriorly into the subseapular sinus (s.sc.v.), which in turn enters the posteardinal sinus except in types like Heptanchus. A system of cross-trunks in the regions of the dorsal fins puts the lateral cutaneous in connection with the dorsal cutaneous vein (c., fig. 199A). In a number of Elasmobranchs (Squalus sucklii, fig. 198) an accessory lateral cutaneous vein $\left(\right.$ l.c.v. $\left.{ }^{1}\right)$ extends from the pelvic to the pectoral segments, parallel with the lateral cutaneous proper. This vessel has segmental comnections with the lateral cutaneous above it and the ventral cutaneous below it.

The ventral cutaneous vein is divided into pre- and posteloacal parts (p.v.c.). The precloacal part, not shown in figure $199 \mathrm{~B}$, extends as an umpaired median vein between the pelvic and pectoral regions. In the region of the pectoral it bifurcates, sending a right and a left branch to the lateral abdominal vein. These branches seem to be the same as those which I described for Heptanchus maculatus as the coracoid veins (Daniel, 1918). Posteriorly in the pelvic area, the vessel also divides ( $p l$, fig. 199B). Here its right and left branches in Squalus sucklii empty into a sinus $\left(s_{\text {. }}\right)$, from which the blood enters the lateral abdominal vein (l.a.v.).

The postcloacal division of the ventral cutaneous extends from the tail to the cloacal area. It arises as a pair of vessels on the right and left sides of the caudal fin, which do not meet around the tip of the ventral lohe of the fin. These vessels communicate with the caudal vein. If an anal fin be present (Scyllium) the ventral cutaneous forms a loop around the anal fin and then extends to the cloaca (p.c., fig. 1998), bifureating into right and left branches. The blood collected by this vein also passes into the sinus $\left(s_{.}\right)$and thence into the lateral abdominal system.

\section{NATURE OF CUTANEOUS SYSTEM OF VESSELS}

It was early observed that the cutaneous vessels in Elasmobranchs are not accompanied by arterial trunks. From this fact it was argued that they are not blood vessels but are lymphatic in nature. Work done by Miss Coles (1928) in this laboratory, however, showed that while no longitudinal arterial trunks accompany these ressels in Squalus sucklii, yet they are provided with a rich arterial supply which is given off by branches from the segmental arteries. 
Moreover, Burne (1923) has shown for Lamna that well marked cutaneous arteries do accompany some of these veins. Parker (1886) called attention to the presence of hlood in these vessels and Mayer (1888) proved that they are provided with valves. Furthermore, the cutaneous vessels are put into direct connection with the deeper veins, for example, the caudal vein. Also, Mayer reported the circulation of blood in these ressels in a semitransparent embryo.

All the above points made it likely that these vessels are true blood-vessels. The actual proof that they are haemal and not lymphatic in nature was made by Edith Stoker (see Daniel and Stoker, 1927) in the following way. The shark was first anaesthetized and a glass canula was inserted into a cut through the lateral cutaneous vessel. In this experiment the blood will circulate through the canula, demonstrating that the vessels are for the circulation of blood.

\section{Lymphatic Vessels}

Lymphatic vessels have been difficult to demonstrate in Elasmobranchs. Within recent years, however. Hoyer (1928) has succeeded in injecting these ressels, and reports that they have the following arrangement. Right and left trunks (thoracic ducts) accompany the dorsal aorta from the tip of the tail to the head. These trumks collect lymph from the muscles of the tail and trunk through tiny branches which run with the intersegmental arteries. They receive lymph from other vessels which run with the arteries and veins along the myosepta and the longitudinal septa separating dorsal and ventral bundles. A net of these vessels is present under the peritoneum and over the kidney. Lymphaties from the intestine unite in a plexus at the base of the mesentery and these plexuses are put into connection with the thoracic ducts throngh cross-trunks. In addition to these right and left ducts in the tail and trunk, there are two jugular trunks in the area of the head and pharynx, which accompany and finally enter the eardinal sinuses. Further, accompanying the subclavian arteries there are two branches which also enter the cardinal sinuses. 


\section{BIBLIOGRAPHY}

\section{Chapter VIII}

1878. BaLfour, F. M., A Monograph on the Development of Elasmobranch Fishes. London, pp. 1-295, 9 pls., 9 text figs.

1923. Burne, R. H. (see p. 195).

1918. Daniel, J. Frank, The Subclavian Vein and Its Relations in Elasmobranch Fishes. Univ. Calif. Publ. Zool., Vol. 18, pp. 479-484, 2 text figs.

1927. DANiel, J. Frank, and SToker, Edith, The Relations and Nature of the Cutaneous Vessels in Selachian Fishes. Univ. Calif. Publ. Zool., Vol. 31, pp. 1-6, 4 text figs.

1931. Daniel, J. Frank, and Bennett, L. H., Veins in the Roof of the Buecopharyngeal Carity of Squalus sucklii. Univ. Calif. Publ. Zool., Vol. 31, pp. 35-40, 3 text figs.

1833. Duvernoy, G. L., Sur quelques particularités du système sanguin abdominal et du canal alimentaire de piusieurs poissons cartilagineux. Ann. Sci. Nat. Zool., Vol. III (1835), Sér. 2, pp. 274-281, pls. 10-11.

1887. Hocłsтетter, F., Beiträge zur vergleichenden Anatomie und Entwicklungsgeschichte des Venensystems der Amphibien und Fisehe. Morph. Jahrb., Bd. 13, pp. 119-172, pls. 2-4, 7 text figs.

1893. Hochstetter, F., Entwicklung des Venensystems der Wirbeltiere. Ergebn. d. Anat. u. Entwick., Bd. 3, pp. 460-489, 24 text figs.

1906. Hochstetwer, F., Die Entwicklung des Blutgefässystems. Hertwig's Handb. vergl. u. expt. Entwick., Bd. 3, Teil 2, p. 116.

1893. Hoffrax, C. K., Zur Entwieklungsgeschichte des Venensystems bei den Selachiern. Morph. Jahrb., Bd. 20, pp. 289-304, pl. 12.

1901. Hofarann, Max, Zur vergleichenden Anatomie der Gehirn- und Rückenmarksvenen der Vertebraten. Zeitschr. Morph. u. Anthropol., Bd. 3, pp. 239-299, pls. 16-20, 6 text figs.

1859. Jourdain, S., Recherehes sur la veine port rénale. Ann. Sei. Nat., T. 12 (Sér. 4), pp. 134-188, 321-369, 5 pls.

1910. LAfite-Dupont, Sur le développement de la paroi des sinus veineux des poissons cartilagineux. (Réun. biol. Bordeaux.) C.R. Soc. Biol. Paris, T. 68, p. 694.

1785. Monroe, A., The Structure and Physiology of Fishes. Edinburgh, 128 pp., 44 pls.

1900. Neuvilue, H., Note préliminaire sur l'endothelium des veines intestinales chez les Sélaciens. Bull. Mus. Hist. Nat., No. 6, pp. 71-72.

1914. O'Donoghue, C. H., Notes on the Cireulatory System of Elasmobranchs. I. The Venous System of the Dogfish (Scyllium canicula). Proc. Zool. Soc. Lond., 1914, pp. 435-455, pls. 1-2, text figs, 1-4.

1928. O'Donoghue, C. H., and Аввотt, Elleen (see p. 197).

1881. Parker, T. J., On the Venous System of the Skate (Raja nasuta). Trans. N. Z. Inst., Vol. 13, pp. 413-418, pl. 15.

1899. PARKer, G. H., and DAvis, F. K. (see p. 197).

1892. RaBL, C., Ueber die Entwicklung des Venensystems der Selachier. Festsehr. z. 70. Geburtstag R. Leuckarts, pp. 228-235, 3 text figs.

1905. Rand, H. W., The Skate as a Subject for Classes in Comparative Anatomy; Injection Methods. Amer. Nat., Vol. 39, pp. 365-379, 1 text fig.

1905. Rand, H. W., and Ulrich, J. L., Posterior Connections of the Lateral Vein of the Skate. Am. Nat., Vol. 39, pp. 349-364, 5 text figs. 
1891. Rex, H. Beiträge zur Morphologie der Hirnvenen der Elasmobranchier. Morph. Jahrb., Bd. 17, pp. 417-466, Taf. 25-27.

1845. Roвin, Ch., Le Système veineux des poissons cartilagineux. C.R. Acad. Sci. Paris, T. 21 , pp. 12-82.

1845. Robin, CH., Note sur le système lymphatique des Raies et des Squales. L'Institut Paris, T. 13, pp. 144-145, 232-233.

1867. RobiN, CH., Mémoire sur les dispositions anatomiques des lymphatiques des Torpilles, comparées à celle qu’ils présentent chez les autres Plagiostomes. C.R. Acad. Sci. Paris, T. 64, pp. 20-24.

1911. Scaminon, R., Normal Plates of the Development of Squalus acanthias. Normentafeln z. Entw. d. Wirbel., Heft 12, pp. 1-123, 4 pls., 25 text figs.

1902. Vialleton, L., Les Lymphatiques du tube digestif de la Torpille (Torpedo marmorata, Risso). Arch. d'Anat. micr., T. 5, pp. 378-456, pls. 13-14.

1908. WidAKошісн, V., Wie gelangt das Ei der Plagiostomen in den Eileiter? Ein Beitrag zur Kenntnis des Venensystems von Scyllium canicula. Zeitschr. wiss. Zool., Bd. 91, pp. 640-662, Taf. 29, 2 text figs.

1906. WooduANd, W., A Suggestion concerning the Origin and Signifieance of the Renalportal System, with an Appendix relating to the Production of the Subabdominal Veins. Proc. Zool. Soe. London, 1906 (2), pp. 886-901, 1 text fig.

\section{LYMPHATICS}

1928. Hoyer, Henry, On the Lymphatic Vessels of Seyllium canicula. Anat. Record, Vol. 40, pp. 143-145.

1928. Hoyer, Henry, Recherches sur les vaisseaux lymphatiques des Sélaciens. Bull. Internat. Acad. Polon. Sei. et Lett. el. Sei. (Math.-Natur. P), pp. 79-104, pls. 7-10. 


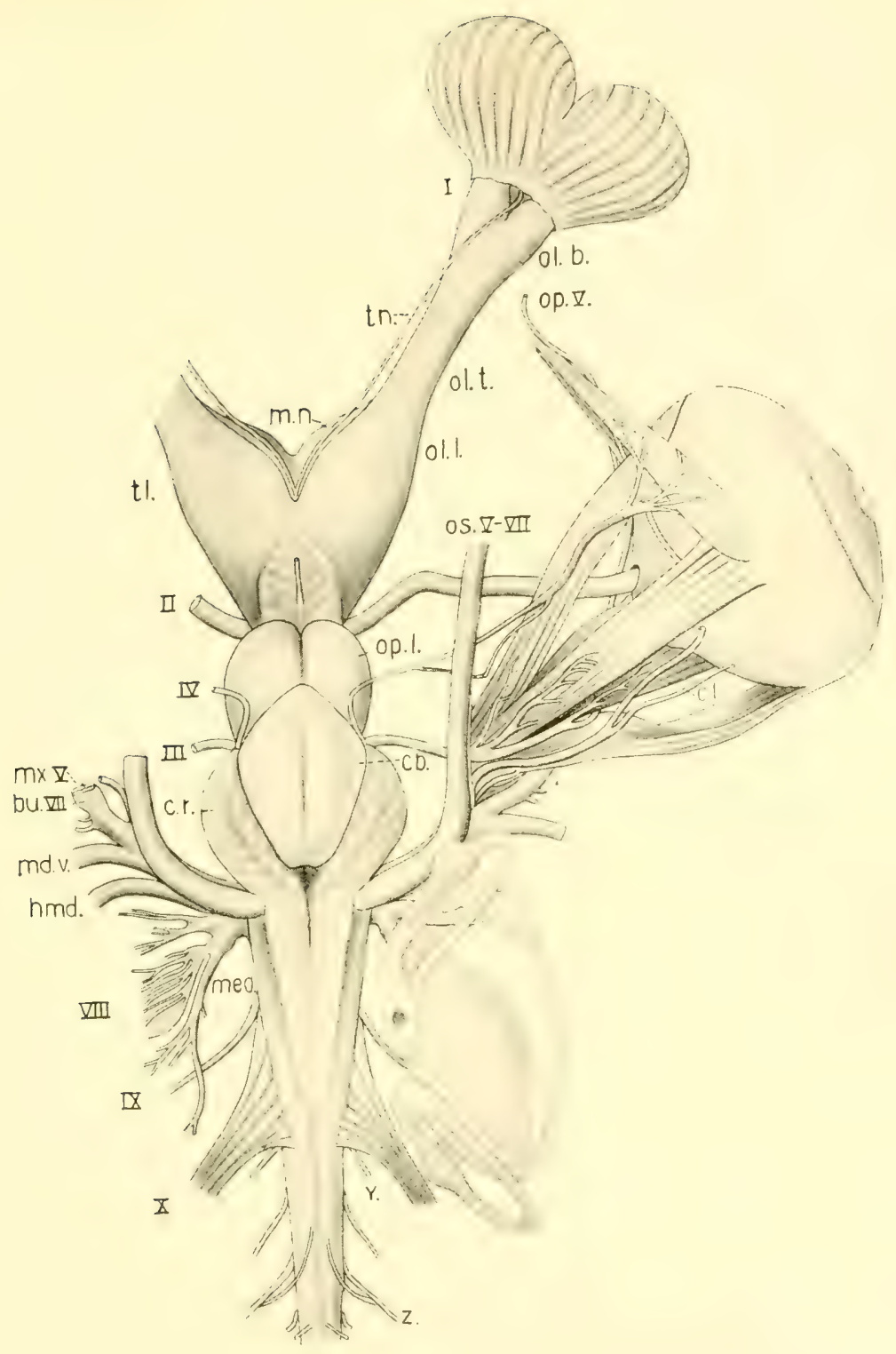

Fig. 200A. The brain and associated sense organs, Heptanchus maculatus, dorsal view. (Dunean Dunning, del.)

$b u . V I I$, buceal branch of facial nerve; $c b$., cerebellum; $c l$, ciliary nerve; $c . r$, restiform body; $d i$, diencephalon; hmd., hyomandibular division of the facial nerve; $i . t$, inferior lobe; md. $V$, mandibular division of the fifth nerve; $m . n$., median olfactory nucleus: med., medulla; ms., mesencephalon; $m x . V$, maxillary division of trigeminal nerve; ol.b., olfactory bulb; ol.l., olfactory lobe; ol.t., olfactory tract; op.l., optie lobe; op.T, ophthalmicus profundus division of the trigeminal nerve; os. $V$ and $T I I$, ophthalmieus superficialis of trigeminal and facial nerves; $t \bar{l}$., telencephalon; $t h$., terminal nerve; $v . s$. , vaseular sac; $w-z$, occipitospinal nerves; $I$, olfactory nerve; $I I$, optic nerve; $I I I$, oculomotor or third nerve; $I V$, trochlearis or fourth cranial nerve; $T I$, abducens or sixth eranial nerve; $V I I I$, auditory or eighth cranial nerve; $I X$, glossopharyngeal nerve; $X$, vagus nerve. 



\title{
NERVOUS SYSTEM
}

\section{NERVOUS SYSTEM OF HEPTANCHUS MACULATUS}

\author{
Central Neryous Systey
}

\section{BRAIN}

The brain of Heptanchus maculatus may be described as made up of five divisions, as is common for the Elasmobranchs. These divisions, beginning anteriorly are: the telencephalon, the diencephalon, the mesencephalon, the metencephalon, and the myelencephalon.

The telencephalon $(t l$., fig. $200 \mathrm{~A})$, if seen from the dorsal side, appears as a bilobed mass which is continued forward by long olfactory tracts (ol.t.). Between the tracts and projecting slightly anteriorly is the median olfactory nucleus (m.n.), better seen in ventral view (fig. 200B). Dorsally the telencephalon is raised up into the socalled pallial eminences. At the angle between the median olfactory nucleus and the pallial eminence is the recessus neuroporicus, at the sides of which arises the terminal nerve $\left(t n_{0}\right)$. The telencephalon is continued posteriorly by the diencephalon (di., fig. 200в).

The diencephalon is provided with a thin roof through which the pineal stalk passes as a slender thread upward and forward to the cartilaginous roof. This segment of the brain continues posteriorly as a gradually narrowing mass back to the place where the optic nerves (II) form the optic chiasma. From the posterior and ventral part of this division arises the infundibulum, at the sides of which are the inferior lobes (i.l.) and the vascular saes

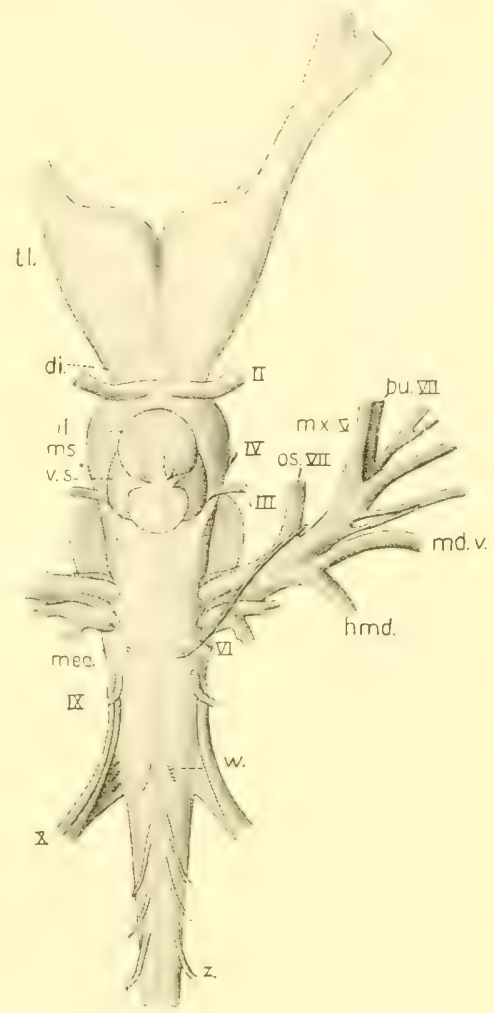

Fig. 200B. Brain and eranial nerves, Heptanchus maculatus, ventral view. For explanation see fig. $200 \mathrm{~A}$. (v.s.) of the brain. In the middle line and ventral to the vaseular sacs are the lobes of the pituitary (see fig. 215).

The mesencephalon is well developed ( $m s$., fig. 200B). Dorsally it consists of two hollow optic lobes (op.l., fig. 200A) or corpora bigemina. These in their posterior part are overlapped by the cerebellum $(c b$.$) and ventrally by the$ infundibulum and its associated structures. Through the posterior roof of 
the mesencephalon and near the cerebellum the fourth cranial or trochlear nerve arises $(I V)$. Ventrally the mesensephalon is composed of large fiber tracts through which the third cranial or oculomotor nerve $(I I I)$ emerges and passes forward to muscles of the eye.

The metencephalon consists, in large part, of the cerebellum (cb.), a large shield-shaped mass, separated dorsally into right and left halves by a median groove. The cerebellum extends anteriorly over the posterior half of the optic

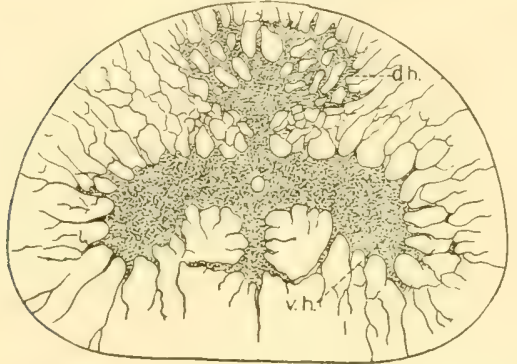

Fig. 201. Cross-section of cord, Heptanchus cinereus. (From Sterzi.) (Grey matter stippled.)

d.h., dorsal horn; v.h., ventral horn. lobes, and posteriorly it overlies the following division of the brain. Ventrally and under the cerebellum are heavy fiber tracts which also belong to the segment of the metencephalon.

The myelencephalon is the last segment of the brain. It comprises the medulla oblongata ( med.) which from above extends upward on each side almost to the tip of the cerebellum as the restiform bodies (corpora restiforme, c.r.). Back of the restiform bodies the medulla grows smaller and smaller in diameter until it joins the cord. Within the myelencephalon and the metencephalon is the fourth rentricle which is covered orer by a thin roof. The myelencephalon gives rise to all the cranial nerves back of the fourth.

\section{SPINAL CORD}

The spinal cord extends from the medulla practically to the tip of the tail. Externally, as is seen in figure 201, it presents no evidence of a dorsal or a ventral groove which in some Elasmobranchs (see fig. 217B) may mark the boundaries of the cord into right and left halves. Superficially the cord consists of numerous fiber tracts surrounding masses of nerve cells.

In the section (fig. 201) the central, more solid part of the cord constitutes the grey matter (cells) roughly in the form of an $\mathrm{X}$, the upper arms of which are the dorsal horns (d.h.) and the lower arms, the ventral horns $(v . h$.) of the cord. The less conspicuous dorsal horns lie near the middorsal line, while the ventral horns extend ontward and downward as an expanded mass on each side. Furthermore there is a median ventral mass extending toward the midventral line from the union of the ventral horns. Where the crossing of the $\mathrm{X}$ takes place there is a considerable thickening, in which is located the neurocoele or eavity of the spinal cord. It will be observed that the neurocoele is practically at the middle of the section and is circular in outline.

\section{Peripheral Nervous System.}

The cranial and spinal nerves arising from the central nervous system perforate the cranium and spinal columm respectively. Also perforating the cranium but back of the last cranial nerve are certain accessory nerves. 
CRANIAL NERVES

The first cranial or olfactory nerve has its end organs in the mucous membrane of the olfactory organ. The nerve passes backward in two short bundles, one median and the other lateral in position ( $I$, fig. 200A) to the olfactory bulbs (ol.b.) The bulbs are joined to the olfactory lobes (ol.l.) of the brain by means of long olfactory tracts (ol.t.).

Running parallel with this tract is the terminal nerve $(t n$. ), which in Heptanchus arises near the recessus neuroporicus and passes along the tract as a slender strand. Near the olfactory bulb it runs laterad and enters the fissure dorsally between the lateral and median divisions of the olfactory nerve. To the median nerve it gives an exceedingly slender strand and continues with the lateral division of the nerve, finally reaching the mucous membrane of the eup.

The second or optic nerve (II, figs. 200A and 200B) has its origin from the retina of the eye. As a thick stem it passes inward, crosses in the optic chiasma, and enters the diencephalon.

The third cranial nerve or oculomotor $(I I I)$ springs from the rentral side of the midbrain and passes to muscles of the eye. In the orbit it divides so as to supply branches to the inferior, the superior, and the anterior rectus, and to the inferior oblique muscles of the eye.

The trochlearis or fourth nerve $(I V)$ also arises from the mesencephalon, but the fibers perforate the roof of the brain instead of the floor. The fibers then as a small band pass under the overhanging cerebelhum and down over the mesencephalon forward and outward to the superior oblique musele of the eye.

The trigeminal or fifth cranial nerve in Heptanchus maculatus arises from the brain in common with, but slightly anterior and ventral to, the seventh nerve. A short distance from its origin it separates into its main branches. The first of these nerves, the ophthalmicus profundus (op. $V$, fig. $200 \mathrm{~A}$ ), runs to the median side of the eyeball. Before reaching the latter, however, it gives off the ciliary branch $(\mathrm{cl}$.) to the eye; it then perforates the cartilaginous capsule surrounding the eyeball and continues forward under the superior rectus, next emerging from the cartilage to pass forward under the anterior rectus muscles and between the superior and inferior obliques. It leaves the orbit by a separate foramen, and finally breaks up in the skin over the nasal capsule. The ophthalmicus superficialis of the fifth (os.V) is a small branch or branches rumning with the ophthalmicus superficialis of the serenth nerve. The maxillary branch ( $m x . V$, fig. 200A) of the trigeminal breaks up into three or four main divisions which go to supply the region of the upper jaw; while the mandibular division of the fifth (md.V) passes hackward and downward around the angle of the mouth to the mandibular region.

The abducens or sixth nerve (VI, fig. $200 \mathrm{~B}$ ), after leaving the midventral line of the myelencephalon back of the fifth-serenth complex, passes under the 
main stems of this complex and out from the eranium through its own foramen. It enters the base of the external rectus muscle.

The facial or seventh cranial nerve like the fifth is composed of four important branches. These are first the superficial ophthalmic nerve (os. TII, figs. $200 \mathrm{~A}$ and $200 \mathrm{~B}$ ) which runs above all the eye muscles through the orbit, gives branches dorsally to the supraorbital sensory canal, and then leaves the orbit hy the large anterodorsal ophthalmic foramen (f.o.VII, fig. 47). Outside of the orbit it supplies hranches to the supraorbital canal and to certain groups of the ampullae of Lorenzini. The second or buccal division of the

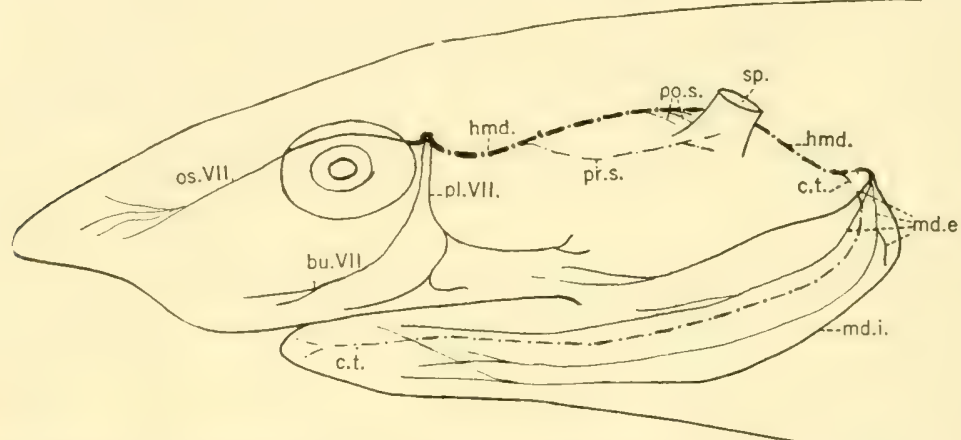

Fig. 202. Branches of the facial nerve, Heptanchus maculatus. (IV. R. Dennes, orig.)

bu.VII, buccalis of facial; c.t., chorda tympani; $h m d .$, hyomandibular (postspiracular) division of seventh nerve; md.e., superior and inferior branches of external mandibularis of seventh; md.i., internal division of mandibularis of seventh; os.VII, ophthalmicus superficialis of seventh nerve; $p l . V I I$, palatinus; po.s., postspiracular twigs; pr.s., prespiracular nerve; sp., spiracle.

facial nerve ( $b u . V I I)$ passes from the brain stem just dorsal to the maxillary division of the fifth $(m x . V)$. In the orbit it divides much like the maxillary division of the fifth. It goes to supply the infraorbital canal and the ophthalmic and buccal groups of ampullae. The palatine division of the seventh (pl.TII, fig. 202) leaves the main stem of the hyomandibular nerve and passes ventralward, dividing into an anterior and a posterior branch, to the palate of the mouth. The most posterior division of the facial, the hyomandibular ( $h m d$., figs. 200A and 202), after giving off the palatine branch, passes sharply backward around the spiracle, downward around the angle of the jaw and forward along the mandible. It first gives a prespiracular branch (pr.s., fig. 202) to the anterior wall of the spiracle; other twigs (po.s.) are next given off to the posterior wall of the spiracle. Back of the angle of the jaw a superficial branch runs forward toward the angle of the jaw, and two branches (md.e.) pass along the external side of the mandible to the hyomandibular canal and mandibular groove ( $m m c$. and $m g$., fig. 228). A deep branch (md.i., fig. 202) given off at the angle runs along the body of the hyoid, and another branch, the chorda tympani (c.t.), passes forward between the hyoid and the mandible.

The auditory or eighth nerve in Heptanchus (VIII, figs. 200A and 200B) is more or less clearly separated from the seventh. It has a large ganglion from 
which run two main branches; the anterior branch passes outward and divides into two divisions; the other passes backward and separates into numerous twigs. This nerve supplies the ampullae of the semicircular canals and sends divisions to other parts of the ear.

The glossopharyngeal or ninth nerve (IX, figs. 200A and 203) arises back of the sixth and farther from the middle line and passes posteriorly under the floor of the auditory capsule. Before reaching the surface it gives off a branch (st.IX, fig. 203) from which supratemporal branches are sent off presumably to the anterior segment of the lateral line canal. Another branch (dr.IX) passes upward and backward from the supratemporal but its destination has not been determined. After leaving the cranium the glossopharyngeal bears a ganglion ( $g n_{\text {. }}$ ) dorsal to the first branchial eleft, from which proceeds the main pretrematicus nerve ( prt.) ; this nerve runs down the hyoidean demibranch in front of the first gill pocket. A pharyngeal branch ( $p h . I X)$ arises from the ganglion over the dorsal angle of the first eleft and passes forward to supply the dorsal pharyngeal wall. From the pharyngeal in Heptanchus maculatus there is given off an internal pretrematic (prt.i.). The third division of the nerve is the post-trematicus (po.t.) which passes back of the first cleft, in the anterior demibranch of the first whole gill. In Heptanchus maculatus the post-trematicus is divided into two distinct bundles, of which the anterior is sensory and the posterior is mixed. The posterior branch of the post-trematicus continues to the ventral pharyngeal region, supplying motor branches to muscles and sensory fibers to the mucous membrane. One of its sensory branches curves forward and runs dorsally past the end of the anterior sensory root.

The vagus or tenth cranial nerve ( $X$, figs. $200 \mathrm{~A}$ and $200 \mathrm{~B}$ ) leaves the brain stem by a number of roots. Some of these roots arise ventrally close to the origin of the ninth. Others arise in a crescentic line from this almost to the middorsal line. The nerve leaves the cranium through a large foramen and outside appears in three main divisions. One of these, the lateralis nerve ( $l l . X$, fig. 203), supplies the lateral line and extends practically to the tip of the tail. The branchial divisions $\left(b r \cdot X^{1-6}\right)$, consisting of six nerves, pass backward and then ventrally to supply the gill area not supplied by the glossopharyngeal; while the third division, the visceral (bi.X), passes on to the viscera.

The lateralis nerve $(l l . X)$ is the most anterior bundle of the vagus arising from the brain (figs. 200A and 200B). It continues backward more or less separate and distinct even in the canal where it gives off two branches, one of which (st.X, fig. 203) passes to the supratemporal and lateral sensory canals, the other $(d r . \mathrm{Y})$ being distributed to the area of the pit organs along the back. The lateralis then runs along the wall of the anterior cardinal sinus and finally passes posteriorly between the dorsal and lateral bundles giving off branches to the lateral line.

The branchial nerves to the gills $\left(b r \cdot X^{1-6}\right)$ lie in the floor of the anterior cardinal simus. Distal to their ganglia each of these nerves comprises the same number of parts as the ninth, pretrematicus, post-trematicus, and pharyngeal 

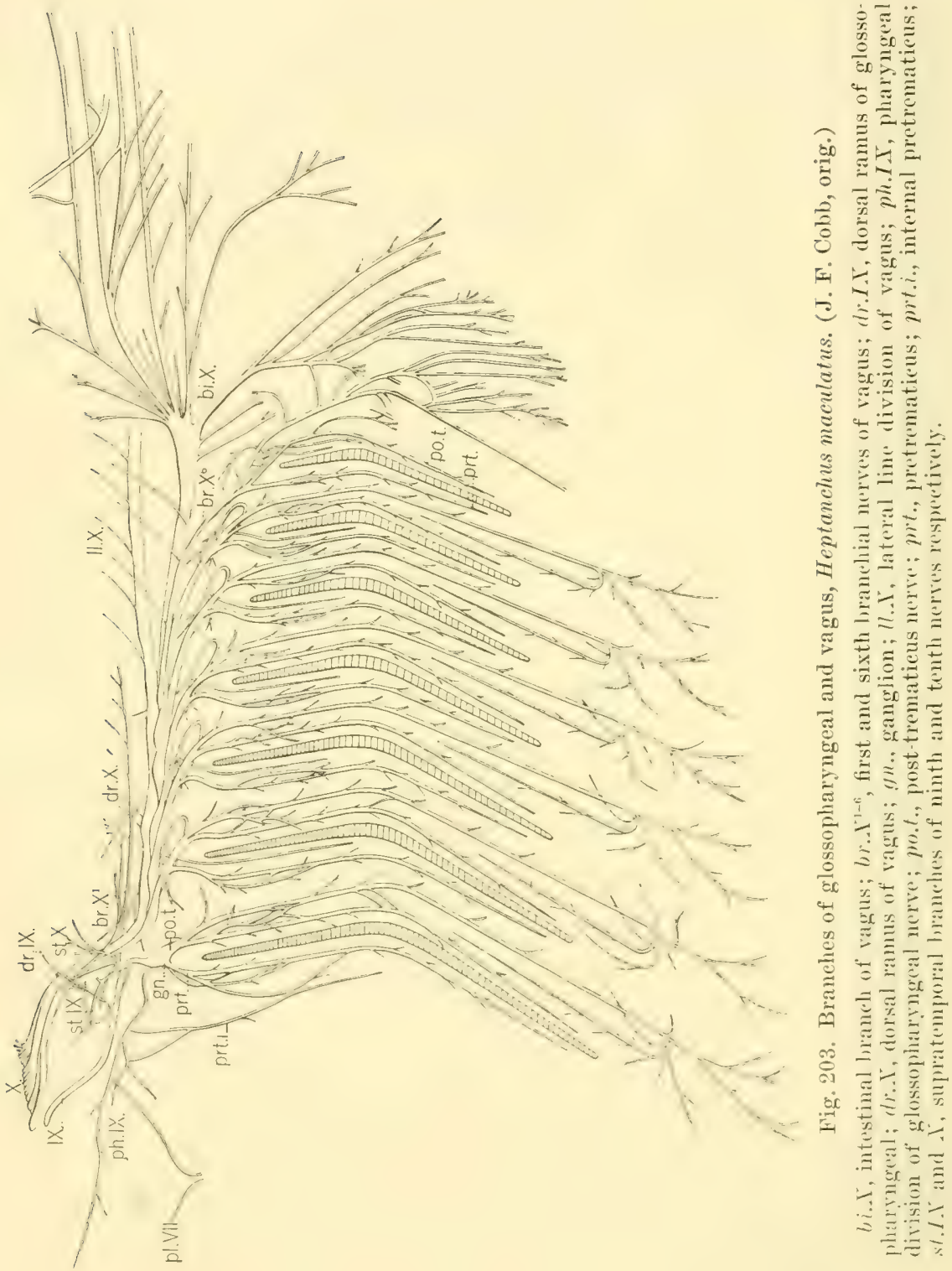
branches. The pharyngeal is unlike that of the ninth only in that it first passes posteriorly and then curves forward. 'The nerves posterior to the seventh cleft have undergone considerable change. The third division of the vagus, the ramus intestinalis (bi.X), breaks up into a number of important divisions, some of which go to the heart, others to the oesophagus, and still others to the stomach and associated parts.

\section{OCCIPITOSPINAL, NERVES}

Arising posterior to the vagus are certain small nerves known as the occipitospinales ( $w$-z, figs. 200A, 200B, and 204). These nerves are unusually numerous in Heptanchus and consist of both ventral and dorsal branches. The first pair to arise ventrally ( $w$, fig. $200 \mathrm{~B}$ ) is near the midventral line and not unlike the sixth or abducens nerve in origin. Posterior to this are three others $(x, y, z)$, making in all four ventral pairs. Dorsally in Heptanchus maculatus (fig. 200A) there are two pairs, the first of which joins the " $y$ " division of the ventral nerve.

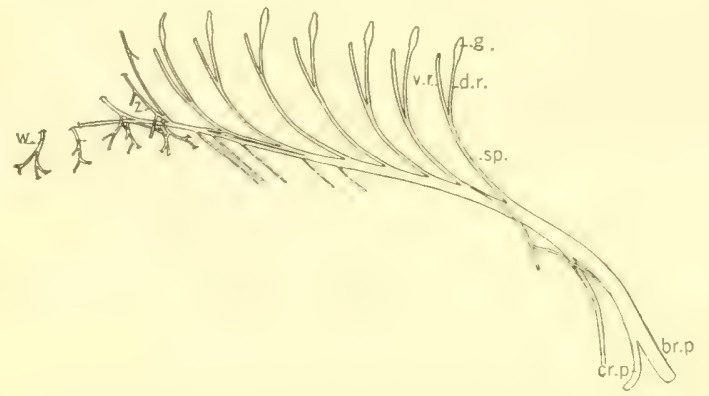

Fig. 204. Cervical and brachial plexus, Heptanchus cinereus. (From Max Fürbringer.)

$b r . p$. , brachial plexus; $c r . p .$, cervical plexus; $d . r$. , dorsal or sensory nerve; $g$., dorsal root ganglion; $s p$., spinal (mixed) nerve; $v . r$, ventral or motor nerve; $w, x, y, z$, oceipitospinal nerves.

These nerves supply the subspinalis and dorsal interareuales muscles (fig. 204) and are like the spinal nerves with which $x, y$, and z form a plexus.

\section{SPINAL NERVES}

A spinal nerve arising from the spinal cord in Heptanchus cinereus (M. Fürbringer, 1897) is composed of a single ventral (motor) and a dorsal (sensory) root. The ventral root comes from cells in the ventral horn of the corck (v.h., fig. 201) and passes ontward to be joined by the dorsal root (fig. 204 ) ; while the dorsal root extends to the dorsal horn of the cord (d.h., fig. 201 ) through the dorsal root ganglion ( $g$. fig. 204). After the union of dorsal and ventral divisions the mixed nerves thus formed, in the region of the neck and the pectoral and pelvic fins, are pressed together.

The cervical (cr.p., fig. 204) and pectoral plexuses (br.p.) may be considered together since they form a continuous bundle. In Heptanchus cinereus these plexuses (fig. 204) are made up of the first seven spinal nerves together with oceipitospinales which were above mentioned. At the region of the scapula the nerve trunk separates, the cervical nerves (cr.p.) going to the hypobranchial or ventral longitudinal muscles, and the pectoral plexus $(b r \cdot p$.) to the pectoral fin. 
Beginning with the twenty-fifth spinal nerve ( $s p .25$, fig. 205), the terminal divisions of some of the spinal nerves are connected at the region of the lateral abdominal vein (l.a.v.) into a nervous collector. This in Heptanchus cinereus as described by Braus (1898) forms a collector of unusual length, which continues to the thirty-eighth spinal nerve $(s p .38)$, but does not perforate the cartilage of the pelvic girdle.

Posterior to the pelvic girdle a pelvic plexus of nerves ( $p l . p$., fig. 205) is also found in Heptanchus. This plexus in the adult Heptanchus cinereus usually involves only the forty-eighth and forty-ninth nerves, and the plexus thus formed is considerably back of the pelvic girdle.

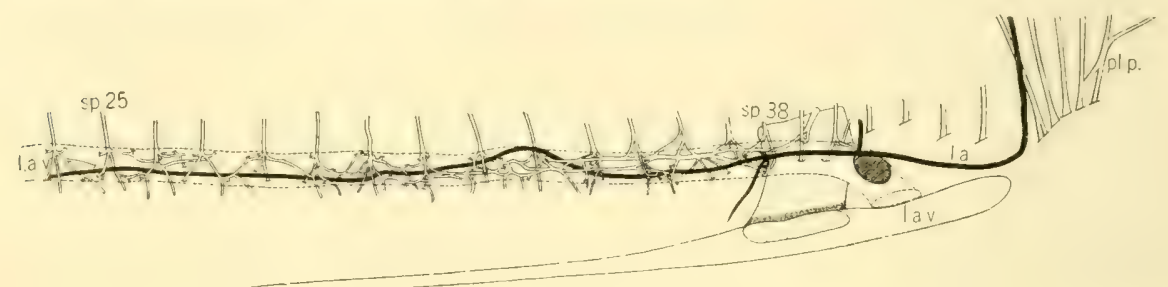

Fig. 205. Nervous collector, Heptanchus cinereus. (From Braus.)

l.a., lateral artery; l.a.v., lateral abdominal vein; pl.p., pelvic plexus; $s p .25$, 38, twentyfifth and thirty-eighth spinal nerves. 


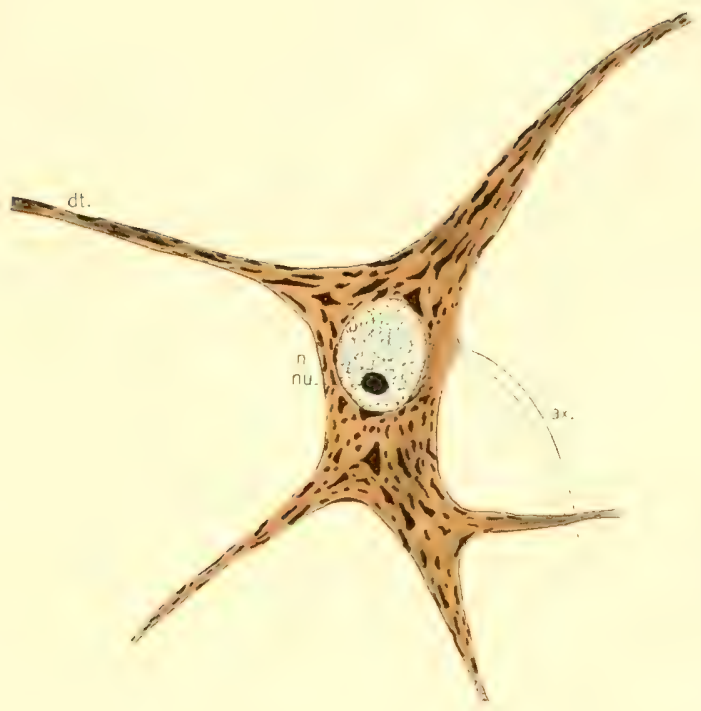

Fig. 206. A multipolar motor eell. (From Houser.) a.x., axone; at., dendrite; n., nueleus; nu., nueleolus. 



\section{NERVOUS SYSTEM OF ELASMIOBRANCHS IN GENERAL}

'The central nervous system, comprising the brain and the spinal cord, is composed of neurones. A neurone consists of a nerve cell from which proceed the axone and dendrites. 'The nerve cells themselves are of three general types. One of these is a multipolar cell (fig. 206) with numerous dendritic processes

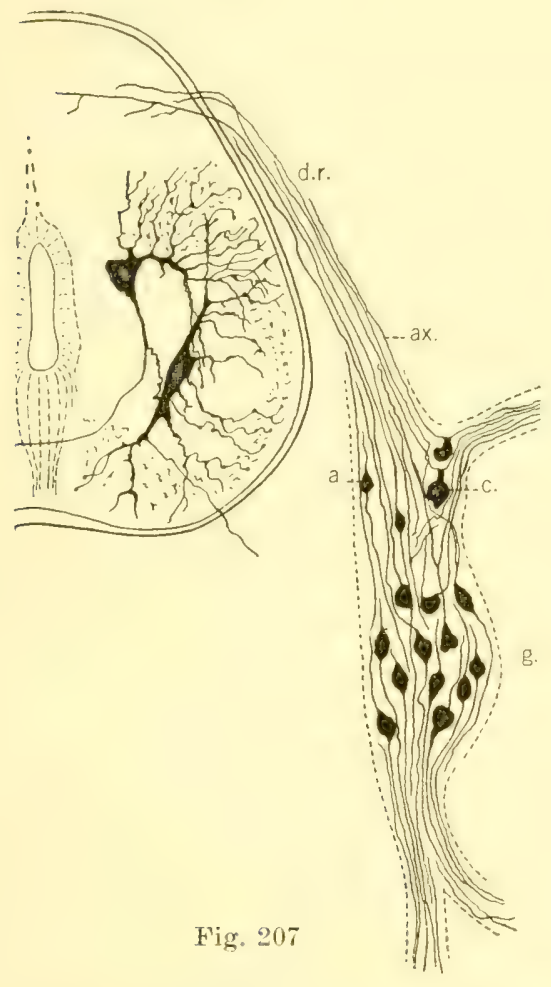

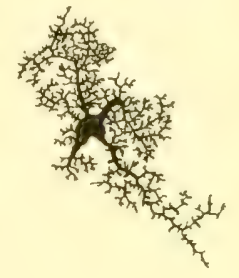

A

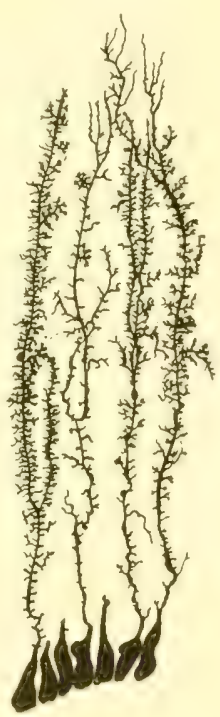

B

Fig. 207. Bipolar cells of cord, Pristiurus. (Modified from Von Lenhossék.)

$a-c .$, stages in development of a bipolar cell; ax., axone or fiber; $c$., adult type of cell; d.r., dorsal root; $g$. , dorsal root ganglion.

Fig. 208. Supporting elements, Mustelus canis. (From Houser.) A. Neurogleal cell. B. Ependymal cell.

$\left(d t_{.}\right)$an axone $\left(a x_{*}\right)$, and a large nucleus $\left(n_{*}\right)$; another is the bipolar type with two processes to the cell body. Figure 207 shows the development of some bipolar cells in the dorsal root ganglion of Pristiurus. An early stage $(a)$ shows the two processes, one of which, the axone proper, passes in toward the cord; the other process extends toward the periphery. Stage (c) shows the union of the two processes to form the stem of a $\mathrm{T}$. In this stage the cell appears to be unipolar or with a single process extending from it.

In addition to the cells and fibers found in the central nervous system, certain supporting elements are also present. The first of these are the ependymal 
cells ( fig. 20sb) which are modifications of the cells bounding the cent ral canal or neurocoele. The processes from these cells often reach entirely across to the external margin of the cord. The second type of supporting cell is the neurogleal cell which may take the form shown in figure $208 \mathrm{~A}$, or its processes may be long.

\section{Developient of Central Neryous System}

In its origin the nervous system is laid down as a flattened, horseshoe-shaped plate of cells, of ectodermal origin, which later becomes spatulate (fig. 209). The broad end of the spatula, which will later form the brain, differs consider-

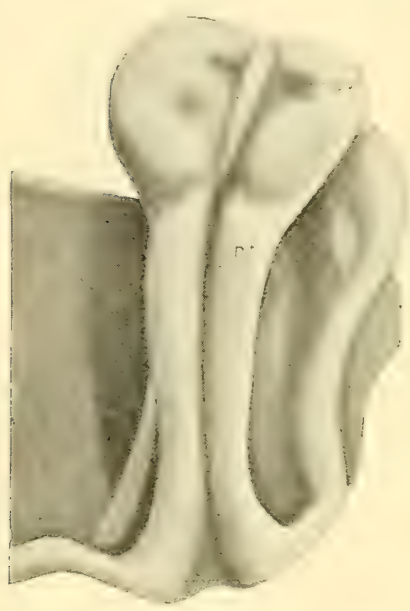

Fig. 209. Derelopment of medullary plate, Acanthias. (From Locy.)

n.f., neural fold; op.v., optic vesicle. ably from the narrower handle which is the rudiment of the spinal cord. The margins of the plate (n.f., fig. 209) fold up and the whole plate then sinks down along the middorsal line. In the region of the brain, where the plate widens, the lips of the plate close slowly; but in the region of the cord the closure goes on with more rapidity. Even before the closure of the plate, however, outpocketings to form the primitive optic vesicles (op.v.) appear. The plate then closes into a tube, the point at which closure last takes place remaining as the neuropore (np., fig. 212).

The tube thus formed is divided into the primitive forebrain, the midbrain, and the hindbrain. By further development the forebrain and the hindbrain are separated into four of the permanent segments of the adult brain, while the mesencephalon does not divide further. The prosencephalon or forebrain becomes the telencephalon and diencephalon and the hindbrain or rhombencephalon becomes the metencephalon and myelencephalon. Thus the five divisions of the adult brain which we have described for Heptanchus are formed.

\section{GROSS FORM OF BRAIN}

Superficially, different Elasmobranch brains present very different appearances. This difference is due largely to the condition of the olfactory tracts and their appended olfactory bulbs. The bulbs, arising as outgrowths from the prosencephalon, may still be practically in contact with it in the adult. In Scymnus (fig. 213A) they may extend but a short distance out from the prosencephalon. In other types, however, as in Heptanchus, they may be drawn far forward so as to be remotely removed from their place of origin (Squatina, Laemargus borealis, and especially Hexanchus). In addition the olfactory tracts may be widely divergent as in Raja (fig. 211B) and Zygaena, or they 
may take a course more or less nearly parallel as in Carcharias and Myliobatis (fig. 212).

In the greater number of Elasmobranchs the brain is elongated so that in a dorsal view at least parts of all the five segments are visible. In a few, however, the brain may appear as a more or less compact mass. As a normal thing

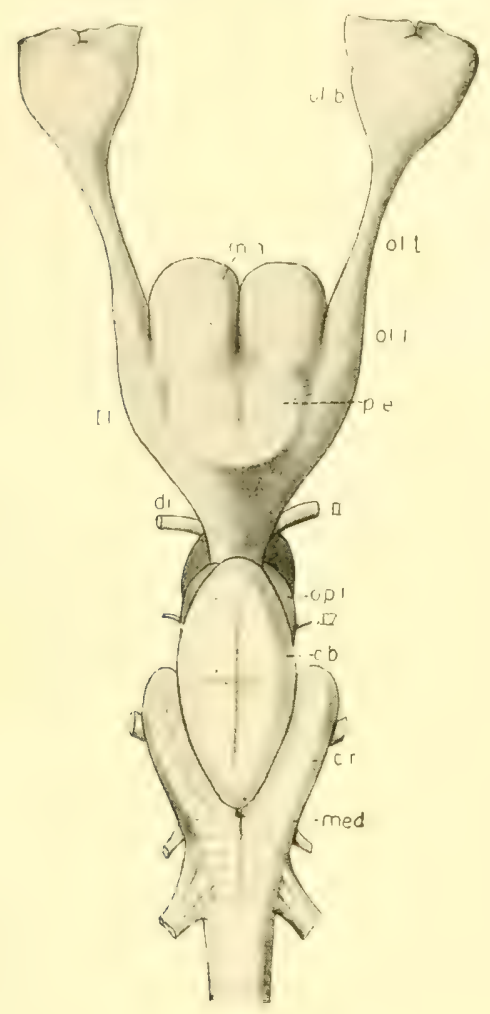

A

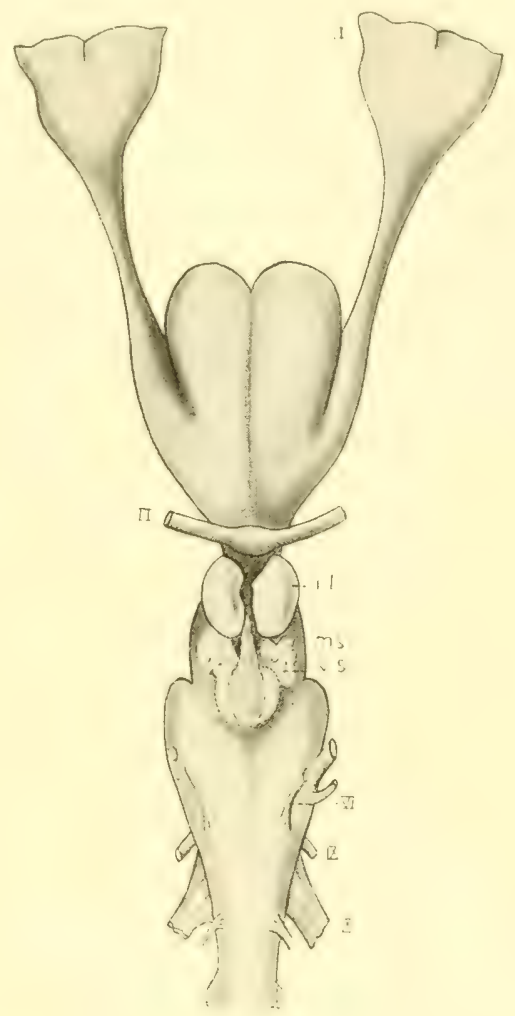

B

Fig. 210. Brain of Heterodontus francisci. (Mildred Bemnett, del.) A. Dorsal view. B. Ventral view.

$c b .$, cerebellum; $c . r$., restiform body; $九 i$, diencephalon or thalamencephalon; $i . l$. , inferior lobe; m.n., median olfactory nucleus: med., medulla; $m s$. mesencephalon; ol.b., olfactory bulb; ol.l., olfactory lobe; ol.t., olfactory tract; op.l., optic lobe; p.e., pallial eminence; $t l$., telencephalon; $v$.s., vaseular sac; $I$, olfactory nerve; $I I$, optic nerve; $I V$, trochlearis or fourth nerve; $V I$, abducens or sixth eranial nerve; $I X$. glossopharyngeal nerve; $X$, vagus nerve.

the compactness is the result of the enlargement of the cerebellum $(c b$. fig. 212 ) whereby it overlies the mesencephalon or, oceasionally, even a part of the diencephalon (Scoliodon, or Myliobatis).

We may now consider in more detail the different segments of the brain. In form the telencephalon $\left(t l_{\text {. }}\right.$ ) depends largely upon the proximity of the right and left halves. In Heterodontus francisci (fig. 210) these are clearly separated by a median anterior sulcus so that the lobes have undergone but slight fusion in the middle line. In Heptanchus we have noted a similar condition 
although in it fusion is greater. From Heterodontus to Scoliodon (fig. 211A) a series of forms may be obtained, showing a progressive specialization to a condition in which practically no sign of right and left lobes remains.

In the component parts of the telencephalon there is also great diversity. The median olfactory nucleus ( $m . n$.) produces very different effects depending on the degree of its own development and also on the degree of fusion of the right and left telencephalic lobes. In Scymmus these nuclei constitute a

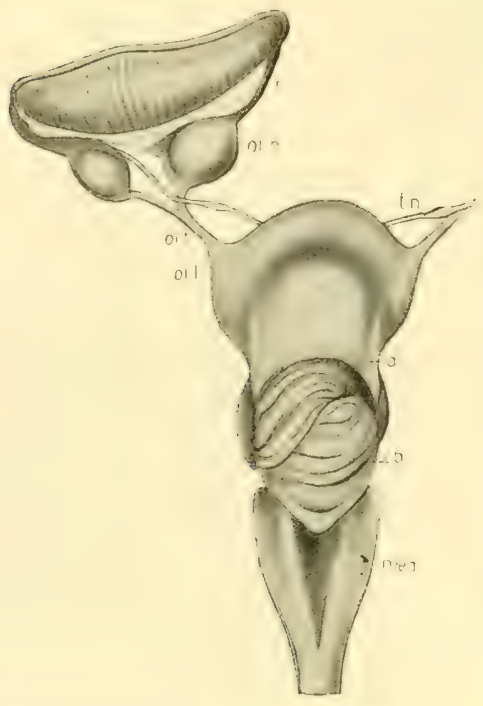

A

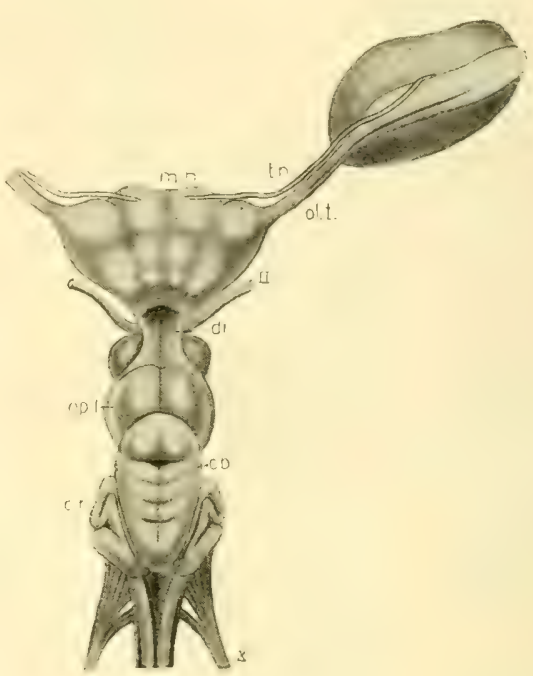

B

Fig. 211. Dorsal view of brain. (From Locy.) A. Scoliodon. B. Raja.

$c b$. , cerebellum; $c . r$. , restiform body; $d i$. , diencephalon; m.n., median olfactory nucleus; med., medulla; np., neuropore; ol.b., olfactory bulb; ol.l., olfactory lobe; ol.t., olfactory tract; op.l., optic lobe; $t l$., telencephalon; $t h$., terminal nerve; $I$, olfactory nerve; $I I$, optic nerre; $I V$, trochlearis or fourth nerve; $\boldsymbol{X}$, vagus nerve.

pair of rounded masses located terminally between the olfactory tracts (m.n., fig. 213) and extending ventrally. Much the same condition obtains in Squalus. sucklii (see p. 183, fig. 172A), but in this form the median nucleus is not projected forward into so sharp a mass. In a type like Heterodontus it stands out in a particularly striking way. In many other forms, on the contrary, the median olfactory nucleus is poorly developed.

The pallial eminences also are very differently developed in different Elasmobranchs. In Scymmus again they are sharply defined as prominent dorsal mounds built up of masses of cells (p.e., fig. $213 \mathrm{~A}$ ). In other forms these lobes are less well developed (Acanthias); while in still others they are searcely discernible.

The diencephalon ( $d i$. ) in general may be said to be narrow from side to side and show no marked swellings. In some forms it is well seen from above, as in Heterodontus (fig.210) and Ruju (fig.211 B). In all such oceurrences the brain stem is well drawn out in this region. In those Elasmobranchs in which a 
greater compactness of brain obtains, or in those where the cerebellum is especially well developed, the diencephalon may be more or less completely hidden (Scoliodon, fig. 211A; Myliobatis, fig. 212).

Both dorsally and ventrally the diencephalon is characterized by outgrow ths which are of interest. From the roof arises the chimney-like epiphysis (pineal stalk) (ep., fig. 213A) which passes upward and forward to the roof of the cranium. In general the stalk terminates at the roof immediately posterior to the anterior fontanelle and is usually spread out terminally into the dise-like pineal body.

In development the pineal region in the early embryo of Acanthias (Minot, 1901) shows a series of arches in the roof of the brain which are separated by a series of projections. The long anterior projection ( $v$., fig. 214) is the velum, an important landmark separating telencephalon from diencephalon. The velum in figure $214 \mathrm{~B}$ separates the paraphysial arch $(p a$.$) from the small postvelar areh \left(p . v_{0}\right)$. Back of the postvelar areh is a projection in which the superior commissure (s.c.) runs. An early stage of the epiphysis (ep., fig. 214A) is shown behind this projection, and in the projection is the posterior commissure (p.c.). Figure $214 \mathrm{~B}$ is a later stage in the development of the pineal stalk in which the surrounding structures have reached a definitive form. The pineal stalk (ep.) has almost reached the surface; the paraphysis $(p a$.$) is enlarged; and the velum$ and commissures are well marked.

From the floor of the diencephalon an evagination, the infundibulum ( $\mathrm{in}$., fig. 213B), drops downward and backward, and at its sides are the inferior lobes (lobi inferiores, i.l., fig. 213A)

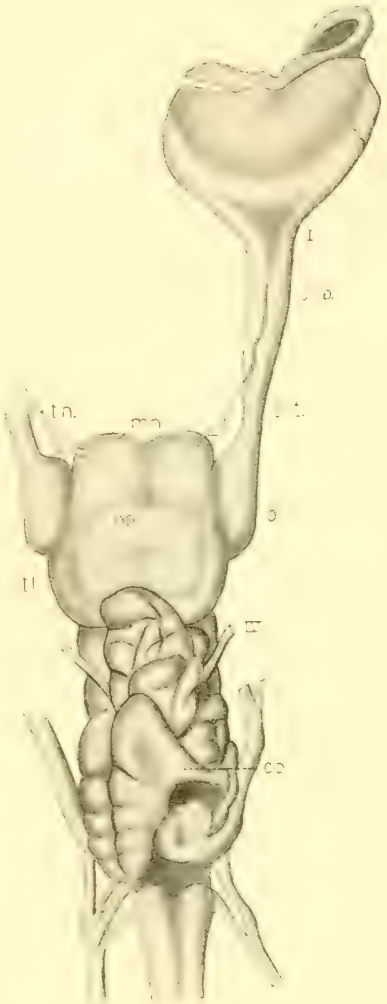

Fig. 212. Dorsal riew of brain, Myliobatis californicus. (For explanation see fig. 211.) and the rascular sacs (sacei vasculosi, v.s.). The infundibulum meets and fuses with the hypophysis, an outgrowth from the buceal cavity, to form the pituitary. The hypophysis may present a complex appearance, or it may be comparatively simple. In Scymmus, as in Heptanchus, it is composed of three well defined divisions, an anterior terminal, a median, and a paired posterior division, the posterior division being considerably removed from the body of the infundibulum and connected with it only by a narrow strand.

Figure 215 is a detailed drawing in side view of the pituitary and surrounding structures, in the adult of Squalus sucklii. In this area, in addition to the inferior lobes (i.l.b.) and vascular sacs (v.s.) of the brain, there are three unpaired parts of the hypophysis lying in the midventral line. These are the 
anterior (a.l.), intermediate (i.l.), and inferior lobes (i.l.h.). To these parts are to be added the paired superior lobes $(s . l$.) which lie at the sides of and above the intermediate lobes.

The mesencephalon (fig. 213, op.l.) is a conservative segment and yet it varies considerably in different forms. In many it is relatively inconspicuous because of the extreme development of the cerebellum, while in others it comes
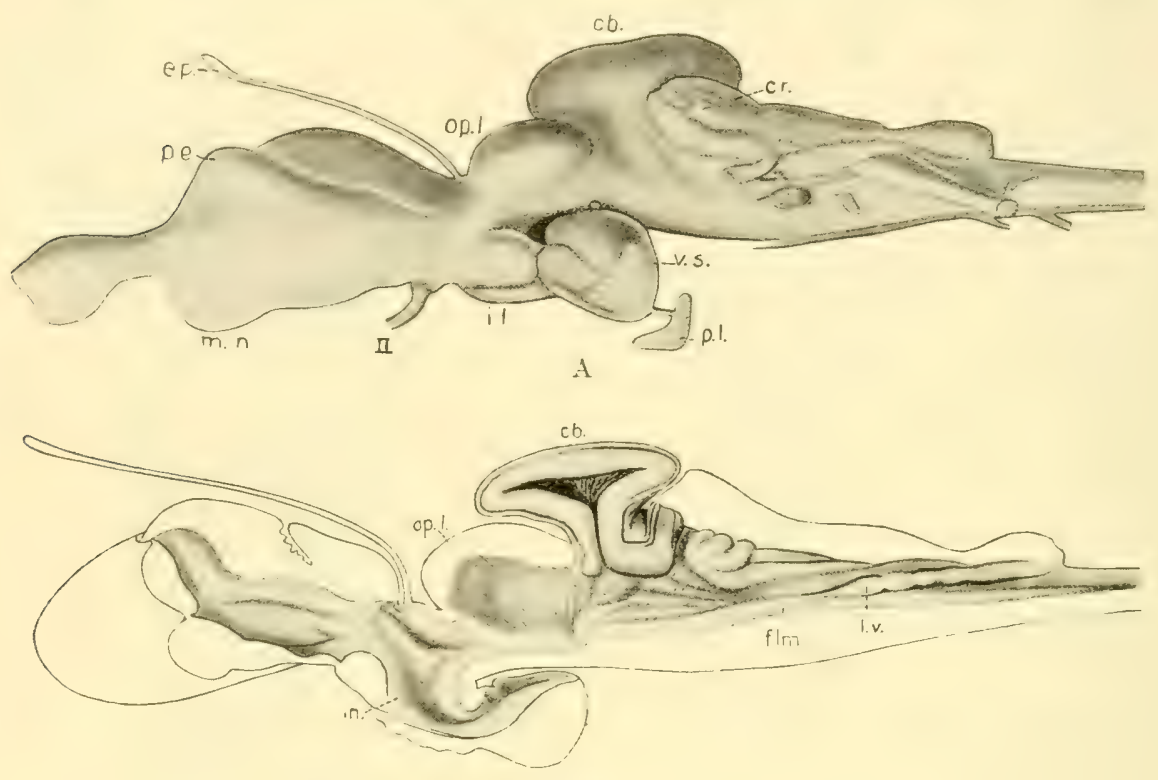

$\mathrm{B}$

Fig. 213. Brain of Scymnus. (From Burekhardt.) A. Side view. B. Median sagittal view. $c b .$, cerebellum; c.r., restiform body ; ep., pineal stalk; flm., median longitudinal bundles; in., infundibulum; i.l., anterior lobe; l.v., lobe of the vagus; m.n., median olfactory nueleus; op.l., optic lobe; p.e., pallial eminence; p.l., posterior or inferior lobe of hypophysis; v.s., vaseular saes; $I I$, optic nerve.

to be unusually large. In all forms the roof of the mesencephalon is composed of a right and a left optic lobe (op.l., figs. 210 and 213) which are hollow outpockets from the dorsal side of the mesencephalie segment. It is largely among the cells of these lobes that the fibers of the optic nerve terminate. The ventrolateral part of this segment of the brain (see fig. $213 \mathrm{~B}$ ) is enlarged by longitudinal swellings, the lateral fiber tracts of the mesencephalon. Through the ventral walls the third cranial or oculomotor nerve passes, and from the roof the fourth nerve leaves the brain stem ( $I V$, figs. 210 and 212 ).

The metencephalon as a segment is usually well developed in the Elasmobranchs. Dorsally it consists of the cerebellum $(c b$. $)$ and ventrally it is swollen by large fiber tracts (Scymmus, fig. $213 \mathrm{~B}$ ). The cerebellum is usually rhomboid in shape and divided dorsally by a median longitudinal furrow into right and left halves (fig. 210A). These may be further separated into anterior and posterior parts by a second furrow at right angles to the first. In some forms, as has been said, the cerebellum comes to be very complex and of immense size. 
It is so in Lamma, Scoliodon (fig. 211 ), Galeus, Trygon, and Myliobatis (fig. 212). In all these the surface is thrown into numerous irregular folds or convolutions.

The myelencephalon (medulla) (med., figs. 211-213) when seen in dorsal view is shaped like the letter $\mathrm{Y}$, the anterior limits of the $\mathrm{Y}$ being made by the restiform bodies, corpora restiforme $(c . r$.$) . These in many of the simpler types$ of sharks, such for example as Scymmus, appear as prominent structures. In others the corpora restiforme are entirely hidden by the enlarged cerebellum (Myliobatis, fig. 212). Both in dorsal and in ventral view the medulla is conical

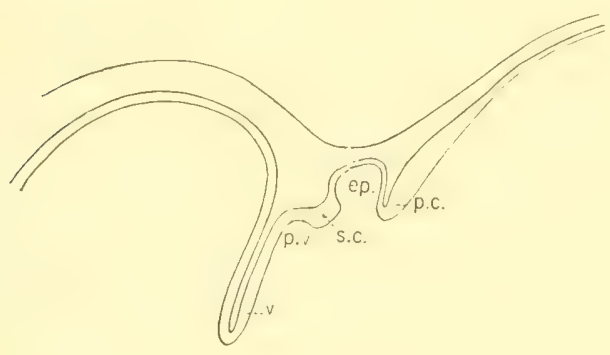

A

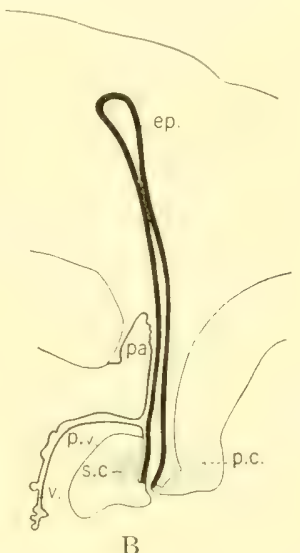

Fig. 214. Stages A and B in the development of the pineal region of Acanthias. (From Minot.)

ep., epiphysis; pa., paraphysis; p.c., posterior commissure; p.v., postvelar arch; s.c., superior commissure; $v$., relum.

in shape and tapers gradually back to the spinal cord. It is from this segment that most of the cranial nerves arise; all in fact except the first four take their origin here.

\section{INTERNAL VIEW OF BRAIN}

A sagittal section through the brain of Scymmus (fig. 213B) shows within the medulla the large cavity of the fourth ventricle. The floor and sides compose the fossa rhomboidealis. Along each side of the middle line of this fossa are two median longitudinal bundles, fasiculi longitudinales mediales ( $f(m$.). Running parallel to these in the posterior part of the fossa are the ventrolateral bundles, fasiculi lateroventrales. Above these bundles and in the side wall are the lobes of the vagus $(l . v$.) which vary in number of segments from types in which only a few are present to those in which there are several nodules (Heptanchus and Hexanchus). Above the lobes is a dorsolateral bundle which continues forward as the bundle to the tuberculum acusticum. Above this are other bundles which continue into the ridge of the restiform bodies or corpora restiforme.

In the region of the mesencephalon the cavity is so large that it is an aqueduct of Sylvius only in name. It comnects the cavity of the metencephalon and 
myelencephalon, the fourth ventricle above mentioned, with the cavity of the diencephalon, the third ventricle. In the wall of the diencephalon is the optic thalamus, and. in its roof, the habenular ganglion from which the pineal

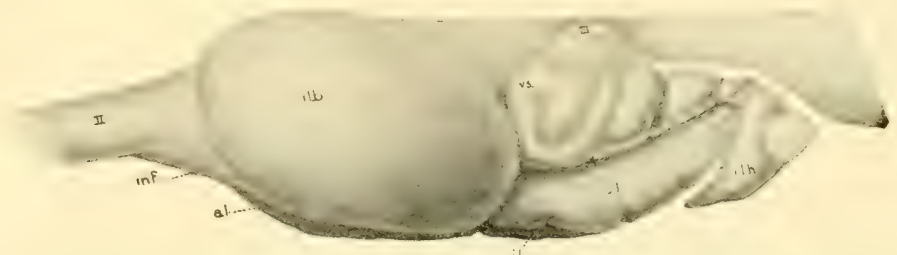

Fig. 215. The pituitary, Squalus suchlii, side riew. (Marie Carlson, orig.)

$a . l .$, anterior lobe ; $i . l .$, intermediate lobe; $i . l . b .$, inferior lobe of brain; $i . l . h$. , inferior lobe of pituitary; inf., infundibulum; s.l., superior lobe; v.s., vaseular sae of brain; $I I, I I I$, second and third nerves.

stalk arises. In the floor of the diencephalon is the infundibulum (in.). The cavities in the right and left lobes of the telencephalon are the lateral ventricles.

Figure 216 (Houser. 1901) is of a transverse section through the medulla of Mustelus to show something of its finer structure. In its median ventral mass lies the abducens nucleus, the fibers of which form the abducens or sixth cranial nerve. Around the nucleus of the sixth nerve the tract cells are scattered. These cells are of interest in that they are exceeded in size only by the cells in the roof nucleus of the mesencephalon (see fig. 206). The lobes of the vagus $(l . v$.$) are made up of masses of cells which receive visceral sensory$ fibers from the seventh, ninth, and tenth cranial nerves. Some of the axones

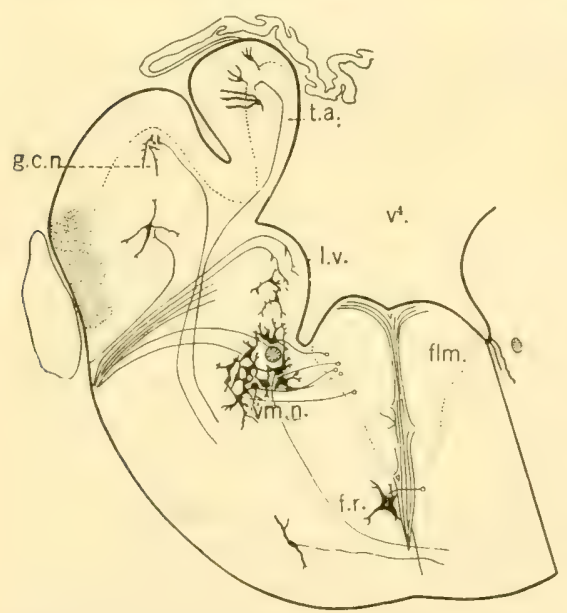

Fig. 216. Transverse section through the medulla, Mustelus. (From Houser.)

flm., median longitudinal bundles; f.r., formatio-reticularis; l.v., lobes of vagus; g.c.n., general cutaneous nucleus; t.a., tuberculum acusticum; vm.n., visceromotor nucleus; $v^{*}$, fourth ventricle. from the cells of these lobes pass downward a short distance to the visceromotor nucleus (vm.n.). The cells in this large nucleus give rise to the motor fibers of the fifth, seventh, ninth, and tenth nerves.

Houser states that the general cutaneous nucleus (g.c.n.) is the terminus for the somatic sensory fibers of the fifth, ninth, and tenth nerves, but according to Norris and Hughes (1920) the ninth and tenth nerves contain no somatic sensory elements.

The tubereulum acusticum ( $t . a_{\bullet}$, fig. 216) forms a swelling on the lateral wall of the fourth ventricle $\left(v^{*}\right)$ and is principally a center for fibers from the lateral line organs and from the internal ear. 


\section{SPINAL CORD}

The spinal cord extends from the brain practically to the tip of the tail. Unlike that in the higher forms it does not possess marked pectoral and pelvic swellings produced by the passage of the nerve bundles to the limbs. In its external aspect and in its internal strueture the cord may be spoken of as a simplification of the medulla. The place occupied in the medulla by the nucleus of the

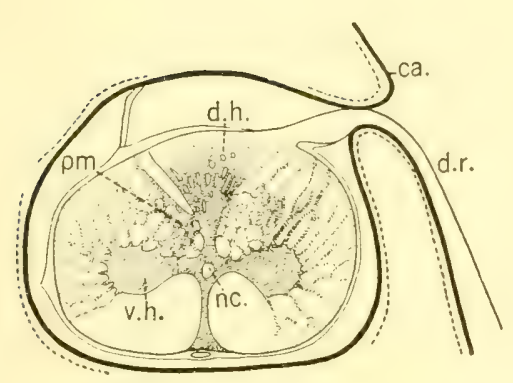

A

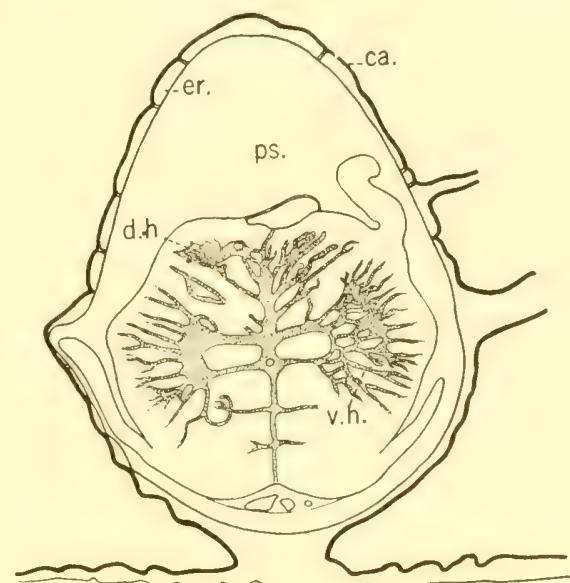

$\mathrm{B}$

Fig. 217. Transverse sections of the spinal cord. (From Sterzi.) A. Acanthias vulgaris. B. Raja clavata.

$c a$. , calcification; $d . h .$, dorsal horn; $d . r$. , dorsal root; er., endorachis; nc., neurocoele ; $p m$. , paracentral mass; $p s$. , perimeningeal space; v.h., ventral horn.

sixth nerve and the grey matter of the formatio-reticularis ( $f . r .$, fig. 216) is occupied in the cord by the ventral horn ( $v . h$. fig. 217); while the general cutaneous nucleus of the medulla (g.c.n.) gives place to the dorsal horn of the cord (d.h., fig. 217); and the lobes of the vagus and the visceromotor nuclei are supplanted by the paracentral mass $(p m$.$) . Furthermore, the enlarged$ fourth ventricle of the medulla becomes the small neurocoele of the cord (nc.).

A transverse section shows the spinal cord lying within the neural canal from which it is separated by a considerable perimeningeal space, especially in the rays (fig. 217 B). The endorachis (er.) lines the neural canal and is further surrounded by calcification $\left(c a_{\circ}\right)$. Directly surrounding the cord is the meningeal lining, through which ventrally the spinal blood-vessels pass. The cord itself (Acanthias, fig. 217A) is much like that of Heptanchus (fig. 201 ) in that the dorsal horns $\left(d . h_{\text {. }}\right)$ are close together and the ventral horns $(v . h$.$) are almost at right angles to the central mass. Above the ventral horns$ are the outgrowing paracentral masses $(p m$.). In the rays, however, the central grey matter of the cord is more diffuse.

The relation of the grey and white matter, cells and fibers, in the Elasmobranchs is essentially like that in higher forms, although the proportion 
of one to the other is greatly altered. Burckhardt (1911) has estimated that in Scymmus the grey to the white is as 1 to 17 , while in man it is as 5 to 12 .

\section{Peripheral Nervous Systemi}

The peripheral nervous system in general, like that in Heptanchus, is made up of cranial and spinal elements. Both the cranial and the spinal nerves originate from cells in or derived from the central nervous system. We may briefly review their development in a type like Acanthias.

At the time when the neural tube closes, the cells which make up its walls form a single layer (fig. 218). These cells later become pear-shaped and collect

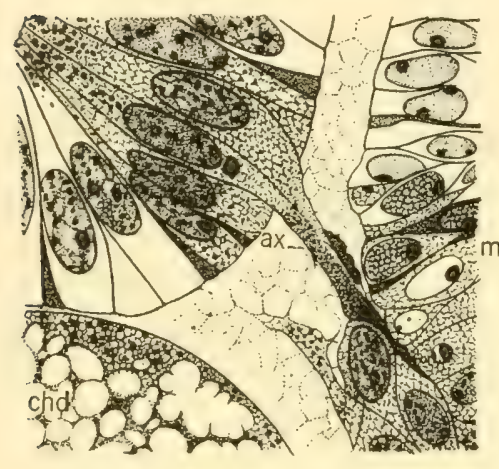

Fig. 218. 'Transverse section through developing cord, notochord (chd.), and myotome (m.), Squalus acanthias. (From Neal.)

$a x$, motor axone growing out to myotome ( $m$. ) from cell in the neural tube. in groups in the region of the ventral horns. In the adult the motor fibers extend from these cells.

The question has often arisen as to the formation of the nerve fiber or axone. Is it formed in place from preëxisting protoplasmie strands, or is the axone an outgrowth from the cell body? An examination of a section by Neal (1914) taken from the posterior region of the cord (fig. 218) shows that the fiber or axone $(a x$. ) here has just reached the myotome $(m$.) and that its end, which is the actively growing part of the fiber, is rhizopod in appearance. As the muscle bud grows outward toward the fin, the fiber becomes attached to it and is drawn out with it, forming a so-called end plate. Such a growing fiber is protected by a thin covering, the neurilemma, and sometimes a medullary sheath is formed between the neurilemma and the axis cylinder of the fiber. The axis cylinder itself becomes differentiated into numerous fibrillae.

In the sensory (dorsal) nerves an overgrowth, the neural crest, is produced on each side along the neural tube at the place of closure. From each crest, dorsal root ganglia result $(g .$, fig. 207) which migrate slightly farther down the sides of the tubes. Composing these ganglia are multitudes of bipolar cells, the fibers from which pass from both ends or poles of the cell. Several of these cells (fig. 207, a to $c$ ) are here seen in different stages of development; (c) represents the mature cell in which the two poles have fused at the base into the stem of a 'T'. One of the fiber's thus formed by the arms of the T enters the central system while the other extends outward and receives sensation.

\section{CRANIAL NERVES}

'The first cranial or olfactory nerve extends from the epithelium of the olfactory capsule as a double nerve backward to the olfactory bulb. In extent it 
varies greatly. In some forms the nerve is so short as hardly to be observed from the outside. 'This is observable in types like Heptanchus (fig. 200A), Galeus, and Scymmus. In Scoliodon (fig. 211 A) the olfactory bulbs are farther separated from the nasal epithelium so that the two divisions of the nerve $(I)$ are distinct. In Echinorhimus the nerves are of an extreme length, rarely met with in any other Elasmobranch.

A sagittal section through the anterior part of the olfactory bulb would show how the fibers come to masses of cells (glomeruli) in the bulb from the olfactory membrane. These are arranged in two bundles. One of these is median and ventral in position; the other is lateral. The fibers from the cells in the glomeruli of the olfactory bulb are continued to the olfactory lobe of the brain by the olfactory tracts (ol.t.). These tracts similarly vary in extent through extremes shown in Echinorhinus and Hexanchus. In the former the bulb and the lobe are practically continnous; in the latter the tracts are greatly drawn ont.

Aceompanying the olfactory nerve is the terminal nerve ( $t n$., fig. 211) studied in detail by Locy (1905). This nerve in Acanthias as a type (t.n., fig. 172A) ends in the thickened lamina terminalis. The right and left nerves at the entrance of the brain would thus be separated by the median fissure. Through growth of the brain and fusion of the median olfactory nuclei it so happens that the terminal nerve instead of passing directly forward may arise dorsally or ventrally. Those forms in which the nerve has a comnection with the brain dorsal to the neuropore are: Raja, Trygon, Myliobatis. In others the connection is more nearly dorsal than ventral (Acanthias, Squatina, Hexanchus). In still others the connection is ventral, as in Galeus, Scoliodon (fig. 211A),

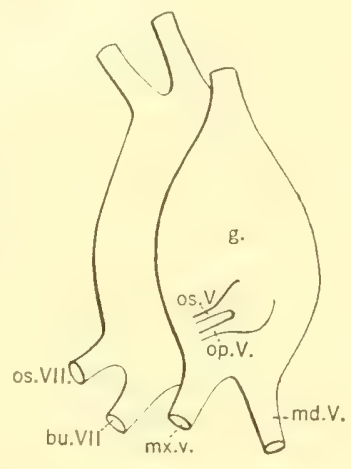

Fig. 219. Ganglia of trigeminal ( $V$ ) and facial ( $V I I)$ nerve, median view, Chlamydoselachus. (From Mrs. Hawkes.)

bu. FII, buecal division of seventh nerve; $g$., gasserian ganglion; md.V, mandibular nerve; $m x . Y$, maxilliary branch of fifth nerve; op.V, ophthalmieus profundus nerve; os. $\overline{\text {, }}$ ophthalmieus superficialis of fifth; os.VII, ophthalmieus superficialis of seventh.

Scyllium, Pristurus, and Carcharias littoralis. In all the above forms the nerve passes forward as a double or triple strand on which is a ganglion (or a series of ganglia). The nerves join the olfactory fila as in Heptanchus and go to the mucous lining of the olfactory cup.

The optic or second nerve ( $I$, figs. 210 and $213 \mathrm{~A}$ ) is sufficiently similar in the different forms to need but little description. It arises from cells in the retina and its fibers cross to form the optic chiasma. 'They then extend to, and terminate in, the diencephalon and mesencephalon.

The oculomotor nerve (III, figs. 200A and 200B) arises in a nueleus under the aqueduct of Sylvius and leaves the brain stem near the middle line of the mesencephaIon. It enters the orbit and gives off a dorsal branch to the superior rectus and the anterior rectus and a ventral branch which divides into an an- 
terior and a posterior division. These divisions supply the inferior oblique and the inferior rectus muscles as in Heptanchus.

The relation of the nerve to the ciliary ganglion in some forms is interesting. Sometimes this ganglion (or ganglia) is on the oculomotor nerve and is called the ganglion oculomotoris. Or, again, it may be on a branch joining the ganglion of the ophthalmicus profundus with the oculomotor nerve.

The trochlearis nerve, as we have said, has its nucleus in the mesencephalon. Its fibers cross and pass out through the roof hetween the mesencephalon and the cerebellum and go to innervate the superior oblique muscle of the eye.

The trigeminal or fifth eranial nerve is composed of an anterior portio minor and a posterior portio major. While both of these roots contain motor

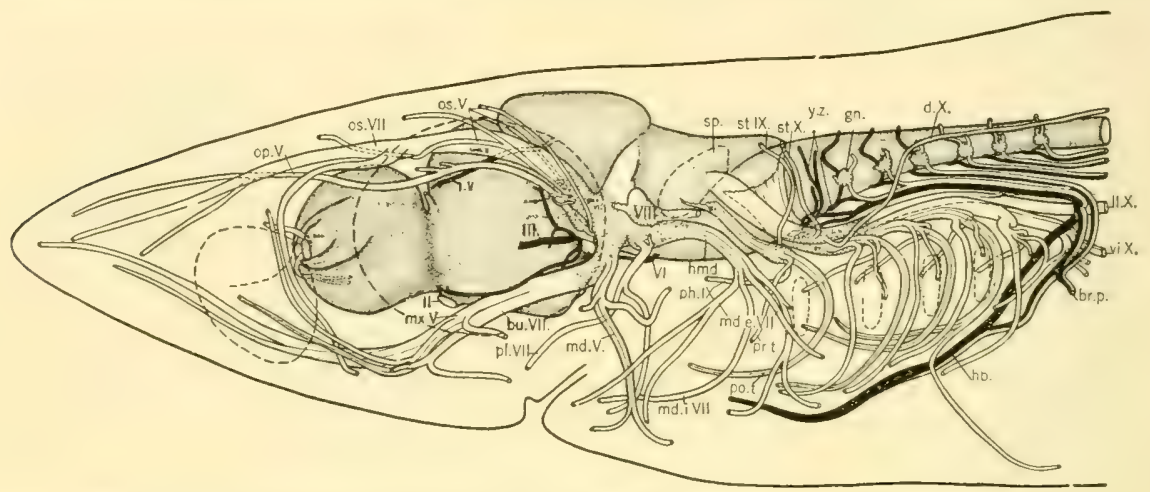

Fig. 220. Cranial nerves, Squalus acanthias. (From Norris and Hughes.)

$b r . p$. , brachial plexus; bu.VII, buccalis of seventh; $d . X$, ramus dorsalis of tenth nerve; $g n$. , first spinal ganglion; $h b$., hypobranchial bundle; $h m d$., hyomandibularis ; $l l . X$, lateral line nerve; md.e.VII, mandibularis externus of seventh; md.i.VII, mandibularis internus of seventh; md.V, mandibularis of fifth ; $m x . V$, maxillaris of fifth; op.V, ophthalmicus profundus; os.V, and os.VII, ophthalmieus superficialis of fifth and seventh; ph.IX, pharyngeal branch of ninth; pl.VII, palatinus of seventh; po.t., post-trematicus of ninth; pr.t., pretrematicus of ninth; $s p$. , spiracle; st.IX, supratemporalis of ninth; st.X, supratemporalis of tenth nerve; vi.X, visceral nerve; $y$ and $z$, occipitospinal nerves; $I I$, optic; III, oculomotor; $I V$, trochlearis; $V I$, abducens; VIII, auditory nerve.

and sensory portions, motor fibers predominate in the anterior part and sensory in the posterior root. The motor fibers arise from the visceromotor mucleus in the medulla ( $m$ m.n., fig. 216) and are distributed principally to the muscles of the jaws. The sensory fihers arise from various ganglia, such as the ganglion of the ophthalmicus profundus, the ophthalmicus superficialis (Mustelus californicus), and the gasserian ganglion. Sensation brought from the region around the nose passes by the ganglion cells and on to the brain.

In the Elasmobranchs the ganglia of the trigeminal and the buceal division of the facial nerves are so intimately associated as often to be inseparable; usually the former are more or less covered up by the latter. In Chlamydoselachus, however (fig. 219), the two are distinct medially (Hawkes, 1906). From the gasserian ganglion (g.) the large maxillaris and the mandibularis divisions of the fifth nerve arise and from the small ganglion on the inner side of the gasserian, the two smaller nerves, the ramus profundus (op.V) and the ramus superficialis $(o s . V)$ of the fifth, take their origin. 
The ophthalmieus profundus (op.V, fig. 220), after leaving its ganglion passes forward deep in the orhit, between superior and inferior rectus muscles and out anteriorly under the anterior rectus and between the obliques. On its way past the eyeball it gives off the ciliary nerves to the eye and then passes to the dorsal and lateral parts of the snout (Squalus), or also to the ventral part (Mustelus).

The ophthalmicus superficialis of the fifth (os.V, fig. 220) may have an extracranial ganglion as in Mustelus culfornicus or it may be connected directly with the gasserian ganglion as in Syualus acanthias. In either form the nerve is closely associated with the superficial ophthalmic of the seventh on its way throngh the orbit. In Squalus acanthias according to Norris and Hughes (1920) there are three or four branches of this nerve which apparently terminate in the skin over the supraorbital crest. In Mustelus californicus the nerve is larger and continues farther anteriorly.

Both the ophthalmicus profundus and the ophthalmicus superficialis of the fifth nerve are sensory.

The maxillaris of the fifth ( $m x . V$, fig. 220 ) originates in the gasserian ganglion and passes to the jaw and on to the skin ventral to the snout. In its course over the floor of the orbit it is accompanied by the buccalis of the seventh. Near its ganglion it is often mediad of the buccalis but farther distally it may lie dorsal to it. As a usual thing the maxillaris branches into two or three main divisions, the most anterior of which passes forward almost to the tip of the snout.

The mandibularis may accompany the maxillaris over the floor of the orbit and separate from it late to turn sharply back around the angle of the jaw as in Laemargus. Or, if the angle of the jaw is relatively far posterior, the mandibularis may leave the maxillaris early and pass over the posterior wall of the orbit to reach the angle of the mouth (Chlamydoselachus, Acanthias). In either form certain sensory bundles from the intracranial part of the gasserian ganglion, after passing the angle of the jaw, turn forward and supply the skin of the lower jaw to the symphysis of the mandible. Motor fibers, dorsal to the sensory fibers, supply the levator maxillae, the first dorsal constrictor, the adductor mandibulae, and a considerable part of the first ventral constrictor muscle (Norris and Hughes).

The abducens or sixth cranial nerve is a motor nerve. It arises, as we have seen, from a nucleus in the medulla and passes forward and outward to the posterior rectus muscle, entering it at its base.

The seventh or facial nerve like the fifth is composed both of motor and of sensory components. Its motor fibers arise in the visceromotor nucleus ( vm.n., fig. 216) just posterior to that of the fifth nerve and extend to the lower jaw and the facial region. Its sensory fibers are connected with large ganglia and are distributed essentially as in Heptanchus. In Acanthias, the nerve may join the brain in common with the branches of the eighth, and it is usually united above with the fifth. In Mustelus canis, however, it may be more or less clearly separate from the fifth (fig. 221). 
For convenience of description we may consider the facial nerve as made up of two groups of fibers. One of these supplies the sensory canal system; the other belongs to the facial proper. Three great nerves are in the service of the sensory canal system. These are: the ophthalmicus superficialis (os. TII, figs. 220 and 221) which goes to the supraorbital canal and associated ampullae of Lorenzini; the bucealis, to the infraorbital canal and associated ampullae of Lorenzini; and the external mandibular, a branch of the hyomandibular nerve. This supplies the hyomandibular and the mandibular canals (figs. 220

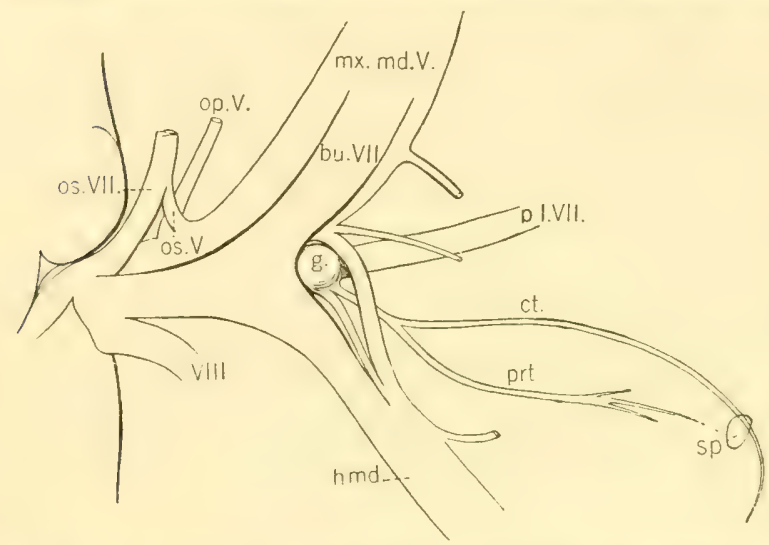

Fig. 221. Roots of fifth and serenth nerves, Mustelus canis. (From Green.)

bu.VII, buccalis of serenth; ct., chorda tympani; g., geniculate ganglion; hmd., hyomandibular nerve; mx.md.I. maxillaris and mandibularis of fifth; $V I I I$, auditory nerve; $o p . V$, ophthalmicus profundus; os. $T$, ophthalmicus superficialis of fifth; $0 s . V I I$, ophthalmicus superficialis of the seventh; $p l . F I I$, palatinus of seventh; prt., pretrematicus ; sp., spiracle.

numerous branches dorsally to the supraorbital canal and associated ampullae and leaves the orbit by a large anterodorsal foramen. It extends forward giving off a large branch which passes downward in front of the eye to supply the lower part of the supraorbital canal and numerous small branches which pass toward the tip of nose.

The buccalis may arise from a large ganglion which is continuous with that of the ophthalmicus superficialis VII (Acanthias, fig. 220, bu.VII). In Mustelus californicus these two ganglia are distinct but the ganglion of the buecalis is in close relation to the ganglion of the external mandibular nerve. The buccalis, as was previously mentioned, runs across the floor of the orbit closely associated with the maxillaris of the fifth. In the anteroventral angle of the orbit it divides into two or three main divisions, the twigs of which go to sup)ply the infraorbital canal and associated ampullae of Lorenzini. From the ganglion the buccalis sends off branches which supply the part of the infraorbital canal posterior to the eye (see p. 279, fig. 24i), and from the dorsalmost part of the ganglion it gives the important ramus oticus VII to a short segment of the most anterior part of the lateral line eanal. 
The external mandibularis is in relation to a ganglion by the same name. It leaves the cranium through the facial foramen (see fig. $47, f . V I I^{3}$, facing p. 44), and passes upward around the spiracle as a part of the ramus hyomandibularis. In Squalus acanthias the external mandibularis (md.e.VII, fig. 220 ) divides into an anterior and a posterior division. The anterior division goes to the hyomandibular and mandibular canals. The posterior division supplies the hyoidean ampullae and pit organs.

The first divisions of the facial which are not connected with lateral line or ampullary organs are certain branches of the hyomandibularis.

The hyomandibular trunk after leaving the brain stem passes backward, the main stem arching posteriorly around the spiracle as was described above for its external branch. Before reaching the spiracle, however, the palatine nerve separates from the hyomandibular trunk. It arises in the geniculate ganglion ( $g$., fig. 221) and passes as a sensory nerve to the roof of the mouth where, as in Heptanchus, some of its fibers pass forward and others extend over the posterior part of the roof to supply "taste buds." After having given off the palatine, the hyomandibularis supplies a small pretrematicus to the anterior side of the spiracle.

At about the place where the external mandibular VII, previously described, is given off from the ramus hyomandibularis the internal mandibular (md.i.VII) separates from the main trunk. This, like the palatine nerve, is sensory and goes to the mucous membrane along the inner side of the mandibular arch.

The ramus hyoidius VII (fig. 220) is a motor branch which in Squalus acanthias divides into an anterior and a posterior division. The anterior branch supplies the second, and the posterior, a part of the first ventral constrictor muscles.

The chorda tympani is variously interpreted for the Elasmobranchs. In Acanthias (ct., fig. 221) it is apparently a continuation from the palatine branch $(p l . V I I)$ and is therefore in front of the spiracle. In Hexanchus it has been considered by Ruge (1897) to be a direct continuation of the hyomandibularis and as such is therefore a post-trematicus. In both it is a sensory nerve and supplies the mucous lining in the floor of the mouth just mediad of the teeth.

The hyomandibularis, in Torpedo, gives rise to a first electric nerve which goes to the anterior and inner part of the electric organ.

The auditory nerve (VIII, fig. 220) has a large ganglion just back of the ganglia of the seventh nerve. From this fibers extend to the ear in two general groups, an anterior vestihular and a posterior saccular group. Root fibers join the ganglion to the medulla just back of the seventh nerve and terminate around cells in the tuberculum acusticum of the medulla. The distribution of the fibers to the ear will be discussed further in a study of the ear.

The glossopharyngeal, as described for Heptanchus, may he taken as a typical "mixed" nerve. It is made up of both motor and sensory fibers, the former arising in its visceromotor nucleus of the medulla and the latter springing 
from a ganglion located on the nerve in or just outside the glossopharyngeal canal (see fig. 220). The main divisions of the nerve are a branch (st. $I X$, fig. 220 ) to the anterior segment of the lateral line canal, and nerves in relation to the first and second demibranchs.

The supratemporalis (st.IX) in Squalus acanthias, according to Norris and Hughes, supplies three neuromasts of the lateral line canal located between the nemromasts supplied hy the supratemporalis of the vagus and the ramus otieus VII, but it is not provided with other branches to pit organs. In Chlamydoselachus, Hawkes (1906) mentioned, in addition to the twigs to the neuro-

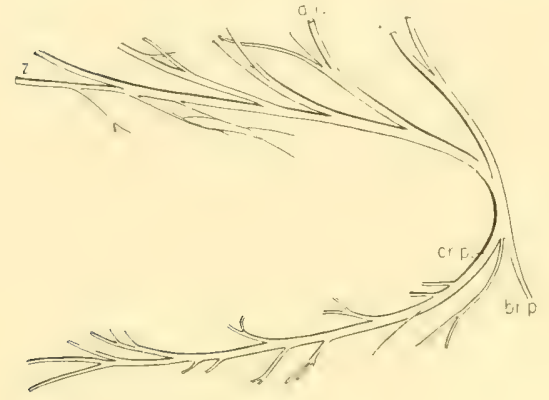

A

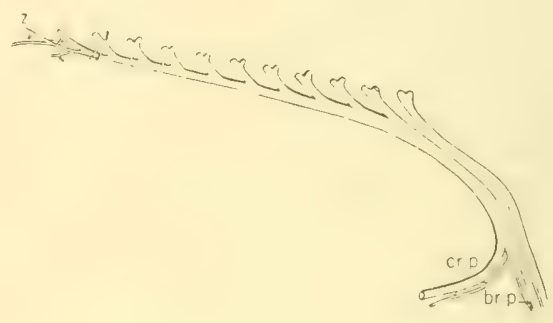

B

Fig. 222. Brachial and cervical plexuses. A. Scyllium. B. Squatina. (From Max Fürbringer.) br.p., brachial plexus; $c r . p$. , cervical plexus; d.r., dorsal root; z., oceipitospinal nerve.

masts of the lateral line canal, other twigs to the skin. These she suggested were cutaneous. They possibly supply pit organs. In Raja radiata according to Norris and Hughes there are no lateral line elements in the ninth nerve.

Above the first branchial pocket, as in Heptanchus, the main part of the ninth nerve, as the first branchial nerve, separates into three divisions, a pretrematicus (pr.t.), a post-trematicus (po.t.), and from the pretrematicus a pharyngeal division ( $p h . I T$ ), the last-named branch being sensory and comparable to the palatine division of the facial nerve. The pretrematicus is also sensory; it extends down the hyoidean demilnranch back of the branchial cartilages, supplying the mucous membrane and gill filaments. Unlike Heptanchus the majority of Elasmobranchs seem to lack the internal pretrematicus. The post-trematicus or larger division, unlike that of Heptanchus, is not always so clearly separated into its components. The post-trematicus supplies the mucous lining along the anterior part of the first holobranch and other sensory fibers continue forward under the gill cleft and are distributed to the mueous membrane of the pharynx and buccal cavity. The motor branches supply muscles associated with the first holobranch.

Accompanying the glossopharyngeal and a part of it, in Torpedo, is the second electric nerve.

The vagus is the most widely distributed of any of the nerves. It is much like the ninth in its supply of the gills, but in addition it gives off a distinct lateral line nerve, and its branchial divisions are bound with intestinal 
branches into a branchio-intestinal bundle. 'The lateral line nerve can be traced from the brain as a distinet stem. As it emerges from the eranium it swells out into a large ganglion from which this branch proceeds posteriorly practically to the end of the tail. From the lateral line ganglion there is given off a dorsal root, the supratemporalis (fig. 245) which passes upward and forward to supply the supratemporal canal, pit organs in the region of the supratemporal canal, and the anterior part of the lateral line canal immediately behind the segment supplied by the supratemporal branch of the ninth nerve. Posterior to this branch there is given off a second branch, the dorsalis (d.X, fig. 220)

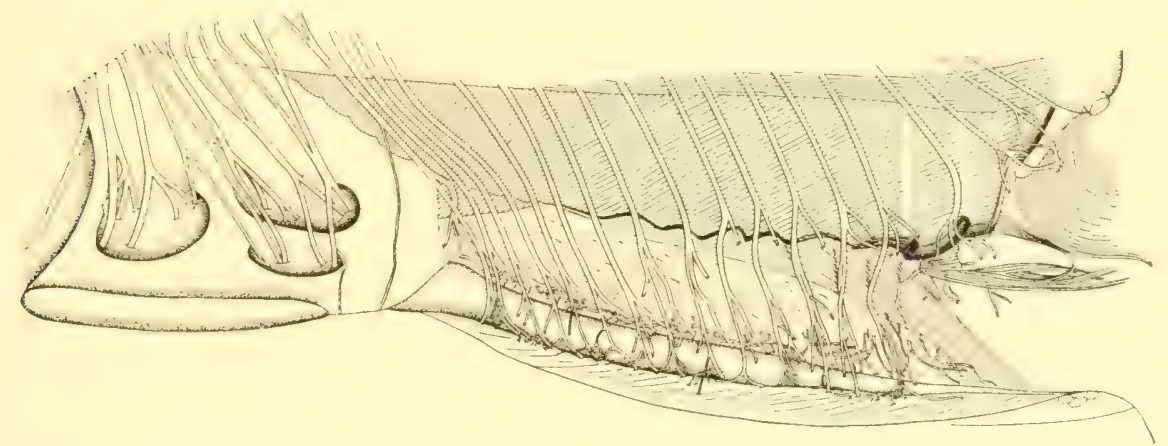

Fig. 223. Brachial and pelvie plexuses, Raja vomer. (From Braus.)

which runs posteriorly almost to the first dorsal fin. This nerve supplies sense organs of the anterior part of the lateral canal and also pit organs above the line and anterior to the dorsal fin. Many branches are given off from the lateral line nerve as it passes backward in the body to the sense organs along the lateral line canal.

The branchial stem in the vagus is a strong bundle which divides into four (pentanchids), five (hexanchids), or six (heptanchids) branchial nerves. The first two or three of these branchial nerves, except in Torpedo, where the first and second branchials give off the third and fourth electric nerves, are essentially like the branchial division of the glossopharyngeal. Each hranchial consists of pharyngeal and pre- and post-trematic nerves. The post-trematicus of the vagus is composed of two strong branches, one of which is motor, the other sensory. The motor division innervates the interareual, interbranchial, adductor, and ventral constrictor muscles. The last branchial nerve is composed only of visceral sensory fibers (Norris and Hughes, 1920).

The ramus intestinalis or visceralis $(v i \cdot X)$ proceeds posteriorly after separating from the branchial stem. Its motor fibers are distributed to the trapezius muscle and to the digestive tract. Its sensory fibers go largely to the digestive tract.

The occipitospinales ( $y, z$, fig. 220), back of the vagus, like spinal nerves consist of dorsal and ventral roots, but dorsal roots to the ones most anterior are frequently absent. In lowly forms, as we have seen in Heptanchus, several pairs may be present. As many as five of the rentral occipitospinales have been 
located on each side of the young of Hexanchus and Chlamydoselachus. In Acanthias there are only two or three of the ventral nerves present and two dorsal rami. These nerves united with the first and second spinals are marked $h b$. in figure 220 . In Torpedo a single ventral oceipitospinal nerve as such is present.

The more posterior of these nerves unite with the first group of spinal nerves to form the cervical plexus which in turn joins the pectoral plexus, the fused trunks of which may run for a short distance, with, although it is no part of, branches of the vagus. The whole group forming the two plexuses may

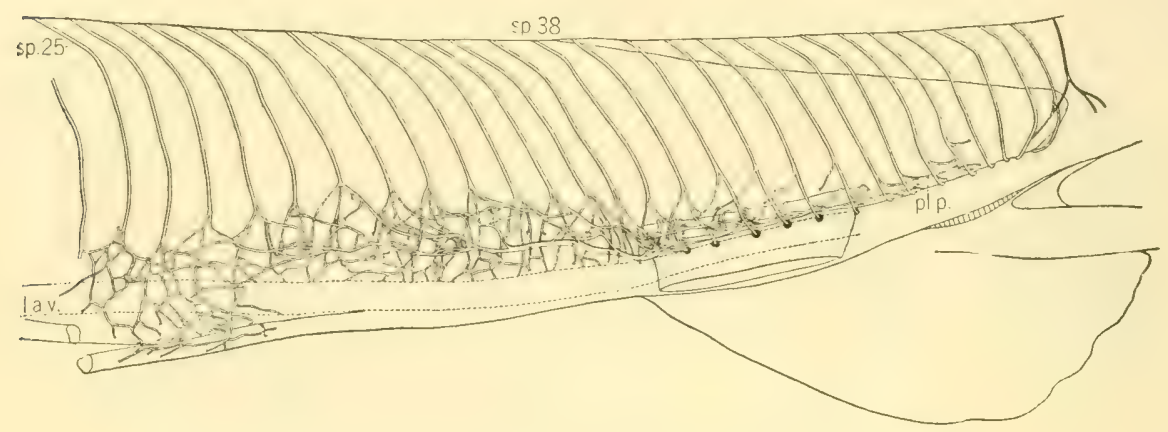

Fig. 224. Nervous collector, Chlamydoselachus. (From Braus.)

l.a.v., lateral abdominal vein; $p l . p$. , pelvic plexus; $s p . .^{25-38}$, twenty-fifth and thirty-eighth spinal nerves.

be composed of relatively few nerves (five in Spinax) or it may include many (twenty in Torpedo). The nerves of the cervical plexus (cr.p., fig. 222) separate from the pectoral plexus and pass in front of the girdle to supply the hypobranchial muscle as in Scyllium and Squatina, while those of the pectoral plexus (br.p.) pass through the girdle and are distributed to the pectoral fin.

\section{SPINAL NERVES}

In the region of the cord proper a sensory root and motor root (solid line, fig. 220 ) unite to form a mixed spinal nerve, much as in Heptanchus. Each of these roots after leaving the cord passes backward within the neural canal, then perforates the basal or dorsal intercalary eartilages as single roots. Shortly before perforating the basal plate the motor branch may bifurcate (fig. 220) and send a branch dorsally to join a branch from the ganglion ( $g n$.) of the dorsal root; or this motor root may pass by the ganglion without receiving from it sensory fibers. This branch passes dorsally to the dorsal longitudinal bundles. When no sensory fibers join this root a sensory bundle runs dorsally from the ganglion. The other branch of the bifurcated ventral root joins a sensory root from the ganglion, the two united passing as a mixed nerve ventrally.

Posterior to the pectoral fin and in the region of the lateral abdominal vein the ventral rami of the various spinal nerves often form a connected strand, 
the nervous collector (fig. 224) as in Heptanchus. 'This has been studied in a number of forms by Braus (1898). Extremes of variation obtain in the number of nerves taking part in this collector. In primitive forms, as in Heptanchus, the number may vary greatly and the collector may consist of multitudes of strands which may or may not fuse togethex. A good example is Chlamydoselachus (fig. 224), in which the twenty-fifth to the thirty-eighth nerves take part. In other forms few nerves take part in its formation (Spinax) or no collector as such is found (Squatina, Raja, fig. 223).

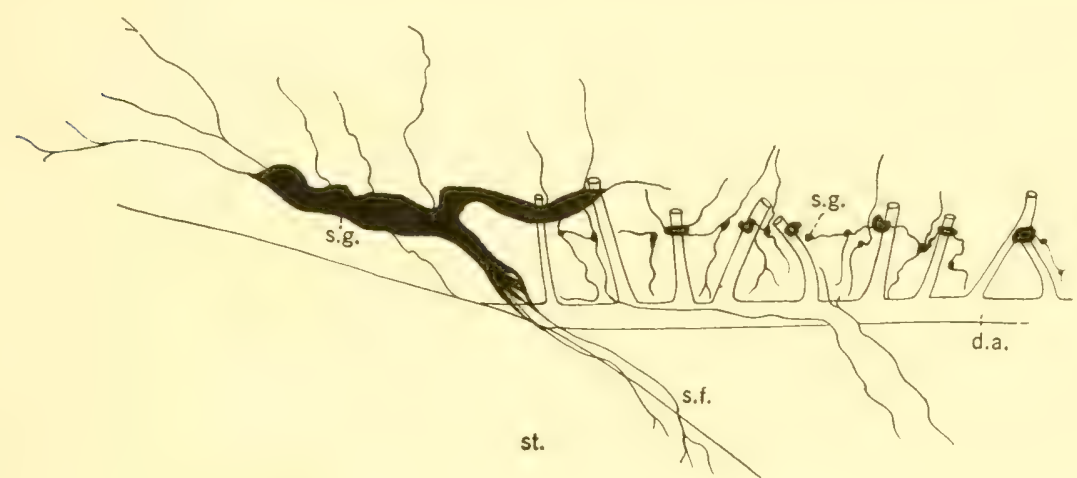

Fig. 225. Sympathetic nervous system, Scyllium canicula. (From Botazzi.)

d.a., dorsal aorta; s.f., sympathetic fibers to stomach (st.); s.g., sympathetic ganglia.

The collector has been studied in great detail as to the relation which it bears to the origin of paired fins. By those who hold to the gill-arch theory of origin of the fins the collector is an argument for the posterior migration of the pelvic fins, while those who accept the lateral fin-fold theory believe that the collector shows principally that the paired fins formerly had a wider extent than they have at the present time. A greater extent is indicated further by the fact that there may be a plexus posterior to the pelvic fin (fig. 224).

In Chlamydoselachus the posterior collector (fig. 224) comprises a number of segments. In the embryo of Acanthias a posterior collector is present, although it is absent in the adult. The pelvic plexus in Raja vomer is shown in figure 223 .

\section{SYMPATHETIC OR AUTONOMIC NERVOUS SYSTEM}

Although the sympathetic nervous system has been studied by many workers but little is known concerning its form in the different Elasmobranchs. It extends from the region of the head to the posterior part of the kidney or mesonephros.

The ciliary ganglion in the region of the oculomotor nerve represents the sympathetic system in the head. In various Selachians one or more small ganglia are related to the third nerve. These in Acanthias are located near the branching of the oculomotor nerve into its dorsal and ventral rami. The ganglion (or ganglia) gives rise to non-medullated fibers which make up the short 
ciliary nerve. Norris and Hughes say that in Squalus acanthias these ganglia are connected hy fibers with the oculomotoris, the ophthalmicus profundus $T$, and the palatinus VII nerves.

In sharks the sympathetic system in the trunk is divided into two parts. The anterior part only is associated with the suprarenal bodies. The first trunk ganglion (s.g., fig. 225) of this system is the result of a fusion of several ganglia and further it is fused more or less intimately with the first suprarenal hody. It receives many fibers from the anterior spinal nerves and gives off splanchnic fibers to the viscera. The ganglia in the posterior region are small and are separated from the suprarenal (interrenal) bodies. Furthermore, these ganglia of the sympathetic system seldom have connecting strands putting the various ganglia of a side in longitudinal communication, as occurs in the higher animals. The posterior ganglia are never thus comnected into a longitudinal chain. From the posterior ganglia fine branches go to the kidneys and the genital ducts as well as to the posterior viscera. 


\title{
BIBLIOGRAPHY
}

\author{
Chapter IX
}

\section{CENTRAL NERVOUS SYSTEM}

1915. Baumgartner, E. A., The Development of the Hypophysis in Squalus acanthias. Jour. Morph., Vol. 26, pp. 391-446, 43 text figs.

1903. Borchert, M., Zur Kenntnis des Zentralnervensystems ron Torpedo. I. Mitt. Neurobiol. Arb., hrsg. Oskar Vogt. Serie 2. Weitere Beiträge zur Hirnanatomie. Denkschr. Mred.naturw. Ges. Jena, Bd. 10, 59 pp.

1906. Borchert, M., Zur Kenntnis des Zentralnervensystems von Torpedo. Morph. Jahrb., Bd. 36, pp. 52-81, Taf. 5- 7 .

1894-95. Botazzi, P., Il cervello anteriore dei Selacei. Ricerehe Lab. di Anat. d. R. Unir. d. Roma ed in altri Lab. biol., Vol. 4, Fase. 3-4.

1895. Botazzi, P., Il cervello anteriore e le rie olfattori rentrali dei pesei cartilagene. Atti 2. Congr, med. internaz., Roma, 1894, Vol. 4, Psychiatrie, pp. 110-112.

1894. Burckhard, Rudolf, Zur vergleichenden Anatomie des Vorderhirns bei Fischen. Anat. Anz., Bd. 9, pp. 375-382, 5 text figs.

1895. Burckhardt, Rudolf, Der Bauplan des Wirbeltiergehirns. Morph. Arb., Bd. 4, pp. 131-149, Taf. 8.

1897. Burckhardt, Rudolf, Beitrag zur Morphologie des Kleinhirns der Fisehe. Areh. f. Anat. u. Physiol. (Anat. Abt. Suppl, Bd.), pp. 111-136, pl. 7.

1907. Burckinard, Rudolf, Das Zentralnervensystem der Selachier als Grundlage für eine Phylogenie des Vertebratenhirns. I. Teil. Einleitung und Seymnus lichia. Nora Acta Acad. Leop.-Carol.-Halle, Bd. 73, pp. 245-449, 5 Taf., 64 text figs.

1911. BurckHARDt, Rudolf, Das Zentralnervensystem der Selachier als Grundlage für eine Phylogenie des Vertebratenhirns. II. Teil. Die übrigen Paläoselachier. Nova Acta Acad. Leop.-Carol.-Halle, Bd.94, No. 2, pp. 1-112, 1 Tafo, 14 text figs.

1848. Busch, W., De Selachiorum et Ganoideorum encephalo. Inaug. Diss. Berlin, 18 $18,4^{\circ}$, 46 pp., 3 Taf.

1889. CARrière, J., Neuere Untersuchung über das Parietalorgan. Biol. Centralb]., Bd. 9, pp. 136-149.

1897. Cators, E., Note sur l'histogenèse du bulbe olfactif chez les Sélaciens. Bull. Soc. Linnéenne de Normandie, Sér. 5, T. 1, pp. 79-84, 1 text fig.

1897. Cators, E., Sur l'histologie et l'anatomie microseopique de l'encéphale chez les poissons. C.R. Acad. Sei. Paris, T. 124, pp. 204-206.

1900. CAtois, E., Recherches sur l'histologie et l'anatomie microseopique de l'encéphale chez les poissons. $172 \mathrm{pp}$. Lille.

1902. Cators, E., Recherches sur l'histologie et l'anatomie microseopique de l'encéphale des poissons. Bull. Sei. France-Belgique, Paris, T. 34, pp. 1-166, pls. 10.

1882. Catrie, J. Тн., Recherches sur la glande pinéale (Epiphysis cerebri) des Plagiostomes, des Ganoïdes et des Téléostéens. Areh. de Biol., T. 3, pp. 101-194, pls. 5-6.

1890. Edinger, L., Untersuchungen über die rergleichende Anatomie des Gehirns. I. Das Vorderhirn. Teleostres, Selachier, ete. Abh. d. Senckenberg Naturf. Ges., Bd. 15, pp. 91-112, pls. 1-4. 
1892. Edinger, L., Untersuehungen über die vergleichende Anatomie des Gehirns. II. Das Zwischenhirn. I. Teil. Das Zwischenhirn der Selachier und der Amplibien. Anat. Anz., Bd. 7, pp. $472-476$.

1901. Edinger, L., Das Cerebellum von Scyllium canicula. Arch. mikr. Anat., Bd. 58, pp. 661-678, pls. 33-34.

1878. Ehlers, Ernst, Die Epiphyse am Gehirn der Plagiostomen. Zeitschr. wiss. Zool., Bd. 30, Suppl., pp. 607-634, pls. 25-26.

189-. Eurich, F. W., Contributions to the Comparative Anatomy of the Neuroglia. Jour. Anat. and Pliysiol., Vol. 32, pp. 688-708, pls. 16-17.

1878. Fritsch, G., Untersuchungen über den feineren Bau des Fischgehirns mit besonderer Berüchsichtigung der Homologien bein andern Wirbeltierklassen. Berlin, Fol. 94 pp., 13 Taf.

1908. FuCHS, F., Ueber die Entwicklung des Vorderhirns bei niederen Vertebraten. Zool. Jahrb. (Abt. Anat.), Bd. 25, pp. 547-610, 8 Taf., 1 text fig.

1906. GeMeiti, Fr. A., Sur la structure de la région infundibulaire des poissons. Jour. de l'Anat. et Physiol., Paris, Vol. 42, pp. 77-86, pl. 2.

1898. Haller, B., Vom Bau des Wirbeltiergehirns. I. Salmo und Seyllium. Morph. Jahrb., Bd. 26, pp. 345-641, pls. 12-22, 23 text figs.

1898. HALLER, B., Untersuchungen über die Hypophyse und Infundibularorgane. Morph. Jahrb., Bd. 25, pp. 31-113, Taf. 2-7, 4 text figs.

1846. Harless, E., Briefliche Mittheilung über die Ganglienkugeln der Lobi electrici von Torpedo galvanii. Müller's Arch. f. Anat., pp. 283-291, Taf. X (figs. 1-9).

1918. Herrick, C. J., and Crosbr, E. C., A Laboratory Outline of Neurology, pp. 16-36, 6 text figs. W. B. Sanders Company.

1911. Herring, P. T., The Development of the Elasmobranch Pituitary. Quart. Jour. Exp. Physiol. Lond., pp. 183-191.

189:. Hrs, W., Zur allgemeinen Morphologie des Gehirus. Areh. f. Anat. u. Pliysiol., 1892, pp. 346-383, 36 text figs.

1893. His, W., Ueber das frontale Ende des Gehirnrohres. Arch. f. Anat. u. Physiol. (Abt. Anat.), 1893, pp. 157-171, 8 figs.

1865. Hollard, H., Recherches sur la structure de l'encéphale des poissons et sur la signifieation homologique de ses différentes parties. C.R. Acad. Sci. Paris, T. 60, pp. 768-770.

1896. Houser, G. L., The Nerve Cells of the Shark's Brain. Proc. Iowa Acad. Sci., Vol. 4, pp. 151-153.

1901. Houser, G. L., The Neurones and Supporting Elements of the Brain of a Selachian. Jour. Comp. Neurol., Vol. 11, pp. 65-175, pls. 6-13.

1904. Hxde, I. H., Localization of the Respiratory Center in the Skate. Am. Jour Physiol., Vol. 10, pp. 236-258, 3 text figs.

1S76. JACKSON, W. H., and Clarke, W. B., The Brain and Cranial Nerves of Echinorhinus spinosus, with notes on the other Viscera. Jour. Anat. and Plysiol., Vol. 10, pp. 75107, pl. 7.

1902. Johnston, J. B., An Attempt to Define the Primitive Functional Divisions of the Central Nervous System. Jour. Comp. Neurol., Vol. 12, pp. 87-106, 2 text figs.

1905. Johnston, J. B., The Morphology of the Vertebrate Head from the Viewpoint of the Funetional Divisions of the Nervous System. Jour. Comp. Neurol., Vol. 15, pp. 175275,4 pls., 1 ehart.

1910. Johnston, J. B., The Morphology of the Forebrain Vesicle in Vertebrates. Jour. Comp. Neurol., Vol. 19, pp. 457-539, 45 text figs.

1911. Johnston, J. B., The Telencephalon of Selachians. Jour. Comp. Neurol., Vol. 21, pp. 1-113, 85 text figs. 
1904. Kappers, C. U. A., Die Bahnen und Zentren im Gehirn der Teleostier und Selachier. (Duteh) Amsterdam, 194 pp., 7 Taf.

1906. Kappers, C. U. A., The Structure of the Teliostian and Selachian Brain. Jour. Comp. Neurol., Vol. 16, pp. 1-109, pls. 1-16.

1897. Kingsbury, B. F., The Structure and Morphology of the Oblongata in Fishes. Jour. Comp. Neurol., Vol. 7, pp. 1-44, pls. 1-4.

1892. LenHosséK, M. von, Beobachtungen an den Spinalganglien und dem Rüekenmark von Pristiurusembryonen. Anat. Anz., Bd. 7, pp. 519-539, 19 text figs.

1893. Locy, W. A., The Formation of the Medullary Groove and Some Other Features of Embryonic Development in the Elasmobranchs. Jour. Morph., Vol. 8, pp. 367-378, pl. 19.

1894. Locy, W. A., The Mid-Brain and the Accessory Optie Vesicles. Anat. Anz., Bd. 9, pp. $486-488$.

1894. Locy, W. A., The Derivation of the Pineal Fye. Anat. Anz., Bd. 9, pp. 169-180, 5 text figs.

1894. Locy, W. A., Metamerie Segmentation in the Medullary Folds and Embryonie Rim. Anat. Anz., Bd. 9, pp. 393-415, 11 text figs.

1896. Locy, W. A., Contributions to the Strueture and Development of the Vertebrate Head. Jour. Morph., Vol. 11, pp. 497-594, pls. 26-30, 11 text figs.

1909. Meek, A., The Encephalomeres and Cranial Nerres of an Embryo of Acanthias rulgaris. Anat. Anz., Bd. 34, pp.473-475, 1 text fig.

1870. Miklucho-Maclay, N. von, Beiträge zur vergleichenden Neurologie der Wirbeltiere. I. Das Gehirn des Selaehier. II. Das Mittelhirn der Ganoiden und Teleostier. Leipzig, $4^{\circ}$, pp. 1-74, pls. 7, 1 text fig.

1901. Мinot, C. S., On the Morphology of the Pineal Region, based upon its Derelopment in Acanthias. Amer. Jour. Anat., Vol. 1, pp. 81-98, 14 text figs.

1890. Mitrophanow, P., Úber die erste Anlage des Gehörorgans bei niederern Wirbeltieren. Biol. Centralbl., Bd. 10, pp. 190-192.

1871. Müller, W., Über Entwieklung und Bau der Hypophysis und des Processus infundibuli cerebri. Jena. Zeitsehr. Naturwiss., Bd. 6, pp. $354-425$, pls. 9-12.

1896. Neal, H. V., A Summary of Studies on the Segmentation of the Nervous System in Squalus aicanthias. Anat. Anz., Bd. 12, pp. 377-391, 6 text figs.

1898. Neat, H. V., The Segmentation of the Nervous System in Squalus acanthias. Bull. Mus. Comp. Zool. Harrard Col., Vol. 31, pp. 147-294, pls. 1-9.

1914. Neal, H. V., The Morphology of the Eye-Muscle Nerves. Jour. Morph., Vol. 25, 187 pp., 9 pls., 2 text figs. Also in Tufts Col. Studies, Vol. 3, No. 4.

1920. Norris, H. W., and Hughes, Sally P., The Cranial, Occipital, and Anterior Spinal Nerves of the Dogfish, Squalus acanthias. Jour. Comp. Neurol., Vol. 31, pp. 293-402, 53 text figs.

1887. Osborn, H. F., The Origin of the Corpus Callosum, a Contribution upon the Cerebral Commissures of the Vertebrata. Morpl. Jahrb., Bd. 12, pp. 223-251, pls. 13-14, 2 text figs.

1853. Philipeaux and Vulpian, Mémoire sur la structure de l'encéphale des poissons cartilagineux et sur l'origine des nerfs craniens chez ces poissons. (Extrait par les auteurs.) C.R. Acad. Sci., Paris, T. 37, pp. 341-344.

1905. Pighini, Giacono, Sur l'origine et la formation des cellules nerveuses chez les embryons de Sélaciens. Bibliogr. anat. Nancy, T. 14, pp. 94-105, 3 text figs.

1911. Polimanti, Osv., Contributi alla fisiologia del sistema nervoso centrale e del movimento dei pesei. I. Selacoidei (Scyllium catulus Cuvier e Scyllium canicula L.). Zool. Jahrb. (Abt. allg. Zool. Physiol.), Vol. 30, pp. 473-716. 
1893. RABL-RÜCHKARD, H., Der Lobus olfactorius impar der Selachier. Anat. Anz., Bd. 8, pp. 728-731, 3 text figs.

1904. RABL-RÜCHKARD, H., Das Vorderhirn der Cranioten, eine Antwort an Herrn F. K. Studnička. Anat. Anz., Bd. 9, pp. 536-547, 16 text figs.

1873. Reichenheir, M., Beiträge zur Kenntnis des elektrischen Centralorgans von Torpedo. Arch. f. Anat. u. Physiol., 1873, pp. 751-759, pls. 15-16.

1877. Reichenheim, M., Ueber das Rüekenmark und den elektrischen Lappen von Torpedo. Berlin, 24 pp., $4^{\circ}, 3$ Taf.

1877. Reichenheim, M., Sopra il midollo spinale ed il lobo elettrico della Torpedine. Mem. R. Acad. Lincei Roma (Ser. 3), I, pp. 1142-1162, pls. I-III.

1895. Retzius, G., Ueber den Bau des Rückenmarkes der Selachier. Biol. Untersuch., Bd. 7 , pp. 34-39, Taf. 10-12.

1877. Rohon, J. V., Das Centralorgan des Nervensystems der Selachier. Denkschr. K. Akad. Wiss. Wien, Bd. 38, Abt. 2, pp. 44-108, 9 Taf. Also: Arb. Zool. Inst. Wien, 1877, pp. 1-68, 9 Taf.

1878. RoHoN, J. V., Ueber den Ursprung des Nerrus vagus bei Selachiern mit Berücksichtigung der Lobi electrici von Torpedo. Arb. Zool. Inst. Wien u. Triest, Bd. 1, pp. $151-172$.

1897. Rourano, A., Sopra le fibre commissurali del proencefalo dei Selacei. Monit. Zool. Ital. Firenze, Vol. 8, pp. 206-212, 1 text fig.

1899. Romano, A., Sopra i centri nervosi elettrici dei Selacei. Monit. Zool. Ital. Firenze, Vol. 10, Suppl., pp. III-XXIII, tav. 6-7.

1867. SANDER, J., Ueber die Gehirnventrikel von Acanthias vulgaris. Sitzber. Ges. nat. Freunde Berlin, 1867-68, p. 26.

1882. Sanders, A., Contributions to the Anatomy of the Central Nervous System in Vertebrate Animals. Plagiostomata. Trans. Roy. Soc. Lond., Vol. 177, Pt. 2, pp. 733-766, pls. $38-41$.

1900. Sargent, P. E., Reissner's Fiber in the Canalis Centralis of Vertebrates. Anat Anz., Bd. 17, pp. 33-44, pls. 1-3, 1 text fig.

1904. SARgent, P. E., The Optic Reflex Apparatus of Vertebrates for Short Circuit Transmission of Motor Reflexes through Reissner's Fiber; its Morphology, Ontogeny, Phylogeny, and Function. Part I. The Fish-like Vertebrates. Bull. Mus. Comp. Zool. Harvard Col., Vol.45, pp. 131-258, 11 pls.

1896. SAURBEck, E., Beiträge zur Kenntnis vom feineren Bau des Selachiergehirns. Anat. Anz., Bd. 12, pp. 41-52, 9 text figs.

1902. SchACHERL, M., Zur Rückenmarksanatomie der Plagiostomen (Myliobatis). Arb. Neurol. Inst. Wien. Univ., pp. 405-416, 4 text figs.

1898. Schaper, A., The Finer Structure of the Selachian Cerebellum (Mustelus vulgaris) as shown by Chrome-Silver Preparations. Jour. Comp. Neurol., Vol. 8, pp. 1-20, pls. 1-4, 1 text fig.

1876. SchenK, S. L., Die Entwicklungsgeschichte der Ganglien und Lobus electricus. Sitzber. Wien. Akad., Bd. 74, Abt. 3, pp. 13-38, 2 Taf.

1897. Solger, B., Schnitte durch Ganglienzellen des Lobus electricus von Torpedo. Biol. Centralbl., Bd. 17, p. 512.

1886. Steiner, J., Ueber das Zentralnervensystem des Haifisehes und des Amphioxus lanceolatus und über den halbzirkelförmigen Kanal des Haifisehes. Sitzber. Akad. Berlin, 1886, pp. 495-499, 542-543.

1900. Steiner, J., Die Funktionen des Zentralnervensystems und ihre Phylogenese. II. Fische. Braunschweig, $8^{\circ}$, xii $+127 \mathrm{pp}$.

1899. Sterzi, G., Le meningi spinale dei pesci. Contributo alla filogenesi delle meningi spinali. Monit. Zool. Ital. Firenze, Vol, 10, pp. 38-42. 
1909. Sterzi, G., Il sistema nervoso centrale dei vertebrati. Vols. 1 and 2. Pisei. Libro I. Selaci, Pt. I: Anatomia, pp. x+986, 385 text figs. (Pt. II, 1912). (Sviluppo., pp. 9871361, 159 text figs.)

187 ‥ STIEDA, L., Sul cervello e sul midollo spinale della Raje e degli squali e sulla struttura del sistema nervoso della Sepia offieinale. R. R. Acad. Seienze fisiche e mat. Napoli, Vol. 10, pp. 243-247.

1573. Stieda, L., Ueber den Bau des Rückenmarkes der Rochen und der Haie. Zeitschr. wiss. Zool., Bd. 23, pp. 435-442, Taf. 25, text figs. 1-4.

1573. Stieda, P., Ueber die Deutung der einzelnen Theile des Fischgehirns. Zeitschr. wiss. Zool., Bd. 23, pp. 443-450.

1904. StudnıčKa, F. K., Zur Lösung einiger Fragen aus der Morphologie des Vorderhirns der Cranioten. Anat. Anz., Bd. 9, pp. 307-320, 2 text figs.

1876. Viault, F'R., Recherches histologiques sur la structure des centres nerveux des Plagiostomes. Arch. de Zool. expér. et gén., T. 5 (Sér. 1), pp. 441-528, pls. 19-22.

1907. Walleburg, A., Beiträge zur Kenntnis des Gehirns der Teleostier und Selachier. Anat. Anz., Bd. 31, pp. 369-399, 46 text figs.

1876. Wilder, B, G., On the Brains of Fishes. Proe. Phil. Acad. Sei., Vol. 38, pp. 51-53.

1876. Wilder, B. G., Note on the Development and Homologies of the Anterior Brain-Mass with Sharks and Skates. Amer. Jour. Sei., Vol. 12, pp. 103-105, 1 text fig.

190.). WILDER, B. G., On the Brains of Seymnus, Mitsukurina and Chlamydoselachus, with remarks upon Selachian Brains from Standpoints Morphic, Ontogenic, Taxonomic, Phylogenic, and Pedagogic. Science (n. s.), Vol. 21, pp. 812-814.

\section{CRANIAL AND SPINAL NERVES}

1914. Allis, E. P., The Pituitary Fossa and Trigemino-fascialis Chamber in Selachians. Anat. Anz., Bd. 46, pp. 225-253, 1 text fig.

1875. Balfour, F. M., On the Development of the Spinal Nerves in Elasmobranch Fishes. (Abstract.) Proc. Roy. Soc. Lond., Vol. 24, pp. 135-136.

1876. Balfour, F. M., On the Development of the Spinal Nerves in Elasmobranch Fishes. Phil. Trans. Roy. Soe. Lond., 1876, Vol. 166, Pt. I, pp. 175-195, pls. 16-18.

1855. BEARD, J., The System of Branchial Sense Organs and Their Associated Ganglia in Iehthyopsida; a contribution to the Ancestral History of Vertebrates. Quart. Jour. Mier. Sei. (n. s.), Vol. 26, pp. 95-156, pls. 8-10.

1885. Beard, J., On the Cranial Ganglia and Segmental Sense Organs of Fishes. Zool. Anz., Bd. 8, pp. 220-223.

1887. Beard, J., The Ciliary or Motoroculi Ganglion and the Ganglion of the Ophthalmicus profundus in Sharks. Anat. Anz., Bd, 2, pp. 565-575, 5 text figs.

1888. Beard. J., Morphological Studies. II. The Development of the Peripheral Nervous System of Vertebrates. Part I. Elasmobranchii and Aves. Quart. Jour. Mier. Sci. (n. s.), Vol. 29, pp. 153-228, pls. 16-21.

1892. Beard, J., The Histogenesis of Nerves. Anat. Anz., Bd. 7, pp. 290-302.

1892. Beard, J., The Transient Ganglion Cells and Their Nerves in Raja batis. Anat. Anz., Bd. 7, pp. 191-206, 8 text figs.

1896. BEARD, J., The History of a Transient Nervous Apparatus in Certain Ichtliyopsida, An Account of the Development and Degeneration of Ganglion-Cells and NerveFibers. Part I. Raja batis. Zool. Jahrb. (Anat. Abt.), Bd. 9, pp. 319-426, Taf. 22-29.

1896. Beard, J., On the Disappearance of the Transient Nervous Apparatus in the Series: Scyllium, Acanthias, Mustelus and Torpedo. Anat. Anz., Bd. 12, pp. 371-374. 
1904. BoRCHERT, MAX, Ueber Markseheidenfährbung bei niederen Wirbelthieren. Areh.f. Anat. und Pliysiol. (Abt. Physiol.), 1904, pp. 572-575.

1901. Botтazzi, P., Ueber die Innervation des Herzens ron Seyllium canicula und Maja squinado. Zentral. Physiol., Bd. 14, pp.665-670, 7 text figs.

1902. Boтtazzi, P., Untersuchungen über das viecerale Nervensystem der Selachier. Zeitschr. f. Biol., Bd. 43, pp. 372-442, 2 Taf., 13 text figs.

1892. Brads, H., Ueber die Rami ventrales der vorderen Spinalnerven einiger Selachier. Jena, $8^{\circ}, 35 \mathrm{pp}$. (Diss.).

1898. Braus, H., Ueber die Innervation der paarigen Extremitäten bei Selachiern, Holocephalen und Dipnoern. Ein Beitrag zur Gliedmassenfrage. Jena. Zeitschr. Naturwiss., Bd. 31, pp. 239-468, Taf. 9-17, 3 text figs.

1899: Braus, H., Beiträge zur Entwieklung der Muskulatur und des Peripheren Nervensystems der Selachier. Die metatischen Urwirbel und spino-oceipitalen Nerven. Morph. Jahrb., Bd. 27, pp. 415-496, pp. 501-629, 4 Taf., 11 text figs.

1909. Braus, H., Experimentelle Untersuchungen über die Segmentalstruktur der motorisehen Nervenplexus. Anat. Anz., Bd. 34, pp. 529-551, 5 text figs.

1910. BRAUs, H., Präparatorische und experimentelle Untersuchungen über die motorischen Nerven der Selachierflosse. Eine Erwiderung auf die Arbeit von E. Müller: "Die Brustflosse der Selachier." Anat. Hefte, Bd. 40, pp. 423-488, 10 text figs.

1910. Braus, H., Ueber Nervengeflechte. Anat. Anz. (Ergänzungsheft zum) 37. Bd., pp. 14-30, 1 Taf., 3 text figs.

1891. DoHRN, A., Studien zur Urgesehichte des Wirbelthierkörpers. XVI. Ueber die erste Anlage und Entwicklung der Augenmuskelnerven der Selachier und das Einwandern von Medullarzellen in die motorisehen Nerven. Mitt. Zool. Stat. Neapel, Bd. 10, pp. 1-40, Taf. 1-5.

1891. DонRN, A., Studien zur Urgeschichte des Wirbelthierkörpers. XVII. Nervenfaser und Ganglienzelle. Histogenetische Untersuchungen. Ibid., Bd., 10, pp. 256-341, Taf. $16-23$

1892. Dohrn, A., Die Sehwann'sehen Kerne der Selachierembryonen. Anat. Ànz., Bd. 7, pp. 348-351.

1901. DoHRN, A., Studien zur Urgeschichte des Wirbelthierkörpers. XVII-XXI. Ibid., Bd. 15, pp. 1-279, Taf. 1-15.

1902. DoHRN, A., Studien zur Urgeschichte des Wirbelthierkörpers. XXII. Weitere Beiträge zur Beurtheilung der Oecipitalregion und der Ganglienleiste der Selachier. Ibid., Bd. 15, pp. 555-654, Taf. 24-30.

1907. DoHRN, A., Studien zur Urgesehichte des Wirbelthierkörpers. XXV. Der Trochlearis. Mitt. Zool. Stat. Neapel, Bd. 18, pp. 143-436, Taf. 10-22.

1889. Ewart, J. C., On the Cranial Nerves of Elasmobranch Fishes. (Prelim. comm.) Proc. Roy. Soc. Lond., Vol. 45, pp. 524-537, 2 text figs.

1890. Ewart, J. C., On the Development of the Ciliary or MIotor Oculi Ganglion. Proc. Roy. Soc. Lond., Vol. 47, pp. 287-290.

1890. Ewart, J. C., The Cranial Nerves of Torpedo. (Prelim. note.) Proc. Roy. Soc. Lond., Vol. 47, pp. 290-291.

1892-95. Ewart, J. C., and Cole, F. J., On the Dorsal Branehes of the Cranial and Spinal Nerves of Elasmobranchs. Proc. Roy. Soc. Edinburgh, Vol. 20, pp. 475-480, 2 text figs.

1887. Froriep, A., Über das Homologon der Chorda tympani bei niederen Wirbeltieren. Anat. Anz., Bd. 2, pp. 486-493, 1 text fig.

1891. Froriep, A.,Zur Entwickelungsgesehichte der Kopfnerven. I. Ueber die Entwickelung des Trochlearis bei Torpedo. II. Ueber die Kiemenspaltenorgane der Selachierembryonen. Anat. Anz. (Verh.), Bd. 5, pp. 55-65, 6 text figs. 
1901. Frorrep, A., Ueber die Ganglienleisten des Kopfes und des Rumpfes und ihre Kreuzung in der Oceipitalregion. Beitrag zur Entwiekelungsgesehichte des Selachierkopfes. Arch. f. Anat. u. Physiol. (Anat. Abt.), Jahr. 1901, pp. 371-394, pl. 17, 3 text figs.

1897. Fürbringer, Max, Ueber die spino-oceipitalen Nerven der Selachier und Holocephalen und ihre vergleichende Morphologie. Festschrift z. 70. Geburtstage von C. Gegenbaur. Bd. III, Leipzig, pp. 349-788, pls. 1-8, 1 text fig.

1902. Fürbringer, Max, Morphologisehe Streitfragen. 1. Nervus trochlearis. Rabl's Methode und Behandlung der Extremitätenfrage. Morph. Jahrb., Bd. 30, pp. 85-274.

1909. GAsт, R., Die Entwickelungen des Oculomotorius und seiner Ganglien bei Selachierembryonen. Mitt. Zool. Stat. Neapel, Bd. 19, pp. 269-444, Taf. 12-16.

1871. Gegenbaur, C., Ueber die Kopfnerven von Hexanchus und ihr Verhältnis zux "Wirbeltheorie" des Schädels. Jena. Zeitschr. Naturwiss., Bd. 6, pp. 497-559, p1. 13.

1910. Goodrich, E. S., On the Segmental Structure of the Motor Nerve-Plexus. Anat. Anz., Bd. 36, pp. 109-112, 1 text fig.

19100. Green, H. A., On the Homologies of the Chorda Tympani in Selachians. Jour. Comp. Neurol., Vol. 10, pp. 411-421, 3 text figs.

1907. Guthke, ERNst, Embryologische Studien über die Ganglien und Nerven des Kopfes ron Torpedo ocellata. Jena. Zeitschr. Naturwiss., Bd. 42, pp. 1-60, Taf. 1-3, 7 text figs.

1906. Hawkes, O. A. M., The Cranial and Spinal Nerves of Chlamydoselachus anguineus Garman. Proc. Zool. Soc. Lond., 1906 (2), pp. 959-991, pls. 68-69, 2 text figs.

1897. Hofrarann, C. K., Beiträge zur Entwicklungsgeschichte der Selachii. Morph. Jahrb., Bd. 25, pp. 250-304, Taf. 13-14.

1899. HofruanN, C. K., Beiträge zur Entwicklungsgeschichte der Selachii. (Fortsetzung.) Morph. Jahrb., Bd. 27, pp. 325-414, Taf. 14-18, 5 text figs.

1901. Hoffmann, C. K., Zur Entwicklungsgeschichte des Sympathicus. (I. Bei den Acanthias vulgaris.) Verh. K. Akad. Wet., Amsterdam, Bd. 7, pp. 1-80, 3 Taf.

1887. His, W., Die morphologisehe Betrachtung der Kopfnerven. Arch. Anat. u. Entwick., 1887, pp. 379-453, 8 text figs.

1898. Holmgren, E., Kurze vorläufige Mitteilungen über die Spinalganglien der Selachier und Teleostier. Anat. Anz., Bd. 15, pp. 117-125, 11 text figs.

1901. Houser, G. L., The Neurones and Supporting Elements of the Brain of a Selachian. Jour. Comp. Neurol., Vol. 2, pp. 65-175, pls. 6-13.

1905. Johnston, J. B., The Radix Mesencephalica Trigemini. The Ganglion Isthmi. Anat. Anz., Bd. 27, pp. 364-379, 8 text figs.

1914. KAPPers, C. V. A., Der Geschmack, perifer und central, zugleich eine Skizze der phylogenetischen Veränderungen in den sensibilen VII, IX, und $\mathrm{X}$ Wurzeln. Psychiatr. en neur. Bloden, Bd. 1 u. 2.

1905. KlinkнаRDt, W., Beiträge zur Entwicklungsgeschichte der Kopfganglien und Sinneslinien der Selachier. Jena. Zeitschr. Naturwiss., Bd. 40, pp. 423-486, Taf. 14-16, 6 text figs.

1857. KöLliker, A., Ueber die Ausbreitung der Nerven in der Geruchsschleimhaut ron Plagiostomen. Verh. d. Phys.-med. Ges. Würzburg, Bd. 8, pp. 31-37.

1911. Kuntz, A., The Derelopment of the Sympathetic Nervous System in Certain Fishes. Jour. Comp. Neurol., Vol. 21.

1891. KUPFFER, C. vos, Die Entwickelung der Kopfnerven der Vertebraten. Verh. d. Anat. Ges. 1891. Trans. by Strong, Jour. Comp. Neurol., Vol. 1, pp. 246-264, 315-332, pl. XXII.

1916. LANDACre, F. L., The Cerebral Ganglion and Early Nerves of Squalus acanthias. Jour. Comp. Neurol., Vol. 27. 
1892. LenhosséK, M. voN, Beobachtungen an den Spinalganglien und dem Rüekenmark von Pristiurusembryonen. Anat. Anz., Bd. 7, pp. 519-539, 19 text figs.

1899. Locx, WM. A., New Facts Regarding the Development of the Olfactory Nerve. Anat. Anz., Bd. 16, pp. 273-290, 14 text figs.

1905. Locy, WM. A., On a Newly Recognized Nerve Connected with the Fore-Brain of Selachians. Anat. Anz., Bd. 26, pp. 33-63, 111-123, 32 text figs.

1914. McKrbben, Paul, Ganglion Cells of the Nervus Terminalis in the Dogfish (Mustelus canis). Jour. Comp. Neurol., Vol. 24, pp. 437-439, pls. 1-2.

1881. Marshall, A. M., On the Head Cavities and Associated Nerves of Elasmobranchs. Quart. Jour. Mier. Sei., Vol. 21, pp. 72-97, pls. V-VI.

188:. Marshall, A. M., The Segmental Value of the Cranial Nerves. Jour. Anat. and Physiol., Vol. 16, pp. 305-354, pl. 10.

1881. Marshali, A. M., and Spencer, W. B., Observations on the Cranial Nerres of Seyllium. Quart. Jour. Mier. Sei., Vol. 21, pp. 469-499, pl. 27.

1904. MERritt, O. A., The Theory of Nerve Components. Jour. Anat. and Physiol., Vol. 39, pp. 199-241, 2 text figs.

18.93. Mitrophanow, P., Note on the Structure and the Development of Nervous Elements. Jour, Comp. Neurol., Vol. 3, pp. 163-167.

1898. Neat, H. V. See Central Nervous System.

1903. NeAL, H. V., The Development of the Ventral Nerves in Selachii. I. Spinal Ventral Nerves. Mark Anniv. Vol., pp. 291-313, pls. 22-24.

1907. Neat, H. V., The Morphology of the Eye Muscle Nerres. Proc. 7 th Internat. Zool. Congr. Boston, pp. 204-214, figs. 1-10.

1911. NeaL, H. V., The Histogenesis of the "Transient" (Rohon-Beard) Cells in Selachian Embryos. Science (n. s.), Vol. 33, p. 273.

19.24. Norris, H. W., Branchial Nerve Homologies. Zeitsehr. f. Morph. u. Anthrop., Bd. 24, pp. 211-226, 7 text figs.

1884. Ónodr, A., Ueber die Entwicklung der Spinalganglien und der Nervenwurzeln. Math. nat. Ber. Ungarn, Bd. 2, pp. 310-336, Taf. 10.

1๖87. Ónodi, A., Neurologische Untersuchungen an Selachiern: 1. Das Ganglion ciliare. 2. Die Vagus Gruppe. Math.-nat. Ber. Ungarn, Bd. 5, pp. 179-188.

1901. ónodi, A., Das Ganglion ciliare. Anat. Anaz., Bd. 19, pp. 118-124.

1889. Ostroumoff, A., Ueber die Froriep'schen Ganglien bei Selachiern. Zool. Anz., Bd. 12, pp. 363-364.

1853. Philipeaux and Vulpiax. See Central Nervous System.

1910. Pitzorno, Marco, Sulla struttura dei gangli simpatici nei Selaci. Monit. Zool. Ital. Firenze, Anno 21, pp. 53-61, pls. 3-5.

1891. Platt, J. B., A Contribution to the Morphology of the Vertebrate Head, based on a study of Acanthias vulgaris. Jour. Morph., Vol. 5, pp. 79-112, pls. 4-6.

1901. PUnnetT, R. C., On the Composition and Variations of the Pelvic Plexus in Acanthias rulgaris. (Abstract.) Proc. Roy. Soc. Lond., Vol. 68, pp. 140-142. Also: Zool. Anz., Bd. 25, pp. 233-235.

1887. RabL, C., Ưber das Gebiet des Nerrus facialis. Anat. Anz., Bd. 2, pp. 219-227.

1878. Rоном, J. V., Ueber den Ursprung des Nervus vagus bei Selachiern mit Berücksichtigung der Lobi electrici von Torpedo. Arb. Zool. Inst. Wien u. Triest, Bd. 1, pp. 151172, 6 text figs.

1897. Ruge, G., Ueber das peripherische Gebiet des Nervus facialis bei Wirbelthieren. Festsch. zum. 70. Geburtstage v. C. Gegenbaur, pp. 195-348, 76 text figs.

1879. Schwalbe, G., Das Ganglion oculomotorii. Jena. Zeitsehr. Naturwiss., Bd. 13, pp. 173-268, Taf. XII-XIV. 
1911. Sewertzokf, A. N., Die Kiemenbogen-Nerven der Fische. Anat. Anz., Bd. 38, pp. 487494,4 text figs.

1888. SHore, T. W., The Morphology of the Vagus Nerve. Jour. Anat. and Physiol., Vol. 22, p p. 372-390.

1889. Shore, T. W., On the Minute Anatomy of the Vagus Nerve in Selachians, with remarks on the Segmental Value of the Cranial Nerves. Jour. Anat. and Physiol., Vol. 23 , pp. 428-451, pls. 20-21.

1894. Strong, O. S., Dorsal View of the Cranial Nerres of the Leopard Shark (Galeocerdo maculatus Ranzani). A single plate published by Marine Biol. Lab., Woods Hole, Mass.

1903. Strong, O. S., The Cranial Nerres of Squalus acanthias. (Abstract.) Science (n. s.), Vol. 17, pp. 254-255.

1904. Strong, O. S., The Cranial Nerves of Squalus acanthias. Biol. Bull., Vol. 6, p. 314.

1895. Turner, W. A., The Central Connections and Relations of the Trigeminal, VagoGlossopharyngeal, Vago-Accessory, and Hypoglossal Nerves. Jour. Anat. and Physiol., Vol. 29, pp. 1-15.

1885. Vincenzi, L., Sull' origine reale del nervo ipoglosso. Atti R. Acad. Sci., Torino, Vol. 20 , pp. 798-806, tav. 7.

1882. WiJhe, J. W. vaN, Ueber die Mesodermsegmente und die Entwickelung der Nerven des Selachierkopfes. Natuurk. Verh. K. Akad. Amsterdam, Deel 22, pp. 1-50, 5 pls. (Also Groningen, 1915.)

1897. Wikströм, D. A., Ueber die Innervation und den Bau der Myomeren der Rumpfmuskulatur einiger Fische. Anat. Anz., Bd. 13, pp. 401-408. 


\section{SPECTAL SENSES}

\section{SPECIAL SENSES OF HEPTANCHUS MACULATUS}

Under the organs of special sense in Heptanchus we may consider the olfactory organ, the eye, the ear, and the lateral line and associated organs. For the relation of the first three of these to the brain see figure $200 \mathrm{~A}$.

\section{OLFACTORY Organ}

The olfactory organ in Heptanchus is an almost terminal encapsulated structure, with a convoluted mueous lining. From the outside this organ is reached by the nasal aperture which is separated by an overlapping median flap into an upper and a lower opening through which the water current circulates. Upon dissecting away the narial flaps the eup appears elliptical in outline and the lamellae are arranged in a series of folds which radiate outward from a central hub, like the spokes in a wheel.

Located in the convoluted lining of the olfactory membrane are the primary olfactory cells (receptors). These cells send fine projections, hair cells, into the cup and they also send fibers posteriorly to the olfactory bulb in two bundles. These bundles compose the olfactory nerve, one part of which passes to the olfactory organ externally and the other internally ( $I$, fig. 200A). Olfactory sensations are carried backward by the olfactory tracts or peduncles (ol.t.) to the olfactory lobes (ol.l.) of the brain.

\section{EYF}

The eye in Heptanchus is provided with dorsal and rentral membranous and non-functional lids, but it is umprovided with a third eyelid or nietitating membrane. It appears to fit the orbit but poorly, especially in the young in which the orbit is unusually large.

If the eyeball be dissected free from the orbit (figs. 91 and 200A) it is seen to be slightly pear-shaped and to be held in position by the optic pedicel (o.p., fig. 91) and the eye muscles which were described in a study of the muscular system (pp. 89-90). The coat which appears externally covering the eye is the heavy selera. In Heptanchus the selera is chondrified and surrounds the ball, except laterally over the clear elliptical cornea; in the center of the cornea is the pupil surrounded by a dark colored curtain, the iris.

\section{EAR}

The ear proper (figs. 200A and 226 ) is located in the otic capsule. It is composed of the semicircular canals with their ampullae and the utricular and saceular regions. The anterior oblique and the horizontal canals have their anterior 
ends enlarged into ampullae (a.a. and $a . h$. respectively) which are placed close together. These two canals join the utriculus $(u$.) above. 'The ampulla of the posterior canal (a.p.) is located ventrally and that part of the canal lying near the sacculus is by some considered to be a second or posterior utriculus.

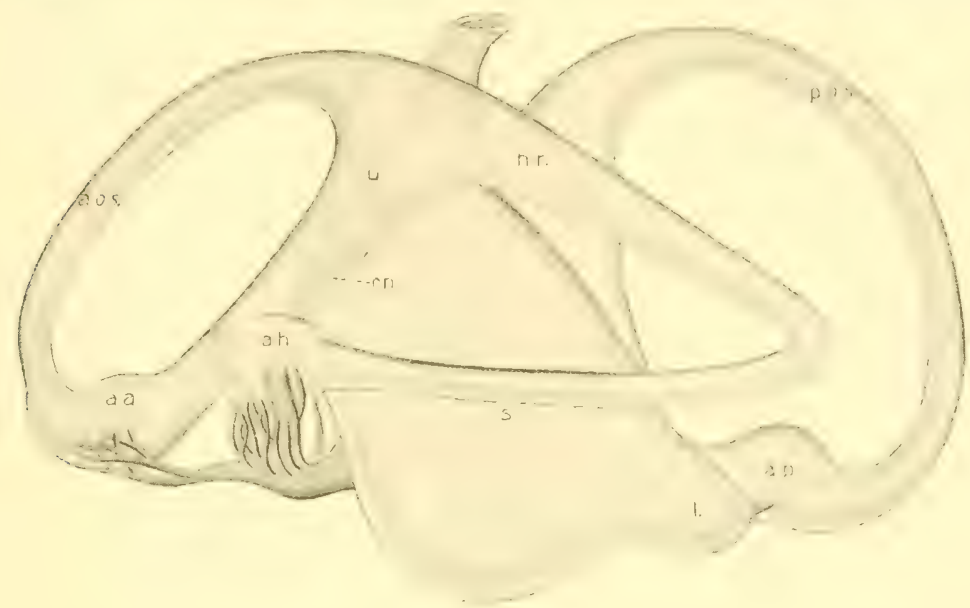

A

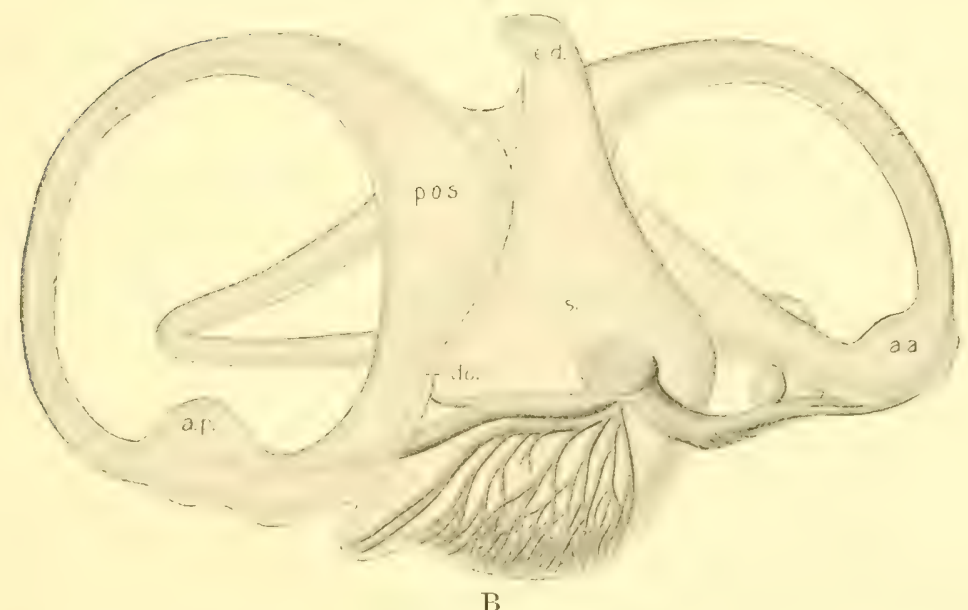

Fig. 226. Ear of Heptanchus maculatus. (Dunean Dunning, del.) A. Left ear, lateral view. B. Left ear, median view.

a.a., ampulla of anterior oblique semicireular canal; a.h., ampulla of horizontal canal; aos., anterior oblique semicircular canal; $a . p$. , ampulla of posterior canal; cn., connection between utriculus and sacculus; d.c., connection between saceulus and posterior oblique semicircular eanal; e.d., endolymphatic duct; hr., horizontal canal; l., lagena; pos., posterior oblique semicircular canal; s., saceulus; $u$, utriculus.

At its base the utriculus is comnected with the sacculus (s.) by a recessus utriculi (at $c n$.). The sacculus is pear-shaped and continues upward in the chimney-like endolymphatic duct, the outer opening of which we saw in a study of the skull (ed., p. 42, fig. 45). From the posterior part of the floor of the saceulus a tongue-like sae, the lagena (l.), projects backward and downward. 


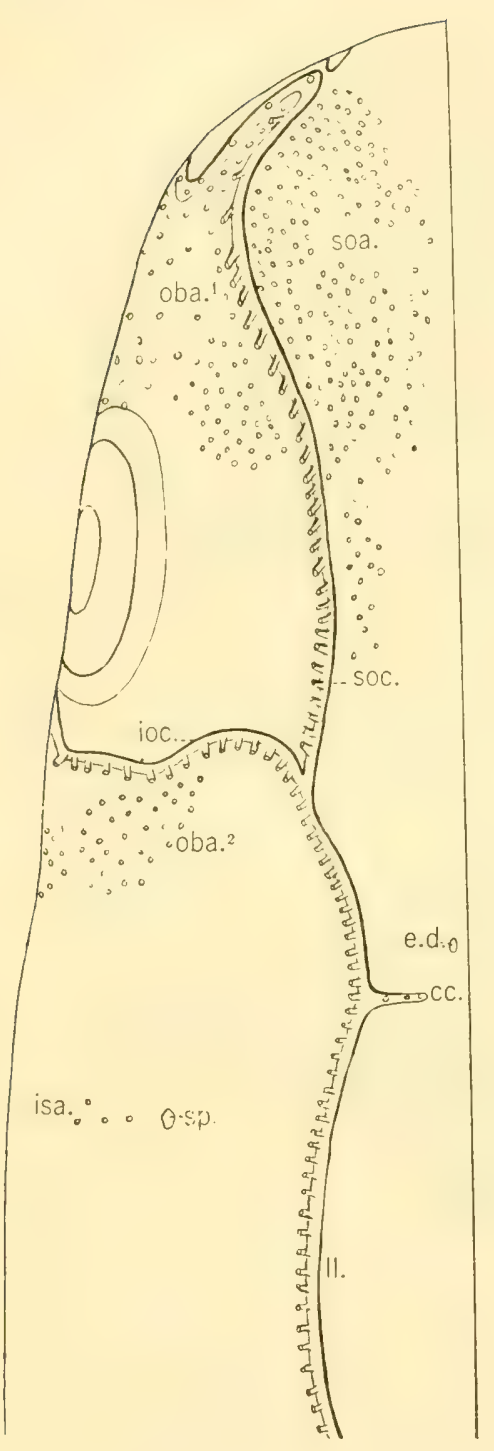

A.

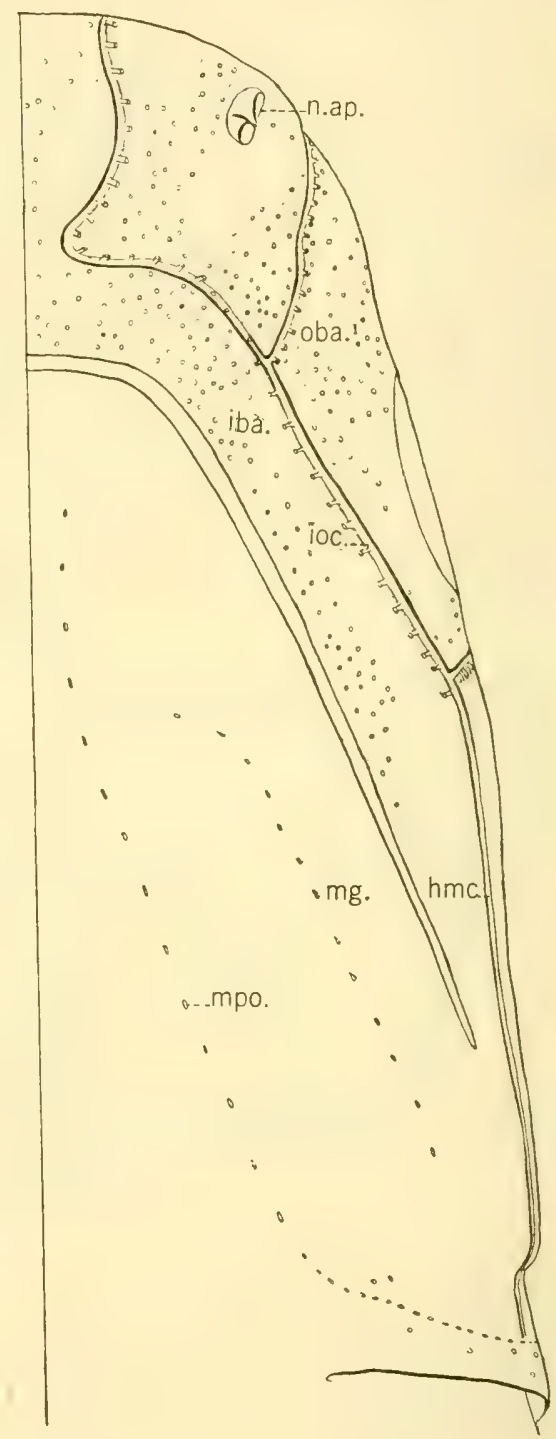

B

Fig. 227. Cephalic canals and ampullae of Lorenzini, Heptanchus maculatus. (G. L. Hanner, orig.) A. Dorsal view. B. Ventral view.

ce., supratemporal canal; e.d., endolymphatic duct; $h m c$. , hyomandibular canal; iba., inner buceal ampullae; ioc., infraorbital canal; isa., infraspiracular ampullae; $1 l$., lateral line; mg., mandibular groove; mpo., pit organs in gular line (gl.); n.ap., nasal aperture; oba. ${ }^{1-2}$, outer buecal and posterior outer buceal ampullae; soa., supraophthalmic ampullae; $s o c$, supraorbital canal; $s p$. spiracle. 


\section{INNERVATION}

The ear receives its inmervation from the auditory or eighth nerve. This nerve as it leaves the brain stem separates into two main divisions, each of which further subdivides. Principal among the branches are the rami to the ampullace of the anterior oblique, the horizontal, and the posterior oblique semicircular canals; and those rami to the utriculus, the sacculus, and to the lagena.

\section{Sensory Canal System}

The sensory canal system in Heptanchus consists of cranial canals in the head connected with a canal over the pharynx and a lateral open groove in the body region (see figs. 15, 227, and 228). The lateral canal in Heptanchus is

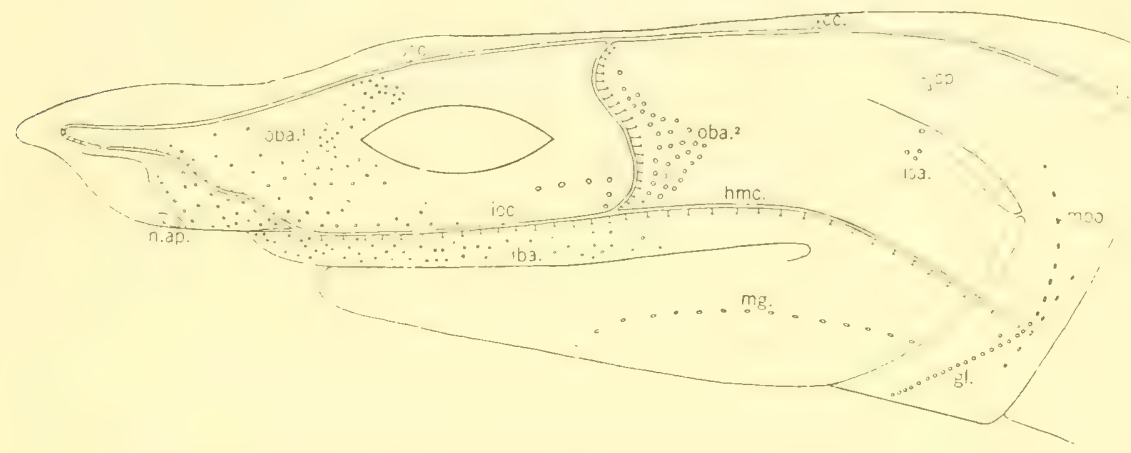

Fig. 228. Cephalic canals and ampullae of Lorenzini, Heptanchus maculatus, side view. (G. L. Hanner, orig.) (For explanation see fig. 227.)

especially simple for even in large specimens the canal as such is closed posteriorly only to about the fifth cleft, back of which it remains an open groove toward the tip of the tail.

Anterior to the spiracle and just posterior to the endolymphatic ducts a small transverse or supratemporal canal (cc., figs. 15 and $227 \mathrm{~A}$ ) passes off: from the lateral canal toward the median line. This, however, does not meet and fuse with the similar canal from the opposite side. In Heptanchus maculatus there may be two supratemporal canals on a side, one posterior to the endolymphatic duct as just deseribed, the other anterior to it. From the supratemporal canal the lateral line canal passes slightly outward and forward to join the cranial canals. The cranial canal passing above the eye is the supraorbital canal (figs. 227 and 228, soc.). In front of the eye the supraorbital swerves outward and then sharply inward; it then turns backward and downward above the nasal aperture. The infraorbital canal (ioc.) back of the eye drops downward, sends the hyomandibular canal ( $h m c$.) backward, and then continues forward under the eye. Before reaching the nasal aperture this canal is joined by the supraorbital canal (fig. 228). The main infraorbital next bends sharply toward the middle line, without joining the canal of the 
opposite side, and then passes outward and forward to the tip of the rostrum, where it ends blindly (fig. 227B). A mandibular groove (mg., fig. 227B) rums along the lower jaw parallel with the membranous lower lip.

In the groove on the body and in the canals on the head are located sense organs, the neuromasts, of the sensory canal system. In Heptanchus, as in other Elasmolranchs, the sense cells joining these organs are specializations of the cells in the wall of the canal or groove. The sense organs along the lateral line are supplied largely by branches of the vagus nerve. The glossopharyngeal and the otic division of the facial supply a few of the anterior neuromasts of the lateral line canal. The canals of the head are innervated

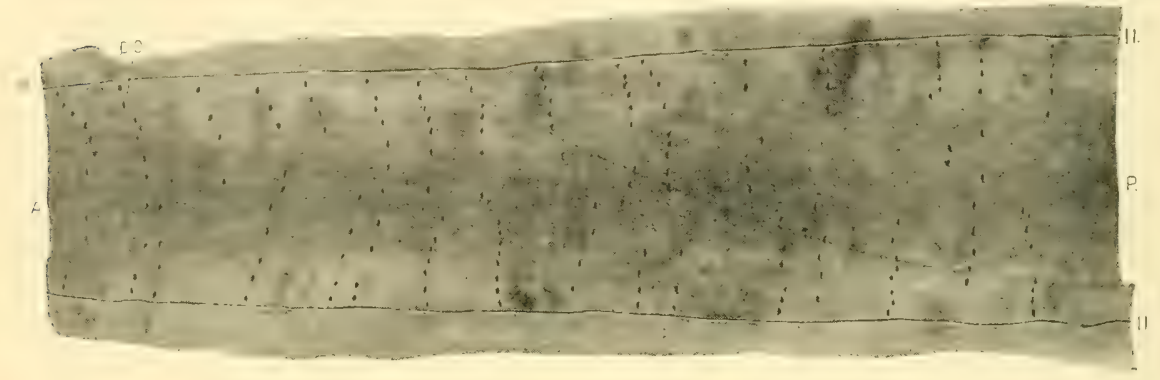

Fig. 229. Pit organs, Heptanchus maculatus. (Madeline Marlowe, orig.) A., anterior; $l l$., lateral line; p.o., pit organs; $P$., posterior.

wholly by the facial nerve. The superficial ophthalmic division supplies the supraorbital; the buccal branch, the infraorbital; and branches of the hyomandibular nerve supply the hyomandibular canal and the mandibular groove.

In addition to the sense organs characteristic of the sensory canal system in the head are other integumentary sense organs of a tubular nature. The first of these tubular organs are the ampullae of Lorenzini, which take the same relative position as do the canals of the head, and like them are similarly named. 'The ampullae, however, are grouped together, five or six such groups . in Heptanchus maculatus being shown in figures 227 and 228. These are the supraophthalmic (soa.) ampullae above the supraorbital canal and in front of the eye; outer buceal $\left(o b a .^{1}\right)$, posterior outer buccal $\left(o b a^{2}\right)$, and inner buceal (iba.) groups located respectively above and below the infraorbital (anal and a part of the hyomandibular canal. A small bundle of ampullae lies ventral to the spiracle (isa., fig. 228). Each sense organ of an ampulla of Lorenzini sinks into the integument and is put into connection with the outside by means of a longer or shorter canal (or canals) opening by a mucous pore (see p. 280, fig. 246). Connecting with the base of such an organ is a nerve twig, the twigs being furnished by the branches of the facial nerves which also supply the canals of the head region.

A second kind of sense organ is the pit organ (figs. $227 \mathrm{~B}$, mpo., and especially 229). These pit organs are particularly interesting in Heptanchus maculatus in that they have a wide distribution and are distinctly segmental in 
their arrangement. Most of these pits lie between the segment of the spiracle and the dorsal fin although four of them lie near the middorsal line in front of the apertures for the endolymphatic ducts. Further, a line extends down the arch back of the spiracle, as the so-called gular line ( $g l$., fig. 228) described by Garman (1888) for Chlamydoselachus. This passes downward and forward in front of the first branchial cleft and ends ventrally before reaching the mandibular symphysis (fig. 227B). 


\section{SPECIAL SENSES OF ELASIIOBRANCHS IN GENERAL}

The organs of special sense, olfactory, gustatory, optic, auditory, and sensory canal organs, although very different in the adult are, with the exception of the taste buds and the eye, similar in the beginning. In general, with the exceptions made, these organs arise as thickened plates or placodes of ectoderm. An anterior placode gives rise to the nasal pit and a posterior placode sepa-

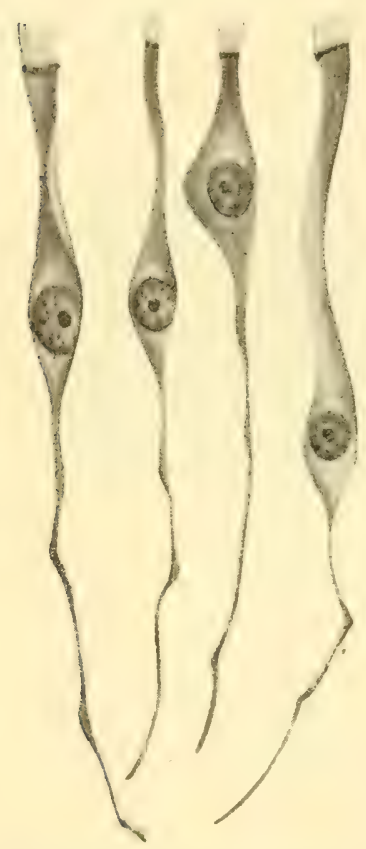

Fig. 230. Types of olfactory sensory cells, Mustelus laevis. (From Asai.) rates into three parts (Mitrophanow, 1893). The first or anterior of these gives origin to a branchial sense organ over the first gill; the second gives rise to the ear, and the third or posterior part produces the lateral line organ which, in the sharks, later extends to the tip of the tail.

\section{Olfactory Organ}

The olfactory organ in the adult is a blind sac, which in simpler forms like the notidanids and Chlamydoselachus is more or less terminal in position. In many other Elasmobranchs, however, its position is more ventral. The olfactory sac or pit itself varies greatly as to its shape, the nature of its lining, and the number and depth of the folds produced in it. In general it may be said to be elliptical in form, the long axis pointing anteromedially. The sac may be single or it may be double. In either case the lining is thrown into two series of ridges, the Schneiderian folds (fig. 231), which greatly increase the extent of its surface. The so-called secondary folds are usually anterior and dorsal in position while the primary folds are posterior and ventral. In certain forms the folds become exceedingly numerous, more than eighty primary folds being present.

The sensory cells (fig. 230) have a group of hair-like processes which extend into the olfactory cup, and fibers which run back as the olfactory nerves to the glomeruli of the olfactory bull. From the bulb, fibers extend posteriorly in the olfactory tract to the olfactory lobe of the brain, as we have described for Heptanchus.

When seen from the outside the aperture to the olfactory organ is usually separated by flaps across its middle part into two divisions. One of these apertures is incurrent, the other is excurrent. In Heterodontus the excurrent aperture leads backward so that the water current, instead of passing out, passes backward and in to the mouth. In some Elasmolranchs two flaps, instead of one, may pass over the nasal pit. When this occurs, the one passes inward from the ventral margin, while the other hangs down and slightly overlaps it 
from the dorsal side. In certain forms more than a single dorsal flap obtains. In scyllium a double dorsal, and in Wyliobatis numerons dorsals are present. In some of the rays (also in syuatina) these dorsal flaps extend downward as loose extensions of skin and are of slight value in forming a tube of the cup. Tye the meeting of dorsal and ventral flaps the normally elliptical aperture is changed into a figure 8 , thus producing an anteromedial and a posterolateral opening to the olfactory organ.

As the fish moves forward a current is produced mechanically through the olfactory eup and over the olfactory membrane. The importance of such a current in forms which have no direct connection from the nose to the mouth, that is, in which the olfactory organ is solely an organ of sense taking no part secondarily in respiration, is elearly seen. That the sense of smell is well developed in Elasmobranchs has been demonstrated by the experiments of Sheldon (1911). If for example the nostrils of the shark be plugged with

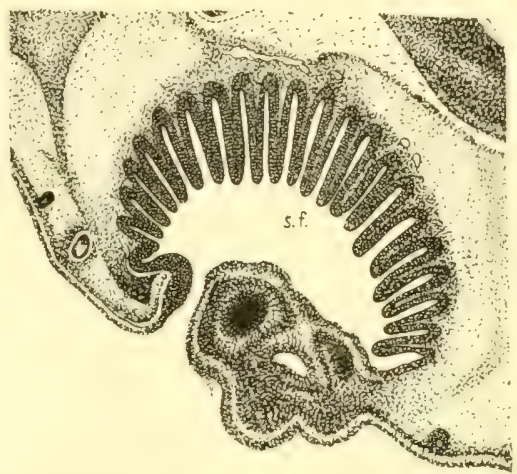

Fig. 231. Sagittal section of developing nasal pit, Acanthias. (From Berliner.) s.f.. Sehneiderian folds. cotton so as to prevent a circulation of the water over the olfactory membrane, the shark will swim over food without detecting it by sight; but if the nostrils now be inplugged, or even a single nostril, food will be found although it has been concealed. In fact, of all the special senses the sense of smell is probably of the most service.

\section{DEVELOPMENT OF OLFACTORY ORGAN}

We may now notice briefly the development of the olfactory organ in the Elasmobranchs. As is common for vertebrates in general this organ first appears as a thickened epidermal placode or plate which early pits in from the outside toward the brain so as to form a shallow vesicle. By further growth this vesicle sinks deeper and forms a blind sac (fig. 231) in which arise the Schneiderian folds (s.f.) of the primary and secondary types. Furthermore these folds have produced from their sides numerous accessory folds in which are found the olfactory sense-cells above mentioned (fig. 230). The two divisions of the olfactory nerve put these two areas of folds into communication with the olfactory bulb, but each division of the nerve may be connected with both of the areas of the folds.

\section{Gustatory or Taste Organs}

Taste buds are present in the Elasmohranchs often in considerable numbers. These are located in the buceal cavity and pharynx and are distributed over the floor and tongue, along the sides, and over the roof of both cavities. An in- 
dividual organ is well illustrated in Heterodontus, in figure 34D, where it is seen as a papilla arising from the floor of the mouth. These organs often are surrounded by a more or less circular group of stomodeal denticles.

A section through such a taste bud shows it to be placed over a cup-shaped base which looks something like the base of a placoid scale. The organ itself is made up of cells elongated in a vertical direction. These cells are of two sorts. One is a supporting cell and the other is a sense cell.

\section{Elasitobranch Eye}

Extremes to which the Elasmobranch eye may be developed may be exemplified in two trpes like Isistius and Squatina. In the former, which is a deep sea shark, the eye reaches a size which makes it a conspicuous structure standing out from the sides of the head. In the latter, which is slow moving and noc-

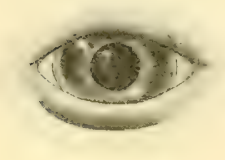

A

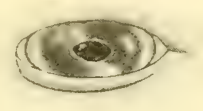

B

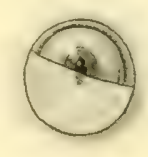

C

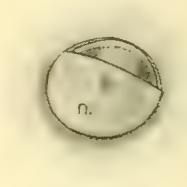

$\mathrm{D}$

Fig. 232. Types of Elasmobranch eyes. (From Garman.) A. Parmaturus pilosus. B. Triakis henlei. C. Scoliodon. D. Carcharias milberti.

n., nictitating membrane.

turnal, there is but little exact vision and the eye is therefore more or less rudimentary. Between the two extremes are multitudes of types.

In external view (fig. 232) the eye varies greatly in the type of its pupil and the nature of its lids. The pupil may be large, denoting a type of eye unused to a great deal of light. Figure 233c of Spinax, a deep sea form, shows such a condition. In Triakis henlei the pupil is smaller and assumes a horizontal position, while in Scoliodon and Carcharias (fig. 232C and D) the pupil is vertical.

The eyelids, especially the third or nictitating membrane ( $n$., fig. 232), are also marked characters in external view. In fact on this character alone the Elasmobranchs were separated by J. Müller into two groups: (1) those having a nictitating membrane and (2) those devoid of it. To the former group belong Galeus, Mustelus, etc., and to the latter Heptanchus, Acanthias, etc. The nictitating membrane varies greatly in the degree of its development. In a type like Carcharias (fig. 2320) it reaches an optimum development where it can be drawn entirely over the eye.

There has been considerable interest over the relation of the nictitating membrane to the lower membranous lid. The question is: Is the nictitating membrane the made-over lower lid with the present lower lid formed anew, or does it arise from the lower lid? In Mustelus, at least, it has been shown by Harman (1899) to arise as a ridge on the inner (ocular) side of the lower lid. 
From an external view the eye is seen to be further protected by the orbit and in a way by upper and lower membranous lids. In Chlamydoselachus the lower lid is a deep fold which is interesting because a part of its inner surface is eovered with placoid seales. The same is true of Mustelus. In fact it was from the possession of seales that the lower lid was formerly incorrectly supposed to be a newly formed structure.

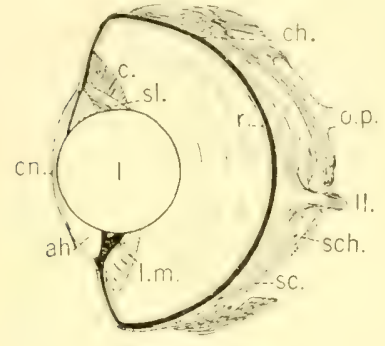

A

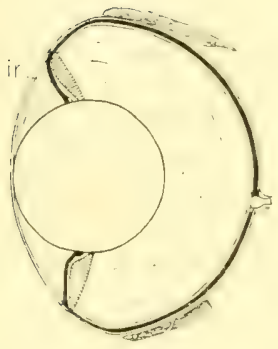

C

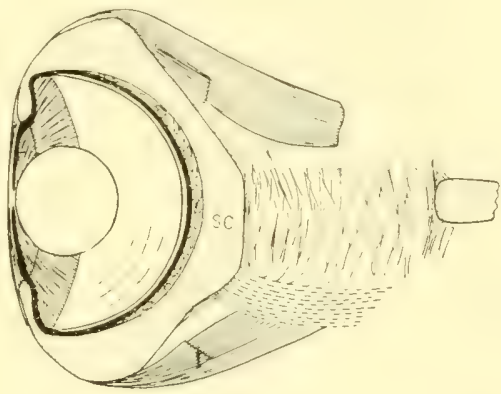

B

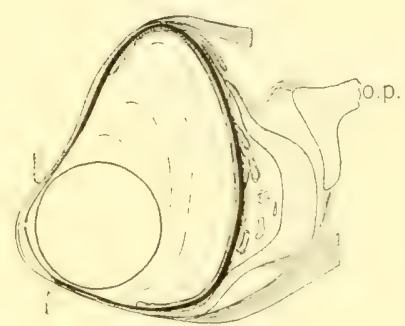

$\mathrm{D}$

Fig. 233. Sagittal section of eye. (From Franz.) A. Acanthias. B. Cetorhinus. C. Spinax. D. Raja batis.

$a h .$, space for aqueous humor; $c_{\text {., }}$ ciliary body; ch., choroid coat; $c n$. , cornea; ir., iris; $l$. lens; l.m., lens muscle; o.p., optic pedicel; $r$. , retina; so., selerotic coat; sl., dorsal suspensory ligament; sch., suprachoroidea; $I I$, optic nerve.

The eyelids are movable in only a few Elasmobranchs. In Scyllium, while they are so sluggish as rarely to close, yet the eye has been observed to bat. In many other forms the lids are more or less completely devoid of musculature and are therefore immovable. In others musculature may be fairly well developed (see p. 104, fig. 106). In the rays the eyes are firmly fixed so that movement is impossible.

\section{Structure of Adult Eye}

The structure of the adult eye in a number of Elasmobranchs has been studied in detail by Franz. (1905). In a median sagittal section through the eye of Aconthics striking the optic pedicel (fig. $23: 3_{\mathrm{A}}$ ) the various structures making up the eye appear. In the anterior part is the clear cornea $(c n$.$) and extending$ almost against it is the spherical crystalline lens $(l$.$) . The clear space between$ the two (ah.) is filled with aqueous humor. The dark layer ( $\mathrm{ir}$., fig. 233c) is the pigmented iris, a circular curtain which contains the color of the eye; the 
aperture within the iris is the pupil. At (c.) is the ciliary body. The large carity back of the lens is filled with the vitreous body. The lining of this cavity is the retina $\left(r_{\text {. }}\right)$ under which is the pigmented choroid layer (ch.). Between the choroid and the sclerotic layers there is a suprachoroidea (sch.) of connective tissue. As an outer protective capsule, and continuing in front to the cornea, is the strong sclerotic laver (sc.) through which the optic nerve passes.

If the eye of Acanthias be compared with that of the closely allied Spinax niger (figs. 233A and $\mathrm{c}$ ), which is an inhabitant of the deep sea, several important differences will he noted. In the first place the eyeball in s pinax bulges out in front, and the enlarged lens extends far into the pupil. As a result, in Spinax the pupil is of immense size and is thus correlated with the environment in which little light is present. The

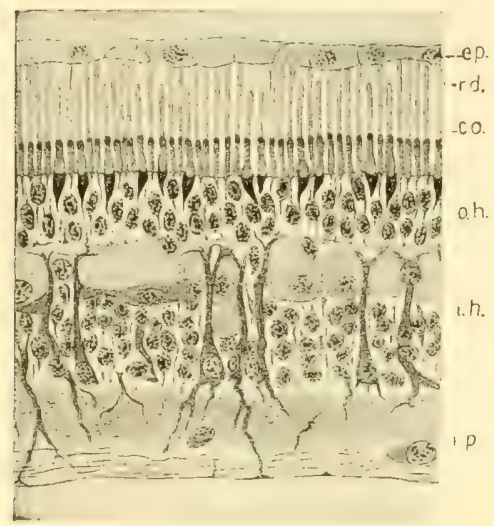

Fig. 234. Section through the retina of the eye, Mustelus vulgaris. (From Schaper.)

co., cone; ep., epithelial lining; $i . h$. , inner wide layer; i.p., inner plexus layer; o.h., outer heavy layer; rd., rod. within the eye. The pupil here is of minute size and the layers of the anterior part of the eye are exceedingly thin. On the posterior boundary of the eye, however, the sclera is heavy and is separated from the choroid by a highly vaseular suprachoroidea. The optic pedicel $(o . p$.$) is wide and is joined to the$ sclera by connective tissue.

\section{FINER STRUCTURE OF RETINA}

A section through the retina of the eye of II ustelus (fig. 234) (Schaper, 1899) shows that this important coat of the eve is made up of numerous strata of cells and filers. These may be briefly described from the inner to the outer side of the retina as an inner ganglionic layer containing fibers and cells, then an inner plexus layer (i.p.). Following this is an inner wide layer (i.h.) and an outer narrow heavy layer $(o . h$.). There then follows the important area of 
cones (co.) and rods ( $r\left(l_{\text {. }}\right)$ which are intimately associated with vision. These occupy the layer farthest removed from the lens and next to the epithelial lining $(e p$.$) . The rods and cones together with the cells from the first or gan-$ glionic layer may be described more fully.

The rods $(r d$.$) and cones (c o$.$) are characterized by the extreme length of$ the cell body. 'The nuclei of the rods extend almost to the heavy onter layer, and the slender cells reach the epithelial lining. The cones are heavier hut are fewer in number with their nuclei staining as dark bodies also in the heavy outer layer. The cone cells extend toward the outer epithelium, but unlike the rods they do not reach the outer layer.

It is the axones from cells of the retina that pass to the brain as the optic nerves.

\section{Developaient of Eye}

For convenience the development of the eye may be considered in two parts: (1) the development of the retina and its associated parts; and (2) the development of the lens.

The first indication of the eye makes its appearance as a slight down-pitting of the cephalic plate even before the plate closes (see fig. 209, op.v.). Upon its closure these pits are directed ontward toward the ectoderm, as the optic vesicles. The optic vesicles are therefore direct outgrow ths from the forebrain. As each vesicle nears the ectoderm it sinks in at its outer margin forming a two-layered cup, the stem of which as the optic stalk binds the bowl of the cup to the brain. The outer layer of the bowl does not develop as nerve tissue but be-

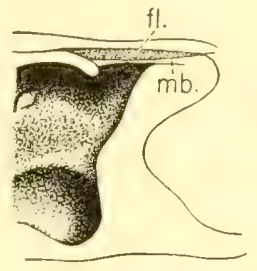

A

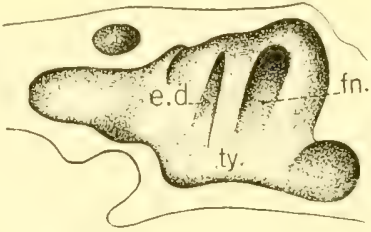

B

Fig. 235. Sagittal section through fenestra to ear, Raja. (From Howes.) A. Median sagittal. B. Parasagittal.

e.d., enrolymphatic duet; fl., fluid; $f n$., fenestral tube; $m b$., tympanic membrane; ty., tympanie cavity. comes pigmented. The choroid coat develops back of this. The inside (invaginated) layer thickens to form the retina, the fibers from which pass along the old optic stalk to the brain as the optic nerve.

The first indication of the lens is seen as a thickening of the ectoderm at the place where the optic vesicle touches it and before the vesicle invaginates to form the optic cul). The lens then becomes spherical, pinches off from the ectoderm, and sinks into the cup.

\section{ACCOMMODATION APPARATUS}

In almost all the Elasmobranchs, excepting types like Squatina, the eyes are so far separated that it would be impossible for both eyes to focus on a given point at the same time. In all these, binocular vision is impossible and monocular vision is the rule. Little adjustment of the lens is here possible. It 
will be observed that in a type like Acanthias (fig. 233A) the lens is suspended by a dorsal suspensory ligament $(s l$. ) and is joined ventrally and laterally by a muscle $(l . m$.$) from the iris. This might be regulatory in that it would draw$ the lens slightly forward but the lens cannot be focused with precision as it can in man and other higher animals.

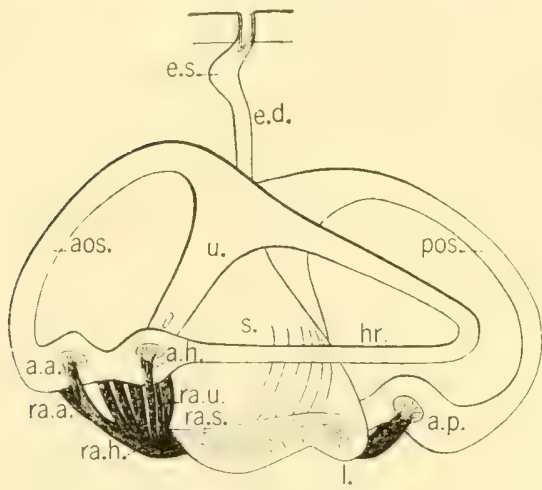

A

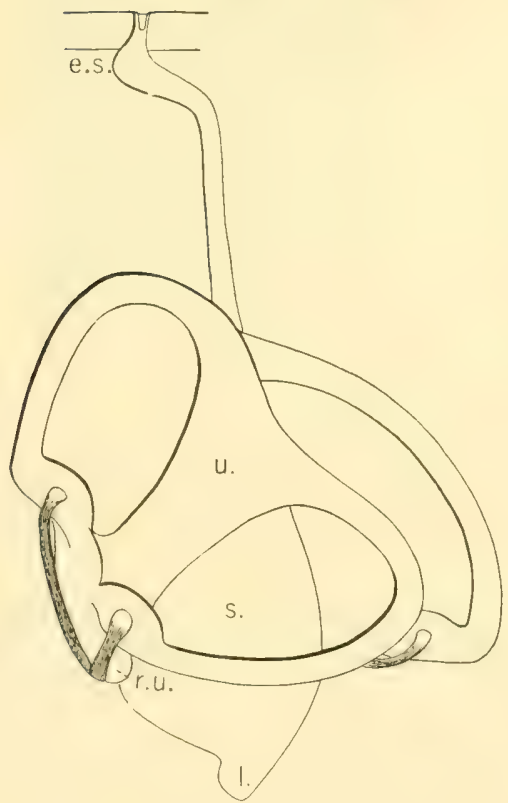

$\mathrm{C}$

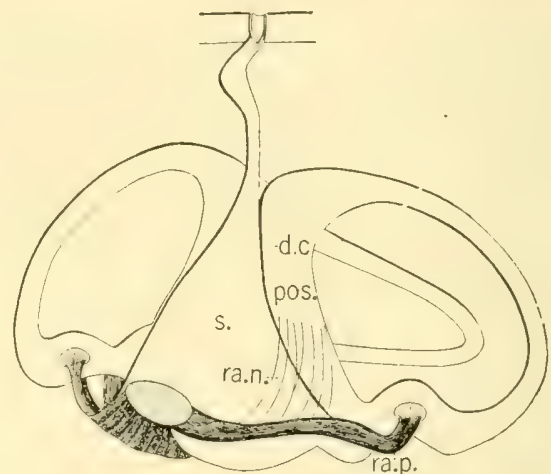

B

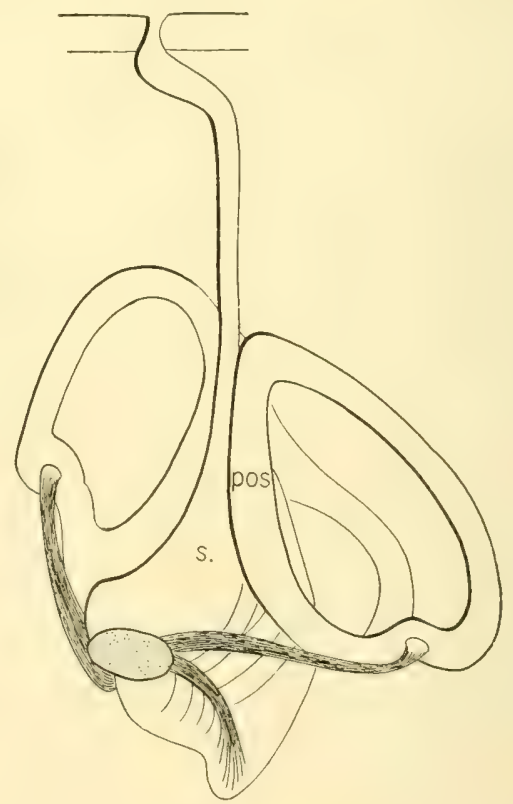

$\mathrm{D}$

Fig. 236. Ear of Elasmobranchs. (Olive Swezy, orig.)

Squalus sucklii: A. Onter view of left ear. B. Inner view of right ear.

Heterodontus franoisci: C. Outer view of left ear. D. Inner view of right ear.

a.a., ampulla of anterior oblique semicireular canal; $a . h_{\text {., }}$ ampulla of horizontal canal; aos., anterior oblique semicircular canal; a.p., ampulla of posterior eanal; d.c., connection from posterior eanal to sacculus; e.d., endolymphatic duct; e.s., endolymphatic sac; $h r$., horizontal canal; l., lagena; pos., posterior oblique semicireular canal; ra.a., ramus of eighth nerve to ampulla of anterior oblique canal; ra.h., ramus to horizontal ampulla; ra.n., ramus to macula neglecta; ra.p., ramus to posterior ampulla; ra.s., ramus to saceulus; ra.u., ramus to utriculus; r.u., recessus utriculi ; s., saceulus; u., utriculus. 


\section{Auditory Organ}

Superficially the ear is protected by the cartilaginous auditory capsule which, in the embryo, joins the parachordal cartilages of the cranium (see p. 53, fig. 58 ). In certain types the capsule is so thin as to give indications of the semi-

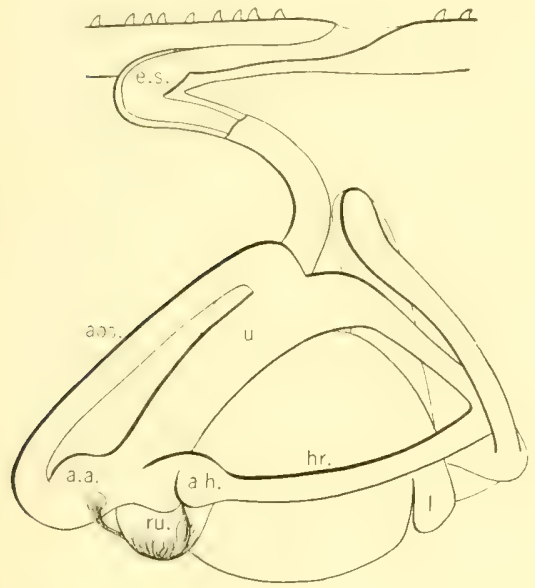

A

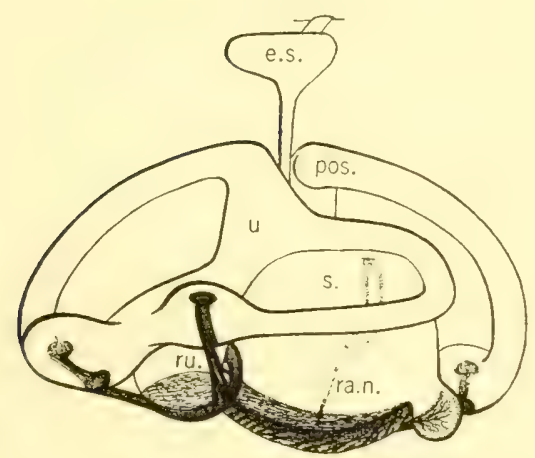

C

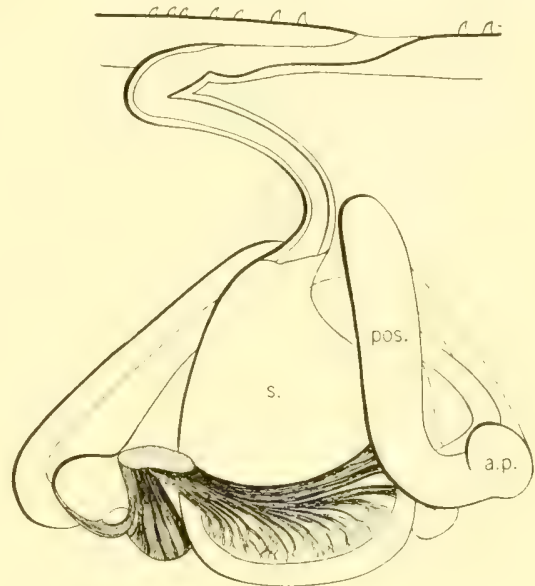

B

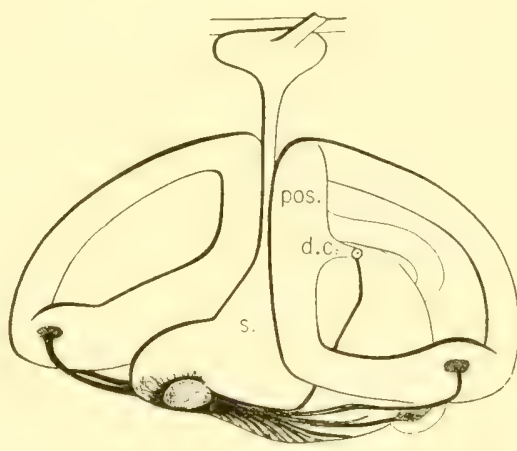

D)

Fig. 237. Ear of Elasmobranchs. (From Retzius.) Squatina: A. Outer view of left ear. B. Inner view of right ear. Raja: C. Outer view of left ear. D. Inner view of right ear.

(For explanation see fig. 236.)

circular canals superficially. Two pairs of apertures may enter the capsule from the parietal fossa in the middorsal line. The first and smaller of these is for the endolymphatic ducts ( $\ell . d$., figs. 59 and 62), while the second and larger pair of apertures are the fenestrae $(f n$. $)$. These apertures may be considered more in detail.

I have previously mentioned fenestrae for a number of sharks and for some of the rays (p.55). If we refer to figures of the dorsal view of the skull (figs. 59 and 62) we observe that these openings are well marked and take up their 
position posterior to the apertures for the endolymphatic ducts. A sagittal section through the cranium of the skate as given by Howes (1883) shows that each fenestra enters a well defined cavity or tympanum ( $t y$. , fig. 235B) within the ear capsule, and further (fig. 235 A ) that the aperture is closed dorsally by a membrane $(m b$.). Over the membrane is a semifluid layer $(f$. $)$, above which is the integument. In a type in which the head is flattened (ray) this membrane fits closely over the fenestrae, and may serve to transmit sound waves

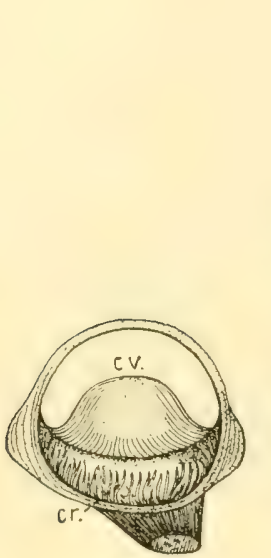

A

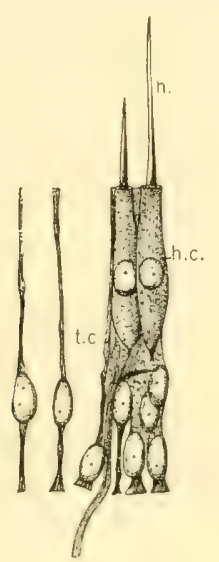

B

Fig. 238. Finer anatomy of an otic ampulla, Acanthias. (From Retzius.) A. Showing the erista acustica. B. Detail of cells.

$c r$. , crista acustica ; $c u .$, cupula terminalis; h., hair of hair cell (h.c.) ; t.c., thread cell.

to the cavity below it and thus to act something after the fashion of the tympanic membrane of the middle ear of higher forms.

The endolymphatic duct (e.d., figs. 236 and 237) is normally small proximally and then enlarges into a more or less tortuous endolymphatic sac (e.s.). In Squatina, on the contrary, and to a certain extent in Acanthias, the mouth of the duct is enlarged and although bent at its upper part it is little changed in caliber throughout its course. At its base the duct broadens out into the sacculus $(s$.$) . In$ some forms this is relatively small ( $A$ lopias; Heterodontus, fig. $236 \mathrm{c}$ ), but it may be of large size (Squalus sucklii, fig. $236 \mathrm{~A}$, s.). It is within this cavity as well as in the utriculus that the otoliths or so-called ear stones are lodged. These in Squalus consist of a mass of calcareons material con-

tained within the endolymph. In some of the other forms they are small, and in the embryo of Squatina they are apparently absent. In the adult squatina a most interesting condition is reported. Here it is said that the place of the concretions of other forms is taken by sand grains which enter the wide endolymphatic duct.

From the inferior and posterior angle of the sacculus (figs. 2:36 and 2:37) the lagena $(l$. $)$ arises. This is usually a tongue-like projection as in Heptanchus, but it may assume a form greatly enlarged at the end, as in Lamna. The lagena is that part of the ear in the Elasmohranchs which is probably the forerumer of the complex cochlea of higher forms.

At its inferior and anterior angle the sacculus is connected with the utriculus ( $u$.) by the recessus utriculi. In figure $236 \mathrm{~A}$, the aperture from the utriculus to the recessus utriculi is shown as a solid ellipse. The utriculus itself is sometimes considered as made up of an anterior and a posterior component, the anterior of which is entered by the recessus utriculi, and if seen in side view may represent a $\mathrm{T}$, the right and left arms of which are the horizontal 
$(h r$.$) and anterior oblique semicircular (aos.) canals. 'The posterior utriculus$ is the posterior connective of the posterior oblique semicircular canal. This frequently, as in Heterodontus francisci (pos., fig. 236D), may be well developed, the two parts of the utriculus being widely separated by the saceulus and endolymphatic duct. The posterior part of the utriculus has its connection with the sacculus by an elliptical aperture (d.c.) in Squalus, but this conneetion is much longer in a type like Heterodontus. In Laemargus borealis the posterior part of the utriculus is connected with the sacculus by a long tube as it is also in Raja clavata (d.c., fig. 237D).

The semicircular canals, although assuming different degrees of compression, as is shown by a comparison of the compact ear of Heptanchus with the elongate ear of Squalus, are similarly arranged in three planes. One of these planes is anterior and oblique, another posterior and oblique, and the third horizontal in position. The anterior and horizontal canals join the utriculus proper, pass forward and backward respectively and then downward to their ampullae, which are in close proximity. The posterior canal is similarly a continuation of the posterior part of the utriculus upward and backward and downward to its ampulla (figs. 236 and 237B and D).

The ampullae (a.a., a.p., and a.h., figs. 236 and

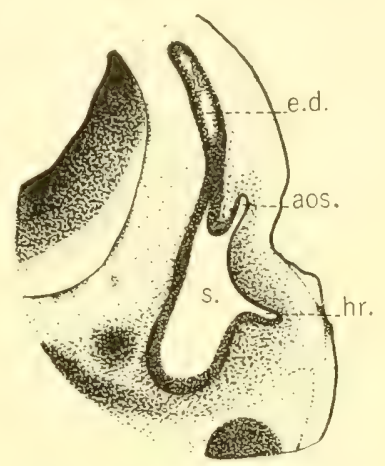

Fig. 239. Development of the ear of Scyllium. (From Krause.)

aos., anterior oblique semicircular canal; e.d., endolymphatic duct; $h r .$, horizontal canal; s., sacculus. 237 ) are interesting from their terminal relations as end organs of the nerve. A section through such an otic ampulla (fig. 238A) by Retzius (1881) shows the crista acustica $(c r$.$) which is the terminal mass of sense cells capped by$ the cupula terminalis $\left(c u_{0}\right)$. A more detailed view eutting through the ampulla demonstrates two kinds of cells in the crista. One of these is the supporting or thread cell (t.c., fig. 238B ) and the other is the sense or hair cell (h.c.). The latter of these projects into the endolymph of the ampullary cavity and is capable of receiving sensations. Multitudes of cells of this sort are located in all the ampullae and also in the sacculus, lagena, and macula neglecta.

\section{INNERVATION OF EAR}

The innervation of the ear is, as we have said for Heptanchus, through the eighth or auditory nerve. Just before reaching the ear the nerve separates into two main divisions (figs. 236 and 237). The anterior division, the vestibular nerve, separates into an anterior ramus (ra.a.) to the anterior ampulla and a second ramus to the ampulla of the horizontal canal (ra.h.). Other branches from the stem supply the area of the recessus utriculi. The posterior of these, the saccular nerve, finally reaches the ampulla (a.p.) of the posterior canal. On its way it gives off a dorsal branch, the ramus neglectus (ra.n.) to the macula neglecta of the sacculus, and ventral branches to the lagena and to the saceulus (ra.s.). 


\section{DEVELOPMENT OF EAR}

The ear (Scyllium, fig. 239), like the nose, forms as a pit. In the development of the ear, however, the vesicle thus formed sinks in and, as the saceulus $(s$.$) ,$ becomes far removed from the exterior. It does not, however, lose entire connection with the outside for as it sinks inward it becomes flask-shaped, the

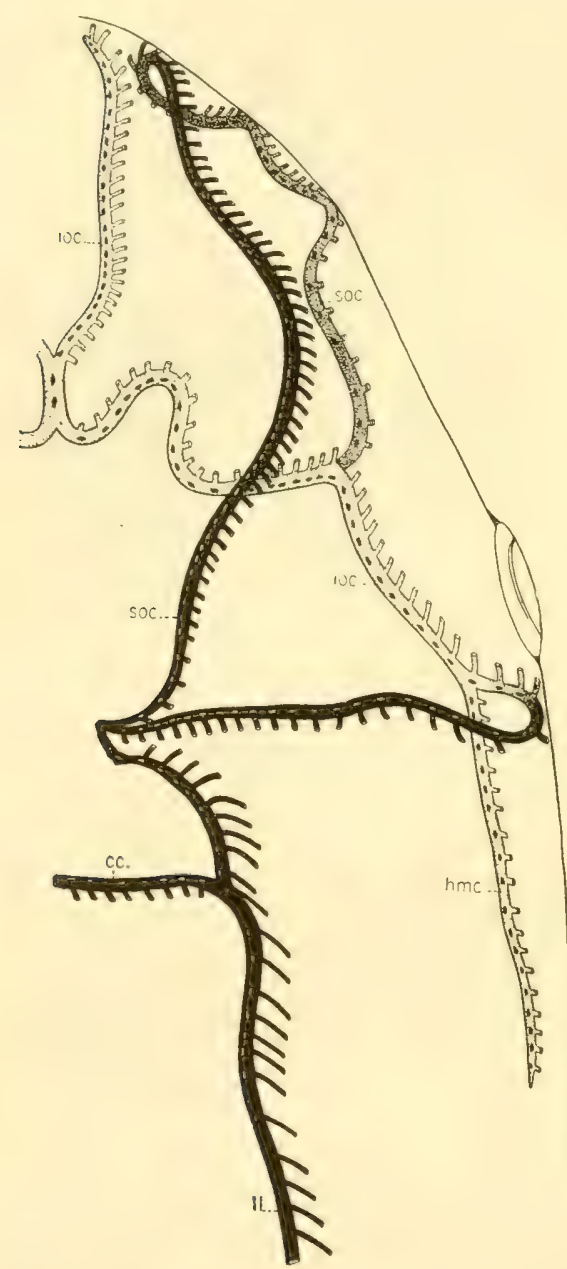

Fig. 240. Dorsal view of cephalic canals in Laemargus. (From Ewart.) (Drawn as transparent object.)

cc., commissural or supratemporal eanal; hmc., hyomandibular canal; ioc., infraorbital canal; $l l$., lateral canal; soc., supraorbital canal.

orbital canal ( $s o c$., figs. 240-242), runs above the eye; another, the infraorbital (ioc.), passes back of and forward below the eye; the third or hyomandibular long neck being the endolymphatic duct (e.d.). At this stage the outer wall of the vesicle becomes thin and the anterior oblique and horizontal semicircular canals (aos, and $h r$.) develop from them.

\section{Sensory Canal System and Ampullary and Pit Organs}

The sensory canal system as we have seen in Heptanchus consists of extensive sensory canals over the head and along the side of the body. The ampullary organs associated with certain of the canals and innervated by the same nerves are confined to the region of the head. Certain modifications of the latter, the vesicles of Savi, may also be present. The pit organs are mainly in the anterodorsal trunk region but some of them are in the segment of the head.

\section{Sensory Canal System}

The sensory canals take a general course parallel to the long axis of the body. In the region of the trunk and tail they compose the lateral line observed in our study of external form, and in the region of the head they form the cephalic canals, three or four main divisions of which are present in the sharks. One of these, the supra- 
canal (hmc.) passes backward from the infraorbital to the region of the hyoid areh; and a fourth, the mandibular (mc.), traverses the lower jaw. Various modifieations of these and their accessory parts will be noted later.

The formation of the lateral and cephalic canals may first be briefly deseribed. The earliest rudiment of the lateral line appears as a flattened plate

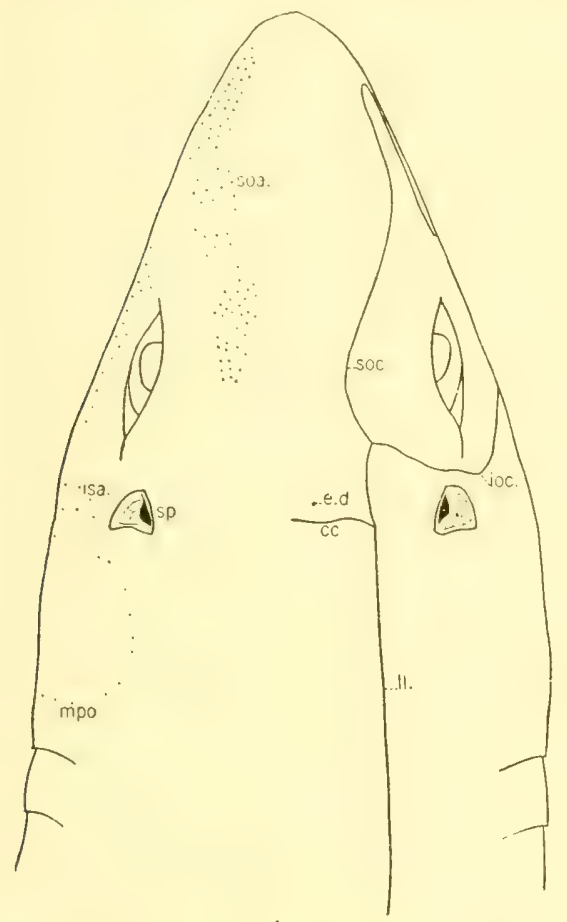

A

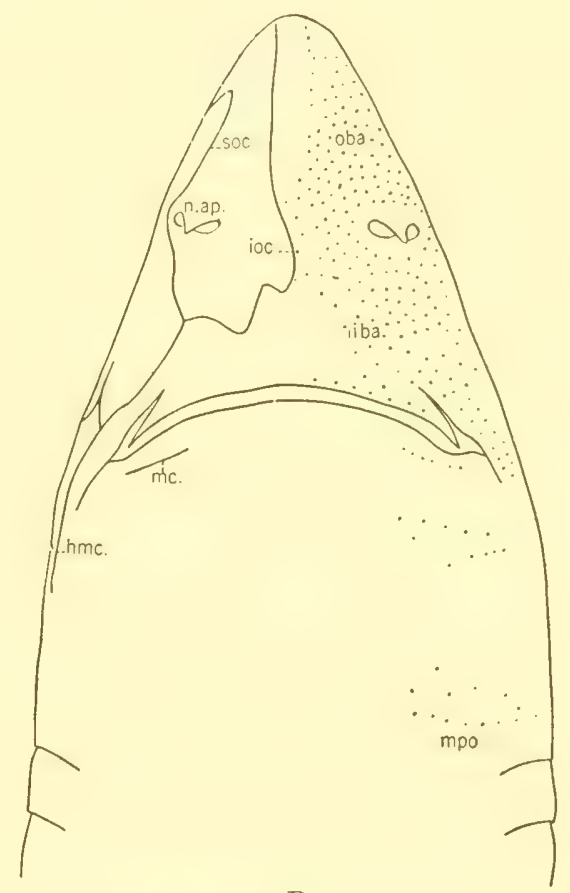

B

Fig. 241. Sensory canals and ampullae of Lorenzini, Squalus suclcti. (Olive Swezy, orig.) A. Dorsal view. B. Ventral view.

$c c .$, commissural or supratemporal canal ; e.d., endolymphatic duct; $h m c$. , hyomandibular canal; iba., inner buccal ampullae; ioc., infraorbital canal; isa., infraspiracular (hyoid) ampullae; $\imath$., lateral line; me., mandibular canal; mpo., mandibular ampullae; n.ap., nasal aperture; oba., outer buccal ampullae; soa., supraophthalmic ampullae; soc., supraorbital canal; sp., spiracle.

of ectoderm contimuous with, and like that of, the placode for the ear, but this extends both forward and backward. Forward it gives rise to the long canals of the head region. Backward it becomes the lateral line organ. Either way, in order to become a canal rather than an open groove the sensory cord or plate of ectoderm, usually as a pocket, pushes deep into the underlying corium. It may be mentioned here that at regular intervals throughout its course the sensory cord differentiates into patches of ectoderm, the end organs or neuromasts characteristic of these canals.

In the adult Elasmobranch the lateral line canals (figs. 240-242) are similar in distribution. They extend in or under the skin from the tip of the tail to the segment of the ear. The lateral line canal in Chlamydoselachus is an 
open groove practically to the supratemporal canal, and in the notidanids it is open as far forward as the anterior region of the pectoral fin. In Acanthias on the contrary the canal is closed excepting in the region toward the tip of the tail. In all higher Elasmobranchs it is usually closed throughout the entire length. In some of these the canals run to a considerable depth, but in all such they still remain in communication with the exterior by tubules. The tubules

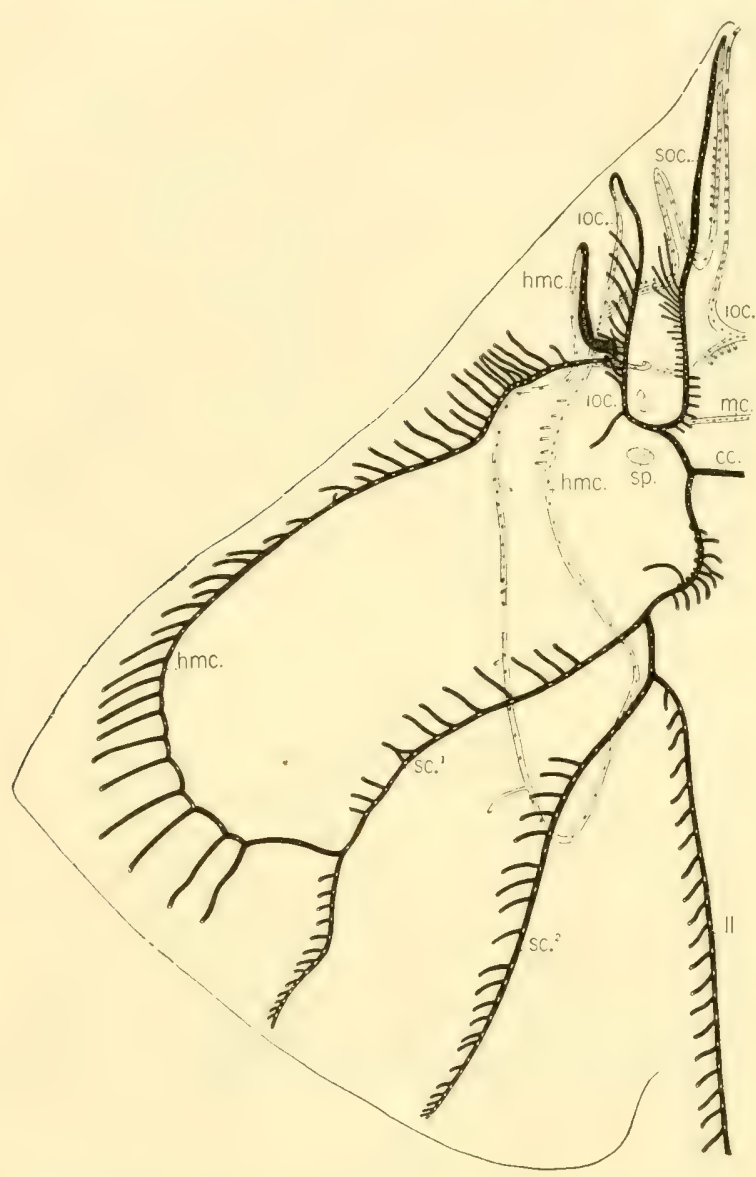

Fig. 242. The cephalic eanals, Raia batis, dorsal view. (From Ewart and Mitchell, modified.)

$c c$. commissural or supratemporal canal; hme., hyomandibular canal; ioc., infraorbital canal; $l l$., lateral line; me., mandibular canal; soc., supraorbital canal; $s c^{1-2}$, first and second scapular canals; sp., spiracle. putting the canal in communication with the outside may be as numerous as are the branches of nerves (ramuli) reaching them (fig. 244). In certain forms, however, they are fewer in number.

In its anterior segment the lateral line of each side is joined to its fellow, posterior to the endolymphatic ducts, by the supratemporal canal (cc.). This canal, however, is incomplete in Heptanchus. Furthermore, on each side it may branch so as to send a part anterior to the endolymphatic ducts in addition to the regular branch posterior to the duets. In Chlamydoselachus the supratemporal connection passes anterior to the endolymphatic ducts. It seems reasonable to suppose that this branch is comparable to the occasional anterior branch of Heptanchus. The lateral line canal usually passes directly into the cephalic canals, but in Heterodontus francisci at its anterior end it swerves sharply toward the middorsal line and joins the supratemporal canal; it then joins the supraorbital canal by making a sharp bend laterally.

The cephalic canals are usually, as we have said, a direct continuation of the lateral line canal. In Laemargus (fig. 240) these canals are made up of the divisions above named. The supraorbital (soc.) passes forward above the eye 
and at the tip of the nose passes through to the ventral side. It then continues backward to meet the infraorbital (ioc.). This condition is unlike that in Heptanchus (fig. 228) in which the terminal part going to the infraorbital is usually broken in its course. The infraorbital drops back of the eye to a ventral position and then forward under the eye; after passing the ventral terminus of the supraorbital, it turns inward toward the middle line, where it approximates or meets (Laemargus) the infraorbital of the opposite side. It then continues forward and slightly outward to the tip of the nose. The hyomandibular canal (hmc.) in the sharks branches off posteriorly from the infraorbital at the place where the latter reaches a ventral position back of the eye. Essentially the same plan obtains in Squalus sucklii (fig. 241) as that here described for Laemargus.

This plan is considerably modified in the rays. In these, the supraorbital canal (soc., fig. 242) in its ventral course is characterized by a peculiar loop forward and outward. It then meets the infraorbital ventrally as in sharks. The hyomandibular ( $h m c .$, fig. 242)

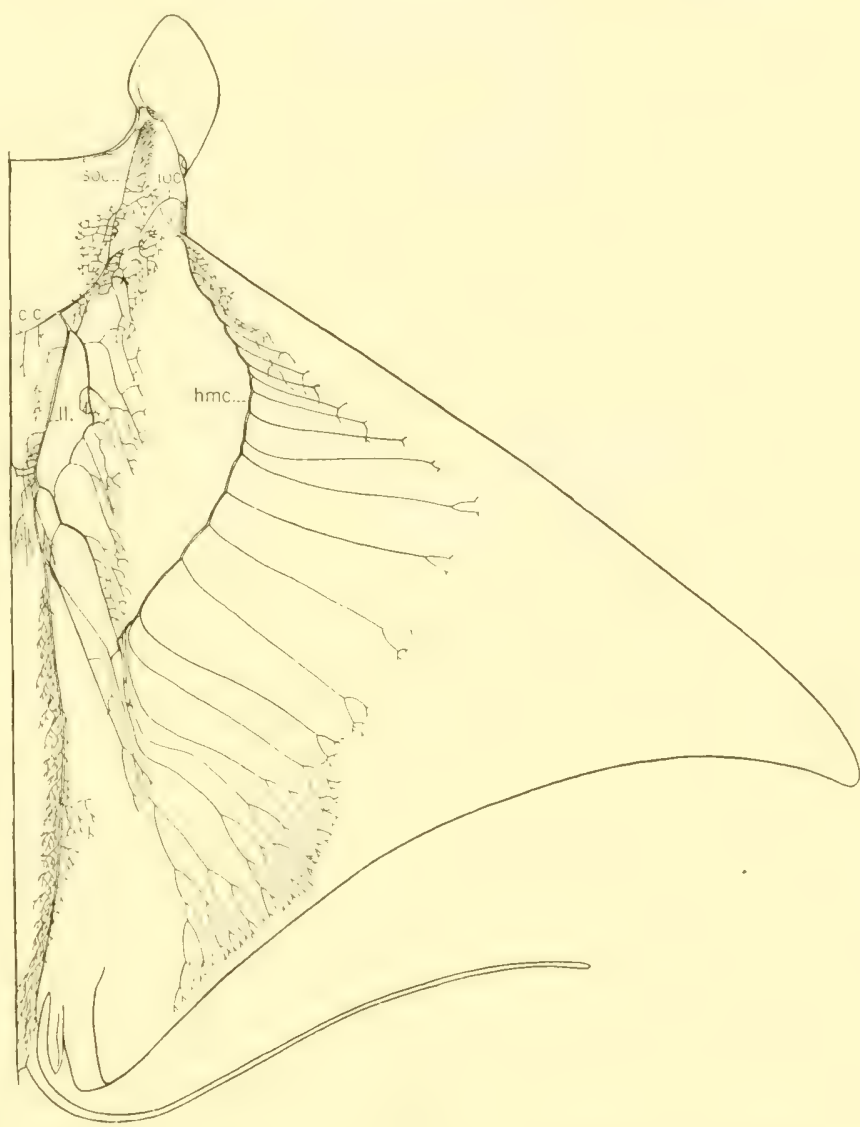

Fig. 243. Cephalic canals in Dicerobatis, dorsal view. (From Garman.)

c.c., commissural or supratemporal canal; $h m c .$, hyomandibular canal; ioc., infraorbital canal; 11 ., lateral line; soc., supraorbital canal. in the rays is greatly modified. It passes from the infraorbital backward, outward, and then forward on the ventral side of the pectoral fin, making a large ventral loop (incomplete in Torpedo). It then perforates the fin at the side of the olfactory capsule, and continues its course on the dorsal side of the fin, first inward and backward; then it swerves far outward and backward and then inward to join an anterior scapular branch $\left(s c .{ }^{1}\right)$ from the lateral canal, forming with the scapular branch dorsally on the pectoral fin a characteristic loop. 
In addition to what we have said of this system in a typical ray, it may be added that in a sluggish type like Torpedo certain of the cephalic canals may be lacking ventrally while in an active form like Dicerobates (Cephalopoda) tubules may branch off of the canal, unlike the simple tubules of Raja clavata, and form a complex net (fig. 243).

The internal structure of the canals may be studied in a transverse section through the lateral sensory canal of the leopard shark, Triatis semifasciatus (see p. 26, fig. 29, $l l . c$. ). In such a figure it will be seen that the walls of the canal are unequal in thickness. Both in the lateral line and the dorsal cephalic

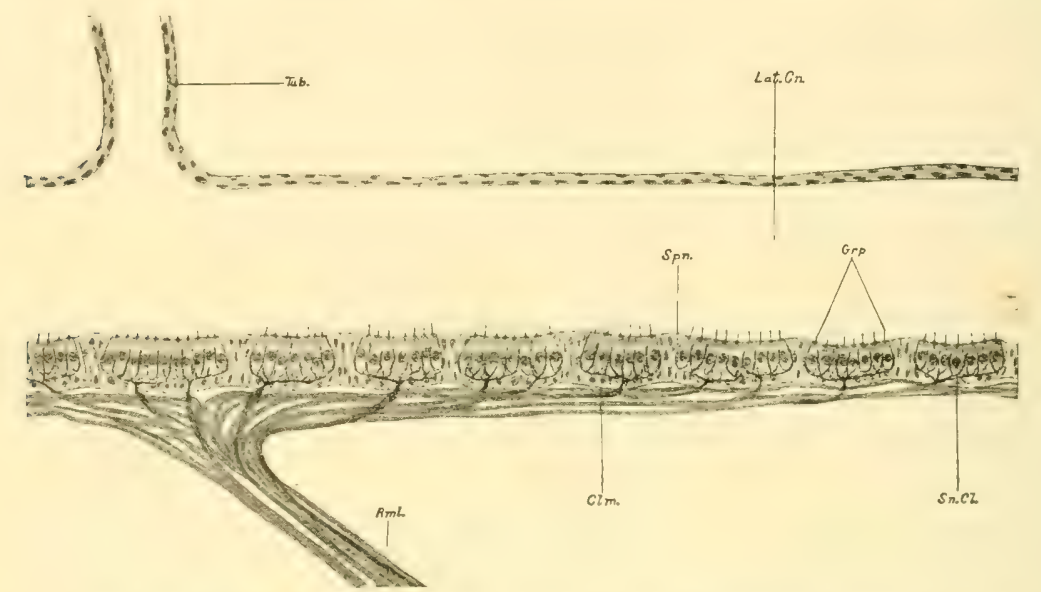

Fig. 244. Longitudinal section of lateral sensory canal, Mustelus canis. (From S. E. Johnson.)

Grp., neuromasts; Clm., nerve; Lat.Cn., lateral sensory canal; $R m l$., ramus of lateral nerve; Sn.Cl., primary hair cell; Spn., supporting cells; Tub., tubule to exterior.

canals the lumen is flattened; but in the ventral canals it is rounded. On the median wall of the canal the section passes through a sense organ or neuromast, composed of cells derived from the basal layer of epidermis (s.c.). These are of two types, one a crescentic supporting cell and the other an elongated club-shaped sense cell. A longitudinal section through the lateral sensory canal of Mustelus canis (fig. 244) by Johnson (1917) shows that the neuromasts are much more numerous than are the tubes ( $T u b$.) which open to the surface. Each of these groups $(G r p$. ) is composed of primary hair cells $(S n . C l$. ), secondary sense cells at the sides of the primary cells, and underlying these the supporting cells.

Innervation of the lateral line in the body is by means of the lateral division of the vagus or tenth cranial nerve. It will be observed from figure 244 that the ramuli $(R m l$. ) reach the canal at about the position of the tubules, but that they break up into numerous fibers, which supply a multitude of neuromasts (Grp.). In the most anterior part of the lateral line canal, however, a few twigs are received from the ramus dorsalis $X(d r \cdot X$, fig. 245) and the supratemporalis $\mathrm{X}$. Other twigs of the supratemporal is X supply the supratemporal canal. The segment of the lateral canal immediately anterior to the supratem- 
poral canal is supplied by a few twigs of the supratemporalis IX (chlamydoselachus, Laemargus, squalus acanthias, fig. 2ti), st.IT) and the most anterior part of this segment is supplied by a few fibers from the ramus oticus VII.

The supraorbital canal is supplied by branches from the ophthalmicus superficialis of the facial nerve, and the infraorbital by the buccalis nerve, while the neuromasts of the hyomandibular and mandibular canals are supplied by the external mandibular division of the seventh nerve.

\section{FUNCTION OF SENSORY CANAL SYSTEM}

The function of the sensory canal system has been made the subject of many studies. It was observed by early workers that the pores contained mucus. The

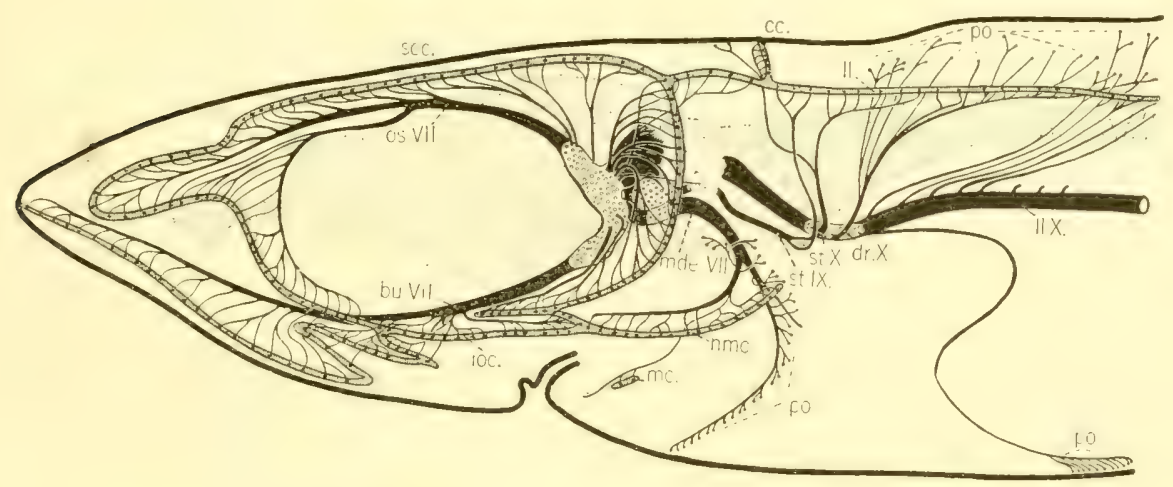

Fig. 245. Innervation of the sensory canal system and certain of the pit organs, Squalus acanthias. (From Norris and Hughes.)

$b u . V I I$, bucealis nerve; $c c$. , supratemporal canal; $d r . \mathrm{X}$, ramus dorsalis of tenth nerve; $h m c .$, hyomandibular canal; ioc., infraorbital canal; $l l$., lateral line canal; $l l . X$, lateral line nerve; mc., mandibular canal; mde.VII, external mandibular nerve; os.VII, ophthalmicus superficialis of seventh nerve; po., pit organs; soc., supraorbital canal; st.IX, supratemporalis of ninth nerve; st.X, supratemporalis of tenth nerve.

system was therefore taken to function in the production and distribution of mucus and the pores were therefore called mucous pores. Later study also demonstrated the relation of these organs to the nervons system.

It has been shown by G. H. Parker (1904) that a shark which has been deprived of hearing and sight responds to wave movement, like that produced by throwing a stone into the water, so long as the nerves to the lateral line are intact. When these nerves are cut, however, no further response is given.

\section{Ampullary Organs}

The ampullary sense organs, as in Heptanchus, are confined to the head and are generally arranged in four or five groups. These are, in Squalus sucklii (fig. 241), the supraophthalmic (soa.), the inner (iba.) and outer buccal (oba.) groups; and the mandibular just behind the mandible; and the hyoid 
groups (isa. and mpo.). In addition to these there is a modified ampulla in the spiracular wall. In active forms the pores to these organs may be very numerous as in Mustelus canis in which practically 1600 have been counted. In a sluggish type like Torpedo there are as few as 162 (Norris, 1929).

Each ampullary organ (fig. 246) consists of three parts: (1) a pore or opening to the exterior ( $a p) ;.(2)$ a canal or tubule $(t b$.$) ; and (3) the ampulla$

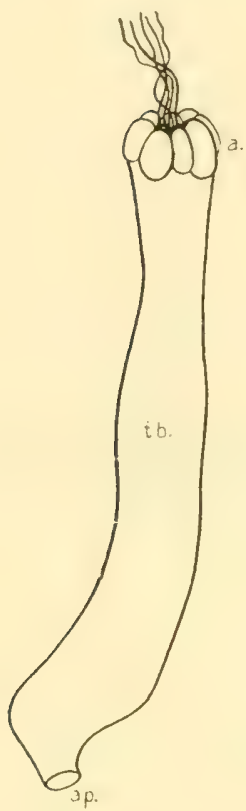

Fig. 246. Ampullary organ of Lorenzini. (From Peabody.)

a., ampulla; ap., aperture to outside; tb. tubule. proper $(a$.$) , located in the in-$ tegument. The ampulla varies as to pattern in the different Elasmobranchs. In some it is not divided up into ampullary pockets. In others it may have from eight to twelve pockets. These pockets are usually connected by a single canal with the outside pore. In Hexanchus, however, Dotterweich (1932) has recently shown that each ampullary pocket in a group has its own canal and that a group of canals empties by a common pore. A transverse section through the ampulla (fig. 247A) shows how they and the partitions separating them are eut. Aceording to Peabody (1897) each ampullary pocket $(p k$. ) has a double lining, the inner layer of which is of cells of large size. The pockets are surrounded by connective tissue and may

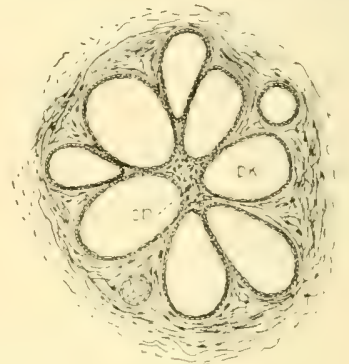

A

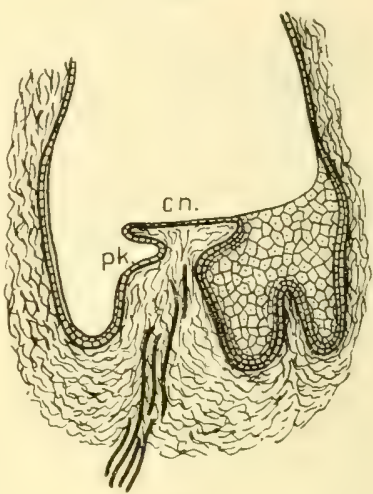

B

Fig. 247. A. Transverse section. B. Sagittal section of an ampulla, Galeus. (From Peabody.)

$c n$. , centrum; $p k$., ampullary pocket.

themselves surround a central part, the ampullary centrum (cn.). Figure $247 \mathrm{~B}$ is a sagittal section through the centrum. The section is through a pocket on the left and a partition between two pockets on the right. In figure 248 it is seen that the nerve to the ampulla enters through the centrum and spreads out over the ampullary pockets.

It was formerly supposed that the cap over the centrum was the sensory area in which the nerve terminated, but in figure 248 it appears that, while the nerves lose their medullary sheaths and only the axis cylinders run toward the central cap, the fibers turn outward as the fibrils surround the ampullary sacs. Dotterweich (1932) has recently shown that the wall of an ampulla of Lorenzini is made of a single layer but that this layer consists of two important types of cells. One of these is a flask-like cell ( $g$., fig. 249) which forms mucus. The other is a pyramidal or sensory cell $(s$.$) . These pyramidal re-$ 
ceptor cells, as hexagonal plates, line the ampulla. They are apparently not provided with hair-like processes which extend into the ampullary cavity but each pyramidal cell has a sensory nerve $(a f$. ) leaving from the apex of the cell. A motor axone (ef.) extends to each of the secreting or flask-like cells.

In their derelopment the ampullary organs, like the long canals, form as pits of the epidermis. These pits sink deeply into the integument and often extend far forward or backward forming more or less elongate tubules. At the end of the deepest part the tubule swells out, forming an ampulla of Lorenzini.

The vesicles of Savi found in Torpedo consist of from one hundred to two hundred hollow saes

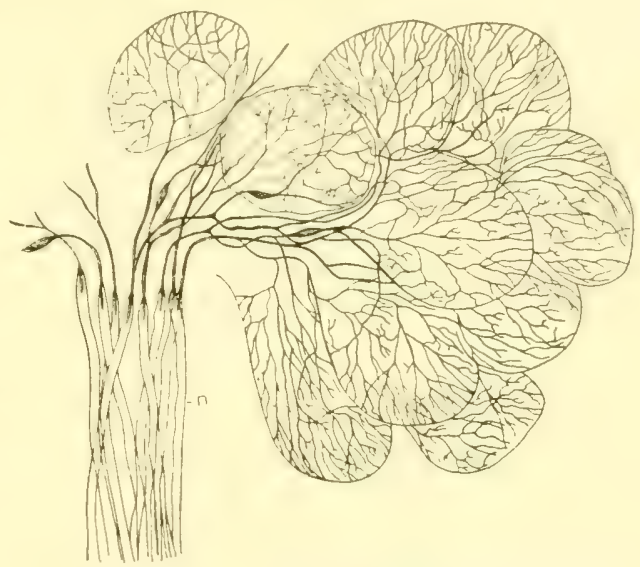

Fig. 248. Section showing ending of nerres (n.) in ampulla. (From Retzius.) in the region of the nasal pit and ventrally between the cartilage of the pectoral fin and the electric organ. Each vesicle is a transformed canal organ which, unlike an ampulla of Lorenzini, is unconnected with the exterior. Such a vesicle is composed of three dises, one of which is large and occupies a median position while at the sides of this are two lateral and smaller ones.

\section{Pit Organs}

In addition to the above-mentioned organs, pit organs found in sharks and rays may here be described. These organs were early seen in the rays along the back just mediad of the lateral line and from the suprascapular line to the

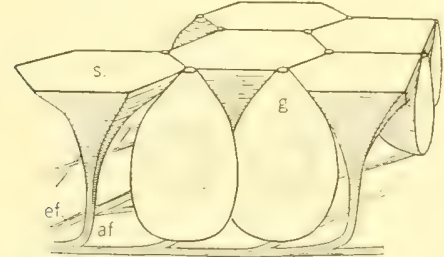

Fig. 249. Receptor cells and gland cells in an ampulla of Lorenzini. (From Dotterweich.)

af., afferent nerve; ef., efferent nerve; g., gland cells; $s$., sensory cell.

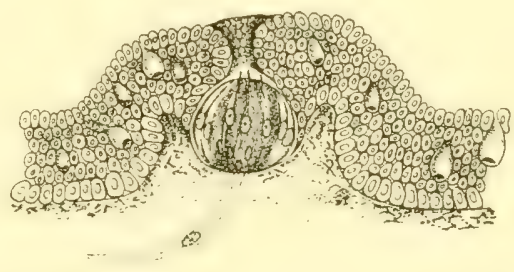

Fig. 250. Pit organ, Raia batis. (From Ewart and Mitchell.)

first dorsal fin. Others occur along the hyomandibular and the infraorbital canals in the head.

Ewart and Mitchell (1891) have given a section through a pit organ of the ray (fig. 250) which shows it to be not unlike a taste bud. The narrow neck leads to a group of sense cells which form a ball. Each of the sense cells is long 
and has passing from it dorsally a sensory process. A sensory nerve leaves the base of the organ and passes along with the lateral line nerve.

Attention has been directed by several workers to the pit organs in sharks. These have been studied recently for Squalus acanthias by Norris and Hughes (1920). Pit organs are here distributed between the lateral lines and anterior to the first dorsal fin, and are supplied by the dorsal ramus ( $d r . X)$ of the tenth nerve. In Heptanchus maculatus (fig. 229) this system of organs is especially wortly of note since its organs have a segmental arrangement. In places the lines of organs from one side to another are in almost unbroken continuity, while other lines are limited to one side. 


\section{BIBLTOGRAPHY}

\section{Chapter X}

\section{ORGANS OF SMELL}

1919. Allis, E. P., The Lips and the Nasal Apertures in the Gnathostome Fishes. Jour. Morph., Vol. 32, pp. 145-205, pls. 1-4.

1913. Asar, T., Untersuchungen über die Struktur der Riechorgane bei Mustelus laevis. Anat. Hefte, Bd. 49, pp. 441-521, Taf. 28-31, 8 text figs.

1902. Berdiner, KuRT, Die Entwicklung der Geruchsorganes der Selachier. Arel. mikr. Anat., Bd. 60, pp. $386-406$, Taf. 20,7 text figs.

1884. BlaUe, Julius, Untersuchungen über den Bau der Nasensehleimhaut bei Fisehen und Amphibien, namentlich über Endknospen als Endapparate des Nervus olfactorius. Arch. f. Anat. u. Physiol. (Abt. Anat.), Jahr 1884, pp. 231-309, pls. 12-14.

1895. Houm, J. F., Some Notes on the Early Derelopment of the Olfactory Organs of Torpedo. Anat. Anz., Bd. 10, pp. 201-207, 6 text figs.

1857. KöLLIKER, A., Ueber die Ausbreitung der Nerven in der Geruchsschleimhaut von Plagiostomen. Verh. d. phys.-med. Ges. Würzburg, Bd. 8, pp. 31-37.

1879. Marshald, A. M., Morphology of the Vertebrate Olfactory Organ. Quart. Jour. Mier. Sei. (n. s.), Vol. 19, pp. 300-340, pls. XIII-XIV.

1910. PARker, G. H., The Olfactory Sense of Fishes. (Proc. Amer. Physiol. Soc.) Amer. Jour. Plyysiol., Vol. 27, p. xix.

1909. Sheldon, R. E., Reactions of the Dogfish to Chemical Stimuli. Jour. Comp. Neurol., Vol. XIX, pp. 273-311, text figs. 1-3.

1911. Sheldon, R. E., The Sense of Smell in Selachians. Jour. Exper. Zool., Vol. 10, pp. 5162. Also abstract in Seience (n. s.), Vol. 33, pp. 389-390.

1904. Sund, O., Entwickelung des Gerusehsorganes bei Spinax niger. Biol. Centralbl., Bd. 24, pp. 651-659, 10 text figs.

\section{ORGANS OF SIGHT}

1903. Addario, C., Sulla istogenesi del vitreo nell' ocehio dei Selaci. Monit. Zool. Ital, Firenze, Vol. 13 (Suppl.), p. 18.

1894. Beer, Theodor, Die Accommodation des Fischauges. Arelı. f. d. Ges. Physiol., Bd. 58, pp. 523-650, Taf. III, 35 text figs.

1883. Berger, E., Beiträge zur Anatomie der Sehorgane der Fische. Morph. Jahrb., Bd. 8, pp. $97-168$, pls. $4-5$.

1896. Bernard, H. M., An Attempt to Deduce the Vertebrate Eye from the Skin. Quart. Jour. Micr. Sci., Vol. 39, pp. 343-370, pl. 22.

1899. Doenecke, F. W., Untersuchungen über Bau und Entwicklung der Augenlider beim Vogel und Haifische. Leipzig, $8^{\circ}, 45$ pp., 14 text figs. (Diss.).

1886. DoHrn, A., X Studien, ete. Zur Phylogenese des Wirbelthierauges. Mitt. Zool, Stat. Neapel, Bd. 6, pp. 432-480.

1905. Franz, Viktor, Zur Anatomie, Histologie und funktionellen Gestaltung des Selachierauges. Jena. Zeitseh. Naturwiss., Bd. 40 (N. F. 33), pp. 697-840, pl. 29, 32 text figs. Inaug. Diss., pp. 757-801, 3 text figs.

1891. FrorieP, AUG., Über die Entwickelung des Sehnerven. Anat. Anz., Vol, 6, pp. 155-161, 12 text figs. 
1899. HARMAN, N., The Palpebral and Oculomotor Apparatus in Fishes. Observations on Morphology and Development. Jour. Anat. and Physiol., Vol. 34, pp. 1-40, pls. 1-6.

1894. Locr, W. A., The Optic Vesicles of Elasmobranchs and Their Serial Relations to Other Structures on the Cephalic Plate. Jour. Morph., Vol. IX, pp. 115-122, 6 text figs.

1880. Matthiessen, L., Untersuchungen über den Aplanatismus und die Periscopie der Krystall-linsen in den Augen der Fische. Areh. f. d. ges. Physiol., Vol. 21, pp. 281307, Taf. VI.

1896. Neuarayer, Ludwig, Der feinere Bau der Selachier-Retina. Areh. mikr. Anat., Bd. 48, pp. 83-111, 25 text figs.

1909. PARKer, G. H., Influence of the Eyes, Ears and Other Allied Sense Organs on the Movements of the Dogfish Mustelus canis (Mitchell). Bull. Bur. Fish., Vol. 29, pp. $43-57$.

1899. Schaper, A., Die nervösen Elemente der Selachier-retina in Methylenblaupräparaten. Nebst einigen Bemerkungen über das "Pigmentepithel" und die konzentrischen Stützzellen. Festschr. z. 70. Geburtstag von Kupffer, pp. 1-10, Taf. 1-3.

1905. Schinaudiget, O. A. F., Neurofibrillen in den Retinalganglienzellen der Selachier. (Ber. Ophthalm. Ges. Heidelberg) Bd. 32, pp. 329-331.

1898. Shearer, Crestweld, On the Nerve Terminations in the Selachian Cornea. Jour. Comp. Neurol., Vol. 8, pp. 209-217, 4 text figs.

\section{ORGANS OF HEARING}

1892. Ayers, H., Vertebrate Cephalogenesis. II. A Contribution to the Morphology of the Vertebrate Ear, with a Reconsideration of Its Functions. Jour. Morph., Vol. VI, pp. $1-360$, pls. 1-12, 26 text figs.

1884. BEard, J., On the Segmental Sense Organs of the Lateral Line, and on the Morphology of the Vertebrate Auditory Organ. Zool. Anz., Bd. 7, pp. 123-126, 140-143.

1899. Bethe, A., Die Locomotion des Haifisches (Scyllium) und ihre Beziehungen zu dem einzelnen Gehirntheilen und zum Labyrinth. Arch. f. d. ges. Physiol., Bd. 76, pp. 470493, 2 text figs.

1896. Everett, W. H., Anatomy of the Ear of the Dogfish (Galeus canis). (Prelim.) Trans. N. Y. Acad. Sci., Vol. 15, pp. 176-182, pls. 12-13.

1902. GAGLio, G., Expériences sur l'anesthésie du labyrinthe du l'oreille chez les chiens de mer (Seyllium catulus). Arch. Ital. Biol., T. 38, pp. 383-392.

1883. Howes, G. B., On the Presence of a Tympanum in the Genus Raia. Jour. Anat. and Physiol., Vol. 17, pp. 188-190, pl. 8.

1901. Krause, R., Die Entwickelung des Aquaeductus restibuli s. Ductus endolymphaticus. Anat. Anz., Bd. 19, pp. 49-59, 21 text figs.

1907. Lafite-Dupont, Recherehes sur l'audition des poissons. C.R. Soc. Biol. Paris, T. 63, pp. $710-711$.

1899. Laudenbach, J., Zur Otolithen-Frage. Arch. f. d. Ges. Physiol., Bd. 77, pp. 311-320, 1 text fig.

1893-94. LeE, F. S., A Study of the Sense of Equilibrium in Fishes. Part I. Jour. Physiol., Vol. 15, pp. 311-348, 1893. Part II. Ibid., Vol. 17, pp. 192-210, 1894.

1898. LEE, F. S., The Funetions of the Ear and the Lateral Line in Fishes. Amer. Jour. Physiol., Vol. 1, pp. 128-144.

1900. Lrow, E. P., Compensatory Motions in Fishes. Amer. Jour. Physiol., Vol. 4, pp. $77-82$.

1910. Maxwell, S. S., Experiments on the Functions of the Internal Ear. Univ. Calif. Publ. Pliysiol., Vol. 4 (1910-1915), p. 1.

1911. Maxwell, S. S., On the Exciting Cause of Compensatory Morements, Amer. Jour. Physiol., Vol. 29, p. 367. 
1919. MAXWELL, S. S., Labyrinth and Equilibrium. I. A Comparison of the Effeets of Removal of the Otolith Organs and of the Semicireular Canals. Jour. Gen. Physiol., Vol. 2, pp. 123-132.

1920. MaxwelL, S. S., II. The Mechanism of the Dynamic Funetions of the Labyrinth. Ibid., pp. 349-355, 1 text fig.

1920. MaxivelL, S. S., III. The Mechanism of the Static Functions of the Labyrinth. Ibid., Vol. 3, pp. 157-162.

1921. Maxweld, S. S., The Equilibrium Functions of the Internal Ear. Science (n. s.), Vol. 53, pp. $423-429$.

1897. Morrilu, A. D., Innervation of the Auditory Epithelium of Mustelus canis De Kay. Jour. Morph., Vol. 14, pp. 61-82, pls. 7-8.

1903. Parker, G. H., The Sense of Hearing in Fishes. Amer. Nat., Vol. 37, pp. 185-204.

1909. Parker, G. H., The Sense of Hearing in the Dogfish. Science (n. s.), Vol. 29, p. 428.

1903. Quix, F. H., Experimenten over de Functie van het Labyrinth bij Haaien. Tijdschr. Nederland Dierk. Ver. (Ser. 2), Deel. 8, pp. 35-61, 1 text fig.

1881. Retzius, G., Das Gehörorgan der Wirbeltiere. Morph.hist. Stud., Bd. 1, Pt. I, pP. 1-217, Taf. 1-35. Stockholm.

1883. SEWALL, H., Experiments upon the Ears of Fishes with reference to the Function of Equilibrium. Jour. Physiol., Vol. 4, pp. 339-349.

1906. Stewrart, Ch., On the Membranous Labyrinths of Certain Sharks. Jour. Linn. Soe. Zool., Vol. 29, pp. 407-409, pl. 40.

\section{LATERAL LINE AND ASSOCIATED ORGANS}

1901. Aluis, E. P., The Lateral Sensory Canals, the Eye-Museles, and the Peripheral Distribution of Certain of the Cranial Nerves of Mustelus laevis. Quart. Jour. Micr. Sei., Vol. 45, pp. 87-236, pls. 10-12.

1884. BEARD, J., On the Segmental Sense Organs of the Lateral Line, and the Morphology of the Vertebrate Auditory Organ. Zool. Anz., Vol. 7, pp. 123-126, 140-143.

1868. Bolu, Franz, Die Lorenzini'schen Ampullen der Selachier. Arch. mikr. Anat., Bd. 4, pp. 375-390, pl. 23.

1875. Bolt, Franz, Die Savi'sehen Bläschen von Torpedo. Areh. f. Anat, u. Physiol., Jahrg. 1875, pp. 456-468, Taf. 11.

1898. Brandes, G., Die Lorenzini'sehen Ampullen. Verh. deutsch. zool. Ges. 8. Vers. Heidelberg, pp. 179-181. (Histologie.)

1900. Brandes, G., Die Lorenzini'sehen Ampullen. Zool. Centralbl., 7. Jahrg., p. 567.

1908. Brohmer, P., Die Sinneskanäle und die Lorenzini'schen Ampullen bei Spinax-Embryonen. Anat. Anz., Bd. 32, pp. 25-40, 8 text figs.

1891. Coggr, A., Le visicole di Savi e gli organi della linea laterale nelle Torpedini. Atti Acc. Lincei Roma (4), Vol. 7, pp. 197-205, 7 text figs. Arch. Ital. Biol., Vol. 16, pp. 216224 , pl. 1.

1902. Coggr, A., Nouove richerche sullo sviluppo delle ampolle di Lorenzini. Atti Accad. Lincei (Ser. 5), Vol. 11, pp. 289-297, 338-340. Arch. Ital. Biol., Vol. 38, pp. 321-333.

1902. Coggr, A., Sviluppo degli organi di senso laterale delle ampulle di Lorenzini e loro nervi rispettivi in Torpedo. Arch. Zool. Napoli, Vol. 1, pp. 59-107, 2 tav.

1905. Coggr, A., Sullo sviluppo e la morfologia delle ampolle di Lorenzini e loro nervi. Areh. Zool., Napoli, Vol. 2, pp. 309-383, 3 tav., 4 text figs.

1896. Cole, F. J., On the Cranial Nerves of Chimaera monstrosa with a diseussion of the Lateral Line System, and of the Morphology of the Chorda Tympani. Trans. Roy. Soc. Edinburgh, Vol. 38, pp. 631-680, 2 pls.

1878. Dercum, Francis, The Sensory Organs-Suggestions with a View to Generalization. Amer. Nat., Vol. 12, pp. 579-593. 
1932. Dotterweich, Heinz, Bau und Funetion der Lorenzini'sehen Ampullen. Zool. Jahrb. (Abt. Zool.), Bd. 50, pp. 347-418, 43 text figs.

1891. EtVART, J. C., The Lateral Sense Organs of Elasmobranchs. I. The Sensory Canals of Laemargus. Trans. Roy. Soc. Edinburgh, Vol. 37, pp. 59-85, pls. 1-2, 1 text fig.

1891. Emart, J. C., and Mrtcheli, J. C., The Lateral Sense Organs of Elasmobranehs. II. The Sensory Canals of the Common Skate (Raia batis). Trans. Roy. Soc. Edinburgh, Vol. 37, pp. 87-105, pl. Irr.

1899. Forselt, G., Beiträge zur Kenntnis der Anatomie der Lorenzini'schen Ampullen bei Acanthias vulgaris. Zeitsehr. wiss. Zool., Bd. 65, pp. 725-744, Taf. 34.

1888. Fritsch, G., Ueber Bau und Bedeutung der Kanalsysteme unter der Haut der Selachier. Sitzber. wiss. Akad. Berlin, 1888, pp. 273-306, 4 text figs.

1895. Fuchs, S., Ueber die Function der Organe der Seitenlinie bei den Selachiern. Centralbl. Physiol., Bd. 9, pp. 692-693. Also: 1895, Areh. d. Ges. Physiol., Bd. 59, pp. 454-478, Taf. 6.

1888. Garman, S., On the Lateral Canal System of the Selachia and Holocephala. Bull. Mus. Comp. Zool. Harvard Col., 1888-89, Vol. 17, pp. 57-120, 63 pls.

1892. GARMan, S., The Vesicles of Savi. Science, Vol. 19 (n. s.), p. 128.

1917. Johnson, S. E., Structure and Development of the Sense Organs of the Lateral Canal System of Selachians (Mustelus eanis and Squalus acanthias). Jour. Comp. Neurol., Vol, 28, pp. 1-74, 83 text figs.

1918. Johnson, S. E., The Peripheral Terminations of the Nervus Lateralis in Squalus sucklii. Jour. Comp. Neurol., Vol. 28, pp. 279-289, 10 text figs.

1902. Johnston, J. B., The Homology of the Selachian Ampullae. A Note on Allis' Recent Paper on Mustelus laevis. Anat. Anz., Bd. 21, pp. 308-313.

1905. KlinkHardt, Werner, Beiträge zur Entwickelungsgeschichte der Kopfganglien und Sinneslinien der Selachier. Jena. Zeitsehr. Naturwiss., Bd. 40, pp. 423-486, pls. 14 16,6 text figs.

1678. Lonenzini, S., Osservazioni intorno alle Torpedini. Firenze, per l'Onofri.

1678-79. Lorenzini, S. (1693). De anatomia Torpedinis. Ephemer. Acad. Nat. Cur., Ann. 9 et 10 , pp. 389 395 .

1901. MinckerT, W., Zur Topographie und Entwickelungsgeschichte der Lorenzini'schen Ampullen. Anat. Anz., Bd. 19, pp. 497-527, 10 text figs.

1929. NORRIS, H. W., The Distribution and Innervation of the Ampullae of Lorenzini of the Dogfish Squalus acanthias. Some Comparisons with Other Plagiostomes and Correetions of Prevalent Errors. Jour. Comp. Neurol., Vol. 47, pp. 449-465.

1904. Parker, G. H., The Function of the Lateral-Line Organs in Fishes. Bull. Bur. Fish., Vol. 24, pp. 185-207.

1897. Peabody, J. E., The Ampullae of Lorenzini of the Selachii. Zool. Bull., Vol. 1, pp. $163-178,9$ text figs.

1898. Retzius, G., Zur Kenntnis der Lorenzini'schen Ampullen der Selachier. Biol. Untersuch. (N. F.), Bd. 8, pp. 75-82, Taf. 18.

1880. Solgkir, B., Neue Untersuchungen zur Anatomie der Seitenorgane der Fische. II. Die Seitenorgane der Selachier. Arch. mikr. Anat., Bd. 17, pp. 458-479, pl. 39.

\section{ORGANS OF TASTE AND TOUCH}

1915. Fahrneholz, Curt, Über die Verbreitung von Zahnbildungen und Sinnesorganen im Vorderdarm der Selachier und ihre phylogenetische Beurteilung. Jena. Zeitschr. Naturwiss., Bd. 53, pp. 389-444, Taf. 6-7, 7 text figs.

1890. Purvis, G. C., Note on Certain Terminal Organs resembling Touch-Corpuscles or End-Bulbs in Intra-Muscular Connective-Tissue of the Skate. Quart. Jour. Mier. Sei., Vol. 30 (n. s.), pp. 515-518, pl. 33 (figs. 1-4). 


\section{UROGENITAL SYSTEM}

\section{UROGENITAL SYSTEM OF HEPTANCHUS MACULATUS}

\section{URINARY SySTEM}

The mesonephrotic kidneys in Heptanchus (kd., fig. 251) appear as right and left longitudinal bands lying along the entire roof of the body cavity and at the sides of the spinal column. Each kidney extends as a narrow ribbon of tissue from the pericardio-peritoneal septum posteriorly one-half the length of the body cavity; back of this it broadens out and becomes much thicker so that the main mass of the tissue lies posterior to the region of the superior mesenteric artery.

In general it may be said that the kidney is made up of multitudes of small lohules which in ventral view give little evidence of segmentation. A close study, however, reveals the fact that a division into segments is present. This may be further verified by the segmental arrangement of the collecting tubules which extend from the kidney tissue to the Wolffian duct $\left(w_{*} d_{0}\right)$, or in the posterior part to the ureter $(u$.).

From the upper part of the kidney the collecting tubules enter the Wolffian duct and in the lower part they join the enlarged ureter. In an immature female ten of these collecting tubules may be seen to join the Wolffian duct on its median side and twelve to join the ureter laterally, twenty-two in all being present. A similar condition is present for the upper part of the kidney of the adult female as is seen in figure 252 (facing p. 290). But in that figure the ureter has not been thrown to the side and so not all the ducts entering it appear.

In the immature female (fig. 251 A, $70.3 \mathrm{~cm}$. in length) the Wolffian duct passes the entire length of the kidney apparently as a straight tube, increasing from 0.5 to $1 \mathrm{~mm}$. in size. In its anterior segment it lies just ventral to the kidney, and in the posterior division it passes along the ventral and median margin of the ureter. In the lower part of its course it does not receive collecting tubules.

The Wolffian duct of the adult female (fig. 252) presents a most interesting condition in its upper segment where it is singularly coiled like that of the male. This distinct torsion, however, extends only a little over one-half of the anterior segment or to the posterior part of the sex gland (ov.). The remaining part of this segment is straight and the posterior segment, like that in the immature female, passes ventral to the enlarged ureter.

The ureter in Heptanchus is a thin walled, elongated blind sac which in the immature specimen above described reaches a diameter of $7 \mathrm{~mm}$. Anteriorly, and essentially at the segment where the kidney begins to increase in size, the 


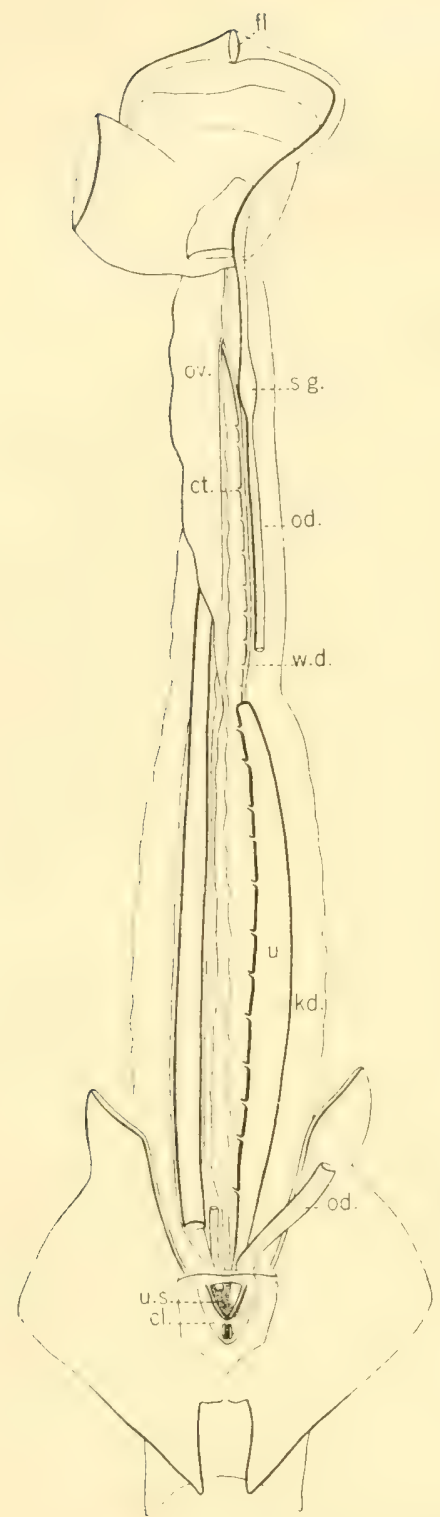

A

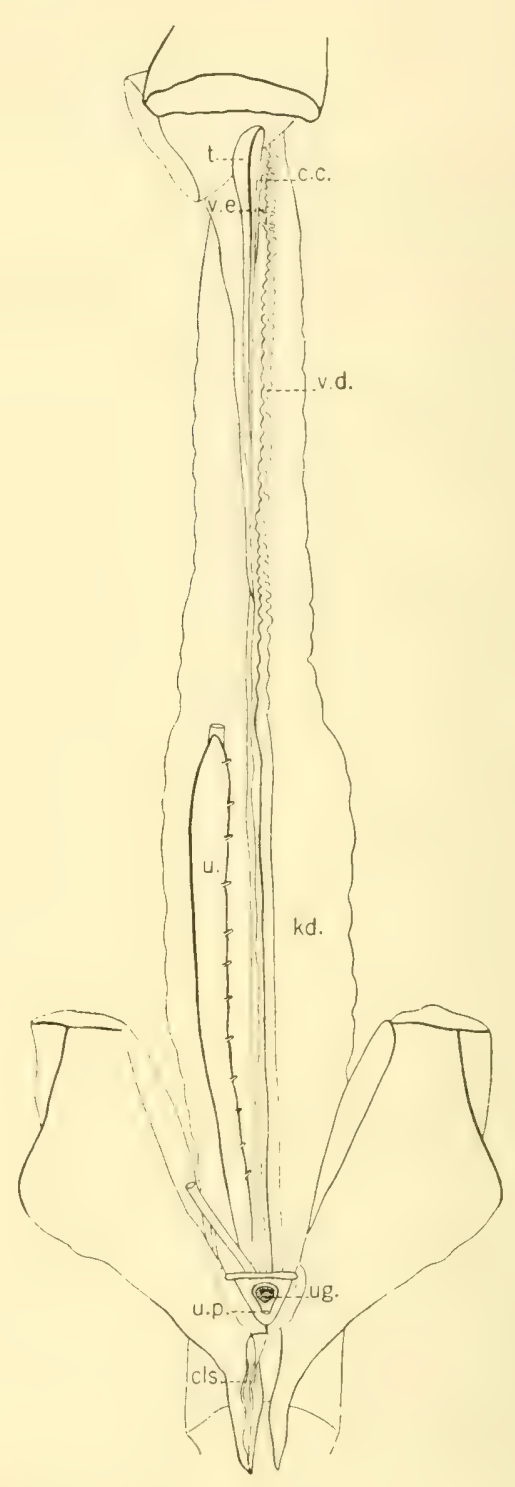

B

Fig. 251. Urogenital system of immature Heptanchus maculatus. (Frances Torrey, orig.) A. Female. B. Male.

c.c., central canal of testis; $c l$, cloaca; cls., clasper; ct., collecting tube; $f$., funnel; k.d., kidney; od., oviduct; ov., ovary; S.g., shell gland; t., testis; $u$., ureter; ug., urogenital sinus; u.p., urinary papilla; u.s., urinary sinus; v.d., vas deferens; v.e., vas efferens; $w . d$. Wolffian duct. 
ureter ends blindly. In its median segment it increases somewhat in diameter and then tapers gradually to its posterior part where as a usual thing it joins the Wolffian duct. The collecting tubules which enter the ureter are arranged with regularity throughout the greater part of its course, but the anterior two or three join as a common duet and enter a kind of pocket in the median side of the ureter (see fig. 252). In the short common segment formed by the union of ureter and Wolffian duct, near the cloaca, considerable variation prevails. In one immature female the left combined Wolfian duct and ureter entered slightly posterior to the right and in another these relations were reversed. In figure 252 it will be observed that the Wolffian duct and the ureter enter the urinary sinus (u.s.) separately and that in this specimen a singular condition obtains in which there are two urinary sinuses, one on the right, the other on the left side.

The urinary sinus terminates in a urinary papilla (two papillae in fig. 252) which is perforated at its end. Nitrogenous waste matter collected from the kidney is ejected through this into the cloaca $(c l$.) and thence to the exterior.

It would appear from general proportions that the posterior part of the kidney is by far the more effective part of the organ in the removal of nitrogenous waste matter. If this is so the greater part of the waste passes through the ureter.

The urinary organs in the male have much the same appearance in general as those in the female. In the male, however, some of the tissue and ducts have undergone great change correlated with the fact that in the adult they entered secondarily into the service of the genital system.

The kidney of an immature male of $75 \mathrm{~cm}$. in length is shown in figure $251 \mathrm{~B}$. It is $18.8 \mathrm{~cm}$. long and has 12 segments in the anterior part and 14 in the posterior. In general it extends farther forward and is somewhat better developed anteriorly than is that of the female. But this is due, as we shall see presently, to its relation to the genital organs.

The collecting tubules (ct., fig. 251A) entering the Wolffian duct are exceedingly small and could be made out with care in the most anterior part of the kidney. Posterior to this region they are distinctly arranged segmentally, each tubule leaving the segment at about its middle part. At the proximal end of the kidney there are certain other tubules (v.e., fig. 251B) which are a part of another system which will be described presently.

The Wolffian duct, in the upper part of its course, is thrown into numerous coils like those of the adult female, but here they are more pronounced and continue to the beginning of the enlarged part of the kidney. From this place posteriorly the tube increases in diameter and passes ventral to the enlarged ureter as it does in the female.

The ureter ( $u$, fig. $251 \mathrm{~B}$ ) is much like that of the female and receives practically the same number of collecting tubules. After it unites with the vas deferens (modified Wolffian duet) the two empty into the urogenital sinus (ug.). 


\section{Genital System}

The genital system in Heptanchus is of an interesting type. Each ovary (ou., fig. 252) of the adult female is large and is located in the anterior part of the body eavity where it is suspended by a mesentery, the mesovarium. It contains numerous ova which can be seen through the thin wall. From the main mass of the ovary there is a posterior continuation of tissue which is devoid of ova. This is possibly the rudiment of an epigonal organ (epg.) found in some of the other Elasmobranchs.

A singular condition is found in Heptanchus, similar to that deseribed by Semper (1875) for Hexanchus, in which a rudimentary testis is associated with the ovary. In Heptanchus maculatus this testis ( $t$., fig. 252) lies in the mesovarium at the base of the ovary and runs parallel with it. It consists of an anterior larger part and a marked ridge or swelling which extends posteriorly practically the entire length of the ovary. It will be noted that the posterior extent of this rudimentary testis is about the same as that of the coil in the Wolffian duct previously described.

Unconnected with the ovaries are the tubes or ovidnets (od.) through which the ova reach the exterior. Right and left oviducts are reached from the body cavity by a common opening or wide funnel ( $/$., figs. 251A and 252) located just ventral to the base of the liver. The oviducts pass outward from the funnel and then inward to the anterior margin of the mesovarium where they enlarge to form the shell gland (s.g.). Posterior to the shell gland the oviduct passes rentral to the Wolffian duct as a tube of considerable size, but it is not so greatly enlarged in Heptunchus as in many other Elasmobranchs in which it forms the conspicuous uterus (see fig. 253A, Squalus sucklii). At their termini the two oviducts enter the cloaca separately and not in common with ureters or Wolffian ducts, that is, not through the urinary papilla.

The genital glands of the male are the paired testes which like the ovaries of the female oceupy an anterior position in the body cavity. In figure 251B of the immature specimen the testis $(t$. ) appears as a long mass of tissue. Only the anterior part of this, however, is functional. The posterior part represents the rudimentary epigonal organ like that in the female. The testis is swung from the body wall by a mesentery, the mesorchinm, which is comparable to the mesovarium suspending the ovary.

Rumning along the median and anterior part of the test is is the central canal (c.c.), which is put into communication with the vas deferens (Wolffian duct) by vasa efferentia (v.e.), six of which are present in Heptanchus. The vasa efferentia are derived from fumnels, present on the mesorchium. We shall describe this system more completely in the general part, but here attention may he directed to it briefly. The general plan of these tubes may be made out in figure $254 \mathrm{~A}(n p h$.) where several of them open on the mesorectum which suspends the rectal gland. These openings are the nephrostomes, the tubes of which pass out toward the kidney tissue. In the region of the testis the mouths 


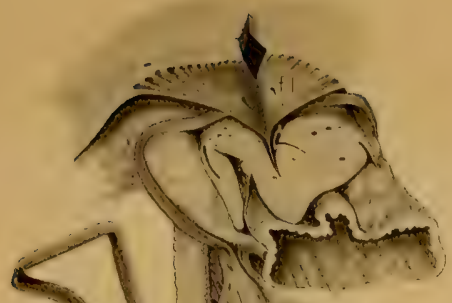

$\checkmark\left(f^{\prime}\right) \quad \cdots$

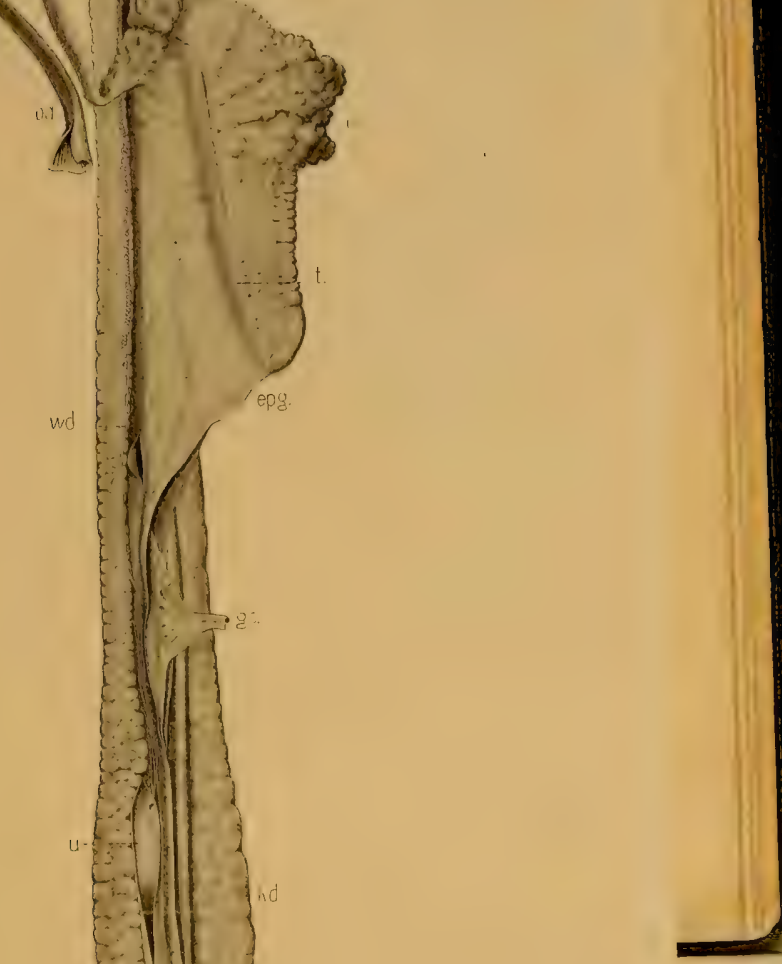

1.1 1

A.

wd 

of the most anterior of these are united with the central canal of the testis, and the tubes pass down over the mesorchium and join the upper part of the coiled vas deferens.

The vas deferens in Heptanchus is very simple in that it is a single convoluted tube which increases only slightly in size back to the anterior tip of the ureter. From here it passes backward in the immature specimen more or less as a straight tube. After having received the ureter, as we have seen, it enters the urinary sinus. Since in the adult this urinary sinus also receives sex cells from the vas deferens it becomes a urogenital sinus in the male. The spermatozoa and the fluid collected in the urogenital sinus are forced through the papilla and out through the cloaca. As they leave the cloaca they are directed through a groove on the clasper and may be transferred to the cloaca of the female.

In a number of immature males examined, right and left rudimentary oviducts were present. These were united at the midventral line and had a common funnel as in the female. In all the specimens examined, however, they were of short extent, all of them ending blindly posterior and being attached to the body wall anterior to the segment of the shell gland. 


\section{TROGENITAL SYSTEM OF ELASMOBRANCHS IN GENERAL}

The two systems, urinary and genital, included mder this head, although differing in function, are so closely associated anatomically that they are usually considered together. First, however, we shall consider them separately and then discuss their secondary relationship.

\section{URINARy System}

\section{KIDNEY (MESONEPHROS)}

Tpon opening the body cavity by a ventral incision and removing the viscera, the urinary organs of an Elasmobranch appear as dorsally placed structures on each side of the spinal column. In the sharks they may extend as ribbonlike bands, narrow at the base of the liver anteriorly, and only slightly wider at the cloacal region posteriorly. In the rays they are characteristically enlarged posteriorly where most of the tissue is confined. These statements are true only in general, for great variation is present in different species of sharks and rays; differences are further to be noted in the different sexes of the different species.

The long ribbon-like type of mesonephros or kidney characteristic of Squalus (fig. 25.3A ) and Guleus loses something of this shape in scyllium where its anterior part is narrower and, in the female, ends short of the hase of the liver. Again, the type of kidney characteristic of the shark although extending far anteriorly may be at the same time like the kidneys of the rays, broader posteriorly (Squatina, fig. $25+\mathrm{A}$ ). In the rays, excepting Torpedo, the kidney rarely extends far forward, but sometimes a large part of it is located back of the cloaca (Raja clavata, fig. $254 \mathrm{~B}$, Trygon).

Sexual differences which are marked in the kidney of the Elasmobranchs are produced by two factors: one is the reduction of the anterior part of the kidney in the female; the other is the hypertrophy of this part in the male. This hypertrophy results from the fact that the anterior part in the male comes into the service of the genital system and takes on a secondary function. In Torpedo sexual differences are slight, for a ray. In the female a band of tissue is continuous forward, and this is only slightly less developed than in the male. Sexual differences are evident in a type like Squatina in which the kidney of the adult female does not extend anteriorly to the liver. In s'cyllium, where the difference in the two sexes is marked, the anterior part of the kidney of the female falls short of the base of the liver; and in R. clavata the kidney is limited to the posterior segment, while the anterior part in the male (fig. $254 \mathrm{~B}$ ) represents a great mass of tissue.

Furthermore, the kidney varies greatly in its degree of complexity in the different Elasmobranchs. In some of the sharks it retains in part a simple metameric arrangement by which in dorsal view it agrees with the segmentation of the body, characteristic of the embryo (Squatina, fig. 254A). In most other sharks, however, this simple arrangement is lost at least in the posterior 


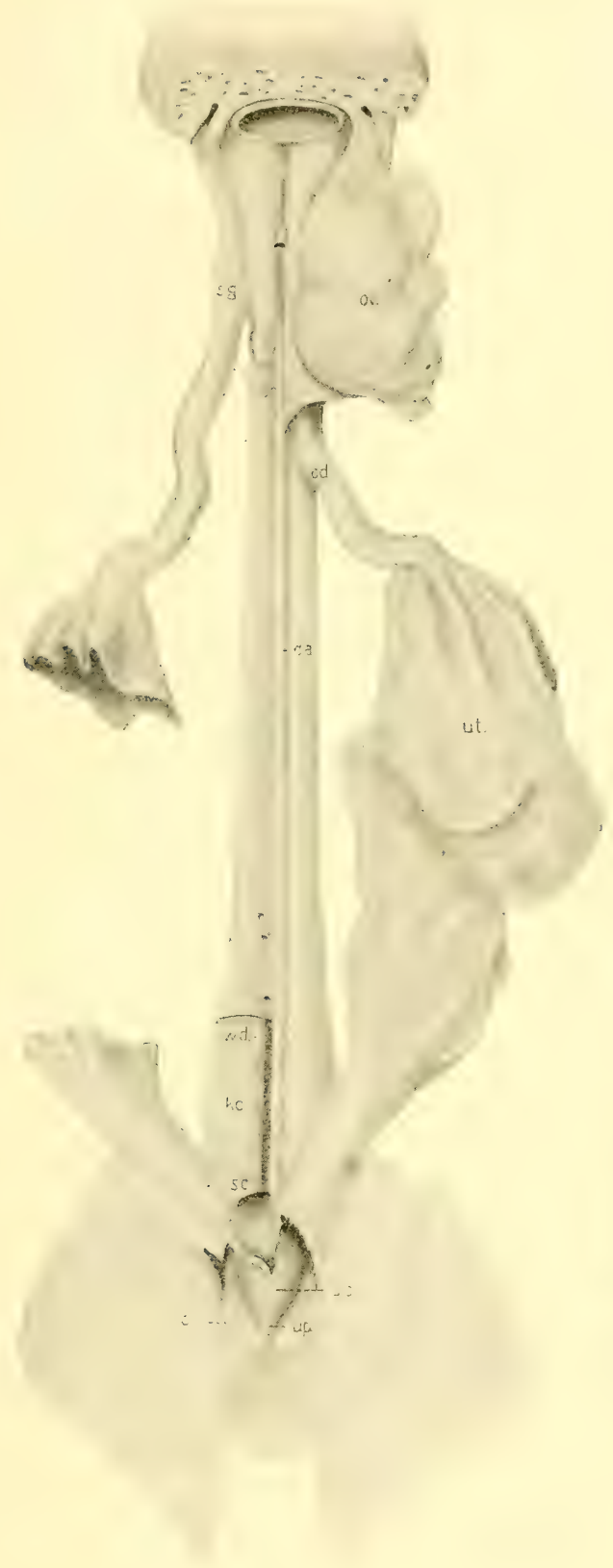

A

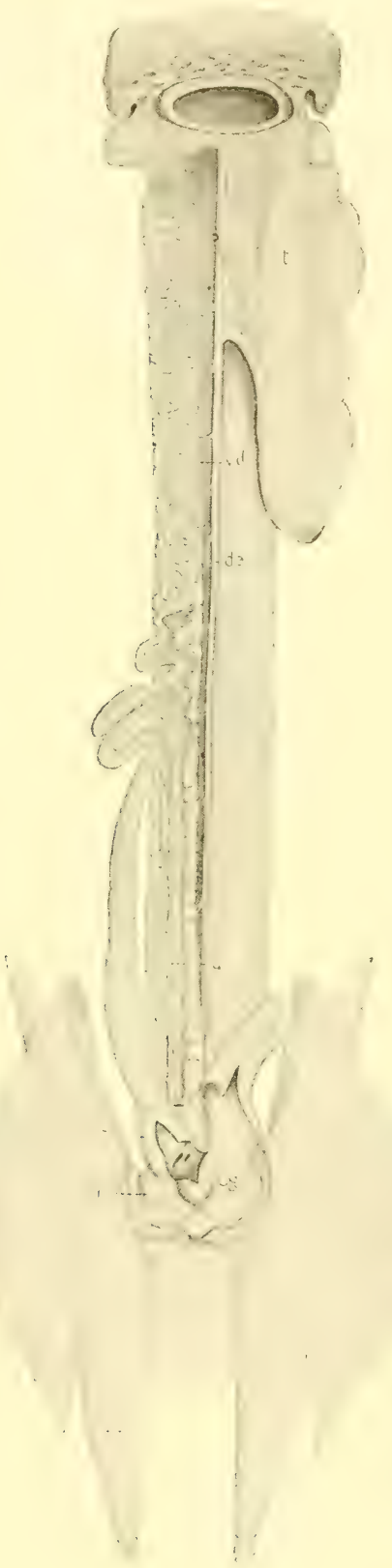

B

Fig. 253. Urogenital system, Squalus sucklii. (Duncan Dunning, orig.) A. Female. B. Male. cl., cloaca; cls., clasper; d.a., dorsal aorta; kd., kidney; od., oviduet; ov., ovary; sc., in male, sperm sac; s.g., shell gland; t., testis; $u$., ureter; up., urinary papilla; u.s., urinary sinus; ut., uterus; ug., urogenital sinus; v.s., vesieula seminalis; v.d., vas deferens; $w_{\text {.d., }}$ Wolffian duet. 
part and the only way that the number of segments can be determined is by the number of collecting tubules leaving the kidney. In the rays the kidneys may be divided into numerous asymmetrical lobules, which show little tendency toward orderly arrangement; or the kidneys of the two sides may be entirely dissimilar. This is seen sometimes in Raja clavat a where the left kidney,

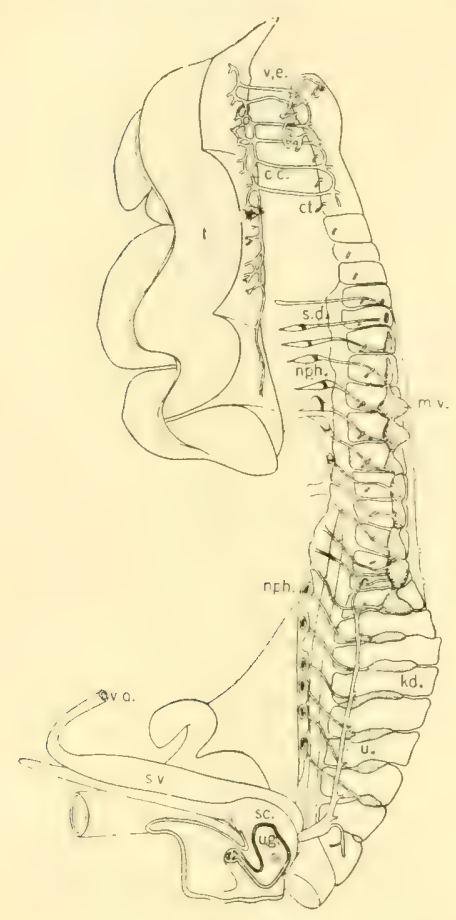

A

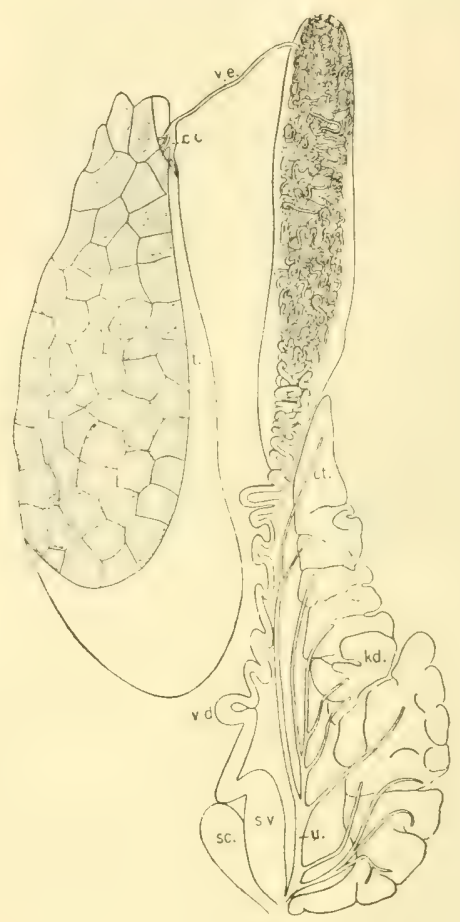

B

Fig. 254. Urogenital system of male. A. Squatina. B. liaja. (From Boreea.)

$c . c$. , central canal of testis; ct., collecting tube; $k d .$, kidney; m.v., median vesicle; $n p h$. , nephrostome; sc., sperm sac; s.d., segmental duct; s.v., vesicula seminalis; $t$. , testis; $u$., ureter; ug., urogenital sinus; v.d., vas deferens; v.e., vas efferens.

probably because of pressure from the digestive organs, becomes divided into widely separated parts.

\section{DUCTS OF KIDNEY}

In a type like Squatina (see male, fig. $254 \mathrm{~A}$ ) the collecting tubules (ct.) which drain the anterior part of the kidney empty directly into the Wolffian duct, and those of the posterior part join a ureter $(u$. ). This is essentially the condition in Heptanchus, except that in Heptanchus the ureter is of immense size. In Scyllium (see p. 189, fig. 177 A) the Wolffian duct is terminated by an enlarged portion, the urinary vesicle ( $1 . v^{\circ}$ ), and the collecting tubules in the posterior part of the kidney are dispersed at their termini, several of them joining to form a diminutive ureter only at the place where they empty into the urinary sinus. A modification of this plan is met with in the rays in 
which the part of the kidney lying posterior to the minary sinus is drained by collecting tubules (fig. 254B) some of which unite anteriorly into one or two groups (ureters), while others of them enter enlarged horns of the urinary sinus (female of $R$. clavata). In the female of the sting ray, Trygon, all the

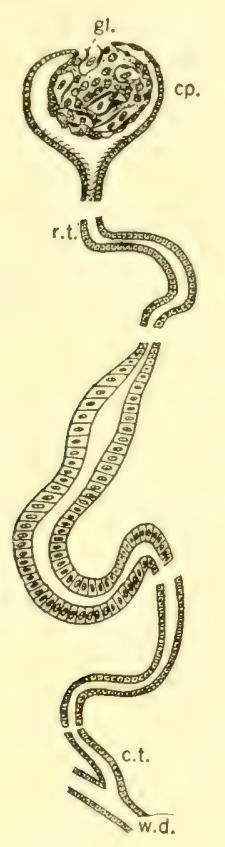

A

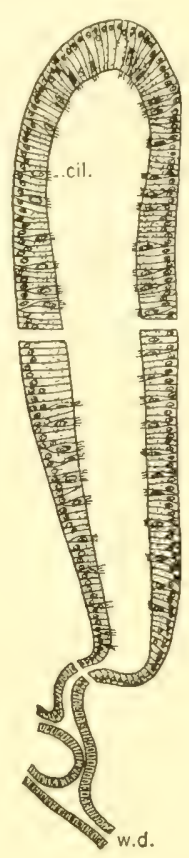

B

Fig. 255. Renal corpuscles, Acanthias. (From Borcea.) A. Active. B. Atrophied and in the service of the male sex system.

cil., ciliated cells; cp., Bowman's eapsule; c.t., collecting tube; gl., glomerulus; r.t., renal tubule; w.d., Wolffian duct.

collecting tubules enter the large horns of the urinary sinus independently, excepting the single anterior one which is a direct continuation of the small Wolffian duct.

The lower part of the Wolffian duct in a type in which this does not receive tubules may be enlarged as the so-called urinary vesicle. In Squatina the duct is swollen and in Scyllium it is of large size (p. 189 , fig. $177 \mathrm{~A}, u . v$.).

From this it is seen that the Wolffian duct decreases in importance in the female as we approach the rays. In a type like Squalus sucklii, however, a plan is given in which the Wolffian duct assumes a more important rôle. Here in the female (fig. 25:3 ) the ducts receive the collecting tubules from practically the whole of the kidney, so that a ureter may be said to be absent, or if present to receive only a few tubules.

The urinary sinus (u.s., fig. 253) into which the Wolffian ducts empty varies greatly in size and shape. In the sharks it is simpler in its external form than in the rays and may be described as a delta-shaped sac which empties posteri- 
orly by a conical urinary papilla. Its complexity in the rays results from the anterior extension of the horns of the sinus, which take the shape of the arms of a tuning fork, the narrower urinary sinus being the base (Trygon).

An incision through the papilla (Squalus, fig. 253A) gives a view of the inner walls of the urinary sinus. Emptying into it on each side of the female is the Wolffian duct ( $w . d$.$) , and as evaginations of its walls are certain wide$ pockets (sc.) comparable to the sperm sacs of the male.

The relation of the ureter to the Wolffian duct (vas deferens) in the male is markedly different from that of the female. Only the ureter will be described at this place since a deseription of the Wolffian duct will be given in a study of the genital system. The ureter in the male is confined to the posterior part of the kidney where it receives collecting tubules from ten to fourteen segments. These may enter regularly as short tubules along its course (Squalus and Squatina) or they may join it in two groups, one at its anterior end and the other near its entrance to the urinary sinus (Scyllium, Raja). In Scyllium the ureter of the male is an enlarged sinus, as in Heptanchus.

\section{FINER ANATOMY OF KIDNEY}

In a section through the Elasmobranch kidney multitudes of structures are met which are the effective organs for the removal of nitrogenous waste; these are the renal corpuscles. A renal corpuscle, in simple terms (fig. 255A), is like a hollow rubber ball (Bowman's capsule), one side of which has been pushed in to form a double wall and the opposite side pulled ont over a small area into a long neck (renal tubule, r.t.). Into the eavity of this invagination a blood vessel enters, coiling up as the glomerulus $(g l$. $)$ or knot of vessels. Nitrogenous waste matter collected by the blood is brought by the glomerulus into the capsule through the walls of which it passes into the renal tubule. The renal tubule (r.t.) earries it into the collecting tuble (c.t.) which joins the Wolffian duct $(w . d$. ) (or the ureter). Thus it passes through the urinary papilla and out at the cloaca.

\section{NEPHROSTOME AND SEGMENTAL DUCT}

In order to understand the origin of a Bowman's capsule a second series of correlated structures may first be considered. Each one of these when complete, consists of a nephrostome ( $m p h$.) or fumnel (fig. 258) opening from the body eavity, a terminal part, the median vesicle (m.v.), and between the two a segmental duet (s.d., fig. 258B).

The nephrostome may best be studied in the Elasmobranchs by treating them first with Flemming's fluid. T'o get the best results the digestive tract should be removed from a fresh specimen and a little of the fluid allowed to remain for a short time in the dorsal part of the body cavity. Under such a procedure the nephrostomes are colored as dark patches of the dorsal peritoneal lining of the body cavity near the middle line and on the mesentery. These are the fumnels which may be relatively large as in Squatina ( $n$ ph., 
fig. $25+\mathrm{A}$ ), where some of them are two to three and a half millimeters in diameter; or they may be small as in Scyllium. Frequently when funnels are present in the embryo they become rudimentary or wholly absent in the adult ( Raja). When the nephrostomes are present they may be traced along the mesorectal mesentery and the mesenteries proper, the most anterior of which reach the mesenteries of the sex glands. The number of nephrostomes varies according to the species, the individual, the sex, and the age. In a type like Squatina (fig. 254A) there are usually nineteen or twenty pairs present, but these may be reduced in number. In the female the number is always smaller than in the male. Twenty-three or twenty-four pairs are present in the adult Acanthias; while in the embryo there may be as many as thirty-five pairs.

The segmental ducts lead from the fumnels (nephrostomes) outward toward the kidney tissue. These may be clearly marked as in Squatina or they may

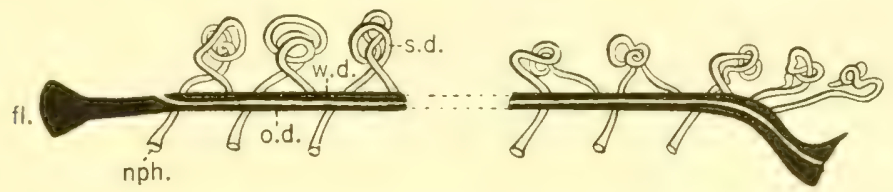

Fig. 256. Diagram of development of segmental ducts and their relation to the Wolftian and Mïllerian ducts in the embryo of Seyllium. (From Balfour.)

$f$., funnel; nph., nephrostome; o.d., Müllerian duet (oviduct) ; s.d., segmental duet; $w . d .$, Wolffian duet.

partly degenerate so that the nephrostome is sessile (Scyllium). In some other types no trace either of the ducts or of the fumnels remains in the adult. In those types in which they are developed, the ducts may rum more or less directly outward in the midbody region (Squatina), or they may be $V$-shaped with the apex pointing forward (Squalus sucklii). In the region of the rectal gland they may be more difficult to see by reason of the thickness of the mesorectum. Here in general they extend obliquely backward and may be long drawn out (Squatina) or short as in Scyllium. As the segmental duets pass outward they pass above the Wolffian ducts (Acanthias).

It was formerly supposed that the segmental ducts were directly continued into collecting tubules of the urinary system. If this were so it would be possible for waste substances to be collected from the body cavity and passed out through the Wolffian duct or ureter to the exterior (see fig. 256, Scyllium). Such a connection between the two systems, however, probably does not exist for the adult of any forms since in the adult the segmental duct ends blindly as the median resicle ventral to the kidney tissue (see Squatina, fig. 254 A, m.v.).

Proof that no comnection exists between segmental duct and collecting tubule has been beautifully shown by the experiments of Schmeider (1897) who injected india ink mixed with carmine into the body cavity of the living Squatina. If a connection exist between the nephrostomes of the body cavity and the kidney tissue the ink should be eliminated to the exterior through the Wolffian duct or through the ureters. Upon killing the fish a few days after the experiment Schneider found that the ink and grains of carmine had col- 
lected in the median vesicles at the end of the segmental duct (see fig. $254 \mathrm{~A}$, $m . l^{\prime}$.) and there appeared as large colored patches. In no specimen did the ink or carmine which entered the nephrostome gain access to the tissue of the kidney.

\section{DEVELOPMENT OF NEPHROSTOME AND SEGMENTAL DUCT}

A section through the body cavity of an embryo of Heterodontus francisci (fig. 257) cuts through the nephrostome or fumnel ( $n p h$.). If traced farther

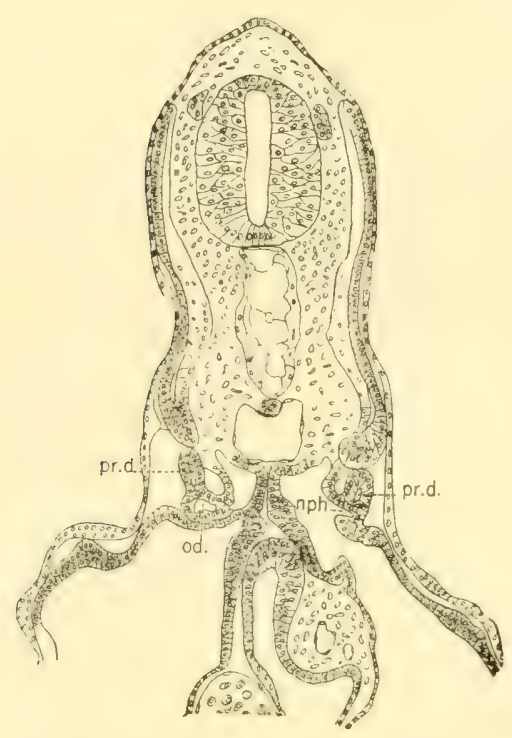

Fig. 257. Development of nephrostome, Heterodontus francisci. (H.M. Williamson, orig.)

nph., nephrostome; od., oviduct; pr.d., pronephrotic duct. back, it would be found that this funnel by means of the segmental duct joins the pronephrotic duct $(p r . d$.$) . At first the$ most anterior of such funnels may provide a passageway from the body eavity to the pronephrotic duct, but later the most anterior of these fuse into a single enlarged funnel. Those segmental funnels arising back of this have segmental ducts (s.d., fig. 258) which join the pronephrotic duct only secondarily.

In the segments farther back, however, each segmental duet of Acanthias grows from its funnel laterally, enlarging into a median vesicle ( $m . v$, fig. $258_{\mathrm{A}}$ ). From this it may even continue inward to join an outgrowth from the pronephrotic duct $(p r . d$.$) . The following structures are$ found in order from the funnel or nephrostome to the pronephrotic duct: (1) the nephrostome $(n p h) ;.(2)$ its segmental duct (s.d.); (3) a median vesicle (m.v.) which supplies the tissue for Bowman's capsules; (4) the tube leaving the capsule which becomes the renal tubule $(r . t$.$) ; and (5) the primitive collecting tubule (c.t.) which according to$ Borcea (1906) buds off from the pronephrotic duct and later lengthens out into the collecting tubule of the adult.

At this point in its development, connection is made from the nephrostome to the pronephrotic duct (Scyllium, fig. 256), and it is not impossible that while this temporary connection lasts nitrogenous waste may pass from the body eavity through the pronephrotic (now the Wolffian) duct and out through the cloaca. But this connection is early lost even in Scyllium. Such connection between the coelom and the kidney tissue is never actually present in Acanthias, for in it the tube early fragments at the median vesicle before its terminal part, the renal tubule, has reached the pronephrotic (Wolffian) duct. It is from the fragmenting tissue of the median mass that Bowman's capsules are formed. 


\section{BOWMAN'S CAPSULES}

According to Borcea (1906) a Bowman's capsule is produced from a part of the median vesicle in the following manner (Acanthias). The median vesicle (fig. 258B-C) divides into two parts, a median part connected with the segmental duct (s.d.) and an outer (deeper) part continued by the renal tubule $(r . t$.$) . The outer part is the first to give rise to a Bowman's capsule (fig. 258c)$ and this is accomplished by the loose cells from the lining forming over the aperture caused by the separation of the median vesicle. Into this the knot of

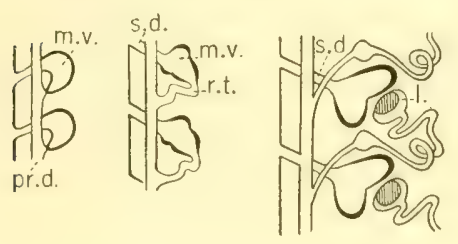

A
$\mathrm{B}$

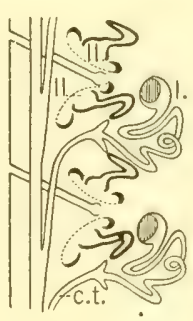

D

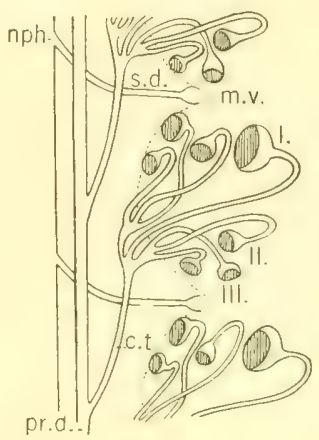

$\mathrm{E}$

Fig. 258. Diagrams $A$ to $E$ to show stages in the development of Bowman's capsules, Acanthias. (From Borcea.)

c.t., collecting tubule; m.v., median vesicle; $n p h .$, nephrostome; $p r . d .$, pronephrotic duct; $r . t .$, renal tubule; s.d., segmental duet; $I, I I$, and $I I I$, primary, secondary, and tertiary renal corpuscles.

blood ressels (the glomerulus) pushes. The body segment is thus provided at first with a single primary $(I)$ renal corpusele on each side, and a true metamerism obtains in the kidney tissue. As development progresses, however, secondary and tertiary Bowman's capsules are formed. Some of these pass over into the adjacent segments and soon destroy the primitive metamerism.

The formation of the secondary Bowman's capsules and their connection with the pronephrotic duct takes place as follows: from that part of the median vesicle of the segmental canal which remains after the formation of a primary, that is, from the superior and inferior vesicles, other Bowman's capsules (secondary and tertiary) arise. The secondary capsules are formed from the median part of each superior and inferior vesicle and then extend in the shape of a gourd toward the collecting tubule (see fig. $258 \mathrm{D}, I I$ ). It will be further noted that enlargements arise on each collecting tubule (c.t.) and that these send out processes which meet and fuse with the tips of the gourdlike structure, the superior processes fusing with the terminus of the secondary Bowman's capsule derived from the inferior vesicle. Upon the fusion of this terminus of the gourd with the process of the collecting tubule and the breaking through of the connection between them, a secondary urinary tubule results (II, fig. 258E). 
Tertiary Bowman's capsules result from the further fragmentation of the remains of the inferior and superior parts of the median vesicle. These, like the secondary capsules, are gourd-like and their termini unite with tertiary processes. The tertiary collecting tubules (III, fig. $258 \mathrm{E}$ ) result in part as processes which spring from the sides of the origin of the secondary process. 'These pass to meet and fuse with the tertiary Bowman's eapsules.

At this stage, Acanthias, $8 \mathrm{~cm}$., each body segment has one primary $(I)$, two secondary $(I I)$, and four tertiary Bowman's capsules $(I I I)$. Four of these, one primary, one secondary, and two tertiary, belong to the median vesicle from which the primary was derived; the remainder arise from the following

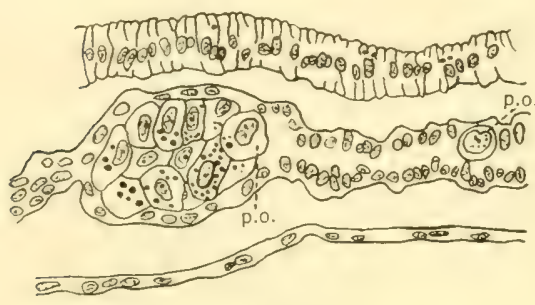

Fig. 259. Early sex cells, Acanthias. (From Woods.)

p.o., primitive ora. vesicle. By the time the adult stage is reached numerous renal corpuscles and renal tubules are present in each segment. In fact it is these, together with connective tissue, which make up the mass of the kidney.

\section{Genital System}

The genital system consists of the sex glands and their tubes. The adult glands arise as a collection of germ cells ( $p . o$. , fig. 259), which, before passing into the glands are scattered more or less widely in the tissues. These cells appear very early and are well shown before a genital ridge is formed. They later, through migration, take up their position in the sex gland. At this early "indifferent" stage it is impossible to tell what the sex of the individual will be. The cells then begin to specialize and to take on the characters of the sex cell of the male or the female, whereupon the glands become the testes or the ovaries, respectively. We shall describe these organs in the male first.

\section{GENITAL ORGANS OF MALE}

\section{TESTES}

The paired testes of the male vary considerably in size. In some of the Elasmobranchs they are relatively small (Torpedo); while in many others, especially during the breeding season, they are of large size (Heterodontus; Raja clavatu, fig. $25+\mathrm{B}$ ). It often happens at this time that the testes are irregular in outline, being made up of numerous lobes ( $t$., fig. $253 \mathrm{~B}$, Squalus sucklii). In certain forms the testes may be connected posteriorly with the rectal gland by a heavy mass of tissue, the epigonal organ (Heterodontus, Scyllium), a vestige of which we saw in Heptanchus. An epigonal organ, however, is only slightly developed or entirely wanting in many types (Acanthias, fig. 253; Squatina, fig. $254 \mathrm{~A}$; and Torpedo). 
The test is is divided into columns, each of which consists of connective tissue and follicular cells. The sex cells appear in various stages of development which may be followed from the indifferent stage, previously mentioned, to the mature sperm cell or spermatozoön. Through division, the primitive ova

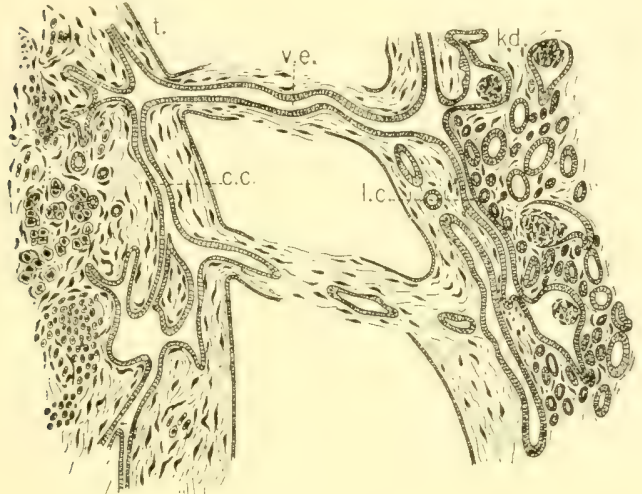

Fig. 260

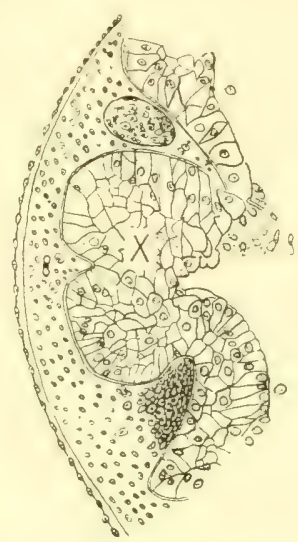

Fig. 261

Fig. 260. Horizontal section cutting testis and anterior part of kidney of Squatina. (From Borcea.)

c.c., central canal of testis; l.c., longitudinal canal of epididymus; v.e., vas efferens.

Fig. 261. Section through ovary of Spinax to show corpus luteum $(X)$, which fills the place occupied by the ovum. (From Wallace.)

of the male form multitudes of spermatogonia, which after a period of rest form spermatids. The spermatids next undergo an interesting series of changes in shape and form, becoming the adult spermatozoa.

\section{VASA EFFERENTIA}

The sex cells in the male instead of passing into the body cavity and out at the abdominal pores, as they do in the Cyclostome fishes, pass out through the Wolffian duct, now called the vas deferens, which they reach through the vasa efferentia. The vasa efferentia arise as metamorphosed tubules of the anterior segmental ducts. Those ducts in the region of the sex glands of the male have some of their funnels opening into the tissues of the testis or into the central canal at its base and afford a passageway for the sex cells.

A horizontal section through the testis and anterior part of the kidney of a young Squatina (fig. 260) shows that the segmental ducts themselves thus become the efferent ducts or vasa efferentia within the tissues of the testis; the parts of the nephrostomes representing the funnels fuse to form a central canal (c.c.) while the median vesicles of the segmental ducts similarly join the kidney to form the longitudinal canals (l.c.) of the epididymus. From this canal a connection is effected, through collecting tubules, with the Wolffian 
ducts. Several of the anterior segmental ducts may now become vasa efferentia, but others which are on the mesorchium may fail to reach the tissue of the testis. Those actually penetrating each testis in Squatina (v.e., fig. 254A) are six in number. In Squalus four such enter, while four others end on the mesorchium. In Scyllium two or three vasa efferentia are present and in the rays (fig. $25+\mathrm{B}$ ) a single vas efferens is present. In this form the vas efferens joins the vas deferens directly withont the intermediation of a longitudinal canal.

The passageway for the sex cells of the adult male, then, is from the testes throngh the vasa efferentia into the greatly coiled Wolffian ducts each of which is now a vas deferens. We may next notice in detail the changes which the Wolffian duct and its associated parts undergo in its metamorphosis into the vas deferens. We shall first consider the changes undergone in the anterior segment of the kidney.

The anterior part of the kidney, which in the young male is in the service of the urinary system, undergoes profound modification in the adult male, characteristically coming to be of large size (Borcea, 1906). If a transverse section is taken of this area in the adult it will be found to be devoid of the Bowman's capsules which were previously present in it (see fig. 255B, Acanthias). In their places will be found numerous enlarged sacs the walls of which have become greatly thickened. The two types of cells which compose the walls are: (1) ciliated cells (cil., fig. 255B), which border on the lumen, and (2) nonciliated cells with hasal nuclei. These cells secrete a viscous whitish substance which acts as a seminal fluid. The upper end of the kidney, therefore, which at first functioned in the young male in the removal of the nitrogenous waste, has thus entirely changed its function in the adult so that it now acts as a gland for the secreting of a kind of spermatic fluid.

Upon the transformation of the anterior part of the kidney, the vas deferens becomes a coiled tube (Squalus, fig. 253B; Ra.ja, fig. 254B; Torpedo) which as it passes posteriorly receives collecting tubules. In the region of the posterior kidney it becomes the enlarged vesicula seminalis into which no collecting tubules empty. The vesicula Seminalis in many of the sharks (Squalus, fig. $253 \mathrm{~B}, v . s$.) is a long tube but in the rays (fig. $254 \mathrm{~B}$ ) it is much shorter.

When opened longitudinally the vesicula seminalis in Squalus shows a series of transverse semipartitions which give to the inner wall a corrugated appearance. Along this wall in the breeding season are found myriads of sperm cells or spermatozoa.

The seminal vesicles of the right and left side empty into the enlarged urogenital simus (u.s., fig. 253B) usually ventral to and laterad of the entrance of the ureter $\left(u_{0}\right)$. Passing forward on each side of the urinary sinus is the blind sperm sac $(s c$.) which appears to be an evagination of the urinary sinus but which is formed from the posterior remmants of an oviduct like that of the female. The sperm sac of Squalus or of Raja is of small size and in the rays it has been spoken of as a urinary bladder. In Squatina (fig. 254A) and Scyllium (see p. 189, fig. 177A) the saes reach a much greater length. Since the sinus receives both the nitrogenous waste and spermatozoa it is properly designated 
urogenital. The urogenital sinus, as in Heptanchus, then empties by means of a urogenital papilla into the cloaca.

Leigh-Sharpe (1920-21) has deseribed fully the siphons of a number of Elasmobranchs. These are composed of longer or shorter closed saes which end posteriorly by siphon tubes. In a type like Acanthias the sac lies under the skin ventral to the base of the pelvic fin, and its tube empties into the proximal part of the clasper tube. In a large specimen of Galiorhinus this siphon sae extended almost to the pectoral girdle. The walls of the sac are muscular and its function appears to be the foreing of the sperm cells through the clasper groove. Glands may line the whole sac as in Lamma or the dorsal side of its wall only (see p.28, fig. 31). The function of the elasper gland in the latter condition is not definitely known.

\section{GENITAL ORGANS OF FEMALE}

\section{OVARIES}

The ovaries of the adult female usually arise as paired structures, and are bound to the anterodorsal wall of the body cavity by a mesentery, the

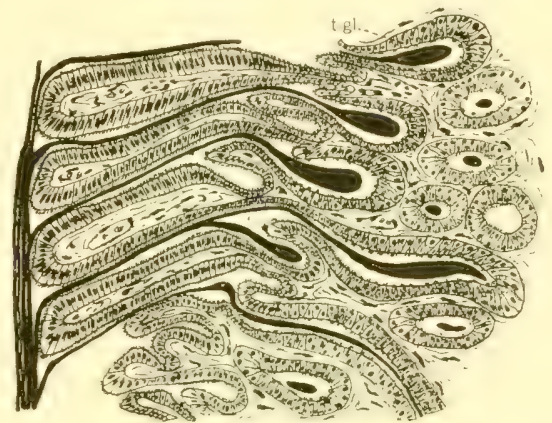

Fig. 262. Section through shell gland, Scyllium. (From Borcea.)

t.gl., secretory cells. mesovarium (Squalus, fig. 253A). Not infrequently, however, the left ovary atrophies in the adult (Scyllium, Pristiophorus, Curcharias, Galeus, Mustelus, and Zygaena.). They oceupy the anterior part of a mass of tissue which, as the epigonal organ, may extend along the dorsal wall of the body cavity posteriorly where it joins the rectal gland. In numerous forms, however, the epigonal organ is wanting as, for example, in Acanthias. The ovary varies greatly, depending upon the stage of maturity of the ova contained. It appears as a sac through the walls of which the ova may be seen varying in size from relatively minute spots to mature ova often from 3 to $5 \mathrm{~cm}$. in diameter (see ov., fig. 252).

In development an indifferent sex cell divides several times forming oögonia. Each oögonium then undergoes a period of growth to become a primary oöcyte. By the first maturation division, this primary oöcyte gives rise to the secondary oöcyte and first polar cell. The former soon undergoes the second maturation division, thereby forming the oötid and second polar cell. The oötid without further division increases in yolk content to become the ovum. The ovum then breaks through the wall of the ovary. At this stage it contains only one-half the number of chromosomes characteristic of the body cells. If it be fertilized by a spermatozoan, which also bears only one-half the normal number of chromosomes, the number of chromosomes characteristic for the species is restored.

The place where the egg was located in the ovary now becomes filled up by a corpus luteum ( $x$, fig. 261). 


\section{OVIDUCTS}

The oviducts in an immature female consist of a pair of slender tubes extending the entire length of the body cavity and emptying into the cloaca. They take their origin by splitting off from the Wolffian duct (see fig. 257,od.) and therefore retain the primitive funnel ( $f$., fig. 256) by means of which they open anteriorly into the body cavity. Occasionally one of the oviducts is rudimentary in the adult (Trygon). This in all probability is due to the

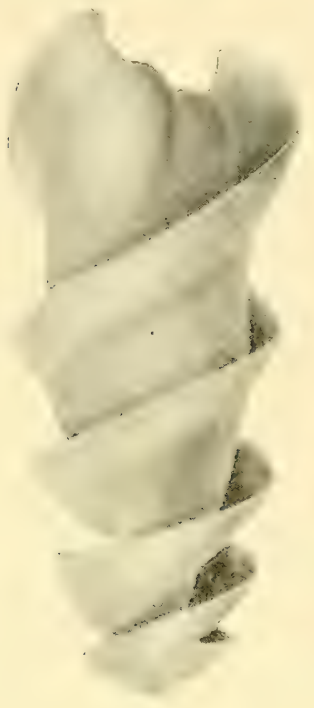

A

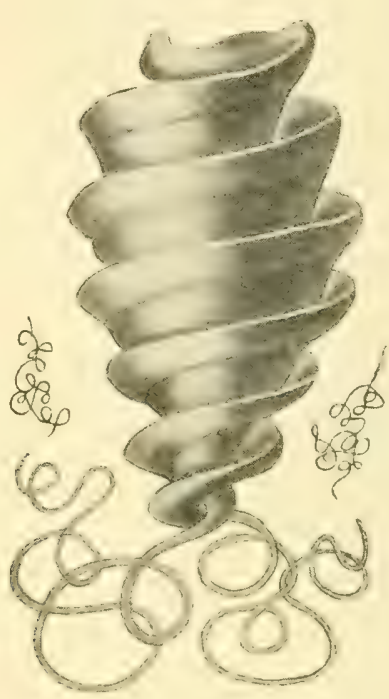

B

Fig. 263. The egg shell of Heterodontus. A. H. francisci (orig.). B. H. galeatus. (From Waite.)

crowding of the unusually large valvular intestine. In the adult the oviduct is divided into several functional sections which may now be discussed.

The oviducal funnel or the opening into the body cavity is formed as a common aperture for the two oviducts ( $f l$., fig. 251A). This is slit-like and is lined with eiliated cells, the cilia of which may have something to do with directing the eggs into the oviduct after they have reached the body cavity from the ovary. Just below the funnel, in the part comparable to the fallopian tube of higher forms. fertilization of the mature egg takes place. The egg then passes downward to the area of the shell gland, where such exists, to receive its shell.

\section{SHELL GLANDS}

The shell glands ( $s . g$. , fig. $253 \mathrm{~A}$ ) vary greatly in the different Elasmobranchs. In Torpedo there are present in this region of the oviduct only a few strands of granular tissue, which are incapable of producing a shell. In a type like 


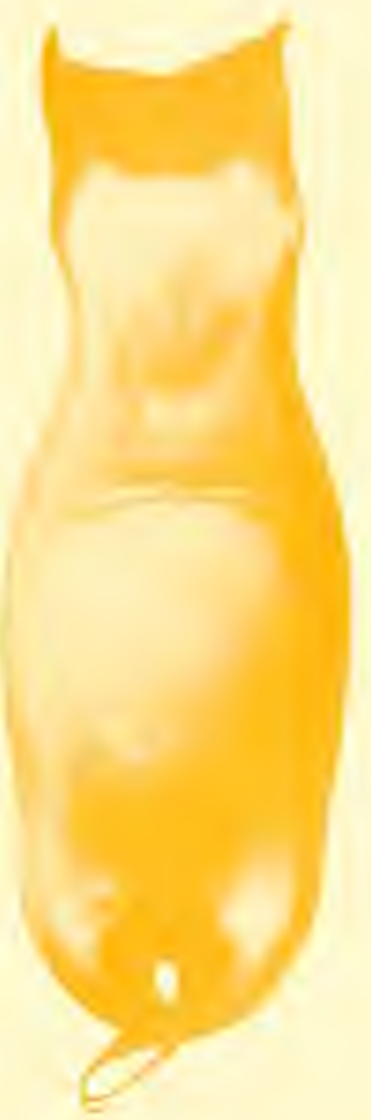

Fig. 264. Eigg shell, Cephatoscyllinm. 

Squalus the gland is considerably increased in size and in Raja, scyllium, and Heterodontus francisci it becomes relatively of immense dimensions. If the gland in scyllium he taken as a type for study we find that it is divided into a dorsal and a ventral half. A section through it shows that these halves are divided into anterior and posterior areas; the former secretes albumen, the latter the shell proper. 'The glands which are actively engaged in secreting the shell are seen to advantage in figure 262 . Here the folds are very high and the secretory cells $(t . g l$. ) at their bases are large. As the horny substance is formed for the shell it passes into the cavity of the shell gland which acts as a mold for the shell.

\section{TYPES OF EGG SHELLS}

Two types of shells are formed: the permanent and the temporary shells. In the permanent shell the young undergoes its development to the form of the adult, after which it emerges (Scyllium, Raja, Heterodontus). In both Scyllium and Raja the shell is a rectangle, from the angles of which projections extend. These projections function either as tendrils (Scyllium) which coil around solid objects and anchor the egg, or they serve as spikes to fix the developing egg in mud or sand flats (rays). Figure 264 shows the shell of the California swell shark, Cephaloscyllium, which in all essential respects is like that of the other Scyllidae except that in the figure its tendrils appear shorter. These tendrils are, however, long

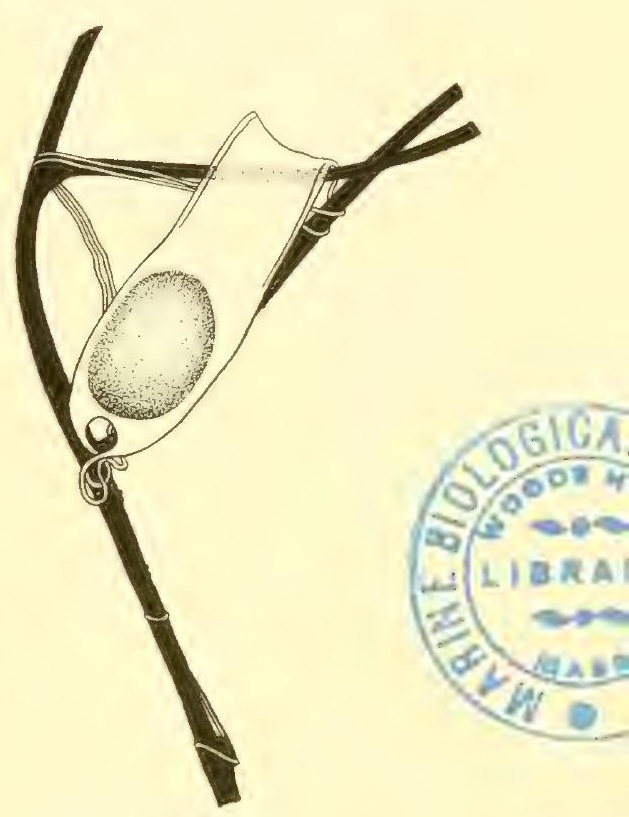

Fig. 265. Attachment of egg of Scyllium. (After Kopseh.) and are produced both from the upper and the lower angles. In color the mature shell is clear amber of equal shade throughout. Such shells of Cephaloscyllium, however, which are in the process of formation are whitish when first removed from the oviducts; but these color with age.

In Heterodontus the shell is shaped like a serew with a characteristic double flange extending from its apex to the large perforate end. The flange in Heterodontus francisci (fig. 263A) or H. philippi is broad and is thrown into four or five coils. In Heterodontus galeatus (fig. 263B) the flanges are narrower, and tendrils are present which may reach the extreme length of more than seven feet (Waite, 1896).

The attachment of the egg in egg-laying has been studied in Scyllium by Kopsch (1897). It is found that as the egg passes through the eloaca its tendrils, upon coming in contact with a solid, coil firmly around it, thus fixing the egg in place (fig. 265). Two eggs are usually deposited at about the same time and many are laid during the season. 
The young, thus protected by the shell and supplied with an abundance of food yolk, undergo a period of development outside of the body. This period varies greatly depending largely upon the temperature of the surrounding water. Under favorable conditions the

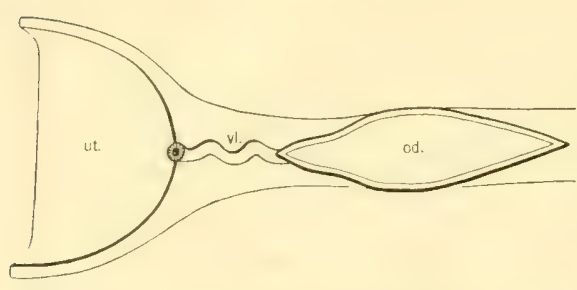

Fig. 266. Ovidueal valve, Squalus sucktii. (F. Hurni, orig.) od., oviduct; ut., uterus; vl., valre. eggs may hatch in six or seven months, but the period is more likely to approximate nine months. At the end of this time hatehing is accomplished by the perforation of the upper end (Scyllium), or the lower end (Raja) of the shell. In Heterodontus the two layers at the large or perforate end separate making a large aperture through which the young emerges.

In many of the Elasmobranchs a temporary shell is formed which serves the young fish only through its early development. From this temporary shell the embryos emerge and undergo more or less of their development in the oviduct of the mother (Acanthias, Mustelus, Rhinobatis).

A temporary shell is very often a structure of exquisite beauty. In Squalus sucklii it consists of a long thin-walled tube of a clear amber color, each shell containing from four to six eggs. The eggs undergo their early development incased and protected until the time when the external gills begin to be absorbed. The shell then ruptures and the young embryos take up their development in the uterus of the mother. In Rhinobatis a similar shell is found and after it has been discarded by the embryos it may be found rolled up in the uterus.

\section{UTERUS}

We have said that the uterus is much more highly developed in those sharks which

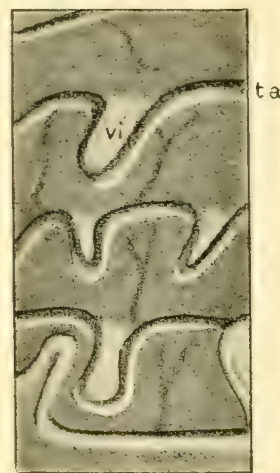

A

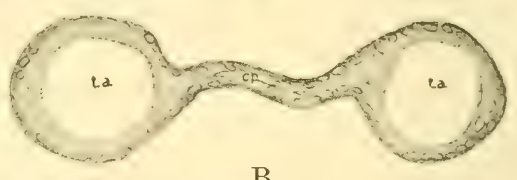

B

Fig. 267. A. Section of uterine lining to show villi and blood supply, Squalus. B. Transverse section through a single villus, Acanthias. (From Brinkmanu.)

cp., capillaries; t.a., terminal artery; $v i$, villus.

give birth to living young; for in these it serves as a place in which a considerable part of the development is undergone. Such a uterus is that of Squalus sucklii (ut., fig. 253) in which it may be a greatly enlarged sac with well defined boundaries. Anteriorly the uterus of Squalus is separated from the forward part of the oviduct by a well defined oviducal valve (fig. 266) which is a wavy constriction with a very narrow lumen effectively closing the uterus to the upper part of the oviduct. 
The lining of the uterus differs greatly in oviparous and viviparous types. In the former it may be practically smooth or it may be thrown into low folds as in Scyllium. In viviparous types it may he singularly modified as maturity is reached. In an immature specimen of Squalus the lining is smoother than

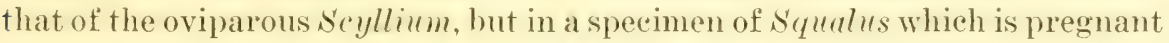
the whole surface of the lining is thrown into oblique rows of flaps or villi (vi., fig. $267_{\mathrm{A}}$ ), each of which is a leaf-like structure with exceedingly thin walls. In a type like Torpedo or the butterfly ray, Pteroplatea micrura, the uterine wall may be thickly covered with long papillae some of which in the latter may reach 10 to $20 \mathrm{~mm}$. in length. The terminal part of such a papilla is shown in figure $269 \mathrm{~B}$, in which it is seen that the wall is like a sponge.

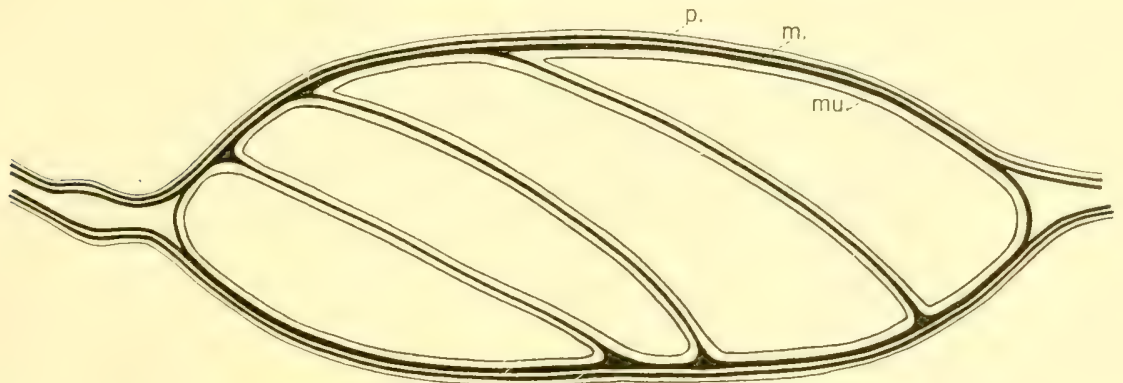

Fig. 268. Section through the uterus of Mustelus antarcticus. (From T. J. Parker.) $m$. muscular layer; mu., mucous lining; $p$. , peritoneal layer.

Viviparous females injected during pregnancy show that the blood supply to the uterus is exceedingly profuse. The arterial supply, in Acanthias, for example, consists in part from anterior and in part from posterior oviducal arteries which break up into branches to the oblique rows of villi. Each terminal artery courses along the free border or fold of the row of villi $(t$. $a$., fig. 267 A) supplying each individual villus with blood. If a cross-section be taken through a single villus of Acanthias (fig. 267B) the finer vessels of the villus may be made out. The large openings are for the terminal artery $\left(t_{.} a_{0}\right)$ and the central and smaller apertures are for the central veins which drain the villus into a main uterine vein. Around the surface of the villus is the capillary net (cp.) connecting the two systems. The same arterial arrangement is present in Scymnus, although here a single villus is not so wide.

\section{RELATION OF UTERUS TO EMBRYO}

The relation of the villi to the embryo is seen to advantage upon opening the uterus of Acanthias. Here the villi come in close contact with the embryo and multitudes of them are found clinging to the yolk sac on which the embryonic blood system is profusely spread out. By the close relation of the embryo to the maternal tissue an exchange between the two is insured.

In Mustelus laevis the blood system of the yolk sac comes into still eloser relation with the walls of the uterus than in Acanthias. For here, branched 
processes from the yolk sac of the embryo form close attachment to the uterine wall. Through this attachment nutriment may be secured by the embryo.

The relation of the uterine wall to the embryo in Mustelus antarcticus (fig. 268 ) shows still another widely different relationship. In this form, according to T. J. Parker (1882), the uterus, by the ingrowth of its lining, becomes

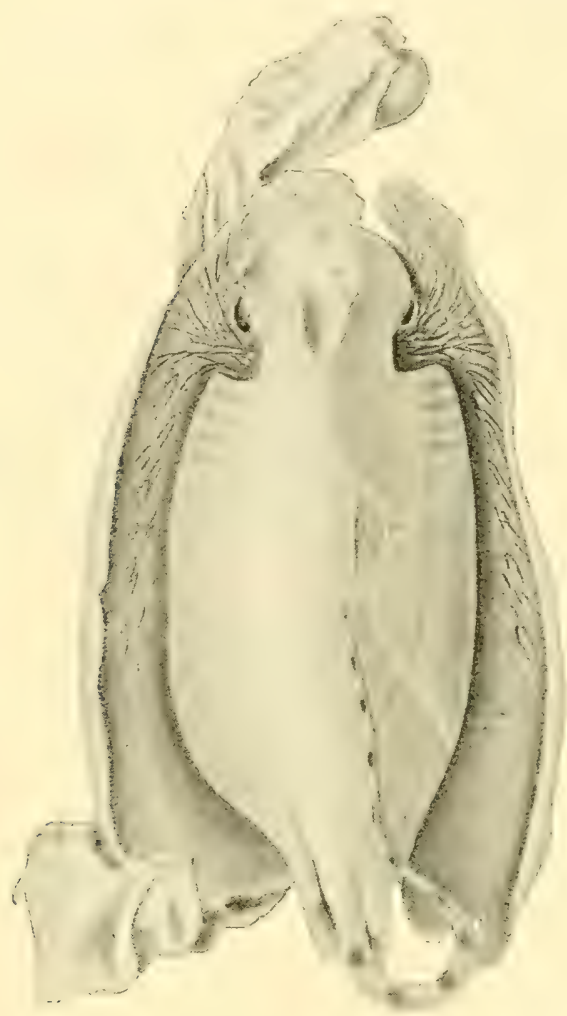

A

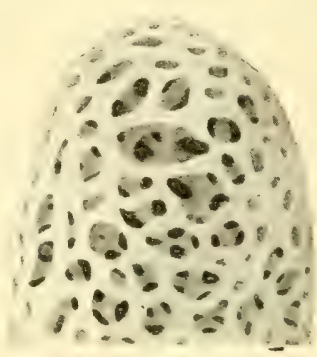

B

Fig. 269. Development of the butterfly ray, Pteroplatea micrura. (From Alcock.) A. The embryo in the uterus. B. A tip of a single villus highly magnified.

divided up into as many rooms as there are embryos within the uterus. The uterine wall is composed of an outer peritoneal lining ( $p$.$) , a second or thin$ muscular layer ( $m$.), and a third or inner mucous lining ( $m$.). It is the lastnamed layer that grows out to form the partitions separating the uterus into rooms. These rooms are filled with fluid in which the embryos lie and by which they are protected. In this type of Elasmobranch we see a device for protecting the developing young which, in a way, is like that in higher animals. In this form, however, the protective sac is produced by the maternal tissue, while in higher forms it is formed by the embryo.

In Pteroplatea micrura the villi or papillae on the uterine wall of the mother may be numerous and those which are over the spiracle of the embryo become long and strap-shaped (fig. 269A). In an embryo that is far advanced the yolk 
sac is small and its blood supply is lacking. There is therefore no passage of nutriment from the villi of the female through the hlood system on the yolk sac. But the long strap-like villi (fig. 269B) enter the spiracle and supply nutriment direct to the digestive tract, as can be demonstrated by opening up the digestive tract of the embryo (Aleock, 1892).

At their posterior terminus the two uteri in an immature female may be separated from the cloaca by a membrane or hymen across the oviduct. The relation of the hymen (in Torpedo) may be seen from figure 270 by Widakowich (1908). The median union of the right and left uteri is prolonged hackward toward the cloaca by the uterine septum $(s$.$) and a fold on each side$ separates the oviduct from the cloaca. During pregnancy the uterus is filled with a fluid and the apertures remain closed.

In Elasmobranchs in which the shape of the claspers of the male is flat, the openings into the uteri are slit-shaped, and in those forms in which the claspers of the male are provided with sharp hooks the lining of the terminal part of the uterus is thickened.

\section{Secondarx Sexual Characters}

Barring the fact that the female may be slightly larger than the male, the most important secondary character separating the sexes in the Elasmobranchs is the presence of claspers in the male. These, as we have seen, are formed as modifica-

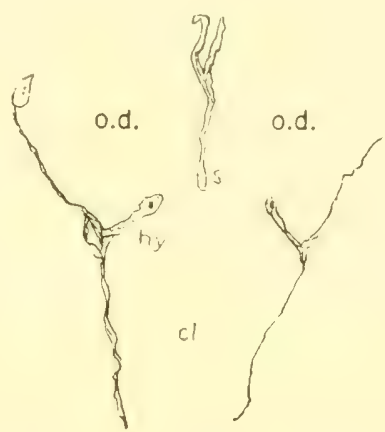

Fig. 270. Diagram to show the hymen between oviduct and cloaca. (From Widakowich.)

cl., cloaca; hy., hymen; o.d., oviduet; s., uterine septum. tions of the inner lobe of the pelvic fin. In types like Heptanchus maculatus the claspers in immature specimens are relatively insignificant so that it is often difficult upon casual examination to distinguish male from female. In most other types, however, the claspers are well developed and in the rays they may be of enormous size.

In one immature specimen of Heptanchus supposed to be a male, in addition to the rudimentary oviduct only one of the pelvic fins bore a clasper. The condition of gynandromorphism, in which one side of the body is male, the other female, has been found in insects and birds, and its oceurrence in the Elasmobranchs has also been previously noted (Vayssière and Quintaret, 1915).

The mucous covering of the claspers is usually devoid of placoid scales and is provided with a lubricant. Distally, as we have seen in a study of the skeleton, the claspers are provided with one or more terminal pieces. These by muscular action may be erected at right angles to the main axis of the clasper.

The claspers have long been known to function in uniting the male and female in copulation. This process among the Selachians was early studied by Agassiz (1871) who discovered that one (or both) of the claspers is inserted 
into the cloacal opening of the female and fixed in position by the erection of terminal pieces. The sperm cells reach the groove or tube in the claspers and are forced thence into the oviduct of the female by a current produced by the siphon (Acanthias). The cells traverse the oviduct to the region of the fallopian tube where they remain until the mature eggs enter the oviduct and fertilization takes place. 


\section{BTBLTOGRAPHY}

\section{Chap'Ter XI}

1858. Agassiz, L., (On the Reproduction of Selachians). Boston Soe. Nat. Hist., Vol, 6, p. 376 .

1871. Agassiz, L., Note on Copulation among Selachians. Proc. Boston Soc. Nat. Hist., Vol. 14, pp. 339-341.

1886. Albrecht, Paul, Vergleichende anatomische Untersuchungen. Erster Band. Erstes Heft. Inhalt: Über Penis, Penoid und Pseudopenis der Wirbelthiere. Hamburg, pp. $1-42,5$ text figs.

1890. Alcock, A., Observations on the Gestation of Some Sliarks and Rays. Jour. Asiat. Soc. Bengal, Vol. 59, Pt. 2, pp. 51-56, pl. 1.

189.. Alcock, A., Some Observations on the Embryonic History of Pteroplataea micrura. Ann. Mag. Nat. Hist., Ser. 6, Vol. 10, pp. 1-8, pl. IV.

1908. Alsberg, C. L., and Clarke, E. D., On a Globulin from the Egg Yolk of the Spiny Dog-Fish, Squalus acanthias L. Jour. Biol. Chem., Vol. 5, pp. 243-246.

1913. Backman, Gaston, Die Bauchflosse der Selachier. Erste Abtheilung. Die Bauchflosse der Batoidei. Kungl. Svenska Vetenskapsakademiens. Handlingar., Bd. 50, pp. 141, 11 pls.

1874. Balfour, F. M., A Preliminary Account of the Development of Elasmobranch Fishes. Quart. Jour. Mier. Sci., Vol. 14 (n. s.), pp. 323-364, pls. 13-15.

1875. BaLfour, F. M., On the Origin and History of the Urogenital Organs of Vertebrates. Jour. Anat. and Physiol., Vol. 10, 1876, pp. 17-48, 8 text figs.

1876. Balfour, F. M., On the Development of Elasmobraneh Fishes. Jour. Anat. and Physiol., Vol. 10, pp. 377-411, pls. 15, 16; pp. 517-570, pls. 21-26, 3 text figs.; pp. $672-688$, pl. 29.

18i8. Batfour, F. M., A Monograph on the Development of Elasmobranch Fishes. $8^{\circ}$. London, pp. 1-295, 9 pls., 9 text figs.

1914. Bates, Geo. A., The Pronephric Duct in Elasmobranchs. Jour. Morph., Vol. 25, pp. $345-373$, pls. 1-5.

1887. Beard, J., The Origin of the Segmental Duet in Elasmobranehs. Anat. Anz., Bd. 2, pp. 646-652.

1890. Beard, J., On the Derelopment of the Common Skate, Raia batis. Pt. 3,19 pp., 3 pls.

1896. BeArd, J., The Yolk-sae, Yolk and Meroeytes in Scyllium and Lepidosteus. Anat. Anz., Bd. 12, pp. 334-347.

1900. Beard, J., The Morphological Continuity of the Germ-Cells in Raia batis. Anat. Anz., Bd. 18, pp. 465-485.

1902. Beard, J., The Germ Cells. Part I. Raia batis. Zool. Jahrb. (Abt. Anat.), Bd. 16, pp. 615-702, pls. 43-44, 3 text figs.

1902. Beard, J., The Germ Cells of Pristiurus. Anat. Anz., Bd. 21, pp. 50-61.

1904. BEARD, J., A Morphological Continuity of Germ-Cells as the Basis of Heredity and Variation. Rev. Neurol. Psyehiatry, Edinburgh, Vol. 2, pp. 1-34, 114-142, 185-217, 2 pls., 5 text figs.

1910. BiedL, A., Die funktionelle Bedeutung des Interrenalorganes der Selachier. Verh. 8. intern. Zool. Kongr. Graz., pp. 505-511.

1908. Blatzot, L., Observations sur ]a gestation chez Acanthias vulgaris R. Bull. Soe. Zool. Paris, T. 33, pp. 57-59. 
1908. Вцатzот, L., L'Épithélium utérin chez Acanthias vulgaris Risso avant la première gestation. C.R. Soc. Biol. Paris, T. 64, pp. 339-341, 453-454.

1909. Blaizot, L., Recherches sur l'évolution de l'utérus d'Acanthias rulgaris Risso. Mem. Soc. Zool. Paris, T. 22, pp. 5-47, pls. 1-3.

1898. Bles, E. J., The Correlated Distribution of Abdominal Pores and Nephrostomes in Fishes. Jour. Anat. and Physiol., Vol. 32, pp. 484-512, 6 text figs.

1879. BouAu, H, Entwicklung von Scyllium catulus im Hamburger Aquarium. Zool. Garten, Zool. Anz., 1879.

1881. Bolav, H., Ueber die Paarung und Fortpflanzung der Seyllium-Arten. Zeitsehr. wiss. Zool., Bd. 35, pp. 321-325, 2 text figs.

1904. Borcea, I., Sur un cas de conformation abnormale de l'oviducte droit chez une petite Roussette (Scyllium canicula). Bull. Soc. Zool. Paris, T. 29, pp. 138-140.

1904. Borcea, I., Considérations sur l'appareil urinaire des Élasmobranches. Bull. Soc. Zool. Paris, T. 29, pp. 143-148.

1904. Borcea, I., Note complémentaire sur la morphologie du rein des Élasmobranches. Bull. Soc. Zool. Paris, T. 29, pp. 209-210.

1904. BorceA, I., Des différences de structure histologique et de sécrétion entre le rein antérieur et le rein postérieur chez les Élasmobranches mâles. (Note.) C.R. Acad. Sci. Paris, T. 138, pp. 1342-1343.

1904. Borcea, I., Sur le développement du rein et de la glande de Leydig chez les Élasmobranches. C.R. Acad. Sei. Paris, T. 139, pp. 747-749.

1904. Borcea, I., Sur la glande nidamentaire de l'oviducte des Élasmobranches. (Note.) C.R. Acad. Sei. Paris, T. 138, pp. 99-101.

1905. BorceA, I., Sur quelques faits relatifs au développement du rein des Élasmobranches. C.R. Acad. Sci. Paris, T. 140, pp. 672-674, 4 text figs.

1906. BorceA, I., Recherehes sur le système uro-génital des Élasmobranches. Areh. Zool. expér. et gén., Sér. 4, T. 4, pp. 199-484, pls. 15-16, 103 text figs.

1894. BorN, G., Die Entwickelung der Geschlechtsdrüsen. Ergebn. d. Anat. u. Entwick., Bd. 4, pp. 592-616.

1906. Braus, H., Zur Entwieklungsgeschichte niederer Haie. Sitzber. preuss. Akad. Wiss., Berlin, 1906, pp. 907-932.

1903. BRInkMANN, A., Histologie, Histogenese und Bedeutung der Mucosa uteri einiger viviparer Haie und Rochen. Mitt. Zool. Stat. Neapel, Bd. 16, pp. 365-408, Taf. 12-14.

1908. Brommer, P., Exkretionssystem eines Embryos von Chlamydoselachus anguineus Garm. Anat. Anz., Bd. 33, pp. 621-627, 5 text figs.

1909. BuiJtendiJk, F. J. G., On the Constitution of the Urine of Sharks with Normal and Increased Diuresis. (Proc.) Akad. Wet. Amsterdam, XII, p. 380.

1897. Collinge, W. E., The Suprarenal Bodies of Fishes. Nat. Sci., Vol. 10, pp. 318-322.

1867. Coste, M., On Incubation of the Eggs of the Small Spotted Dog-Fish (Scyllium catulus). Ann. Mag. Nat. Hist., Ser. 3, Vol. 19, p. 227.

1839. Davy, John, On the Male Organs of Some of the Cartilaginous Fishes. Phil. Trans. Roy. Soc. Lond., 1839, pp. 139-149.

19(1). DEAN, B., Reminiscence of Holoblastic Cleavage in the Egg of the Shark Heterodontus (Cestracion) japonicus Macleay. Anno. Zool. Japonens., Vol. 4, 7 pp. Abstract: Zool. Centralbl., Bd. 8, pp. 841-842.

1902. Dean, B., The Early Development of Sharks from a Comparative Standpoint. Science (n.s.), Vol. 15, p. 626.

1903. DeAn, B., The Early Development of Sharks from a Comparative Standpoint. Ann. N. Y. Acad. Sci., Vol. 15, 45-46. 
1906. Dean, B., Chimaeroid Fishes and Their Development. Publ. Carnegie Inst., No. 32, 194 pp., 4, 144 figs., 11 pls. Washington.

1904. D'Evant, Tr., Rudimentäre Amnionbildungen der Selachier. Beiträge zur Phylogenie und Entwickelungsmeehanik des Amnion. Anat. Anz., Bd. 24, pp. 490-192.

1901. DoHrs, A., Studien zur Urgesehichte des Wirbelthierkörpers. XVIII-XXI. Mitt. Zool. Stat. Neapel, Bd. 15, pp. 1-279, Taf. 1-15.

1903. Eisiond, J., Ueber das verhalten des Periblastes beim Wachstum der abgefurchten Scylliumkeime. Anat. Anz., Bd. 23, pp. 106-112, 4 text figs.

1878. Fürbringer, M., Das Exeretionssystem der übrigen kranioten Wirbelthiere und seine Entwickelung. Morph. Jahrb., Bd. 4, pp. 36-111, pls. 1-3.

1877. Garman, S. W., On Pelvis and External Sexual Organs of Selachians, with especial references to the New Genera Potamotrygon and Disceus (with Descriptions). Proc. Boston Soe. Nat. Hist., Vol. 19, pp. 197-214.

187:. Gerbe, Z., Recherehes sur la segmentation de la cicatricule et la formation des produits adventifs de l'oeuf des Plagiostomes et particulièrement des Raies. Jour. de l'Anat. et de Physiol., pp. 609-616, pls. 20-22.

1895. Gracomini, E., Sulla regressione del saceo vitellino nei Selacei. Proc. R. Acad. Fisioerit. Siena. Anno 1895, Acad. 203. Extr. in Monit. Zool. Ital., Vol. 6, pp. 24-25.

1896. Giacomins, E., Contributo all' istologia dell' ovario dei Selaci con speciale rigardo sopra ad alcune particolarita di struttura riscontrate nell' ovario di Myliobatis bovina. Geoffr. Ric. Labor. anat. Roma, Vol. 5, pp. 221-274, 2 tar., 2 text figs.

1897. Gregory, Emint R., Origin of the Pronephric Duct in Selachians. Zool. Bull., Vols. 1-2, pp. 123-129, 8 text figs. Also: Science (n. s.), Vol. 5, p. 1000.

1902. Grynfeltt, E., Sur les corps suprarénaux des Plagiostomes. C.R. Assoc. frane. Av. Se. 31me Sess., Pt. 1, p. 236.

1902. Grynfeltw, E., Distribution des corps suprarénaux des Plagiostomes. C.R. Acad. Sci. Paris, T. 135, pp. 330-332, 439-440.

1903. GRyNFELTT, E., Recherches anatomiques et histologiques sur les organes surrénaux des Plagiostomes. Bull. Sci. France-Belgique, Paris, T. 38, pp. 1-136, pls. 1-7, 13 text figs.

1898. Guirel, F., Sur un procéde facilitant la recherche des entonnoirs segmentaires du rein des Sélaciens. Areh. Zool, expér, et gén., Sér. 3, T. 5, 385-400, pl. 18.

1900. Guitel, F., Sur les néphrostomes et les eanaux segmentaires de quelques Sélaciens (Squatina, Scyllium, Centrina, ete.). Arch. Zool. expér. et gén., Sér. 3, T. 8. (Notes et revue), pp. xxxiii-xl.

1901. HALLer, B., Über die Uniere von Acanthias vulgaris, ein Beitrag zur Kenntnis sekundärer Metamerie. Morph. Jahrb., Bd. 29, pp. 283-316, pls. 15-16, 5 text figs.

1840. Hallmann, E., Ueber den Bau des Hodens und die Entwickelung der Saamenthiere der Rochen. Müllers Arch. f. Anat., Bd. 1840, pp. 467-474, pl. XV.

1884. Haswelu, W. A., Note on the Claspers of Heptanchus. Proc. Linn. Soc. N. S. Wales, Vol. 9, pp. 381-382, pl. X.

1897. Hasweld, W. A., On the Development of Heterodontus (Cestracion) philippi. Part I. Proc. Linn. Soe. N. S. Wales, Vol. 22, pp. 96-103, pls. 4-5.

1881. Iferrmann, G., Sur la spermatogénèse chez les Sélaciens. C.R. Acad. Sei. Paris, T. 39, pp. $858-860$.

1882. Herrmann, G., Recherches sur la spermatogénèse chez les Sélaciens. Jour. de l'Anat. et Physiol., T. 18, pp. 373-432, pls. 24-26.

1877. Hrs, W., Ueber die Bildung der Haifischembryonen. Zeitschr. Anat. u. Entrick., Bd. 2, pp. 108-124, Taf. 7. 
1894. Hıs, W., Sonderung und Charakteristik der Entwickelungsstufen junger Selachierembryonen. Arch. f. Anat. u. Physiol. (Anat. Abt.), pp. 337-354, Taf. 21.

1897. His, W., Ueber den Keimhof oder Periblast der Selachier. Eine histogenetische Studie. Arch. f. Anat. u. Physiol., 1897 (Anat. Abt.), pp. 1-64, 32 text figs.

1881. Hoffuann, C. K., Contributions à l'histoire du développement des Plagiostomes. Arch. Neerland., T. 16, pp. 97-115, pl. 5.

1896. Hoffmann, C. K., Beiträge zur Entwicklungsgeschichte der Selachii. Morpl. Jahrb., Bd. 24, pp. 209-286, Taf. 2-5; Bd. 25, 1897, pp. 250-304, Taf. 13-14, 9 text figs.

1890. Howes, G. B., Variation in the Kidney of the Common Thornback (Raia clavata): its Nature, Range, and Probable Significance. Jour. Anat. and Physiol., Vol. 24, pp. $407-422, \mathrm{pl} .17$.

1901. Huber, O., Die Kopulationsglieder der Selachier. Zeitschr. wiss. Zool., Bd. 70, pp. 592-674, pls. 27-28, 12 text figs.; Anat. Anz., Bd. 19, pp. 299-307.

1908. Hussakof, Louis, and Welker, W. H., Notes on the Chemical Nature of Egg Cases of Two Species of Sharks. Proc. Amer. Soc. Biol. Chemists, Vol. 1, pp. 138-139; Jour. Biol. Chem., Vol. 4, pp. 44-45.

1861. HхrтL, J., Úber die Nierenknäuel der Haifische. Verh. Zool.-bot. Ges. Wien, Bd. 11, pp. 125-132.

1898. Jungersen, H. F. E., Ueber die Bauchflossenanhänge (Copulationsorgane) der Selachiermännchen. Anat. Anz., Bd. 14, pp. 498-513, 16 text figs.

1888. Kastschenko, N., Zur Frage über die Herkunft der Dotterkerne im Selachierei. Anat. Anz., Bd. 3, pp. 253-257, 1 Taf.

1890. Kastschenko, N., Ueber den Reifungsprocess des Selachiereies. Zeitsehr. wiss. Zool., Bd. 50, pp. 428-442, Taf. 17.

1899. KoHn, Alfred, Die Nebenniere der Selachier nebst Beiträgen zur Kenntnis der Morphologie der Wirbelthiernebenniere im allgemeinen. Arch. mikr. Anat., Bd. 53, pp. 281-312, Taf. 15.

1890. KollmanN, J., Über Furchung an dem Selachier Ei. Verh. Naturf. Ges. Basel, Vol. 8, pp. 103-105. Abst. Jour. Roy. Mier. Soc. Lond., Ser. 2 (1887), pp. 43-44, pl. 1.

1897. Корsch, Fr., Ueber die Ei-Ablage von Seyllium canicula in dem Aquarium der zoologischen Station zu Rovigno. Biol. Centralbl., Bd. 17, pp. 885-893, 3 text figs.

1870. Kowalevsky, A., Zur Entwicklungsgesehichte der Haifische nach den Untersuchungen an Mustelus laevis und Acanthias vulgaris. (Russian.) Sitzber. d. Naturf. Ges. Kiev.

1908. Kralu, A., Die männliche Beckenflosse von Hexanchus griseus M. u. H. Ein Beitrag zur Kenntnis der Copulations-organe der Selachier und deren Herkunft. Morph. Jahrb., Bd. 37, pp. 529-585, pls. 12-13, 17 text figs.

1920. Leigh-Sharpe, W. H., The Comparative Morphology of the Secondary Sexual Characters of Elasmobranch Fishes. The Claspers, Clasper Siphons, and Clasper Glands. Memoir I. Jour. Morph., Vol. 34, pp. 245-265, 12 text figs.

1921. Leigh-Sharpe, W. H., II. Ibid., Vol. 35, pp. 359-380, 15 text figs.

1850. LeucKart, R., Ueber die allmähliche Bildung der Körpergestalt bei den Rochen. Zeitschr. wiss. Zool., Bd. 2, pp. 254-267, Taf. 16.

1852. LeYDiG, F., Beiträge zur mikroskopischen Anatomie und Entwicklungsgeschichte der Rochen und Haie. Leipzig, 127 pp., Taf. 1-4.

1875. Lunwig, Hubert, Formation de l'oeuf dans les Plagiostomes. Arch. Zool. expér. et gén., T. 4, Notes et Rerue, pp. xv.-xvi.

19(14. MarếChaL, J., Ueber die morphologisehe Entwickelung der Chromosomen im Keimbläschen des Selachiereies. Anat. Anz., Bd. 25, pp. 383-398, 25 text figs. 
1910. Maréchal, J., and Saedeler, A. De, Le premier développement de l'ovocyte. I. Chez les Rajidés. La Cellule, T. 26, pp. 1-24, pl. 1.

1846. Martino, A. DE, Observations sur le développement des spermatozoïdes des Raies et des Torpilles. Ann. Sci. Nat. Zool., Sér. 3, T. 5, pp. 171-174.

1848. Martino, A. DE, Lettera sulla struttura del testicolo e sullo schiudimento degli spermatozoi nelle Raie e nelle Torpedini. Mem. Acead. Torino, Sér. 2, T. 9, pp. lxviii-lxxi.

1890. MEHRDoRf, C., Beiträge zur Kenntnis des anatomisehen Baues und der Entwicklungsgesehichte der embryonalen Anhangsgebilde bei den lebendig gebärenden Haifischen. Diss. Rostock, 1890, pp. 1-51, pls. 1-2.

1875. Merer, Anatomie des Urogenitalsystems der Selachier und Amphibien. Sitzber. Natur. Ges., pp. 38-44, Leipzig, 2 Jahr.

1893. Mitrophanow, P., Étude embryogénique sur les Sélaciens. Arch. Zool. expér. et gén., pp. 161-220, pls. 9-14.

1895. Moore, J. E. S., On the Structural Changes in the Reproductive Cells during the Spermatogenesis of Elasmobranchs. Quart. Jour. Micr. Sei., Vol. 38, pp. 275-313, pls. 13-16, 4 text figs.

1909. MorgerA, A., Ricerehe sulla glandola ed il canale di Leydig nei maschi di Seyllium. Arch. Zool. Napoli, Vol. 4, pp. 179-193, tav. 2.

1831. MülLeR, J., Ueber den körnigen Bau der Hoden bei mehreren Fischen, insbesondere bei Rochen u. Haien. Trevir. Zeitschr., Bd. 4, pp. 106-112.

1840. Müller, J., Ueber den glatten Hai des Aristoteles, und über die Verschiedenheiten unter den Haifischen und Rochen in der Entwickelung des Eies. Abh. Akad. Wiss. Berlin, 1840, pp. 187-258; Berlin Akad., 1839, pp. 49-52.

1842. MülLeR, J., Sur les viscères des poissons, les organes de la génération des poissons cartilagineux, ete. L'Inst., T. X, pp. 430-431.

1903. Mulon, P., Réaction de Vulpian au niveau des corps surrénaux des Plagiostomes. C.R. Soe. Biol. Paris, T. 55, p. 1156.

1899. Nishikawa, T., Notes on Some Embryos of Cllamydoselachus anguineus Garm. Anno. Zool. Japonens., Vol. 2, pp. 95-102.

1882. PARKer, T. J., Notes on the Anatomy and Embryology of Scymnus lichia. Trans. N. Z. Inst., Vol. 15, pp. 222-234, pls. 31-42.

1882. PARker, T. J., On the Gravid Uterus of Mustelus antaretieus. Trans. N. Z. Inst., Vol. 15, pp. 219-222, pl. 30 .

1889. PARker, T. J., Note on the Foetal Membranes of Mustelus antareticus. Ibid., Vol. 22, pp. 331-333, pl. 19.

1896. Peabody, J. E., Embryos of the Smooth Dogfish (Galeus canis). Science (n. s.), Tol. 4, p. 535 .

1905. Perravex, E., Sur la formation de la eoque des oeufs du Scyllium canicula et du Seyllium catulus. C.R. Acad. Sci. Paris, T. 5, No. 24, p. 1080.

1878. Petri, K. R., Die Copulationsorgane der Plagiostomen. Zeitschr. wiss. Zool., Bd. 30, pp. 288-335, Taf. 16-18.

1874. Phipson, F. L., Les Raies et leurs oeufs. Canadian Naturalist, T. 6, pp. 370-374, text figs. 18-19.

1902. Policard, A., Constitution lympho-myéloïde du stroma conjonetif, du testicule des jeunes Rajidés. C.R. Acad. Sci. Paris, T. 134, pp. 297-299.

1903. Polı, H., Die Anlage der Zwisehenniere dei den Haifischen. Arch. mikr. Anat., Bd. 62 , pp. 138-174, Taf. 8, 2 text figs.

1875. Putnam, F. W., On the Male and Female Organs of the Sharks and Skates with special reference to the Claspers. (Abst.) Proc. Amer. Assoc. Adv. Sci., $23 d$ Meeting (1874), Pt. 2, pp. 143-144, pl. II. 
1896. RABt, C., Über die Entwicklung des Urogenitalsystems der Selachier. Morph. Jahrb., Bd. 24, pp. 632-767, pls. 13-19, 32 text figs.

1898. REDEKE, H. C., Onderzoekingen betreffende het Urogenitalsysteem der Selachiers en Holocephalen. Inaug. Diss., Helder, 87 pp., 2 pls., $8^{\circ}$.

1899. Redeke, H. C., Kleiner Beitrag zur Anatomie der Plagiostomen. Tijdschr. Nederland Dierk. Ver. (2 Serie), Deel 6, pp. 110-136, tav. 4-5.

1902. Retzius, G., Ueber einen Spiralfaserapparat am Kopfe der Spermien der Selachier. Biol. Untersuch., Bd. 10, pp. 61-64, Taf. 18.

1909. Retzius, G., Zur Kenntnis der Spermien der Elasmobranchier. Biol. Untersuch., Bd. 14, pp. 79-88, Taf. 32-36.

1885. RüCKERT, J., Zur Keimblattbildung bei Selachiern. Ein Beitrag zur Lehre vom Periblast. München, $58 \mathrm{pp}$.

1887. RÜCKERT, J., Ueber die Anlage des mittleren Keimblattes und die erste Blutbildung bei Torpedo. Anat. Anz., Bd. 2, pp. 97-112, 1 text fig.

1888. RüCKERT, J., Ueber die Entstehung der Exeretionsorgane bei Selachiern, Areh. f. Anat. u. Physiol., pp. 205-278, pls. 14-16.

1859. Rückert, J., Weitere Beiträge zur Keimblattbildung bei Selachiern. Anat. Anz., Bd. 4, pp. 353-374, 1 pl.

1891. Rückert, J., Zur Befruchtung des Selachiereies. Anat. Anz., Bd. 6, pp. 308-322.

1891. Rückert, J., Entwicklung der Exkretionsorgane. Ergebn. d. Anat. u. Entwick., Bd. 1, pp. 606-695.

1892. Rückert, J., Zur Entwickelungsgesehichte des Ovarialeies bei Selachiern. Anat. Anz., Bd. 7, pp. 107-158, 6 text figs.

1892. RüCKERT, J., Ueber physiologische Polyspermie bei meroblastischen Wirbeltiereiern. Anat. Anz., Bd. 7, pp. 320-333, 2 text figs.

1899. RückeRT, J., Die erste Entwicklung des Eies der Elasmobranchier. Festschr. zum 70. Geburtstag von V. v. Kupffer, pp. 581-704, 8 T'af., 7 text figs. or sep. pp. 1-124.

1896. SABAtier, A., La Spermatogénèse chez les poissons Sélaciens. Trav. Inst. Zool. Univ. Montpellier. No. 4, $191 \mathrm{pp.}$

1872. Schenk, S. L., Die Eier von Raja quadrimaculata (Bonap.) innerhalb der Eileiter. Sitzber, der math.-naturwiss. Kl., Bd. 68, pp. 363-374, Wien, pl. 1.

1897. Schnemper, Gumo, Ueber die Niere und die Abdominalporen von Squatina angelus. Anat. Anz., Bd. 13, pp. 393-401, 3 text figs.

1875. Schultz, A., Die embryonale Anlage der Selachier. Med. CentralbI., Bd. 13, pp. 545547.

1875. Schultz, A., Zur Entwickelungsgeschichte des Selachiereies. Areh. mikr. Anat., Vol. 11, pp. 569-582, Taf. 34.

1877. Schultz, A., Beitrag zur Entwickelungsgeschichte der Knorpelfisehe. Areh. mikr. Anat., Bd. 13, pp. 465-478, Taf. 30.

1902. SeDGwick, A., Notes on Elasmobranch Development. Quart. Jour. Mier. Sei. London. (2), Vol. 33, pp. 559-586, pl. 35.

1890. SmMon, RichaRd, U̇ber die morphologische Bedeutung der Urniere in ihrem Verhältnis zur Vorniere und Nebenniere und über ihre Verbindung mit dem Genitalsystem. Anat. Anz., Bd. 5, pp. 455-482, 8 text figs.

1874. Semper, C., Segmental Organe bei erwachsenen Haien. Med. Centralbl., Bd. 12, pp. $817-819$.

1875. Semper, C., Segmental Organs in Adult Selachia. Amn. Mag. Nat. Hist., Ser. 4, Vol. 15, pp. 95-96.

1×75. Semper, C., Bildung und Wachstum der Keimdrüsen bei den Plagiostomen. Merl. Centralbl., Bd. 13, pp. 117-182. 
1875. SeMrPer, C., Das Urogenitalsystem der Plagiostomen und seine Bedeutung für das der übrigen Wirbeltiere. Arb. Zool.-zoot. Inst. Würzburg, Bd. 2, pp. 195-509, Taf. 10-22.

1911. SHANN, EDward W., A Deseription of the Advanced Embryonic Stage of Lamna cor. nubica. 28th Ann. Rept. Fish. Board Scotland, Pt. 3, pp. 73-79, pl. 1.

1840. Stannius, H., Ueber månnliche Gesehlechtsteile der Roehen und Haien. Müller's Arch. f. Anat., 1840, pp. 41-43.

1902. Stephan, P., L'Evolution de la cellule de Sertoli des Sélaciens après la spermatogénèse. C.R. Soc. Biol. Paris, T. 54, pp. 775-776.

1902. Stephan, P., Sur le développement de la cellule de Sertoli chez les Sélaciens. C.R. Soc. Biol. Paris, T. 54, pp. 773-775.

1903. Stephan, P., Recherehes sur quelques points de la spermiogénèse des Sélaciens. Arch. d'Anat. Mie., T. 6, pp. 43-60, pl. 3.

1899. Suzukr, B., Notiz über die Entstehung des Mittelstückes der Samenfäden von Selachiern. Anat. Anz., Bd. 15, pp. 125-131, 6 text figs.

1887. Swaen, A., Etudes sur le développement de la Torpille. (Torpedo occellata.) Areh. de Biol., T. 7, pp. 537-585, pls. 14-16.

1866-67. Trors, E. F., Sull' intima struttura delle villosita uterine dell' Acanthias vulgaris sotto il punto di vista zootomico fisiologico osservazioni. Atti R. Inst. Ven. Sei. Lett. et Art, Vol. 12, pp. 1-6, pl. 1.

1883. Trois, E. F. Recherches expérimentales sur la spermatozoïde des Plagiostomes. Jour. Micrographie, T. 7, pp. 193-196.

1878. Turner, W., Note on the Oviducts of the Greenland Shark (Laemargus borealis). Jour. Anat. and Physiol., Vol. 12, Pp. 604-607, 2 text figs.

1884. VaILlant, L., Remarques sur l'orientation des oeufs dans l'utérus chez les poissons Élasmobranches ovipaires. Bull. Soc. Philo.-Math. Paris, Sér. 7, T. 8, pp. 178-179.

1915. Vafssit̀re and Quintaret, Ann. Mus. Nat. Marseille, T. XV, p. 4.

1898. Virснот, H., Ueber Oberflächenbilder von Selachierkeimen und Mesodermursprungszone. Anat. Anz. (Verh. Kiel), Bd. 14, pp. 43-49, 4 text figs.

1859. Vogt, C., and Pappenheim, Recherches sur l'anatomie comparée des organes de la génération chez les animaux vertébrés. Ann. Sci. Nat., Sér. 4, T. 11, pp. 331-369, 1 pl.

1896. Waite, E., On the Egg-Cases of Some Port Jackson Sharks (Cestracion philippi and Galeatus). Jour. Limn. Soc. Zool. Lond., Vol. 25, pp. 325-329, pl. 12.

1903. WaLlace, War., Observations on Orarian Ova and Follicles in Certain Teleostean and Elasmobranch Fishes. Quart. Jour. Mier. Sei., Lond., Vol. 47 (n.s.), pp. 161213, pls. 15-17.

1907. WidAkowich, VikTor, Über dell Uterus von Squalus acanthias. Bemerkungen zur Entwicklungsgeschichte der Haie. Zeitschr. wiss. Zool. Leipzig, Bd. 88, pp. 499-544, pls. 30-31, 5 text figs.

1907. WidAKowICH, VIKToR, Über eine Verschlusserrichtung im Eileiter von Squalus acanthias. Zool. Anz., Bd. 31, pp. 636-613, 2 text figs.

1908. WIDAKowich, VIKToR, Über einen Musculus sphineter uterorum bei Torpedo ocellata und über das Hymen der Plagiostomen. Areh. f. Anat. u. Physiol. (Anat. Abt.), Jahrg. 1908, pp. 352-370, 4 text figs.

1888. WIJHE, J. W. VAN, Ủber die Entwickelung des Exkretionssystems und anderer Organe bei Selachiern. Anat. Anz., Bd. 3, pp. 74-75.

1888. WiJHe, J. W. VAN, Bemerkung zu Dr. Rückert's Artikel über die Entstehung der Exeretionsorgane bei Selachiern. Zool. Anz., Bd. 11, pp. 539-540.

1889. WiJHe, J. W. van, Ueber die Mesodermsegmente des Rumpfes und die Entwicklung des Exeretionssystems bei Selachiern. Areh. mikr. Anat., Bd. 33, pp. 461-516, pls. $30-32$. 
1898. WiJнE, J. W. VAN, Ueber die Beteiligung des Ektoderms an der Bildung des Vornierenganges bei Selachiern. Anat. Anz. (Verh.), Bd. 12, pp. 31-36, 7 text figs.

1891. Wood-MAson, J., and Alcock, A., On the Uterine Villiform Papillae of Pteroplataea micrura, and their Relation to the Embryo. Proc. Roy. Soc. Lond., Vol. 49, pp. 359367.

1891. Wood-Mason, J., and Alcock, A., Further Observations on the Gestation of Indian Rays. Proc. Roy. Soc. Lond., Vol. 50, pp. 202-209.

1902. Woods, F. A., Origin and Migration of the Germ-Cells in Acanthias. Amer. Jour. Anat., Vol. 1, pp. 307-320, 14 text figs.

1864. Wrman, J., Observations on the Development of Raja batis. Mem. Amer. Acad. Arts Sci., Vol. 9, pp. 37-44. Also: Ann. Mag. Nat. Hist., Vol. 14, p. 399.

1904. ZDAREK, EMLL, Untersuchung der Eier von Acanthias vulgaris, Risso. Zeitschr. physiol. Chem. Strassburg, Bd. 41, pp. 524-529.

1892. Ziegler, H. E., and Ziegler, F., Beiträge zur Entwickelungsgeschichte von Torpedo. Arch. mikr. Anat., Bd. 39, pp. 56-102,pls. 3-1, 10 text figs.

1894. ZiEGLER, H. E., Ueber das Verhalten der Kerne im Dotter der meroblastichen Wirbeltiere. Ber. d. natur. Ges. Freiburg, Bd. 8 (Festschr. f. Weismann), pp. 192-209.

1898. ZIEGLER, H. E., Der Ursprung der mesenehymatischen Gewebe bei den Selachiern. Arch. mikr. Anat., Bd. 32, pp. 378-400, pl. 13.

1902. ZieGLER, H. E., Lehrbuch der vergleichenden Entwickelungsgeschichte der niederen Wirbeltiere. Jena.

1908. Ziegler, H. E., Ein Embryo von Chlamydoselachus anguineus Garm. Anat. Anz., Bd. 33 , pp. 561-574, 7 text figs. 


\section{INDEX*}

Abdominal pores, 126,142 ; function of, in Cyclostomes, 142

Abducens nerve, 223-224, 236, 241; foramen of, 44, 60; muscle supplied by, 100, 223-224, 241; nucleus of, 236

Abyssal habitat, 1

Acanthias, 2, fig. 5; ef. Urolophus, 8, 10, 11

Acanthodes, 1

Accessory efferent-collector arteries, 180

Accessory lateral cutaneous vein, 217

Accessory valves of conus, 172

Accommodation of eye, 269-270

Adductor mandibulae, 93, 107 ; artery to, 182 ; function of, 93 ; nerves of, 241

Adductor muscles, 93, 107; absent from hyoid, 93, 107; of Chlamydoselachus, 107-108; of claspers, 95, 110-112; of visceral arches, $90,103,107$

Adductores arcus, 107

Advehentes, 200, 208

Afferent arteries, 149, 161, 172-173; branchial, 161, 172, 173; formation of, 178; hyoidean, 161, 172, 173; in holobranch, 149, 153, 157, 173

Alisphenoidal cartilage, 53, 55

Alopias, 2, fig. 2

Amphistylic, 45

Ampullae of Lorenzini, 7, 262, 274, 279280 ; development of, 281 ; distribution of, 262, 279-280; modified in spiracle, 153,280 ; nerves to, 224, 242, 243, 262, 280

Ampullae of semicircular canals, 258-259, 273 ; nerves to, 224-225; 261,273 ; strueture of, 273

Ampullary centrum, 280

Ampullary organs. See Ampullae of Lorenzini

Ampullary pockets, 280

Anal fin, 6, 12, 52; absence of, 12 ; arteries to, 194; skeleton of, 52,83 ; vein from, 217

Aneient sharks, 1, 2

Angel fish. See Squatina

Annular arteries, 167, 188

Annular veins, 201, 210, 211

Anterior cardinal sinus, 198, 205, 206, 207

Anterior cardinal system, 204-208
Anterior cardinal vein, 198, 204

Anterior cerebral artery, 165, 183

Anterior cerebral vein, 204, 206-207; fo. ramen for, 44 ; tributaries of, 206-207

Anterior dorsolateral artery, 168, 191

Anterior facial vein, 204

Anterior fontanelle, 43, 57

Anterior gastric artery, 166, 190

Anterior gastric vein, 201

Anterior gastro-pancreaticosplenic artery, 167, 189-190; in Dasyatis, 188

Anterior gastro-pancreaticosplenic vein, 200,211

Anterior gastrosplenic artery, 188

Anterior intestinal artery, 166, 188; branches of, 166

Anterior intestinal vein, 201, 210-211; in rays, 210; tributaries of, 201, 210-211

Anterior lateral artery, 192. See also Lateral abdominal artery

Anterior lobe of hypophysis, 234

Anterior mesenteric artery. See Superior mesenteric artery

Anterior oblique semicireular canal, 258, 261,273

Anterior rectus muscle. See Internal reetus muscle

Antorbital process, 44, 60 ; function of, 60 ; muscle from, 93

Aortic arches. See Embryonic aortic arches Appendicular skeleton, 49-52, 75-83; divisions of, 49

Aqueduct of Sylvius, 235-236

Aqueous humor, 267

Areuales communes muscles, 93

Arcus communes, 108, 109

Argentium, 27

Armament, 1

Arteria spinalis, 165, 193

Arteries, 161, 170, 172; cf. veins, 170; in Elasmobranchs in general, 172-194; in Heptanchus, 161-169; to deeper structures, 169, 192-193; to digestive tract, 166-168, 186-191; to extremities, 168, $169,191-192$; to head, $165,180-186$; to heart, $163-164,179-180$; to hypobranchial area, 162-165, 178-180; to trunk, 186 ; to tail, $169,186,193-194$

Ascending aorta. See Ventral aorta

\footnotetext{
*For coördination of entries see Contents.
} 
Asterospondyly, 75

Atrium. See Auricle

Auditory (otic) capsule, 43, 55, 258, 271; in embryo, 55

Auditory nerve, 224-225, 243, 261, 273; ganglion of, 224-225, 243

Auditory organ (ear), 258-259, 264, 271273

Auricle, 160, 170-171

Auriculoventricular valves, 161, 171

Autonomic nervous system. See Sympathetic system

Axial cartilage. See Basal cartilage

Axial skeleton, 43-49, 53-75

Axis cylinder, 238

Axone, 229, 238; origin of, 238

Basal angle, 44,55 ; origin of, $53-55$; relation of, to orbital process, 44

Basal (axial) cartilage, 50, 51, 81

Basal (germinative) layer of epidermis, 23,26

Base of scale, 24, 32

Basibranchial cartilage, $46,65,66$

Basilar artery, 186

Basipterygium, 50, 51, 81, 82

Batoidei, 8

Beaker cell. See Gland cell

"Beta" cartilage, 50, 51, 80, 95

Bile, 137

Bile duct, 124, 137

Bipolar nerve cell, 229, 238; development of, 229,238

Blood, 204

Blood stream, 170

Body eavity. See Coelom

Body shape. See External form

Bowman's capsule, 296, 298, 299-300, 302; origin of, 299-300; transformation of, in male, 302

Brachial artery, 168, 191; in ray, 191

Brachial vein, 202, 213, 214

Brachioseapular artery, 168, 179

Brachioscapular vein, 214

Brain, 221-222; 229-236; arteries to, 165, 183-186; development of, 230 ; form of, 230-235; finer structure of, 236 ; veins of, 198, 205, 206-207

Branchial adductors, 93, 107

Branchial afferent arteries, 161, 172-173; in Chlamydoselachus, 173

Branchial arehes, 45-46, 64-66; museles of, 93, 105-108; relation of, to gill pouch, 147-148; segments of, $45-46$,
64-66; supernumerary rudimentary, 47, $65-67$

Branchial basket, 46, 204

Branchial clefts, external, see Gill clefts; internaI, see Internal branchial apertures

Branchial efferent arteries, 165, 182

Branchial nerves: of glossopharyngeal, 244 ; of vagus, $149,225-226,245$

Branchial rakers. See Gill rakers

Branchial rays, 45, 46, 67; in Torpedo, 67 ; on hyoid arch, 45, 67; relation of, to gill septum, 91, 152; relation of, to muscles, 93, 105-106, 152

Buceal ampullae, 262, 279; divisions of, 262, 279; nerve to, 224, 242

Buccal artery, 182

Buceal cavity, 121-122, 128; lining of, 128; stomodeal denticles in, $31,38,128$; teeth in, 38, 128-131.

Buccalis nerve, 224, 242; function of, 262, 279 ; ganglion of, 242

Bursa entiana, 136

Calcification, 53, 74-75

Canals of head, 261-262, 274, 276-277; development of, 275 ; divisions of, $274-$ 275 ; in rays, $277-278$; nerves to, 262 , 278-279

Capillaries, 153, 157, 161, 170, 173, 212

Carcharias, 2, 9, fig. 16

Cardiac stomach, 123, 135

Cartilage, 53

Cartilaginous branchial rays. See Branchial rays

Caudal (aorta) artery, 166, 169, 186

Caudal fin, 6, 12, 14; skeleton of, 51-52. 74

Caudal vein, 199, 208

Caudal vertebrae, 72, 74

Caudate lobe of liver, 124, 137

Central canal of testis, 290, 301 .

Central nervous system, 221-222, 229238 ; development of, 230

Centrum, 48, 69, 71; calcification of, 70 ; development of, 70

Cephalic canals. See Canals of head

Cephaloptera, 3 ; locomotion in, 13

Cephatoscyllium, 2, fig. 1; color in, 27

Ceratobranchial cartilages, $45,46,64,65$, 67 ; muscles to, 92,152

Ceratohyoid cartilage, 45

Cerebellum, 22:, 234 
Cerebral arteries, 165, 183-186; divisions of, 165,183

Cervieal plexus, 227, 246

Cetorhinus (Selache) maximus, 3, fig. 4; gill rakers of, $37,38,154,155$

Cheiloscyllium, color of, 26

Chlamydoselachus anguineus, adductor muscles of, 108 ; afferent arteries of, 172173; cranium of, fig. 46 ; dorsal fin of, 6 ; duct to thyroid, 134 ; nervous collector of, 247 ; plan of fin skeleton, 77; teeth of, 128-130

Chorda. See Notochord

Chorda tympani, 224, 243

Chordae tendineae, 161, 171

Choroid coat of eye, 269

Chromatophores, 26

Circular constrictor museles. See Superficial constrictors

Ciliary body, 267, 268

Ciliary ganglion, 240 ; relation to sympathetic, 247

Ciliary nerve, 223, 241

Circle of Willis, 184

Circulation of blood, in gill filament, 157

Circulatory system, 160, 170, 198, 204; divisions of, 170; of Elasmobranchs in general, 170-194, 204-218; of Heptanchus maculatus, 160-169, 198-203

Cladoselachus, 1, fig. 10; muscle fibers of, 1 ; paired fins of, 15

Clasper, 6; as secondary sexual characteristic, 309 ; function of, 291, 309 ; museles of, $95,110-112$; relation of, to apertures of uterus, $309-310$; relation of, to siphon, 310 ; skeleton of, 51, 8182

Climatius (?), 1, fig. 11

Cloaca, 126, 141; ducts to, 126, 141, 291, 298; lining of, 126, 141

Cloacal papillae, 126, 141

Cloacal pits, 141

Cloacal vein, 203, 213

Coeliac axis, 166, 186; branches of, 166 , 167, 186-188

Coeliacomesenteric artery, 190

Coelom, 96

Collecting tubules, 287, 289, 294, 295, 297, 298, 299; development of, 299-300

Colon, 126, 141

Color, 6, 26-27

Commissural arteries, $162,178-179$

Compressor musele, 95, 111-112

Cones of retina, 269
Constrictor of sac, 95

Constrictor spiraculae, 103

Conus arteriosus, $160-161,170$, 172 ; valves of, 161, 172

Coracoarcuales muscles, 93, 94, 108

Coracobranchial museles, 94, 109

Coracohyoideus muscles, 94, 109

Coracoid artery, 163, 168, 179, 192

Coracoid cartilage, $49,79,80,81$

Coracoid vein, 202, 203, 217

Coracomandibularis muscles, 93-94, 109

Corium, 23, 26; origin of, 96

Cornea, 258, 267

Coronary artery, $164,179-180$; posterior, 164,168

Coronary vein, 215

Corpora bigemina. See Optic lobes

Corpora restiforme, 222, 235

Corpus luteum, 301, 303

Cranial canals. See Canals of head

Cranial nerves, 223-227, 238-246; abducens, 223-224, 241; auditory, 224-225, 243 ; facial, 224, 241-243; glossopharyngeal, 225, 243-244; oculomotor, 223 , 239-240; olfactory, 223, 238-239; optic, 223, 239; trigeminal, 223, 240241; trochlearis, 223, 240; vagus, 225 227, 244-245

Cranium, 42-44, 53-61; development of, 53-55; of Chlamydoselachus, 43; of Zygaena, 58-60

Cross-trunks, $162,174,175,176-177$

Crystalline lens. See Lens

Cupula terminalis, 272, 273

Cutaneous veins, 204, 216-217; nature of, 217-218

Cuticular plate. See Dermatome

Cyclospondyly, 74

Danielian sinus, 198, 199

Dasyatis dipterura, anterior gastro-pancreaticosplenic artery of, 190; sting of, 37

Demibranch, 148; absent behind last eleft, 176 ; kinds of, 148

Dendrite, 229

Dental ridge, 128

Dentinal canals, 32, 35, 37, 130-131

Dentinal papillae, 128

Dentine, 32, 33, 131; of fin spine, 33-34; of saw tooth, 35; of sting, 37 ; types of, $33-35$

Depressor hyomandibularis, 104, 105

Depressor of lid, 102 
Depressor mandibulae, 105

Depressor rostri, 105

Dermal fin-rays, 89, 94

Dermal papilla, 30

Dermatome, 96

Dermis. See Corium

Digestive tract, 121-126; 127-142; arteries to, 166-168, 186-191; development of, 127-128; mesenteries of, 121, 127 ; veins of, 200-201, 210-212

Diencephalon, 221, 230-233; eavity of, 236 ; outgrowths from, 233

Digitiform gland. See Rectal gland

Dilator muscle of sac, 95, 111, 112

Dilator spiraculae, 102-103

Diphycercal, 74

Diplospondyly, 51, 72, 74; function of, 74 ; incomplete, 49

Disceus thayeri, 10, fig. 21

Diverticula of spiracle, 148,153 ; nerve to, 153

Dorsal aorta, 165-166, 186; development of, 186 ; paired, 165,186 ; tributaries of, 166,186 ; unpaired, 165, 186

Dorsal bundles, 89, 96, 99

Dorsal constrictor muscles, 90-91, 102104

Dorsal cutaneous vein, 202, 203, 216-217

Dorsal fin, 6, 12, 14; in notidanids, 6; position of, 12 ; skeleton of, $51,82-83$

Dorsal gastric artery, 187

Dorsal horn of cord, 222, 237

Dorsal intercalary plate, $47,48,70,71$

Dorsal intestinal artery, 167, 190

Dorsal intestinal vein, 200-201, 211; tributaries of, 211

Dorsal marginal cartilage, 82

Dorsal myelonal vein, 208

Dorsal plate, $47,48,72$; foramen of, 48 ; incomplete diplospondyly, 49

Dorsal pterygial vein, 213

Dorsal root ganglion, 227,246

Dorsal root nerve, 227, 246; foramen of, $48,210,246$

Dorsal spinal vein of ray, 210

Dorsal suspensory ligament of eye, 270

Dorsolateral artery, 168, 191

Dorsolateral bundle, 97

Dorsomedian bundle, 97

Duet of Cuvier, 171 ; tributaries to, 198 $199,200,202,205,210,212,214$

Ductless glands, 134

Ducts of kidney, 294-296

Ductus choledochus, 124, 137-138
Duodenum, 124, 136-137; arteries to, 166167 ; blind saes of, 137 ; derivatives of, 136-137; ducts to, 124, 137, 138; mesen. tery of, 121

Ear, 258-261, 264, 270-274; capsule of, 258,271 ; development of, 274 ; nerve of, 261,273 ; parts of, $258-259$

Ear stones. See Otoliths

Ectethmoidal process. See Antorbital process

Efferent arteries, 165, 182; branchial, 165, 175, 182; development of, 175; hyoidean, 165, 182

Efferent branchial arterioles, 157

Efferent-collector arteries, 161-162, 173177 ; branches of, 163-165, 178-180; development of, 175-177; in holobranchs, $149,153,157,162$

Egg (ovum), 303; development of, 303; hatching of, 305-306

Egg shell, 305-306; attachment of, 305; flanges on, 305 ; perforation of, 306 ; production of, 305 ; teudrils of, 305 ; types of, $305-306$

Elasmobranch fishes, divisions of, 8 ; series of, $9-10$

Elastica externa, 69, 70

Elastica interna, 69,70

Electric cone, 114

Electric dises, 112, 113, 114; layers of, 114

Electric nerve, 115, 243, 244

Electric organ, 112 ; anatomy of, 114-115; in Torpedo, 115; nerves of, 115, 243, 244 ; origin of, in rays, 114

Electric ray (Torpedo), 3

Embryonic aortic arches, 175; derivatives of, 178

Enamel, 30, 32; derived from, 132-133; in rays, 32 ; nature of, 32 ; of fin spine, 33 ; of saw tooth, 35 ; of sting, 37 ; of teeth, 128, 130; in Carcharias, 132-133

Enamel organ, 30, 33, 35, 128

Endolymphatic duets, 5, 43, 55, 259, 271 . 272,273

Endorachis, 237

Endoskeleton. See Skeleton

Ependymal cells, 229-230

Epiblastic fold, 15

Epibranchial cartilages, 45, 64, 65, 93, 107 Epidermis, 23, 28, 30 ; derivatives of, 2838 ; layers of, $23,26,30$

Epididymus, 301 
Epigastric artery, 163, 179

Epigonal organ, 190, 300, 303; artery to, 190 ; relation of, to rectal gland and testes, 300

Epiphysis, 233; development of, 233

Erythrocytes, 170

Etmopterus, light organs of, 29-30

External branehial apertures. See Gill elefts

External carotid artery, 164, 180

External filaments of embryo, 148, 151, 152

External flexor musele, 95, 110-112

External form, 5-7, 8-16; in development, $10-12$

External mandibular (VII) nerve, 243; divisions of, 243; ganglion of, 243

External (posterior) rectus muscle, 90, 100 ; nerve to, 100 , 223-224, 241 ; origin of, 99

Extrabranchial cartilages, 47, 67,69 ; relation to gill septum, 69, 149

Extrahyal cartilage, 67,69

Extraseptalia, 69

Extravisceral cartilages, 47, 67, 69

Eye, 5, 258, 266-270; development of, 269; muscles of, $89-90,99-100$; orbit of, 58 ; pupil of, 258 ; structure of, 267 269

Eyeball, 60, 258; muscles to, 89-90, 99, 101

Eyelid, 5, 258, 267; museles to, 102; movable, in Scyllium, 267

Eye muscles, 89-90, 99-100, 258; development of, 99-100; nerves to, 221, 223, $240,241,242$

Facial nerve, 224, 241-242; divisions, 224, 241-242; nucleus of, 241 ; sensory fibers of, 241

Fallopian tube, 304, 310

Fasieuli lateroventrales, 235

Fasiculi longitudinales mediales, 235

Femoral artery, 169, 192

Femoral vein, 202, 213

Fenestrae, 43, 55, 271

Fibrillae of nerve, 238

Filaments. See Gill filaments

Fins, 1; anal, Heptanchus, 6, 12 ; ancestral type of, 14-16; caudal, Heptanchus, 6, 12; dorsal, Heptanchus, 6, 12, 13; form and position of, $12-16$; function of, 1214

Fin-fold theory, 14-15, 247
Fin spine, 33; development of, 33-34; parts of, 33

Foramen of (foramina): abducens nerve, 44 ; 60 ; anterior cerebral vein, 44 ; dorsal plate, 48; dorsal root nerve, 48 , 246; facial, 44, 60; interealary plate, 48; internal carotid artery, 53 ; interorbital canal, 44; magnum, 57; oculo. motor nerve, 44, 60; ophthalmicus profundus nerve, 43,60 ; ophthalmieus superficialis (VII) nerve, 44, 60 ; orbitonasal canal, 44 ; optie, 44, 60 ; pectoral girdle, 49,81 ; pelvic girdle, 51 ; ramus anastomoticus artery, 44 ; trochlear, 44 . 60 ; ventral root nerve, 48,246

Forebrain, 230

Formatio-reticularis, 237

Fossa rhomboidalis, 235

Fourth ventricle, 222, 235, 236

Funnel (nephrostome), 296

Funnel of oviduet, 290

Galeus, color of, 26

Gall bladder, 124, 137

Ganglion: gasserian, 240, 241; geniculate, 242, 243; habenular, 236; oculomotor, 240 ; ophthalmicus profundus, 240; ophthalmicus superficialis (V), 240; sympathetic, $247-248$

Gastric artery, 166-167, 187

Gastric juice, 135

Gastric veins, 200, 201

Gastroduodenal artery, 166, 167, 188

Gastrohepatic artery, 166, 186

Gastro-pancreaticosplenic artery, 188

Gastrosplenic vein, 201

General cutaneous nucleus, 236

Genital glands, 290

Genital organs: of female, 290, 291, 303309 ; of male, $290,291,300-303$

Genital ridge, 300

Genital system, 290-291, 300-309; relation of, to urinary system, 292

Germ cells, 300

Germinative layer of epidermis, 23

Gill. See Holobranch

Gill-arch theory of Gegenbaur, 14-15

Gill elefts, $5,11,132,147,148,150$; in Heptanchus, 147 ; in rays, 150 ; in Squatina, 9

Gill filaments, 147, 148, 149, 151, 152, 154, 173 , attachment of, 149, 151; blood to, 153, 157, 175; eireulation in, 157; embryonic, 148,152 ; on spiracular pocket, 153 
Gill pocket, 147, 150; accessory, 151; apertures of, 147, 151; development of, 151; filaments on, 147; in Heptanchus, 147

Gill rakers, 37, 147, 154; of Cetorhinus, 37, 154; of Squalus sucklii, 37, 154

Gill septum, 147, 148-149; attachment of, 149

Gill supports, 148

Gland cell, 23, 28; in buccal cavity, 28; in cloaca, 28 ; lumen of, 28 ; modified, in light organs, 29; of claspers, 28; of sting, 28; origin of, 28

Glomeruli of olfactory bulb, 239, 264

Glomerulus, 296, 299

Glossal projection, 65

Glossopharyngeal nerve, 225, 243-244; branches of, 225, 244; ganglion of, 225 , 244; nucleus of, 243

Goblet cells. See Gland cells

Golden cells, 27

Grey matter of cord, 237

Guanin, 27

Gular line, 263

Gustatory organs, 264, 265-266

Gynandromorphism, 309

Habenular ganglion, 236

Haemal arch, 47

Haemoglobin, 170

Hair cell, 273, 278; of ampulla, 273; of neuromast, 278

Hammerhead shark (Zygaena), 2.

Head somite, 99

Heart, 160, 170-172; arteries to, 163-164, 178-180; nerves to, 227; position of, 160 ; rooms of, 160,170 ; veins of, $215-$ 216

Hepatic artery, 166, 187

Hepatic portal system, 200, 204, 210-212; development of, 212 ; parts of, 200$201,210-212$; relation of, to subintestimal, 208, 212

Hepatic portal vein, 201, 211; tributaries of, 211

Hepatic vein, 200, 201, 211, 213

Heptanchus, figs. 12, 13, 14, 15

Heptanchus maculatus, 2, 3; antorbital process of, 44; arteries of, 161-169; digestive tract of, 121-126; endoskele. ton of, 43-52; external form of, 5-7; genital system of, 290-291; integument of, 23-25; musculature of, 89-95; nervous system of, 221-228; respiratory tract of, 147-149; special senses of, 258-263; veins of, 198-203

Heptranchias, 3 note

Heterocercy, 74

Heterodontus francisci, 2, fig. 17; egg case of, 305 ; melanophores of, 27 ; teeth of, 130

Hexanchus, 2, 3; hypobranchial arteries of, fig. 169

Hindbrain, 230

Holobranch, 148

Horizontal semicircular canal, 258, 273; development of, 274

Horns of cord, 222, 237; dorsal, 222, 237 ; ventral, 222,237

Hymen, 309

Hyoid arch, 45, 63; attachment of, 45, 58,63 ; museles of, 92

Hyoidean afferent artery, 161, 172

Hyoidean ampullae, 279-280

Hyoidean efferent artery, 165, 182

Hyoidean nerve. See Ramus hyoideus (VII)

Hyoidean sinus, 208

Hyoidean somite, 99

Hyoidean vein, 208

Hyomandibula, 63-64

Hyomandibular canal, 261, 274, 277; modification of, in rays, 277 ; nerves to, 224, 242, 243, 279

Hyomandibular nerve, 224, 242, 243; branches of, 224 ; foramen of, 44

Hypobranchial arteries, 162-165, 178180 ; lateral, 163, 178; median, 163, 179

Hypobranchial cartilages, 45-46, 64, 65; attachment of, 46 ; muscles to, 94

Hypobranchial muscles, 90, 93, 108-109; nerves to, 227,246 ; origin of, 108

Hypophysis, 233; divisions of, 233

Iliac artery, 169, 192

Iliac vein, 213

"Indifferent stage" of sex, 300

Inferior jugular vein, 199, 204; tributaries of, 199

Inferior lobes of brain, 221, 233

Inferior lobes of hypophysis, 234

Inferior mesenteric artery, 167-168, 186, 190-191

Inferior oblique muscle, 89, 100; in Pristiophorus, 100 ; origin of, 99 ; nerve to, 100, 223, 239-240

Inferior rectus muscle, 90,99 ; origin of, 99 ; nerve to, $100,223,239-240$ 
Infraorbital canal, 242, 261, 274, 277; nerve to, $224,242,279$

Infraorbital plate, 53, 57; absence of, 57

Infundibulum, 221, 233, 236

Inner buecal ampullae, 262, 279

Inner zone, 70

Integument, 23, 26; in Elasmobranchs in general, 26-38; in Heptanchus, 23-25

Interarcuales museles, 90, 92, 106; dorsal, 92,106 ; lateral, 92, 106-107

Interbranchial muscles, 91, 105-106, 149, 151

Intercalary plate, 48,72

Intercostal arteries, 169, 193

Intermediate lobe of hypophysis, 234

Internal branchial aperture, 37, 147, 154; relation to gill rakers, 154

Internal carotid artery, $165,182-183$; foramen of, 53 ; relation to ramus anastomoticus, 165, 183

Internal flexor muscle, 95, 112

Internal mandibular nerve, 243

Internal pretrematicus (IX), 225

Intermal (anterior) rectus muscles, 90,99; nerve to, 100, 239; origin of, 99

Interorbital canal, 44, 205

Interorbital vein, 198, 205

Intima, 170

Intraintestinal artery, 166, 188

Intraintestinal vein, $200,210,212$; in Zygaena, 210 ; relation of, to subintestinal vein, 210,212

Iris, 258, 267; of light organ, 29

Kidney, 287, 289, 292; arteries to, 169, 193; ducts of, 294-296; finer anatomy of, 296; in Elasmobranchs in general, 292-294; in Heptanchus, 287 ; in rays, 292 ; metamerism of, 292 , 299 ; metamorphosis in male, 292, 302 ; sexual differences in, 289, 292; veins of, 200, 208, 209,210

Labial cartilage, 67, 68; in Heptanchus, 68 ; in Hexanchus, 68

Laemargus, photophores of, 29

Lagena, 261, 272; nerre to, 273

Lamina terminalis, 239

Lamna cornubica, 9 ; muscles in tail of, 97

Lateral (abdominal) artery, 168, 179

Lateral abdominal system, 202, 204, 214, 217 ; history of, 214-215

Lateral abdominal vein, 202, 213; tributaries to, 202, 213-214
Lateral bundles, 97

Lateral cutaneous veins, 203, 214, 217; relations of, 203,217

Lateral fin-fold, 14, 15, 214

Lateral fin-fold theory, 14; evidence for, 15

Lateral hypobranchial artery, 162-163, 178

Lateral line, 264, 274, 275, 276; in Acanthias, 276; development of, 264, 275276, 278; function of, 279; in Heptanchus, $7,89,261$; nerves to, $225,242,243$, 278 ; section through, 278

Lateral plate, 96, 109

Lateral pterygial artery, 191

Lateral pterygial vein, 213

Lateral septum, 97

Lateral ventricles, 236

Lateralis nerve, 225, 245, 278

Lens cell of light organ, 29

Lens of eye, 267 ; development of, 269

Leopard shark (Triakis), color of, 26

Levator hyomandibularis, 103

Levator labialis muscles, 93, 100-101

Lerator maxillae, 90, 101, 102; nerves of, 241 ; relation of, to first dorsal constrictor, 90

Levator rostri, 104

Lipochrome, 27

Lipophores, 27 ; in Heterodontus, 27

Littoral, 1

Liver, 124, 137; artery to, 166, 187; ducts of, 124, 137; lobes of, 124, 137; oil of, 137 ; veins of, $211-212$

Lobes of ragus, 236,237

Lobi inferiores, 233

Locomotion: caudal, 13; pectoral, 12, 13

Longitudinal canal of epididymus, 301

Lymphatic vessels, 218

Lymphocytes, 133

Lymphoid organ, 133

Macula neglecta of ear, 273; hair cells of, 273 ; nerve to, 273

Mandible, 63, 92, 279; museles to, 92, 9394

Mandibular ampullae, 279

Mandibular arch, 44, 45, 62, 63; articulation of, 45,63 ; attachment of, in Heptanchus, 45; in embryo, 62 ; parts of, 45,62

Mandibular branch (V), 223, 240, 241; ganglion of, 240 ; motor fibers of, 240; sensory fibers of, 240 
Mandibular canal, 275 ; nerves to, 243

Mandibular groove, 262; nerve to, 224

Mandibular somite, 99 ; muscle derivatives of, 99

Marginal cartilage of clasper, 81-82

Maxillaris branch (V), 223, 240, 241; ganglion of, 240,241 ; origin of, 241

Meckel's cartilage. See Mandible

Median anterior suleus, 231

Median cardiac vein, 215

Median cerebral artery, 165, 183

Median hypobranchial artery, 163, 178, 179

Median hypobranchial piece, $46,65,67$

Median longitudinal bundles of medulla, 235

Median olfactory nucleus, $221,232,239$

Median pterygial artery, 191

Median pterygial vein, 213

Median vesicle, 296, 298; derivation of, 298,300 ; relation of, to segmental duct, 296 , 298; relation of, to collecting tubules, 297

Medulla, 222, 235, 236; finer structure of, 236 ; section through, 236

Melanophore, 26; in Heterodontus, 26

Meningeal lining, 237

Mesencephalon, 221, 222, 230, 234; fibers terminating in, 239; in Heptanchus, 2:21-222

Mesenteric arteries: inferior, 167-168, 190-191; superior, 167, 188-190

Mesenteries, 121, 127-128; in Heptanchus, 121; in Hypnos, 127

Mesopterygium, 50, 77, 78

Mesorchium, 290 ; vasa efferentia on, 302

Mesorectum, 121, 297; nephrostomes on, 290

Mesorarium, 290, 303

Metapterygium, 50, 77; development of, $77-79$

Metencephalon, 221, 222, 230, 234; cavity of, 235-236; in Heptanchus, 221-222

Midbrain. See Mesencephalon

Mixed nerve, 243,246

Motor fibers, 236; origin of, 236

Motor (ventral) root, 246

Mouth, 5, 121, 128

Mucous pores, 7, 262

Multipolar nerve cell, 229

Muscle buds, 109, 110; growth of, 238; of fin, 109, 110; bearing of, on origin of fin, 110

IIuscles of eye. See Musculature
Muscle fibers, 96-97; in Cladoselachus, 1; metamorphosis of, to electric dises, 114115

Muscularis, 170

Musculature: buecal and pharyngeal, 9093, 101-108; dorsal bundles, 89 ; of claspers, $95,110-112$; of Elasmobranchs in general, 96-112; of electric organ (developing), 112-114; of eye, 89-90, 99-100; of eyelid, 102-103; of fin, 89, 95, 109-110; of Heptanchus, 89-95; of hypobranchial region, $93,108-109$; to lens, 269-270; ventral bundles, 89, 97

Musculospinal artery, 192

Mustelus californicus, 9 ; color of, 26 ; nictitating membrane of, 102

Myelencephalon, 221, 222, 235; cavity of, 235-236; in Heptanchus, 221; nerres from, 235

Myelonal artery, 186, 192

Myelonal veins, 208

Myliobatis californicus, 3 , fig. 8

Myoblast, 96

Myocoele, 96

Myosepta, 89, 96, 97; direction of, 89, 96, 97 ; in electric organ, 112

Myotome, 96, 109; derivative of, 109

Nasal apertures, 5; in Elasmobranchs in general, 264-265; in Heptanchus, 5, 44, 258

Nasal capsule. See Olfactory capsule

Nasal cartilage, $43-44,58$

Nasal pit or cup, 5; relation of, to oronasal groove, 122

Neopterygium, 79

Nephrostome, 296, 297, 298, 301; development of, 298

Nerve cells, 229

Nerve fiber. See Axone

Nerves: cranial, 223-227, 238-246 ; oceipitospinales, 227, 245-246; spinal, 227228, 246-247; sympathetic, 247-248

Nervous collector, 228, 247; relation of, to origin of paired fins, 247

Nervous system: central, 221-228, 229248; development of, 230; in Elasmobranchs in general, 229-248; in Heptanchus, 221-228; peripheral, 222, 238

Neural arehes, 47,69 ; composition of, 47 48

Neural canal, lining of, 237

Neural crest, 238

Neural fold, 230 
Neural tube, 230, 238; eells of, 229-230, 238

Neurilemma, 238

Neurocoele, 230

Neurogleal cell, 230

Neuromast, 262, 275, 278

Neurone, 229

Neuropore, 230, 239

Nictitating membrane, 5, 102, 266; absent in Heptanchus, 5; development of, 266 ; muscles of, 102-103

Nictitator muscle, 102,103

Nitrogenous waste matter, removal of, 289 , 296,298

Notidanids, 3, 6, 71, 364; auditory region of, 58

Notochord, 47, 70; constructions, 47-48; relation of, to spinal column, 47, 70; section through, 48, 70; sheath of, 47 , 70

Notochordal sheath, 48, 70, 75; zones of, 48,70

Notorhynchus (Heptanchus), 3 note

Nutrient arteries, 180

Nutrient vein, 205, 207

Occipital condyle, 57 ; in rays, 57

Oecipital erest, 43

Occipitospinales nerves, 71, 227, 245-246

Oculomotor nerve, 222, 223, 234, 239; division to eye muscles, 239-240; foramen of, 44; ganglion of, 240 ; museles supplied by, 100; origin of, 239

Odontoblasts, $30,33,34,130$

Oesophagus, 123,134 ; cells of, 134 ; folds of, 123 ; lining of, 123, 134

Olfactory bulbs, 223, 239, 258, 264

Olfactory bundle. See Olfactory nerve

Olfactory capsule, $43,53,57,238$; in embryo, 53-55; in Zygaena, 55

Olfactory cells, 264

Olfactory fila, 239

Olfactory lobe of brain, $223,239,258,264$

Olfactory membrane, 239, 258, 265

Olfactory nerve, 223, 238-239, 258, 264, 265

Olfactory organ, 258, 264-265; circulation in, 265; divisions of, 264-265; funetion of, 265 ; nerves of, 264

Olfactory receptors, 258

Olfactory sac, 264

Olfactory tract, 221, 223, 239, 258, 264

Omentum, 121

Omphalomesenteric vein, 212
Oöcyte, 303 ; primary, 303 ; secondary, 303

Oögonium, 303

Oötid, 303

Ophthalmica magna artery, 165, 181

Ophthalmicus profundus (V), 223, 241; ganglion of, $240-241$; origin of, 240 ; sensory fibers, 240

Ophthalmieus superficialis (V), 223, 240, 241 ; ganglion of, 240,241 ; origin of, 240 ; sensory fibers, 240

Ophthalmicus superficialis (VII), 224 , 242

Optic artery, 183

Optic chiasma, 221, 223, 239

Optic cup, 269

Optic lobes, 221

Optic nerve, 221,234 ; origin of, 239,269 ; relation of, to sclera, 268 ; termination of, 234,239

Optic organ. See Eye

Optic pedicel, $60,90,268$; function of, 258

Optic stalk, 269

Optic thalamus, 236

Optic vesicles, 230, 269

Orbit, 53, 55, 60, 89; in Heptanchus, 5, 44; muscle attachment to, 89

Orbital artery, 180

Orbital fissure, 44, 60; in embryo, 60 ; reduced, in Mustelus, 60

Orbital process, 44, 62; in embryo, 62

Orbital sinus, veins to, 198, 204, 205

Orbitonasal canal, 44

Organ of special sense, 258, 264

Oronasal groove, 122

Otolith, 272

Outer buceal ampullae, 262,279

Outer (heavy) layer of retina, 268

Ova, 290, 303

Ovary, 290, 303; development of, 303

Ovidueal artery, 169, 193; anterior, 193; posterior, 193

Oviducal funnel, 290, 304

Oviducal valve, 306

Oviducal vein, 209

Oviduct, 290, 304; arteries to, 169, 191, 193; development of, from Wolffian duct, 304 ; divisions of, 304 ; rudimentary, in male Heptanchus, 291, 309

Oviparous, 307

Paired fins, muscles of, 94,109 ; origin of, 14-16; skeleton of, 50 
Palatine nerve, 224, 243

Palatoquadrate cartilage, 45,62 ; muscles to, 90

Pallial eminence, 221, 232

Pancreas, 124, 138; arteries to, 166; duct of, 124,138 ; lobes of, 124, 138

Pancreatic duct, 124, 138

Papillae of oesophagus, 134

Paracentral mass, 237

Parachordal plates, 53

Paraphysial arch, 233

Paraphysis, 233

Parietal fossa, 43, 55, 271

Pectoral fin, 6, 12; arteries to, 168, 191; function of, 12, 13, 14; fusion of, to sides in rays, 12; muscles of, 89,94 ; nerves of, 227, 246-247; veins of, 202, 213

Pectoral girdle, 49, 79-81; development of, 77 ; muscles to, 89 ; parts of, 49,79 81

Pectoral muscles, 89, 94; development of, 110

Pectoral plexus, 227, 246

Pelagic, 1

Pelvic fin, 6, 14; claspers of male on, 6 Pelvic girdle, 6, 51, 82, 228; origin of, 82

Pelvic plexus, 228, 247

Pentanchid types, 150

Pepsin, 135

Peptic cells, 135

Pericardial artery, 163, 179

Pericardial cavity, 151, 171

Pericardio-peritoneal septum, 287

Perimeningeal space, 237

Peripheral nervous system, 223-228, 238248; development of, 238

Pharyngeal nerve (IX), 225, 244; (X), 225-227, 245

Pharyngobranchial cartilages, 46,64 ; fusion of, in last arch, 65 ; muscles of, 92, 106-107

Pharynx, 122, 131-134; lining of, 132; museles of, 90-93, 101-108; perforations of, 122, 131; stomodeal denticles in, 122

Photogenic cell, 29

Photophore, 29

Pigment, 23, 27, 29, 33; function of, 27

Pineal stalk, 221, 233, 236; development of, 233

Pit organs, 262, 274, 281-282; nerres to, $225,244,282$

Pituitary, 221, 233
Placodes, 264

Placoid scales, 7, 30-32; absence of, 32, 309 ; base of, 24,32 ; canals of, 30,32 ; development of, 30 ; finer anatomy of, 32 ; modified, 24-25, 33, 154; spines of, 32,33

Plasma, 170

Pleuracanthus, 1

Poison gland of ray, 28

Pori abdominales. See Abdominal pores

Portal vein. See Hepatic portal

Portio major (V), 240

Portio minor $(V), 240$

Postbranchial body, 151

Posteardinal sinus, 200, 204, 210; in rass, 210 ; relation of, to subscapular vein, 214

Posteardinal vein, 200, 204, 210; tributaries of, 200,210

Posterior cerebral artery, 165, 184

Posterior cerebral vein, 207

Posterior commissure, 233

Posterior coronary artery, 168, 179, 192

Posterior dorsolateral artery, 168

Posterior efferent-collector artery, 176

Posterior gastro-pancreaticosplenic artery, 166,188

Posterior gastro-pancreaticosplenic vein, 211

Posterior gastrosplenic artery, 166, 188

Posterior intestinal artery, 167, 188, 190 ; in rays, 190

Posterior intestinal vein, 200, 211; tributaries of, 200

Posterior mesenteric artery. See Inferior mesenteric

Posterior oblique semicircular canal, 259, 261,273

Posterior (outer) buccal ampullae, 262, 279

Posterior rectus muscle. See External rectus

Posterior thyroid artery, 164

Postorbital groove, 205

Postorbital process, 43, 44, 45, 58, 60 ; in Chlamydoselachus, 58; in notidanids, 58 ; in rays, 58

Post-trematicus nerve (IX), 225, 244; (X) , 225, 245

Postvelar arch, 233

Premandibular somite, 99

Preorbital process, 44, 58; in Zygaena, 58

Prespiracular ligament, 63

Prespiracular nerves, 224, 243 
Pretrematicus nerve (VII), 243; (IX), 225, 244; (X), 149, 225, 245

Primary renal corpusele, 299

Primitive ora, 301

Pristis, 3, 9, fig. 19; tooth of, figs. 39, 41

Pristiurus, development of fin skeleton of, 15-16

Proctodeum, 128

Pronephrotic duct, 298, 299

Propterygium, 50, 77; development of, 77

Prosenceplahon, 230; derivatives of, 230

Pseudobranchial axtery, 165, 182; in embryo, 182; in rays, 180

Pterygial arteries, 191

Pulp cavity, 32,35

Pupil of eye, 268

Pyloric stomach, 123, 135

Pyloric valre, 123, 136

Quadrate, 45,62

Radial cartilages, $50,51,77,78,79$; development of, 77-78; of pectorals, 7576 ; of pelvic, 81 ; postaxial radials, 50 , 79 ; preaxial radials, 50

Radial muscle, 94-95

Raia erinacea, 9 , fig. 20

Ramuli to lateral line canal, 278

Ramus anastomoticus artery, 165, 183; foramen of, 44; function of, 181

Ramus dorsalis artery, 192

Ramus dorsalis nerve (IX), 225; (X), $225,245,278$

Ramus hyoideus (VII), 243

Ramus oticus (VII), 242, 279 ; relation of, to spiracle, 153

Ramus palatinus, 224, 243

Ramus ventralis artery, 192

Ramus visceralis (or intestinalis) $(\mathrm{X})$, 227,245

Rays: batfish, 3 ; Cephaloptera, 3 ; eleetric, 3; guitar fish, 9; sawfish, 3, 9; small sting, 8 ; spiracle of, 150

Recessus neuroporicus, 221

Recessus utriculi, 259, 272; nerve to, 273

Rectal gland, 121, 126, 141; artery of, 167 , 191; function of, unknown, 141; relation of, to epigonal organ, 300 ; structure of, 141; veins of, 200, 211

Rectal artery, 169, 192

Rectum, 126, 141; artery to, 169, 192; in Heptanchus, 126 ; mesentery to, 121; veins of, 213

Rectus abdominalis, 97
Red blood cells. See Erythrocytes

Renal artery, 169, 192, 193

Renal corpuscle, 296, 299, 300; development of, 299-300; function of, 296 ; primary, 299; secondary, 299

Renal portal system, 204, 208-209; relation of, to subintestinal vein, 208

Renal portal vein, 208

Renal tubule, 297, 298, 299, 300

Respiration, 157

Respiratory current, 155; course of, 156 ; direction of, 156 ; reversal of, in rays, 156; in Urolophus, 157

Respiratory membrane, 149

Respiratory tract, 147, 150; of Elasmobranchs in general, 150-157; of Heptanchus, 147-149

Restiform bodies. See Corpora restiforme Retina, 268; cells of, 268-269; development of, 269; nerve from, 269; structure of, 268-269

Retractor palpebrae superioris, 102

Revehentes, 210

Rhinobatis productus, 9, fig. 7 .

lihinodon (Rhineodon) typicus, 3 ; color of, 26,27

Rhombencephalon, 230

Ribs, 48, 72

Rods of retina, 269

Rostrum, 43, 55, 57; in Acanthias, 57

Sacei vaseulosi, 233

Saccular nerve, 273

Sacculus, 259, 272

Sawfish (Pristis), 9

Saw tooth, 35; development of, 35 ; strueture of, 35

Scales. See Placoid scales

Scapula, 49, 79; muscles to, 94, 104

Scapular canal, 277

Schneiderian folds, 264 ; development of, 265 ; primary, 265 ; secondary, 265

Sclera, 258, 268; in Cetorhinus, 268

Selerotome, 70, 96

Seroll valve, 139

Scyllium, development of pectoral girdle of, 15

Scymnus, epidermis of, 26

Secondary dentine, 34 ; origin of, 34

Segmental artery, 169; branches of, 169 , 192-193; caudal, 169, 193

Segmental duct, 296, 297, 298; development of, 298

Selachii, 8 
Semicireular canal, 55, 258, 271, 273; ampullae of, 259,273 ; anterior oblique, 43, 258, 273; development of, 275; nerves to, 261, 273; posterior oblique, $43,259,273$

Seminal vesicle, 302

Sense of smell, 265

Sensory canal system, 261-263; canals of, 261-262; function of, 279; nerves to, 262; neuromasts of, 262, 278; of Elasmobranchs in general, 274-279; of Heptanchus, 261-263; structure of, 278

Sensory fibers, 238; origin, 238

Sensory (dorsal) root nerve, 246

Septum, constricting notochord, 48; of gill, 147, 148, 149

Serosa, 170

Serum, 170

Sex cells, 301, 302, 303; passage of, to cloaca of female, 310 ; passage of, to elasper of male, 303 ; sex gland, 300

Sex characters (secondary), 309 ; claspers, 309

Shagreen denticles, 7, 23

Sharks: angel fish (Squatina), 9, fig. 18; ancient, 1 ; basking, 3 ; blue, 3 ; flattened, 3 ; generalized, 2 ; hammerhead, 2 ; heptanchid, 5-7, figs. 12, 13, 14; heterodont, 1, fig. 17; lamnoid, 9; man-eater, 2, 9, fig. 16 ; modern or recent, 2,3 ; predacious, 9 ; specialized, 2 ; swell, 2, fig. 1 ; thresher, 2, fig. 2

Shell gland, 290, 304-305; secretory cells of, 305

Sinu-auricular aperture, 171

Sinu-auricular valve, 160, 171

Sinus, 204

Sinus of photophore, 29

Sinus venosus, $160,170,171$; tributaries to, $201,211,215$

Siphon, 28, 303; function of, 303; relation of, to clasper tube, 303

Skeleton, 43-52, 53-83 ; development of, $77-79$; nature of, 53 ; in anal fin, 52,83 ; of caudal fin, 51 ; of clasper, $51,81-82$; of dorsal fin, 51, 82-83; of pectoral fin, $49,75-79$; of pelvic fin, $51,81-82$; of paired fins, 50-51, 75-82; of unpaired fins, 51, 82-83

Skin. See Integument

Skull, 43-47, 53-69; components of, 43, 53

Somatic layer, 96

Somatic sensory fibers; terminus of, 236
Somite, 70, 96; degeneration of, 97 ; of head, $99-100$; parts of, 96

Special senses, of Elasmobranchs in general, 264-282; of Heptanchus, 258-263. See also Organs of special sense

Sperm sac, 302

Spermatagonia, 301

Spermatic fluid, 302

Spermatid, 301

Spermatozoa, 291, 301, 302; course of, to female, 309

Spinal artery, 186

Spinal column, 47,69 ; calcifieation in, $74-$ 75 ; in Elasmobranchs in general, $69-$ 75; in Heptanchus, 47-48; relation of, to notochord, 70

Spinal cord, 222, 237-238; arteries to, $169,192,193$; development of, 230,237 ; in Elasmobranchs in general, 237-238; in Heptanchus, 222

Spinal nerves, 227, 246; in Elasmobranchs in general, $246-247$; roots of, 227,237 , 246

Spinalis artery, 186

Spinax, color in, 27 ; photophores of, 29

Spiracle, absence of, 150 ; blood supply to, 181-182; divertieula of, 147-148, 153; filaments of, 147,153 ; in rays, 150 ; relation of, to gill clefts, 150

Spiracular ampulla, 280

Spiracular cartilage, 63, 153

Spiracular diverticulum. See Diverticula of spiracle

Spiracular valve, 153; muscles of, 153154; support of, 153

Spiral intestine, 139-140; mesentery to, 121

Spiral valve, 124, 126, 139; arteries to, 167; development of, 140 ; extent of, 126, 139-140; function of, 140; lining of, 126,140 ; turns of, 124,140 ; veins of, 210-211

Splanehinic layex, 96

Spleen, arteries to, $166,167,188$; in Heptanchus, 124, 138; position of, 138-139

Spouting, 156-157; course of, 156-157; in Squatina, 156-157

Squalus sucklii, gill rakers of, 37 ; relations of subscapular vein of, 214

Squatina, 9, fig. 18; clasper gland of, 28; spouting in, 156-157

Stapedeal artery. See Orbital artery

Sting, 35, 37; function of, 37; glands of, 28 ; structure of, 37 
Stomach, 123, 135-136; arteries to, 166, $167,186,188,189-190$; erypts of, 135; glands of, 135; limbs of, 123; lining of, 123,135 ; mesentery to, 121; nerves to, 227 , 245; secretion of, 135 ; veins of, $200-201,211$

Stomodeal denticles, 25, 38, 122, 266; function of, 38 ; in thyroid, Chlamydoselachus, 134; location of, 38, 122; of Heptanchus, 25, fig. 27 ; rudimentary, 38

Stomodeum, 127

Subclavian artery, 168, 191; in Heptanchus, 168, 191-192

Subelavian vein, 202, 214

Subintestinal vein, 208, 212; derivatives of, 208,210

Subseapular sinus, 203; tributary to, 203 Subseapular vein, 202, 214; in Squalus, 214

Subspinalis muscle, 92,106 ; nerve to, 227

Superficial constrictors, 90, 101; function of, 90

Superficial intercostal artery, 169

Supraophthalmic ampullae, 262, 279

Superior commissure, 233

Superior lobes of hypophysis, 233-234

Superior mesenteric artery, 167, 188-190; in rays, 190 ; its branches, 167, 188-190

Superior oblique muscle, 89,99 ; nerres to 44, 100, 223, 240; origin of, 99

Superior rectus muscle, 90,99 ; nerve to, 100, 223, 241; origin of, 99

Supernumerary branchial arches, 47

Supporting cells in ampulla, 273

Suprachoroidea, 268

Supracranial fontanelle, 57 ; in rays, 57

Supraorbital eanal, 261, 274, 276-277; in nervation of, $224,242,274$

Supraorbital erest, 44, 57, 58, 241

Suprapericardial body, 151

Suprarenal body, 248

Supraseapula, 49

Supratemporal canal, 261, 276, 278; in Elasmobranchs in general, 278; in Hep. tanchus, 261; nerves to, 225, 245, 278

Supratemporal nerve (IX), 244, 279 ; (X), 245,278

Suspensory ligament of liver, 121

Sympathetic nervous system, 247-248

Tail (caudal fin); electric organ in, 112; of Heptanchus, 6; of Pristis, 9; of Phinobatis, 9
Taste buds, 265 , 266 ; nerve to, 243

Taste organ, 265-266

Teetospondyly, 75

Teeth, 1, 38, 122, 128; development of, 128; finer structure of, 130 ; of Carcharodon, 38; of Heptanchus, 122; of Heterodontus, 130; of Lamna, 9; of Mustelus, 9; of Myliobatis, 38; pavement, 130 ; replacement of, 131

Telencephalon, 221, 230

Tendineae. See Chordae tendineae

Terminal cartilage, of clasper, $81-82$

Terminal nerve of Locy, 221, 223, 239; in IIentanchus, 221, 223

Tertiary renal corpuseles, 300

Testes, 290-291, 300, 301; central canal of, 290-291, 301; development of, 300 ; relation of, to epigonal organ, 300 ; rudimentary, in female Heptanchus, 290; structure of, 300,301

Third ventricle, 236

Thread cell of ear, 273

Thymus gland, 122-123, 132-133; development of, 132; with duet in Heptanchus, 122-123; function of, 133

Thyroid artery, 164-165

Thyroid gland, 122, 123, 133-134; arteries to, 164-165; capsule of, 133 ; denticles of, in Chlamydoselachus, 134; development of, 134; duet of, in Chlamydoselachus, 134; follicles of, 133, 134; history of, 133-134

Thyroidean sinus, 208

Tongue, 122, 128

Tooth germs, 128

Torpedo, 3, fig. 6 ; color of, 26,27 ; electric organ of, 112, 115

Trabecular cartilage, 53

Tract eells, 236

Tractus arteriosus lateralis, 192

Trapezius muscle, 92, 104

Triakis semifasciatus, integument of, 26

Trigeminal nerve, 223, 240-241; divisions of, 223, 240-241; ganglion of, $240-241$; nucleus of, 240

Trochlear nerve, 223, 240; foramen of. 44; musele supplied by, 100; origin of, 234

T'runk myotome. See Myotome

T'ubereulum aeusticum, 236

Tympanic membrane, 272

Tympanum, of Heptanchus, 272 ; of rays, 272 
Unpaired arteries, 186

Ureter, 287, 289, 291, 295; relation of, to collecting tubules, 294, 295; relation of, to male Wolffian duct, 296

Urinary papilla, 289, 290, 291, 296, 303

Urinary sinus, 289, 291, 294, 295; duets to, 294-295; horns of, 295, 296; walls of, 296

Urinary system, in Elasmobranchs in general, 292-300; in Heptanchus, 287-289

Urinary vesicle, 294

Urogenital sinus of male, 291; relation of, to seminal vesicle, 302 ; relation of, to vas deferens, 302

Urogenital system, in Elasmobranchs in general, 292-310; in Heptanchus, 287291

Urolophus halleri, fig. 9 ; ef. Acanthias, 8, 10-12; poison gland of, 28

Uterine septum, 309

Uterus, 290, 306-309 ; blood supply to, 193, 307 ; lining of, 307,308 ; partitions of, 308 ; relation of, to embryo, 307-309

Utriculus of ear, 259, 272, 273

Vagus nerve, 225-227, 244-245; divisions of, 225-227, 244-245; lobes of, 236; nucleus of, 236 ; visceral sensory fibers of, 236

Valves, oviducal, 306 ; of heart, 160-161, 171,172 ; of spiral intestine, 124,126 , 139,140 ; of uterus, 306 ; of veins, 204

Valvular intestine, 124, 126, 139-140; arteries to, 166, 167, 188, 190; veins of, 201, 210-211

Vas deferens, 290, 291; relation of, to Wolffian duct, 290, 296

Vasa efferentia, 290,301-302 ; origin of, 301

Vaseular saes, 208, 221, 233

Vasodentine, 35, 130

Veins, 170, 198, 204; cf. arteries, 170, 204; of body wall, 202, 204; from digestive tract, 200-201, 204, 210-213; from head, Heptanchus, 198, 204; of heart, 215-216; of kidney, 208, 210; of skin, 202-203, 204, 216-217; of tail, Heptanchus, 199; walls of, 170, 204

Velum, 233

Tena limitans, 210

Yena profunda, 217

Venous system, in Elasmobranchs in general, 204-218; in Heptanchus, 198-203

Ventral aorta, 161, 172, 175

Ventral bundles, $89,9 \tau$
Ventral constrictor muscles, 91, 104-105; nerves to first ventral constrictor, 243

Ventral cutaneous veins, 203, 217; relation of, to eloacal vein, 217

Ventral gastric artery, 166, 187

Ventral gastric vein, 201, 211

Ventral horn of cord, 222, 237, 238; cells of, 238

Ventral intercalary piece, 48

Ventral intestinal artery, 167, 188; absent in rays, 188

Ventral intestinal vein, 201, 210; tributaries of, 201, 210-211

Ventral lobe of pancreas, 124, 138

Ventral longitudinal muscles. See Hypobranchials

Ventral myelonal vein, 208

Ventral root nerve, 227; foramen of, 48

Ventricle, $160,161,170,171,179$; arteries to, $163-164,172$; walls of, $160-161,170,171$

Ventrolateral bundles in medulla, 235

Ventrolateral musele bundles, 89, 97

Ventromedian muscle bundles, 97

Vertebrae, 69, 70, 71, 72; in Alopias, 69

Vertebral plate, in rays, 71

Vertebromuscularis artery, 192, 193-194

Vertebrospinalis artery, 192

Vertebrospinal vein, 210

Vesicula seminalis, 302

Vesicles of Savi, 274, 281

Vessels of Thebesius, 215-216

Vestibular nerve, 273

Villus, arteries of, 307 ; of intestine, 140; nutriment from, 307-308; of uterus, $307-309$; veins of, 307

Visceral arches, 44-47,62-67; in embryo, 62; muscles to, 100-108

Visceral nerve $(\mathrm{X}), 225$

Visceral sensory fibers, 236

Visceral skeleton, of Elasmobranchs in general, 62-69; of Heptanchus, 44-47

Visceromotor nucleus, 236, 240

Vitelline vein, 212, 213

Vitreous body (humor), 268

Vitrodentine, 35

Viviparous, 307

White blood cells, 170

White matter of cord, 237

Wolffian duct, 287, 289, 294, 295, 296, 297; modified as vas deferens, 290, 296, 301; relation of, to collecting tubules, 294; relation of, to vas deferens, 302

"Wonder net," 181 








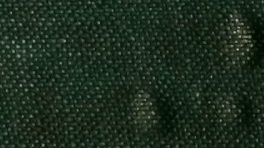

Xx

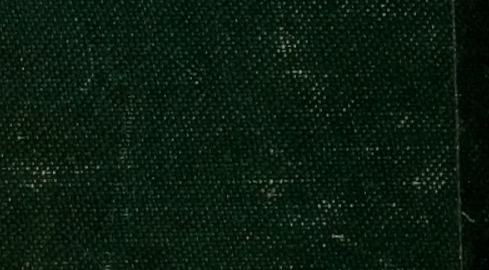

(7)

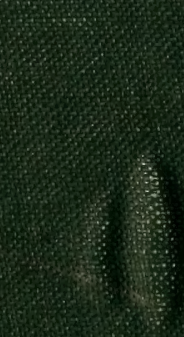

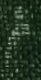

$\ldots$

-

.

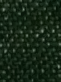

-

\section{- 5}

$\sqrt{2+5}$

-

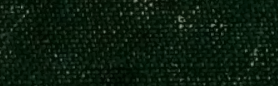

(2)

\%

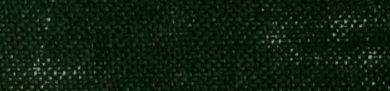

